\title{
Technical Support Document: Development of the Advanced Energy Design Guide for K-12 Schools-30\% Energy Savings
}

Technical Report NREL/TP-550-42114

September 2007

S. Pless, P. Torcellini, and N. Long 


\section{Technical Support Document: Development of the Advanced Energy Design Guide for K-12 Schools-30\% Energy Savings}

S. Pless, P. Torcellini, and N. Long

Prepared under Task No. BEC71011

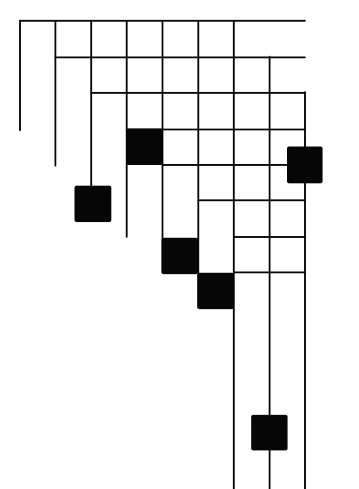




\section{NOTICE}

This report was prepared as an account of work sponsored by an agency of the United States government. Neither the United States government nor any agency thereof, nor any of their employees, makes any warranty, express or implied, or assumes any legal liability or responsibility for the accuracy, completeness, or usefulness of any information, apparatus, product, or process disclosed, or represents that its use would not infringe privately owned rights. Reference herein to any specific commercial product, process, or service by trade name, trademark, manufacturer, or otherwise does not necessarily constitute or imply its endorsement, recommendation, or favoring by the United States government or any agency thereof. The views and opinions of authors expressed herein do not necessarily state or reflect those of the United States government or any agency thereof.

Available electronically at http://www.osti.gov/bridge

Available for a processing fee to U.S. Department of Energy and its contractors, in paper, from:

U.S. Department of Energy

Office of Scientific and Technical Information

P.O. Box 62

Oak Ridge, TN 37831-0062

phone: 865.576 .8401

fax: 865.576 .5728

email: mailto:reports@adonis.osti.gov

Available for sale to the public, in paper, from:

U.S. Department of Commerce

National Technical Information Service

5285 Port Royal Road

Springfield, VA 22161

phone: 800.553.6847

fax: 703.605.6900

email: orders@ntis.fedworld.gov

online ordering: http://www.ntis.gov/ordering.htm 


\section{Acknowledgments}

The authors would like to thank the U.S. Department of Energy's (DOE) Office of Building Technologies and Drury Crawley, Technology Development Manager for Commercial Buildings. This document was prepared by NREL's Center for Buildings and Thermal Systems as FY 2007 Deliverable 1.1.2 under Task 1.1 in the Commercial Building's Statement of Work.

The authors would like to thank all the members of the project committee for their valuable input and willingness to share their expertise. Much work went into producing the lighting and daylighting recommendations, many types of HVAC systems, and envelope considerations. Without the committee's expertise and differing views and the support of the Project Committee's employers, this document would not have been possible.

Additional thanks to those who helped to edit and review the document: Stefanie Woodward, Michael Deru, Dan Macumber, Brent Griffith, Chad Lobato (all of NREL), and Lilas Pratt (ASHRAE). And finally, the authors greatly appreciate the assistance of Brent Griffith and NREL's EnergyPlus analysis and modeling team. Their simulation development and support allowed us to evaluate the many variations of energy efficiency technologies. 


\section{Executive Summary}

\section{Background}

This Technical Support Document (TSD) describes the process and methodology for the development of the Advanced Energy Design Guide for K-12 School Buildings (K-12 AEDG), a design guidance document intended to provide recommendations for achieving $30 \%$ whole-building energy savings in K-12 Schools over levels achieved by following the ANSI/ASHRAE/IESNA Standard 90.1-1999, Energy Standard for Buildings Except Low-Rise Residential Buildings. The K-12 AEDG was developed in collaboration with the American Society of Heating, Refrigerating and Air-Conditioning Engineers (ASHRAE), the American Institute of Architects (AIA), the Illuminating Engineering Society of North America (IESNA), the U.S. Green Building Council (USGBC), and the U.S. Department of Energy (DOE).

The 30\% energy savings target is the first step toward achieving net-zero energy schools; schools that, on an annual basis, draw from outside sources less or equal energy than they generate on site from renewable energy sources. Previous guides in this series include the Advanced Energy Design Guide for Small Office Buildings, the Advanced Energy Design Guide for Small Retail Buildings, and the Advanced Energy Design Guide for Small Warehouses and Self Storage Buildings. Each guide in the AEDG series provides user-friendly design assistance and recommendations to design, architectural and engineering firms to achieve energy savings. Included in the K-12 AEDG are prescriptive recommendations by climate zone for the design of the building envelope, fenestration, lighting systems (including electrical lights and daylighting), HVAC systems, building automation and controls, outside air treatment, and service water heating. Additional savings recommendations are also included, but not necessary for 30\% savings. Additional savings recommendations are provided for electrical distribution, plug loads, renewable energy systems, and using the building as a teaching tool. The K-12 AEDG contains recommendations only and is not a code or standard.

Our task in developing the $30 \% \mathrm{~K}-12$ AEDG included:

- Document the process and schedule used for developing the Guide.

- Develop prototypical, baseline, and low-energy EnergyPlus K-12 school models.

- Document the EnergyPlus modeling assumptions needed to verify 30\% energy savings.

- Present the recommendations for 30\% savings over ASHRAE 90.1-1999 for use in the K-12 AEDG.

- Present the recommendations for 30\% savings over ASHRAE 90.1-2004.

- Demonstrate that the recommendations result in 30\% or greater energy savings by climate zone.

\section{Development Process}

The K-12 AEDG was developed by a project committee (PC) that represents a diverse group of professionals. Guidance and support was provided through a collaboration of ASHRAE, AIA, IESNA, USGBC, and DOE. Members of the PC came from these partner organizations, the ASHRAE Standing Standards Project Committee 90.1 (SSPC 90.1), the ASHRAE Technical Committee on Educational Facilities (TC 9.7), the Sustainable Building Industry Council, the Collaborative for High Performance Schools Project (CHPS), and the National Clearinghouse for Educational Facilities at the National Institute of Building Sciences. A steering committee (SC) made up of representatives of ASHRAE, AIA, IESNA, USGBC, and DOE issued a charge to the PC to develop the Guide. The charge included a timeline for the task, an energy savings goal, an intended target audience, space types to include, and desired design assistance characteristics.

Following the guidance from the SC, the PC developed a one-year plan for completing the document. Key milestones in the development schedule were determined based on a final publication date such that it would be ready for the Winter ASHRAE Meeting in January 2008. The PC used a similar schedule to the one developed for the previous guides to plan for two peer review periods that corresponded with a 
$65 \%$ completion draft (technical refinement review) and a 90\% completion draft (final review for errors). A focus group reviewed the conceptual 35\% draft. Six PC meetings were held at ASHRAE Headquarters or at the National Renewable Energy Laboratory (NREL). Five conference calls with the full PC were also held.

\section{Evaluation Approach and Results}

The purpose of the building energy simulation analysis presented in this TSD is to assess and quantify the energy savings potential of the Guide's recommendations. The AEDGs contain a set of energy efficiency recommendations for eight climate zones across the country. To provide prescriptive $30 \%$ recommendations, a specific quantitative energy savings goal must be measured against a specific version of Standard 90.1, that is, 90.1-1999, the "turn of the Millennium" standard for each climate zone. The energy savings of the prescriptive recommendations are also determined against ASHRAE 90.1-2004. The following steps were used to determine $30 \%$ savings:

\section{1) Develop "typical" K-12 school prototype characteristics}

For building characteristics that are not specified by ASHRAE 90.1-1999, ASHRAE 90.1-2004, or ASHRAE 62, but that are needed to develop code-compliant baseline models, we surveyed the available data sets in order to develop "typical" school characteristics. Data sets evaluated include:

- The 2003 Commercial Building Energy Consumption Survey (CBECS).

- The School Planning and Management (SPM) and American School and University (ASU) annual construction survey and report.

- Additional data sets from the PC, including plug load surveys, actual floor plates, and space programming requirements.

From the survey of "typical" school characteristics, we developed prototype elementary, middle, and high school models as documented in Table ES-1.

Table ES-1 K-12 AEDG Prototype Characteristics and Data Sources

\begin{tabular}{|l|l|l|}
\hline School Characteristic & \multicolumn{1}{|c|}{ K-12 AEDG Prototype } & \multicolumn{1}{c|}{ Source } \\
\hline School types & Elementary, middle, and high school & ASU, SPM, AEDG PC \\
\hline Size & $\begin{array}{l}73,930 \mathrm{ft}^{2} \text { elementary, 116,080 } \mathrm{ft}^{2} \text { middle, 210,810 } \mathrm{ft}^{2} \\
\text { high }\end{array}$ & $\begin{array}{l}\text { ASU, SPM, CBECS 2003, } \\
\text { AEDG PC }\end{array}$ \\
\hline Number of floors & 1 for elementary, 1 for middle, 2 for high schools & CBECS 2003 \\
\hline Number of students & Elementary: 650, middle: 800, high: 1200 & SPM, ASU, \\
\hline Space types & See Table 3-4 & SPM \\
\hline Constructions & Mass walls, insulation entirely above deck & CBECS 2003, AEDG PC \\
\hline Floor plan & $\begin{array}{l}\text { North- and South-facing classrooms similar to } \\
\text { example floor plans in Section 3.2.3.2 }\end{array}$ & AEDG PC \\
\hline Window area & 35\% fenestration to gross wall area & CBECS 2003, AEDG PC \\
\hline Occupancy & $\begin{array}{l}\text { Fully occupied during school hours, partially } \\
\text { occupied year round and into the evening }\end{array}$ & CBECS 2003, AEDG PC \\
\hline Peak plug loads & 1.1 w/ft ${ }^{2}$ for elementary, 1.0 W/ft ${ }^{2}$ for middle and high & AEDG PC \\
\hline Percent conditioned & Fully heated and cooled & CBECS 2003 \\
\hline HVAC system types & $\begin{array}{l}\text { Baseline: PSZ } \\
\text { Low-energy: PSZ, PVAV, and VAV }\end{array}$ & $\begin{array}{l}\text { 2003 CBECS } \\
\text { AEDG PC }\end{array}$ \\
\hline
\end{tabular}




\section{2) Create baseline models from the prototypes that are minimally code compliant for both ASHRAE 90.1-1999 and ASHRAE 90.1-2004.}

We documented the baseline elementary, middle, and high school energy modeling assumptions and methods, including the building form and floor plate, envelope characteristics, building internal loads and operating schedules, ventilation rates and schedules, HVAC equipment efficiency, operation, control and sizing, fan power assumptions, and service water heating. The baseline models for the elementary, middle, and high schools were developed by applying the criteria in ASHRAE 90.1 and ASHRAE 62 to the prototype characteristics. We used the criteria in ASHRAE 90.1-1999 and ASHRAE 62-2001 as the baselines to calculate energy savings for the K-12 AEDG recommendations. For the baselines needed to verify $30 \%$ savings for our DOE analysis, we updated the K-12 AEDG baselines to be minimally code compliant with ASHRAE 90.1-2004.

\section{3) Create the low-energy models based on the recommended energy efficiency technologies in the Guide.}

The final recommendations included in the Guide were determined based on an iterative process using the PC's expertise and results from modeling the recommendations. To quantify the potential energy savings from the final recommended energy efficiency measures in the Guide, we simulated the low-energy building models by implementing the energy efficiency technologies listed below. We documented the EnergyPlus modeling assumptions and methods needed to model the final recommended energyefficiency measures. The energy efficiency measures included in the energy saving calculation are:

- Enhanced building opaque envelope insulation

- Enhanced window glazings with overhangs

- Reduced lighting power density and occupancy controls

- Classroom and gym daylighting

- Demand-controlled ventilation with automatic motorized outdoor air damper control

- Energy recovery ventilation

- Economizers

- Lower pressure ductwork design

- Higher efficiency heating, ventilation, and air-conditioning (HVAC) equipment

- High-efficiency service water heating.

Any possible plug loads reductions are not credited to the calculated 30\% energy savings, as these energy efficiency opportunities are not part of the prescriptive recommendations. However, they form a prominent part of the additional savings section in the Guide.

4) Verify $30 \%$ energy savings across the various HVAC system types and daylighting options over the 15 climate zones and sub-zones in the country.

Energy savings from the final recommendations in the Guide are documented, along with the recommendations for 30\% savings over ASHRAE 90.1-1999 and ASHRAE 90.1-2004.

Recommendations are provided based on the availability of daylighting for the school and by the type of HVAC system. To verify savings over this range of design options, we modeled low-energy versions of the elementary, middle, and high schools, each with the daylit option and the non-daylit option. For each daylit and non-daylit option, we modeled three HVAC types. The low-energy HVAC system types included a constant volume package rooftop DX system, a package variable-air volume direct expansion system with a central boiler, and a VAV air cooled chiller and central boiler. The recommendations in the K-12 AEDG result in more than 30\% savings in all climate zones, for each daylit and non-daylit elementary, middle, and high school, with a range of HVAC system types. For 30\% savings over ASHRAE 90.1-2004, the recommendations are almost the same as those that are in the K-12 AEDG. The non-daylit option presented in the K-12 AEDG is not available for 30\% savings over ASHRAE 90.12004, as 30\% savings were not possible over all climate zones for the non-daylit recommendations. 
To inform the future development of more stringent K-12 AEDGs, we performed a scoping study to understand which energy efficiency technologies would be needed to achieve $50 \%$ energy savings. Recommendations included in the 50\% scoping analysis include the most stringent of each recommendation included in the $30 \%$ guide, combined with plug load reductions brought about by highefficiency distribution transformers and Energy Star ${ }^{\circledR}$ equipment, daylighting in all zones, infiltration reduction, and water-cooled chillers. We modeled these recommendations in a daylit middle school to determine energy savings over ASHRAE 90.1-2004 in each of the 15 climate zones. Based on this initial scoping study, $50 \%$ savings should be possible in all climates. For the most temperate climates such as $3 \mathrm{C}$ and $4 \mathrm{C}$, energy savings are just above $50 \%$. Findings from this scoping study suggest that $50 \%$ savings are possible, but that nontraditional efficiency measures such as plug load reductions and infiltration reduction are required. Additional focus on "typical" plug load schedules in K-12 schools and the expected energy savings from Energy Star equipment will be needed to accurately predict the plug load savings. Baseline infiltration inputs will also need to be further researched. In addition, only certain types of HVAC systems, such as water cooled chillers, high efficiency condensing boilers, or ground source heat pumps, may be available for a 50\% low-energy school. Standard systems such as package single zone equipment or unit ventilators may not be able that meet the high efficiency needs for a $50 \%$ savings school without additional lighting, plug load, or envelope measures. 


\section{Contents}

ACKNOWLEDGMENTS ........................................................................................................................... III

EXECUTIVE SUMMARY ........................................................................................................IV

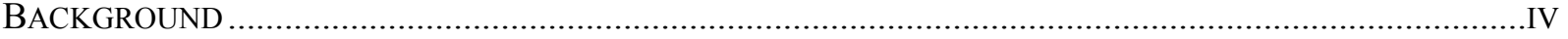

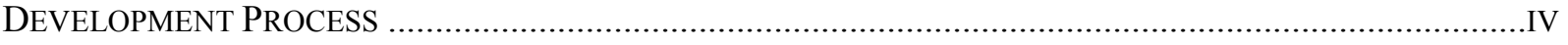

EVALUATION APPROACH AND RESULTS.....................................................................................

CONTENTS...........................................................................................................................................

FIGURES, TABLES, AND EQUATIONS …………..........................................................................XII

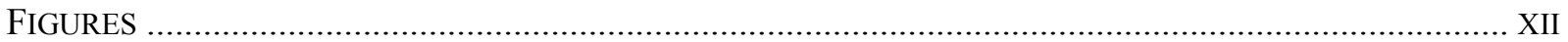

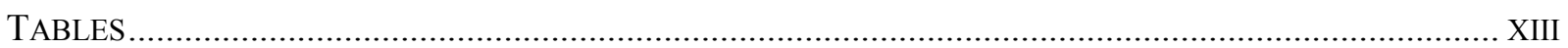

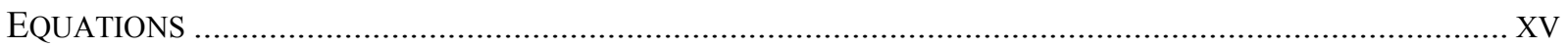

NOMENCLATURE ...................................................................................................................

1. INTRODUCTION.......................................................................................................................... 1

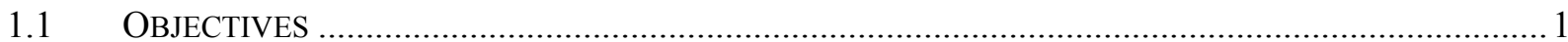

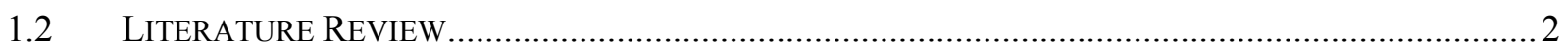

1.3 SCOPE OF THE K-12 AEDG AND TECHNICAL SUPPORT DOCUMENT............................................... 3

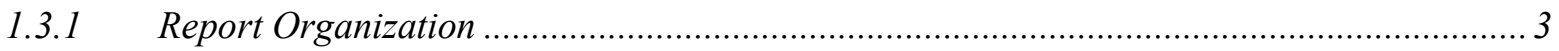

2. DEVELOPMENT PROCESS..........................................................................................................4

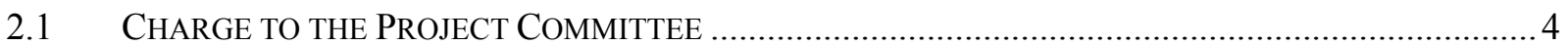

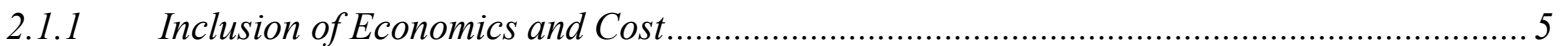

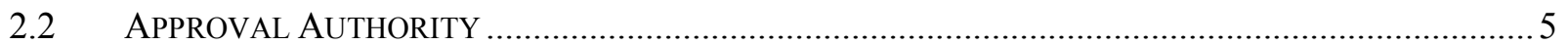

2.3 PRoJeCt CoMmitTEe ORGANIZATION AND MEMBERShIP.......................................................... 5

2.4 DEVELOPMENT SCHEDULE AND PROCESS ............................................................................... 6

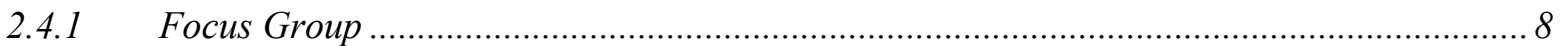

3. EVALUATION APPROACH........................................................................................................ 11

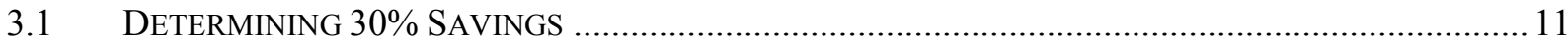

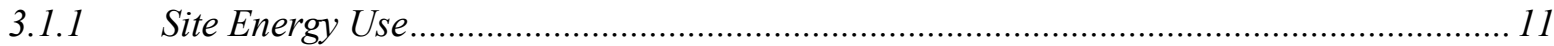

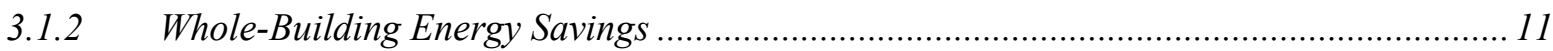

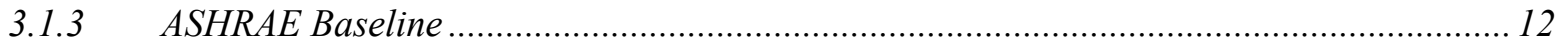

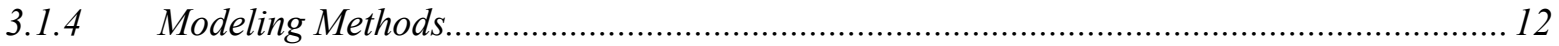

3.2 PRototyPe Model DeVElopment AND ASSUMPTIONS........................................................ 14

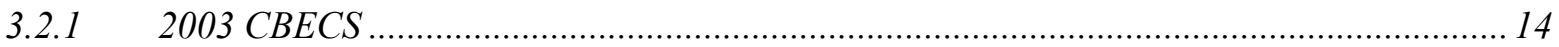




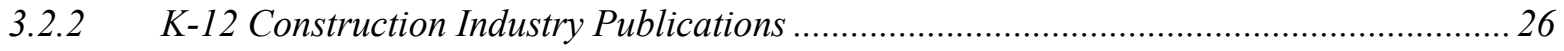

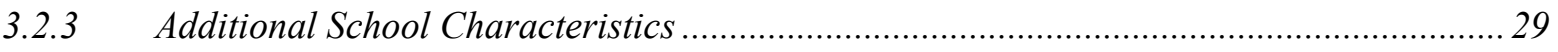

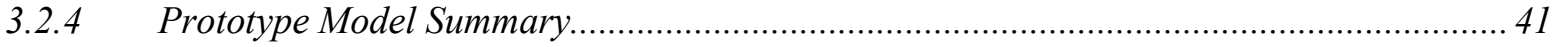

3.3 BASELINE MODEL DEVELOPMENT AND ASSUMPTIONS.......................................................... 45

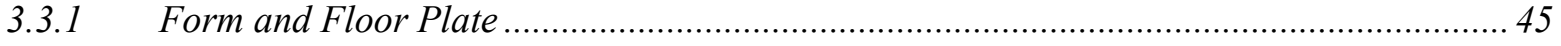

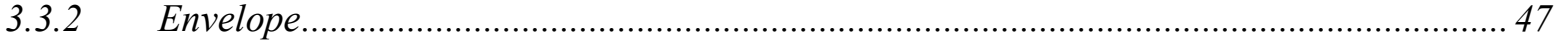

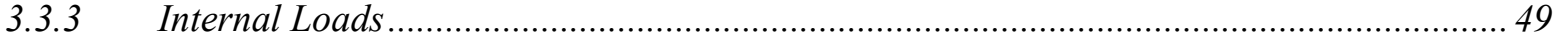

3.3.4 HVAC Systems and Components........................................................................... 51

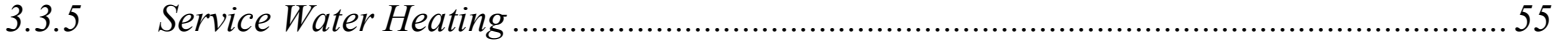

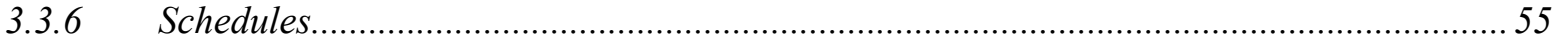

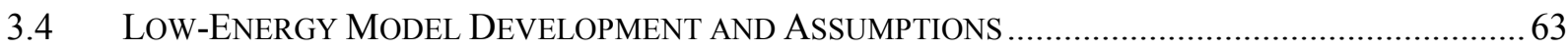

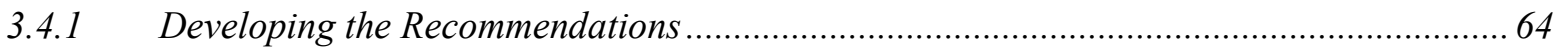

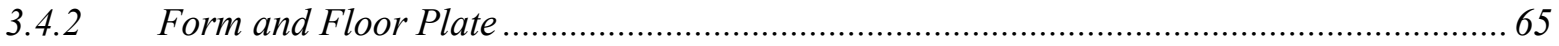

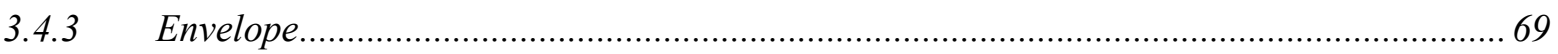

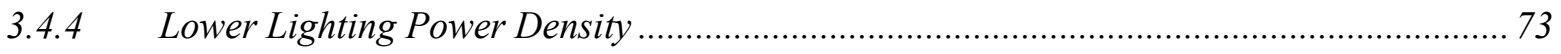

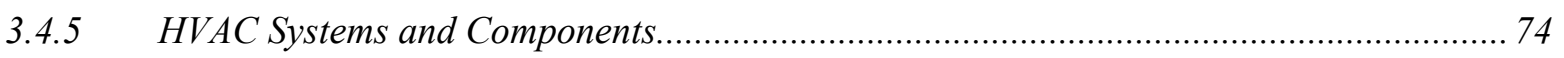

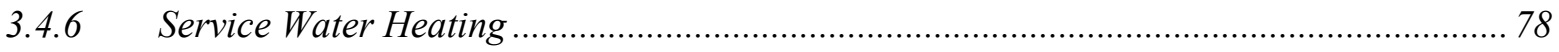

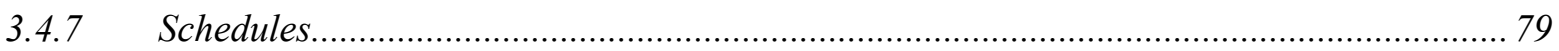

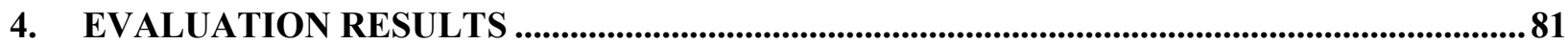

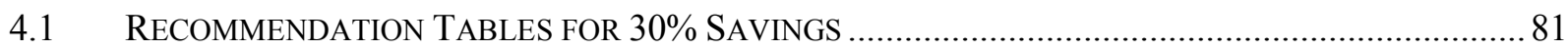

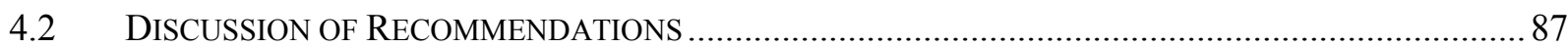

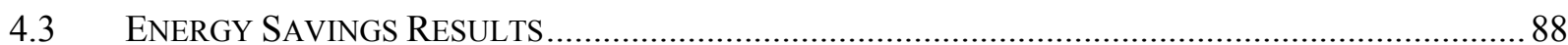

4.3.1 End Uses for 30\% Savings over ASHRAE 90.1-1999 ...................................................... 92

4.3.2 End uses for 30\% Savings over ASHRAE 90.1-2004 …................................................. 95

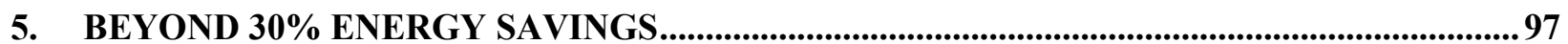

$5.150 \%$ ENERGY SAVINGS MODEL INPUTS AND ASSUMPTIONS..................................................... 97

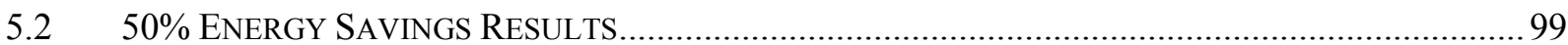

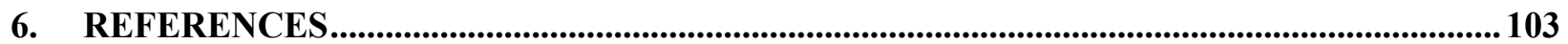

APPENDIX A. PROJECT COMMITTEE MEETING AGENDAS.............................................105

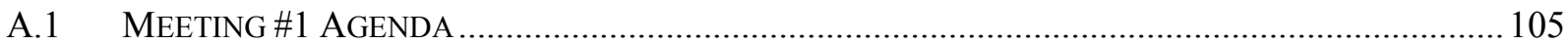

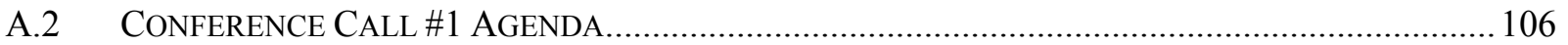

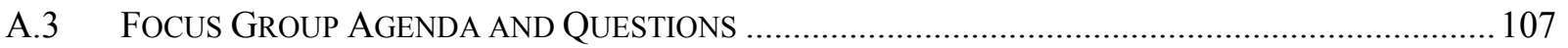

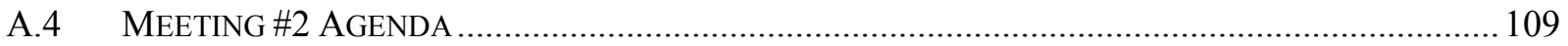

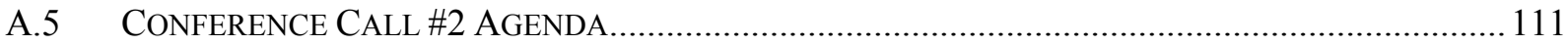

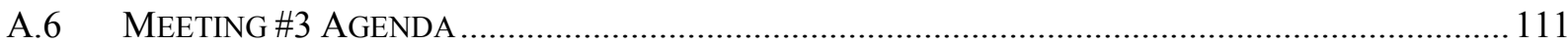




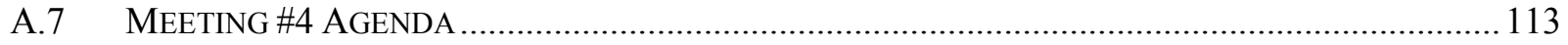

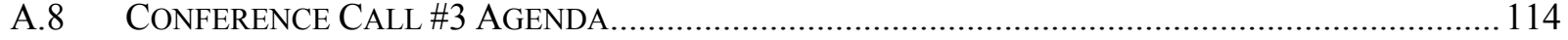

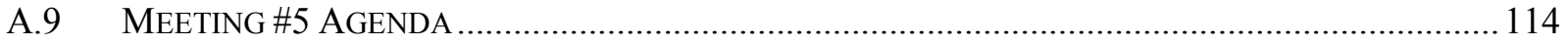

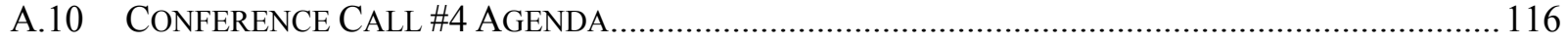

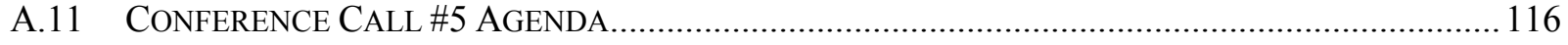

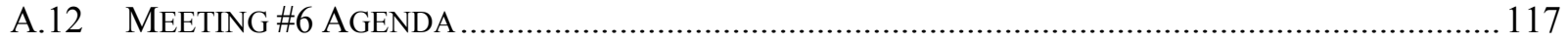

APPENDIX B. RESPONSES TO 65\% DRAFT REVIEW REMARKS....................................... 119

APPENDIX C. ELEMENTARY SCHOOL BASELINE SCORECARDS ..................................123

APPENDIX D. MIDDLE SCHOOL BASELINE SCORECARD .................................................... 129

APPENDIX E. HIGH SCHOOL BASELINE SCORECARD ........................................................ 135

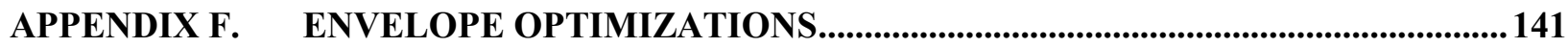

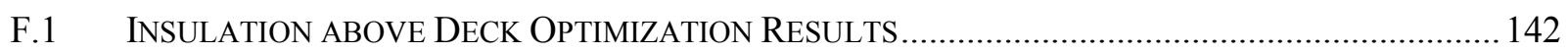

F.2 MASS WALL INSULATION OPTIMIZATION RESULTS .......................................................... 146

APPENDIX G. ENERGY SAVINGS END USE TABLES: ASHRAE 90.1-1999 BASELINE.. 150

APPENDIX H. ENERGY SAVINGS END USE TABLES: ASHRAE 90.1-2004 BASELINE.. 156 


\section{Figures, Tables, and Equations}

\section{Figures}

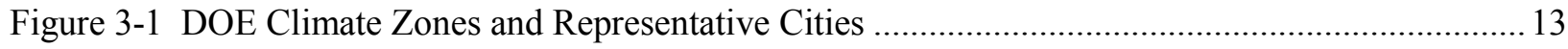

Figure 3-2 Area Weighted Average Daylit Floor Area..................................................................... 15

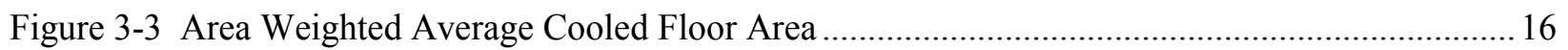

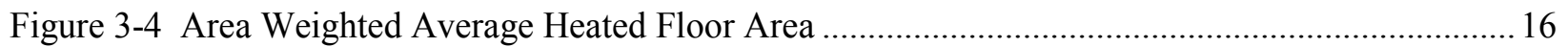

Figure 3-5 Area Weighted Average Months per Year of Use ............................................................... 17

Figure 3-6 Area Weighted Average Weekly Operating Hours................................................................. 18

Figure 3-7 Area Weighted Average Number of Computers ...................................................................... 19

Figure 3-8 Area Weighted Average Wall and Roof Construction Type................................................. 20

Figure 3-9 Area Weighted Average Primary Heating and Cooling System Types ..................................2 21

Figure 3-10 Area Weighted Average Window to Wall Ratio.................................................................22

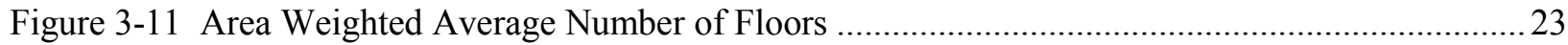

Figure 3-12 Area Weighted Average Elementary/Middle School Size …............................................... 24

Figure 3-13 Area Weighted Average High School Size ................................................................... 24

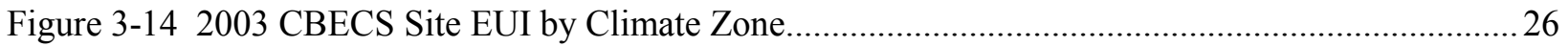

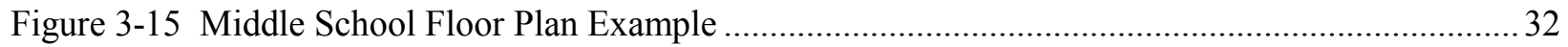

Figure 3-16 Elementary School Floor Plan Example …..................................................................... 32

Figure 3-17 High School Floor Plan Example_East or West Entry ......................................................33

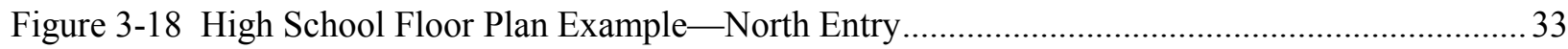

Figure 3-19 High School Floor Plan Example—South Entry................................................................. 33

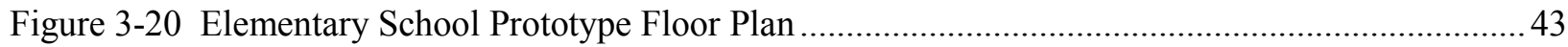

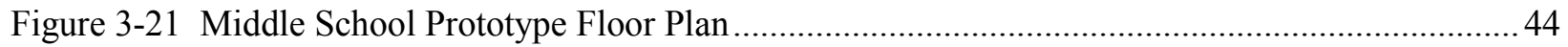

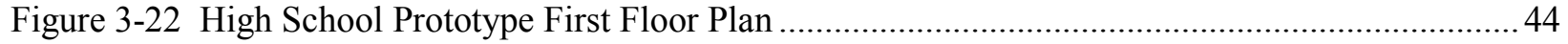

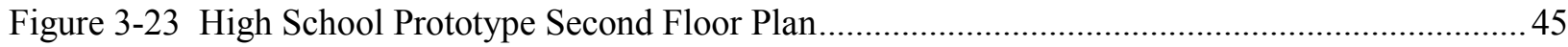

Figure 3-24 Elementary School Baseline Model Rendering: View from Southwest............................... 46

Figure 3-25 Middle School Baseline Model Rendering: View from Southwest .................................... 46

Figure 3-26 High School Baseline Model Rendering: View from Southwest....................................... 47

Figure 3-27 Elementary School Low-Energy Model Rendering: No Daylighting ….............................. 65

Figure 3-28 Middle School Low-Energy Model Rendering: No Daylighting ....................................... 66

Figure 3-29 High School Low-Energy Model Rendering: No Daylighting.......................................... 66

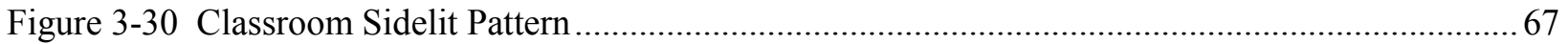

Figure 3-31 Elementary School Low-Energy Model Rendering: Daylit ............................................... 68

Figure 3-32 Middle School Low-Energy Model Rendering: Daylit...................................................... 68

Figure 3-33 High School Low-Energy Model Rendering: Daylit ........................................................ 69 


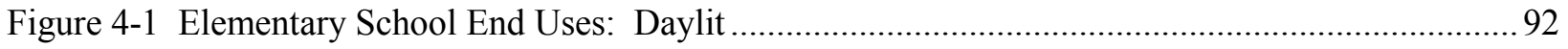

Figure 4-2 Elementary School End Uses: No Daylighting ................................................................ 92

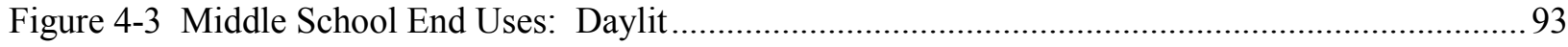

Figure 4-4 Middle School End Uses: No Daylighting ........................................................................ 93

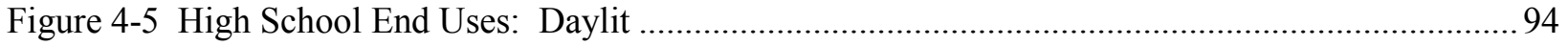

Figure 4-6 High School End Uses: No Daylighting....................................................................... 94

Figure 4-7 Elementary School End Uses: Daylit, ASHRAE 90.1-2004 Baseline .................................. 95

Figure 4-8 Middle School End Uses: Daylit, ASHRAE 90.1-2004 Baseline ......................................... 95

Figure 4-9 High School End Uses: Daylit, ASHRAE 90.1-2004 Baseline .............................................96

Figure 5-1 50\% Savings Fully Daylit Middle School Model Rendering ............................................... 98

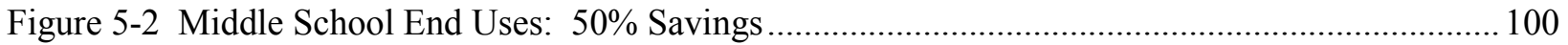

\section{Tables}

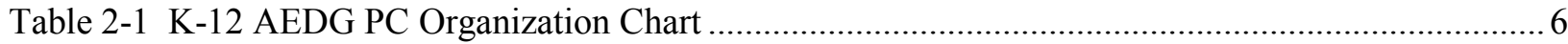

Table 2-2 K-12 AEDG Project Committee Development Schedule ............................................................ 8

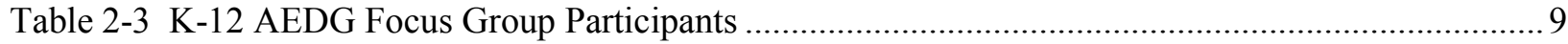

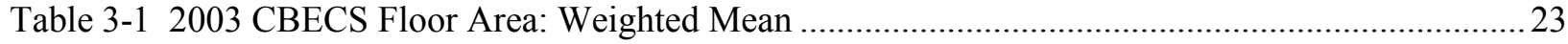

Table 3-2 Area Weighted Average Site EUI by ASHRAE Climate Zone .............................................25

Table 3-3 National Average Schools Sizes, Costs, and Number of Students (ASU Construction Report, SPM Construction Report)

Table 3-4 Space Types Included in Schools: 2006 SPM National Average, Wake County, NC, and in

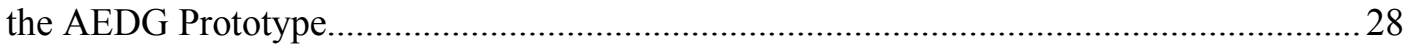

Table 3-5 Roanoke District High School Plug Load Density Survey ....................................................29

Table 3-6 Roanoke District Middle School Plug Load Density Survey .................................................. 30

Table 3-7 Roanoke District Elementary School Plug Load Density Survey .......................................... 30

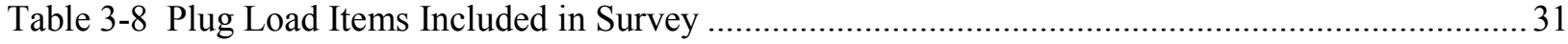

Table 3-9 North Carolina Elementary School Typical Space Profiles..................................................... 35

Table 3-10 North Carolina Middle School Typical Space Profiles ….......................................................36

Table 3-11 North Carolina Middle School Typical Space Profiles (Cont.) ................................................37

Table 3-12 North Carolina High School Typical Space Profiles ............................................................... 38

Table 3-13 North Carolina High School Typical Space Profiles (Cont.)................................................. 39

Table 3-14 North Carolina High School Typical Space Profiles (Cont.)................................................. 40

Table 3-15 Elementary/Middle School National Average Schools Sizes: ASU, SPM, AEDG, CBECS .. 41

Table 3-16 High School National Average Schools Sizes: ASU, SPM, AEDG, CBECS ….................... 41

Table 3-17 K-12 AEDG Prototype Characteristics and Data Sources.................................................... 42

Table 3-18 Total Space Sizes Included in the AEDG Prototypes........................................................... 43

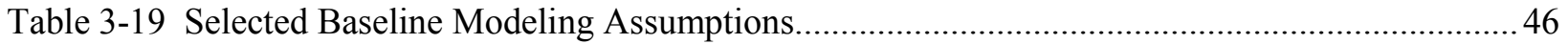


Table 3-20 Elementary School Baseline Internal Loads by Space Type …........................................... 50

Table 3-21 Middle School Baseline Internal Loads by Space Type .....................................................50

Table 3-22 High School Baseline Internal Loads by Space Type........................................................51

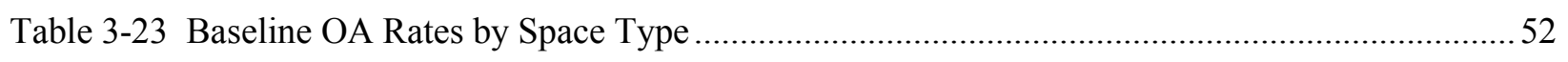

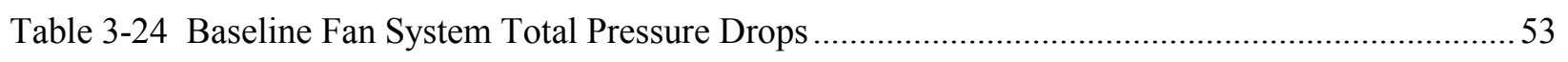

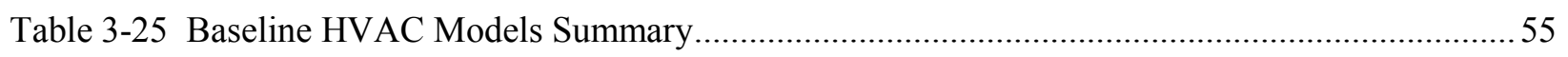

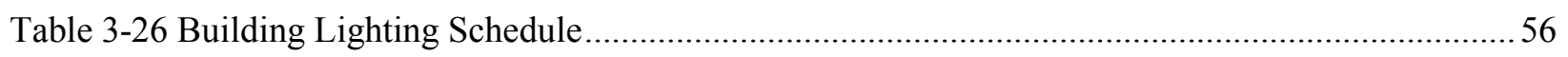

Table 3-27 Building Heating and Cooling Set Point Schedules .............................................................. 57

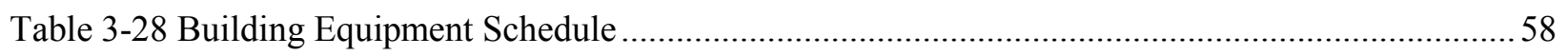

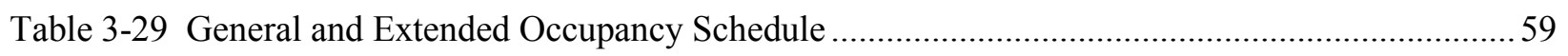

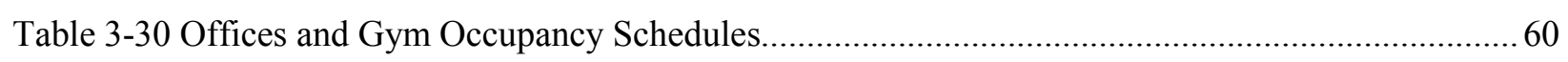

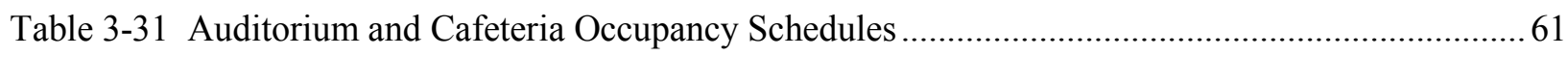

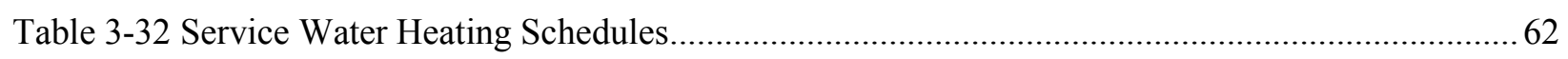

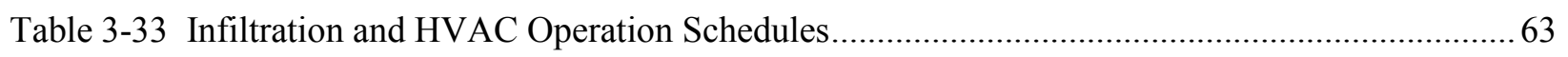

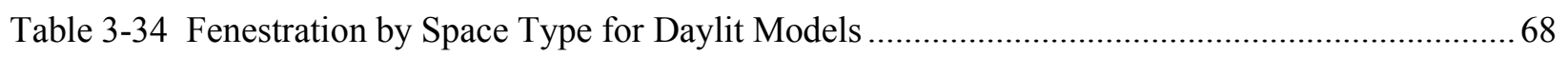

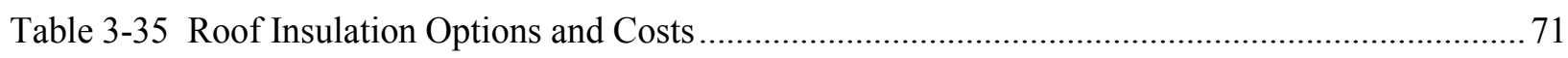

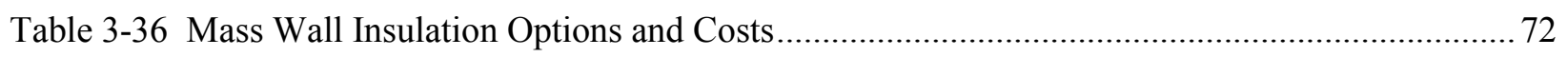

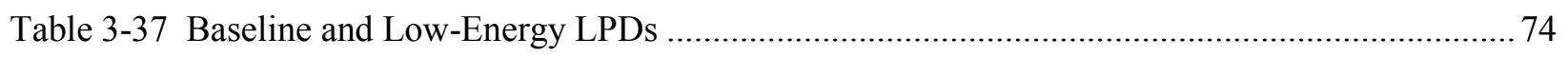

Table 3-38 Low Energy Fan System Total Pressure Drops .................................................................. 77

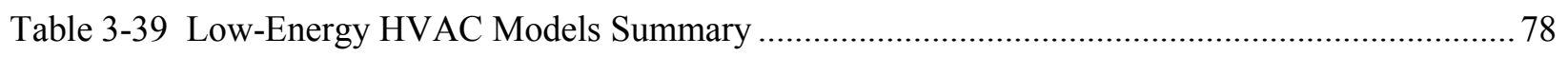

Table 3-40 Building Lighting Schedule with Occupancy Sensors ........................................................ 79

Table 3-41 General and Extended Occupancy Schedules for Demand Controlled Ventilation ................. 80

Table 4-1 K-12 AEDG Recommendations for 30\% Savings over ASHRAE 90.1-1999: Climate

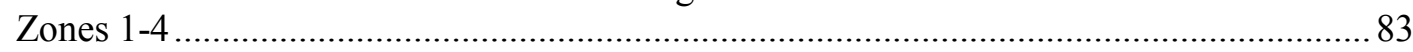

Table 4-2 K-12 AEDG Recommendations for 30\% Savings over ASHRAE 90.1-1999: Climate

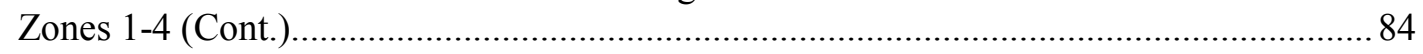

Table 4-3 K-12 AEDG Recommendations for 30\% Savings over ASHRAE 90.1-1999: Climate

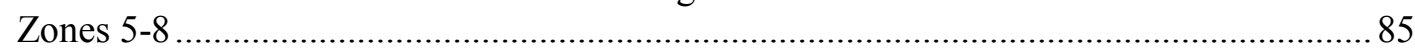

Table 4-4 K-12 AEDG Recommendations for 30\% Savings over ASHRAE 90.1-1999: Climate

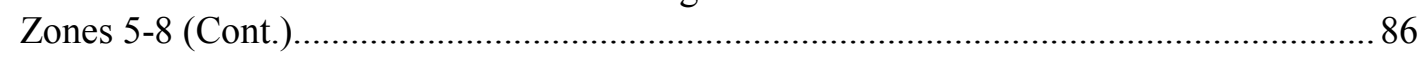

Table 4-5 Energy Savings: ASHRAE 90.1-1999 Baseline ............................................................... 90

Table 4-6 Energy Savings: ASHRAE 90.1-2004 Baseline ................................................................. 91

Table 5-1 50\% Savings Building Equipment Schedule .......................................................................... 99

Table 5-2 Recommendations for 50\% Savings over ASHRAE 90.1-2004: Climate Zones 1-4 ............. 101

Table 5-3 Recommendations for 50\% Savings over ASHRAE 90.1-2004: Climate Zones 5-8 ............. 102

Table C-1 Elementary Baseline Scorecard: Climate Zones 1-3 …..................................................... 123

Table C-2 Elementary Baseline Scorecard: Climate Zones 1-3 (Cont.) .............................................. 124 
Table C-3 Elementary Baseline Scorecard: Climate Zones 3-5 ....................................................... 125

Table C-4 Elementary Baseline Scorecard: Climate Zones 3-5 (Cont.) ….......................................... 126

Table C-5 Elementary Baseline Scorecard: Climate Zones 5-8........................................................ 127

Table C-6 Elementary Baseline Scorecard: Climate Zones 5-8 (Cont.) ................................................ 128

Table D-1 Middle Baseline Scorecard: Climate Zones 1-3 .................................................................... 129

Table D-2 Middle Baseline Scorecard: Climate Zones 1-3 (Cont.) ...................................................... 130

Table D-3 Middle Baseline Scorecard: Climate Zones 3-5 …............................................................... 131

Table D-4 Middle Baseline Scorecard: Climate Zones 3-5 (Cont.) ....................................................... 132

Table D-5 Middle Baseline Scorecard: Climate Zones 5-8 ............................................................... 133

Table D-6 Middle Baseline Scorecard: Climate Zones 5-8 (Cont.) ...................................................... 134

Table E-1 High Baseline Scorecard: Climate Zones 1-3 ................................................................ 135

Table E-2 High Baseline Scorecard: Climate Zones 1-3 (Cont.) ....................................................... 136

Table E-3 High Baseline Scorecard: Climate Zones 3-5 ............................................................... 137

Table E-4 High Baseline Scorecard: Climate Zones 3-5 (Cont.) ........................................................ 138

Table E-5 High Baseline Scorecard: Climate Zones 5-8 .................................................................. 139

Table E-6 High Baseline Scorecard: Climate Zones 5-8 (Cont.) ......................................................... 140

Table G-1 Elementary End Uses: Climate Zones 1-4 ..................................................................... 150

Table G-2 Elementary School End Uses: Climate Zones 4-8 ............................................................. 151

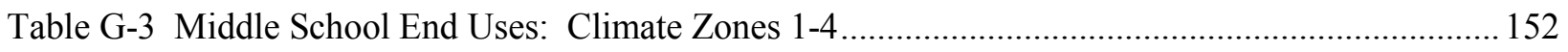

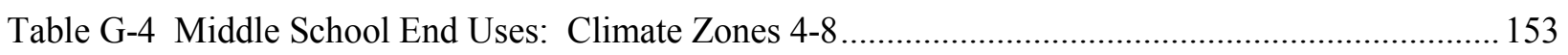

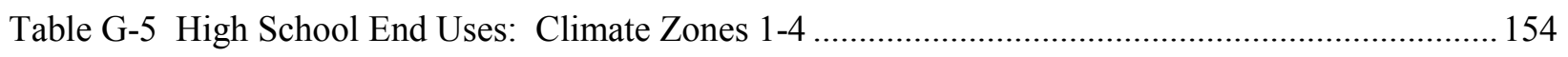

Table G-6 High School End Uses: Climate Zones 4-8 …............................................................. 155

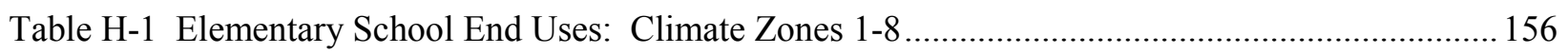

Table H-2 Middle School End Uses: Climate Zones 1-8 ................................................................. 157

Table H-3 High School End Uses: Climate Zones 1-8 ................................................................... 158

\section{Equations}

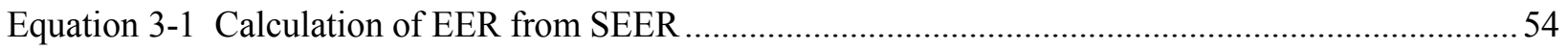

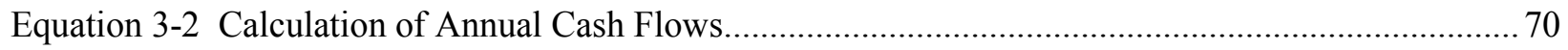

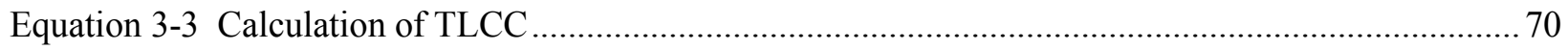




\section{Nomenclature}

$\mathrm{ACH}$

AEDG

AIA

ASHRAE

CBECS

CDD

CFR

CHPS

ci

$\mathrm{CO}_{2}$

COP

DOE

DX

EER

ERV

EUI

HDD

HVAC

IECC

IESNA

IPLV

LPD

NCEF

NIBS

NREL

$\mathrm{OA}$

O\&M

PC

PSZ

PVAV

RMS

SBIC

$\mathrm{SC}$ air changes per hour

Advanced Energy Design Guide

American Institute of Architects

American Society of Heating, Refrigerating and Air-Conditioning Engineers

Commercial Buildings Energy Consumption Survey

cooling degree day

Code of Federal Regulations

Collaborative for High Performance Schools

continuous insulation

carbon dioxide

coefficient of performance

U.S. Department of Energy

direct expansion

energy efficiency ratio

energy recovery ventilator

energy use intensity

heating degree day

heating, ventilation, and air conditioning

International Energy Conservation Code

Illuminating Engineering Society of North America

integrated part load value

lighting power density

National Clearinghouse for Educational Facilities

National Institute of Building Sciences

National Renewable Energy Laboratory

outside air

operations and maintenance

project committee

A package single zone DX rooftop unit

A package multi-zone DX rooftop with a VAV

root mean square

Sustainable Building Industry Council

steering committee 
SEER

SHGC

SO AEDG

SPM

SR AEDG

SRI

TLCC

TSD

USGBC

VAV

VLT

WD

w.c.

XML seasonal energy efficiency ratio

solar heat gain coefficient

Small Office Advanced Energy Design Guide

School Planning and Management

Small Retail Advanced Energy Design Guide

Solar Reflective Index

total life cycle cost

Technical Support Document

U.S. Green Building Council

variable air volume

visible light transmittance

Weekday

water column

extensible markup language 
xviii 


\section{Introduction}

The Advanced Energy Design Guide for K-12 School Buildings (K-12 AEDG) (referred to as the Guide in this report) was written to help owners and designers of elementary, middle, and high schools achieve whole-building energy savings of at least $30 \%$ compared to the minimum requirements of the ANSI/ASHRAE/IESNA Standard 90.1-1999, which serves as a baseline (ASHRAE 1999). "K-12" refers to kindergarten through twelfth grade schools. Depending on the school districts, these grades are divided roughly into elementary schools with grades K through 5, middle schools with grades 6 through 8, and high schools with grades 9 through 12. Included in the Guide are prescriptive recommendations by climate zone for the design of the building envelope, fenestration, lighting systems (including electrical lights and daylighting), HVAC systems, building automation and controls, outside air (OA) treatment, and service water heating. Additional savings recommendations are also included, but not necessary for $30 \%$ savings. Additional savings recommendations are provided for electrical distribution, plug loads, renewable energy systems, and using the building as a teaching tool. The Guide contains recommendations only and is not a code or standard.

The Guide is intended to show that achieving the $30 \%$ target is not only possible, but easily achievable. Case studies in the Guide show schools around the country that have achieved and surpassed the 30\% energy savings target. Best practices and cautions are also provided to demonstrate how to implement the recommendations. The recommendation tables do not include all the components listed in ASHRAE 90.1-1999. Though this Guide focuses only on the primary energy systems in a building, the underlying energy analysis presumes that all the other components are built to the criteria in ASHRAE 90.1 and ASHRAE 62.1 (ASHRAE 2001, ASHRAE 2004b).

By specifying a target goal and identifying paths for each climate zone to achieve the goal, the Guide provides some ways, but not the only way, to meet the $30 \%$ target and build energy-efficient K-12 schools that use substantially less energy than those built to minimum energy code requirements. There may be other means of achieving the target goal, and we hope the Guide generates ideas for innovation as well.

The Guide was developed by a project committee (PC) representing a diverse group of professionals. Guidance and support was provided through a collaboration of the ASHRAE, the American Institute of Architects (AIA), the IESNA, the U.S. Green Building Council (USGBC), and the U.S. Department of Energy (DOE). Members of the PC came from these partner organizations, the ASHRAE Standing Standards Project Committee 90.1 (SSPC 90.1), the ASHRAE Technical Committee on Educational Facilities (TC 9.7), the Sustainable Building Industry Council (SBIC), the Collaborative for High Performance Schools Project (CHPS), and the National Clearinghouse for Educational Facilities (NCEF) at the National Institute of Building Sciences (NIBS).

The 30\% energy savings target is the first step toward achieving net zero-energy schools; schools that, on an annual basis, draw from outside sources less or equal energy than they generate on site from renewable energy sources. Other guides in this series include the Advanced Energy Design Guide for Small Office Buildings(SO AEDG) (AEDG-SO 2004), the Advanced Energy Design Guide for Small Retail Buildings (SR AEDG) (AEDG-SR 2006), and the Advanced Energy Design Guide for Small Warehouses and Self Storage Buildings (www.ashrae.org/aedg).

\subsection{Objectives}

Our task in developing of the $30 \% \mathrm{~K}-12$ AEDG was to provide the analysis and modeling support to:

- Verify energy savings - The specific prescriptive recommendations that must, in aggregate, yield 30\% savings beyond a benchmark building built to the Standard 90.1-1999 for each climate region contained in the guide. The $30 \%$ is measured based on the total energy consumption, not just the regulated loads. It is not an average of the national energy savings. Cities used for testing in the SO AEDG were also used for the K-12 schools guide (Jarnagin 2006). 
- Develop recommendations that meet a numeric goal value - The energy savings goal is a hard value as opposed to an approximate target. The 30\% energy savings value was set to be as consistent as feasible with LEED criteria (USGBC 2006), given that LEED works from a cost basis and this document is based on energy savings. As in past AEDGs, we intend for this Guide to be used for obtaining LEED Energy and Atmosphere credits.

- Identify methods to achieve the goal - The goal of the guide is to save energy by identifying packages of design measures and strategies combined with selecting state-of-the shelf building systems and design concepts (multiple suppliers of a given technology or system) which result in efficient and high-quality spaces.

Separate from the Guide itself, this Technical Support Document (TSD) has been developed to document the process used to develop the $30 \% \mathrm{~K}-12$ AEDG and the analysis and modeling done to support that development. The specific objectives for this TSD include:

- Document the process and schedule used for developing the Guide.

- Develop prototypical K-12 school characteristics.

- Document the EnergyPlus modeling assumptions needed to verify $30 \%$ energy savings.

- Develop the baseline and low-energy EnergyPlus K-12 school models.

- Present the recommendations for 30\% savings over ASHRAE 90.1-1999 for use in the K-12 AEDG.

- Present the recommendations for 30\% savings over ASHRAE 90.1-2004 (ASHRAE 2004a).

- Demonstrate that the recommendations result in $30 \%$ or greater energy savings by climate zone.

\subsection{Literature Review}

The first step in developing the $30 \% \mathrm{~K}-12$ AEDG was a literature review and summary of highperformance K-12 school guidelines. To ensure that the K-12 AEDG did not duplicate previous work in the relatively mature field of high-performance schools, we performed a literature review of the available design guides and rating systems for high-performance K-12 schools. Efforts focused on compiling a summary of the available high-performance school guides available throughout the country. Based on our review of many such guidelines and rating systems, we concluded that the K-12 AEDG will be a unique guideline. None of the guides reviewed include prescriptive design guidance for targeted levels of energy savings based on climate. The K-12 AEDG should provide a needed resource and complement many of the available guides and criteria. Another intent is for the K-12 AEDG to provide an alternative energy efficiency compliance path for the high-performance schools rating and criteria systems such as LEED for Schools and CHPS for California, New York, and Massachusetts. There is a need in these systems for an alternative energy efficiency compliance path that does not require significant simulation analysis.

In addition to the vast selection of school design guides, there are many sets of physical school characteristics and performance data. The currently available data sources represent existing school stock as well as annual updates for new school construction. We surveyed these data sets to develop "typical" school characteristics and energy performance. Typical school characteristics helped to inform our development of realistic prototypical models for the 30\% AEDG analysis, as documented in Section 3.2 of this TSD. Data sets that we evaluated include:

- The 2003 Commercial Building Energy Consumption Survey (CBECS)

- The School Planning and Management (SPM) and American School and University (ASU) annual construction survey and report

- Additional data sets from the PC, including plug load surveys, actual floor plates, and space programming requirements from North Carolina 
- The DOE High Performance Buildings Database

- The Energy Star® Target Finder and Energy Star labeled building database

- DOE Commercial Buildings Benchmark project

\subsection{Scope of the K-12 AEDG and Technical Support Document}

Each guide in the AEDG series provides recommendations and user-friendly design assistance to designers, developers and owners of commercial buildings that will encourage steady progress toward net-zero energy buildings. The K-12 AEDG provides prescriptive recommendation packages that are capable of reaching the energy savings target for each climate zone in order to ease the burden of the design and construction of energy-efficient K-12 schools.

The Guide applies to all sizes of K-12 school buildings (classified as elementary, middle, and high schools) with administrative and office areas, classrooms, hallways, restrooms, gymnasiums, assembly spaces, food preparation spaces, and dedicated spaces such as media centers and science labs. This Guide does not consider atypical specialty spaces such as indoor pools, wet labs such as chemistry, "dirty" dry labs such as woodworking and auto shops, or other unique spaces with extraordinary heat or pollution generation. It is primarily intended for new construction, but it may be equally applicable to many school renovation, remodeling, and modernization projects.

Certain aspects of energy-efficient school design, including steam heat, modular classrooms, vehicles and other maintenance areas, domestic water well piping, kitchen process loads (e.g., ovens, coolers, freezers), and sewage disposal, are excluded from this Guide. They were too complex to include given the scope of the project. Significant energy efficiency opportunities may be available with these aspects. Guide users are encouraged to take advantage of these opportunities and treat them as "bonuses" beyond the $30 \%$ target.

In addition, the Guide is not intended to substitute for rating systems or references that address the full range of sustainable issues in schools, such as acoustics, productivity, indoor air quality, water efficiency, landscaping, and transportation, except as they relate to operational energy consumption. Nor is this Guide a design text - we assume good design skills as well as expertise in school design.

The guides in the AEDG series do not provide a detailed documentation for the development of the recommendations or the actual energy savings. This TSD describes the process and methodology for the development of the Advanced Energy Design Guide for K-12 School Buildings and provides the technical details for determining 30\% energy savings, including model inputs and assumptions, the development of the $30 \%$ recommendations, and the energy savings.

\subsubsection{Report Organization}

This report is presented in four sections: Section 1 introduces the K-12 AEDG and the supporting background information; Section 2 describes the charge given to the PC for developing of the Guide and outlines the process and development schedule; Section 3 provides the evaluation approach, including baseline and low-energy modeling methods and assumptions; Section 4 documents the final recommendations and energy savings; Section 5 describes an additional scoping analysis for beyond 30\% savings.

Additional information on the PC development process is included in Appendix A. Appendix B includes the summary responses to the remarks received on the $65 \%$ review draft. Appendixes C, D, and E summarize baseline model inputs. Appendix F provides the results of determining optimal envelope insulation levels. Appendixes $\mathrm{G}$ and Appendix H provide EUIs for the primary end uses for both the recommendations for 30\% savings over ASHRAE 90.1-1999 and for 30\% saving over ASHRAE 90.12004. 


\section{Development Process}

The Guide was developed by a PC that represents a diverse group of professionals. Guidance and support was provided through a collaboration of ASHRAE, AIA, IESNA, USGBC, and DOE. PC members came from these partner organizations, the ASHRAE Standing Standards Project Committee 90.1 (SSPC 90.1), the ASHRAE Technical Committee on Educational Facilities (TC 9.7), the SBIC, CHPS, and the NCEF at NIBS.

\subsection{Charge to the Project Committee}

A steering committee (SC) made up of representatives of the partner organizations issued a charge to the PC to develop the Guide. The charge included a timeline for the task, an energy savings goal, an intended target audience, and desired design assistance characteristics. These elements of the charge to the committee are contained below:

- To develop and document a process to achieve a savings of $30 \%$ progress toward a net zeroenergy building for K-12 schools.

- To produce recommendations in a technically sound Advanced Energy Design Guide for K-12 schools.

- To publish the Guide within a year.

- To constrain the scope and duration of the analysis effort so that the schedule is maintained. The PC should rely on current knowledge of energy-efficient building design, supplemented with energy design analysis that can be completed while maintaining the schedule.

- To produce a document that is to the point and not voluminous. Use the SO AEDG as guide for size and technical depth, with an expected overall size limit of 100 to 200 published pages.

Additional guidance from the SC to the PC was provided in a Scope Document. Elements of the Scope Document are contained below:

1. The baseline for energy usage evaluation is annual site energy consumption.

2. Address the practical how-to, user-friendly information needs of its intended users who are designers in medium to large firms, design/build contractors, and construction firms.

3. The interaction of building components and systems will likely need to be considered rather than having all the savings come from individual parts (savings from integration of systems is encouraged). Accommodate, to the extent practical, some level of design flexibility through use of packages of efficiency measures that users may choose from.

4. Adopt a prescriptive recommendation approach with packages of measures. This will include envelope, mechanical, lighting, and water heating measures. The document will be formatted for easy use, provide specific procedures, convey best practices, and avoid code language. The apparent complexity of the typical standard/guideline layout and format should be avoided to ease usability by the target audience.

5. In addition to prescriptive energy efficiency measures, the guide should contain "how to" guidance that will help the designer construct an energy-efficient school facility. In recognition of the constrained design fees available, the document should be presented in a very user-friendly manner to reduce design time. By focusing on user-friendly layouts and presentation as well as prescriptive design recommendations, the guide should ease the burden for the designers and give school decision-makers an overview of specific, easy-to-follow recommendations.

6. The prescriptive recommendations presented should be sufficient to allow innovative firms to extend the information when designing facilities that might be evaluated on performance-based 
criteria. That is, some additional allowance or flexibility should be provided for those accustomed to performance-based documents.

7. Several case studies should be included to illustrate the energy efficiency components identified. These case studies can focus on the geographic regions (as in the SO AEDG) or to illustrate particular items or techniques recommended.

\subsubsection{Inclusion of Economics and Cost}

The purpose of the guidance provided in the K-12 AEDG is to assist designers in the design of energyefficient schools. The goal of 30\% energy savings is to be considered the primary focus of the Guide, i.e. the focus is on high performance buildings and the energy savings related thereto, not on installations that have a payback less than some given number of years. Cost and payback are factors, but they are secondary to achieving buildings that use $30 \%$ less energy.

Therefore, energy use is to be considered the independent variable that is specified, and cost effectiveness (as measured by, for example, simple payback period) is the dependent (or resulting) variable. Although some of the products or recommendations may be considered premium, products of similar performance must be available from multiple manufacturers.

\subsection{Approval Authority}

The final approval for the Guide is the responsibility of the SC. SC members represent various interested parties and are responsible for reflecting the opinions of the group represented. This includes consulting with the groups and getting buy-in from them during the entire process and providing the peer review. Efforts should be made to agree on the content, like the ASHRAE Handbook: Fundamentals (ASHRAE 2005); however, it is not a consensus document.

\subsection{Project Committee Organization and Membership}

The Guide was developed by a PC administered under ASHRAE's Special Project procedures. The K-12 AEDG PC was designated as ASHRAE Special Project 111 (SP-111), and included membership from each partner organization. Table 2-1 lists the project committee members and the organizations that they represent. 
Table 2-1 K-12 AEDG PC Organization Chart

\begin{tabular}{|l|l|}
\hline \multicolumn{1}{|c|}{ Member } & \multicolumn{1}{c|}{ Organization } \\
\hline \hline Paul Torcellini & Chairman \\
\hline Merle McBride & Vice-Chairman \\
\hline Don Colliver & SC Liaison \\
\hline Jyoti Sharma & USGBC Representative \\
\hline Larry Schoff & USGBC Representative \\
\hline John Murphy & SBIC Representative \\
\hline Bill Brenner & NIBS/NCEF Representative \\
\hline Jim Benya & IESNA Representative \\
\hline Leslie Davis & IESNA Representative \\
\hline Charles Eley & CHPS Representative \\
\hline Mike Nicklas & AIA Representative \\
\hline Kathleen O'Brien & AIA Representative \\
\hline Carol Marriott & ASHRAE SSPC 90.1 Representative \\
\hline Milton S. Goldman, M.D. & ASHRAE TC 9.7 Representative \\
\hline Lilas Pratt & ASHRAE Staff Liaison \\
\hline Bruce Hunn & ASHRAE Staff Liaison \\
\hline
\end{tabular}

The SC selected PC members with energy efficiency experience in K-12 schools. Each representative organization was given the chance to provide peer review input on the various review drafts produced by the PC. In effect, these representatives were intended to be the interfaces to their respective organizations to ensure a large body of input into the development of the document.

\subsection{Development Schedule and Process}

Following the guidance from the SC, the SP-111 committee developed a one-year plan for completing the document. Key milestones in the development schedule were determined based on a final publication date in December, 2007 (ready for the Winter ASHRAE Meeting in January 2008). With this final publication date, the PC determined the time needed for the publication process and then determined the dates of review periods for the various completion stages for the draft document. The PC used a similar schedule to the one developed for the previous guides to plan for two peer review periods that corresponded with a $65 \%$ completion draft (technical refinement review) and a $90 \%$ completion draft (final review for errors). A focus group reviewed the conceptual 35\% draft. Six PC meetings were held at ASHRAE Headquarters or at NREL. Five conference calls were also held. The following schedule shown in Table 2-2 outlines key dates in the development of the K-12 AEDG.

The development of the prototype, baseline, and low-energy models was an iterative process, with discussion of the model inputs and the current model results at every meeting and conference call. Results from the modeling, combined with input from the PC, led to the development of the final recommendations. The following steps show the modeling process used, from the initial prototype development to the final recommendations:

1. Determine prototype models inputs from the PC, ASHRAE 90.1-1999, ASHRAE 62.

2. Present preliminary baseline results for the prototype elementary school.

3. Develop a consensus from the PC on the prototype model inputs. 
4. Extend elementary baseline inputs to the middle and high school prototypes.

5. Develop initial recommendations and the corresponding low-energy models, including daylighting types, HVAC systems, and envelope recommendations.

6. Present the low-energy modeling results and identify recommendations that do not result in $30 \%$ energy savings.

7. Fine tune the recommendations to achieve at least $30 \%$ whole-building energy savings in all climate zones for the various daylighting and HVAC options and school types.

8. Determine final recommendations for the K-12 AEDG that achieve $30 \%$ savings.

The following sections of this TSD present the prototype development results from Step 3, the baseline model results from Step 4, and the final recommendations and energy savings results as determined in Step 8.

Because the document was developed under the ASHRAE special project procedures, and not the standards development procedures, the peer reviews were not considered true "public" reviews. However, review copies were made available to all partner organizations, as well as the various bodies within ASHRAE represented by the PC membership. In addition, interested members could download review copies from the ASHRAE Web site. The responses to the remarks and suggestions received from the $65 \%$ review draft are summarized in Appendix B.

Further information about each meeting and conference call are included in the meeting agendas and conference call agendas in Appendix A. For future reference, these agendas were updated after each meeting or call to reflect the actual discussions and length of time spent on each item. After each conference call and meeting, we compiled the meeting notes, agenda, action items, future schedules, and other related documents into a meeting report. These meeting reports were very useful for reference and organizational purposes during the development of the Guide. 
Table 2-2 K-12 AEDG Project Committee Development Schedule

\begin{tabular}{|c|c|c|}
\hline Date & Event & Description \\
\hline $12 / 8 / 06-12 / 9 / 06$ & Kickoff/PC meeting \#1 & Kickoff introduction meeting, first PC meeting \\
\hline $1 / 8 / 07$ & Concept draft complete & Draft $35 \%$ concept draft for PC and Focus group review \\
\hline $1 / 12 / 07$ & Conference call \#1 & Conference call to discuss concept draft \\
\hline $1 / 18 / 07$ & Focus Group Meeting & Solicit input from industry on concept \\
\hline $1 / 19 / 07-1 / 20 / 07$ & PC meeting \#2 & $\begin{array}{l}\text { Discuss results of focus group and baseline modeling } \\
\text { assumptions }\end{array}$ \\
\hline 2/9/07 & Conference Call \#2 & Discuss progress of $65 \%$ draft \\
\hline $2 / 23 / 07-2 / 24 / 07$ & PC meeting \#3 & Discuss progress of $65 \%$ draft and fill missing pieces \\
\hline $3 / 9 / 07$ & $65 \%$ Draft complete & $65 \%$ Draft complete \\
\hline $3 / 12 / 07-3 / 23 / 07$ & $65 \%$ Draft review & $65 \%$ Draft review \\
\hline $4 / 12 / 07-4 / 13 / 07$ & PC meeting \#4 & Review simulation results, address $65 \%$ review remarks \\
\hline $5 / 18 / 07$ & Conference Call \#3 & Discuss progress to $90 \%$ draft \\
\hline $6 / 4 / 07-6 / 5 / 07$ & PC meeting \#5 & $\begin{array}{l}\text { Further develop } 90 \% \text { draft, finalize responses for } 65 \% \\
\text { review remarks }\end{array}$ \\
\hline $6 / 16 / 07$ & $\begin{array}{l}\text { Draft Technical Support } \\
\text { Document }\end{array}$ & Draft Technical Support Document \\
\hline $6 / 19 / 07$ & Conference Call \#4 & Review simulation results \\
\hline $7 / 2 / 2007$ & Conference Call \#5 & Identify missing pieces in $90 \%$ draft \\
\hline $7 / 6 / 07$ & $90 \%$ Draft complete & $90 \%$ Draft complete \\
\hline $7 / 9 / 07-7 / 20 / 07$ & $90 \%$ Draft review & $90 \%$ Draft review \\
\hline $8 / 2 / 07-8 / 3 / 07$ & PC meeting \#6 & Address $90 \%$ review remarks, finalize draft for $100 \%$ \\
\hline $8 / 10 / 07$ & Final $100 \%$ document & Final $100 \%$ document \\
\hline week of $8 / 12 / 07$ & $\begin{array}{l}\text { Steering Committee } \\
\text { approval }\end{array}$ & Steering Committee approval \\
\hline week of $9 / 10 / 07$ & $\begin{array}{l}\text { Final } 100 \% \text { document to } \\
\text { Publications }\end{array}$ & Final $100 \%$ document to Publications \\
\hline $9 / 15 / 07$ & $\begin{array}{l}\text { Final Technical Support } \\
\text { Document to DOE }\end{array}$ & Final Technical Support Document to DOE \\
\hline $10 / 12 / 07$ & Proof review complete & Proof review complete \\
\hline $10 / 15 / 07$ & Document to printers & Document to printers \\
\hline December, 2007 & Printed document complete & Printed document complete \\
\hline
\end{tabular}

\subsubsection{Focus Group}

To evaluate the concept of the K-12 AEDG, ASHRAE convened a focus group of school administrators, school designers, and school energy management staff to review the $35 \%$ completion draft. The focus group was brought to ASHRAE headquarters to discuss the concept of the K-12 AEDG. Members of the Focus Group are shown in Table 2-3. Before the focus group meeting, the participants reviewed the 35\% concept draft, the SC Scope Document, and examples of the recommendation tables and case studies from 
the previous guides. The questions asked of the Focus Group to stimulate discussion and solicit feedback are shown in Appendix A.3. The highlights of the Focus Group discussion are shown below:

- Keep it simple: Need to keep the energy recommendations simple and avoid complex systems preference within the focus group for passive types of controls. "Avoid complications wherever possible." There was a general perception that high-performance schools are too complicated and cost too much.

- Capital rich, maintenance poor: Operations and maintenance (O\&M) are a big concern. Capital for construction is plentiful, but general funds for O\&M are much harder to come by. Maintenance staff training needs to be addressed. They felt that "green" schools would cost $5 \%$ to $25 \%$ more than standard schools, and be achievable for wealthy districts while not possible for poorer districts.

- Effective in multiple elements: Green schools must be effective on several levels: operation, cost, learning opportunities for students, community partnerships. Often, new green schools are not just schools but community resources that require extended hours of use.

- Owner and designer audience: The involvement of school boards in supporting energy efficiency and having buy-in is important. The target audience differs from the SO AEDG and SR AEDG (i.e., mainly architects and engineers) (Liu 2006 and Jarnagin 2006). School districts, as decision makers, should be strongly inclined to provide this guide to their designers. School districts typically rely on the advice of facilities, so the audience comprises owners and designers. In addition, the school architectural and engineering firms that design schools are typically medium to large firms. The K-12 AEDG should be a common reference point for all these audiences.

- They are not risk takers: Therefore, the guide should be at least "on the edge of mainstream." There is a need for verified, credible, monitored data in the case studies to prove performance. They also want persistence, track record, and cost data in the case studies.

- Recommendations too limiting: The focus group was worried that the K-12 AEDG recommendations might limit the architecture, site, or programming. There is a need to assure the group that energy-efficient equipment specifications apply to all items, including appliances and other packaged HVAC items.

Table 2-3 K-12 AEDG Focus Group Participants

\begin{tabular}{|l|l|}
\hline \multicolumn{1}{|c|}{ Member } & \multicolumn{1}{c|}{ Organization } \\
\hline Kevin Chisholm & Energy Manager: Arlington Public Schools \\
\hline Susan Cook & School Superintendent, Kenton County Schools \\
\hline Rick Dames & $\begin{array}{l}\text { Director of Buildings \& Grounds: Boone County } \\
\text { Schools }\end{array}$ \\
\hline Chad Loomis & $\begin{array}{l}\text { Cornell University, Planning Design and } \\
\text { Construction }\end{array}$ \\
\hline Forrest Miller & $\begin{array}{l}\text { Director of Facilities and Planning: Lake Washington } \\
\text { School District }\end{array}$ \\
\hline Karen Reager & $\begin{array}{l}\text { National Energy Education Development (NEED) } \\
\text { Project }\end{array}$ \\
\hline Ervin Ritter & Ritter Consulting Engineers \\
\hline Bryan Welsh & Welsh Commissioning Group \\
\hline
\end{tabular}


In developing the K-12 AEDG, the PC attempted to include the results from the focus group by:

- Including discussion for the decision makers, such as the superintendents and school boards.

- Covering administrative policy issues for items such as administration policy on no plug in mini fridges or assigning a dollar figure to discourage use of inefficient plug loads.

- Focusing on simple(r) systems.

- Emphasizing O\&M.

- Addressing plug loads.

- Addressing specialty spaces.

- Providing a wider range of daylighting and HVAC recommendations.

- Providing case studies with at least two years of measured energy performance as well as examples of cost-effective implementation of the Guide's recommendations. 


\section{Evaluation Approach}

This chapter describes the analysis methods used to support development of the K-12 AEDG. It presents how we quantified the $30 \%$ energy savings, developed prototype models, baseline models and the lowenergy models.

\subsection{Determining $30 \%$ Savings}

The purpose of the building energy simulation analysis presented in this TSD is to assess and quantify the energy savings potential of the Guide's final recommendations. The AEDGs contain a set of energy efficiency recommendations for eight climate zones across the country. To provide prescriptive $30 \%$ recommendations, a specific quantitative energy savings goal must be measured against a specific version of Standard 90.1. For the K-12 AEDG, this is 90.1-1999, the "turn of the Millennium" standard (ASHRAE 1999). The energy savings of the prescriptive recommendations were also examined relative to ASHRAE 90.1-2004 (ASHRAE 2004).

The following steps were used to determine $30 \%$ savings:

1. Develop "typical" K-12 school prototype characteristics.

2. Create baseline models from the prototypes that are minimally code compliant for both ASHRAE 90.1-1999 and ASHRAE 90.1-2004.

3. Create the low-energy models based on the recommended energy-efficient technologies in the Guide.

4. Verify $30 \%$ energy savings across the various HVAC system types and daylighting options over the 15 climate zones and sub-zones in the country.

These steps are presented in a linear fashion, but there is some iteration among the steps. For example, certain baseline model inputs were determined by features included in the low-energy models, such as glass and skylight areas. In addition,

\subsubsection{Site Energy Use}

The 30\% energy savings goal of the AEDG series is based on site energy savings between a minimally code compliant school and a low-energy school that uses the recommendations in the Guide. Other metrics, such as energy cost savings, source energy savings, or carbon savings, could be used to determine energy savings (Torcellini et al. 2006). Each metric has advantages and disadvantages from an implementation and calculation perspective, and each can favor different technologies and fuel types. The K-12 AEDG uses site energy savings, as directed by the SC, to retain consistency from the previous AEDGs.

\subsubsection{Whole-Building Energy Savings}

Historically, energy savings have been expressed in two ways: Energy savings of regulated loads and energy savings of the whole building. The "regulated loads" energy savings indicates the savings when the loads that are not code regulated are not included in the total loads of the building. These unregulated loads typically include plug and some process loads. The "whole-building" energy savings indicate the savings when all the loads (regulated and unregulated) are included in the energy savings calculations. In general, for the same level of percent savings, whole-building savings is more challenging than regulated loads savings. In LEED 2.1, plug loads are included in the simulation (to capture proper heat loads), but not in the denominator of the energy savings calculation. In the case of Appendix G in ASHRAE 90.12004 and in LEED 2.2, plug loads are included in the denominator, i.e., the whole-building method, which includes the unregulated loads for calculating energy savings. The K-12 AEDG uses the "wholebuilding" energy savings method for determining 30\% energy savings. See Section 3.2.3.1 for additional information about determining the plug loads for schools. 


\subsubsection{ASHRAE Baseline}

The K-12 AEDG was written to help owners and designers of elementary, middle, and high schools achieve energy savings of at least $30 \%$ compared to the minimum requirements of ANSI/ASHRAE/ IESNA Standard 90.1-1999, which serves as a baseline. The baseline level energy use was set for buildings built at the turn of the millennium, which are assumed to be based on ANSI/ASHRAE/IESNA Standard 90.1-1999 (ASHRAE 1999), Energy Standard for Buildings except Low-Rise Residential Buildings. The selection of ASHRAE 90.1-1999 for the baseline was also based on the fact that the standard was the most recent for which DOE had issued a formal determination of energy savings at the time of preparation of the first AEDG.

The use of ASHRAE 90.1-1999 for the baseline for determining 30\% energy saving for the K-12 AEDG is also consistent with other AEDGs in the series (Jarnagin 2006, Liu 2006). There has been considerable discussion between the SC and the K-12 AEDG PC about having the energy savings based on a percentage below a specific version of 90.1 (1999, 2001, 2004, 2007, etc). The SC realized that this would always provide for a moving baseline if the most current version of the standard was used. It would cause considerable confusion in the marketplace because the recommendations would always be changing based on which version of 90.1 was being used as the baseline for determining savings. Two very similar buildings could have different recommendations, solely because a different baseline was being used. Therefore, the SC decided to look at the other end of the scale, and describe the energy savings as the progress toward a net zero-energy building. The top end of the scale, or $0 \%$ progress, would be set as the energy used by a structure built to the energy standards at the turn of the millennium (i.e., 90.1-1999). The bottom end of the scale, or 100\%, is the net zero-energy building.

For our analysis for DOE, we have also determined the recommendations needed to achieve $30 \%$ savings over ASHRAE 90.1-2004. Recommendation tables and energy savings are provided for $30 \%$ savings over both 90.1-1999 and 90.1-2004.

\subsubsection{Modeling Methods}

\subsubsection{EnergyPlus}

EnergyPlus version 2.0 (DOE 2007) was used to complete the energy simulations. All simulations were completed with the NREL analysis platform (currently called OptEPlus) that manages inputs and outputs of the EnergyPlus simulations. The core functionality of the analysis platform is the user's ability to pass high-level parameters of the building (building area, internal gains per zone, HVAC system configuration, etc.) to generate a fully parameterized input file for EnergyPlus. Such files are generated rapidly and can be easily changed to incorporate changes during the evolution of the model. The high-level parameter file is an eXtensible Markup Language (XML) file, which is basically a structured text file. Modifying the high-level parameters is preferred over modifying the EnergyPlus input file because it greatly simplifies the modeling input development process. Modifying EnergyPlus input files can be time intensive when the high-level parameters have a one-to-many relationship with the input objects in the low-level input file.

We selected EnergyPlus because it is the contemporary DOE tool that accounts for the complicated interactions between climate, internal gains, building form and fabric, HVAC systems, and renewable energy systems. The simulations are run with EnergyPlus Version 2.0 compiled to run on a 64-bit cluster computer at NREL. EnergyPlus is a heavily tested program with formal BESTEST validation efforts repeated for every release (Judkoff and Neymark 1995).

\subsubsection{Climate Zones}

The AEDGs contain a unique set of energy efficiency recommendations for a range of climate zones across the country. The three AEDGs developed to date have standardized climate zones that the International Energy Conservation Code (IECC) and ASHRAE have adopted for residential and commercial applications. The common set of climate zones includes eight zones covering the entire United States and is shown in Figure 3-1. Climate zones are categorized by heating degree days (HDDs) 
and cooling degree days (CDDs), and range from the very hot zone 1 to the very cold zone 8 . In addition, some of the climate zones are divided into sub-zones based on humidity levels. Humid sub-zones are A zones, dry sub-zones are B zones, and marine sub-zones are $\mathrm{C}$ zones. These climate zones may be mapped to other climate locations for international use (ASHRAE 2004a).

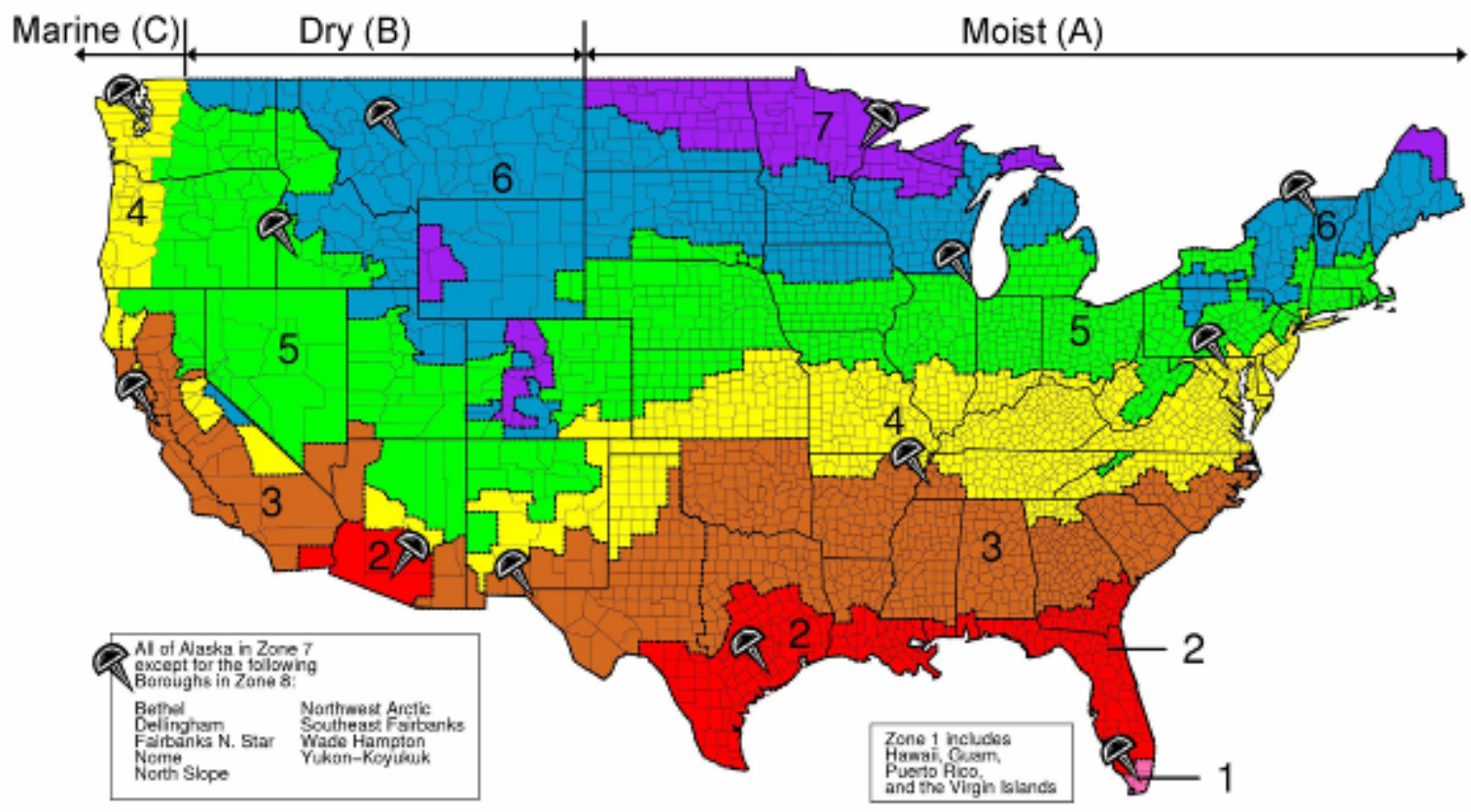

Figure 3-1 DOE Climate Zones and Representative Cities

When the climate zones were being developed, 15 specific climate locations (cities) were selected as being most representative of each zone, as shown in Figure 3-1 and in the list below. To determine energy savings, we used weather files for each of the 15 climate zones to simulate the baseline and lowenergy models.

Zone 1: $\quad$ Miami, Florida (hot, humid)

Zone 2A: $\quad$ Houston, Texas (hot, humid)

Zone 2B: $\quad$ Phoenix, Arizona (hot, dry)

Zone 3A: $\quad$ Memphis, Tennessee (hot, humid)

Zone 3B: $\quad$ El Paso, Texas (hot, dry)

Zone 3C: $\quad$ San Francisco, California (marine)

Zone 4A: $\quad$ Baltimore, Maryland (mild, humid)

Zone 4B: $\quad$ Albuquerque, New Mexico (mild, dry)

Zone 4C: Seattle, Washington (marine)

Zone 5A: $\quad$ Chicago, Illinois (cold, humid)

Zone 5B: $\quad$ Boise, Idaho (cold, dry)

Zone 6A: $\quad$ Burlington, Vermont (cold, humid)

Zone 6B: Helena, Montana (cold, dry)

Zone 7: $\quad$ Duluth, Minnesota (very cold)

Zone 8: $\quad$ Fairbanks, Alaska (extremely cold) 


\subsection{Prototype Model Development and Assumptions}

Unlike some of the other principal commercial building types, there are many data sets of K-12 school characteristics and performance data. The currently available data sources represent existing K-12 school stock as well as annual updates for new school construction. We surveyed these data sets to develop "typical" school characteristics and energy performance. Typical school characteristics helped to inform our development of realistic models for the $30 \%$ AEDG analysis. Data sets that we evaluated include:

- $\quad$ The 2003 CBECS (EIA 2005)

- The SPM (2007) and ASU (2006) annual construction survey and report

- Additional data sets from the project committee, including plug load surveys, actual floor plates, and space programming requirements from North Carolina.

Section 3.2.4 summarizes the inputs from each of these data sources and how we used them as inputs in the K-12 AEDG model development.

\subsubsection{CBECS}

This section summarizes the data available in the 2003 CBECS for elementary/middle schools and high schools (EIA 2005). The CBECS is a survey of U.S. buildings that the EIA conducts every four years. The 2003 CBECS includes data from 5,215 commercial buildings and provides weighting factors to indicate how many buildings are represented by each building type in the survey. For each building, the CBECS presents data about numerous characteristics and performance data, including floor area, number of floors, census division, basic climatic design criteria, principal building activity, number of employees, energy use, and energy expenditures.

The 2003 CBECS includes 126 high schools and 330 elementary/middle schools. The high school more specific principal building activity and elementary/middle school more specific principal building activity are part of the Educational Buildings principal building activity. Each school has a weighting factor that indicates how many buildings are represented in CBECS. When the weighting factor is combined with the area of each school, we can determine area weighted multipliers for each school in CBECS. Our results used area weighted multipliers for each characteristic and performance data histogram. Section 3.2.4 shows how we used this CBECS analysis as inputs to our K-12 AEDG model development.

We used the CBECS Analysis capabilities in the OptEPlus platform (V0.1.0.93) to analyze 2003 CBECS for an understanding of "typical" parameters for schools. Floor-area-weighted histograms of CBECS public use data were generated for HVAC system type, percent cooled, operational characteristics such as percent daylit, total weekly operating hours, number of computers, and number of months of use. Area weighted average form and fabric characteristics such as percent exterior glass, number of floors, area, building shape, and wall and roof constructions are also graphed and shown. All of these analyses were done based on a floor area weighting rather than a number of buildings weighting.

We also calculated the national area weighted average site EUI for high schools and for elementary/middle schools. To investigate the regional variation in EUI, we mapped each school in CBECS to the approximate ASHRAE climate zone based on the available CBECS information related to location. The CBECS region, HDDs, and CDDs were used to determine the AEDG climate zone for each school in CBECS. Understanding the "typical" energy use characteristics increases our confidence in our energy use predictions for our prototype models.

\subsubsection{2003 CBECS K-12 Trends}

By analyzing trends of the 456 schools and their weighting factors in the 2003 CBECS, we can help to inform the model development of "typical" schools. This section provides histograms to show the most typical characteristics and how we used this information to develop model input for the K-12 AEDG analysis. 
The area weighted percent of all the K-12 schools floor area that is daylit in CBECS is shown in Figure 3-2. This trend suggests that schools are not typically daylit. According to ASHRAE 90.1, daylighting is not required, and our K-12 AEDG baseline models do not use daylighting. Some of our low-energy models used daylighting in the classrooms and gyms.

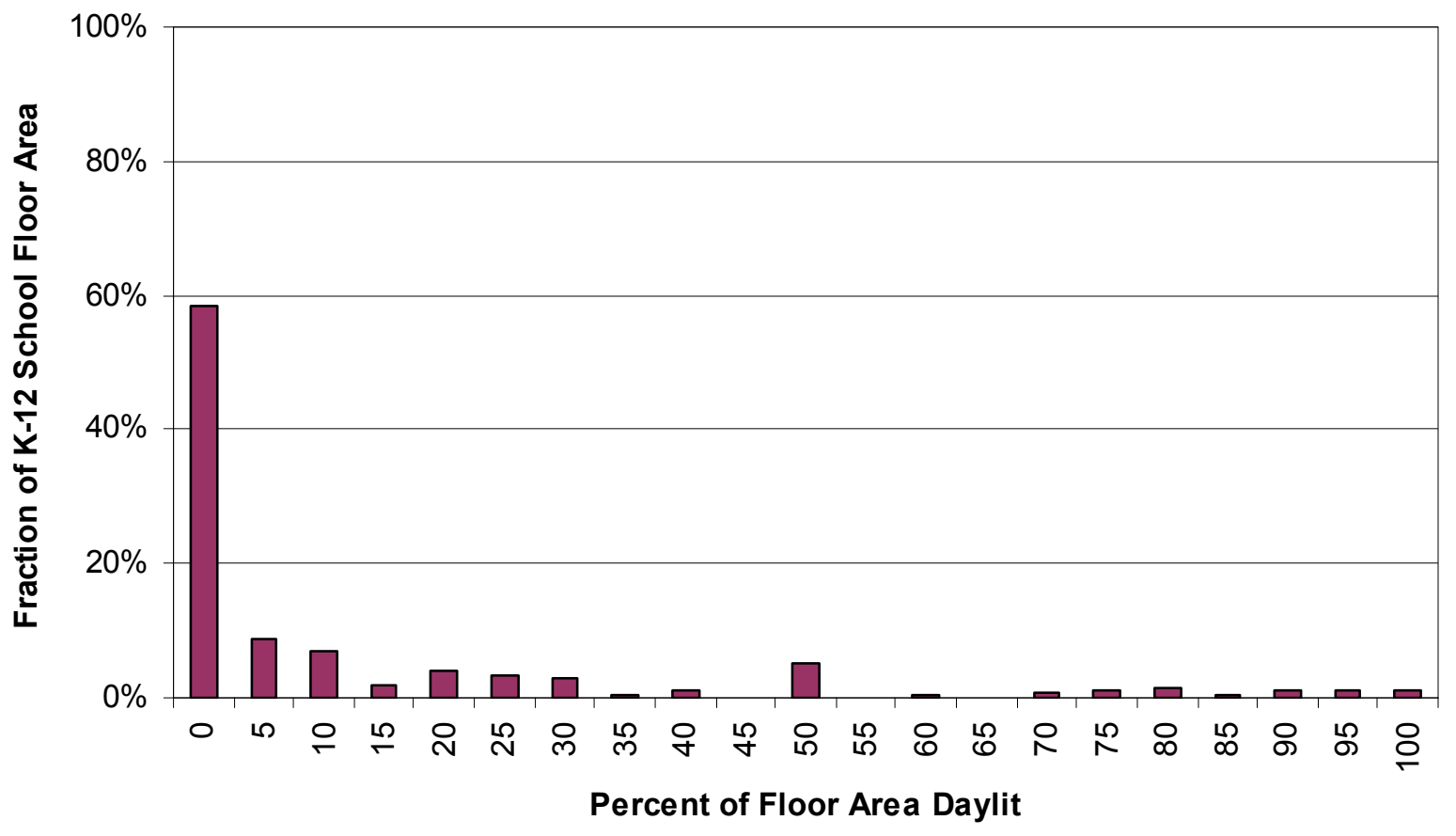

Figure 3-2 Area Weighted Average Daylit Floor Area 
The area weighted percent of all the K-12 schools floor area that is cooled in CBECS is shown in Figure $3-3$. This trend suggests that schools are typically fully cooled, but some $(10 \%$ of the total floor area) do not have cooling. The K-12 AEDG prototype models are mostly cooled, with some setup only cooling in the mechanical and bathrooms.

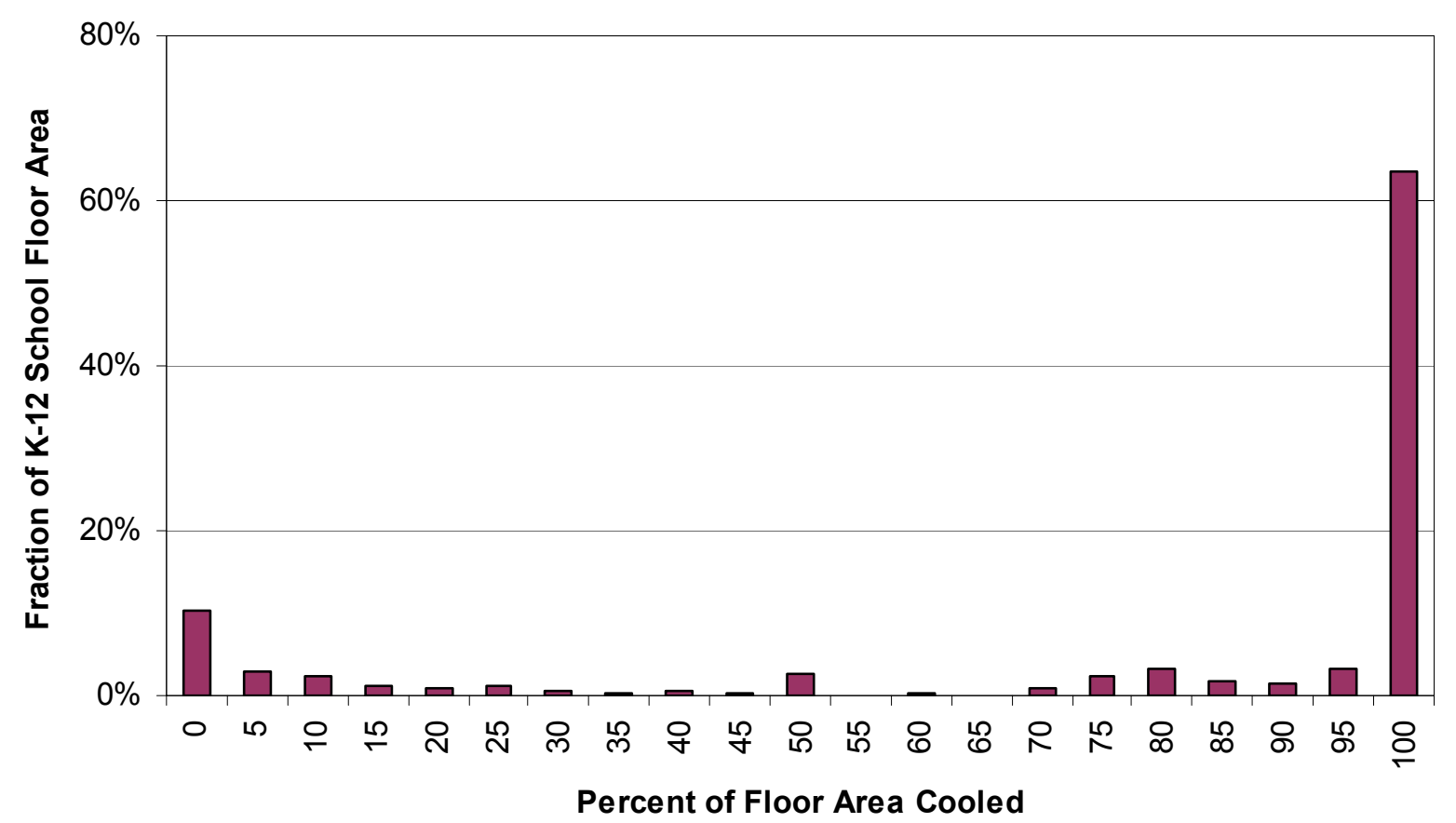

Figure 3-3 Area Weighted Average Cooled Floor Area

The area weighted percent of all the K-12 schools floor area that is heated in CBECS is shown in Figure 3-4. This trend suggests that schools are typically fully heated (90\% of all K-12 school floor area is fully heated), but some area is not. The K-12 AEDG prototype models are mostly heated, with some setback only heating in the bathrooms and mechanical spaces.

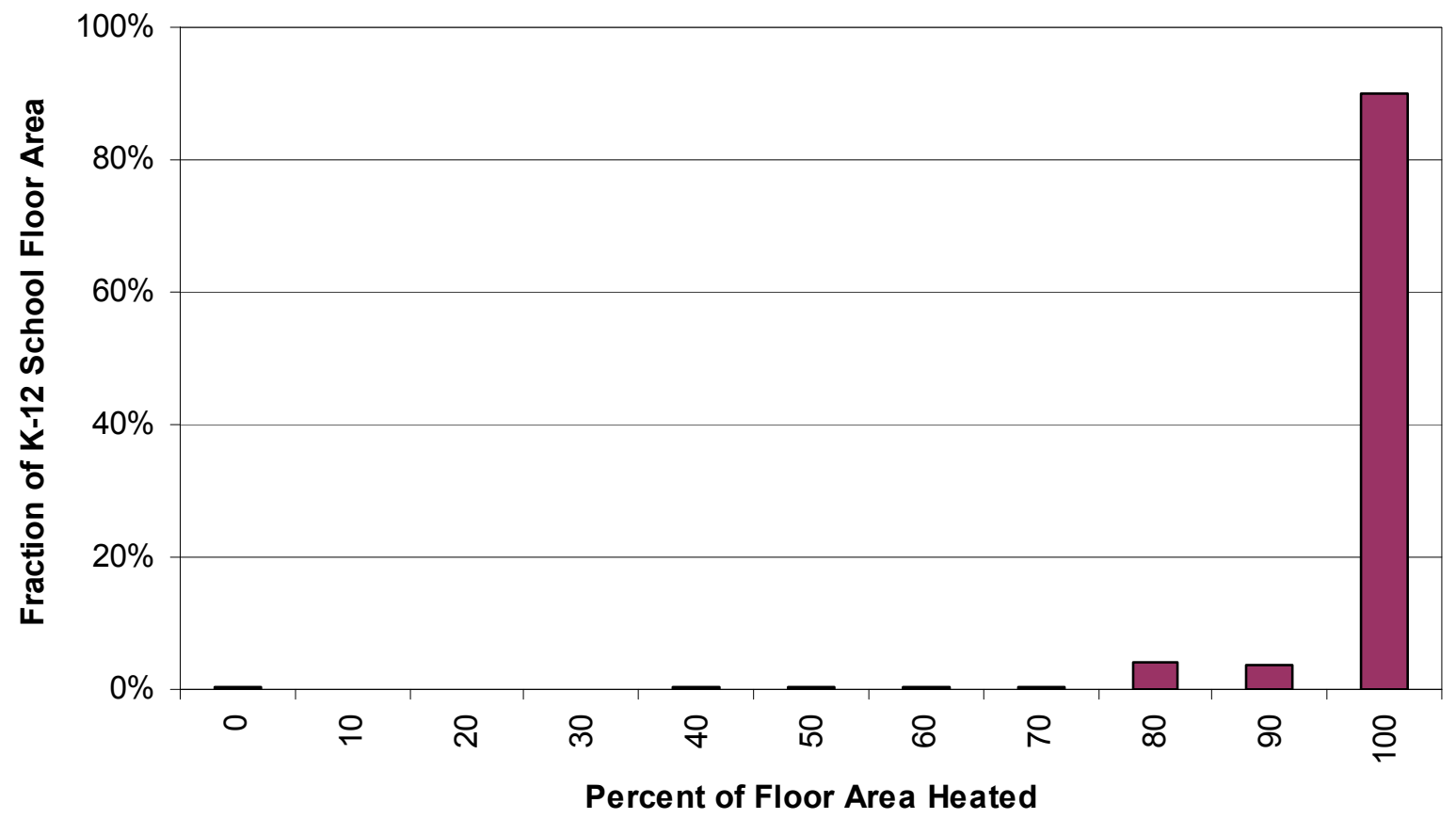

Figure 3-4 Area Weighted Average Heated Floor Area 
The number of months per year of use for all the K-12 schools is shown in Figure 3-5. More than 40\% of $\mathrm{K}-12$ school floor area is used year round, $26 \%$ of K-12 school floor area is used 10 months per year, and $18 \%$ is used 9 months per year. The K-12 AEDG prototypes have some year round use in the gym and community use areas, and the classrooms are used 9 months per year.

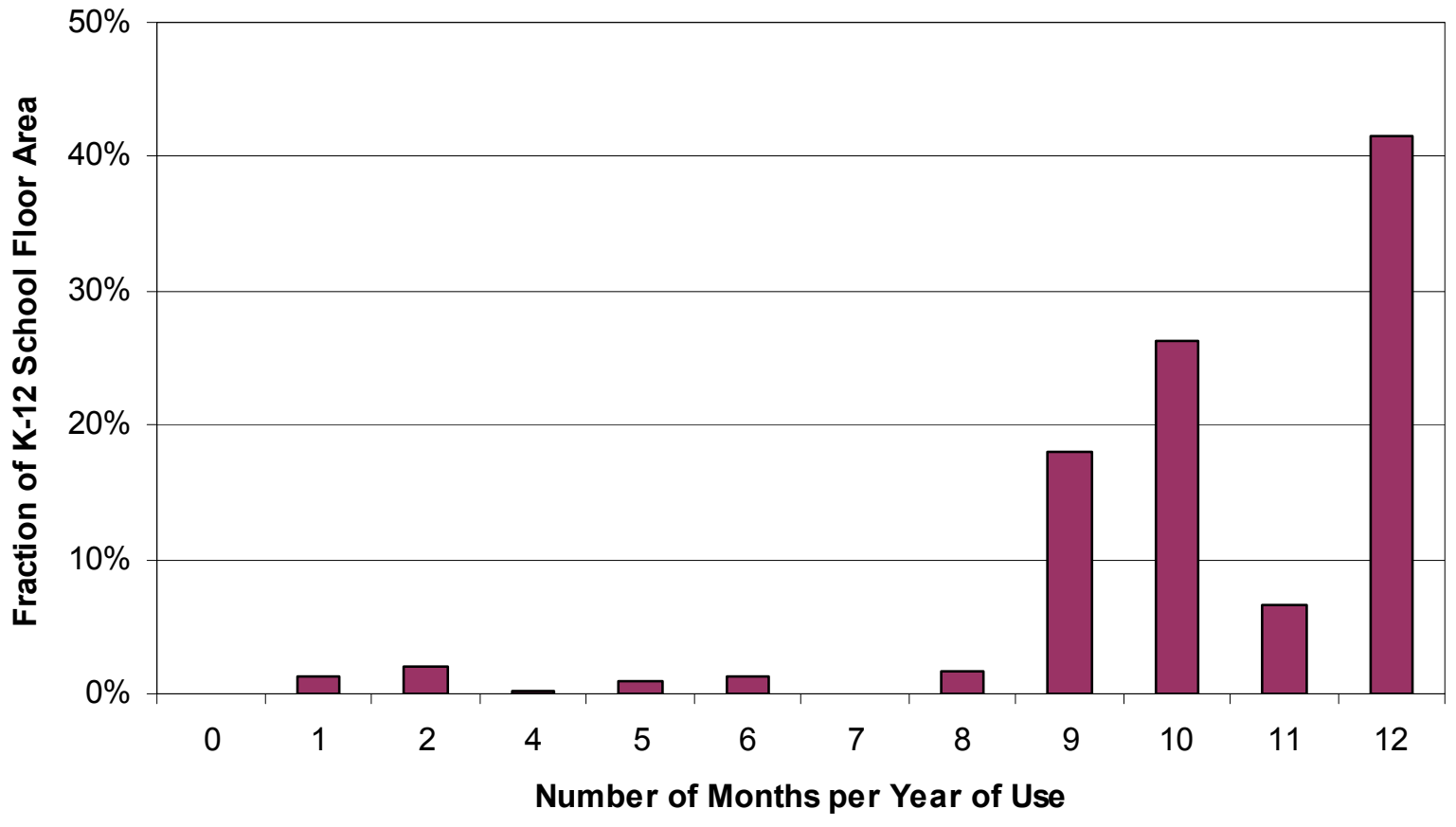

Figure 3-5 Area Weighted Average Months per Year of Use 
The number of operating hours per week for all the K-12 schools is shown in Figure 3-6. More than 25\% of school floor area is operated 42 hours per week. However, $13 \%$ of schools are operated 48, 54, or 60 hours per week. The weighted average operating hours is 50 hours per week. Therefore, our K-12 AEDG prototype models are operated 50 hours per week during the school year. Operational schedules for spaces such as the gyms and auditoriums include after hours use.

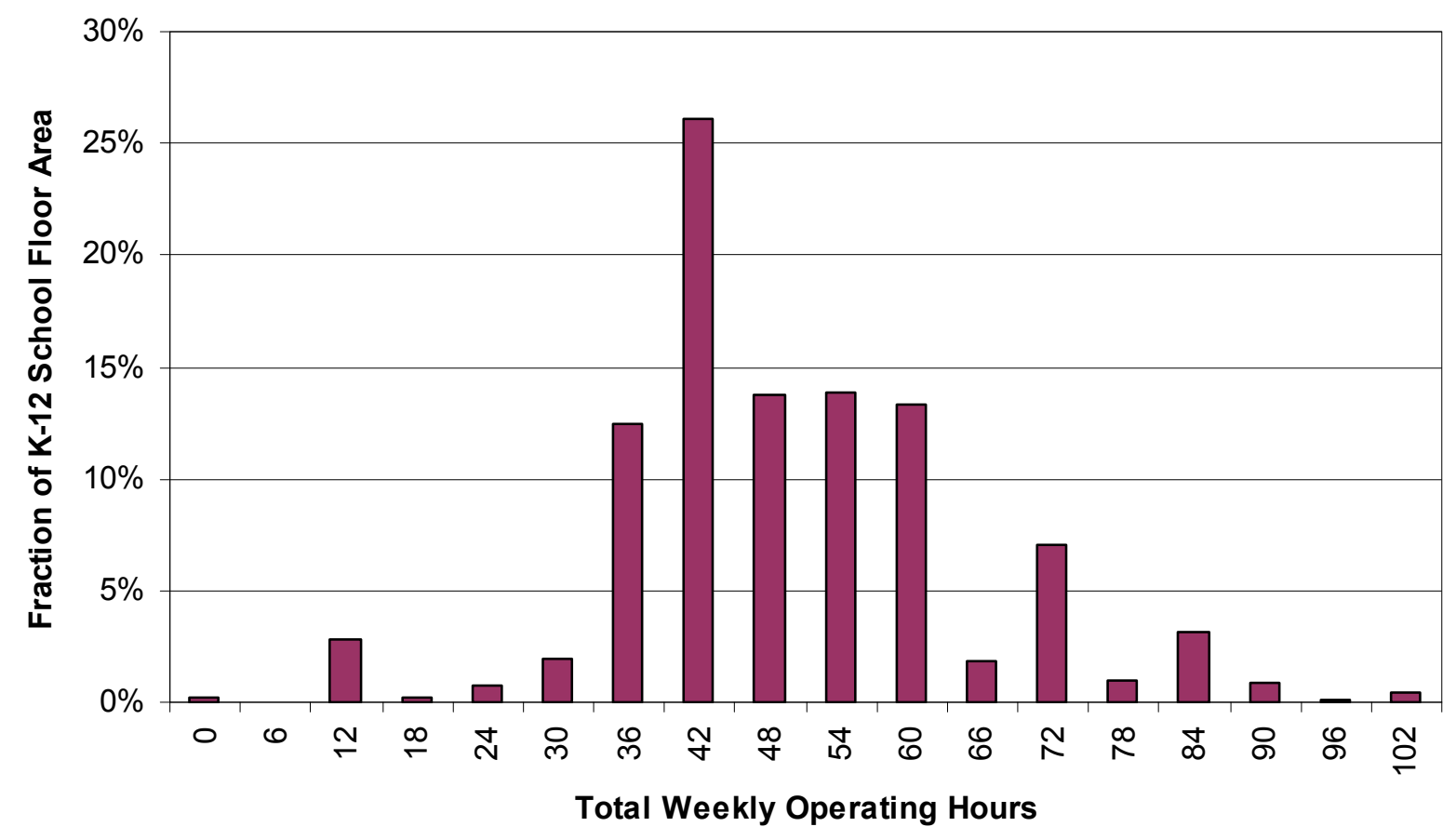

Figure 3-6 Area Weighted Average Weekly Operating Hours 
The total number of computers over all the K-12 schools is shown in Figure 3-7. There is a wide range in numbers of computers in K-12 schools; many schools have only one to four computers. Many schools have 100 to 249 computers; some have 20 to 49 and others have 50 to 99 . Because of this wide range, additional data were needed to determine plug load density for our K-12 AEDG models. See Section 3.2.3.1 for additional information used to determine plug loads in K-12 schools.

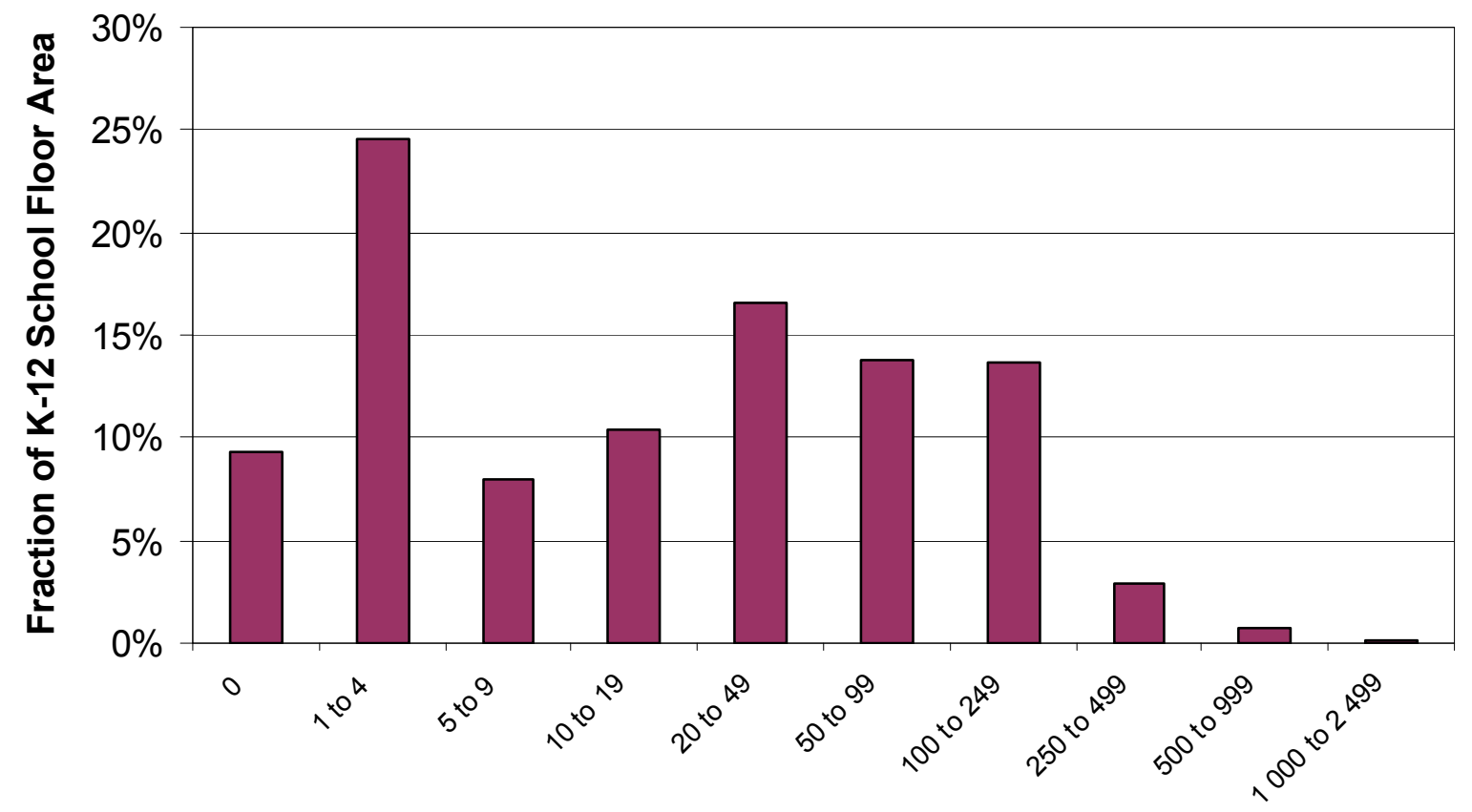

Number of Computers

Figure 3-7 Area Weighted Average Number of Computers 
The types of wall and roof constructions over all the K-12 schools are shown in Figure 3-8. Walls with brick, stone, or stucco exteriors are the most common construction type, and built-up insulation above deck roofs is the most common roof type. Mass walls and insulation above deck roofs were used in the K-12 AEDG models. The construction materials are only the outer surface of the construction.

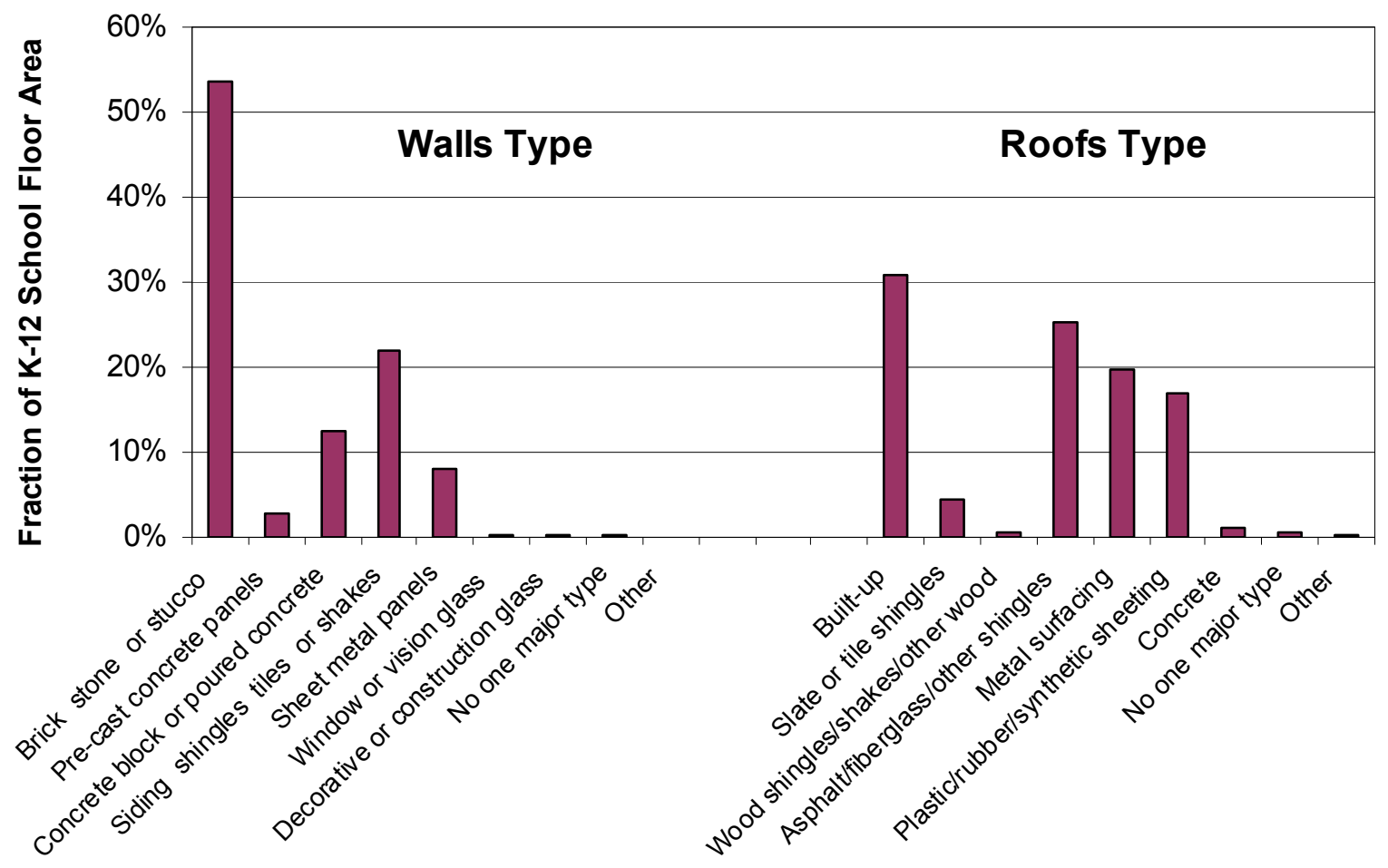

Figure 3-8 Area Weighted Average Wall and Roof Construction Type 
The different types of heating and cooling systems for the 2003 CBECS schools are shown in Figure 3-9. The most common heating systems are furnaces, boilers, and package heating units. The most common cooling systems are package rooftop units, individual room air-conditioning units, heat pumps, and central chillers. The K-12 AEDG models use the most common of these heating and cooling units. The AEDG baseline models use package rooftop air-conditioning units with package heating units. The lowenergy models also include a package variable air volume (VAV) system with direct exchange (DX) cooling coils and a boiler, as well as a VAV with central air-cooled chillers and boilers. See Section 3.3.4.1 for further discussion on selecting the HVAC systems in the baseline and low-energy models.

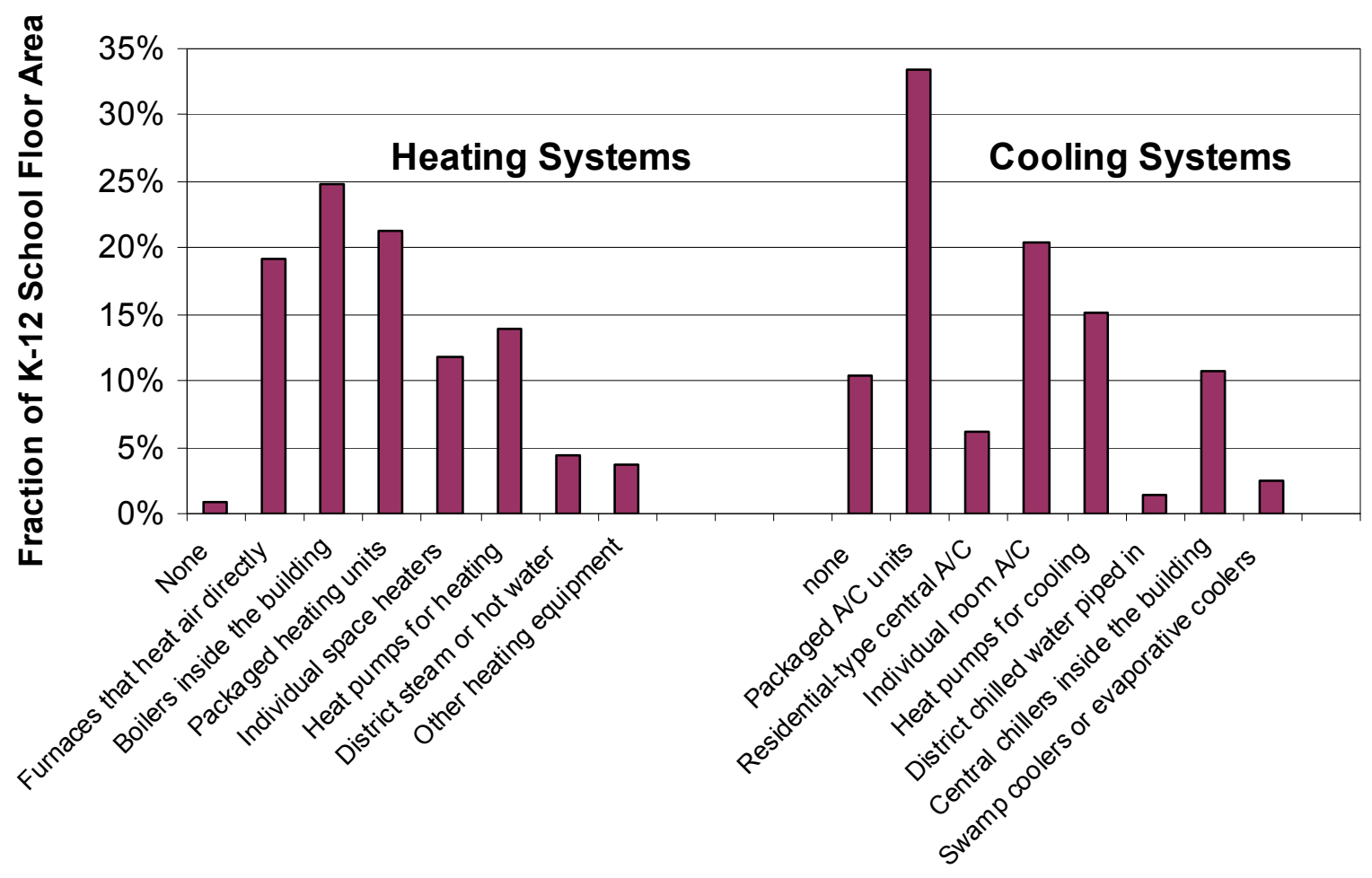

Figure 3-9 Area Weighted Average Primary Heating and Cooling System Types 
The range of fenestration to gross wall area for all of the 2003 CBECS schools is shown in Figure 3-10. The most common range of fenestration area is $11 \%$ to $25 \%$. For the K-12 AEDG baseline models, we used the fenestration to gross wall area ratio that was specified to provide the required daylighting in the low-energy models. Based on input from the AEDG project committee, this area was set at $35 \%$. This is on the higher end for typical fenestration area, but is still within a reasonable range.

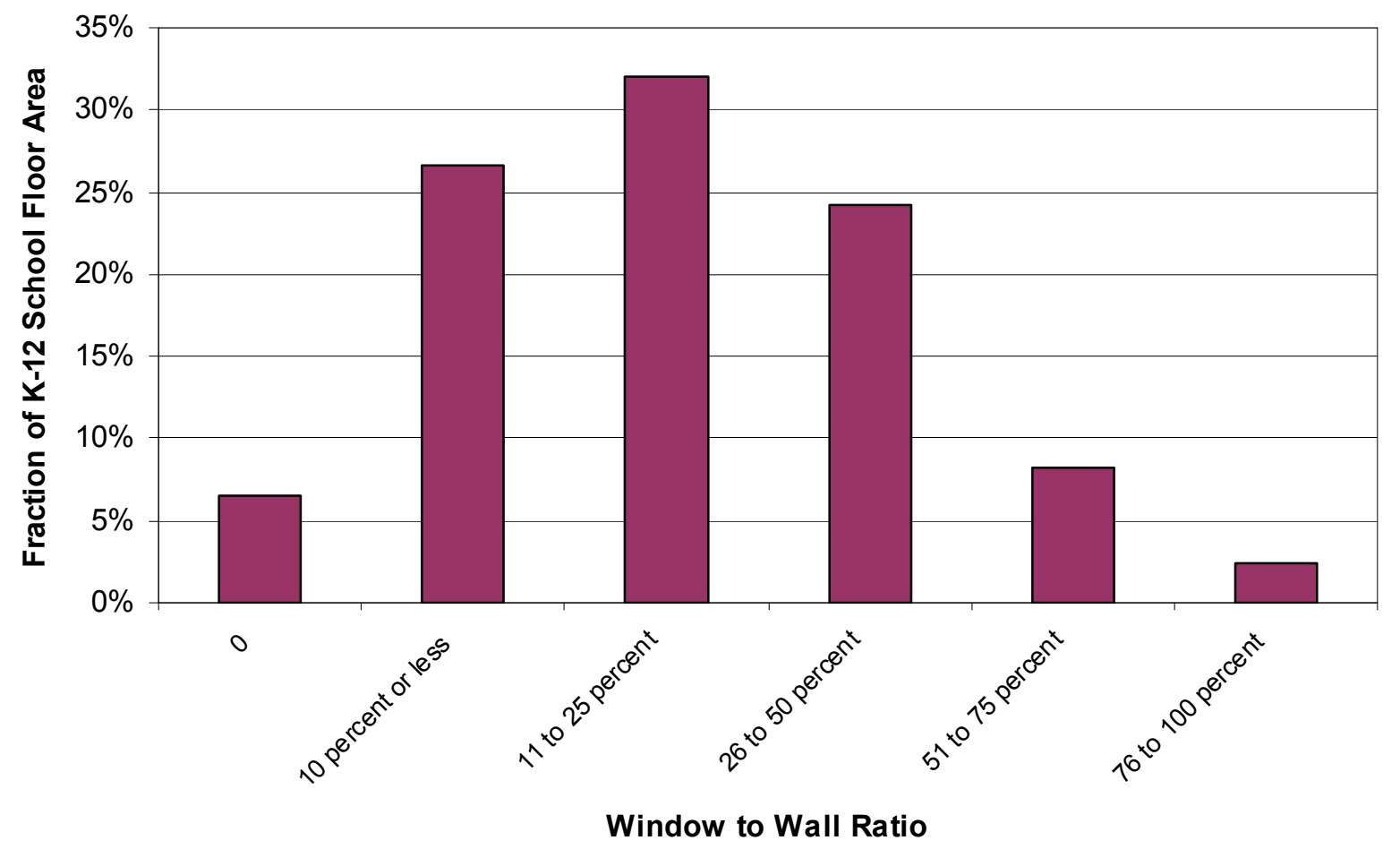

Figure 3-10 Area Weighted Average Window to Wall Ratio 
The number of floors for elementary/middle and high schools in the 2003 CBECS is shown in Figure 3-11. The K-12 AEDG elementary and middle school prototypes have one floor, and the high schools have two floors.

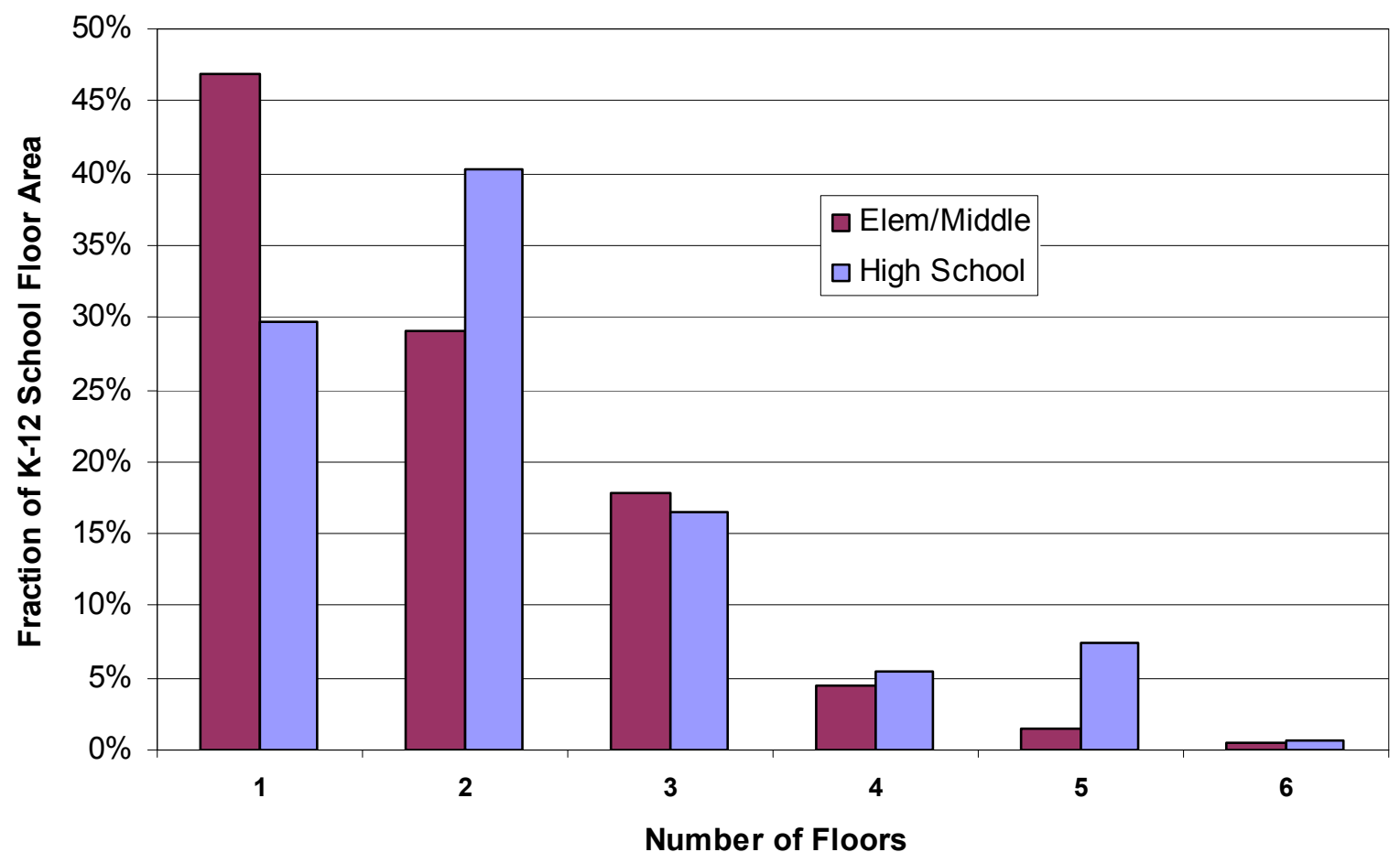

Figure 3-11 Area Weighted Average Number of Floors

The range of floor area for the elementary/middle schools in the 2003 CBECS is shown in Figure 3-12. The range of floor area for the high schools in the 2003 CBECS is shown in Figure 3-13. The area weighted average floor area over all the elementary/middle schools and high schools is shown in Table 3-1. The average CBECS school sizes were not used explicitly in our K-12 AEDG models; rather, the CBECS average school sizes were used in combination with additional data sources that provide further and more current schools size details.

Table 3-1 2003 CBECS Floor Area: Weighted Mean

\begin{tabular}{|c|c|c|}
\hline $\begin{array}{c}\text { National } \\
\text { Averages }\end{array}$ & $\begin{array}{c}\text { Elementaryl } \\
\text { Middle } \\
\text { School }\end{array}$ & $\begin{array}{c}\text { High } \\
\text { School }\end{array}$ \\
\hline Size $\left(\mathrm{ft}^{2}\right)$ & 77,174 & 223,964 \\
\hline
\end{tabular}




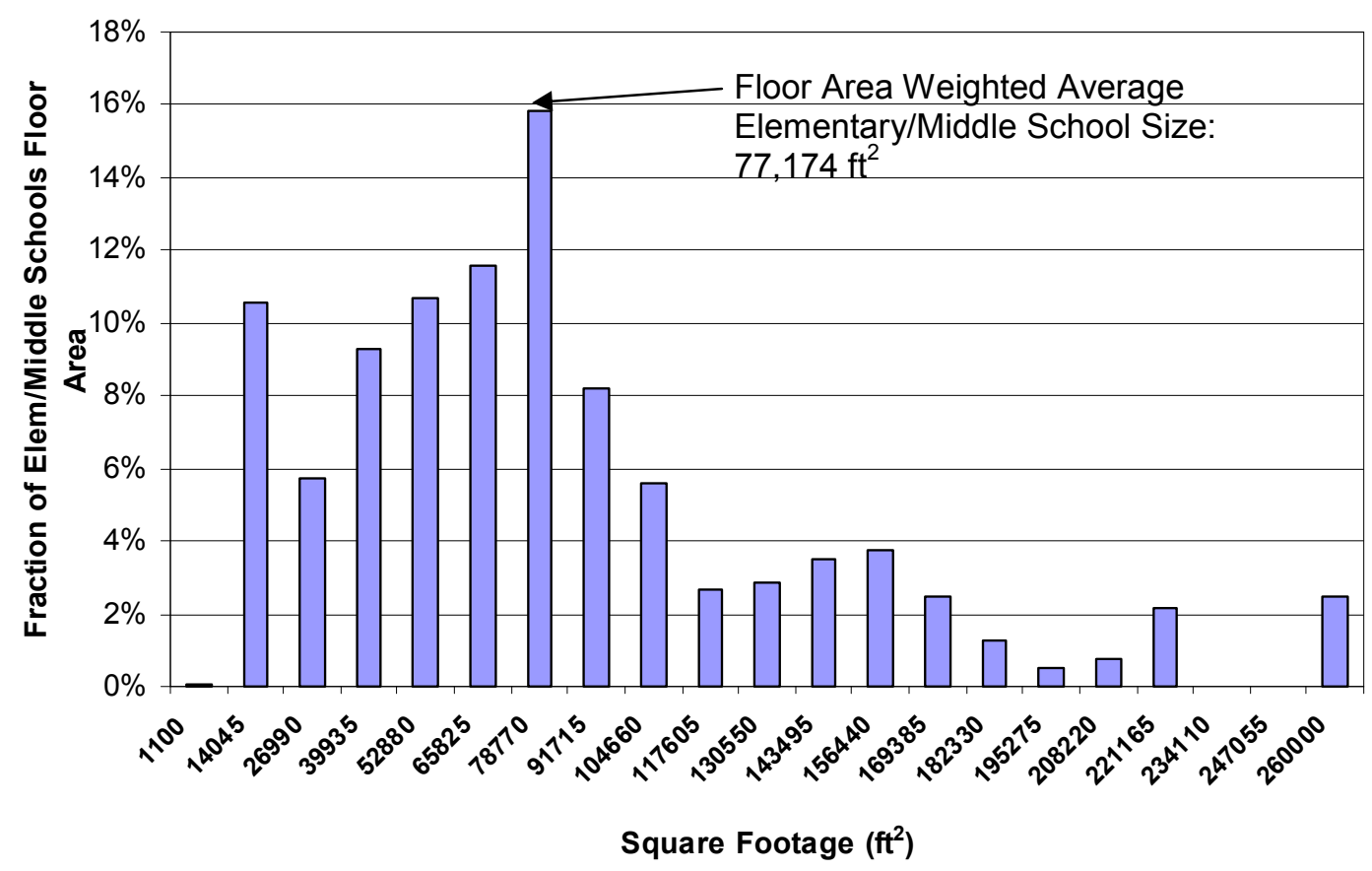

Figure 3-12 Area Weighted Average Elementary/Middle School Size

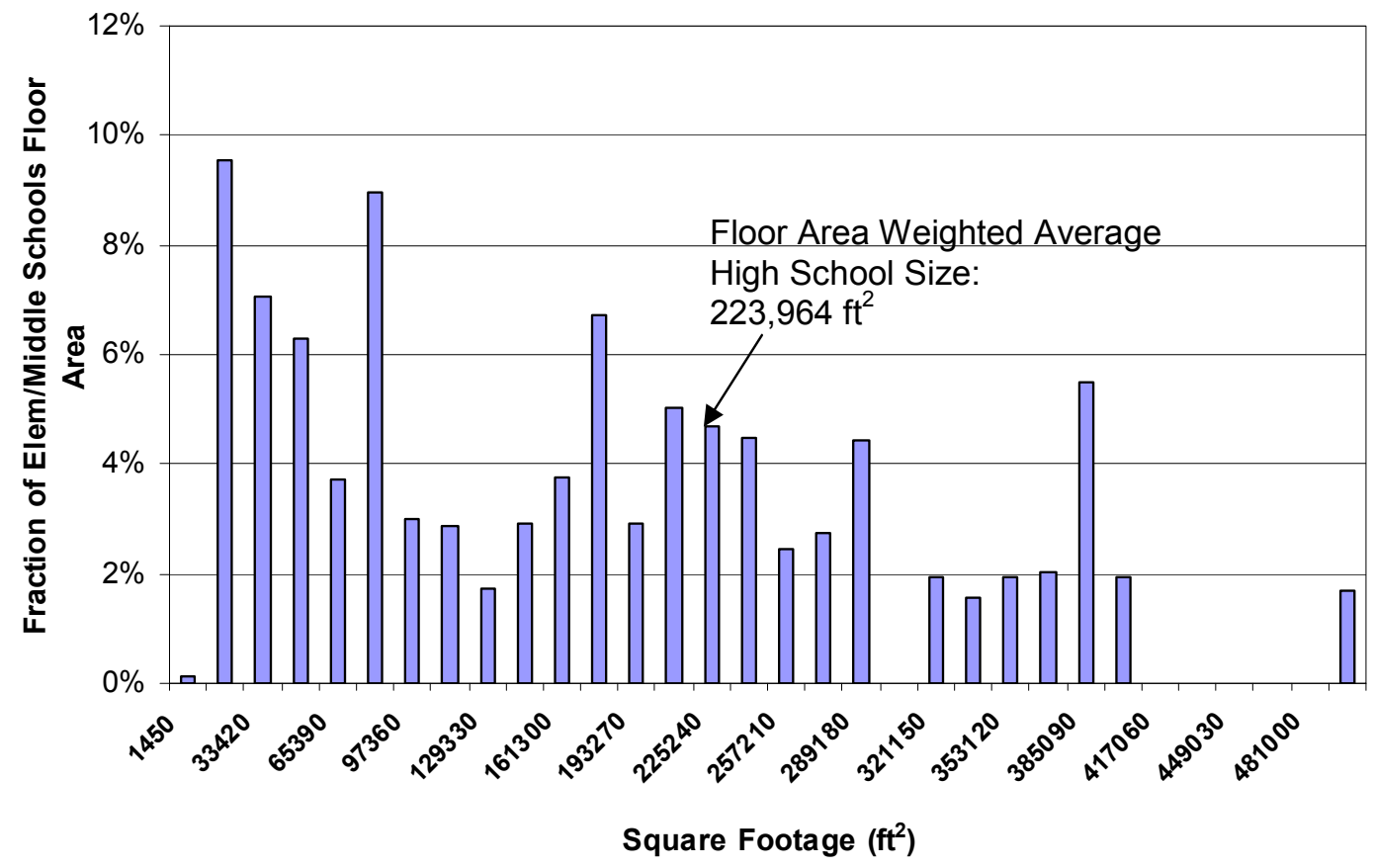

Figure 3-13 Area Weighted Average High School Size

\subsubsection{CBECS K-12 Energy Use Trends}

In addition to the physical and operational characteristics of the schools in the 2003 CBECS, we investigated the area weighted average site EUI. The average K-12 schools site EUI by ASHRAE climate zone is shown in Table 3-2.

To analyze the schools in the 2003 CBECS by ASHRAE climate zone, we used the climate zone to show CBECS assignment results as discussed in Griffith et al. (2007). This assignment selects an ASHRAE climate zone to assign each building in the 2003 CBECS data set. The location of the building determines several aspects, including simulation weather file, utility tariffs, emissions factors, site-to-source 
conversion factor, latitude, longitude, and elevation, that are important to the modeling. CBECS masks the actual locations of buildings for anonymity but does provide data for the census division and values for HDDs and CDDs. An assignment algorithm is used to select the location in the following manner. An initial set of candidate locations was assembled that was formed by a set of 232 EnergyPlus weather files that are based on TMY2 or TMY weather data locations. HDD and CDD data (base $65^{\circ} \mathrm{F}$ ) from the weather data were also used in the location assignments. For each CBECS building, we then selected a subset of these candidate locations that lie within the CBECS census division. This subset of candidate locations is subsequently searched to find the location that most closely matches the reported HDDs and CDDs. A "brute force" search algorithm was used where, for each possible assignment, we calculated the root mean square (RMS) of the combined deviations for HDDs and CDDs. The resulting array of RMS error values was then searched for the minimum and the location with the lowest error selected for the assignment.

Also shown in Table 3-2 is the number of K-12 schools in the 2003 CBECS in each climate zone. There are no CBECS elementary/middle or high schools in climate zone 8 , only a few elementary schools in climate zone 1, and none in zone 7 . There are a few high schools in climate zone 7 , and none in zone 1. Some restraint is needed in using the energy use data from climate zones that are not well represented by the survey, such as in climate zones 1,7 , and 8 .

Table 3-2 Area Weighted Average Site EUI by ASHRAE Climate Zone

\begin{tabular}{|c|c|c|}
\hline $\begin{array}{c}\text { ASHRAE Climate } \\
\text { Zone }\end{array}$ & $\begin{array}{c}\text { Number of K-12 } \\
\text { Schools in CBECS }\end{array}$ & $\begin{array}{c}\text { Area Weighted Average Site EUI } \\
\left(\mathbf{k B t u} / \mathrm{ft}^{2} \text { ) }\right.\end{array}$ \\
\hline 1 & 2 & 46 \\
\hline 2 & 67 & 58 \\
\hline 3 & 78 & 57 \\
\hline 4 & 91 & 74 \\
\hline 5 & 152 & 80 \\
\hline 6 & 63 & 86 \\
\hline 7 & 3 & No data \\
\hline 8 & 0 & 72 \\
\hline All & 456 & \\
\hline
\end{tabular}

The national area weighted average site EUI for all the K-12 2003 CBECS schools is $72 \mathrm{kBtu} / \mathrm{ft}^{2}(818$ $\left.\mathrm{MJ} / \mathrm{m}^{2}\right)$. The national area weighted average site EUI for high schools is $80 \mathrm{kBtu} / \mathrm{ft}^{2}\left(909 \mathrm{MJ} / \mathrm{m}^{2}\right)$ and is $68 \mathrm{kBtu} / \mathrm{ft}^{2}\left(773 \mathrm{MJ} / \mathrm{m}^{2}\right)$ for elementary schools. The site EUI by climate zone for all $\mathrm{K}-12$, elementary/middle, and high schools is shown in Figure 3-14. The climatic variation in energy use is evident in Figure 3-14; the highest EUI is in the coldest climates. 


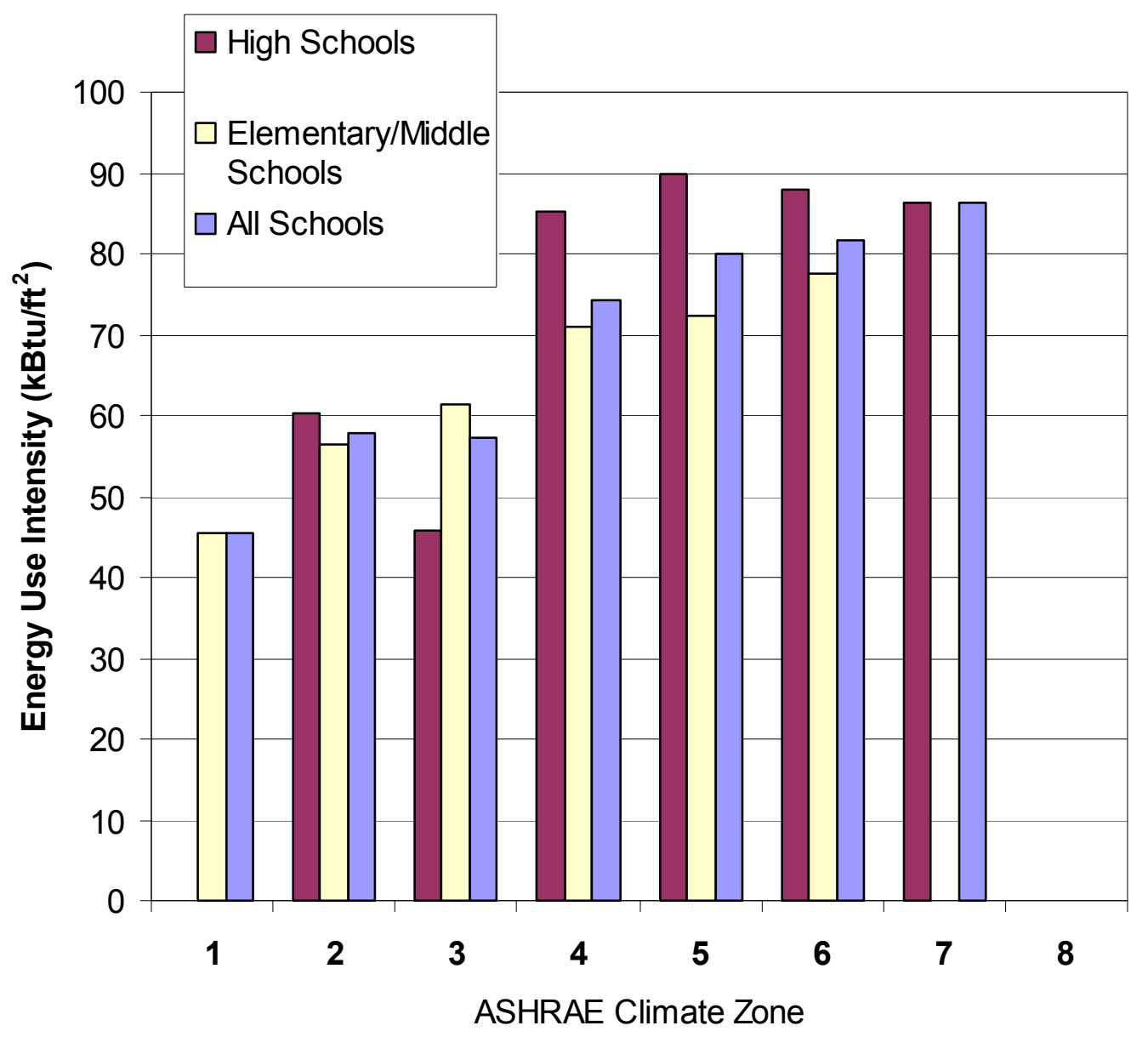

Figure 3-14 2003 CBECS Site EUI by Climate Zone

\subsubsection{K-12 Construction Industry Publications}

In addition to analyzing schools in the 2003 CBECS, we surveyed multiple sources of "typical" new school characteristics data to determine appropriate characteristics for our AEDG baseline and lowenergy models. Based on input from the K-12 AEDG PC, ASU (www.ASUmag.com) and SPM (http://www.peterli.com/spm/) provide accurate and up-to-date school construction data. Table 3-3 shows results from the most recent surveys from both ASU and SPM that document average size, cost, and number of students for elementary, middle, and high schools (ASU 2006, SPM 2007). Average elementary schools range from $73,000 \mathrm{ft}^{2}$ to $80,000 \mathrm{ft}^{2}\left(6,782 \mathrm{~m}^{2}\right.$ to $\left.7,432 \mathrm{~m}^{2}\right)$, with 700 to 725 students. This is similar to the average 2003 CBECS elementary school at $77,174 \mathrm{ft}^{2}\left(7,170 \mathrm{~m}^{2}\right)$. Average middle schools are $104,880 \mathrm{ft}^{2}$ to $119,000 \mathrm{ft}^{2}\left(9,744 \mathrm{~m}^{2}\right.$ to $\left.11,055 \mathrm{~m}^{2}\right)$, with 750 to 825 students. Average high schools are between $148,569 \mathrm{ft}^{2}$ and $224,000 \mathrm{ft}^{2}\left(13,803 \mathrm{~m}^{2}\right.$ to $\left.20,810 \mathrm{~m}^{2}\right)$, with 1,055 to 1,200 students. The higher side of the high school size range from ASU and SPM is similar to the 2003 CBECS average high school. Based on the results from the 2006 ASU and the 2007 SPM survey combined with 2003 CBECS size data, we identified up-to-date "typical" school size ranges for use in the K-12 AEDG prototype model development. The actual sizes of the K-12 AEDG models were determined based on the number of students and the space planning profiles, as documented later in Section 3.2.3.3 and summarized in Section 3.2.4. 
Table 3-3 National Average Schools Sizes, Costs, and Number of Students (ASU Construction Report, SPM Construction Report)

\begin{tabular}{|l|c|c|c|c|c|c|}
\hline \multirow{2}{*}{$\begin{array}{c}\text { National } \\
\text { Averages }\end{array}$} & \multicolumn{2}{|c|}{ Elementary Schools } & \multicolumn{2}{c|}{ Middle Schools } & \multicolumn{2}{c|}{ High Schools } \\
\cline { 2 - 7 } & ASU & SPM & ASU & SPM & ASU & SPM \\
\hline \hline \multirow{2}{*}{ Size $\left(\mathrm{ft}^{2}\right)$} & 73,000 & 80,000 & 104,880 & 119,000 & 148,569 & 224,000 \\
\cline { 2 - 7 } & 77,174 national area weighted average 2003 CBECS & $\begin{array}{r}223,964 \text { national area } \\
\text { weighted average 2003 } \\
\text { CBECS }\end{array}$ \\
\hline Cost/ft $^{2}$ & $\$ 141$ & $\$ 148$ & $\$ 195$ & $\$ 150$ & $\$ 180$ & $\$ 152$ \\
\hline $\begin{array}{l}\text { Number } \\
\text { of pupils }\end{array}$ & 725 & 700 & 750 & 825 & 1055 & 1200 \\
\hline $\begin{array}{l}\text { Size } \\
\mathrm{ft}^{2} / \text { pupil }\end{array}$ & 100.7 & 122.2 & 139.8 & 143.8 & 140.8 & 166.7 \\
\hline
\end{tabular}

The SPM survey also documents the types of spaces that are in new elementary, middle, and high schools across the country. As shown in Table 3-4, the percent of new schools with each space type was determined. Space types that are included in more than $50 \%$ of new schools are included in our "typical" baseline and low-energy models. Similar data provided by the K-12 AEDG PC from Wake County, North Carolina, are also shown. Differences in space types over the three types of K-12 schools include:

- Science laboratories are standard in new middle and high schools, but are included in only $6.3 \%$ of elementary schools.

- New high schools typically include an auditorium; middle and elementary schools do not.

- High schools typically have a second auxiliary gym; elementary and middle schools do not.

- Elementary schools typically have a multipurpose room, but not a full gym with spectator seating. 
Table 3-4 Space Types Included in Schools:

2006 SPM National Average, Wake County, NC, and in the AEDG Prototype

\begin{tabular}{|c|c|c|c|c|c|c|c|c|c|}
\hline \multirow[b]{2}{*}{ Space Type } & \multicolumn{3}{|c|}{ Elementary School } & \multicolumn{3}{|c|}{ Middle School } & \multicolumn{3}{|c|}{ High School } \\
\hline & Nation & $\begin{array}{l}\text { Wake } \\
\text { Co. }\end{array}$ & $\begin{array}{c}\text { AEDG } \\
\text { Prototype }\end{array}$ & Nation & $\begin{array}{c}\text { Wake } \\
\text { Co. }\end{array}$ & $\begin{array}{c}\text { AEDG } \\
\text { Prototype }\end{array}$ & Nation & $\begin{array}{l}\text { Wake } \\
\text { Co. }\end{array}$ & $\begin{array}{c}\text { AEDG } \\
\text { Prototype }\end{array}$ \\
\hline \multicolumn{10}{|c|}{ Core Facilities } \\
\hline Classrooms & $100.0 \%$ & $x$ & $x$ & $100.0 \%$ & $x$ & $x$ & $100.0 \%$ & $x$ & $x$ \\
\hline Library & $91.3 \%$ & & $x$ & $94.4 \%$ & & $x$ & $92.6 \%$ & & $x$ \\
\hline Media center & $66.3 \%$ & $x$ & $x$ & $100.0 \%$ & $x$ & $x$ & $92.6 \%$ & $x$ & $x$ \\
\hline $\begin{array}{l}\text { Computer } \\
\text { lab }\end{array}$ & $74.5 \%$ & $x$ & $x$ & $96.3 \%$ & $x$ & $x$ & $98.1 \%$ & $\mathrm{x}$ & $\mathrm{x}$ \\
\hline Science lab & $6.3 \%$ & & & $98.1 \%$ & $x$ & $x$ & $100.0 \%$ & $x$ & $x$ \\
\hline Music & $94.2 \%$ & $x$ & $x$ & $96.3 \%$ & $x$ & $x$ & $92.6 \%$ & $x$ & $x$ \\
\hline Arts/crafts & $99.0 \%$ & $x$ & $x$ & $98.1 \%$ & $x$ & $x$ & $88.9 \%$ & $x$ & $x$ \\
\hline $\begin{array}{l}\text { Gymnasium/ } \\
\text { multipurpose } \\
\text { room }\end{array}$ & $92.3 \%$ & $x$ & $x$ & $100.0 \%$ & $x$ & $x$ & $100.0 \%$ & $x$ & $x$ \\
\hline Stage & $17.3 \%$ & $x$ & & $40.7 \%$ & $x$ & & $72.2 \%$ & $x$ & $x$ \\
\hline $\begin{array}{l}\text { Auditorium/ } \\
\text { theater }\end{array}$ & $6.3 \%$ & & & $35.2 \%$ & $x$ & & $63.5 \%$ & $x$ & $\mathrm{x}$ \\
\hline $\begin{array}{l}\text { Special ED/ } \\
\text { Resource }\end{array}$ & $72.1 \%$ & $x$ & $x$ & $74.1 \%$ & $x$ & $\mathrm{X}$ & $64.8 \%$ & $\mathrm{x}$ & $x$ \\
\hline Home arts & $0.0 \%$ & & & $7.4 \%$ & $x$ & & $33.3 \%$ & $x$ & \\
\hline $\begin{array}{l}\text { Industrial } \\
\text { tech. }\end{array}$ & $0.0 \%$ & & & $1.9 \%$ & $x$ & & $13.0 \%$ & $\mathrm{x}$ & \\
\hline $\begin{array}{l}\text { Vocational } \\
\text { shops }\end{array}$ & $0.0 \%$ & & & $3.7 \%$ & $x$ & & $14.8 \%$ & $x$ & \\
\hline Photo lab & $0.0 \%$ & & & $0.0 \%$ & & & $3.7 \%$ & & \\
\hline $\begin{array}{l}\text { TV/radio } \\
\text { studio }\end{array}$ & $0.0 \%$ & & & $0.0 \%$ & & & $7.4 \%$ & & \\
\hline \multicolumn{10}{|c|}{ Support Facilities } \\
\hline Offices & $100.0 \%$ & $x$ & $x$ & $100.0 \%$ & $x$ & $x$ & $100.0 \%$ & $x$ & $x$ \\
\hline $\begin{array}{l}\text { Infirmary/ } \\
\text { clinic }\end{array}$ & $100.0 \%$ & $x$ & $x$ & $100.0 \%$ & $x$ & $x$ & $100.0 \%$ & $x$ & $x$ \\
\hline Cafeteria & $98.1 \%$ & $x$ & $x$ & $100.0 \%$ & $x$ & $x$ & $98.1 \%$ & $x$ & $x$ \\
\hline Kitchen & $97.6 \%$ & $x$ & $x$ & $98.1 \%$ & $x$ & $x$ & $96.3 \%$ & $x$ & $x$ \\
\hline Hall lockers & $4.3 \%$ & & & $92.6 \%$ & $\mathrm{X}$ & $\mathrm{x}$ & $100.0 \%$ & $x$ & $\mathrm{x}$ \\
\hline
\end{tabular}




\subsubsection{Additional School Characteristics}

\subsubsection{Plug Load Audits}

Historically, the energy use and installed capacity of plug loads in commercial buildings have been a significant uncertainty. A project committee member, Larry Schoff from Energy Efficient Solutions, has attempted to quantify plug loads in schools. We obtained data from Schoff through personal communication on plug loads and the savings that could result if actions are taken to control the plug and resulting phantom loads. As part of a survey for Roanoke, Virginia, County Schools, he compiled detailed plug load information for five high schools, five middle schools, and 17 elementary schools in the Roanoke school district. For each school, a detailed plug load/phantom load survey was conducted to identify the plug and phantom loads in the schools. (See Table 3-8 for a list of plug loads identified, and the peak wattage for the plug load item.) A plug load is any electrical device that is plugged into a 120or 208-volt outlet in the school and is used continuously or periodically during the school year. The plug loads identified in these audits do not include electrical or gas process loads such as elevators, transformers, cooking appliances, kitchen walk-in refrigerators, or other loads that are not associated with HVAC, lighting, service water heating, or plug loads. A phantom load is defined as an electrical device that still draws electrical energy when it is turned off. Examples of plug loads in a school are TVs, VCRs, computers, copiers, and any devices that have or need a wall cubic (transformer) to operate. Computers represented the largest single plug load type in these schools; the total number for each school is also shown in Table 3-5 through Table 3-7.

From this plug load survey, we calculated the noncoincident peak plug load intensity for each school. Based on the size of each school, we then calculated the weighted average plug load intensity for the high, middle, and elementary schools. These results are shown in Table 3-5 through Table 3-7. The average peak plug load density in the high schools and middle schools was $1.0 \mathrm{~W} / \mathrm{ft}^{2}\left(10.8 \mathrm{~W} / \mathrm{m}^{2}\right)$, and $1.1 \mathrm{~W} / \mathrm{ft}^{2}$ $\left(11.8 \mathrm{~W} / \mathrm{m}^{2}\right)$ in the elementary schools. The PC felt these peak plug load densities were reasonable for the prototype models; these were used in the K-12 AEDG baseline and low-energy energy models. The plug load schedules were based on PC input and modified standard educational building schedule sets available in ASHRAE 90.1-1989 (ASHRAE 1989). Schedules are documented in Section 3.3.6.

Table 3-5 Roanoke District High School Plug Load Density Survey

\begin{tabular}{|l|c|c|c|}
\hline \multicolumn{1}{|c|}{ School Name } & Size $\mathbf{( f t}^{2}$ ) & $\begin{array}{c}\text { Number of } \\
\text { Computers }\end{array}$ & $\begin{array}{c}\text { Plug Load Density } \\
\text { (W/ft }{ }^{2} \text { ) }\end{array}$ \\
\hline \hline Northside High & 138,871 & 231 & 1.25 \\
\hline Cave Spring High & 162,100 & 235 & 0.95 \\
\hline Glenvar High & 120,914 & 129 & 0.80 \\
\hline Hidden Valley High & 191,575 & 188 & 0.70 \\
\hline William Byrd High & 154,166 & 274 & 1.33 \\
\hline \multicolumn{2}{|c|}{ Area Weighted Average } & \\
\hline
\end{tabular}


Table 3-6 Roanoke District Middle School Plug Load Density Survey

\begin{tabular}{|l|c|c|c|}
\hline \multicolumn{1}{|c|}{ School Name } & Size $\mathbf{( f t}^{2}$ ) & $\begin{array}{c}\text { Number of } \\
\text { Computers }\end{array}$ & $\begin{array}{c}\text { Plug Load Density } \\
\text { (W/ft }{ }^{2} \text { ) }\end{array}$ \\
\hline Northside Middle & 109,889 & 134 & 1.00 \\
\hline Glenvar Middle & 101,595 & 129 & 0.72 \\
\hline William Byrd Middle & 145,624 & 174 & 0.77 \\
\hline Hidden Valley Middle & 119,824 & 249 & 1.07 \\
\hline Cave Spring Middle & 85,130 & 173 & 1.0 \\
\hline \multicolumn{2}{|c|}{ Area Weighted Average } \\
\hline
\end{tabular}

Table 3-7 Roanoke District Elementary School Plug Load Density Survey

\begin{tabular}{|c|c|c|c|}
\hline School Name & Size $\left(\mathrm{ft}^{2}\right)$ & $\begin{array}{l}\text { Number of } \\
\text { Computers }\end{array}$ & $\begin{array}{l}\text { Plug Load Density } \\
\left(\mathrm{W} / \mathrm{ft}^{2}\right)\end{array}$ \\
\hline Bonsack Elementary & 57,472 & 167 & 1.49 \\
\hline Fort Lewis Elementary & 33,913 & 80 & 1.28 \\
\hline Burlington Elementary & 65,649 & 114 & 0.94 \\
\hline Glenvar Elementary & 52,325 & 108 & 1.01 \\
\hline Glen Cove Elementary & 60,010 & 115 & 0.78 \\
\hline Mason Cove Elementary & 38,253 & 77 & 0.94 \\
\hline Herman Horn Elementary & 65,145 & 103 & 1.10 \\
\hline WE Cundiff Elementary & 60,010 & 97 & 1.00 \\
\hline Oak Grove Elementary & 65,057 & 104 & 0.96 \\
\hline Mt. View Elementary & 63,778 & 112 & 0.91 \\
\hline Clearbrook Elementary & 44,020 & 98 & 1.23 \\
\hline Mt. Pleasant Elementary & 43,991 & 81 & 0.98 \\
\hline Back Creek Elementary & 48,631 & 83 & 1.16 \\
\hline Bent Mt. Elementary & 14,251 & 41 & 1.62 \\
\hline Penn Forest Elementary & 65,047 & 73 & 0.81 \\
\hline Green Valley Elementary & 42,111 & 114 & 1.66 \\
\hline Cave Spring Elementary & 48,675 & 118 & 1.23 \\
\hline \multicolumn{3}{|c|}{ Area Weighted Average } & 1.1 \\
\hline
\end{tabular}


Table 3-8 Plug Load Items Included in Survey

\begin{tabular}{|c|c|c|c|}
\hline Plug Load Item & $\begin{array}{c}\text { Peak } \\
\text { Wattage } \\
\text { (W) }\end{array}$ & Plug Load Item & $\begin{array}{c}\text { Peak } \\
\text { Wattage } \\
\text { (W) }\end{array}$ \\
\hline Personal Items & & Computer/Equipment & \\
\hline Microwaves & 800 & Computers & 200 \\
\hline Toaster ovens & 1000 & Printers & 50 \\
\hline $1.5 \mathrm{ft}^{3}$ refrigerator & 96 & Scanner & 100 \\
\hline Portable heaters & 900 & Laser printer & 250 \\
\hline Coffee Pots & 750 & PC docking station & 25 \\
\hline $2.0 \mathrm{ft}^{3}$ refrigerators & 150 & Other & \\
\hline Dehumidifier & 900 & TV distribution & 600 \\
\hline Electronic Items & & Freezer & 1000 \\
\hline Televisions & 110 & Battery charge for portables & 300 \\
\hline Laser disc player & 100 & Aquarium & 100 \\
\hline VCRs & 25 & LCD projectors & 350 \\
\hline DVD player/keyboards & 30 & File server & 1500 \\
\hline Boom box radio/tape & 30 & Humidifier & 150 \\
\hline Kitchen refrigerator & 750 & Network hub & 1800 \\
\hline Beverage machine & 600 & Ice cream box & 900 \\
\hline Snack machine & 110 & Typewriter/sewing machine & 100 \\
\hline Instructional Equipment & & Stove & 4000 \\
\hline Overhead projectors & 600 & Router & 1200 \\
\hline Film strip projectors & 500 & Washer and dryer & 5000 \\
\hline Audio tape & 30 & Water cooler & 300 \\
\hline Sound system & 500 & Window AC & 1500 \\
\hline Electronic piano & 110 & Office Equipment & \\
\hline Fans & & Copiers - large & 1500 \\
\hline Wall & 200 & Laminators & 2400 \\
\hline Ceiling & 100 & Fax & 200 \\
\hline Box & 100 & Copier - small & 600 \\
\hline Lamps & 60 & & \\
\hline
\end{tabular}

\subsubsection{Example Floor Plans}

To aid in the development of the K-12 AEDG prototype models, we requested actual school plans from the PC members. We received floor plans and sections for a daylit elementary school and a middle school, as well as some orientation specific floor plan options for a daylit high school from Mike Nicklas at Innovative Design. The daylit middle school floor plan is shown in Figure 3-15, the daylit elementary school floor plan is shown in Figure 3-16. Orientation-specific high school floor plans are shown in Figure 3-17 to Figure 3-19 for different street configurations. These plans provide options for a daylit school with the entryway always facing the street.

Each example floor plan has most of the classrooms on an exterior wall oriented either to the south or to the north. Double loaded classroom wings are typically used to allow for this classroom orientation. This type of floor plan allows for each classroom to have a north or south window, but the exterior wall surface area is greater than that of a rectangular building. The exterior wall to total envelope area (all gross wall and roof area) is approximately $25 \%$ for the single floor schools, and $37 \%$ for the two floor schools. A square single floor school is approximately $18 \%$ wall to total envelope, and a two floor square school is 
approximately $21 \%$ wall to total envelope. The K-12 AEDG models use floor plates similar to these examples, with most of the classrooms in wings that allow for north- or south-facing classrooms.

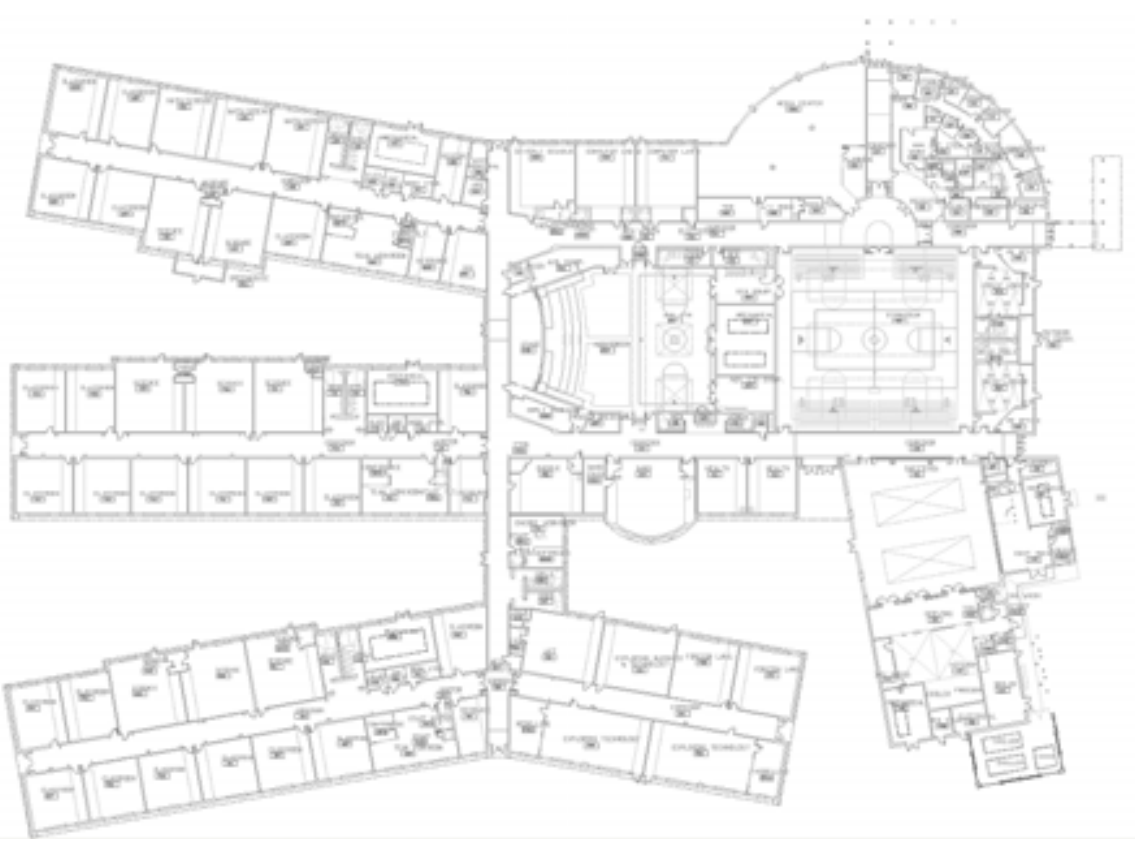

Figure 3-15 Middle School Floor Plan Example

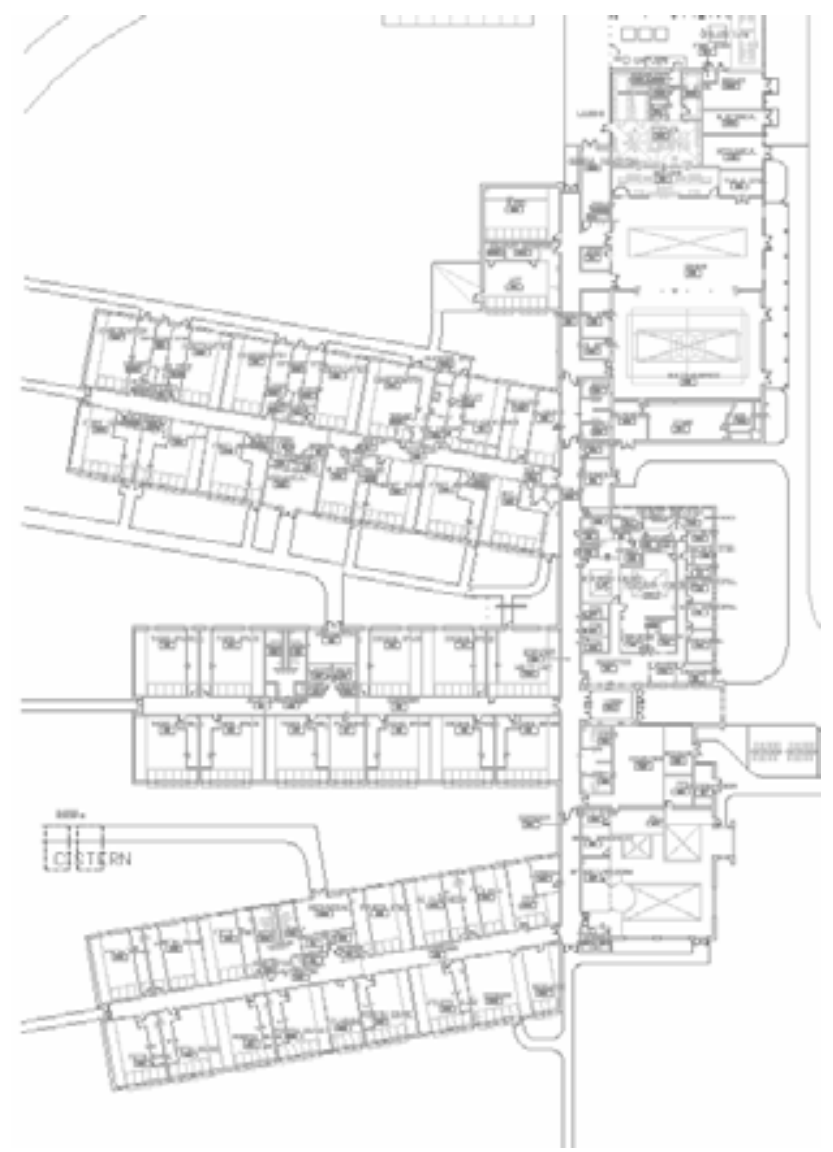

Figure 3-16 Elementary School Floor Plan Example 


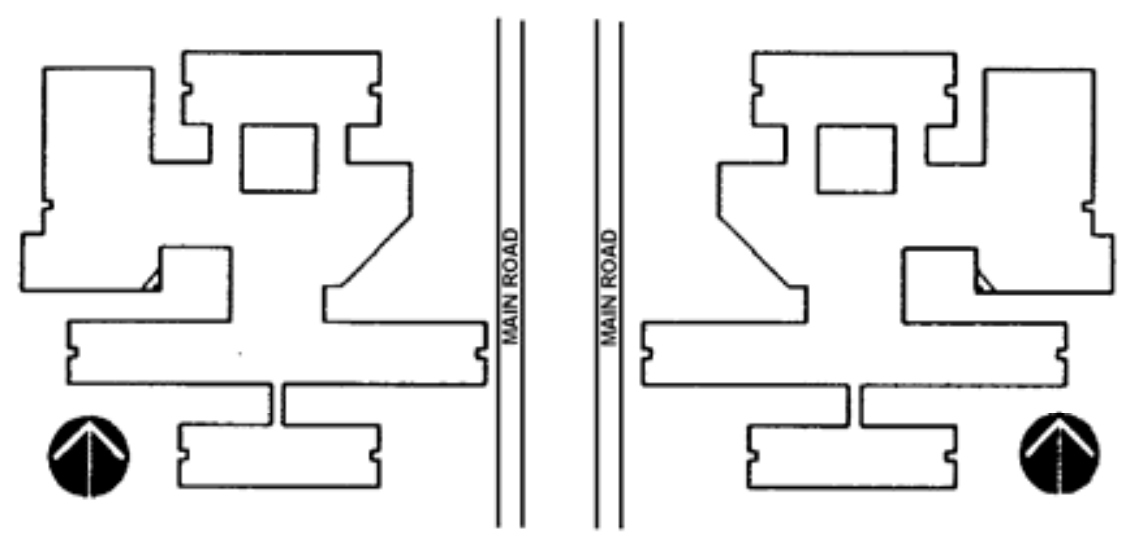

Note: Entry faces the main road

Figure 3-17 High School Floor Plan Example-East or West Entry
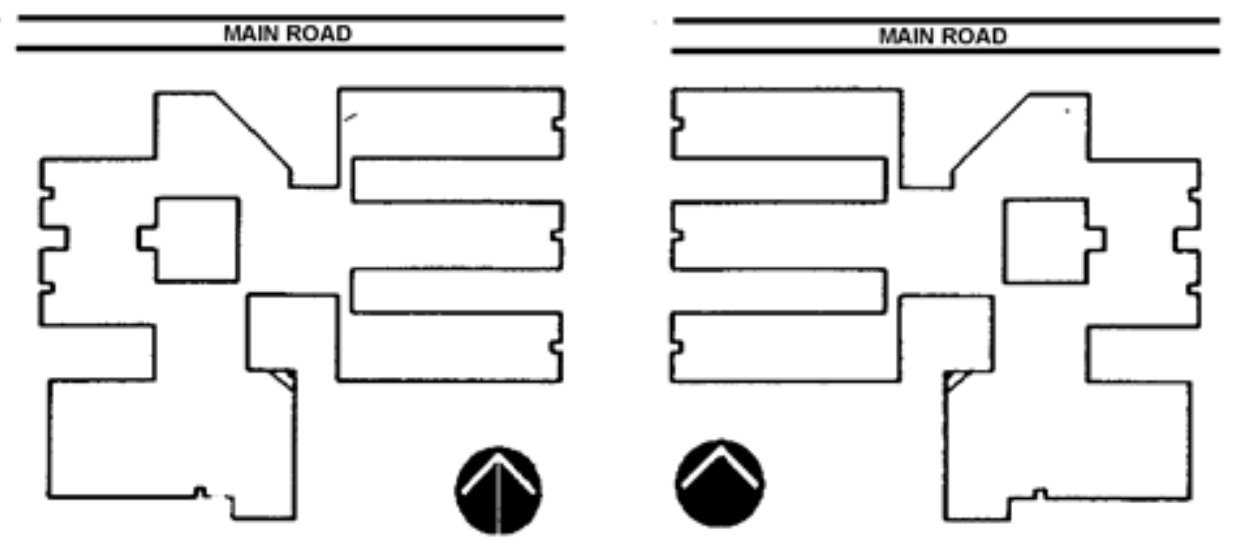

Figure 3-18 High School Floor Plan Example-North Entry
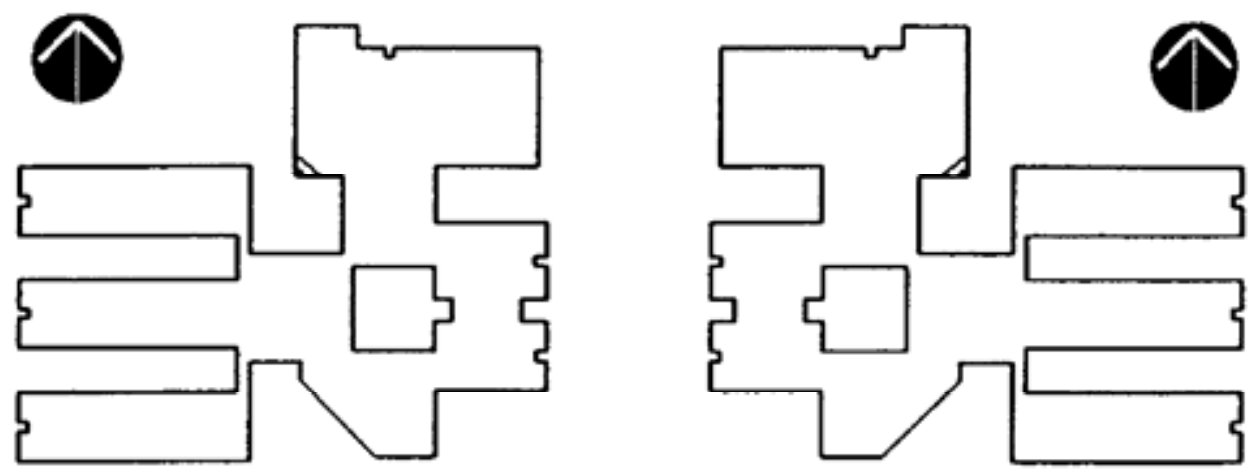

Figure 3-19 High School Floor Plan Example-South Entry 


\subsubsection{Space Programming Profiles}

The SPM report documented the typical school space types (Table 3-4), but did not provide the space profile information needed to fully develop the K-12 AEDG models. We reviewed various K-12 school programming profiles to obtain typical space profiles, including area by space type. The North Carolina Schools area profiles were typical and the most detailed and complete (North Carolina 2007). They include specific space types and the size of the spaces based on the number of students and on the school type (elementary, middle, or high school). The North Carolina-suggested space profiles for elementary, middle, and high schools are shown in Table 3-9 to Table 3-14.

These data help to define the area for each space type included in the K-12 AEDG elementary, middle, and high school models. For the K-12 AEDG elementary school model, the number of students is 650, which corresponds to the third column in Table 3-9. For the K-12 AEDG middle school model, the number of students is 800 , which corresponds to the third column in Table 3-10 and Table 3-11. For the K-12 AEDG high school model, the number of students is 1,200, which corresponds to the third column in Table 3-12 through Table 3-14. Each has significant space requirements for corridors, restrooms, and mechanical rooms; for elementary schools, $27 \%$ of the total floor area is for these spaces. For middle and high schools, $28 \%$ of the total floor area is for corridors, restrooms, and mechanical rooms. 
Table 3-9 North Carolina Elementary School Typical Space Profiles

(Extracted from North Carolina 2007)

ELEMENTARY SCHOOL PK-5

TYPICAL SPACE PROFILE

\begin{tabular}{|c|c|c|c|c|c|c|c|c|c|c|}
\hline & & & & & & & & & & $0 / 6 / 2004$ \\
\hline Number of students* & \multicolumn{2}{|c|}{300} & \multicolumn{2}{|c|}{450} & \multicolumn{2}{|c|}{600} & \multicolumn{2}{|c|}{700} & \multicolumn{2}{|c|}{800} \\
\hline Core capacity & \multicolumn{2}{|c|}{300} & \multicolumn{2}{|c|}{600} & \multicolumn{2}{|c|}{700} & \multicolumn{2}{|c|}{800} & \multicolumn{2}{|c|}{920} \\
\hline Special Education (S/C) & \multicolumn{2}{|c|}{1} & \multicolumn{2}{|c|}{1} & & & & & & \\
\hline Dance/Drama classrooms & & & & & & & & & & \\
\hline Pre-kindergarten clrms. & & & & & & & & & & \\
\hline Core Classrooms (K-5) & & & & & & & & & & \\
\hline Other Teaching Stations & & & & & & & & & & \\
\hline & No. & sq.ft. & No. & sq.ft. & No. & sq.ft. & No. & sq.ft. & No. & sq.ft. \\
\hline Elementary (PK-5) Classrooms & & & & & & & & & & \\
\hline Pre-K Classrooms @ 1200s.f. & 1 & 1,200 & 1 & 1,200 & 2 & 2,400 & 2 & 2,400 & 3 & 3,600 \\
\hline Kindergarten Clrms@1200s.f. & 3 & 3,600 & 4 & 4,800 & 5 & 6,000 & 6 & 7,200 & 6 & 7,200 \\
\hline Grade1 Clrms@1000s.f. & 2 & 2,000 & 3 & 3,000 & 5 & 5,000 & 5 & 5,000 & 6 & 6,000 \\
\hline Grade 2-3 Clrms@1000s.f. & 5 & 5,000 & 7 & 7,000 & 9 & 9,000 & 11 & 11,000 & 12 & 12,000 \\
\hline Grade 4-5 Clrms @ 850s.f. & 4 & 3,400 & 6 & 5,100 & 8 & 6,800 & 9 & 7,650 & 10 & 8,500 \\
\hline Resource roomss@450s.f. & 2 & 900 & 4 & 1,800 & 5 & 2,250 & 6 & 2,700 & 7 & 3,150 \\
\hline Exceptional S/C @ 1200s.f. & 1 & 1,200 & 1 & 1,200 & 1 & 1,200 & 2 & 2,400 & 2 & 2,400 \\
\hline Arts/Computer Classrooms & & & & & & & & & & \\
\hline Art (w/150 sf stor/kiln) & & & 1 & 1,350 & 1 & 1,350 & 1 & 1,350 & 1 & 1,350 \\
\hline Music & & & 1 & 1,000 & 1 & 1,000 & 1 & 1,000 & 1 & 1,000 \\
\hline Dance/Drama & & & & & & & & & 1 & 1,800 \\
\hline Computer Clrms@ @ 850s.f. & 1 & 850 & 1 & 850 & 1 & 850 & 1 & 850 & 1 & 850 \\
\hline Art/Project room & 1 & 1,000 & & & & & & & & \\
\hline classrooms total area & & 19,150 & & 27,300 & & 35,850 & & 41,550 & & 47,850 \\
\hline Media Center & & & & & & & & & & \\
\hline Media RLV (sf/student \& total sf) & 6.00 & 1,800 & 4.86 & 2,914 & 4.48 & 3,133 & 4.10 & 3,276 & 4.00 & 3,680 \\
\hline Support spaces & & 1,200 & & 1,200 & & 1,200 & & 1,500 & & 1,500 \\
\hline sub-total & & 3,000 & & 4,114 & & 4,333 & & 4,776 & & 5,180 \\
\hline Food Service & & & & & & & & & & \\
\hline Dining (no. of servings) & 2.3 & 1,800 & 3 & 2,800 & 3 & 3,267 & 3 & 3,733 & 3 & 4,293 \\
\hline Kitchen & & 1,261 & & 1,518 & & 1,938 & & 1,938 & & 2,208 \\
\hline Serving (serving lines) & 1 & 400 & 2 & 620 & 2 & 620 & 2 & 620 & 2 & 620 \\
\hline sub-total & & 3,461 & & 4,938 & & 5,825 & & 6,291 & & 7,121 \\
\hline Physical Education & & & & & & & & & & \\
\hline Multipurpose & 1 & 3,600 & 1 & 3,600 & 1 & 4,000 & 1 & 4,400 & 1 & 4,880 \\
\hline Stage & & 600 & & 600 & & 600 & & 600 & & 850 \\
\hline Storage/Office & & 450 & & 450 & & 450 & & 450 & & 600 \\
\hline sub-total & & 4,650 & & 4,650 & & 5,050 & & 5,450 & & 6,330 \\
\hline Administration,Misc. & & & & & & & & & & \\
\hline Principal & & 200 & & 200 & & 200 & & 200 & & 200 \\
\hline Assistant Principal @150 & & & 1 & 150 & 1 & 150 & 2 & 300 & 2 & 300 \\
\hline Secretary/reception & & 300 & & 400 & & 400 & & 400 & & 400 \\
\hline Secretary & 1 & 150 & 1 & 150 & 1 & 150 & 2 & 300 & 2 & 300 \\
\hline Sims & & 120 & & 120 & & 120 & & 120 & & 120 \\
\hline Health & & 120 & & 200 & & 200 & & 200 & & 200 \\
\hline Office work room & & 190 & & 230 & & 240 & & 250 & & 270 \\
\hline Conference & & 200 & & 200 & & 200 & & 250 & & 250 \\
\hline Records & & 90 & & 130 & & 140 & & 150 & & 170 \\
\hline Office storage & & 90 & & 130 & & 140 & & 150 & & 170 \\
\hline Guidance room & & 300 & & 300 & & 300 & & 300 & & 300 \\
\hline Office/testing@150 & 1 & 150 & 2 & 300 & 2 & 300 & 3 & 450 & 3 & 450 \\
\hline Other student services & & 150 & & 150 & & 150 & & 200 & & 200 \\
\hline Teacher workroom & & 300 & & 450 & & 450 & & 600 & & 600 \\
\hline Teacher lounge(s) & & 300 & & 450 & & 450 & & 600 & & 600 \\
\hline Itinerant teacher offices & 2 & 200 & 3 & 300 & 4 & 400 & 4 & 400 & 5 & 500 \\
\hline Book storage & & 650 & & 800 & & 850 & & 900 & & 960 \\
\hline General storage \& receiving & & 750 & & 900 & & 950 & & 1,000 & & 1,060 \\
\hline sub-total & & 4,260 & & 5,560 & & 5,790 & & 6,770 & & 7,050 \\
\hline Total Net Sq. Ft. & & 34,521 & & 46,562 & & 56,848 & & 64,837 & & 73,531 \\
\hline Circulation, toilets \& Mech. @ 37.0\% & & 12,773 & & 17,228 & & 21,034 & & 23,990 & & 27,206 \\
\hline GRAND TOTAL (sq.ft.) & & 47,294 & & 63,790 & & 77,882 & & 88,827 & & 100,737 \\
\hline Total Capacity (K-5+Pre-K+S/C) & & 342 & & 478 & & 653 & & 752 & & 838 \\
\hline Sq.Ft./Student (incl. Pre-K+S/C) & & 138 & & 133 & & 119 & & 118 & & 120 \\
\hline
\end{tabular}


Table 3-10 North Carolina Middle School Typical Space Profiles

(Extracted from North Carolina 2007)

MIDDLE SCHOOL 6-8

TYPICAL SPACE PROFILE

\begin{tabular}{|c|c|c|c|c|c|c|c|c|c|c|}
\hline Number of students & \multicolumn{2}{|r|}{475} & \multicolumn{2}{|r|}{650} & \multicolumn{2}{|r|}{800} & \multicolumn{2}{|c|}{950} & \multicolumn{2}{|c|}{1120} \\
\hline Core capacity & \multicolumn{2}{|r|}{650} & \multicolumn{2}{|r|}{800} & \multicolumn{2}{|r|}{950} & \multicolumn{2}{|c|}{1120} & \multicolumn{2}{|c|}{1120} \\
\hline Exceptional Children (S/C) & \multicolumn{2}{|r|}{1} & \multicolumn{2}{|r|}{2} & \multicolumn{2}{|r|}{2} & \multicolumn{2}{|c|}{3} & \multicolumn{2}{|c|}{3} \\
\hline Dance/Drama classrooms & & & & & & 1 & & & & \\
\hline Auditorium (Y/N) & & $\mathbf{N}$ & & $\mathrm{N}$ & & $\mathrm{N}$ & & & & \\
\hline Number of seats & & & & & & & & & & \\
\hline & No. & sq. ft. & No. & sq. ft. & No. & sq. ft. & No. & sq. ft. & No. & sq. ft. \\
\hline Classrooms: & & & & & & & & & & \\
\hline Sixth grade & & & & & & & & & & \\
\hline Math/Sci Clrms@1000s.t. & 1 & 1,000 & & & 1 & 1,000 & & & 1 & 1,000 \\
\hline LASSS/Math Clrms@ @50s.f. & 4 & 3,400 & 6 & 5,100 & 7 & 5,950 & 9 & 7,650 & 10 & 8,500 \\
\hline Science Clrms@1100s.f. & 1 & 1,100 & 2 & 2,200 & 2 & 2.200 & 3 & 3,300 & 3 & 3,300 \\
\hline Science Prep/Stor @ 200s.f. & 1 & 200 & 1 & 200 & 1 & 200 & 2 & 400 & 2 & 400 \\
\hline Seventh grade & & & & & & & & & & \\
\hline Math/Sci Clrms@1000s.t. & 1 & 1,000 & & & 1 & 1,000 & & & 1 & 1,000 \\
\hline LASS/Math Cirms @8 850s.t. & 4 & 3,400 & 6 & 5,100 & 7 & 5,950 & 9 & 7,650 & 10 & 8,500 \\
\hline Science Clrms@1100s.f. & 1 & 1,100 & 2 & 2,200 & 2 & 2,200 & 3 & 3,300 & 3 & 3,300 \\
\hline Science Prep/Stor (d) 200 s.t. & 1 & 200 & 1 & 200 & 1 & 200 & 2 & 400 & 2 & 400 \\
\hline Eighth grade & & & & & & & & & & \\
\hline Math/Sci Clrms@1000s.f. & 1 & 1,000 & & & 1 & 1,000 & & & 1 & 1,000 \\
\hline LASS/Math Clrms @ 850s.t. & 4 & 3,400 & 6 & 5,100 & 7 & 5,950 & 9 & 7,650 & 10 & 8,500 \\
\hline Science Clrms@1100s.f. & 1 & 1,100 & 2 & 2,200 & 2 & 2,200 & 3 & 3,300 & 3 & 3,300 \\
\hline Science Prep/Stor@200s.f. & 1 & 200 & 1 & 200 & 1 & 200 & 2 & 400 & 2 & 400 \\
\hline Small Group/Exceptional & & & & & & & & & & \\
\hline Resource rooms @ 450 s.f. & 4 & 1,800 & 5 & 2,250 & 6 & 2,700 & 7 & 3,150 & 8 & 3,600 \\
\hline Exceptional S.C 1200 s.f. & 1 & 1,200 & 2 & 2,400 & 2 & 2,400 & 3 & 3,600 & 3 & 3,600 \\
\hline Arts/Computer & & & & & & & & & & \\
\hline Art (w/200sf stor) & 1 & 1,400 & 1 & 1.400 & 1 & 1,400 & 1 & 1,400 & 2 & 2,800 \\
\hline Instrumental music (w/stor) & & & 1 & 1,600 & 1 & 1,750 & 1 & 1,920 & 1 & 1,920 \\
\hline Vocal Music & & & 1 & 1,200 & 1 & 1,200 & 1 & 1,200 & 1 & 1,200 \\
\hline Dance/Drama & & & & & 1 & 1,800 & 1 & 1,800 & 2 & 3,600 \\
\hline Computer Clrms @ 1000 s.t. & 1 & 1,000 & 1 & 1,000 & 2 & 2,000 & 2 & 2,000 & 2 & 2,000 \\
\hline Music @ 1200 (w/stor) & 1 & 1,400 & & & & & & & & \\
\hline Vocational & & & & & & & & & & \\
\hline Keyboarding lab & 1 & 1,000 & 1 & 1,000 & 1 & 1,000 & 1 & 1,000 & 1 & 1,000 \\
\hline Exploratory labs & 2 & 2,800 & 2 & 2.800 & 2 & 2,800 & 3 & 4,200 & 3 & 4,200 \\
\hline classrooms total area & & 27,700 & & 36,150 & & 45,100 & & 54,320 & & 63,520 \\
\hline Media Center & & & & & & & & & & \\
\hline Media RLV (sfistu \& sf) & 5.33 & 3,467 & 4.83 & 3,868 & 4.34 & 4,118 & 4.00 & 4,480 & 4.00 & 4,480 \\
\hline Support spaces & & 1,800 & & 1,800 & & 1,800 & & 2,000 & & 2,000 \\
\hline sub-total & & 5,267 & & 5,668 & & 5,918 & & 6,480 & & 6,480 \\
\hline Food Service & & & & & & & & & & \\
\hline Dining (\# servings \& sf) & 3 & 3,033 & 3 & 3,733 & 3 & 4,433 & 3 & 5,227 & 3 & 5,227 \\
\hline Kitchen & & 1,938 & & 1,938 & & 2.208 & & 2,208 & & 2,208 \\
\hline Serving (\# serv. lines \&sf) & 2 & 620 & 2 & 620 & 2 & 620 & 2 & 620 & 2 & 620 \\
\hline sub-total & & 5,591 & & 6,291 & & 7,261 & & 8,055 & & 8,055 \\
\hline Physical Education & & & & & & & & & & \\
\hline Gym (incl lockers) & 1 & 10,000 & 1 & 10,000 & 1 & 12,000 & 1 & 12,000 & 1 & 12,000 \\
\hline Auxiliary Gym & & & & & & & & & 1 & 5,000 \\
\hline Health/PE Clms @750 s.f. & 1 & 750 & 2 & 1,500 & 2 & 1,500 & 3 & 2,250 & 3 & 2,250 \\
\hline sub-total & & 10,750 & & 11,500 & & 13,500 & & 14,250 & & 19,250 \\
\hline Auditorium & & & & & & & & & & \\
\hline Seating & & & & & & & 448 & 4,032 & 448 & 4,032 \\
\hline Stage/dress./stor & & & & & & & & 2,500 & & 2,500 \\
\hline Lobby & & & & & & & & 1,000 & & 1,000 \\
\hline sub-total & & & & & & & & 7,532 & & 7,532 \\
\hline
\end{tabular}


Table 3-11 North Carolina Middle School Typical Space Profiles (Cont.)

\begin{tabular}{|c|c|c|c|c|c|c|c|c|c|c|}
\hline Number of students & & 475 & & 650 & & 800 & & 950 & & 120 \\
\hline Core capacity & & 650 & & 800 & & 950 & & 120 & & 120 \\
\hline Administration,Misc. & & & & & & & & & & \\
\hline Principal & & 200 & & 200 & & 200 & & 200 & & 200 \\
\hline Asst Principal @150 & 1 & 150 & 1 & 150 & 2 & 300 & 2 & 300 & 2 & 300 \\
\hline Reception & & 400 & & 400 & & 400 & & 500 & & 500 \\
\hline Secretary & 1 & 150 & 2 & 300 & 2 & 300 & 2 & 300 & 2 & 300 \\
\hline Sims & & 150 & & 150 & & 150 & & 150 & & 150 \\
\hline Health & & 200 & & 200 & & 200 & & 200 & & 200 \\
\hline Office work room & & 230 & & 250 & & 270 & & 290 & & 290 \\
\hline Conference & & 200 & & 250 & & 250 & & 250 & & 250 \\
\hline Records & & 130 & & 150 & & 170 & & 190 & & 190 \\
\hline Office storage & & 130 & & 150 & & 170 & & 190 & & 190 \\
\hline Guidance room & & 300 & & 300 & & 300 & & 300 & & 300 \\
\hline Office/testing @ 150 & 2 & 300 & 3 & 450 & 3 & 450 & 4 & 600 & 4 & 600 \\
\hline Other student services & & 150 & & 200 & & 200 & & 200 & & 200 \\
\hline Team office/workrooms & 3 & 1,350 & 3 & 1,350 & 3 & 1,350 & 3 & 1,350 & 3 & 1,350 \\
\hline Teacher lounge(s) & & 450 & & 600 & & 600 & & 600 & & 600 \\
\hline Book storage & & 825 & & 900 & & 975 & & 1,060 & & 1,060 \\
\hline General storage & & 925 & & 1,000 & & 1,075 & & 1,160 & & 1,160 \\
\hline Commons & & 1,490 & & 1,600 & & 1,710 & & 1,840 & & 1,840 \\
\hline sub-total & & 7,730 & & 8,600 & & 9,070 & & 9,680 & & 9,680 \\
\hline Total Net Sq. Ft. & & 57,038 & & 68,209 & & 80,849 & & 100,317 & & 114,517 \\
\hline Circulation, toilets \& Mech.@ $39.0 \%$ & & 22,245 & & 26,602 & & 31,531 & & 39,124 & & 44,662 \\
\hline GRAND TOTAL SQ.FT. & & 79,283 & & 94,811 & & 112,380 & & 139,441 & & 159,179 \\
\hline Sq.Ft/Student & & 167 & & 146 & & 140 & & 147 & & 142 \\
\hline Optimal capacity & & 478 & & 644 & & 800 & & 966 & & 1,122 \\
\hline Classroomsigrade & & 6 & & 8 & & 10 & & 12 & & 14 \\
\hline Teaching Stations (core) & & 18 & & 24 & & 30 & & 36 & & 42 \\
\hline
\end{tabular}

"Typical Space Profiles" are examples of possible school space programs that apply the NC Public Schools Facilities Guidelines. Profiles are not standards or mandates.

Auditoriums are not usually included in middle schools, but have been provided at some larger schools. 
Table 3-12 North Carolina High School Typical Space Profiles

(Extracted from North Carolina 2007)

\section{HIGH SCHOOL (9-12)}

TYPICAL SPACE PROFILE

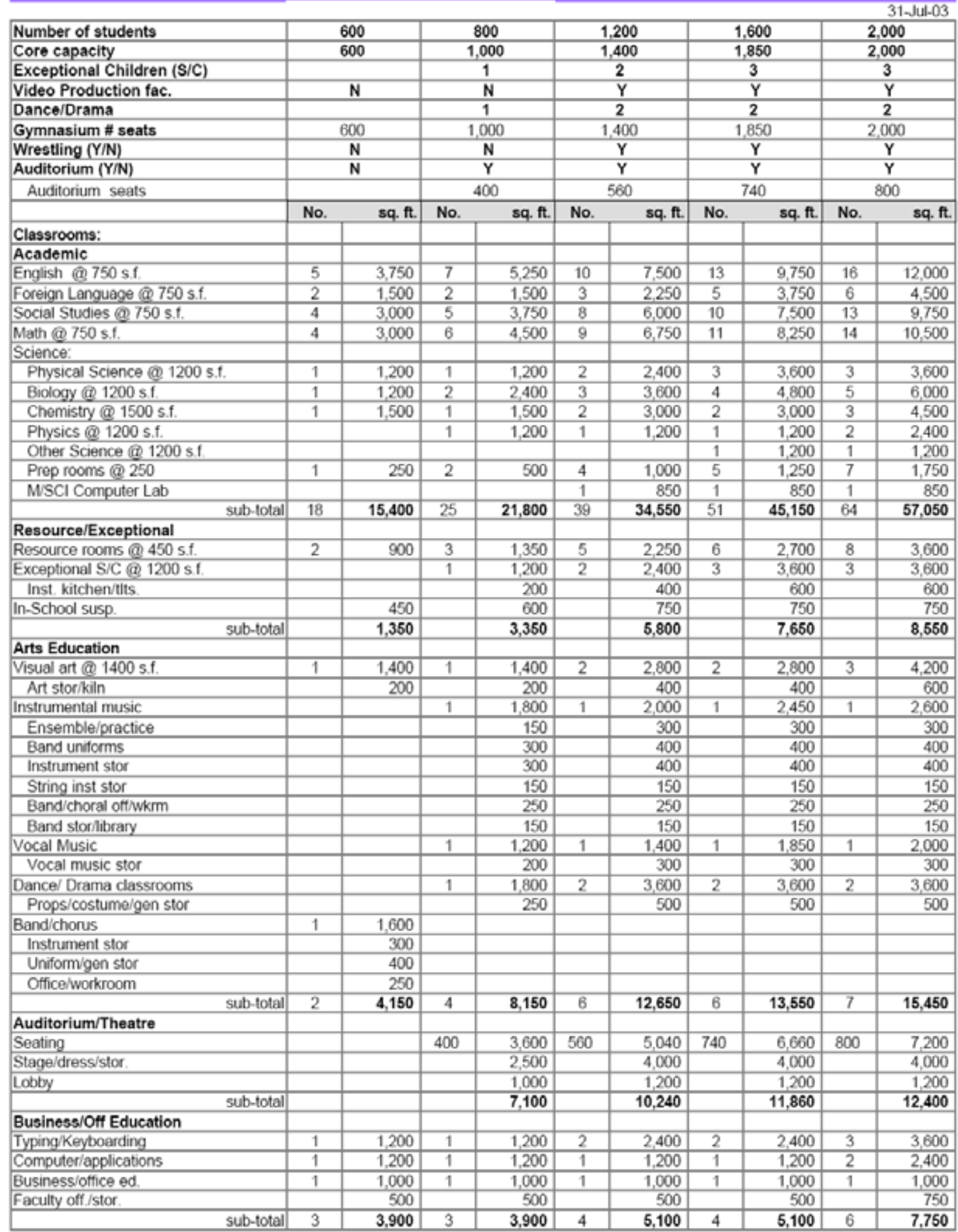


Table 3-13 North Carolina High School Typical Space Profiles (Cont.)

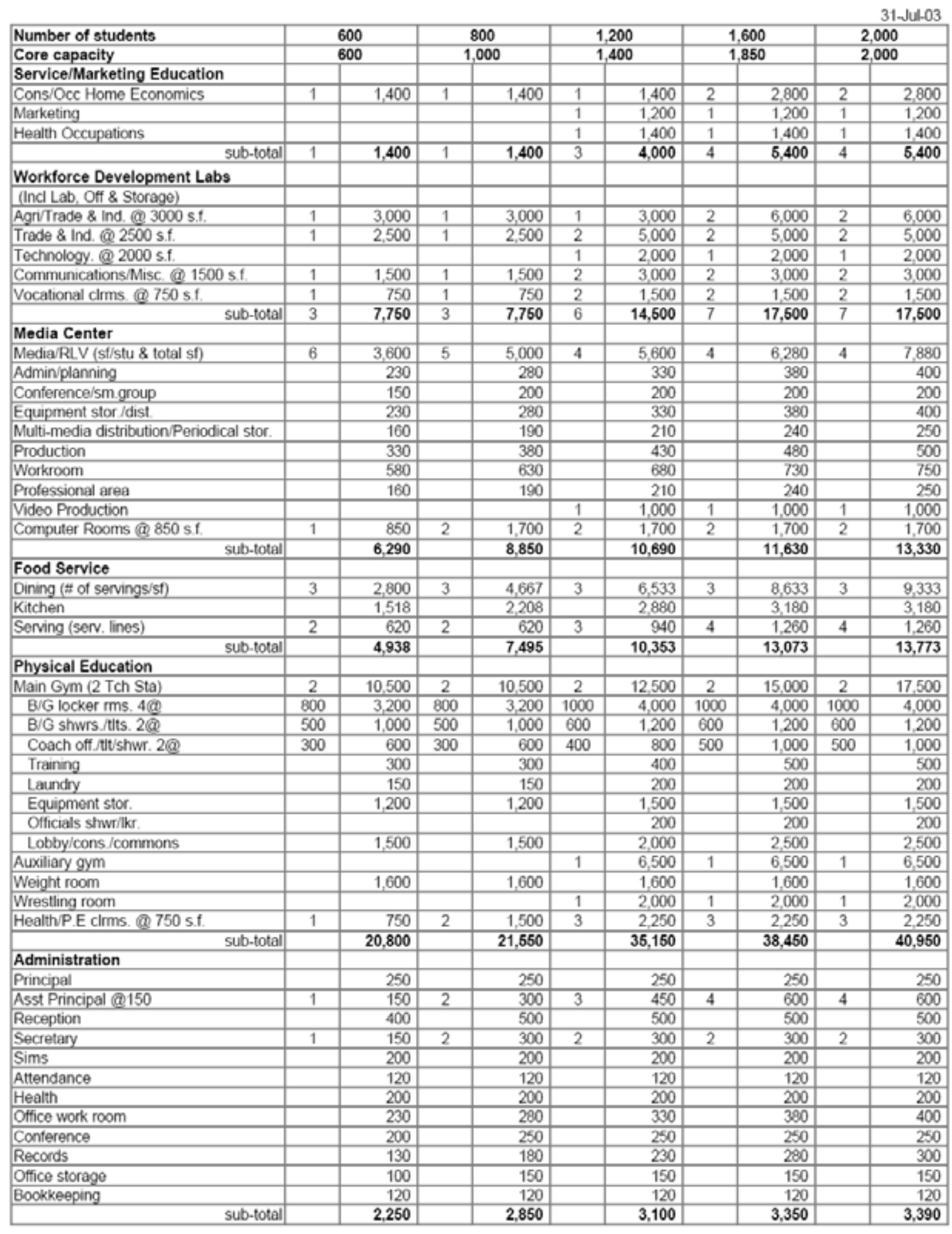


Table 3-14 North Carolina High School Typical Space Profiles (Cont.)

\begin{tabular}{|c|c|c|c|c|c|c|c|c|c|c|}
\hline \multirow{3}{*}{\begin{tabular}{|l|} 
Number of students \\
Core capacity \\
Guidance \\
\end{tabular}} & \multirow{2}{*}{\multicolumn{2}{|c|}{$\begin{array}{l}600 \\
600\end{array}$}} & \multirow{2}{*}{\multicolumn{2}{|c|}{$\begin{array}{c}800 \\
1,000\end{array}$}} & \multirow{2}{*}{\multicolumn{2}{|c|}{$\begin{array}{l}1,200 \\
1,400\end{array}$}} & \multirow{2}{*}{\multicolumn{2}{|c|}{$\begin{array}{l}1,600 \\
1,850\end{array}$}} & \multirow{2}{*}{\multicolumn{2}{|c|}{$\begin{array}{l}2,000 \\
2,000\end{array}$}} \\
\hline & & & & & & & & & & \\
\hline & \\
\hline Sect'y /nto center & & 600 & & 800 & & 1,000 & & 1,000 & & 1,000 \\
\hline Conference/testing & & 200 & & 250 & & 250 & & 250 & & 250 \\
\hline Counselor offices @ 150 & 2 & 300 & 3 & 450 & 4 & 600 & 5 & 750 & 5 & 750 \\
\hline Vocational counselor & & 150 & & 150 & & 150 & & 150 & & 150 \\
\hline Other student services & & 200 & & 200 & & 200 & & 200 & & 200 \\
\hline Student offices (yearbook, etc.) & & 500 & & 700 & & 800 & & 1,000 & & 1,000 \\
\hline sub-total & & 1,950 & & 2,550 & & 3,000 & & 3,350 & & 3,350 \\
\hline \multicolumn{11}{|l|}{ Staff Support } \\
\hline Teacher office/wkrms & & 600 & & 900 & & 1,350 & & 1,350 & & 1,350 \\
\hline Teacher lounge(s) & & 600 & & 900 & & 900 & & 900 & & 900 \\
\hline Floatinglitin. offices & 4 & 400 & 7 & 700 & 9 & 900 & 12 & 1,200 & 13 & 1,300 \\
\hline sub-total & & 1,600 & & 2,500 & & 3,150 & & 3,450 & & 3,550 \\
\hline \multicolumn{11}{|l|}{ Storage } \\
\hline Book storage & & 800 & & 1,000 & & 1,200 & & 1,430 & & 1,500 \\
\hline General storage/Receiving & & 900 & & 1,100 & & 1,300 & & 1,530 & & 1,600 \\
\hline sub-total & & 1,700 & & 2,100 & & 2,500 & & 2,960 & & 3,100 \\
\hline Total Net Sq. Ft. & & 73.478 & & 101,345 & & 154,783 & & 182.473 & & 205.543 \\
\hline Walls, toilets, circ, mech @ $39.0 \%$ & & 28,656 & & 39,525 & & 60,365 & & 71,164 & & 80,162 \\
\hline GRAND TOTAL SQ,FT. & & 102,134 & & 140,870 & & 215,148 & & 253,637 & & 285,705 \\
\hline Sq.Ft./Student & & 170 & & 176 & & 179 & & 159 & & 143 \\
\hline Optimal capacity & & 632 & & 856 & & 1,334 & & 1,638 & & 1,988 \\
\hline Total teaching stations & & 30 & & 40 & & 64 & & 78 & & 94 \\
\hline Students/teaching station & & 20 & & 20 & & 19 & & 21 & & 21 \\
\hline
\end{tabular}

"Typical Space Profiles" are examples of possible school space programs that apply the NC Public Schools Facilities Guidelines. Profiles are not standards or mandates. 


\subsubsection{Prototype Model Summary}

This section summarizes how we used the results of the schools characteristics data to formulate the prototype models for the AEDG for K-12 Schools. For school characteristics not specified by ASHRAE 90.1-1999, ASHRAE 90.1-2004, or ASHRAE 62.1-2001 but needed to develop code compliant baseline and low-energy models, we attempted to document "typical" K-12 practices, characteristics, and features. We used CBECS 2003, the SPM Annual Construction Review, the ASU Annual Construction Review, and input from the K-12 AEDG PC to document the following "typical" K-12 school characteristics to formulate the prototype K-12 AEDG models.

The first characteristic to determine was the K-12 school type. Based on input from the project committee, industry standard K-12 school type classifications, and the typical space types included in the different "typical" K-12 school types, we determined that there was enough physical and operational variation over elementary, middle, and high schools to develop different prototypes for each. To determine the approximate size of each K-12 school type, we combined average sizes from ASU, SPM, and 2003 CBECS. The final size used in our K-12 AEDG models was determined by applying the space type recommendations from Section 3.2.3, the typical space types from SPM (Table 3-4), and the number of students (from ASU and SPM). The actual K-12 AEDG model sizes are shown in relation to average school sizes from ASU, SPM, and 2003 CBECS in Table 3-15 and Table 3-16. Additional inputs, K-12 AEDG characteristic, and sources that we reviewed are shown in Table 3-17.

Table 3-15 Elementary/Middle School National Average Schools Sizes: ASU, SPM, AEDG, CBECS

\begin{tabular}{|c|c|c|c|c|c|c|}
\hline \multirow{2}{*}{$\begin{array}{c}\text { National } \\
\text { Averages }\end{array}$} & \multicolumn{3}{|c|}{ Elementary School } & \multicolumn{3}{c|}{ Middle School } \\
\cline { 2 - 7 } & ASU & SPM & $\begin{array}{c}\text { AEDG } \\
\text { Prototype }\end{array}$ & ASU & SPM & $\begin{array}{c}\text { AEDG } \\
\text { Prototype }\end{array}$ \\
\hline \hline \multirow{2}{*}{ Size $\left(\mathrm{ft}^{2}\right)$} & 73,000 & 80,000 & $\mathbf{7 3 , 9 3 0}$ & 104,880 & 119,000 & $\mathbf{1 1 6 , 0 8 0}$ \\
\cline { 2 - 7 } & \multicolumn{3}{|c|}{77,174 national area weighted average 2003 CBECS } \\
\hline
\end{tabular}

Table 3-16 High School National Average Schools Sizes: ASU, SPM, AEDG, CBECS

\begin{tabular}{|l|c|c|c|}
\hline \multirow{2}{*}{$\begin{array}{c}\text { National } \\
\text { Averages }\end{array}$} & \multicolumn{3}{|c|}{ High School } \\
\cline { 2 - 4 } & ASU & SPM & AEDG Prototype \\
\hline \hline \multirow{2}{*}{ Size $\left(\mathrm{ft}^{2}\right)$} & 148,569 & 224,000 & $\mathbf{2 1 0 , 8 1 0}$ \\
\cline { 2 - 4 } & 223,963 & national area weighted average 2003 CBECS \\
\hline
\end{tabular}


Table 3-17 K-12 AEDG Prototype Characteristics and Data Sources

\begin{tabular}{|l|l|l|}
\hline School Characteristic & \multicolumn{1}{|c|}{ K-12 AEDG Prototype } & \multicolumn{1}{|c|}{ Source } \\
\hline \hline School Types & Elementary, middle, and high school & ASU, SPM, AEDG PC \\
\hline Form and Fabric & & $\begin{array}{l}\text { ASU, SPM, CBECS 2003, } \\
\text { AEDG PC }\end{array}$ \\
\hline Size & $\begin{array}{l}73,930 \mathrm{ft}^{2} \text { elementary, 116,080 } \mathrm{ft}^{2} \text { middle, } \\
210,810 \mathrm{ft}^{2} \text { high }\end{array}$ & CBECS 2003 \\
\hline Number of floors & 1 for elementary, 1 for middle, 2 for high & SPM, ASU, \\
\hline Number of students & Elementary: 650, middle: 800, high: 1200 & SPM \\
\hline Space types & See Table 3-4 & CBECS 2003, AEDG PC \\
\hline Constructions & Mass walls, insulation entirely above deck & AEDG PC \\
\hline Floor plan & $\begin{array}{l}\text { North- and south-facing classrooms similar to } \\
\text { example floor plans in Section 3.2.3.2 }\end{array}$ & CBECS 2003, AEDG PC \\
\hline Window Area & $35 \%$ fenestration to gross wall area & CBECS 2003, AEDG PC \\
\hline Operations & $\begin{array}{l}\text { Fully occupied during school hours, partially } \\
\text { occupied year round and into the evening }\end{array}$ & 2003 CBECS, AEDG PC \\
\hline Occupancy & $\begin{array}{l}1.1 \text { w/ft }{ }^{2} \text { for elementary, 1.0 W/ft }{ }^{2} \text { for middle } \\
\text { and high }\end{array}$ & AEDG PC \\
\hline Peak plug loads & Fully heated and cooled & CBECS 2003 \\
\hline HVAC & $\begin{array}{l}\text { Baseline: PSZ } \\
\text { Low-energy: PSZ, PVAV, and VAV }\end{array}$ & \\
\hline System types & & \\
\hline
\end{tabular}

\subsubsection{Space Type Sizes and Layout}

We used the average sizes of elementary, middle, and high schools, and the "typical" space types as documented in Section 3.2.2, combined with the North Carolina Schools area profiles from Section 3.2.3.3 and the sample floor plans from Section 3.2.3.2, to develop our prototypical floor plans and space layouts. In general, $30 \mathrm{ft} \times 32 \mathrm{ft}(9.1 \mathrm{~m} \times 9.8 \mathrm{~m})$ double loaded classrooms, $10 \mathrm{ft}(3.0 \mathrm{~m})$ wide corridors in the elementary schools and $15 \mathrm{ft}(4.6 \mathrm{~m})$ wide corridors and lockers in the middle and high schools were used to construct the prototype models. Classrooms at the end of a wing are modeled as individual thermal zones, and classrooms with similar configurations are modeled as a lumped thermal zone. Classrooms that are expected to have significantly different use or internal gain schedules, such as the computer classrooms or extended use/community use classrooms, are modeled as separate zones. The classrooms were located in a configuration similar to the example school layouts as shown in Section 3.2.3.2. A main corridor and lobby separate the classroom wing from the support spaces, located on the east side of the prototype model configurations. The overall dimensions are:

- Elementary school: $270 \mathrm{ft}$ by $340 \mathrm{ft}(82 \mathrm{~m}$ by $104 \mathrm{~m})$

- Middle school: $450 \mathrm{ft}$ by $300 \mathrm{ft}(137 \mathrm{~m}$ by $91 \mathrm{~m})$

- High school: $465 \mathrm{ft}$ by $340 \mathrm{ft}$ (142 m by $104 \mathrm{~m})$

Total space sizes of the prototype models are shown in Table 3-18. The floor plans for the elementary, middle, and high school prototypes are shown in Figure 3-16 through Figure 3-23. 
Table 3-18 Total Space Sizes Included in the AEDG Prototypes

\begin{tabular}{|c|c|c|c|c|c|c|}
\hline \multirow[b]{2}{*}{ Space Type } & \multicolumn{2}{|c|}{ Elementary School } & \multicolumn{2}{|c|}{ Middle School } & \multicolumn{2}{|c|}{ High School } \\
\hline & $\begin{array}{c}\text { Total Size } \\
\left(\mathrm{fft}^{2}\right)\end{array}$ & $\begin{array}{l}\% \text { of } \\
\text { total }\end{array}$ & $\begin{array}{c}\text { Total Size } \\
\left(\mathrm{ft}^{2}\right)\end{array}$ & $\begin{array}{l}\% \text { of } \\
\text { total }\end{array}$ & $\begin{array}{c}\text { Total Size } \\
\left(\mathrm{ftt}^{2}\right)\end{array}$ & $\begin{array}{l}\% \text { of } \\
\text { total }\end{array}$ \\
\hline $\begin{array}{l}\text { Classrooms (all types } \\
\text { except computer } \\
\text { classrooms) }\end{array}$ & 35,443 & $47.9 \%$ & 47,161 & $40.6 \%$ & 64,108 & $30.4 \%$ \\
\hline Offices & 4,745 & $6.4 \%$ & 8,586 & $7.4 \%$ & 11,449 & $5.4 \%$ \\
\hline Multipurpose room/gym & 3,841 & $5.2 \%$ & 12,008 & $10.3 \%$ & 34,690 & $16.5 \%$ \\
\hline Computer classrooms & 1,743 & $2.4 \%$ & 2,227 & $1.9 \%$ & 10,265 & $4.9 \%$ \\
\hline Kitchen & 1,808 & $2.4 \%$ & 2,324 & $2.0 \%$ & 2,324 & $1.1 \%$ \\
\hline Cafeteria & 3,389 & $4.6 \%$ & 5,229 & $4.5 \%$ & 6,714 & $3.2 \%$ \\
\hline Media center & 4,293 & $5.8 \%$ & 5,810 & $5.0 \%$ & 9,038 & $4.3 \%$ \\
\hline Corridors/lobby & 13,913 & $18.8 \%$ & 25,351 & $21.8 \%$ & 49,711 & $23.6 \%$ \\
\hline Mechanical/restrooms & 4,756 & $6.4 \%$ & 7,381 & $6.4 \%$ & 11,879 & $5.6 \%$ \\
\hline Auditorium & 0 & $0.0 \%$ & 0 & $0.0 \%$ & 10,631 & $5.0 \%$ \\
\hline Total & 73,932 & & 116,079 & & 210,810 & \\
\hline
\end{tabular}

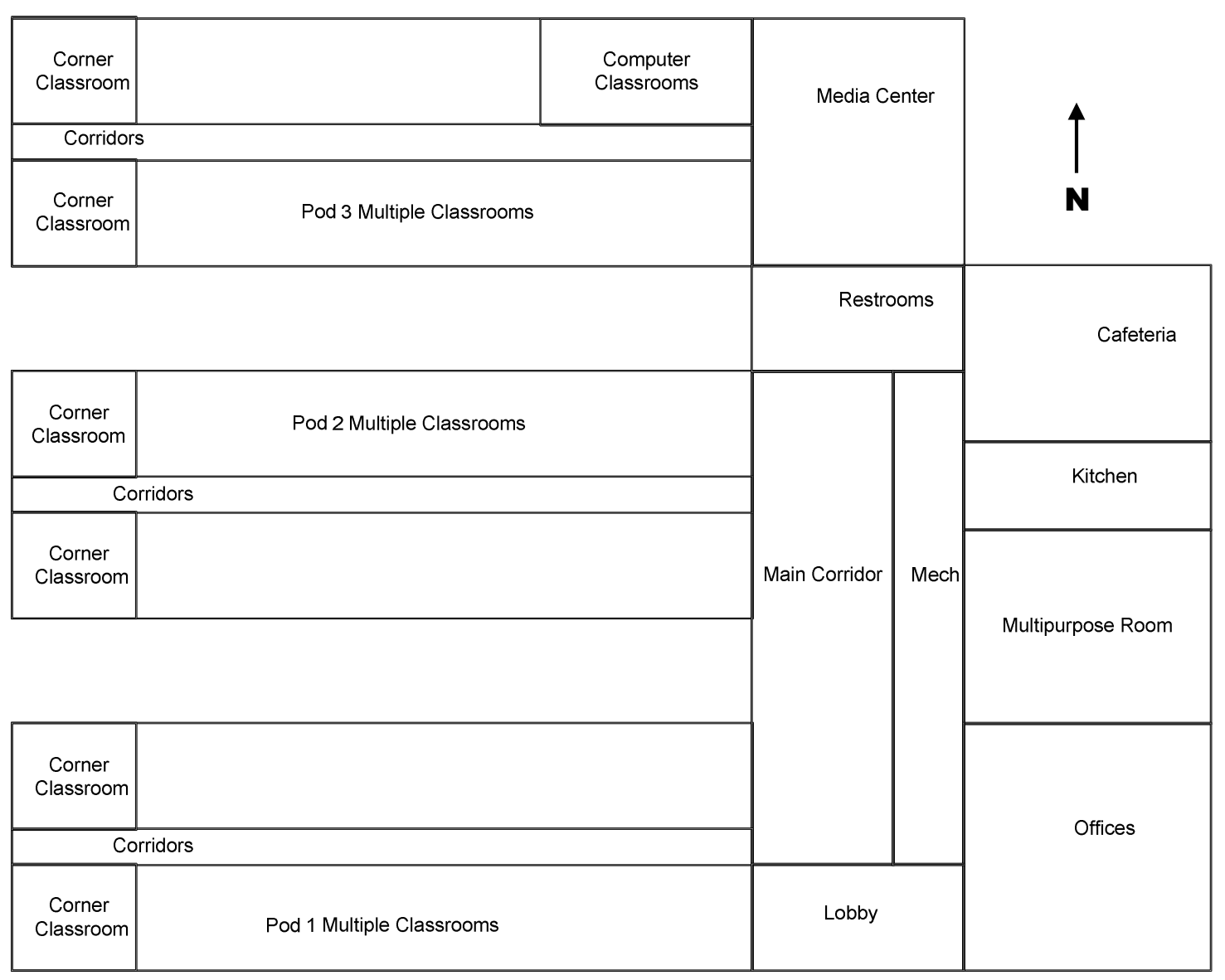

Figure 3-20 Elementary School Prototype Floor Plan 


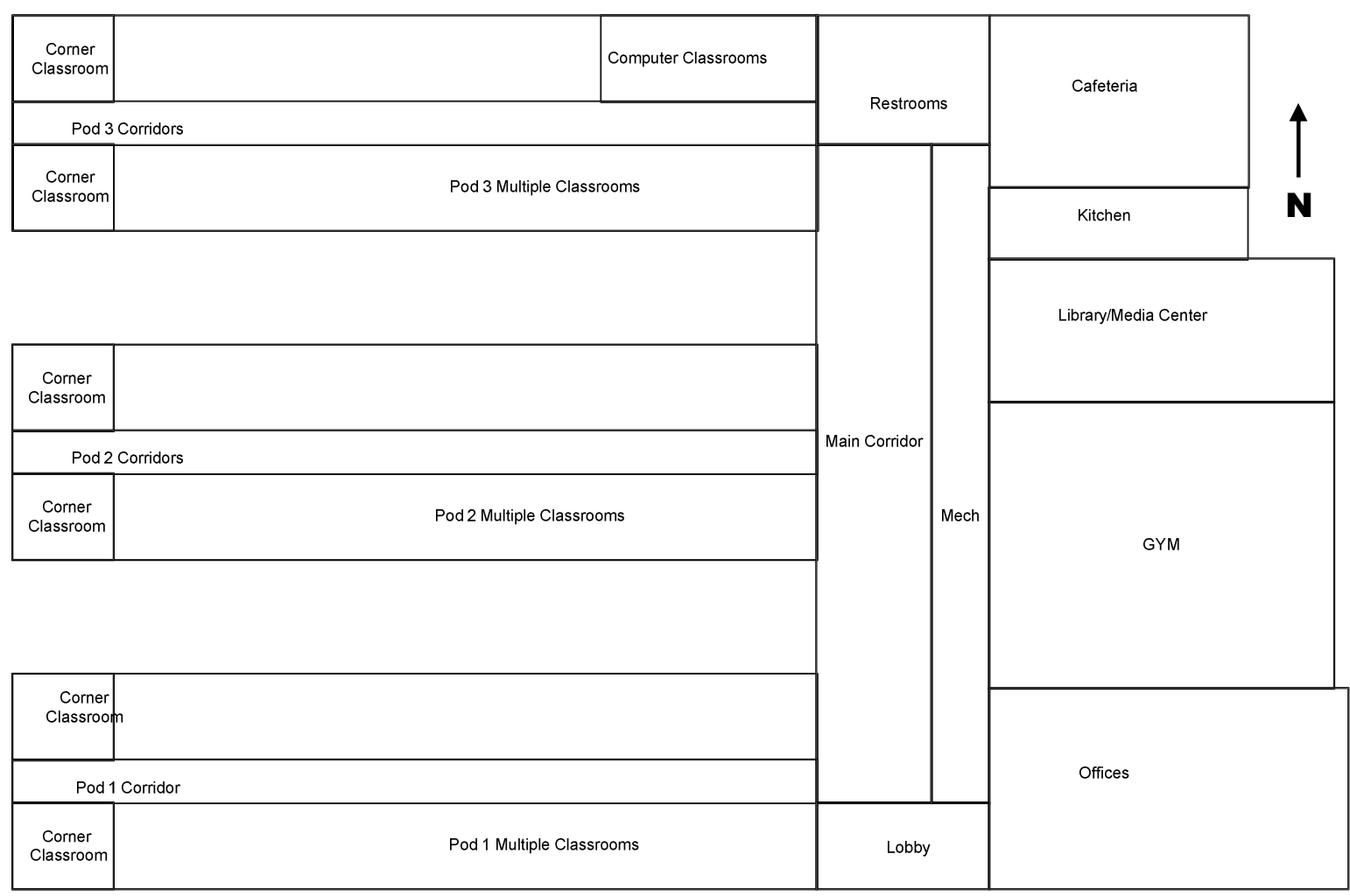

Figure 3-21 Middle School Prototype Floor Plan

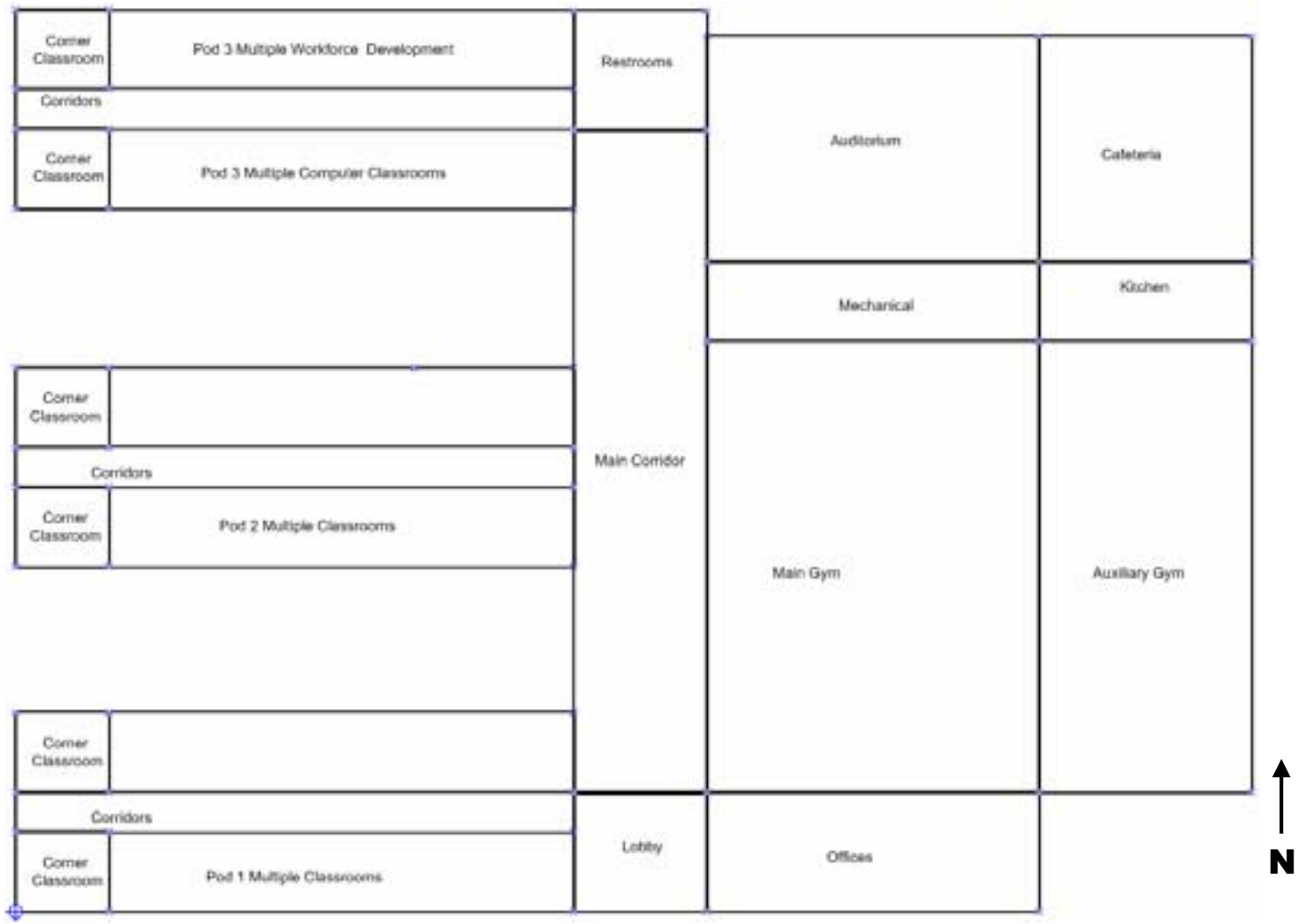

Figure 3-22 High School Prototype First Floor Plan 


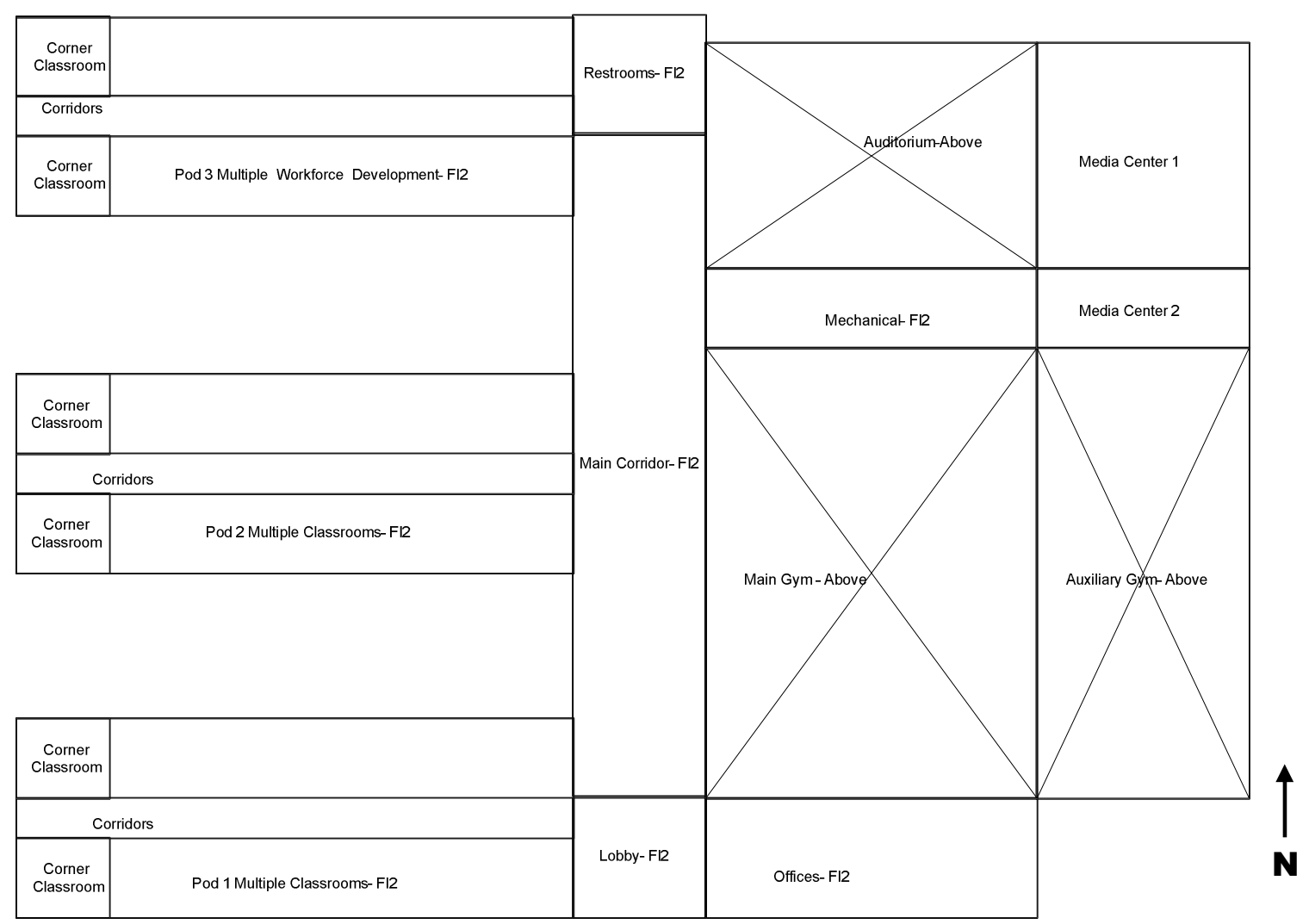

Figure 3-23 High School Prototype Second Floor Plan

\subsection{Baseline Model Development and Assumptions}

This section contains a topic-by-topic description of the baseline building models EnergyPlus model inputs, including the building form and floor plate, envelope characteristics, building internal loads and operating schedules, ventilation rates and schedules, HVAC equipment efficiency, operation, control and sizing, fan power assumptions, and service water heating. The baseline models for the elementary, middle, and high schools were developed by applying the criteria in ASHRAE 90.1 and ASHRAE 62 to the prototype characteristics. We used the criteria in ASHRAE 90.1-1999 and ASHRAE 62-2001 for the baselines to calculate $30 \%$ savings for the K-12 AEDG recommendations. For the baselines needed to verify $30 \%$ savings for our DOE analysis, we updated the K-12 AEDG baselines to be minimally code compliant with ASHRAE 90.1-2004. The ASHRAE 90.1-1999 elementary school baseline inputs are summarized in a table format in Appendix C. The middle school ASHRAE 90.1-1999 baseline input tables are summarized in Appendix D, and the high school tables in Appendix E.

\subsubsection{Form and Floor Plate}

The prototype characteristics as documented in the previous section, combined with modeling assumptions, were used to generate the baseline models form and floor plate. The following form and floor plate modeling assumptions, as shown in Table 3-19, were scrutinized by the PC to verify they were typical characteristics for K-12 schools. The baseline fenestration to gross wall area and skylight area in the gym were determined based on the expected window and skylight area needed to provide full daylighting to the classrooms and gym. The fenestration was equally applied over all of the exterior walls. Per ASHRAE 90.1, Appendix G and LEED 2.2 modeling rules, the baseline fenestration and skylight area should be the same as the low-energy model. No overhangs were included. No plenums were modeled. 
Table 3-19 Selected Baseline Modeling Assumptions

\begin{tabular}{|l|c|}
\hline \multicolumn{1}{|c|}{ Model Parameters } & Value \\
\hline \hline Ceiling height & $13.1 \mathrm{ft}$ \\
\hline Fraction of fenestration to gross wall area & $35 \%$ \\
\hline Fraction of gym skylight to roof area & $4 \%$ \\
\hline Glazing sill height & $3.6 \mathrm{ft}$ \\
\hline
\end{tabular}

Renderings of the elementary, middle, and high school baseline models are shown in Figure 3-24, Figure 3-25, and Figure 3-26, respectively. Each rendering shows an isometric view from the southwest.

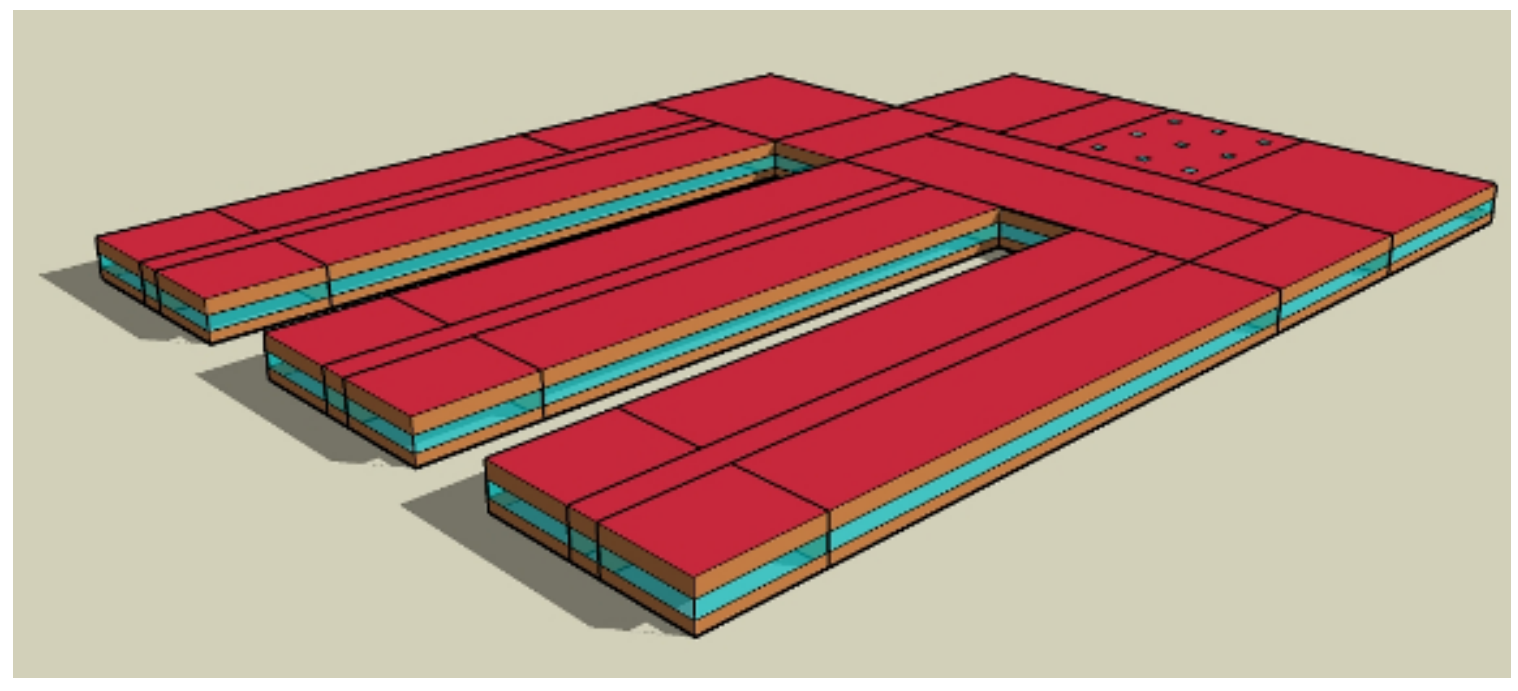

Figure 3-24 Elementary School Baseline Model Rendering: View from Southwest

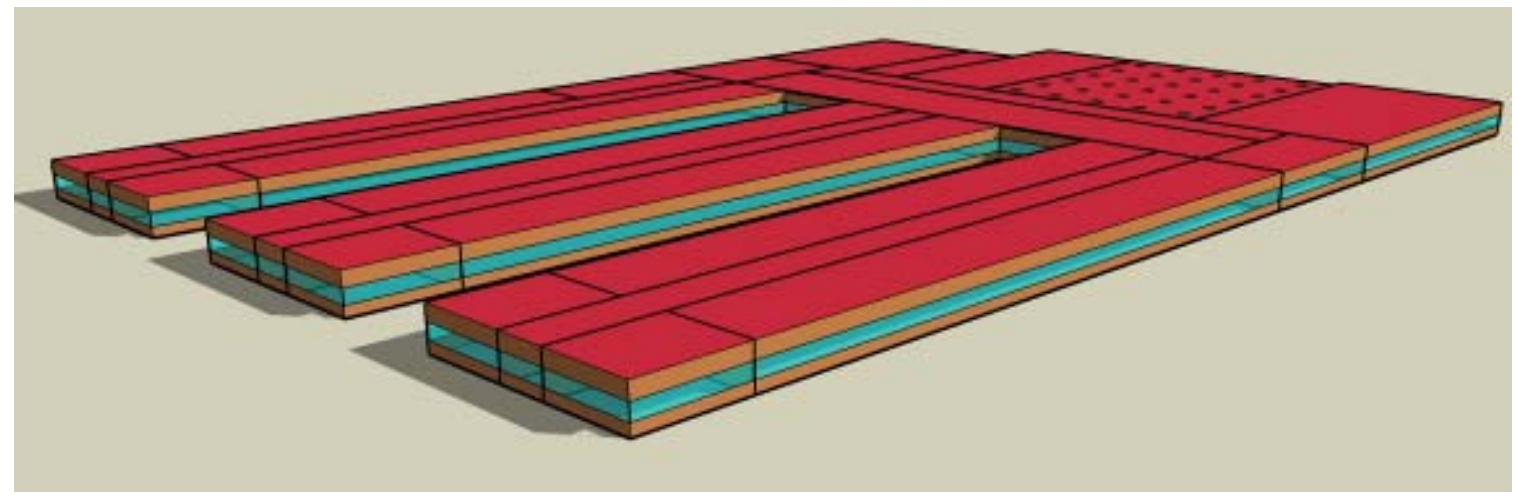

Figure 3-25 Middle School Baseline Model Rendering: View from Southwest 


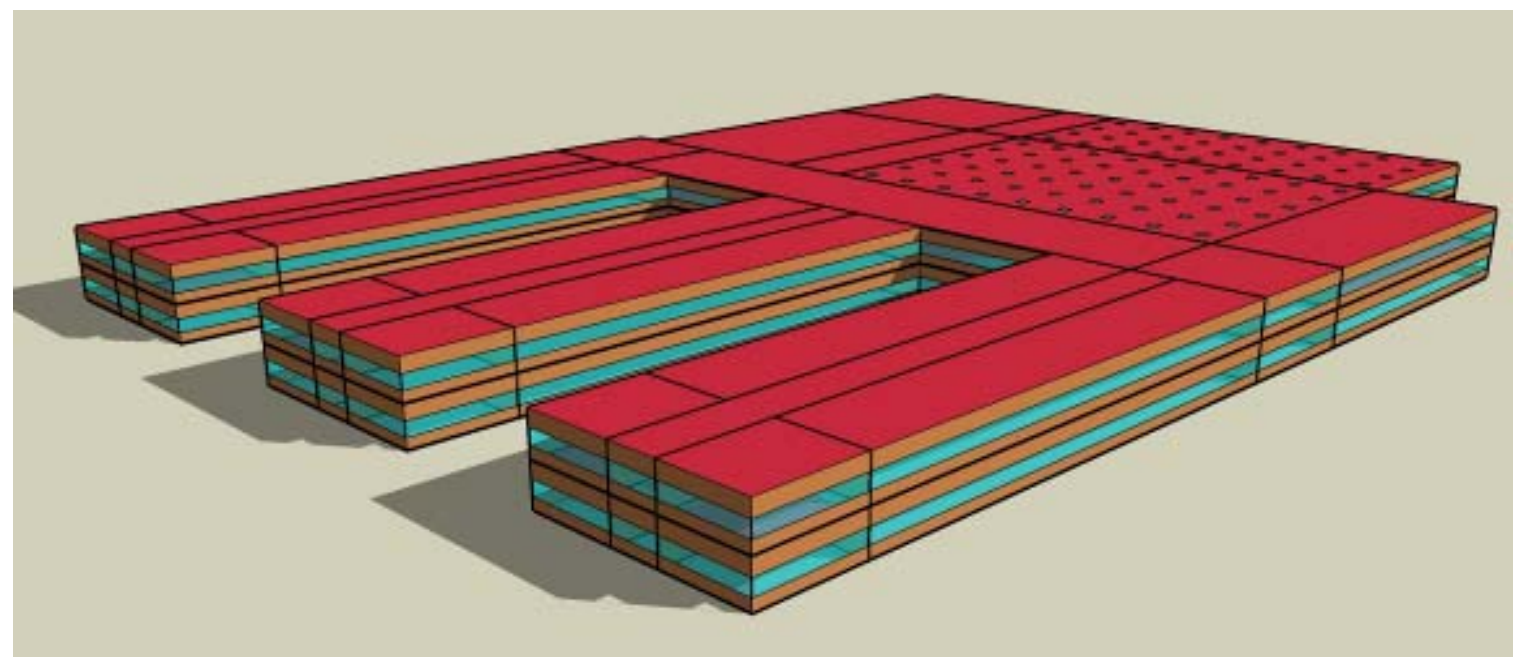

Figure 3-26 High School Baseline Model Rendering: View from Southwest

\subsubsection{Envelope}

The PC assumed, based on experience of those in the K-12 school construction industry, that schools are typically constructed with mass exterior walls, built-up roofs, and slab-on-grade floors. These envelope constructions represent common construction practices for $\mathrm{K}-12$ schools. There is some regional variation in construction techniques, but the PC felt that mass walls and built-up roofs were the most common due to their durability. This assumption is confirmed by the CBECS analysis of construction types, as shown in Figure 3-8.

The baseline school envelope characteristics were developed to meet the prescriptive design option requirements in accordance with ASHRAE 90.1-1999 Section 5.3. For the ASHRAE 90.1-2004 baselines, we used the prescriptive building envelope option in Section 5.5 of the Standard. Layer-bylayer descriptions of the constructions of exterior surfaces were used to model the building thermal envelope in EnergyPlus.

\subsubsection{Exterior Walls}

The baseline schools are modeled with mass wall constructions. The layers consisted of stucco, concrete block, rigid insulation, and gypsum board. The U-values of the insulation varied based on the respective standard and were adjusted to account for the standard film coefficients. R-values for most of the layers were derived from Appendix A of ASHRAE 90.1-1999. Insulation R-values for continuous insulations were selected to meet the insulation minimum R-values required in Appendix B (Building Envelope Requirements) of ASHRAE 90.1-1999, as defined by climate range. The baseline exterior wall U-values are in Appendix C through Appendix E. Similar wall insulation values were modeled in the ASHRAE 90.1-2004 baselines, as the mass wall requirements did not change significantly from ASHRAE 90.11999 to ASHRAE 90.1-2004. The mass wall was assembled assuming 8-in. medium weight concrete blocks with a density of $115 \mathrm{lb} / \mathrm{ft}^{3}$ and solid grouted cores. The mass wall includes the following layers:

- Exterior air film (calculated by EnergyPlus)

- 1 -in exterior Stucco

- 8-in. concrete block, $115 \mathrm{lb} / \mathrm{ft}^{3}$

- 1 -in. metal clips with rigid insulation (R-value various by climate)

- $\quad 0.5$-in. thick gypsum board 
- Interior air film (calculated by EnergyPlus).

To calculate the thermal performance of the interior and exterior air films, we used the "Detailed" algorithm in EnergyPlus for surface heat transfer film coefficients, which is based on linearized radiation coefficients that are separate from the convection coefficients as determined by surface roughness, wind speed, and terrain of the building's location. However, standardized combined film coefficients are used when targeting assembly U-factors.

\subsubsection{Roofs}

Built-up, rigid insulation above a structural metal deck roof was used in the elementary, middle, and high school baseline models. The layers consisted of the roof membrane, roof insulations, and metal decking. The U-values varied based on the respective standard and were adjusted to account for the standard film coefficients. Added insulation is continuous and uninterrupted by framing. Roof insulation R-values were also set to match the minimum roof insulation requirements in Appendix B (Building Envelope Requirements) in ASHRAE 90.1-1999, by climate. The baseline roof U-values are in Appendix C through Appendix E. Similar roof insulation values were modeled in the ASHRAE 90.1-2004 baselines, as the insulation above deck roof requirements did not change significantly from ASHRAE 90.1-1999 to ASHRAE 90.1-2004.

The Standard does not specify either absorptance or other surface assumptions. The roof exterior finish was assumed to be a single-ply roof membrane with gray ethylene propylene diene terpolymer membrane (EPDM) in the baseline models. Therefore, we assumed a solar reflectance of 0.3 , a thermal absorption of 0.9 , and a visible absorption of 0.7 .

\subsubsection{Slab on Grade Floors}

The baseline buildings were modeled with slab-on-grade floors. The layers consist of carpet pad over 8 in. $(0.2 \mathrm{~m})$ of heavyweight concrete. A separate program called slab.exe, which determines the temperature of the ground under the slab based on the area of the slab, the location of the building, and the type of insulation under or around the slab, was used to model the ground coupling (DOE 2007). For the baseline models, slab.exe was used to run a simple building in each location with the slab insulations requirements in ASHRAE 90.1-1999. Slab.exe reports the perimeter ground monthly temperatures, the core ground monthly temperatures, and average monthly temperatures. For this analysis, the average monthly temperatures were used as the input for the ground temperatures under the floor slab in the EnergyPlus input files.

\subsubsection{Fenestration}

Fenestration systems in the baseline schools were modeled as single banded windows with one band per floor per façade, at 35\% fenestration to gross wall area. Windows are collected into a single object and frames are neglected to reduce complexity in the EnergyPlus models and make the simulations run faster. The window performance is modeled as for the entire glazed area. U-factor and solar heat gain coefficient (SHGC) values were treated as whole-assembly. Window U-factor and SHGC were set to match the fenestration performance criteria outlined in Appendix B of ASHRAE 90.1-1999, by climate zone. If the SHGC had no recommendation in ASHRAE 90.1 (1999 or 2004), the SHGC was set to the previous table's value of SHGC. Similar window U-factors and SHGCs were modeled in the ASHRAE 90.1-2004 baselines, as the window requirements did not change significantly from ASHRAE 90.1-1999 to ASHRAE 90.1-2004.

Window fenestration U-factors are listed in Appendix C through Appendix E. These are the target Ufactors used in an iterative process to refine the material properties in the layer-by-layer descriptions to just match the assembly performance level. Window SHGC values are listed in Appendix C through Appendix E. These target SHGC are values used in an iterative process to refine the material properties in the layer-by-layer descriptions to just match the assembly performance level. The multipliers from the visible light transmittance (VLT) tables in ASHRAE 90.1-2004 Appendix C, Table C3.5 (ASHRAE 2004b) were used to calculate baseline VLT values for the windows. 
The K-12 AEDG recommends daylighting in the gyms. One of the gym daylighting options includes skylights with an area of $4 \%$ of the floor area. The baseline models also include the skylights, but without daylighting controls, as recommended in Appendix G of ASHRAE 90.1-2004. The skylights are $4 \mathrm{ft} \times 4$ $\mathrm{ft}(1.22 \mathrm{~m} \times 1.22 \mathrm{~m})$ and spaced equally throughout the gym and multipurpose spaces. Window U-factor and SHGCs are set to match the fenestration performance criteria outlined in Appendix B of ASHRAE 90.1-1999, by climate zone.

\subsubsection{Infiltration}

Building air infiltration is addressed indirectly in the Standard through the requirements in building envelope sealing, fenestration and door air leakage, etc. ASHRAE 90.1 does not specify the air infiltration rate. For this analysis, the infiltration rate was assumed to be a peak of 0.5 air changes per hour $(\mathrm{ACH})$. In addition, the infiltration schedule was also incorporated into the modeling by assuming $0.25 \mathrm{ACH}$ of infiltration when the HVAC system is enabled and the building is pressurized and $0.5 \mathrm{ACH}$ of infiltration when the HVAC system is disabled at night and on weekends.

\subsubsection{Internal Loads}

Internal loads include heat generated from occupants, lights, and appliances (plug loads such as computers, printers, small beverage machines, etc.). For the occupancy loads, the load intensity refers to the maximum occupancy at the peak time of a typical day. Lighting and plug loads are represented by peak power density in watts per square foot. The equipment load intensities for the classrooms are assumed based on the results of the plug load audits as documented in Section 3.2.3.1. The equipment loads include all loads not associated with HVAC, service water heating, and lighting. In addition to all loads that are plugged in, equipment loads include items such as elevators, distribution transformer losses, cooking appliances, and kitchen walk-in refrigerators.

The occupancy loads are based on default occupant density from ASHRAE 62.1-2004 (ASHRAE 2004b). The baseline interior lighting power density (LPD) for each specific area is derived using the space-byspace method described in Standard 90.1-1999. The baseline ASHRAE 90.1-1999 and ASHRAE 90.12004 LPDs, peak occupancy, and peak plug loads are shown in Table 3-20 through Table 3-22. Plug load schedules, occupancy schedules, and lighting schedules are documented in Section 3.3.6. The location of each space type is shown in Figure 3-20 through Figure 3-23. 
Table 3-20 Elementary School Baseline Internal Loads by Space Type

\begin{tabular}{|c|c|c|c|c|}
\hline Space Type & $\begin{array}{c}\text { ASHRAE } \\
90.1-1999 \text { LPD } \\
\left(\mathrm{W} / \mathrm{ft}^{2}\right)\end{array}$ & $\begin{array}{c}\text { ASHRAE } \\
90.1-2004 \text { LPD } \\
\left(\mathrm{W} / \mathrm{ft}^{2}\right)\end{array}$ & $\begin{array}{c}\text { Peak } \\
\text { Equipment } \\
\text { Load }\left(\mathrm{W} / \mathrm{ft}^{2}\right)\end{array}$ & $\begin{array}{l}\text { Maximum } \\
\text { Occupants } \\
\left(\# / 1000 \mathrm{ft}^{2}\right)\end{array}$ \\
\hline Classrooms & 1.6 & 1.4 & 1.4 & 25 \\
\hline Offices & 1.5 & 1.1 & 1.0 & 5 \\
\hline Multipurpose room & 1.9 & 1.4 & 0.5 & 30 \\
\hline Computer classrooms & 1.6 & 1.4 & 1.9 & 30 \\
\hline Kitchen & 2.2 & 1.2 & 1.9 & 15 \\
\hline Cafeteria & 1.4 & 0.9 & 1.0 & 100 \\
\hline Media center & 1.8 & 1.2 & 1.4 & 25 \\
\hline Lobby & 1.8 & 1.3 & 0.4 & 10 \\
\hline Corridors & 0.7 & 0.5 & 0.4 & 1 \\
\hline Restrooms & 1.0 & 0.9 & 0.4 & 10 \\
\hline Mechanical & 1.3 & 1.5 & 0.9 & 1 \\
\hline $\begin{array}{l}\text { Elementary school weighted } \\
\text { average }\end{array}$ & 1.53 & 1.25 & 1.1 & 20 \\
\hline
\end{tabular}

Table 3-21 Middle School Baseline Internal Loads by Space Type

\begin{tabular}{|l|c|c|c|c|}
\hline \multicolumn{1}{|c|}{ Space Type } & $\begin{array}{c}\text { ASHRAE 90.1-1999 } \\
\text { LPD (W/ft }\end{array}$ & $\begin{array}{c}\text { ASHRAE 90.1-2004 } \\
\text { LPD (W/ft })\end{array}$ & $\begin{array}{c}\text { Peak Plug } \\
\left.\text { Load (W/ft }{ }^{2}\right)\end{array}$ & $\begin{array}{c}\text { Number of } \\
\text { Occupants } \\
\left(\# / 1000 \mathbf{f t}^{2}\right)\end{array}$ \\
\hline Classrooms & 1.6 & 1.4 & 0.9 & 25 \\
\hline Offices & 1.5 & 1.1 & 1.0 & 5 \\
\hline Gym & 1.9 & 1.4 & 0.5 & 100 \\
\hline Computer classrooms & 1.6 & 1.4 & 1.9 & 30 \\
\hline Kitchen & 2.2 & 1.2 & 1.9 & 15 \\
\hline Cafeteria & 1.4 & 0.9 & 1.0 & 100 \\
\hline Media center & 1.8 & 1.2 & 1.4 & 25 \\
\hline Lobby & 1.8 & 1.3 & 0.4 & 10 \\
\hline Corridors & 0.7 & 0.5 & 0.4 & 1 \\
\hline Restrooms & 1.0 & 0.9 & 0.4 & 10 \\
\hline Mechanical & 1.3 & 1.5 & 0.9 & 1 \\
\hline \hline $\begin{array}{l}\text { Middle school weighted } \\
\text { average }\end{array}$ & 1.52 & 1.22 & 0.82 & 27 \\
\hline
\end{tabular}


Table 3-22 High School Baseline Internal Loads by Space Type

\begin{tabular}{|c|c|c|c|c|}
\hline Space Type & $\begin{array}{c}\text { ASHRAE } 90.1-1999 \\
\text { LPD }\left(\mathrm{W} / \mathrm{ft}^{2}\right)\end{array}$ & $\begin{array}{c}\text { ASHRAE 90.1-2004 } \\
\text { LPD }\left(\mathrm{W} / \mathrm{ft}^{2}\right)\end{array}$ & $\begin{array}{l}\text { Peak Plug } \\
\text { Load (W/ft') }\end{array}$ & $\begin{array}{l}\text { Number of } \\
\text { Occupants } \\
\left(\# / 1000 \mathrm{ft}^{2}\right)\end{array}$ \\
\hline Classrooms & 1.6 & 1.4 & 0.9 & 25 \\
\hline Offices & 1.5 & 1.1 & 1.0 & 5 \\
\hline Main gym & 1.9 & 1.4 & 0.5 & 100 \\
\hline Auxiliary gym & 1.9 & 1.4 & 0.5 & 30 \\
\hline Computer classrooms & 1.6 & 1.4 & 1.9 & 30 \\
\hline Kitchen & 2.2 & 1.2 & 1.9 & 15 \\
\hline Cafeteria & 1.4 & 0.9 & 1.0 & 100 \\
\hline Media center & 1.8 & 1.2 & 1.4 & 25 \\
\hline Lobby & 1.8 & 1.3 & 0.4 & 10 \\
\hline Corridors & 0.7 & 0.5 & 0.4 & 1 \\
\hline Restrooms & 1.0 & 0.9 & 0.4 & 10 \\
\hline Mechanical & 1.3 & 1.5 & 0.4 & 1 \\
\hline Auditorium & 1.6 & 1.4 & 0.5 & 100 \\
\hline $\begin{array}{l}\text { High school weighted } \\
\text { average }\end{array}$ & 1.57 & 1.25 & 0.74 & 30 \\
\hline
\end{tabular}

\subsubsection{Exterior Lighting}

The baseline schools were modeled with $5.0 \mathrm{~W} /$ linear foot $(16.4 \mathrm{~W} /$ linear $\mathrm{m})$ of exterior façade lighting, per ASHRAE 90.1-2004 Table 9.4.5 (ASHRAE 2004a).

\subsubsection{HVAC Systems and Components}

\subsubsection{System Type and Sizing}

The scope of this Guide covers all sizes of K-12 schools that use multiple HVAC system types. To meet the minimum energy-efficiency requirements of ASHRAE 90.1-1999 and ASHRAE 90.1-2004 for the baseline models, the PC agreed on using single-zone packaged unitary heating and cooling equipment. The types of HVAC systems in K-12 schools are highly variable across the country. The PC felt that package rooftops were an acceptable baseline system based on industry experience and on the CBECS analysis, which showed that package rooftop units are one of the more common system types. To model this system type, we modeled each thermal zone with an auto-sized package single-zone system with a constant volume fan, DX cooling, and gas-fired furnace. To apply ASHRAE 90.1-1999 and ASHRAE 90.1-2004, we assumed the baseline rooftop units would be an individual classroom rooftop in the range of 5 tons and 2,000 $\mathrm{cfm}\left(0.94 \mathrm{~m}^{3} / \mathrm{s}\right)$. For larger spaces, multiple 5 -ton units would be used.

We used the design-day method to autosize the cooling capacity of the DX cooling coil and the heating capacity of the furnace in the packaged rooftop units. The design-day data for all 15 climate locations were developed based on the "Weather Data" contained in the ASHRAE Handbook: Fundamentals (ASHRAE 2005). In this data set, we used the annual heating design condition based on annual percentiles of $99.6 \%$ and the annual cooling design condition based on annual percentiles of $0.4 \%$. The internal loads (occupancy, lights, and plug loads) were scheduled as zero on the heating design day, and at a maximum level on the cooling design day. A 1.2 sizing factor was applied to all autosized heating and cooling capacities and air flow rates. 


\subsubsection{Outside Air}

Ventilation rates by space type were determined based on ASHRAE 62-2001 (ASHRAE 2001), as shown in Table 3-23. Demand controlled ventilation is required by ASHRAE 90.1-1999 in densely occupied spaces such as the auditoriums and cafeterias. The ASHRAE 90.1-2004 baselines used these same outdoor air rates. To model demand controlled ventilation in these spaces, we modified the OA rates to match the baseline occupancy schedules.

For the spaces without demand controlled ventilation, OA was scheduled based on the HVAC system availability schedule. Code allows OA to be controlled with a gravity damper, which opens whenever the fans operate. However, we modeled an OA motorized damper based on HVAC system availability schedules in the baseline models. The motorized damper is closed during unoccupied hours, resulting in no OA when the system night cycles. Using gravity dampers in colder climates that have significant night cycling can result in significant heating energy use, which would inflate the baseline energy use in these climates. Therefore, all the baseline models include motorized OA dampers. The PC also felt that gravity dampers were not a common configuration for OA control.

Table 3-23 Baseline OA Rates by Space Type

\begin{tabular}{|c|c|c|c|c|}
\hline Space Type & $\begin{array}{l}\text { Number of } \\
\text { Occupants } \\
\left(\# / 1000 \mathrm{ft}^{2}\right)\end{array}$ & $\begin{array}{c}\text { OA Rate } \\
\text { (cfm/occupant) }\end{array}$ & OA Rate $\left(\mathrm{cfm} / \mathrm{ft}^{2}\right)$ & $\begin{array}{c}\text { Demand Controlled } \\
\text { Ventilation in } \\
\text { Baseline? }\end{array}$ \\
\hline Classrooms & 25 & 15 & & \\
\hline Offices & 5 & 20 & & \\
\hline Multipurpose room & 30 & 20 & & \\
\hline Main gym & 100 & 20 & & Yes \\
\hline Auxiliary gym & 30 & 20 & & \\
\hline Computer classrooms & 30 & 15 & & \\
\hline Kitchen & 15 & 20 & & \\
\hline Cafeteria & 100 & 20 & & Yes \\
\hline Media center & 25 & 15 & & \\
\hline Lobby & 10 & 15 & & \\
\hline Corridors & 1 & & 0.05 & \\
\hline Restrooms & 10 & & 0.15 & \\
\hline Mechanical & 1 & & 0.15 & \\
\hline Auditorium & 100 & 15 & & Yes \\
\hline
\end{tabular}

\subsubsection{Economizers}

In accordance with ASHRAE 90.1-1999 and ASHRAE 90.1-2004, an economizer is not required if the system is smaller than $65,000 \mathrm{Btu} / \mathrm{h}(19 \mathrm{~kW})$ in cooling capacity, regardless of climate location. Therefore, the 5-ton rooftops do not include economizers in the baseline models.

\subsubsection{Fan Power Assumptions}

The constant volume fan energy use is determined from two primary input parameters: total supply fan static pressure drops and fan/motor efficiency. We have assumed that the package rooftop system contains only a supply fan, and there is no return fan or central exhaust fan in the system. 
The total supply fan static pressure drops were based PC members' input on standard HVAC ductwork design for representative duct runs served by the packaged unitary equipment. Table 3-24 summarizes the breakdown of the fan total static pressure for the baseline rooftop system. A total fan static pressure of 2.50 in. water column (w.c.) (625 Pa) was used for the 5 -ton unit.

Table 3-24 Baseline Fan System Total Pressure Drops

\begin{tabular}{|l|c|}
\hline \multicolumn{1}{|c|}{ Component } & $\begin{array}{c}\text { Package Rooftop, Constant } \\
\text { Volume, 5-ton, 2000 cfm } \\
\text { in. w.c. }\end{array}$ \\
\hline \hline 2-in. plated filters & 0.30 \\
\hline Heat coil/section & 0.25 \\
\hline Cooling coil & 0.60 \\
\hline Fan outlet transition & 0.10 \\
\hline Diffuser & 0.10 \\
\hline Supply ductwork ${ }^{2}$ & 0.80 \\
\hline Return ductwork & 0.30 \\
\hline Grille & 0.05 \\
\hline Total static pressure drop & 2.50 \\
\hline
\end{tabular}

1. Used average difference between clean and dirty filters

2. Used standard practice of $0.1 \mathrm{in}$. w.c./100 ft $(25 \mathrm{~Pa} / 30 \mathrm{~m})$ friction rate for the baseline duct pressure drop combined with typical effective duct runs.

The total fan efficiency is a combination of the supply fan, motor, and drive efficiency. To calculate the total fan efficiency, the power delivered to the airflow by the fan is divided by the maximum allowable motor power. For a 5-ton, 2,000-cfm $\left(0.94 \mathrm{~m}^{3} / \mathrm{s}\right)$ rooftop, the allowable fan motor nameplate power is determined by the fan power limitation from Table 6.3.3.1 in ASHRAE 90.1-1999. For a 2,000-cfm (0.94 $\mathrm{m}^{3} / \mathrm{s}$ ), constant volume system, ASHRAE 90.1-1999 and ASHRAE 90.1-2004 limits the fan motor to 1.2 $\mathrm{hp} / 1000 \mathrm{cfm}\left(1.9 \mathrm{~W} / 1000 \mathrm{~m}^{3} / \mathrm{s}\right)$ of supply air. This translates to a $2.4 \mathrm{hp}(1.8 \mathrm{~kW})$ maximum allowable fan power for the baseline rooftops. To calculate the power delivered to the supply air, the flow and pressure drop are needed. The product of the airflow at $2,000 \mathrm{cfm}\left(0.94 \mathrm{~m}^{3} / \mathrm{s}\right)$ and the pressure drop of 2.5 in w.c. $(625 \mathrm{~Pa})$ results in the power delivered to the airflow of $590 \mathrm{~W}$. This equates to a $33 \%$ efficient fan/motor/drive combination, which was used as the baseline model input for the EnergyPlus package rooftop total fan efficiency.

\subsubsection{Minimum Efficiency}

The code minimum efficiency for cooling equipment is determined based on cooling system type and size. To apply ASHRAE 90.1-1999 and ASHRAE 90.1-2004, we assume the baseline rooftop units would be individual classroom rooftop units in the range of 5 tons and 2,000 $\mathrm{cfm}\left(0.94 \mathrm{~m}^{3} / \mathrm{s}\right)$. ASHRAE 90.1-1999 and ASHRAE 90.1-2004 require that the energy efficiency of single packaged unitary air conditioners at this level (less than $65,000 \mathrm{Btu} / \mathrm{h}(19 \mathrm{~kW})$ ) should be rated by the seasonal energy efficiency ratio (SEER). Therefore, for the elementary, middle, and high school ASHRAE 90.1-1999 baseline models, the minimum efficiency of 9.7 SEER was used for each rooftop. For the ASHRAE 90.1-2004 baseline models, the minimum efficiency requirements were increased to a 12 SEER for this sized package rooftop unit. The gas-fired furnace efficiency levels were incorporated as $80 \%$ efficient gas furnaces in the package rooftops, to match the minimum efficiency requirements for both ASHRAE 90.1-1999 and ASHRAE 90.1-2004.

The minimum efficiency requirements for the baseline ASHRAE 90.1-1999 and ASHRAE 90.1-2004 package rooftops includes fan power, compressors, and condenser power. To model the code minimum 
package rooftop units, the efficiency (coefficient of performance [COP]) of the compressor/condenser is input separately from the fan power. The following method is used to calculate the rooftop compressor/condenser COP from the ASHRAE 90.1-1999 and ASHRAE 90.1-2004 minimum efficiency requirements:

\section{Determine EER from ASHRAE 90.1 minimum SEER:}

For a 5-ton rooftop unit, the minimum efficiency in ASHRAE 90.1-1999 is 9.7 SEER. From Equation $3-1$, we estimated this baseline unit to have an 8.8 energy efficiency ratio (EER), which can also be expressed as $1.36 \mathrm{~kW} /$ ton.

$$
E E R=S E E R \times 0.697+2.04
$$

\section{Equation 3-1 Calculation of EER from SEER ${ }^{1}$}

\section{Determine the portion of this EER that is for the supply fan:}

For the 5-ton, 2,000-cfm rooftop, the allowable fan motor nameplate power is determined by the fan power limitation Table 6.3.3.1 in ASHRAE 90.1-1999, which equates to a 2.4-hp (1.8 kW) fan, or 0.36 $\mathrm{kW} /$ ton.

\section{Determine the COP of the compressor/condenser:}

The compressor/condenser efficiency is the difference between the unit efficiency (expressed in $\mathrm{kW} /$ ton) and the fan power (expressed in $\mathrm{kW} / \mathrm{ton}$ ). For the ASHRAE 90.1-1999 baseline package rooftop with SEER of 9.7, the compressor/condenser efficiency was estimated to be $1.0 \mathrm{~kW} /$ ton, or a COP of 3.5. For the 5-ton ASHRAE 90.1-2004 baseline package rooftop with a SEER of 12, a compressor/condenser COP of 4.4 was modeled in EnergyPlus. These COP values were used for EnergyPlus input and correspond to nominal values for the rated point of operation; see EnergyPlus input documentation for more detail (DOE 2007).

Table 3-25 summarizes the primary HVAC performance characteristics for both the ASHRAE 90.1-1999 baseline and the ASHRAE 90.1-2004 baseline.

\footnotetext{
${ }^{1}$ The conversion from SEER to EER is an approximation based on published data from the Carrier Corporation, as referenced in "Deemed Savings, Installation \& Efficiency Standards: Commercial and Industrial Cooling Equipment,” prepared for the Public Utility Commission of Texas by Nexant, Inc., May 2003, page 3.
} 
Table 3-25 Baseline HVAC Models Summary

\begin{tabular}{|c|c|c|}
\hline HVAC Input & $\begin{array}{c}\text { ASHRAE 90.1-1999 Baseline } \\
\text { PSZ DX, Furnace }\end{array}$ & $\begin{array}{l}\text { ASHRAE 90.1-2004 Baseline } \\
\text { PSZ DX, Furnace }\end{array}$ \\
\hline COP of compressor/condenser & $\begin{array}{l}\text { 3.5 COP } \\
\text { (9.7 SEER) }\end{array}$ & $\begin{array}{l}\text { 4.4 COP } \\
(12 \text { SEER) }\end{array}$ \\
\hline Heating efficiency & $80 \%$ & $80 \%$ \\
\hline Fan efficiency & $33 \%$ & $33 \%$ \\
\hline Fan power limitation & $1.2 \mathrm{hp} / 1000 \mathrm{cfm}$ & $1.2 \mathrm{hp} / 1000 \mathrm{cfm}$ \\
\hline Fan static pressure & 2.5 in. w.c. & 2.5 in. w.c. \\
\hline Economizers & None & None \\
\hline Energy recovery ventilator & None & None \\
\hline OA control & $\begin{array}{l}\text { HVAC operational schedule, } \\
\mathrm{CO}_{2} \text { demand controlled in } \\
\text { cafeteria, gym, auditorium }\end{array}$ & $\begin{array}{l}\text { HVAC operational schedule, } \\
\mathrm{CO}_{2} \text { demand controlled in } \\
\text { cafeteria, gym, auditorium }\end{array}$ \\
\hline
\end{tabular}

\subsubsection{Service Water Heating}

The PC defined the baseline service hot water system for the K-12 schools as a gas-fired storage water heater that meets the minimum Standards requirement for medium-sized water heaters (with rated input power greater than 75,000 Btu/h $(22 \mathrm{~kW})$ and less than 155,000 Btu/h $(45 \mathrm{~kW}))$ under Standard 90.11999. Gas water heaters were chosen for the baseline to be consistent with the use of gas for heating in the baseline prototype schools. The thermal efficiency of the baseline water heaters is $80 \%$ for both ASHRAE 90.1-1999 and ASHRAE 90.1-2004.

The consumption rates of hot water were determined as documented in the ASHRAE Handbook: HVAC Applications (ASHRAE 2007). For the baseline schools, the hot water consumption rate was modeled at $0.8 \mathrm{gal} / \mathrm{student} /$ day $(3 \mathrm{~L} / \mathrm{student} /$ day), with the draw profile as shown in Section 3.3.6. The hot water was assumed to be used at $104^{\circ} \mathrm{F}\left(40^{\circ} \mathrm{C}\right)$. The set point of the water heater was $140^{\circ} \mathrm{F}\left(60^{\circ} \mathrm{C}\right)$. For reporting purposes in Section 4, the gas use for service hot water is stated as "Water Systems."

\subsubsection{Schedules}

The schedules were developed by modifying the standard educational building schedule sets available in ASHRAE 90.1-1989 (ASHRAE 1989) based on input from each PC member and from the typical operating characteristics from CBECS. Schedules are presented as fractions of peak, unless otherwise noted. The following schedules were used in the baseline models. 
Each zone in the baseline models used the lighting schedule, based on the typical school schedule, as shown in Table 3-26.

Table 3-26 Building Lighting Schedule

\begin{tabular}{|c|c|c|c|c|}
\hline Hour & $\begin{array}{c}\text { Weekday } \\
\text { through } 6 / 30\end{array}$ & $\begin{array}{c}\text { Weekday } \\
\text { through } 9 / 01\end{array}$ & $\begin{array}{c}\text { Weekday } \\
\text { through 12/31 }\end{array}$ & $\begin{array}{c}\text { Weekends, } \\
\text { Holidays }\end{array}$ \\
\hline 1 & 0.18 & 0.18 & 0.18 & 0.18 \\
\hline 2 & 0.18 & 0.18 & 0.18 & 0.18 \\
\hline 3 & 0.18 & 0.18 & 0.18 & 0.18 \\
\hline 4 & 0.18 & 0.18 & 0.18 & 0.18 \\
\hline 5 & 0.18 & 0.18 & 0.18 & 0.18 \\
\hline 6 & 0.18 & 0.18 & 0.18 & 0.18 \\
\hline 7 & 0.18 & 0.18 & 0.18 & 0.18 \\
\hline 8 & 0.90 & 0.18 & 0.90 & 0.18 \\
\hline 9 & 0.90 & 0.50 & 0.90 & 0.18 \\
\hline 10 & 0.90 & 0.50 & 0.90 & 0.18 \\
\hline 11 & 0.90 & 0.50 & 0.90 & 0.18 \\
\hline 12 & 0.90 & 0.50 & 0.90 & 0.18 \\
\hline 13 & 0.90 & 0.50 & 0.90 & 0.18 \\
\hline 14 & 0.90 & 0.50 & 0.90 & 0.18 \\
\hline 15 & 0.90 & 0.50 & 0.90 & 0.18 \\
\hline 16 & 0.90 & 0.50 & 0.90 & 0.18 \\
\hline 17 & 0.90 & 0.50 & 0.90 & 0.18 \\
\hline 18 & 0.90 & 0.50 & 0.90 & 0.18 \\
\hline 19 & 0.90 & 0.50 & 0.90 & 0.18 \\
\hline 20 & 0.90 & 0.50 & 0.90 & 0.18 \\
\hline 21 & 0.90 & 0.18 & 0.90 & 0.18 \\
\hline 22 & 0.18 & 0.18 & 0.18 & 0.18 \\
\hline 23 & 0.18 & 0.18 & 0.18 & 0.18 \\
\hline 24 & 0.18 & 0.18 & 0.18 & 0.18 \\
\hline
\end{tabular}


Each zone in the baseline models used the heating and cooling set point schedules as shown in Table 3-27, except for the restrooms, corridors, and mechanical spaces, which used the heating setback and the cooling setup schedule. The HVAC systems are controlled with dual thermostatic control based on dry bulb temperature in the zones. Zone thermostat set points are generally $70^{\circ} \mathrm{F}\left(21^{\circ} \mathrm{C}\right)$ for heating and $77^{\circ} \mathrm{F}$ $\left(25^{\circ} \mathrm{C}\right)$ for cooling. Thermostat setup to $91^{\circ} \mathrm{F}\left(33^{\circ} \mathrm{C}\right)$ and setback to $61^{\circ} \mathrm{F}\left(16^{\circ} \mathrm{C}\right)$ were included in the models. Humidity is addressed indirectly by controlling supply air temperature. Set points for the supply air temperature in the baseline and low-energy models are set by using a outdoor air reset schedule with cold deck temperatures of $55^{\circ} \mathrm{F}\left(13^{\circ} \mathrm{C}\right)$ when outdoor air temperatures are above $70^{\circ} \mathrm{F}\left(21^{\circ} \mathrm{C}\right)$ and $60^{\circ} \mathrm{F}$ $\left(16^{\circ} \mathrm{C}\right)$ when $\mathrm{OA}$ temperatures are below $60^{\circ} \mathrm{F}\left(16^{\circ} \mathrm{C}\right)$.

Table 3-27 Building Heating and Cooling Set Point Schedules

\begin{tabular}{|c|c|c|c|c|c|c|}
\hline Hour & $\begin{array}{l}\text { Weekday } \\
\text { through } \\
12 / 31, \\
\text { Heating }\end{array}$ & $\begin{array}{c}\text { Weekday } \\
\text { through } 12 / 31, \\
\text { Heating Setback }\end{array}$ & $\begin{array}{c}\text { Weekends, } \\
\text { Holidays, } \\
\text { Heating }\end{array}$ & $\begin{array}{c}\text { Weekday } \\
\text { through } \\
12 / 31, \\
\text { Cooling }\end{array}$ & \begin{tabular}{|c|} 
Weekday \\
through \\
$12 / 31$, \\
Cooling Setup
\end{tabular} & $\begin{array}{c}\text { Weekends, } \\
\text { Holidays, } \\
\text { Cooling }\end{array}$ \\
\hline 1 & $61(16)$ & $61(16)$ & $61(16)$ & $91(33)$ & 91 (33) & $91(33)$ \\
\hline 2 & $61(16)$ & $61(16)$ & $61(16)$ & $91(33)$ & $91(33)$ & $91(33)$ \\
\hline 3 & $61(16)$ & $61(16)$ & $61(16)$ & 91 (33) & $91(33)$ & $91(33)$ \\
\hline 4 & $61(16)$ & $61(16)$ & $61(16)$ & $91(33)$ & $91(33)$ & $91(33)$ \\
\hline 5 & $61(16)$ & $61(16)$ & $61(16)$ & 91 (33) & $91(33)$ & 91 (33) \\
\hline 6 & $61(16)$ & $61(16)$ & $61(16)$ & $91(33)$ & $91(33)$ & $91(33)$ \\
\hline 7 & $61(16)$ & $61(16)$ & $61(16)$ & 91 (33) & 91 (33) & 91 (33) \\
\hline 8 & $61(16)$ & $61(16)$ & $61(16)$ & 91 (33) & 91 (33) & 91 (33) \\
\hline 9 & $70(21)$ & $61(16)$ & $61(16)$ & $77(25)$ & 91 (33) & $91(33)$ \\
\hline 10 & $70(21)$ & $61(16)$ & $61(16)$ & $77(25)$ & 91 (33) & 91 (33) \\
\hline 11 & $70(21)$ & $61(16)$ & $61(16)$ & $77(25)$ & $91(33)$ & 91 (33) \\
\hline 12 & $70(21)$ & 61 (16) & $61(16)$ & $77(25)$ & $91(33)$ & 91 (33) \\
\hline 13 & $70(21)$ & $61(16)$ & $61(16)$ & $77(25)$ & $91(33)$ & 91 (33) \\
\hline 14 & $70(21)$ & 61 (16) & $61(16)$ & $77(25)$ & $91(33)$ & 91 (33) \\
\hline 15 & $70(21)$ & $61(16)$ & $61(16)$ & $77(25)$ & $91(33)$ & $91(33)$ \\
\hline 16 & $70(21)$ & $61(16)$ & $61(16)$ & 77 (25) & $91(33)$ & 91 (33) \\
\hline 17 & $70(21)$ & $61(16)$ & $61(16)$ & $77(25)$ & $91(33)$ & $91(33)$ \\
\hline 18 & $70(21)$ & $61(16)$ & $61(16)$ & $77(25)$ & $91(33)$ & $91(33)$ \\
\hline 19 & $70(21)$ & $61(16)$ & $61(16)$ & $77(25)$ & $91(33)$ & $91(33)$ \\
\hline 20 & $61(16)$ & $61(16)$ & $61(16)$ & $91(33)$ & $91(33)$ & $91(33)$ \\
\hline 21 & $61(16)$ & $61(16)$ & $61(16)$ & $91(33)$ & $91(33)$ & $91(33)$ \\
\hline 22 & $61(16)$ & $61(16)$ & $61(16)$ & $91(33)$ & $91(33)$ & 91 (33) \\
\hline 23 & $61(16)$ & $61(16)$ & $61(16)$ & $91(33)$ & $91(33)$ & $91(33)$ \\
\hline 24 & $61(16)$ & $61(16)$ & $61(16)$ & 91 (33) & 91 (33) & 91 (33) \\
\hline
\end{tabular}


Each zone in the baseline models used the equipment schedules as shown in Table 3-28.

Table 3-28 Building Equipment Schedule

\begin{tabular}{|c|c|c|c|c|c|}
\hline Hour & $\begin{array}{c}\text { Weekday } \\
\text { through } 6 / 30\end{array}$ & $\begin{array}{c}\text { Weekday } \\
\text { through } 9 / 01\end{array}$ & $\begin{array}{c}\text { Weekday } \\
\text { through 12/31 }\end{array}$ & $\begin{array}{c}\text { Weekends, } \\
\text { Holidays }\end{array}$ & $\begin{array}{c}\text { Weekends, } \\
\text { Holidays, } \\
\text { Summer }\end{array}$ \\
\hline 1 & 0.35 & 0.25 & 0.35 & 0.35 & 0.25 \\
\hline 2 & 0.35 & 0.25 & 0.35 & 0.35 & 0.25 \\
\hline 3 & 0.35 & 0.25 & 0.35 & 0.35 & 0.25 \\
\hline 4 & 0.35 & 0.25 & 0.35 & 0.35 & 0.25 \\
\hline 5 & 0.35 & 0.25 & 0.35 & 0.35 & 0.25 \\
\hline 6 & 0.35 & 0.25 & 0.35 & 0.35 & 0.25 \\
\hline 7 & 0.35 & 0.25 & 0.35 & 0.35 & 0.25 \\
\hline 8 & 0.35 & 0.25 & 0.35 & 0.35 & 0.25 \\
\hline 9 & 0.95 & 0.5 & 0.95 & 0.35 & 0.25 \\
\hline 10 & 0.95 & 0.5 & 0.95 & 0.35 & 0.25 \\
\hline 11 & 0.95 & 0.5 & 0.95 & 0.35 & 0.25 \\
\hline 12 & 0.95 & 0.5 & 0.95 & 0.35 & 0.25 \\
\hline 13 & 0.95 & 0.5 & 0.95 & 0.35 & 0.25 \\
\hline 14 & 0.95 & 0.5 & 0.95 & 0.35 & 0.25 \\
\hline 15 & 0.95 & 0.5 & 0.95 & 0.35 & 0.25 \\
\hline 16 & 0.95 & 0.5 & 0.95 & 0.35 & 0.25 \\
\hline 17 & 0.95 & 0.5 & 0.95 & 0.35 & 0.25 \\
\hline 18 & 0.35 & 0.25 & 0.35 & 0.35 & 0.25 \\
\hline 19 & 0.35 & 0.25 & 0.35 & 0.35 & 0.25 \\
\hline 20 & 0.35 & 0.25 & 0.35 & 0.35 & 0.25 \\
\hline 21 & 0.35 & 0.25 & 0.35 & 0.35 & 0.25 \\
\hline 22 & 0.35 & 0.25 & 0.35 & 0.35 & 0.25 \\
\hline 23 & 0.35 & 0.25 & 0.35 & 0.35 & 0.25 \\
\hline 24 & 0.35 & 0.25 & 0.35 & 0.35 & 0.25 \\
\hline
\end{tabular}


The classrooms, lobby, mechanical, corridors, and bathrooms in the baseline models used the occupancy schedules as shown in Table 3-29. The computer classrooms and a single classroom wing used the extended occupancy schedules to account for after hours use.

Table 3-29 General and Extended Occupancy Schedule

\begin{tabular}{|c|c|c|c|c|c|c|c|}
\hline Hour & $\begin{array}{c}\text { Weekday } \\
\text { through } \\
\mathbf{6 / 3 0}\end{array}$ & $\begin{array}{c}\text { Weekday } \\
\text { through 6/30 } \\
\text { Extended }\end{array}$ & $\begin{array}{c}\text { Weekday } \\
\text { through } \\
\mathbf{9 / 0 1}\end{array}$ & $\begin{array}{c}\text { Weekday } \\
\text { through 9/01 } \\
\text { Extended }\end{array}$ & $\begin{array}{c}\text { Weekday } \\
\text { through } \\
\mathbf{1 2 / 3 1}\end{array}$ & $\begin{array}{c}\text { Weekday } \\
\text { through 12/31 } \\
\text { Extended }\end{array}$ & $\begin{array}{c}\text { Weekends, } \\
\text { Holidays }\end{array}$ \\
\hline 1 & 0 & 0 & 0 & 0 & 0 & 0 & 0 \\
\hline 2 & 0 & 0 & 0 & 0 & 0 & 0 & 0 \\
\hline 3 & 0 & 0 & 0 & 0 & 0 & 0 & 0 \\
\hline 4 & 0 & 0 & 0 & 0 & 0 & 0 & 0 \\
\hline 5 & 0 & 0 & 0 & 0 & 0 & 0 & 0 \\
\hline 6 & 0 & 0 & 0 & 0 & 0 & 0 & 0 \\
\hline 7 & 0.15 & 0.15 & 0.15 & 0.15 & 0.15 & 0.15 & 0 \\
\hline 8 & 0.95 & 0.95 & 0.15 & 0.5 & 0.95 & 0.95 & 0 \\
\hline 9 & 0.95 & 0.95 & 0.15 & 0.5 & 0.95 & 0.95 & 0 \\
\hline 10 & 0.95 & 0.95 & 0.15 & 0.5 & 0.95 & 0.95 & 0 \\
\hline 11 & 0.95 & 0.95 & 0.15 & 0.5 & 0.95 & 0.95 & 0 \\
\hline 12 & 0.95 & 0.95 & 0.15 & 0.5 & 0.95 & 0.95 & 0 \\
\hline 13 & 0.95 & 0.95 & 0.15 & 0.5 & 0.95 & 0.95 & 0 \\
\hline 14 & 0.95 & 0.95 & 0.15 & 0.5 & 0.95 & 0.95 & 0 \\
\hline 15 & 0.95 & 0.95 & 0.15 & 0.5 & 0.95 & 0.95 & 0 \\
\hline 16 & 0.95 & 0.95 & 0.15 & 0.5 & 0.95 & 0.95 & 0 \\
\hline 17 & 0.15 & 0.95 & 0.15 & 0.5 & 0.15 & 0.95 & 0 \\
\hline 18 & 0.15 & 0.95 & 0.15 & 0.5 & 0.15 & 0.95 & 0 \\
\hline 19 & 0.15 & 0.95 & 0.15 & 0.5 & 0.15 & 0.95 & 0 \\
\hline 20 & 0.15 & 0.95 & 0.15 & 0.5 & 0.15 & 0.95 & 0 \\
\hline 21 & 0.15 & 0.95 & 0.15 & 0.5 & 0.15 & 0.95 & 0 \\
\hline 22 & 0 & 0 & 0 & 0 & 0 & 0 & 0 \\
\hline 23 & 0 & 0 & 0 & 0 & 0 & 0 & 0 \\
\hline 24 & 0 & 0 & 0 & 0 & 0 & 0 & 0 \\
\hline & & & & & & & \\
\hline
\end{tabular}


The offices and media center use the same occupancy schedules as shown in Table 3-30. The multipurpose room in the elementary school and the gym in the middle and high schools use the gym occupancy schedules as shown in Table 3-30.

Table 3-30 Offices and Gym Occupancy Schedules

\begin{tabular}{|c|c|c|c|c|c|c|c|}
\hline Hour & $\begin{array}{c}\text { Weekday } \\
\text { through 6/30 } \\
\text { Offices/Media }\end{array}$ & $\begin{array}{c}\text { Weekday } \\
\text { through 6/30 } \\
\text { Gym }\end{array}$ & $\begin{array}{c}\text { Weekday } \\
\text { through 9/01 } \\
\text { Offices/Media }\end{array}$ & $\begin{array}{c}\text { Weekday } \\
\text { through } \\
\text { 9/01 Gym }\end{array}$ & $\begin{array}{c}\text { Weekday } \\
\text { through 12/31 } \\
\text { Offices/Media }\end{array}$ & $\begin{array}{c}\text { Weekday } \\
\text { through 12/31 } \\
\text { Gym }\end{array}$ & $\begin{array}{c}\text { Weekends, } \\
\text { Holidays }\end{array}$ \\
\hline \hline 1 & 0 & 0 & 0 & 0 & 0 & 0 & 0 \\
\hline 2 & 0 & 0 & 0 & 0 & 0 & 0 & 0 \\
\hline 3 & 0 & 0 & 0 & 0 & 0 & 0 & 0 \\
\hline 4 & 0 & 0 & 0 & 0 & 0 & 0 & 0 \\
\hline 5 & 0 & 0 & 0 & 0 & 0 & 0 & 0 \\
\hline 6 & 0 & 0 & 0 & 0 & 0 & 0 & 0 \\
\hline 7 & 0 & 0 & 0 & 0 & 0 & 0 & 0 \\
\hline 8 & 0.15 & 0 & 0.15 & 0 & 0.15 & 0 & 0 \\
\hline 9 & 0.95 & 0.35 & 0.5 & 0.35 & 0.95 & 0.35 & 0 \\
\hline 10 & 0.95 & 0.35 & 0.5 & 0.35 & 0.95 & 0.35 & 0 \\
\hline 11 & 0.95 & 0.35 & 0.5 & 0.35 & 0.95 & 0.35 & 0 \\
\hline 12 & 0.95 & 0.35 & 0.5 & 0.35 & 0.95 & 0.35 & 0 \\
\hline 13 & 0.95 & 0.35 & 0.5 & 0.35 & 0.95 & 0.35 & 0 \\
\hline 14 & 0.95 & 0.35 & 0.5 & 0.35 & 0.95 & 0.35 & 0 \\
\hline 15 & 0.95 & 0.35 & 0.5 & 0.35 & 0.95 & 0.35 & 0 \\
\hline 16 & 0.95 & 0.35 & 0.5 & 0.35 & 0.95 & 0.35 & 0 \\
\hline 17 & 0.95 & 0.95 & 0.5 & 0.35 & 0.95 & 0.95 & 0 \\
\hline 18 & 0.15 & 0.95 & 0.15 & 0.35 & 0.15 & 0.95 & 0 \\
\hline 19 & 0.15 & 0.95 & 0.15 & 0.35 & 0.15 & 0.95 & 0 \\
\hline 20 & 0.15 & 0.95 & 0.15 & 0.35 & 0.15 & 0.95 & 0 \\
\hline 21 & 0.15 & 0.95 & 0.15 & 0.35 & 0.15 & 0.95 & 0 \\
\hline 22 & 0 & 0 & 0 & 0 & 0 & 0 & 0 \\
\hline 23 & 0 & 0 & 0 & 0 & 0 & 0 & 0 \\
\hline 24 & 0 & 0 & 0 & 0 & 0 & 0 & 0 \\
\hline
\end{tabular}


The auditorium and cafeteria occupancy schedules are shown in Table 3-31.

Table 3-31 Auditorium and Cafeteria Occupancy Schedules

\begin{tabular}{|c|c|c|c|c|c|c|c|}
\hline Hour & $\begin{array}{c}\text { Weekday } \\
\text { through 6/30 } \\
\text { Auditorium }\end{array}$ & $\begin{array}{c}\text { Weekday } \\
\text { through 6/30 } \\
\text { Cafeteria }\end{array}$ & $\begin{array}{c}\text { Weekday } \\
\text { through 9/01 } \\
\text { Auditorium }\end{array}$ & $\begin{array}{c}\text { Weekday } \\
\text { through 9/01 } \\
\text { Cafeteria }\end{array}$ & $\begin{array}{c}\text { Weekday } \\
\text { through 12/31 } \\
\text { Auditorium }\end{array}$ & $\begin{array}{c}\text { Weekday } \\
\text { through 12/31 } \\
\text { Cafeteria }\end{array}$ & $\begin{array}{c}\text { Weekends, } \\
\text { Holidays }\end{array}$ \\
\hline \hline 1 & 0 & 0 & 0 & 0 & 0 & 0 & 0 \\
\hline 2 & 0 & 0 & 0 & 0 & 0 & 0 & 0 \\
\hline 3 & 0 & 0 & 0 & 0 & 0 & 0 & 0 \\
\hline 4 & 0 & 0 & 0 & 0 & 0 & 0 & 0 \\
\hline 5 & 0 & 0 & 0 & 0 & 0 & 0 & 0 \\
\hline 6 & 0 & 0 & 0 & 0 & 0 & 0 & 0 \\
\hline 7 & 0 & 0 & 0 & 0 & 0 & 0 & 0 \\
\hline 8 & 0 & 0 & 0 & 0 & 0 & 0 & 0 \\
\hline 9 & 0.25 & 0 & 0.15 & 0 & 0.25 & 0 & 0 \\
\hline 10 & 0.25 & 0.95 & 0.15 & 0.15 & 0.25 & 0.95 & 0 \\
\hline 11 & 0.25 & 0.95 & 0.15 & 0.15 & 0.25 & 0.95 & 0 \\
\hline 12 & 0.25 & 0.95 & 0.15 & 0.15 & 0.25 & 0.95 & 0 \\
\hline 13 & 0.25 & 0.95 & 0.15 & 0.15 & 0.25 & 0.95 & 0 \\
\hline 14 & 0.25 & 0.95 & 0.15 & 0.15 & 0.25 & 0.95 & 0 \\
\hline 15 & 0.25 & 0.95 & 0.15 & 0.15 & 0.25 & 0.95 & 0 \\
\hline 16 & 0.95 & 0.35 & 0.15 & 0.15 & 0.95 & 0.35 & 0 \\
\hline 17 & 0.95 & 0.35 & 0.15 & 0.15 & 0.95 & 0.35 & 0 \\
\hline 18 & 0.95 & 0.35 & 0.35 & 0.35 & 0.95 & 0.35 & 0 \\
\hline 19 & 0.95 & 0.35 & 0.35 & 0.35 & 0.95 & 0.35 & 0 \\
\hline 20 & 0.95 & 0.35 & 0 & 0 & 0.95 & 0.35 & 0 \\
\hline 21 & 0 & 0 & 0 & 0 & 0 & 0 & 0 \\
\hline 22 & 0 & 0 & 0 & 0 & 0 & 0 & 0 \\
\hline 23 & 0 & 0 & 0 & 0 & 0 & 0 & 0 \\
\hline 24 & 0 & 0 & 0 & 0 & 0 & 0 & 0 \\
\hline
\end{tabular}


The service water heating schedules are shown in Table 3-32.

Table 3-32 Service Water Heating Schedules

\begin{tabular}{|c|c|c|c|c|}
\hline Hour & $\begin{array}{c}\text { Weekday } \\
\text { through 6/30 } \\
\text { SWH }\end{array}$ & $\begin{array}{c}\text { Weekday } \\
\text { through 9/01 } \\
\text { SWH }\end{array}$ & $\begin{array}{c}\text { Weekday } \\
\text { through 12/31 } \\
\text { SWH }\end{array}$ & $\begin{array}{c}\text { Weekends, } \\
\text { Holidays SWH }\end{array}$ \\
\hline \hline 1 & 0.05 & 0.05 & 0.05 & 0.03 \\
\hline 2 & 0.05 & 0.05 & 0.05 & 0.03 \\
\hline 3 & 0.05 & 0.05 & 0.05 & 0.03 \\
\hline 4 & 0.05 & 0.05 & 0.05 & 0.03 \\
\hline 5 & 0.05 & 0.05 & 0.05 & 0.03 \\
\hline 6 & 0.05 & 0.05 & 0.05 & 0.03 \\
\hline 7 & 0.05 & 0.05 & 0.05 & 0.03 \\
\hline 8 & 0.10 & 0.10 & 0.10 & 0.03 \\
\hline 9 & 0.34 & 0.10 & 0.34 & 0.03 \\
\hline 10 & 0.60 & 0.10 & 0.60 & 0.05 \\
\hline 11 & 0.63 & 0.10 & 0.63 & 0.05 \\
\hline 12 & 0.72 & 0.10 & 0.72 & 0.05 \\
\hline 13 & 0.79 & 0.10 & 0.79 & 0.05 \\
\hline 14 & 0.83 & 0.10 & 0.83 & 0.03 \\
\hline 15 & 0.61 & 0.10 & 0.61 & 0.03 \\
\hline 16 & 0.65 & 0.10 & 0.65 & 0.03 \\
\hline 17 & 0.10 & 0.10 & 0.10 & 0.03 \\
\hline 18 & 0.10 & 0.10 & 0.10 & 0.03 \\
\hline 19 & 0.19 & 0.19 & 0.19 & 0.03 \\
\hline 20 & 0.25 & 0.25 & 0.25 & 0.03 \\
\hline 21 & 0.22 & 0.22 & 0.22 & 0.03 \\
\hline 22 & 0.22 & 0.22 & 0.22 & 0.03 \\
\hline 23 & 0.12 & 0.12 & 0.12 & 0.03 \\
\hline 24 & 0.09 & 0.09 & 0.09 & 0.03 \\
\hline
\end{tabular}


The infiltration schedules and HVAC operational schedules are shown in Table 3-33. The OA and fan schedules are the same as the HVAC operational schedules. During off hours, the HVAC system is shut off and only cycles "on" when the setback thermostat control calls for heating or cooling to maintain the setback temperature. During unoccupied hours, the outdoor air is "turned off" with motorized dampers. Therefore, no OA is be available when the system night cycles. A gravity damper OA system would bring in OA whenever the fans operate, including the night cycle operation.

Table 3-33 Infiltration and HVAC Operation Schedules

\begin{tabular}{|c|c|c|c|c|}
\hline Hour & $\begin{array}{c}\text { Weekday } \\
\text { through 12/31 } \\
\text { Infiltration }\end{array}$ & $\begin{array}{c}\text { Weekend/Holiday } \\
\text { through 12/31 } \\
\text { Infiltration }\end{array}$ & $\begin{array}{c}\text { Weekday } \\
\text { through 12/31 } \\
\text { HVAC Operation }\end{array}$ & $\begin{array}{c}\text { Weekend/Holiday } \\
\text { through 12/31 } \\
\text { HVAC Operation }\end{array}$ \\
\hline \hline 1 & 1 & 1 & 0 & 0 \\
\hline 2 & 1 & 1 & 0 & 0 \\
\hline 3 & 1 & 1 & 0 & 0 \\
\hline 4 & 1 & 1 & 0 & 0 \\
\hline 5 & 1 & 1 & 0 & 0 \\
\hline 6 & 1 & 1 & 0 & 0 \\
\hline 7 & 1 & 1 & 0 & 0 \\
\hline 8 & 0.5 & 1 & 1 & 0 \\
\hline 9 & 0.5 & 1 & 1 & 0 \\
\hline 10 & 0.5 & 1 & 1 & 0 \\
\hline 11 & 0.5 & 1 & 1 & 0 \\
\hline 12 & 0.5 & 1 & 1 & 0 \\
\hline 13 & 0.5 & 1 & 1 & 0 \\
\hline 14 & 0.5 & 1 & 1 & 0 \\
\hline 15 & 0.5 & 1 & 1 & 0 \\
\hline 16 & 0.5 & 1 & 1 & 0 \\
\hline 17 & 0.5 & 1 & 1 & 0 \\
\hline 18 & 0.5 & 1 & 1 & 0 \\
\hline 19 & 0.5 & 1 & 1 & 0 \\
\hline 20 & 0.5 & 1 & 1 & 0 \\
\hline 21 & 0.5 & 1 & 1 & 0 \\
\hline 22 & 1 & 1 & 0 & 0 \\
\hline 23 & 1 & 1 & 0 & 0 \\
\hline 24 & 1 & 1 & & 0 \\
\hline
\end{tabular}

\subsection{Low-Energy Model Development and Assumptions}

The final recommendations included in the Guide were determined based on an iterative process using the PC's expertise and results from modeling the recommendations. To quantify the potential energy savings from the final recommended energy efficiency measures in the Guide, we implemented the energy efficiency technologies listed below to simulate the low-energy building models. This section contains a topic-by-topic description of the low-energy building models and how the recommended energy efficiency measures were implemented into the low-energy modeling. The energy efficiency measures included in the $30 \%$ saving calculation are:

- Enhanced building opaque envelope insulation

- High-performance window glazing with overhangs

- Reduced LPD and occupancy controls

- Classroom and gym daylighting 
- Demand controlled ventilation with automatic motorized damper control for (OA) intake

- Energy recovery ventilator (ERV)

- Economizers

- Lower pressure ductwork design and higher efficiency fans

- Higher efficiency HVAC equipment

- High-efficiency service water heating

Plug loads reductions are not credited to the calculated 30\% energy savings, as these energy efficiency opportunities are not part of the prescriptive recommendations. However, they form a prominent part of the additional savings section in the Guide.

\subsubsection{Developing the Recommendations}

The PC used the following guiding principles to develop the final recommendation for the K-12 AEDG:

- Provide recommendations that represent responsible, but not necessarily the best K-12 school design practices. If a recommendation, in general, represents good design practice, it is recommended for all climate zones, even if the resulting savings exceed $30 \%$.

- Use off-the shelf technologies that are available from multiple sources. The PC did not recommend technologies or techniques that are one of a kind or available from a single manufacturer.

- Provide recommendations that are at least as stringent as those in the forthcoming ASHRAE 90.1-2007, including Addenda AS and AT (ASHRAE 2004a). We did not want our recommendations to be less stringent than the most recent version of ASHRAE 90.1.

- Use the recommendations from the previous SO AEDG as a starting point for fine tuning the K12 AEDG recommendations. Develop recommendations to address the focus group's concerns on usability, O\&M, simplicity, and flexibility.

- Verify $30 \%$ energy savings for the recommendations that represent the most typical K-12 school components, or for the components that are the least likely to result in $30 \%$ savings.

\subsubsection{Daylighting Recommendations}

The PC considered daylighting as the most important of the recommendations in the K-12 AEDG. This was because daylighting has many benefits, both real and perceived, in the K-12 school industry. One measurable benefit from daylighting in schools is energy savings. Electrical lighting is one of the largest energy users in schools. Depending on climate, lighting energy use can be as high as about $35 \%$ of the total energy use of a basic, energy code-compliant school (see Figure 4-1 through Figure 4-6). Because lighting-related improvements can be inexpensive and offer rapid payback, these are at the top of the list of recommendations for meeting an overall target of 30\% energy savings or greater. There are two distinctly different approaches to reducing electric lighting power: through daylighting or with highefficiency electrical lighting systems. Either can be used to meet the recommendations in this Guide:

- Designing a daylit school. For the daylighting options, recommendations are given for classrooms and gyms/multipurpose rooms. There are three classroom daylighting patterns: a toplit pattern, a sidelit pattern, and a combined toplit and sidelit pattern. For the gym/multipurpose rooms, there are two toplit daylighting patterns: a roof monitor pattern and a skylight pattern. Recommendations for north- and south-facing versions for each pattern are provided in the Guide. East- and west-facing daylighting systems are not recommended. Recommended patterns are also provided by climate zone.

- Using efficient and state-of-the-art products and techniques to design electric lighting. Site constraints or program requirements may preclude daylighting solutions. Therefore, a non-daylit 
path is provided to meet the recommendations in this Guide. These recommendations include lighting systems that use the most current, energy-efficient lamps, ballasts, and integrated controls.

\subsubsection{HVAC Recommendations}

Recommendations were developed based on the availability of daylighting for the school and by the type of HVAC system. The types of HVAC systems in K-12 schools are highly variable across the country. Therefore, recommendations for multiple HVAC types are provided. To verify savings over this range of design options, we modeled low-energy versions of the elementary, middle, and high schools, each with the daylit option and the non-daylit option. For each daylit and non-daylit option, we modeled three HVAC types. The low-energy HVAC system types included a constant volume package rooftop DX system, a package VAV DX system with a central boiler, and a VAV air-cooled chiller and central boiler. These HVAC system types were chosen based on the PC input as to the systems that were the least stringent as well as the most common.

\subsubsection{Form and Floor Plate}

The low-energy building models had identical conditioned floor area and identical exterior dimensions and orientations as the baseline buildings, except the following components.

\subsubsection{Overhangs}

The Guide recommends overhangs with a projection factor of 0.5 on south-, east-, and west-facing windows in all climate zones. Therefore, both the daylit and non-daylit low-energy models included fixed shading by assuming that the overhang starts $1.5 \mathrm{ft}(0.5 \mathrm{~m})$ above the window and extends out from the façade to provide the projection factor of 0.5 .

\subsubsection{Form: No Daylighting}

For the non-daylighting option, the low-energy orientation, form, and floor plate are identical to the baseline models. The location and amount of fenestration are also the same between the non-daylit lowenergy models and the baseline models. The model rendering of the low-energy non-daylit elementary, middle, and high schools are shown in Figure 3-27, Figure 3-28, and Figure 3-29, respectively.

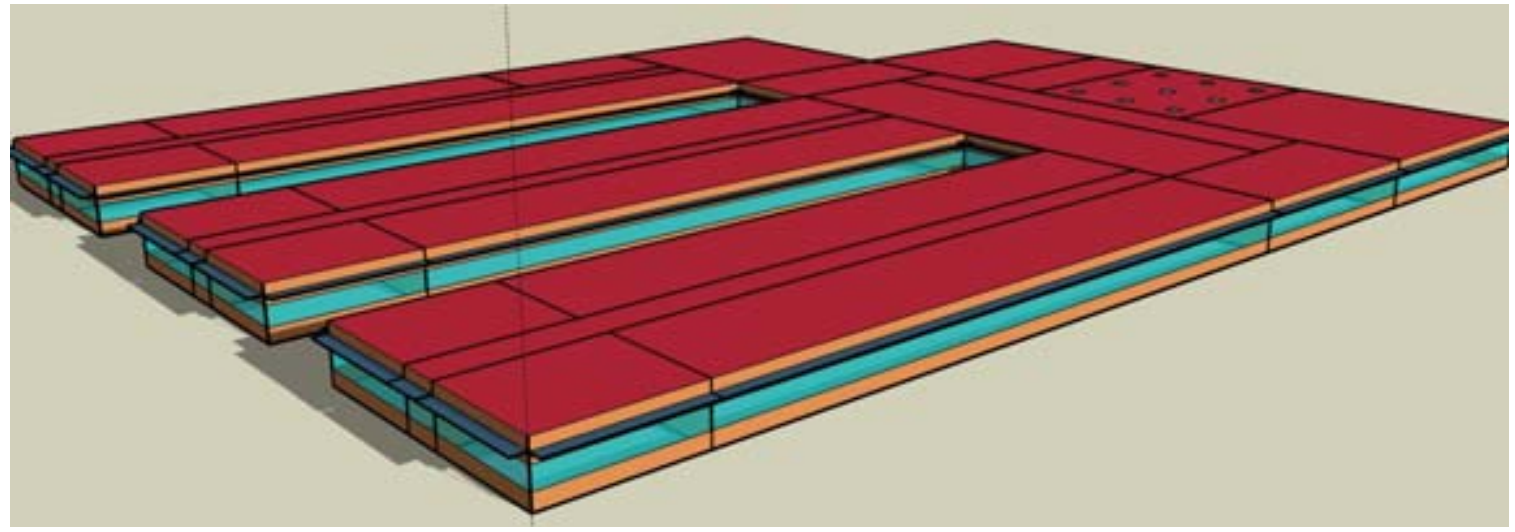

Figure 3-27 Elementary School Low-Energy Model Rendering: No Daylighting 


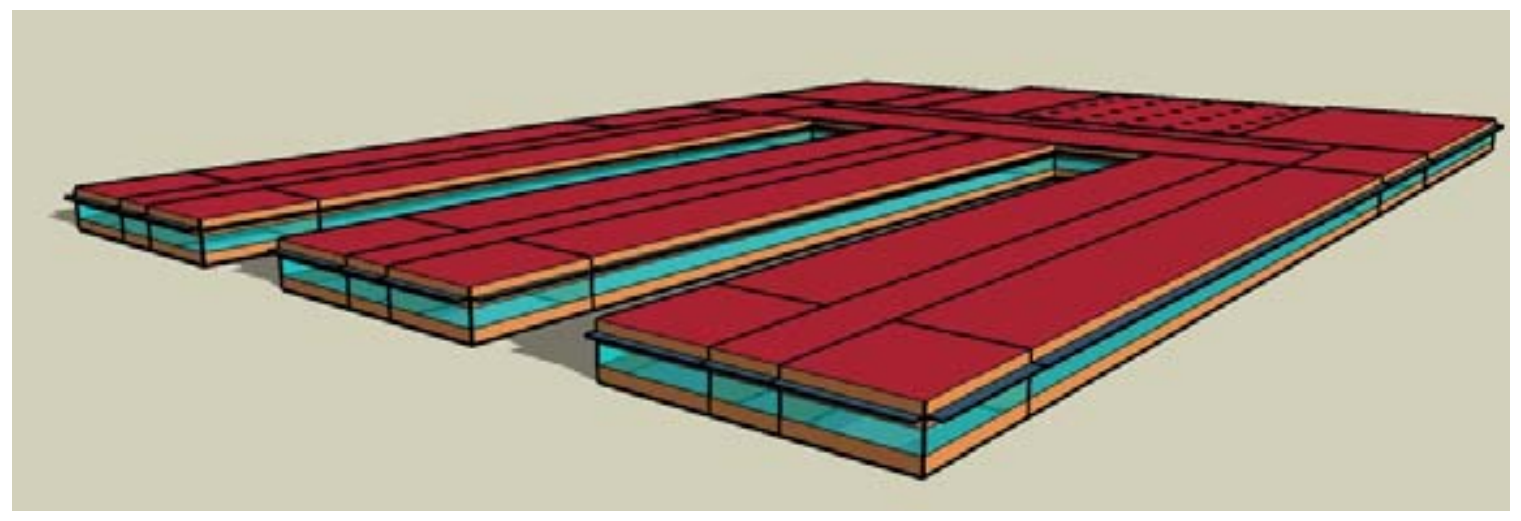

Figure 3-28 Middle School Low-Energy Model Rendering: No Daylighting

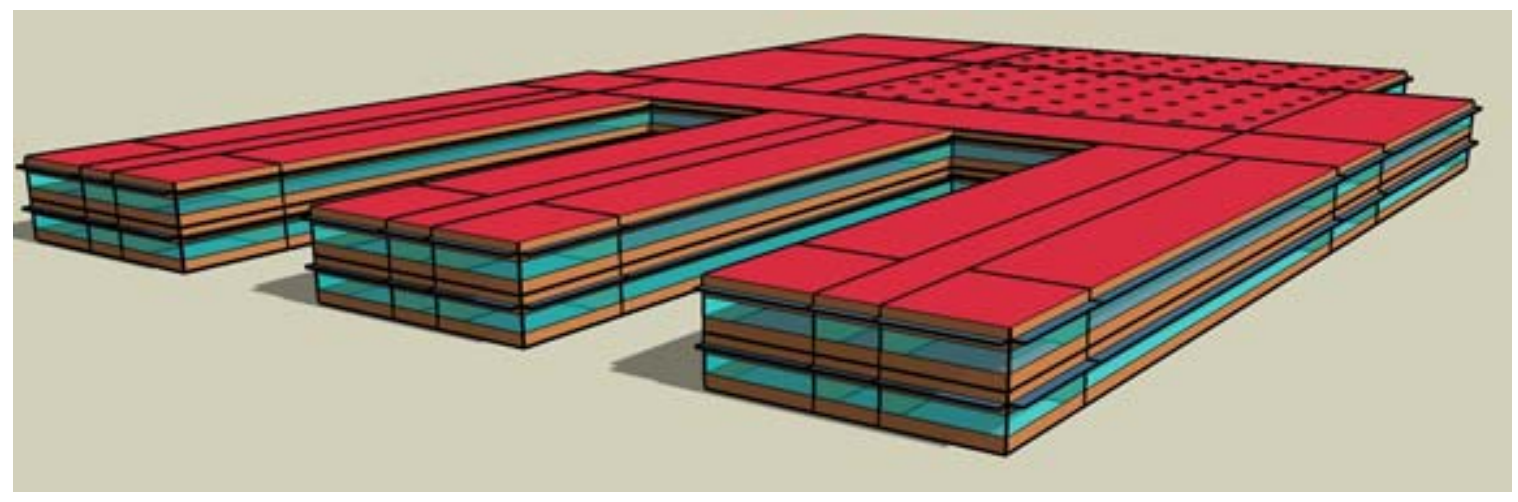

Figure 3-29 High School Low-Energy Model Rendering: No Daylighting

\subsubsection{Form: Daylighting}

For this Guide, four daylighting strategies are presented; three for classrooms and one for gymnasiums. Daylighting the classroom is most critical, since that is where the teachers and the students spend most of their time. In addition, the potential for savings is the greatest in the classrooms. Guidelines are also provided for the gymnasium/multipurpose room because this space is typically used for more hours. For each strategy, there are several options and variations depending on climate and orientation. These daylighting strategies are designed to provide the recommended illuminances for the classrooms and gym over most occupied daytime hours.

These strategies are based on all classroom spaces being oriented so the windows face either north or south. Daylighting can be achieved for other orientations, but the recommendations in the Guide do not apply to those orientations. The four patterns are summarized below:

- Classrooms with Sidelighting Only. Two variations of this are provided, one for north-facing and one for south-facing classrooms. South facing classrooms are assumed to have overhangs and light shelves to bounce the daylighting deeper into the space.

- Classrooms with Toplighting Only. Two variations are provided for toplighting, one for northfacing roof monitors, and one for south-facing roof monitors. Both are positioned in the center of the space and coupled with light baffles to bounce and filter light.

- Classrooms with a combination of Sidelighting and Toplighting. This daylighting pattern combines the south- or north-facing classrooms described in the first bullet with toplighting at the back walls of the classrooms. The toplighting may be provided by either skylights or roof monitors, depending on climate and other design constraints. 
- Gyms with Toplighting. Two variations of this daylighting pattern are provided, one with roof monitors and one with skylights.

The classroom sidelit only option with the skylights in the gym were included in the low-energy models because the PC felt these daylighting patterns would be the least effective daylighting strategies of those recommended. If we could verify $30 \%$ energy savings with the least effective of our recommended daylighting strategies, the PC was confident that the more effective daylighting patterns would also achieve $30 \%$ savings.

To model the classroom sidelit option, we used the recommended fenestration area as shown in Table 3-34. These areas assume the fenestration visible transmittance (VLT) is higher than $65 \%$. Daylighting fenestration with lower VLT would result in more fenestration area to provide a similar amount of daylighting. The sidelit daylighting option in the classrooms has view glass below $7 \mathrm{ft}(2 \mathrm{~m})$ and daylighting glass above $7 \mathrm{ft}(2 \mathrm{~m})$ for north- and south-facing exterior walls. More daylighting glass is recommended for the north classrooms as all of the daylighting is from diffuse daylight. The south daylighting design takes advantage of direct beam daylighting, which requires less daylighting glass for similar daylighting penetration. The corner classrooms do not have west-facing glass. Fenestration to wall area ratios of $20 \%$ were used in the offices, lobby, corridor, cafeteria, media center, and restrooms. No fenestration is included in the gyms, kitchen, or auditorium. The gym/multipurpose room is daylit with skylights, at 4\% skylight area to floor area. These fenestration fractions are based on the PC's best practices and experience designing daylighting systems for K-12 schools. The total fenestration for the daylit elementary, middle, and high school models have the same amount of fenestration as the baseline models ( $35 \%$ fenestration to gross wall area), but the daylit models have more fenestration allocated to the classrooms and less to the non-daylit spaces.

The sidelighting concept is shown in Figure 3-30. The daylit elementary, middle, and high school EnergyPlus model renderings are shown in Figure 3-31 through Figure 3-33.

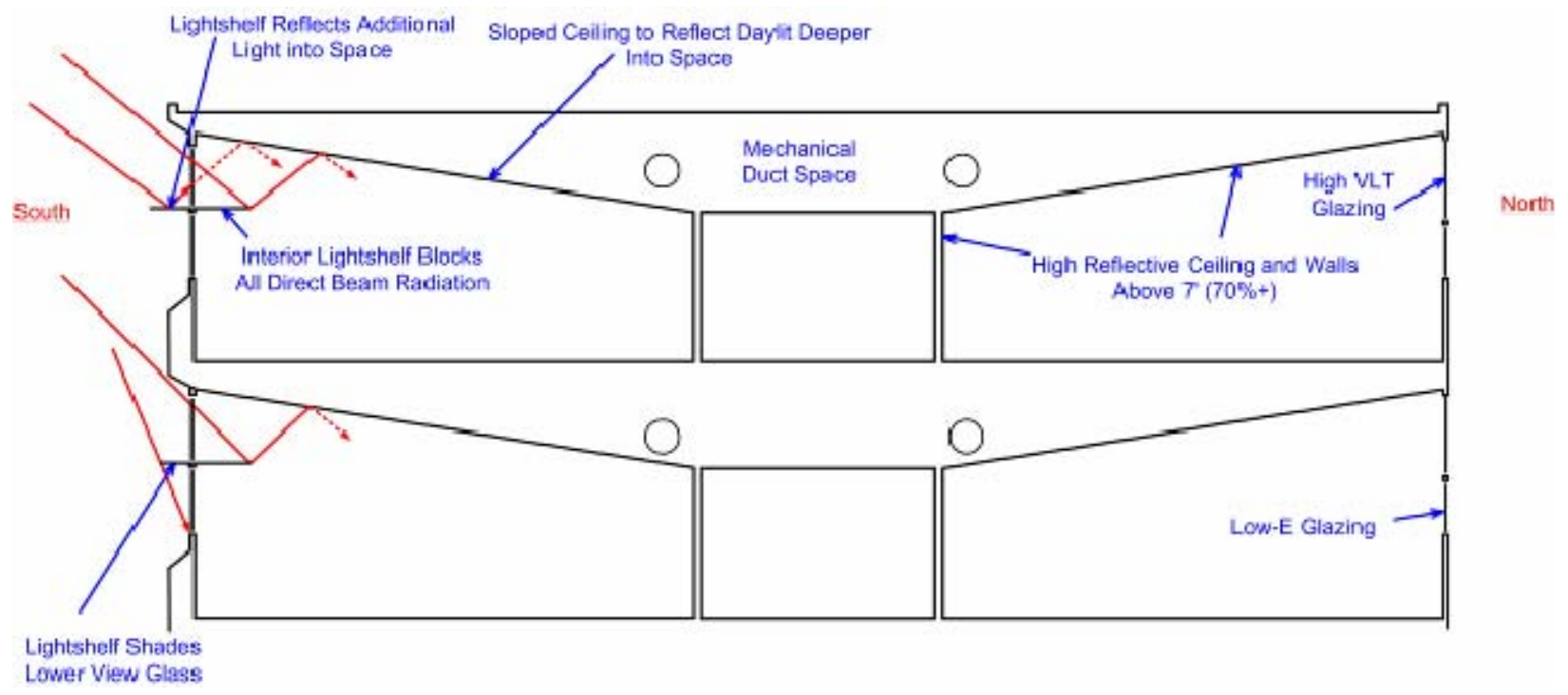

Figure 3-30 Classroom Sidelit Pattern 
Table 3-34 Fenestration by Space Type for Daylit Models

\begin{tabular}{|l|c|c|}
\hline \multicolumn{1}{|c|}{ Daylighting Strategy } & $\begin{array}{c}\text { Fenestration to Zone } \\
\text { Exterior Wall Area Ratio }\end{array}$ & $\begin{array}{c}\text { Gymnasium/Multipurpose Room } \\
\text { Skylight to Floor Area Ratio }\end{array}$ \\
\hline $\begin{array}{l}\text { Classroom south } \\
\text { sidelighting }\end{array}$ & $25 \%$ & \\
\hline Classroom south view & $25 \%$ & \\
\hline $\begin{array}{l}\text { Classroom north } \\
\text { sidelighting }\end{array}$ & $38 \%$ & $4 \%$ \\
\hline Classroom north view & $12 \%$ & \\
\hline Skylights & No vertical fenestration & \\
\hline $\begin{array}{l}\text { Gyms, auditorium, } \\
\text { kitchen }\end{array}$ & $20 \%$ & $<1 \%$ \\
\hline All other zones & $\mathbf{3 5 \%}$ & \\
\hline Total School & & \\
\hline
\end{tabular}

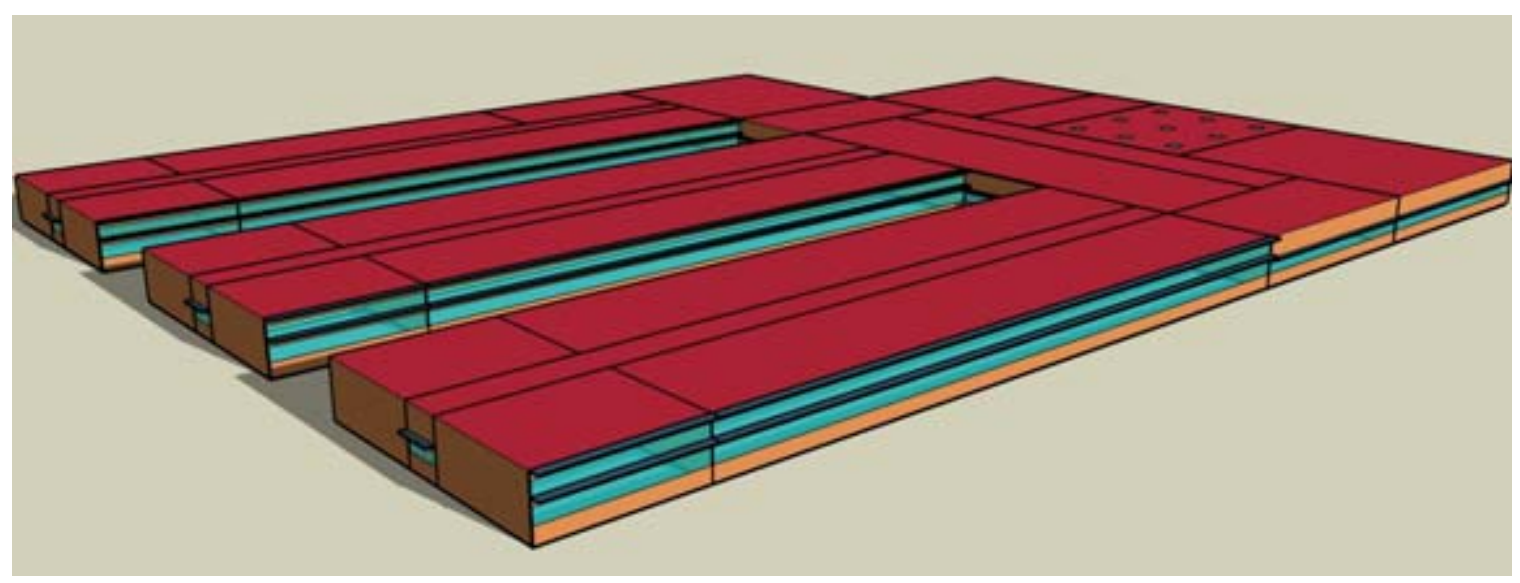

Figure 3-31 Elementary School Low-Energy Model Rendering: Daylit

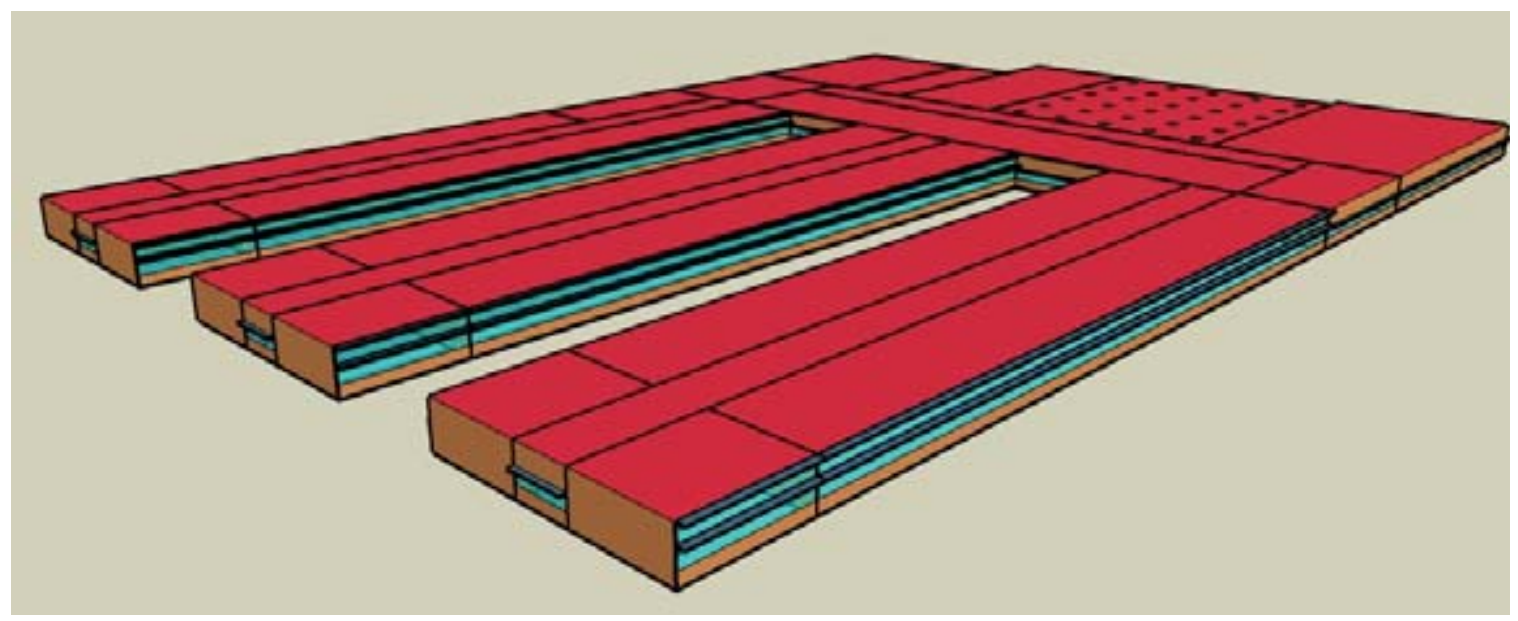

Figure 3-32 Middle School Low-Energy Model Rendering: Daylit 


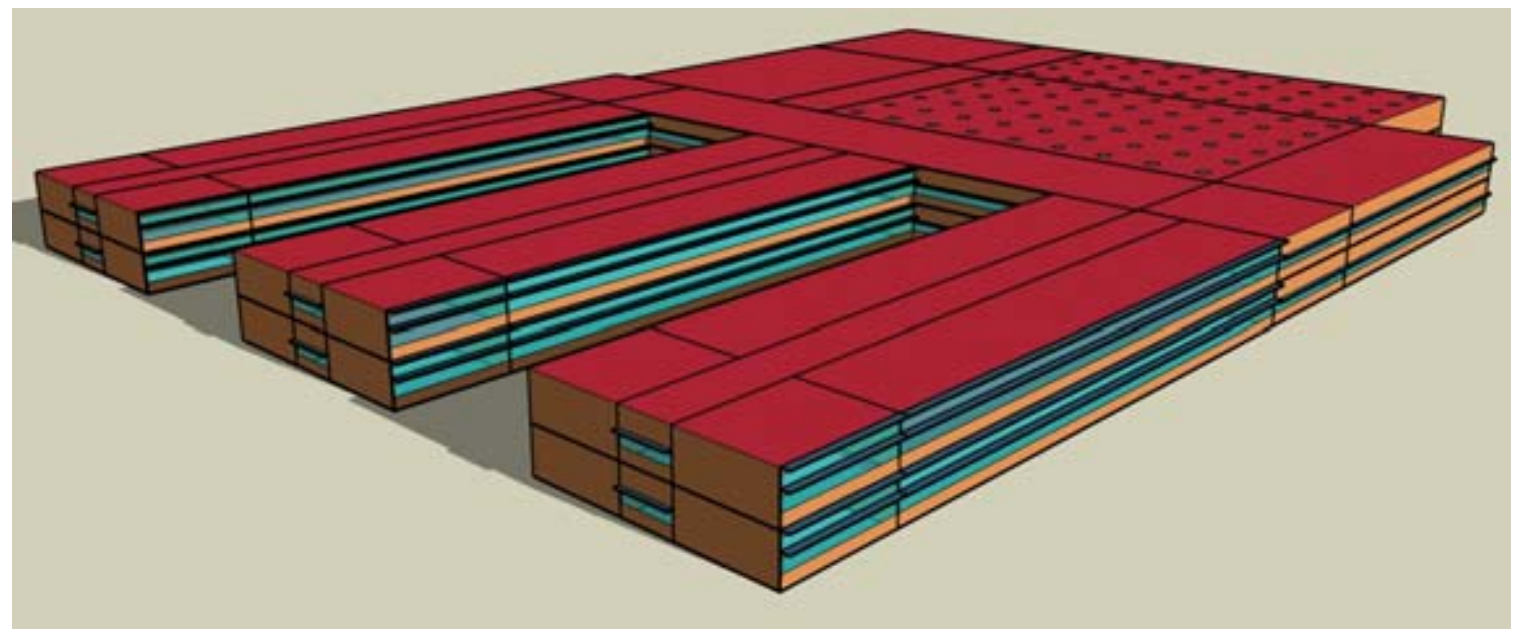

Figure 3-33 High School Low-Energy Model Rendering: Daylit

\subsubsection{Envelope}

The low-energy K-12 school models had identical conditioned floor areas and identical exterior dimensions and orientations as the baseline buildings, except the following components:

\subsubsection{Exterior Walls and Roof}

To determine optimal envelope insulation levels specific to the K-12 schools, we determined the total life cycle costs for various roof and wall insulations levels. The most cost effective roof and wall insulation levels were then used for the recommendations in the Guide. The PC felt that the SO AEDG (AEDG 2004) envelope recommendations would apply sufficiently to K-12 schools, but that fine tuning of the mass wall insulation and insulation above deck recommendations was needed. The recommendations in the K-12 AEDG are all at least as stringent as the most recent version of ASHRAE 90.1 (ASHRAE 90.12007, including addenda AS and AT). Therefore, if the most cost-effective level of insulation was below ASHRAE 90.1-2007, the code minimum was used. All the other envelope recommendations were determined based on the more stringent of the recommendations from the SO AEDG, or ASHRAE 90.12007, including ASHRAE 90.1-2004 addenda AS and AT.

We used an internal NREL building energy and cost optimization research tool titled "Opt-E-Plus" to determine the optimal levels of roof and wall insulation for the K-12 AEDG. Opt-E-Plus is an internal NREL program that allows the user to sift through a database of design options and cost parameters, manages the parametric EnergyPlus simulations, and presents the results to determine the optimal combination of energy-efficient options. For our analysis, the optimal level of insulation results in the lowest total life cycle cost (TLCC). The TLCC is the total expected cost of the whole building (capital and energy costs) over the analysis period. The TLCC accounts for inflation of energy and O\&M, and therefore, the discount rate is used as a nominal discount rate. The typical output of the optimization is an $\mathrm{x}-\mathrm{y}$ graph; the independent axis is site energy savings and the dependent axis is TLCC. The TLCC is calculated for each variation of wall insulation and roof insulation and compared to the TLCC of the reference model to determine the percent change in TLCC.

To calculate the TLCC, the annual cash flow is summed over the analysis period. The annual energy use is assumed to be constant over the whole analysis period, but the energy costs vary based on the inflation rate. The equation to calculate the annual cash flows are shown in Equation 3-2. 


$$
\begin{aligned}
C_{n}= & \left(\sum_{j=0}^{J}\left(1+i_{d}\right)^{n}\left(M C_{n}+I C_{n}-S C_{n}\right)+\left(1+i_{\text {om }}\right)^{n}\left(F O M_{n}+V O M_{n}\right)\right) \\
& +\left(1+i_{g}\right)^{n} C_{g}+\left(1+i_{e}\right)^{n} C_{e}
\end{aligned}
$$

\section{Equation 3-2 Calculation of Annual Cash Flows}

Where:

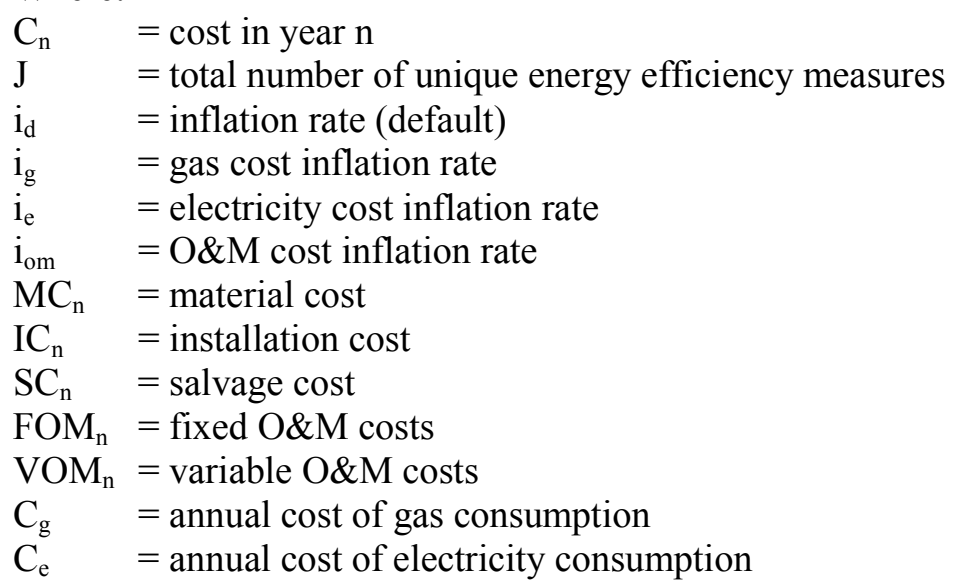

The TLCC is determined in Equation 3-3.

$$
T L C C=\sum_{n=0}^{N} \frac{C_{n}}{(1+d)^{n}}
$$

\section{Equation 3-3 Calculation of TLCC}

Where:

$$
\begin{array}{ll}
\text { TLCC } & =\text { present value of the TLCC } \\
\mathrm{C}_{\mathrm{n}} & =\text { cost in year } \mathrm{n} \\
\mathrm{N} & =\text { analysis period } \\
\mathrm{d} & =\text { annual discount rate }
\end{array}
$$

We used our non-daylit low-energy elementary school as a reference for determining the optimal envelope. This reference model included all the recommendations in the Guide for low LPD for the nondaylit option, the HVAC recommendation for the package rooftop units, and started with the SO AEDG recommendations for the envelope. We then modeled a full range of mass walls and insulation above deck roofs to determine energy savings and TLCC.

To calculate the TLCC of the roof and wall recommendations, we used the opaque wall and roof capital costs used in the ASHRAE 90.1 development construction cost database combined with our default HVAC system costs. The mass walls and roofs considered are shown in Table 3-35 and Table 3-36, along with the material and installation costs. 
Table 3-35 Roof Insulation Options and Costs

\begin{tabular}{|c|c|c|}
\hline $\begin{array}{c}\text { Insulation above } \\
\text { Deck Description }\end{array}$ & Material Cost & Installation Cost \\
\hline $\mathrm{R}-95.0 \mathrm{ci}$ & $\$ 6.35 / \mathrm{ft}^{2}$ & $\$ 2.74 / \mathrm{ft}^{2}$ \\
\hline $\mathrm{R}-85.0 \mathrm{ci}$ & $\$ 6.08 / \mathrm{ft}^{2}$ & $\$ 2.62 / \mathrm{ft}^{2}$ \\
\hline $\mathrm{R}-75.0 \mathrm{ci}$ & $\$ 5.81 / \mathrm{ft}^{2}$ & $\$ 2.51 / \mathrm{ft}^{2}$ \\
\hline $\mathrm{R}-65.0 \mathrm{ci}$ & $\$ 5.55 / \mathrm{ft}^{2}$ & $\$ 2.39 / \mathrm{ft}^{2}$ \\
\hline $\mathrm{R}-60.0 \mathrm{ci}$ & $\$ 5.29 / \mathrm{ft}^{2}$ & $\$ 2.28 / \mathrm{ft}^{2}$ \\
\hline $\mathrm{R}-55.0 \mathrm{ci}$ & $\$ 5.04 / \mathrm{ft}^{2}$ & $\$ 2.17 / \mathrm{ft}^{2}$ \\
\hline $\mathrm{R}-50.0 \mathrm{ci}$ & $\$ 4.77 / \mathrm{ft}^{2}$ & $\$ 2.06 / \mathrm{ft}^{2}$ \\
\hline $\mathrm{R}-40.0 \mathrm{ci}$ & $\$ 4.52 / \mathrm{ft}^{2}$ & $\$ 1.95 / \mathrm{ft}^{2}$ \\
\hline $\mathrm{R}-30.0 \mathrm{ci}$ & $\$ 3.91 / \mathrm{ft}^{2}$ & $\$ 1.68 / \mathrm{ft}^{2}$ \\
\hline $\mathrm{R}-25.0 \mathrm{ci}$ & $\$ 3.67 / \mathrm{ft}^{2}$ & $\$ 1.58 / \mathrm{ft}^{2}$ \\
\hline $\mathrm{R}-20.0 \mathrm{ci}$ & $\$ 3.43 / \mathrm{ft}^{2}$ & $\$ 1.48 / \mathrm{ft}^{2}$ \\
\hline $\mathrm{R}-15.0 \mathrm{ci}$ & $\$ 3.19 / \mathrm{ft}^{2}$ & $\$ 1.37 / \mathrm{ft}^{2}$ \\
\hline $\mathrm{R}-10.0 \mathrm{ci}$ & $\$ 2.95 / \mathrm{ft}^{2}$ & $\$ 1.27 / \mathrm{ft}^{2}$ \\
\hline $\mathrm{R}-7.6 \mathrm{ci}$ & $\$ 2.83 / \mathrm{ft}^{2}$ & $\$ 1.22 / \mathrm{ft}^{2}$ \\
\hline $\mathrm{R}-5.0 \mathrm{ci}$ & $\$ 2.62 / \mathrm{ft}^{2}$ & $\$ 1.13 / \mathrm{ft}^{2}$ \\
\hline $\mathrm{R}-3.8 \mathrm{ci}$ & $\$ 2.55 / \mathrm{ft}^{2}$ & $\$ 1.10 / \mathrm{ft}^{2}$ \\
\hline $\mathrm{NR}$ & $\$ 2.45 / \mathrm{ft}^{2}$ & $\$ 1.06 / \mathrm{ft}^{2}$ \\
\hline & & \\
\hline & & \\
\hline & & \\
\hline & & \\
\hline & & \\
\hline
\end{tabular}


Table 3-36 Mass Wall Insulation Options and Costs

\begin{tabular}{|c|c|c|}
\hline $\begin{array}{c}\text { Mass Wall } \\
\text { Description }\end{array}$ & Material Cost & Installation Cost \\
\hline $\mathrm{R}-62.5 \mathrm{ci}$ & $\$ 7.98 / \mathrm{ft}^{2}$ & $\$ 3.44 / \mathrm{ft}^{2}$ \\
\hline $\mathrm{R}-56.3 \mathrm{ci}$ & $\$ 7.54 / \mathrm{ft}^{2}$ & $\$ 3.25 / \mathrm{ft}^{2}$ \\
\hline $\mathrm{R}-50.0 \mathrm{ci}$ & $\$ 7.08 / \mathrm{ft}^{2}$ & $\$ 3.05 / \mathrm{ft}^{2}$ \\
\hline $\mathrm{R}-43.8 \mathrm{ci}$ & $\$ 6.65 / \mathrm{ft}^{2}$ & $\$ 2.87 / \mathrm{ft}^{2}$ \\
\hline $\mathrm{R}-37.5 \mathrm{ci}$ & $\$ 6.20 / \mathrm{ft}^{2}$ & $\$ 2.67 / \mathrm{ft}^{2}$ \\
\hline $\mathrm{R}-31.3 \mathrm{ci}$ & $\$ 5.76 / \mathrm{ft}^{2}$ & $\$ 2.48 / \mathrm{ft}^{2}$ \\
\hline $\mathrm{R}-25.0 \mathrm{ci}$ & $\$ 5.32 / \mathrm{ft}^{2}$ & $\$ 2.29 / \mathrm{ft}^{2}$ \\
\hline $\mathrm{R}-15.2 \mathrm{ci}$ & $\$ 4.55 / \mathrm{ft}^{2}$ & $\$ 1.96 / \mathrm{ft}^{2}$ \\
\hline $\mathrm{R}-13.3 \mathrm{ci}$ & $\$ 4.41 / \mathrm{ft}^{2}$ & $\$ 1.90 / \mathrm{ft}^{2}$ \\
\hline $\mathrm{R}-11.4 \mathrm{ci}$ & $\$ 4.27 / \mathrm{ft}^{2}$ & $\$ 1.84 / \mathrm{ft}^{2}$ \\
\hline $\mathrm{R}-9.5 \mathrm{ci}$ & $\$ 4.12 / \mathrm{ft}^{2}$ & $\$ 1.78 / \mathrm{ft}^{2}$ \\
\hline $\mathrm{R}-7.6 \mathrm{ci}$ & $\$ 4.00 / \mathrm{ft}^{2}$ & $\$ 1.72 / \mathrm{ft}^{2}$ \\
\hline $\mathrm{R}-5.7 \mathrm{ci}$ & $\$ 3.84 / \mathrm{ft}^{2}$ & $\$ 1.65 / \mathrm{ft}^{2}$ \\
\hline $\mathrm{NR}$ & $\$ 2.70 / \mathrm{ft}^{2}$ & $\$ 1.16 / \mathrm{ft}^{2}$ \\
\hline
\end{tabular}

To account for any HVAC downsizing opportunities that result from increased roof or wall insulation, the absolute cost of the HVAC system was also considered in the building's TLCC. As the HVAC is autosized based on peak loads, there are significant capital cost savings associated with the smaller HVAC systems that can be used as the envelope insulation is increased. The following package rooftop, single-zone system costs were used:

- Units are $\$ / \mathrm{kW}$ of cooling capacity

- Expected life is 15 years

- Material cost is $\$ 450 / \mathrm{kW}$

- Installation cost is $\$ 47 / \mathrm{kW}$

- Fixed annual O\&M is $\$ 4 / \mathrm{kW}$

- One time O\&M is $\$ 33 / \mathrm{kW}$

- Salvage cost is $\$ 1 / \mathrm{kW}$

Opt-E-Plus has several economic measures that are used to calculate real building economics. To calculate the building economics, several economic variables need to be set. The basic economics we included in the calculation of TLCC are:

- $8 \%$ nominal discount rate

- $2.47 \%$ electric and gas escalation rate

- 30-year analysis period

- $5 \%$ interest rate

- No income taxes were included (assuming public school districts) 
- Local utility rates for each city to determine energy cost savings

- Regional capital cost modifier to convert national averages to regional values. The modifiers are available from the RS Means data sets.

For each climate zone, we determined the roof and wall insulation levels with the lowest TLCC. If the insulation levels with the lowest TLCC were less than ASHRAE 90.1-2007 code requirements, we used the code values. The results and graphs for each climate zone are shown in Appendix F. The lowest TLCC insulation levels are highlighted, and the 90.1-2007, 90.1-1999, and SO AEDG insulation levels are noted for each climate zone. For the roof insulation, R-25 continuous insulation (ci) was the most cost effective in all climate zones, and was recommended level of insulation in the Guide. For the mass wall insulation, ASHRAE 90.1-2007 insulation values were the most cost effective for all climate zones, except for 1 and 2, where slightly more stringent insulation levels were cost effective. The insulation levels of the opaque envelope components are included in the low-energy models.

\subsubsection{High Albedo Roofs}

The K-12 AEDG recommends the use of high albedo roofs with a Solar Reflective Index (SRI) of 0.78 in climate zones 1 through 3 . To model the high albedo roofs, we assumed the outer layer of the roof has a thermal absorption of 0.9 , a solar reflectivity of 0.7 , and a visible absorption of 0.3 .

\subsubsection{Fenestration}

The vertical fenestration and skylight $U$-factors were modeled to meet the minimum requirements for the climate, as shown in the recommendations tables in Section 4. The fenestration and skylight thermal characteristics recommendations were developed based on the more stringent of the SO AEDG recommendations or those in ASHRAE 90.1-2004, Addendum AT (ASHRAE 2004a). See Table 4-1 and Table 4-2 for the low-energy fenestration thermal characteristics.

To meet the SHGC recommendations for vertical fenestration in the K-12 AEDG, we used the SHGC multipliers for permanent projections, as provided in Table 5.5.4.4.1 in ASHRAE 90.1-2004 (ASHRAE 2004a). These multipliers allow for a higher SHGC for vertical fenestration with overhangs. For an overhang with a projection factor greater than 0.5 , the recommended SHGC can be increased by $64 \%$. For example, the recommended SHGC in climate zone 1 is 0.25 . However, using the SHGC multipliers for an overhang with a projection factor of 0.5 , a SHGC of 0.41 is allowed. We used these SHGC multipliers in the low-energy fenestration model inputs, as a higher SHGC makes it easier to meet the high visible transmittance recommendations needed for daylighting. The fenestration in the low-energy models includes SHGCs that are 64\% higher than the K-12 AEDG recommendations. For the daylighting fenestration, a visible transmittance of at least $65 \%$ is recommended, and is included in the low-energy fenestration inputs.

\subsubsection{Lower Lighting Power Density}

The K-12 AEDG provides recommendations for LPD for the daylit options and the non-daylit option. The recommended LPDs represent an average LPD for the entire building, and are modeled as such. Individual spaces may have higher power densities if they are offset by lower power densities in other areas. The baseline and K-12 AEDG LPD recommendations are shown in Table 3-37.

The recommended LPD for the non-daylit options in climate zones 1,2 , and 5 through 8 is $1.1 \mathrm{~W} / \mathrm{ft}^{2}(11.8$ $\left.\mathrm{W} / \mathrm{m}^{2}\right)$. In climate zones 3 and 4 , the recommended LPD is $0.9 \mathrm{~W} / \mathrm{ft}^{2}\left(9.7 \mathrm{~W} / \mathrm{m}^{2}\right)$. In these zones, the lighting load is a higher percentage of total energy use because of smaller heating and cooling loads. Therefore, more aggressive LPDs that use the most current, energy efficient lamps, ballasts, and integrated controls are recommended to meet the savings target of 30\%. The daylit options recommend a slightly higher LPD of $1.2 \mathrm{~W} / \mathrm{ft}^{2}\left(12.9 \mathrm{~W} / \mathrm{m}^{2}\right)$. The higher LPD is recommended for the daylit options because significant lighting savings are expected from the lights dimming or turning off from the daylight rather than an aggressive lighting power reduction. Also, dimming can result in slightly lower efficacies of the lamp and ballast combination. 
Table 3-37 Baseline and Low-Energy LPDs

\begin{tabular}{|c|c|c|c|c|}
\hline $\begin{array}{c}\text { Climate } \\
\text { Zone }\end{array}$ & $\begin{array}{c}\text { Baseline LPD } \\
\text { ASHRAE 90.1-1999 } \\
\left(\mathbf{W} / \mathrm{ft}^{2}\right)\end{array}$ & $\begin{array}{c}\text { Baseline LPD } \\
\text { ASHRAE 90.1-2004 } \\
\left(\mathbf{W} / \mathrm{ft}^{2} \mathbf{)}\right.\end{array}$ & $\begin{array}{c}\text { No Daylighting } \\
\text { Option LPD } \\
\left(\mathbf{W} / \mathrm{ft}^{2} \mathbf{)}\right.\end{array}$ & $\begin{array}{c}\text { Daylighting } \\
\text { Option LPD } \\
\left(\mathbf{W} / \mathrm{ft}^{2}\right)\end{array}$ \\
\hline 1 & 1.53 & 1.25 & 1.10 & 1.20 \\
\hline 2 & 1.53 & 1.25 & 1.10 & 1.20 \\
\hline 3 & 1.53 & 1.25 & 0.90 & 1.20 \\
\hline 4 & 1.53 & 1.25 & 0.90 & 1.20 \\
\hline 5 & 1.53 & 1.25 & 1.10 & 1.20 \\
\hline 6 & 1.53 & 1.25 & 1.10 & 1.20 \\
\hline 7 & 1.53 & 1.25 & 1.10 & 1.20 \\
\hline 8 & 1.53 & 1.25 & 1.10 & 1.20 \\
\hline
\end{tabular}

\subsubsection{Lighting Controls}

The K-12 AEDG daylighting option recommends daylighting controls in the daylit classrooms and gyms. For the low-energy daylit models, we modeled continuous dimming daylighting controls that turn off when daylighting can meet the entire lighting load. Each classroom was modeled with two daylighting reference points, each controlling half of the lights in the classroom. The first daylighting reference point was located $3 \mathrm{ft}(0.9 \mathrm{~m})$ off the floor and $10 \mathrm{ft}(3 \mathrm{~m})$ from the daylighting glass. The second daylighting reference point was located $3 \mathrm{ft}(0.9 \mathrm{~m})$ off the floor and $20 \mathrm{ft}(6 \mathrm{~m})$ from the daylighting glass. The lights were controlled based on a daylighting set point of $40 \mathrm{ft}$-candles (400 lux). In the daylit gyms with skylights, the daylighting control point was placed in between four skylights to represent the lowest lighting level in the zone. Daylighting controls were not modeled in the non-daylit low-energy option.

For both the daylit and non-daylit low-energy options, manual on, auto off occupancy sensors for all zones are recommended. This was modeled by adjusting the lighting schedule. See Section 3.4.7 for the schedules used in the low-energy models.

\subsubsection{HVAC Systems and Components}

\subsubsection{Low-Energy System Types and Sizes}

Many types of HVAC systems could be used in K-12 schools; however, the K-12 AEDG assumes that one of the following six system types is to be used.

- Single-zone, packaged rooftop DX units (or split DX systems) with indirect gas-fired heaters, electric resistance heat, or heat pumps. This was used for the baseline models, and is referred to in this report as the PSZ system.

- Water source (or ground source) heat pumps with a dedicated outdoor air ventilation system.

- Unit ventilators with a water chiller and a water boiler or electric resistance heat.

- Fan coils with a water chiller and a water boiler or electric resistance heat and a dedicated OA ventilation system.

- Multiple-zone, VAV packaged DX rooftop units with a hot water coil, indirect gas furnace, or electric resistance in the rooftop unit and a hot water coil or electric resistance in the VAV terminals. This is referred to in this report as the PVAV system. 
- Multiple-zone, VAV air handlers with a water chiller and a hot water coil, indirect gas furnace, or electric resistance in the air handler and a hot water coil or electric resistance in the VAV terminals. This is referred to in this report as the VAV system.

The K-12 AEDG does not cover purchased chilled water for cooling, or solar, steam, or purchased steam for heating.

Unique recommendations are included for each HVAC system type in the climate-specific recommendation tables in Section 4. To verify savings over this range of design options, we modeled three HVAC types. The low-energy HVAC system types included a constant volume package rooftop DX system, a package VAV DX system with a central boiler, and a VAV air cooled chiller and central boiler. These system types were chosen based on the PC input as to the systems that were the least stringent as well as the most common.

The three low-energy HVAC systems were modeled with the following assumptions:

- PSZ: The similar system as the baseline rooftop units, with single-zone, constant volume classroom rooftops in the range of 5 tons and 2,000 $\mathrm{cfm}$. For larger spaces, multiple 5 ton units would be used.

- PVAV: A multiple-zone package DX rooftop with a central hot water boiler and a VAV supply fan and hot water reheat. We assumed multiple PVAV units would be used, each in the range of 50 tons and $20,000 \mathrm{cfm}$. The zone minimum VAV air flow fraction is set to $20 \%$.

- VAV: A multiple-zone VAV air handler with hot water reheat and an air-cooled chiller and water boiler. Typically, multiple air handlers would be used, but we assumed a single VAV air handler for modeling purposes. The zone minimum VAV air flow fraction is set to $20 \%$.

\subsubsection{Outside Air}

Because conditioning OA for ventilation is such a big contributor to the energy use in a K-12 school building, either exhaust-air energy recovery or demand controlled ventilation is recommended. The K-12 AEDG provides multiple options beyond code minimum for reducing OA loads, including scheduled OA control for all zones, carbon dioxide $\left(\mathrm{CO}_{2}\right)$ demand controlled ventilation in all zones, and energy recovery from exhaust air. The $\mathrm{PC}$ felt that the use of $\mathrm{CO}_{2}$ demand controlled ventilation and ERVs was not a practical technology combination and unneeded for 30\% savings. Either demand controlled ventilation or ERVs can significantly reduce OA loads. However, when one of these technologies is applied, the energy savings potential for the other is limited. Therefore, for the PSZ, PVAV, and VAV HVAC system types, either $\mathrm{CO}_{2}$ demand controlled ventilation or an ERV is recommended. For all HVAC types, recommendations are provided for controlling the OA based on a schedule of the expected occupancy.

To model these recommendations, we modeled the $\mathrm{CO}_{2}$ demand controlled ventilation in the low-energy PSZ system, and ERVs in the low-energy PVAV and VAV systems. The PC felt that the application of $\mathrm{CO}_{2}$ demand control ventilation matched the PSZ configuration better because $\mathrm{CO}_{2}$ sensors located in each zone could control OA for each individual zone. Likewise, the application of ERVs matched the single OA intake configuration of the PVAV and VAV systems.

\subsubsection{Demand Controlled Ventilation}

The baseline models required $\mathrm{CO}_{2}$ demand controlled ventilation in the densely occupied zones, such as the cafeteria, gyms, and auditorium. The recommendation of $\mathrm{CO}_{2}$ demand controlled ventilation in all the other all zones was modeled in the low-energy PSZ models by matching the outdoor air schedules to the occupancy schedules. The classrooms, lobby, mechanical, corridors, and restrooms in the low-energy models used the occupancy schedules as shown in Table 3-41, Section 3.4.7. The computer classrooms and the community-use high school classroom wing used the extended occupancy schedules to account for after hours use. These occupancy schedules were slightly refined to approximate the actual occupancy in these zones for use in controlling OA in the demand controlled ventilation recommendation. For the PVAV and VAV low-energy models that include the ERV and scheduled OA recommendation, but not 
the $\mathrm{CO}_{2}$ demand controlled ventilation recommendation, the OA rates match the occupancy schedules used in the baseline schedules. The occupancy schedules for both $\mathrm{CO}_{2}$ demand controlled and scheduled OA ventilation for the offices, media center, gym, auditorium, and cafeteria are the same as the baseline occupancy schedules.

A motorized OA damper should be used instead of a gravity damper to prevent unwanted OA from entering during the unoccupied periods when the unit may recirculate air to maintain setback or setup temperatures. The motorized OA damper for all climate zones should be closed during the entire unoccupied period, except when it may open in conjunction with an unoccupied economizer or preoccupancy purge cycle.

\subsubsection{Energy Recovery Ventilators}

The K-12 AEDG recommends either demand controlled ventilation or exhaust-air ERVs for each HVAC system type. For the PVAV and VAV system types, an ERV is included in the low-energy models, as specified in the Section 4 recommendation tables. OA rates are modeled based on expected occupancy. Additional $\mathrm{CO}_{2}$ demand controlled ventilation beyond the code minimum requirements is not modeled for the PVAV and VAV. As detailed in the K-12 AEDG, the ERV should have a total effectiveness of 50\% for A climate zones (humid), and a sensible effectiveness of $50 \%$ for B climate zones (dry). There is no recommendation for energy recovery for $\mathrm{C}$ climate zones (marine). This is because the PC felt that ERVs would be the least effective in these temperate climate zones because of the slight temperature differences in exhaust and OA. For the low-energy HVAC systems that were modeled with the ERVs, an additional 0.5 in. w.c. $(125 \mathrm{~Pa})$ of static pressure was added to the supply fans to account for the additional pressure drop over the ERV.

\subsubsection{Economizers}

The K-12 AEDG recommends that the non-dedicated OA systems should be able to modulate the OA, return air, and relief air dampers to provide up to $100 \%$ of the design supply air quantity as OA for cooling, when OA conditions allow for free cooling. For units larger than 54,000 Btu/h $(16 \mathrm{~kW})$, economizers are recommended for all systems that do not have a dedicated OA supply in all climate zones except 1 and 2A. Economizers were not included the ASHRAE 90.1-1999 or ASHRAE 90.1-2004 baseline models. The PSZ, PVAV, and VAV system types are all larger than 54,000 Btu/h (16 kW), and therefore all include economizers in the low-energy models for all climate zones except 1 and $2 \mathrm{~A}$. Economizers are controlled with a mix of dry bulb temperature (OA between $36^{\circ} \mathrm{F}$ and $66^{\circ} \mathrm{F}\left(2^{\circ} \mathrm{C}\right.$ and $19^{\circ} \mathrm{C}$ ), and enthalpy limits (OA less than $14 \mathrm{Btu} / \mathrm{lb}[32,000 \mathrm{~J} / \mathrm{kg}]$ ).

The HVAC systems in the K-12 AEDG with dedicated OA systems (such as the fan-coil and heat pump system) recommend either energy recovery or $\mathrm{CO}_{2}$ demand controlled ventilation, but do not extend the use of economizers to smaller HVAC systems or to additional climate zones. This was because dedicated OA systems are typically sized to provide OA only, and not to meet the full cooling load with economizers.

\subsubsection{Higher Efficiency Fans}

The K-12 AEDG provides recommendations for constant volume and VAV fan power limitations, as well as recommendations for pressure drop for the ductwork design. To model the recommended improved ductwork design, the supply fan total static pressure drops were recalculated based on a maximum ductwork friction rate no greater than 0.08 in. w.c. per 100 linear $\mathrm{ft}$ ( $20 \mathrm{~Pa}$ per of 30 linear $\mathrm{m}$ ) duct run, as recommended by the K-12 AEDG. As shown in Table 3-38, the low-energy PSZ total static pressure drop was modeled at 2.3 in. w.c. (575 Pa), and the low-energy PVAV and VAV total static pressure drop was modeled at 3.6 in. w.c. (900 Pa). For the climate zones without ERVs, the total static pressure drop was modeled at 3.1 in. w.c. (775 PA). 
Table 3-38 Low Energy Fan System Total Pressure Drops

\begin{tabular}{|l|c|c|c|}
\hline \multicolumn{1}{|c|}{ Component } & $\begin{array}{c}\text { Baseline PSZ } \\
\text { (in. w.c.) }\end{array}$ & $\begin{array}{c}\text { Low-Energy PSZ } \\
\text { (in. w.c.) }\end{array}$ & $\begin{array}{c}\text { Low-Energy PVAV and VAV } \\
\text { (in. w.c.) }\end{array}$ \\
\hline 2-in. plated filters ${ }^{1}$ & 0.30 & 0.30 & 0.30 \\
\hline Heating coil/section & 0.25 & 0.25 & 0.25 \\
\hline Cooling coil & 0.60 & 0.60 & 0.60 \\
\hline Fan outlet transition & 0.10 & 0.10 & 0.10 \\
\hline Diffuser & 0.10 & 0.10 & 0.10 \\
\hline Supply ductwork ${ }^{2}$ & 0.80 & 0.64 & 1.20 \\
\hline Return ductwork & 0.30 & 0.30 & 0.50 \\
\hline Grille & 0.05 & 0.05 & 0.05 \\
\hline ERV & 0.00 & 0.00 & 0.50 \\
\hline Total static pressure drop ${ }^{3}$ & 2.50 & 2.34 & $3.60(3.10)$ \\
\hline
\end{tabular}

1. Used average difference between clean and dirty filters.

2. Used recommendation of $0.08 \mathrm{in}$. w.c./100 $\mathrm{ft}(20 \mathrm{~Pa} / 30 \mathrm{~m})$ friction rate for the low-energy model duct pressure drop combined with typical effective duct runs.

3. ERVs not recommended in marine climate zones ( $C$ zones). Total static without ERVs shown in italics.

For the constant volume fans in the low-energy PSZ, the fan limitation was reduced from the baseline of $1.2 \mathrm{hp} / 1000 \mathrm{cfm}$ to $1.0 \mathrm{hp} / 1000 \mathrm{cfm}\left(1.9 \mathrm{~W} / 1000 \mathrm{~m}^{3} / \mathrm{s}\right.$ to $\left.1.6 \mathrm{~W} / 1000 \mathrm{~m}^{3} / \mathrm{s}\right)$. The fan power recommendation for the VAV fans in the VAV and PVAV systems is $1.3 \mathrm{hp} / 1000 \mathrm{cfm}(2.1 \mathrm{~W} / 1000$ $\mathrm{m}^{3} / \mathrm{s}$ ). Using the method for calculating fan efficiency from the fan power, flow, and total static pressure drop outlined in Section 3.3.4.4, we determined the fan efficiency inputs for both the low-energy PSZ fans and the low-energy PVAV and VAV fans. With the lowered fan power limitation and reduced total static pressure drop recommendations, we modeled a low-energy PSZ fan efficiency of $36 \%$ and a lowenergy PVAV and VAV fan efficiency of $44 \%$.

\subsubsection{Higher HVAC System Efficiency}

The K-12 AEDG provides recommendations for higher efficiency HVAC systems based on system type and size. For a 5 ton PSZ system, the K-12 AEDG recommends a 13 SEER rooftop unit for all climate zones. We used the method for determining the compressor/condenser COP as shown in Section 3.3.4.5, combined with the reduced fan power limitations and total static pressure to model the COP of the lowenergy PSZ compressor/condenser at 4.5. The furnace efficiency for the PSZ was not increased, as this type of unit is typically located outside. Additional heating efficiency recommendations would result in flue gas condensation, which could cause freezing problems.

The K-12 AEDG recommends increased efficiency for the low-energy PVAV system type of 10.6 EER in climate zones 1 to 4, and 10.0 EER in climate zones 5 to 8 . For the 50-ton, 20,000 cfm $\left(9.4 \mathrm{~m}^{3} / \mathrm{s}\right) \mathrm{PVAV}$ system, we modeled the compressor/condenser with a COP of 4.7 in climate zones 1 to 4 and a COP of 4.3 in climate zones 5 to 8 . An $85 \%$ efficient boiler is also recommended and modeled for this system type in climate zones 5 to 8 .

The K-12 AEDG recommends an air-cooled chiller efficiency for the low-energy VAV system of 2.93 COP for climate zones 1-4. A COP of 2.8 is recommended in climate zones 5 to 8 . The low-energy VAV chillers are modeled with these COPs. An $85 \%$ efficient boiler is also recommended and modeled for this system type in climate zones 5 to 8 . 
The efficiency recommendations in the K-12 AEDG for the boiler, chiller, and package systems for the fan coil, unit ventilator, and heat pump system types are similar, if not more stringent, than the efficiency recommendations for the PSZ, PVAV, and VAV systems.

The HVAC baseline and low-energy modeling inputs are summarized in Table 3-39.

Table 3-39 Low-Energy HVAC Models Summary

\begin{tabular}{|c|c|c|c|c|}
\hline HVAC Input & Baseline PSZ & Low-Energy PSZ & Low-Energy PVAV & Low-Energy VAV \\
\hline $\begin{array}{l}\text { COP of } \\
\text { compressor/ } \\
\text { condenser }\end{array}$ & $\begin{array}{l}3.5 \text { COP } \\
\text { ASHRAE 90.1- } \\
1999 \text { (SEER 9.7) }\end{array}$ & $\begin{array}{l}\text { 4.5 COP } \\
(\text { SEER 13) }\end{array}$ & $\begin{array}{l}\text { CZ 1-4: 4.7 COP } \\
\text { CZ 5-8: 4.3 COP }\end{array}$ & $\begin{array}{l}\text { CZ 1-4: } 2.93 \text { COP } \\
\text { CZ 5-8: } 2.80 \text { COP }\end{array}$ \\
\hline $\begin{array}{l}\text { COP of } \\
\text { compressor/ } \\
\text { condenser }\end{array}$ & $\begin{array}{l}4.4 \text { COP } \\
\text { ASHRAE 90.1- } \\
2004 \text { (SEER 12) }\end{array}$ & $\begin{array}{l}4.5 \text { COP } \\
\text { (SEER 13) }\end{array}$ & $\begin{array}{l}\text { CZ 1-4: 4.7 COP } \\
\text { CZ 5-8: 4.3 COP }\end{array}$ & $\begin{array}{l}\text { CZ 1-4: } 2.93 \text { COP } \\
\text { CZ 5-8: } 2.80 \text { COP }\end{array}$ \\
\hline Heating efficiency & $80 \%$ & $80 \%$ & $\begin{array}{l}\text { CZ 1-2: } 80 \% \\
\text { CZ 3-8: } 85 \%\end{array}$ & $\begin{array}{l}\text { CZ 1-2: } 80 \% \\
\text { CZ 3-8: } 85 \%\end{array}$ \\
\hline Fan efficiency & $33 \%$ & $36 \%$ & $44 \%$ & $44 \%$ \\
\hline $\begin{array}{l}\text { Fan power } \\
\text { limitation }\end{array}$ & $1.2 \mathrm{hp} / 1000 \mathrm{cfm}$ & $1 \mathrm{hp} / 1000 \mathrm{cfm}$ & $1.3 \mathrm{hp} / 1000 \mathrm{cfm}$ & $1.3 \mathrm{HP} / 1000 \mathrm{cfm}$ \\
\hline $\begin{array}{l}\text { Total fan static } \\
\text { pressure }\end{array}$ & 2.5 in. w.c. & 2.3 in. w.c. & $\begin{array}{l}A \text { and B zones: } \\
3.6 \text { in. w.C. } \\
\text { C zones: } 3.1 \text { in. } \\
\text { w.c. }\end{array}$ & $\begin{array}{l}\text { A and B zones: } 3.6 \\
\text { in. w.c. } \\
\text { C zones: } 3.1 \text { in. } \\
\text { w.c. }\end{array}$ \\
\hline Economizers & None & $\begin{array}{l}\text { CZ 1, 2A: None } \\
\text { CZ 2B, 3-8: } \\
\text { Yes }\end{array}$ & $\begin{array}{l}\text { CZ 1, 2A: none } \\
\text { CZ 2B, 3-8: yes }\end{array}$ & $\begin{array}{l}\text { CZ 1, 2A: none } \\
\text { CZ 2B, 3-8: yes }\end{array}$ \\
\hline ERV & None & None & $\begin{array}{l}\text { A zones: } 50 \% \\
\text { total } \\
\text { effectiveness } \\
\text { B zones: } 50 \% \\
\text { sensible } \\
\text { effectiveness } \\
\text { C zones: none }\end{array}$ & $\begin{array}{l}\text { A zones: } 50 \% \text { total } \\
\text { effectiveness } \\
\text { B zones: } 50 \% \\
\text { sensible } \\
\text { effectiveness } \\
\text { C zones: none }\end{array}$ \\
\hline $\begin{array}{l}\text { Outdoor air } \\
\text { control }\end{array}$ & $\begin{array}{l}\text { HVAC } \\
\text { operational } \\
\text { schedule, } \mathrm{CO}_{2} \\
\text { demand } \\
\text { controlled in } \\
\text { cafeteria, gym, } \\
\text { auditorium }\end{array}$ & $\begin{array}{l}\mathrm{CO}_{2} \text { demand } \\
\text { controlled in all } \\
\text { zones }\end{array}$ & $\begin{array}{l}\text { Expected } \\
\text { occupancy } \\
\text { schedule, } \mathrm{CO}_{2} \\
\text { demand } \\
\text { controlled in } \\
\text { cafeteria, gym, } \\
\text { auditorium }\end{array}$ & $\begin{array}{l}\text { Expected } \\
\text { occupancy } \\
\text { schedule, } \mathrm{CO}_{2} \\
\text { demand controlled } \\
\text { in cafeteria, gym, } \\
\text { auditorium }\end{array}$ \\
\hline
\end{tabular}

\subsubsection{Service Water Heating}

The K-12 AEDG provides recommendations for gas storage and electric instantaneous and storage service water heaters. The recommendations were based on the SO AEDG and SR AEDG service water heating recommendations. For our analysis to verify $30 \%$ savings, the low-energy models included $90 \%$ efficient gas storage service water heaters. 


\subsubsection{Schedules}

The schedules used in the low-energy models were the same as the baseline schedules, except when the schedules were modified to model a specific recommendation. The following schedules were modified for use in the low-energy models.

Each zone in the low-energy models used the lighting schedule as shown in Table 3-40. The K-12 AEDG recommends manual on, automatic off occupancy sensor control on all lights. To model the expected reduction in lighting energy use caused by these occupancy sensors, the daytime lighting energy use was reduced by 13\%, as recommended in Appendix G of ASHRAE 90.1-2004 (ASHRAE 2004a). This was modeled by reducing the daytime lighting energy use by $13 \%$, as reflected in the schedules in Table 3-40.

Table 3-40 Building Lighting Schedule with Occupancy Sensors

\begin{tabular}{|c|c|c|c|c|}
\hline Hour & $\begin{array}{c}\text { Weekday } \\
\text { through } 6 / 30\end{array}$ & $\begin{array}{c}\text { Weekday } \\
\text { through } 9 / 01\end{array}$ & $\begin{array}{c}\text { Weekday } \\
\text { through } 12 / 31\end{array}$ & $\begin{array}{c}\text { Weekends, } \\
\text { Holidays }\end{array}$ \\
\hline 1 & 0.18 & 0.18 & 0.18 & 0.18 \\
\hline 2 & 0.18 & 0.18 & 0.18 & 0.18 \\
\hline 3 & 0.18 & 0.18 & 0.18 & 0.18 \\
\hline 4 & 0.18 & 0.18 & 0.18 & 0.18 \\
\hline 5 & 0.18 & 0.18 & 0.18 & 0.18 \\
\hline 6 & 0.18 & 0.18 & 0.18 & 0.18 \\
\hline 7 & 0.18 & 0.18 & 0.18 & 0.18 \\
\hline 8 & 0.77 & 0.18 & 0.77 & 0.18 \\
\hline 9 & 0.77 & 0.43 & 0.77 & 0.18 \\
\hline 10 & 0.77 & 0.43 & 0.77 & 0.18 \\
\hline 11 & 0.77 & 0.43 & 0.77 & 0.18 \\
\hline 12 & 0.77 & 0.43 & 0.77 & 0.18 \\
\hline 13 & 0.77 & 0.43 & 0.77 & 0.18 \\
\hline 14 & 0.77 & 0.43 & 0.77 & 0.18 \\
\hline 15 & 0.77 & 0.43 & 0.77 & 0.18 \\
\hline 16 & 0.77 & 0.43 & 0.77 & 0.18 \\
\hline 17 & 0.77 & 0.43 & 0.77 & 0.18 \\
\hline 18 & 0.77 & 0.43 & 0.77 & 0.18 \\
\hline 19 & 0.77 & 0.43 & 0.77 & 0.18 \\
\hline 20 & 0.77 & 0.43 & 0.77 & 0.18 \\
\hline 21 & 0.77 & 0.18 & 0.77 & 0.18 \\
\hline 22 & 0.18 & 0.18 & 0.18 & 0.18 \\
\hline 23 & 0.18 & 0.18 & 0.18 & 0.18 \\
\hline 24 & 0.18 & 0.18 & 0.18 & 0.18 \\
\hline
\end{tabular}


The classrooms, lobby, mechanical, corridors, and restrooms in the low-energy models used the occupancy schedules, based on typical school schedules, as shown in Table 3-41. The computer classrooms and the community-use high school classroom wing used the extended occupancy schedules to account for after hours use. These schedules were slightly refined to approximate the actual occupancy in these zones for use in controlling $\mathrm{OA}$ in the demand controlled ventilation recommendation.

Table 3-41 General and Extended Occupancy Schedules for Demand Controlled Ventilation

\begin{tabular}{|c|c|c|c|c|c|c|c|}
\hline Hour & $\begin{array}{c}\text { Weekday } \\
\text { through } \\
\mathbf{6 / 3 0}\end{array}$ & $\begin{array}{c}\text { Weekday } \\
\text { through 6/30 } \\
\text { Extended }\end{array}$ & $\begin{array}{c}\text { Weekday } \\
\text { through } \\
\mathbf{9 / 0 1}\end{array}$ & $\begin{array}{c}\text { Weekday } \\
\text { through 9/01 } \\
\text { Extended }\end{array}$ & $\begin{array}{c}\text { Weekday } \\
\text { through } \\
\mathbf{1 2 / 3 1}\end{array}$ & $\begin{array}{c}\text { Weekday } \\
\text { through 12/31 } \\
\text { Extended }\end{array}$ & $\begin{array}{c}\text { Weekends, } \\
\text { Holidays }\end{array}$ \\
\hline 1 & 0 & 0 & 0 & 0 & 0 & 0 & 0 \\
\hline 2 & 0 & 0 & 0 & 0 & 0 & 0 & 0 \\
\hline 3 & 0 & 0 & 0 & 0 & 0 & 0 & 0 \\
\hline 4 & 0 & 0 & 0 & 0 & 0 & 0 & 0 \\
\hline 5 & 0 & 0 & 0 & 0 & 0 & 0 & 0 \\
\hline 6 & 0 & 0 & 0 & 0 & 0 & 0 & 0 \\
\hline 7 & 0 & 0 & 0 & 0 & 0 & 0 & 0 \\
\hline 8 & 0 & 0 & 0 & 0 & 0 & 0 & 0 \\
\hline 9 & 0.80 & 0.80 & 0.05 & 0.15 & 0.80 & 0.80 & 0 \\
\hline 10 & 0.80 & 0.80 & 0.05 & 0.15 & 0.80 & 0.80 & 0 \\
\hline 11 & 0.80 & 0.80 & 0.05 & 0.15 & 0.80 & 0.80 & 0 \\
\hline 12 & 0.30 & 0.30 & 0.05 & 0.15 & 0.30 & 0.30 & 0 \\
\hline 13 & 0.75 & 0.75 & 0.05 & 0.15 & 0.75 & 0.75 & 0 \\
\hline 14 & 0.75 & 0.75 & 0.05 & 0.15 & 0.75 & 0.75 & 0 \\
\hline 15 & 0.75 & 0.75 & 0.05 & 0.15 & 0.75 & 0.75 & 0 \\
\hline 16 & 0.75 & 0.75 & 0.05 & 0.15 & 0.75 & 0.75 & 0 \\
\hline 17 & 0.05 & 0.15 & 0.05 & 0.15 & 0.05 & 0.15 & 0 \\
\hline 18 & 0.05 & 0.15 & 0.05 & 0.15 & 0.05 & 0.15 & 0 \\
\hline 19 & 0.05 & 0.75 & 0.05 & 0.15 & 0.05 & 0.75 & 0 \\
\hline 20 & 0.05 & 0.75 & 0.05 & 0.15 & 0.05 & 0.75 & 0 \\
\hline 21 & 0.05 & 0.75 & 0.05 & 0.15 & 0.05 & 0.75 & 0 \\
\hline 22 & 0 & 0 & 0 & 0 & 0 & 0 & 0 \\
\hline 23 & 0 & 0 & 0 & 0 & 0 & 0 & 0 \\
\hline 24 & 0 & 0 & 0 & 0 & 0 & 0 & 0 \\
\hline & & & & & & & \\
\hline
\end{tabular}




\section{Evaluation Results}

This section contains the recommendations for 30\% savings approved by the PC for the K-12 AEDG. In addition, the recommendations for 30\% savings over ASHRAE 90.1-2004 are discussed. The energy savings results that are achieved as a result of applying these recommendations are presented. Figures of the end use comparisons are provided; the end use data are presented in tabular format in Appendix $\mathrm{G}$ and Appendix H. This section concludes with a scoping analysis for $50 \%$ energy savings.

The recommendations are applicable for all K-12 schools within the scope of the Guide as a means of demonstrating the $30 \%$ energy savings. The Guide recognizes that there are other ways of achieving the $30 \%$ energy savings, and offers these recommendations as "some ways, but not the only way" of meeting the energy savings target. When a recommendation contains the designation "Comply with Standard 90.1," the Guide is providing no recommendation for this component or system. In these cases, the user must meet the more stringent of either the applicable version of Standard 90.1 or the local code requirements. When a recommendation contains the designation "System type not recommended," the Guide is recommending that this specific system type is not be used for a given climate zone.

\subsection{Recommendation Tables for $30 \%$ Savings}

This section provides the recommendation tables that are presented in the K-12 AEDG as well as the recommendations for 30\% savings over ASHRAE 90.1-2004. The opaque envelope recommendations are presented for different climate zones by roof type, wall type, floor type, slab type, and door type. Recommendations for the thermal characteristics of the vertical fenestration and interior reflectances are provided. For this Guide, four daylighting strategies are presented: three for classrooms and one for gymnasiums. Daylighting the classroom is most critical, since that is where the teachers and the students spend most of their time. In addition, the potential for savings is the greatest in the classrooms. Guidelines are also provided for the gymnasium/multipurpose room because this space is typically used for more hours. For each strategy, there are several options and variations depending on climate and orientation. These daylighting strategies are designed to provide the recommended illuminances for the classrooms and gym over most occupied daytime hours.

Site constraints or program requirements may preclude daylighting solutions. Therefore, a non-daylit path is provided to meet the energy savings requirements of the K-12 AEDG. The non-daylit recommendations provided in this Guide include lighting systems that use the most current energyefficient lamps, ballasts, and integrated controls.

Many types of HVAC systems could be used in K-12 schools, but this Guide provides recommendations for one of the following six system types:

- Single-zone, packaged DX units (or split DX systems) with indirect gas-fired heaters, electric resistance heat, or heat pump

- Water source (or ground source) heat pumps with a dedicated OA ventilation system

- Unit ventilators with a water chiller and a water boiler or electric resistance heat

- Fan-coils with a water chiller and a water boiler or electric resistance heat and a dedicated OA ventilation system

- Multiple-zone, VAV packaged DX rooftop units with a hot water coil, indirect gas furnace, or electric resistance in the rooftop unit and a hot water coil or electric resistance in the VAV terminals.

- Multiple-zone, VAV air handlers with a water chiller and a hot water coil, indirect gas furnace, or electric resistance in the air handler and a hot water coil or electric resistance in the VAV terminals.

Unique recommendations for cooling, heating, and fan efficiencies are included for each HVAC system type in the climate-specific recommendations. In addition, either demand controlled ventilation or ERVs are recommended, along with economizer use recommendations for each HVAC system type. Some 
system types, however, are not recommended for certain climate zones, because of the impact of humidity on energy use.

Service water heating efficiency recommendations are provided based on electric or gas water heaters, as well as instantaneous or gas storage units.

The recommendation tables for the K-12 AEDG are shown in Table 4-1 through Table 4-4.

The recommendations for 30\% energy savings over ASHRAE 90.1-2004 are almost the same as the K-12 AEDG recommendations. The only difference in the recommendations for $30 \%$ savings over ASHRAE 90.1-2004 is there are no non-daylit option recommendations. The non-daylit option presented in the K12 AEDG recommendations is not available for 30\% savings over ASHRAE 90.1-2004, as 30\% savings were not possible for all climate zones for the non-daylit recommendations. 
Table 4-1 K-12 AEDG Recommendations for 30\% Savings over ASHRAE 90.1-1999: Climate Zones 1-4

\begin{tabular}{|c|c|c|c|c|c|}
\hline Item & Component & Climate Zone 1 Recommendations & Climate Zone 2 Recommendations & Climate Zone 3 Recommendations & Climate Zone 4 Recommendations \\
\hline \multirow{4}{*}{ Roofs } & Insulation Entirely Above Deck & R-25 ci & $\overline{R-25 \mathrm{ci}}$ & $\overline{\mathrm{R}-25 \mathrm{ci}}$ & R-25 ci \\
\hline & Attic and Other & $R-30$ & $R-38$ & $R-38$ & R-38 \\
\hline & Metal Building & $R-19$ & $\mathrm{R}-13.0+\mathrm{R}-13.0$ & $\mathrm{R}-13.0+\mathrm{R}-13.0$ & $\mathrm{R}-13.0+\mathrm{R}-19.0$ \\
\hline & SRI & 0.78 & 0.78 & 0.78 & Comply with Standard $90.1^{*}$ \\
\hline \multirow{5}{*}{ Walls } & Mass ( $\left.\mathrm{HC}>7 \mathrm{Btu} / \mathrm{ft}^{2}\right)$ & R-5.7 ci & R-7.6 ci & R-7.6 ci & R-9.5 ci \\
\hline & Steel Framed & $\mathrm{R}-13$ & $\mathrm{R}-13$ & R-13+R-3.8 ci & R-13+R-7.5 ci \\
\hline & Wood Framed and Other & $\mathrm{R}-13$ & $R-13$ & $R-13$ & $\mathrm{R}-13$ \\
\hline & Metal Building & $\mathrm{R}-16$ & $R-16$ & R-16 & R-19 \\
\hline & Below Grade Walls & Comply with Standard $90.1^{*}$ & Comply with Standard $90.1^{*}$ & Comply with Standard $90.1^{*}$ & Comply with Standard $90.1^{*}$ \\
\hline \multirow{3}{*}{ Floors } & Mass & $\mathrm{R}-4.2 \mathrm{ci}$ & R-6.3 ci & R-8.3 ci & R-8.3 ci \\
\hline & Steel Framed & R-19 & R-19 & R-19 & $\mathrm{R}-30$ \\
\hline & Wood Framed and Other & R-19 & R-19 & $\mathrm{R}-30$ & $\mathrm{R}-30$ \\
\hline \multirow{2}{*}{ Slabs } & Unheated & Comply with Standard $90.1^{*}$ & Comply with Standard 90.1* & Comply with Standard $90.1^{*}$ & Comply with Standard 90.1* \\
\hline & Heated & $\begin{array}{l}\text { R-7.5 for } 12 \text { in. } \\
\end{array}$ & R-7.5 for 12 in. & R-10 for 24 in. & R-15 for 24 in. \\
\hline \multirow{2}{*}{ Doors } & Swinging & $\mathrm{U}-0.700$ & $\mathrm{JU}-0.700$ & $\mathrm{JU}-0.700$ & U-0.700 \\
\hline & Non-Swinging & $\mathrm{U}-1.450$ & U-1.450 & $\mathrm{U}-1.450$ & $\mathrm{U}-.50$ \\
\hline \multirow{4}{*}{$\begin{array}{l}\text { Vertical } \\
\text { Fenestration }\end{array}$} & Total Fenestration to Gross Wall Area Ratio & $35 \%$ Max & $35 \%$ Max & $35 \% \operatorname{Max}$ & $35 \% \operatorname{Max}$ \\
\hline & Thermal transmittance- all types and orientations & $U-0.56$ & $\mathrm{U}-0.45$ & $\mathrm{U}-0.45$ & $U-0.42$ \\
\hline & Solar heat gain coefficient (SHGC)- all types and orientations & SHGC- 0.25 & SHGC- 0.25 & SHGC- 0.25 & SHGC-0.40 \\
\hline & Exterior Sun Control (S, E, W only) & Projection Factor> 0.5 & Projection Factor> 0.5 & Projection Factor> 0.5 & Projection Factor> 0.5 \\
\hline Interior Finishes & Interior room surface average reflectance & $\begin{array}{l}70 \%+\text { on ceilings and walls above } 7,50 \%+ \\
\text { on walls below } 7^{\prime}\end{array}$ & $\begin{array}{l}70 \%+\text { on ceilings and walls above } 7^{\prime}, 50 \%+ \\
\text { on walls below } 7^{\prime}\end{array}$ & $\begin{array}{l}70 \%+\text { on ceilings and walls above } 7^{\prime}, 50 \%+ \\
\text { on walls below } 7^{\prime}\end{array}$ & $\begin{array}{l}70 \%+\text { on ceilings and walls above } 7^{\prime}, 50 \%+ \\
\text { on walls below } 7^{\prime}\end{array}$ \\
\hline \multirow{8}{*}{$\begin{array}{l}\text { Interior Lighting } \\
\text { Daylighted } \\
\text { Option }\end{array}$} & \multirow{3}{*}{ Classroom Daylighting (Daylighting Fenestration to Floor Area Ratio) } & $\begin{array}{l}\text { Toplit - } \\
\text { South Facing Roof Monitors: 8\%-11\% } \\
\text { North Facing Roof Monitors: } 12 \%-15 \%\end{array}$ & $\begin{array}{l}\text { Toplit - } \\
\text { South Facing Roof Monitors: 8\%-11\% } \\
\text { North Facing Roof Monitors: } 12 \%-15 \%\end{array}$ & $\begin{array}{l}\text { Toplit - } \\
\text { South Facing Roof Monitors: 8\%-11\% } \\
\text { North Facing Roof Monitors: } 12 \%-15 \%\end{array}$ & $\begin{array}{l}\text { Toplit - } \\
\text { South Facing Roof Monitors: } 8 \%-11 \% \\
\text { North Facing Roof Monitors: } 12 \%-15 \%\end{array}$ \\
\hline & & $\begin{array}{l}\text { Sidelit- } \\
\text { South Facing: } 8 \%-11 \% \\
\text { North Facing: } 15 \%-20 \%\end{array}$ & $\begin{array}{l}\text { Sidelit- } \\
\text { South Facing: } 8 \%-11 \% \\
\text { North Facing: } 15 \%-20 \%\end{array}$ & $\begin{array}{l}\text { Sidelit- } \\
\text { South Facing: } 8 \%-11 \% \\
\text { North Facing: } 15 \%-20 \%\end{array}$ & $\begin{array}{l}\text { Sidelit- } \\
\text { South Facing: } 8 \%-11 \% \\
\text { North Facing: } 15 \%-20 \%\end{array}$ \\
\hline & & $\begin{array}{l}\text { Combined Toplit and Sidelit- } \\
\text { South Facing Sidelit: 6\%-8\%, Toplit: } 2 \%-3 \% \\
\text { North Facing Sidelit: } 9 \%-13 \% \text {, Toplit: } 3 \%-5 \%\end{array}$ & \begin{tabular}{|l|} 
Combined Toplit and Sidelit- \\
South Facing Sidelit: 6\%-8\%, Toplit: 2\%-3\% \\
North Facing Sidelit: $9 \%-13 \%$, Toplit: 3\%-5\%
\end{tabular} & \begin{tabular}{|l|} 
Combined Toplit and Sidelit- \\
South Facing Sidelit: $6 \%-8 \%$, Toplit: $2 \%-3 \%$ \\
North Facing Sidelit: $9 \%-13 \%$, Toplit: $3 \%-5 \%$
\end{tabular} & $\begin{array}{l}\text { Combined Toplit and Sidelit- } \\
\text { South Facing Sidelit: 6\%-8\%, Toplit: } 2 \%-3 \% \\
\text { North Facing Sidelit: } 9 \%-13 \% \text {, Toplit: } 3 \%-5 \%\end{array}$ \\
\hline & Gym Toplighting (Daylighting Fenestration to Floor Area Ratio) & $\begin{array}{l}\text { South Facing Roof Monitors: } 5 \%-8 \% \\
\text { North Facing Roof Monitors } 7 \% \text { to } 10 \% \\
\end{array}$ & \begin{tabular}{|l|} 
South Facing Roof Monitors: $5 \%-8 \%$ \\
North Facing Roof Monitors $7 \%$ to $10 \%$ \\
\end{tabular} & $\begin{array}{l}\text { South Facing Roof Monitors: } 5 \% \text { - } 8 \% \text { North } \\
\text { Facing Roof Monitors } 7 \% \text { to } 10 \% \text { C Zones } \\
\text { Only: Skylights: } 2 \%-4 \%\end{array}$ & $\begin{array}{l}\text { South Facing Roof Monitors: } 5 \% \text { - }-8 \% \text { North } \\
\text { Facing Roof Monitors } 7 \% \text { to } 10 \% \quad \text { C } \\
\text { Zones Only: Skylights: } 3 \%-4 \%\end{array}$ \\
\hline & \begin{tabular}{|l|l|l} 
Lighting Power Density (LPD) \\
Light Source system efficacy (linear fluorescent and HID)
\end{tabular} & $\frac{1.2 \mathrm{~W} / \mathrm{ft}^{2} \text { maximum }}{75 \mathrm{~m} \text { lumens/watt minimum }}$ & $\frac{1.2 \mathrm{~W} / \mathrm{ft}^{2} \text { maximum }}{75 \mathrm{~m} \text { man lumens/ watt minimum }}$ & $1.2 \mathrm{~W} / \mathrm{ft}^{2}$ maximum & 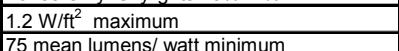 \\
\hline & Light source system efficacy (all other sources) & 50 mean lumens/watt minimum & 50 mean lumens/watt minimum & $\begin{array}{l}75 \text { mean lumens/ watt minimum } \\
50 \text { mean lumens/watt minimum }\end{array}$ & 50 mean lumens/watt minimum \\
\hline & Lighting Controls - general & Manual on, Auto-off all zones & Manual on, Auto-off all zones & Manual on, Auto-off all zones & Manual on, Auto-off all zones \\
\hline & Dimming Controls Daylight Harvesting & $\begin{array}{l}\text { Dim all fixtures in classrooms and gym, and } \\
\text { other fixtures within } 15 \mathrm{ft} \text { of sidelighting } \\
\text { edge, and within } 10 \mathrm{ft} \text { of toplighting edge }\end{array}$ & \begin{tabular}{|l|} 
Dim all fixtures in classrooms and gym, and \\
other fixtures within $15 \mathrm{ft} \mathrm{of} \mathrm{sidelighting}$ \\
edge, and within $10 \mathrm{ft}$ of toplighting edge
\end{tabular} & \begin{tabular}{|l|} 
Dim all fixtures in classrooms and gym, and \\
other fixtures within $15 \mathrm{ft}$ of sidelighting \\
edge, and within $10 \mathrm{ft}$ of toplighting edge
\end{tabular} & $\begin{array}{l}\text { Dim all fixtures in classrooms and gym, and } \\
\text { other fixtures within } 15 \mathrm{ft} \text { of sidelighting } \\
\text { edge, and within } 10 \mathrm{ft} \text { of toplighting edge }\end{array}$ \\
\hline \multirow{5}{*}{$\begin{array}{l}\text { Interior Lighting } \\
\text { - Non- } \\
\text { Daylighted } \\
\text { Option }\end{array}$} & Lighting Power Density (LPD) & $1.1 \mathrm{~W} / \mathrm{ft}^{2}$ maximum & $1.1 \mathrm{~W} / \mathrm{ft}^{2}$ maximum & $0.9 \mathrm{~W} / \mathrm{ft}^{2}$ maximum & $0.9 \mathrm{~W} / \mathrm{ft}^{2}$ maximum \\
\hline & Light Source system efficac (linear fluorescent) & 85 mean lumens/watt minimum & 85 mean lumens/watt minimum & 85 mean lumens/watt minimum & 85 mean lumens/watt minimum \\
\hline & Light source system efficacy (all other sources) & 50 mean lumens/watt minimum & 50 mean lumens/watt minimum & 50 mean lumens/watt minimum & 50 mean lumens/watt minimum \\
\hline & Lighting Controls - general & Manual on, Auto-off all zones & Manual on, Auto-off all zones & Manual on, Auto-off all zones & Manual on, Auto-off all zones \\
\hline & Dimming Controls Daylight Harvesting & $\begin{array}{l}\text { Dim fixtures within } 15 \mathrm{ft} \text { of sidelighting edge, } \\
\text { and within } 10 \mathrm{ft} \text { of toplighting edge }\end{array}$ & \begin{tabular}{|l|} 
Dim fixtures within $15 \mathrm{ft}$ of sidelighting edge, \\
and within $10 \mathrm{ft}$ of toplighting edge
\end{tabular} & $\begin{array}{l}\text { Dim fixtures within } 15 \mathrm{ft} \text { of sidelighting edge, } \\
\text { and within } 10 \mathrm{ft} \text { of toplighting edge }\end{array}$ & $\begin{array}{l}\text { Dim fixtures within } 15 \mathrm{ft} \text { of sidelighting edge, } \\
\text { and within } 10 \mathrm{ft} \text { of toplighting edge }\end{array}$ \\
\hline \multirow{12}{*}{$\begin{array}{c}\text { Packaged DX } \\
\text { Rooftops (or } \\
\text { DX Split } \\
\text { Systems) }\end{array}$} & Air Conditioner $<65 \mathrm{kBtu} / \mathrm{h}$ & 13 SEER & 13 SEER & 13 SEER & 13 SEER \\
\hline & Air Conditioner $>=65$ and $<135 \mathrm{kBtu} / \mathrm{h}$ & 11.3 EER & 11.3 EER & $11.3 \mathrm{EER}$ & $11.3 \mathrm{EER}$ \\
\hline & Air Conditioner $>=135$ and $<240 \mathrm{kBtu} / \mathrm{h}$ & $11 \mathrm{EER}$ & $11 \mathrm{EER}$ & $11 \mathrm{EER}$ & $11 \mathrm{EER}$ \\
\hline & Air Conditioner $>=240 \mathrm{kBtu} / \mathrm{h}$ & 10.6 EER/11.2 IPLV & 10.6 EER/11.2 IPLV & $10.6 \mathrm{EER} / 11.2 \mathrm{IPLV}$ & $10.6 \mathrm{EER} / 11.2 \mathrm{IPLV}$ \\
\hline & Heat Pump $<65 \mathrm{kBtu} / \mathrm{h}$ & 13.0 SEER/7.7 HPSF & 13.0 SEER/7.7 HPSF & 13.0 SEER/7.7 HPSF & $13.0 \mathrm{SEER} / 7.7 \mathrm{HPSF}$ \\
\hline & Heat Pump $>=65$ and $<135 \mathrm{kBtu} / \mathrm{h}$ & $10.6 \mathrm{EER} / 3.2 \mathrm{COP}$ & $10.6 \mathrm{EER} / 3.2 \mathrm{COP}$ & $10.6 \mathrm{EER} / 3.2 \mathrm{COP}$ & $10.6 \mathrm{EER} / 3.2 \mathrm{COP}$ \\
\hline & Heat Pump $>=135 \mathrm{kBtu} / \mathrm{h}$ & 10.1 EER/11.5 IPLV/3.1 COP & 10.1 EER/11.5 IPLV/3.1 COP & 10.1 EER/11.0 IPLV/3.1 COP & $10.1 \mathrm{EER} / 11.0 \mathrm{IPLV} / 3.1 \mathrm{COP}$ \\
\hline & Gas Furnace $<225 \mathrm{kBtuh}$ & $80 \%$ AFUE or $\mathrm{E}_{\mathrm{t}}$ & $80 \%$ AFUE or $E_{t}$ & $80 \%$ AFUE or $E_{t}$ & $80 \%$ AFUE or $E_{t}$ \\
\hline & Gas Furnace >=225 kBtu/h & $80 \% \mathrm{E}_{\mathrm{c}}$ & $80 \% \mathrm{E}_{\mathrm{c}}$ & $80 \% \mathrm{E}_{\mathrm{c}}$ & $80 \% \mathrm{E}_{\mathrm{c}}$ \\
\hline & Economizer & Comply with Standard $90.1^{*}$ & Comply with Standard $90.1^{*}$ & $>54 \mathrm{kBtu} / \mathrm{h}$ & $>54 \mathrm{kBtu} / \mathrm{h}$ \\
\hline & Ventilation & Energy recovery or Demand control & Energy recovery or Demand control & Energy recovery or Demand control & Energy recovery or Demand control \\
\hline & Fans & $\begin{array}{l}\text { constant volume: } 1 \mathrm{hp} / 1000 \mathrm{cfm} \\
\text { variable volume: } 1.3 \mathrm{hp} / 1000 \mathrm{cfm}\end{array}$ & $\begin{array}{l}\text { constant volume: } 1 \mathrm{hp} / 1000 \mathrm{cfm} \\
\text { variable volume: } 1.3 \mathrm{hp} / 1000 \mathrm{cfm}\end{array}$ & $\begin{array}{l}\text { constant volume: } 1 \mathrm{hp} / 1000 \mathrm{cfm} \\
\text { variable volume: } 1.3 \mathrm{hp} / 1000 \mathrm{cfm}\end{array}$ & $\begin{array}{l}\text { constant volume: } 1 \mathrm{hp} / 1000 \mathrm{cfm} \\
\text { variable volume: } 1.3 \mathrm{hp} / 1000 \mathrm{cfm}\end{array}$ \\
\hline
\end{tabular}


Table 4-2 K-12 AEDG Recommendations for 30\% Savings over ASHRAE 90.1-1999: Climate Zones 1-4 (Cont.)

\begin{tabular}{|c|c|c|c|c|c|}
\hline Item & Component & Climate Zone 1 Recommendations & Climate Zone 2 Recommendations & Climate Zone 3 Recommendations & Climate Zone 4 Recommendations \\
\hline \multirow{7}{*}{ WSHP System } & Water-Source Heat Pump >= $65 \mathrm{kBtu} / \mathrm{h}$ & $\begin{array}{l}\text { Cooling: } 12 \text { EER at } 86 \mathrm{~F} ; \text {; Heating: } 4.2 \mathrm{COP} \text { at } \\
68 \mathrm{~F}\end{array}$ & $\begin{array}{l}\text { Cooling: } 12 \text { EER at 86F; Heating: } 4.2 \text { COP } \\
\text { at } 68 \mathrm{~F}\end{array}$ & 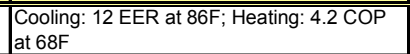 & 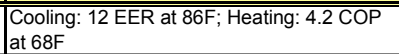 \\
\hline & Ground-Source Heat Pump $<65 \mathrm{kBtu} / \mathrm{h}$ & $\begin{array}{l}\text { Cooling: } 14.1 \text { EER at } 77 \mathrm{~F} \text { and } 17 \text { EER at } \\
\text { 59F; Heating: } 3.5 \mathrm{COP} \text { at } 32 \mathrm{~F} \text { and } 4.0 \mathrm{COP} \\
\text { at 50F }\end{array}$ & $\begin{array}{l}\text { Cooling: } 14.1 \text { EER at } 77 \mathrm{~F} \text { and } 17 \text { EER at } \\
\text { 59F; Heating: } 3.5 \mathrm{COP} \text { at } 32 \mathrm{~F} \text { and } 4.0 \mathrm{COP} \\
\text { at 50F }\end{array}$ & $\begin{array}{l}\text { Cooling: } 14.1 \mathrm{EER} \text { at } 77 \mathrm{~F} \text { and } 17 \mathrm{EER} \text { at } \\
\text { 59F; Heating: } 3.5 \mathrm{COP} \text { at } 32 \mathrm{~F} \text { and } 4.0 \mathrm{COP} \\
\text { at 50F }\end{array}$ & $\begin{array}{l}\text { Cooling: } 14.1 \text { EER at } 77 \mathrm{~F} \text { and } 17 \text { EER at } \\
\text { 59F; Heating: } 3.5 \mathrm{COP} \text { at } 32 \mathrm{~F} \text { and } 4.0 \mathrm{COP} \\
\text { at 50F }\end{array}$ \\
\hline & Ground-Source Heat Pump >= $65 \mathrm{kBtu} / \mathrm{h}$ & $\begin{array}{l}\text { Cooling: } 13 \text { EER at } 77 F \text { and } 16 \text { EER at } 59 F ; \\
\text { Heating: } 3.1 \mathrm{COP} \text { at } 32 \mathrm{~F} \text { and } 3.5 \mathrm{COP} \text { at } \\
\text { 50F }\end{array}$ & $\begin{array}{l}\text { Cooling: } 13 \text { EER at } 77 \mathrm{~F} \text { and } 16 \mathrm{EER} \text { at } 59 \mathrm{~F} ; \\
\text { Heating: } 3.1 \mathrm{COP} \text { at } 32 \mathrm{~F} \text { and } 3.5 \mathrm{COP} \text { at } \\
50 \mathrm{~F}\end{array}$ & $\begin{array}{l}\text { Cooling: } 13 \text { EER at } 77 \mathrm{~F} \text { and } 16 \text { EER at } 59 \mathrm{~F} ; \\
\text { Heating: } 3.1 \mathrm{COP} \text { at } 32 \mathrm{~F} \text { and } 3.5 \mathrm{COP} \text { at } \\
50 \mathrm{~F}\end{array}$ & $\begin{array}{l}\text { Cooling: } 13 \text { EER at } 77 \mathrm{~F} \text { and } 16 \mathrm{EER} \text { at } 59 \mathrm{~F} \text {; } \\
\text { Heating: } 3.1 \mathrm{COP} \text { at } 32 \mathrm{~F} \text { and } 3.5 \mathrm{COP} \text { at } \\
\text { 50F }\end{array}$ \\
\hline & Gas Boiler & $85 \% \mathrm{Ec}$ & $85 \% \mathrm{Ec}$ & $85 \% \mathrm{Ec}$ & $85 \% \mathrm{Ec}$ \\
\hline & Economizer & Comply with Standard $90.1^{*}$ & Comply with Standard $90.1^{*}$ & Comply with Standard $90.1^{*}$ & Comply with Standard 90.1* \\
\hline & Ventilation & $\begin{array}{l}\text { DOAS with either energy recovery or } \\
\text { Demand control }\end{array}$ & $\begin{array}{l}\text { DOAS with either energy recovery or } \\
\text { Demand control }\end{array}$ & $\begin{array}{l}\text { DOAS with either energy recovery or } \\
\text { Demand control }\end{array}$ & $\begin{array}{l}\text { DOAS with either energy recovery or } \\
\text { Demand control }\end{array}$ \\
\hline & WSHP Duct Pressure Drop & Total ESP $<0.2^{\prime \prime}$ & Total ESP $<0.2^{n}$ & Total ESP $<0.2^{\prime \prime}$ & Total ESP $<0.2^{\prime \prime}$ \\
\hline \multirow{6}{*}{$\begin{array}{l}\text { Unit Ventilator } \\
\text { and Chiller } \\
\text { System }\end{array}$} & Air-Cooled Chiller Efficiency & \multirow{6}{*}{ System type not recommended } & $\begin{array}{l}\text { A Zones: System not recommended } \mathrm{B} \\
\text { Zones: } 10.0 \text { EER, } 11.5 \text { IPLV }\end{array}$ & $\begin{array}{l}\text { A Zanes: System not recommended } B \text { and } \\
\text { C Zones: } 10.0 \text { EER, } 11.5 \text { IPLV }\end{array}$ & 10.0 EER, 11.5 IPLV \\
\hline & Water-Cooled Chiller Efficiency & & $\begin{array}{l}\text { A Zones: System not recommended } \mathrm{B} \\
\text { Zones: Comply with Standard } 90.1^{*}\end{array}$ & $\begin{array}{l}\text { A Zones: System not recommended B and } \\
\text { C Zones: Comply with Standard } 90.1^{*}\end{array}$ & Comply with Standard $90.1^{*}$ \\
\hline & Gas Boiler & & $\begin{array}{l}\text { A Zones: System not recommended B } \\
\text { Zones: } 80 \% \text { Ec }\end{array}$ & $\begin{array}{l}\text { A Zones: System not recommended B and } \\
\text { C Zones: } 85 \% \text { Ec }\end{array}$ & $85 \% \mathrm{E}_{\mathrm{c}}$ \\
\hline & Economizer & & $\begin{array}{l}\text { A Zones: System not recommended } \\
\text { Zones: Comply with Standard } 90.1^{*}\end{array}$ & $\begin{array}{l}\text { A Zones: System not recommended B and } \\
\text { C Zones: }>54 \mathrm{kBtu} / \mathrm{h}\end{array}$ & $>54 \mathrm{kBtu} / \mathrm{h}$ \\
\hline & Ventilation & & $\begin{array}{l}\text { A Zones: System not recommended } \mathrm{B} \\
\text { Zones: Energy recovery or Demand control }\end{array}$ & $\begin{array}{l}\text { A Zones: System not recommended B and } \\
\text { C Zones: Energy recovery or Demand } \\
\text { control }\end{array}$ & Energy recovery or Demand control \\
\hline & Pressure Drop & & $\begin{array}{l}\text { A Zones: System not recommended B } \\
\text { Zones: Total ESP }<0.2^{\prime \prime}\end{array}$ & $\begin{array}{l}\text { A Zones: System not recommended B and } \\
\text { C Zones: Total ESP < } 0.2^{\prime \prime}\end{array}$ & Total ESP $<0.2^{n}$ \\
\hline \multirow{4}{*}{$\begin{array}{c}\text { Fancoil and } \\
\text { Chiller System }\end{array}$} & Gas Boiler & $80 \% \mathrm{E}_{\mathrm{c}}$ & $80 \% \mathrm{Ec}$ & $85 \% \mathrm{E}_{\mathrm{c}}$ & $85 \% \mathrm{E}_{c}$ \\
\hline & Economizer & Comply with Standard $90.1^{*}$ & Comply with Standard $90.1^{*}$ & Comply with Standard $90.1^{*}$ & Comply with Standard $90.1^{*}$ \\
\hline & Ventilation & $\begin{array}{l}\text { DOAS with either energy recovery or } \\
\text { Demand control }\end{array}$ & $\begin{array}{l}\text { DOAS with either energy recovery or } \\
\text { Demand control }\end{array}$ & $\begin{array}{l}\text { DOAS with either energy recovery or } \\
\text { Demand control }\end{array}$ & $\begin{array}{l}\text { DOAS with either energy recovery or } \\
\text { Demand control }\end{array}$ \\
\hline & Pressure Drop & Total ESP $<0.2^{\prime \prime}$ & Total ESP $<0.2^{n}$ & Total ESP $<0.2^{n}$ & Total ESP $<0.2^{\prime \prime}$ \\
\hline \multirow{6}{*}{$\begin{array}{l}\text { Packaged } \\
\text { Rooftop VAV } \\
\text { System }\end{array}$} & Rooftop Air Conditioner >=240 kBtu/h & 10.6 EER/11.2 IPLV & 10.6 EER/11.2 IPLV & 10.6 EER/11.2 IPLV & 10.6 EER/11.2 IPLV \\
\hline & Gas Furnace >=225 kBtu/h & $80 \% \mathrm{E}_{\mathrm{c}}$ & $80 \% \mathrm{E}_{\mathrm{c}}$ & $80 \% \mathrm{E}_{\mathrm{c}}$ & $80 \% \mathrm{E}_{\mathrm{c}}$ \\
\hline & Gas Boiler & $80 \% \mathrm{E}_{\mathrm{c}}$ & $80 \% \mathrm{E}_{\mathrm{c}}$ & $80 \% \mathrm{E}_{\mathrm{c}}$ & $85 \% \mathrm{E}_{\mathrm{c}}$ \\
\hline & Economizer & Comply with Standard $90.1^{*}$ & Comply with Standard $90.1^{*}$ & $>54 \mathrm{kBtu} / \mathrm{h}$ & $>54 \mathrm{kBtu} / \mathrm{h}$ \\
\hline & Ventilation & Energy recovery or Demand control & Energy recovery or Demand control & Energy recovery or Demand control & Energy recovery or Demand control \\
\hline & Fans & $1.3 \mathrm{hp} / 1000 \mathrm{cfm}$ & $1.3 \mathrm{hp} / 1000 \mathrm{cfm}$ & $1.3 \mathrm{hp} / 1000 \mathrm{cfm}$ & $1.3 \mathrm{hp} / 1000 \mathrm{cfm}$ \\
\hline \multirow{6}{*}{$\begin{array}{l}\text { VAV and Chiller } \\
\text { System }\end{array}$} & Air Cooled Chiller Efficiency & 10.0 EER, 11.5 IPLV & $10.0 \mathrm{EER}, 11.5 \mathrm{IPLV}$ & $10.0 \mathrm{EER}, 11.5 \mathrm{IPLV}$ & 10.0 EER, 11.5 IPLV \\
\hline & Water-Cooled Chiller Efficiency & Comply with Standard $90.1^{*}$ & Comply with Standard $90.1^{*}$ & Comply with Standard $90.1^{*}$ & Comply with Standard $90.1^{*}$ \\
\hline & Gas Boiler & $80 \% \mathrm{E}_{\mathrm{c}}$ & $80 \% \mathrm{E}_{\mathrm{c}}$ & $80 \% \mathrm{E}_{\mathrm{c}}$ & $85 \% \mathrm{E}_{c}$ \\
\hline & Economizer & Comply with Standard 90.1 & Comply with Standard 90.1* & $>54 \mathrm{kBtu} / \mathrm{h}$ & $>54 \mathrm{kBtu} / \mathrm{h}$ \\
\hline & Ventilation & Energy recovery or Demand control & Energy recovery or Demand control & Energy recovery or Demand control & Energy recovery or Demand control \\
\hline & Fans & $1.3 \mathrm{hp} / 1000 \mathrm{cfm}$ & $1.3 \mathrm{hp} / 1000 \mathrm{cfm}$ & $1.3 \mathrm{hp} / 1000 \mathrm{cfm}$ & $1.3 \mathrm{hp} / 1000 \mathrm{cfm}$ \\
\hline \multirow{5}{*}{$\begin{array}{l}\text { Ducts and } \\
\text { Dampers }\end{array}$} & Outdoor air damper & motorized & Imotorized & Imotorized & Imotorized \\
\hline & Friction rate & 0.08 in w.c./100ft & 0.08 in w.c./100ft & 0.08 in w.c./10oft & 0.08 in w.c./100ft \\
\hline & Sealing & Seal Class B & Seal Class B & Seal Class B & Seal Class B \\
\hline & Location & interior only & interior only & interior only & interior only \\
\hline & Insulation level & $R-6$ & $\mathrm{R}-6$ & $\mathrm{R}-6$ & $\mathrm{R}-6$ \\
\hline \multirow{2}{*}{$\begin{array}{c}\text { Service Water } \\
\text { Heating }\end{array}$} & Gas storage (>75 kBtu/h) & $90 \% \mathrm{Et}$ & $90 \% \mathrm{E}_{\mathrm{t}}$ & $90 \% \mathrm{E}_{\mathrm{t}}$ & $90 \% \mathrm{E}_{\mathrm{t}}$ \\
\hline & Gas instantaneous & $0.81 \mathrm{EF}$ or $81 \% \mathrm{Et}$ & $0.81 \mathrm{EF}$ or $81 \% \mathrm{Et}$ & $0.81 \mathrm{EF}$ or $81 \% \mathrm{Et}$ & $0.81 \mathrm{EF}$ or $81 \% \mathrm{Et}$ \\
\hline
\end{tabular}


Table 4-3 K-12 AEDG Recommendations for 30\% Savings over ASHRAE 90.1-1999: Climate Zones 5-8

\begin{tabular}{|c|c|c|c|c|c|}
\hline Item & Component & Climate Zone 5 Recommendations & Climate Zone 6 Recommendations & Climate Zone 7 Recommendations & Climate Zone 8 Recommendations \\
\hline \multirow{4}{*}{ Roofs } & Insulation Entirely Above Deck & $\overline{R-25 \mathrm{ci}}$ & $\overline{\mathrm{R}-25 \mathrm{ci}}$ & $\overline{R-25 \mathrm{ci}}$ & $\mathrm{R}-25 \mathrm{ci}$ \\
\hline & \begin{tabular}{|l} 
Attic and Other \\
\end{tabular} & $R-38$ & $R-38$ & $R-60$ & $R-60$ \\
\hline & Metal Building & $\mathrm{R}-13.0+\mathrm{R}-19.0$ & $\mathrm{R}-13.0+\mathrm{R}-19.0$ & $R-13.0+R-19.0$ & $\mathrm{R}-19.0+\mathrm{R}-19.0$ \\
\hline & SRI & Comply with Standard 90.1* & Comply with Standard 90.1* & Comply with Standard $90.1^{*}$ & Comply with Standard $90.1^{*}$ \\
\hline \multirow{5}{*}{ Walls } & Mass ( $\left.\mathrm{HC}>7 \mathrm{Btu} / \mathrm{ft}^{2}\right)$ & $\mathrm{R}-11.4 \mathrm{ci}$ & $\mathrm{R}-13.3 \mathrm{ci}$ & $\mathrm{R}-15.2 \mathrm{ci}$ & $\mathrm{R}-15.2 \mathrm{ci}$ \\
\hline & Steel Framed & $\mathrm{R}-13+\mathrm{R}-7.5 \mathrm{ci}$ & $\mathrm{R}-13+\mathrm{R}-7.5 \mathrm{ci}$ & $\mathrm{R}-13+\mathrm{R}-7.5 \mathrm{ci}$ & $\mathrm{R}-13+\mathrm{R}-21.6 \mathrm{ci}$ \\
\hline & Wood Framed and Other & $\mathrm{R}-13+\mathrm{R}-3.8 \mathrm{ci}$ & $\mathrm{R}-13+\mathrm{R}-7.5 \mathrm{ci}$ & $\mathrm{R}-13+\mathrm{R}-7.5 \mathrm{ci}$ & $R-13+R-10 \mathrm{ci}$ \\
\hline & $\begin{array}{l}\text { Metal Building } \\
\end{array}$ & $R-13+R-13$ & $R-13+R-13$ & $R-13+R-13$ & $R-13+R-16$ \\
\hline & Below Grade Walls & $\frac{n-7.5 \mathrm{ci}-10}{R-5}$ & $\frac{n-15+5 \mathrm{ci}}{\mathrm{R}-7.5}$ & 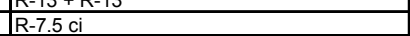 & $\frac{R-15 \mathrm{ci}-10}{\mathrm{n}-10}$ \\
\hline \multirow{3}{*}{ Floors } & Mass & $\mathrm{R}-10.4 \mathrm{ci}$ & R-13.3 ci & $\mathrm{R}-12.5 \mathrm{ci}$ & $\mathrm{R}-16.7 \mathrm{ci}$ \\
\hline & Steel Framed & $\mathrm{R}-30$ & $\mathrm{R}-30$ & $\mathrm{R}-38$ & $\mathrm{R}-38$ \\
\hline & Wood Framed and Other & $\mathrm{R}-30$ & $\mathrm{R}-30$ & $\mathrm{R}-30$ & $\mathrm{R}-30$ \\
\hline \multirow{2}{*}{ Slabs } & Unheated & Comply with Standard $90.1^{*}$ & R-10 for 24 in. & R-15 for 24 in. & R-20 for 24 in. \\
\hline & Heated & R-15 for 24 in. & $\mathrm{R}-15$ for 24 in. & R-15 for full slab & R-15 for full slab \\
\hline \multirow{2}{*}{ Doors } & Swinging & U-0.700 & $U-0.700$ & $U-0.50$ & $U-0.50$ \\
\hline & Non-Swinging & $0-.50$ & U. -50 & U-.50 & $\mathrm{U}-0.50$ \\
\hline \multirow{4}{*}{$\begin{array}{l}\text { Vertical } \\
\text { Fenestration }\end{array}$} & Total Fenestration to Gross Wall Area Ratio & $35 \% \operatorname{Max}$ & $35 \% \operatorname{Max}$ & $35 \% \operatorname{Max}$ & $35 \% \operatorname{Max}$ \\
\hline & Thermal transmittance- all types and orientations & $\mathrm{U}-0.42$ & $\mathrm{U}-0.42$ & $\mathrm{U}-0.33$ & $\mathrm{U}-0.33$ \\
\hline & Solar heat gain coefficient (SHGC)- all types and orientations & SHGC- 0.40 & SHGC- 0.40 & SHGC- 0.45 & SHGC-0.45 \\
\hline & Exterior Sun Control (S, E, W only) & Projection Factor $>0.5$ & Projection Factor $>0.5$ & Projection Factor $>0.5$ & Projection Factor> 0.5 \\
\hline Interior Finishes & Interior room surface average reflectance & $\begin{array}{l}70 \%+\text { on ceilings and walls above } 7^{\prime}, 50 \%+ \\
\text { on walls below } 7^{\prime}\end{array}$ & 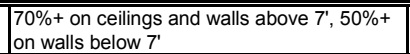 & $\begin{array}{l}\begin{array}{l}70 \%+\text { on ceilings and walls above } 7^{\prime}, 50 \%+ \\
\text { on walls below } 7^{\prime}\end{array} \\
\end{array}$ & $\begin{array}{l}\begin{array}{l}70 \%+\text { on ceilings and walls above } 7^{\prime}, 50 \%+ \\
\text { on walls below } 7^{\prime}\end{array} \\
\end{array}$ \\
\hline \multirow{9}{*}{$\begin{array}{l}\text { Interior Lighting } \\
\text { Daylighted } \\
\text { Option }\end{array}$} & & $\begin{array}{l}\text { Toplit - } \\
\text { South Facing Roof Monitors: } 8 \%-11 \% \\
\text { North Facing Roof Monitors: } 12 \%-15 \%\end{array}$ & \begin{tabular}{|l|} 
Toplit - \\
South Facing Roof Monitors: $8 \%-11 \%$ \\
North Facing Roof Monitors: $12 \%-15 \%$
\end{tabular} & $\begin{array}{l}\text { Toplit - } \\
\text { South Facing Roof Monitors: } 8 \%-11 \% \\
\text { North Facing Roof Monitors: } 12 \%-15 \%\end{array}$ & $\begin{array}{l}\text { Toplit - } \\
\text { South Facing Roof Monitors: 8\%-11\% } \\
\text { North Facing Roof Monitors: } 12 \%-15 \%\end{array}$ \\
\hline & Classroom Daylighting (Daylighting Fenestration to Floor Area Ratio) & $\begin{array}{l}\text { Sidelit- } \\
\text { South Facing: } 8 \%-11 \% \\
\text { North Facing: } 15 \%-20 \%\end{array}$ & $\begin{array}{l}\text { Sidelit- } \\
\text { South Facing: } 8 \%-11 \% \\
\text { North Facing: } 15 \%-20 \%\end{array}$ & $\begin{array}{l}\text { Sidelit- } \\
\text { South Facing: } 8 \%-11 \% \\
\text { North Facing: } 15 \%-20 \%\end{array}$ & $\begin{array}{l}\text { Sidelit- } \\
\text { South Facing: } 8 \%-11 \% \\
\text { North Facing: } 15 \%-20 \%\end{array}$ \\
\hline & & \begin{tabular}{|l|} 
Combined Toplit and Sidelit- \\
South Facing Sidelit: 6\%-8\%, Toplit: $2 \%-3 \%$ \\
North Facing Sidelit: $9 \%-13 \%$, Toplit: $3 \%-5 \%$
\end{tabular} & $\begin{array}{l}\text { Combined Toplit and Sidelit- } \\
\text { South Facing Sidelit: 6\%-8\%, Toplit: } 2 \%-3 \% \\
\text { North Facing Sidelit: } 9 \%-13 \% \text {, Toplit: } 3 \%-5 \%\end{array}$ & $\begin{array}{l}\text { Combined Toplit and Sidelit- } \\
\text { South Facing Sidelit: } 6 \%-8 \% \text {, Toplit: } 2 \%-3 \% \\
\text { North Facing Sidelit: } 9 \%-13 \% \text {, Toplit: } 3 \%-5 \%\end{array}$ & $\begin{array}{l}\text { Combined Toplit and Sidelit- } \\
\text { South Facing Sidelit: } 6 \%-8 \% \text {, Toplit: } 2 \%-3 \% \\
\text { North Facing Sidelit: } 9 \%-13 \% \text {, Toplit: } 3 \%-5 \%\end{array}$ \\
\hline & Gym Toplighting (Daylighting Fenestration to Floor Area Ratio) & $\begin{array}{l}\text { South Facing Roof Monitors: } 5 \%-8 \% \\
\text { North Facing Roof Monitors 7\% to 10\% }\end{array}$ & $\begin{array}{l}\text { South Facing Roof Monitors: } 5 \%-8 \% \\
\text { North Facing Roof Monitors } 7 \% \text { to } 10 \%\end{array}$ & $\begin{array}{l}\text { South Facing Roof Monitors: } 5 \% \text { - } 8 \% \text { North } \\
\text { Facing Roof Monitors } 7 \% \text { to } 10 \%\end{array}$ & $\begin{array}{l}\text { South Facing Roof Monitors: } 5 \% \text { - } 8 \% \text { North } \\
\text { Facing Roof Monitors } 7 \% \text { to } 10 \%\end{array}$ \\
\hline & Lighting Power Density (LPD) & $1.2 \mathrm{~W} / \mathrm{ft}^{2}$ maximum & $1.2 \mathrm{~W} / \mathrm{ft}^{2}$ maximum & $1.2 \mathrm{~W} / \mathrm{ft}^{2}$ maximum & $1.2 \mathrm{~W} / \mathrm{ft}^{2}$ maximum \\
\hline & Light Source system efficacy (linear fluorescent and HID) & 75 mean lumens/ watt minimum & 75 mean lumens/ watt minimum & 75 mean lumens/ watt minimum & 75 mean lumens/ watt minimum \\
\hline & Light source system efficacy (all other sources) & 50 mean lumens/watt minimum & 50 mean lumens/watt minimum & 50 mean lumens/watt minimum & 50 mean lumens/watt minimum \\
\hline & Lighting Controls - general & Manual on, Auto-off all zones & Manual on, Auto-off all zones & Manual on, Auto-off all zones & Manual on, Auto-off all zones \\
\hline & Dimming Controls Daylight Harvesting & $\begin{array}{l}\text { Dim all fixtures in classrooms and gym, and } \\
\text { other fixtures within } 15 \mathrm{ft} \text { of sidelighting } \\
\text { edge, and within } 10 \mathrm{ft} \text { of toplighting edge }\end{array}$ & $\begin{array}{l}\text { Dim all fixtures in classrooms and gym, and } \\
\text { other fixtures within } 15 \mathrm{ft} \text { of sidelighting } \\
\text { edge, and within } 10 \mathrm{ft} \text { of toplighting edge }\end{array}$ & $\begin{array}{l}\text { Dim all fixtures in classrooms and gym, and } \\
\text { other fixtures within } 15 \mathrm{ft} \text { of sidelighting } \\
\text { edge, and within } 10 \mathrm{ft} \text { of toplighting edge }\end{array}$ & $\begin{array}{l}\text { Dim all fixtures in classrooms and gym, and } \\
\text { other fixtures within } 15 \mathrm{ft} \text { of sidelighting } \\
\text { edge, and within } 10 \mathrm{ft} \text { of toplighting edge }\end{array}$ \\
\hline \multirow{5}{*}{$\begin{array}{l}\text { Interior Lighting } \\
\text { - Non- } \\
\text { Daylighted } \\
\text { Option }\end{array}$} & Lighting Power Density (LPD) & $1.1 \mathrm{~W} / \mathrm{ft}^{2}$ maximum & $1.1 \mathrm{~W} / \mathrm{ft}^{2}$ maximum & $1.1 \mathrm{~W} / \mathrm{ft}^{2}$ maximum & $1.1 \mathrm{~W} / \mathrm{ft}^{2}$ maximum \\
\hline & Light Source system efficac (linear fluorescent) & 85 mean lumens/watt minimum & 85 mean lumens/watt minimum & 85 mean lumens/watt minimum & 85 mean lumens/watt minimum \\
\hline & Light source system efficacy (all other sources) & 50 mean lumens/watt minimum & 50 mean lumens/watt minimum & 50 mean lumens/watt minimum & 50 mean lumens/watt minimum \\
\hline & Lighting Controls - general & Manual on, Auto-off all zones & Manual on, Auto-off all zones & Manual on, Auto-off all zones & Manual on, Auto-off all zones \\
\hline & Dimming Controls Daylight Harvesting & $\begin{array}{l}\text { Dim fixtures within } 15 \mathrm{ft} \text { of sidelighting edge, } \\
\text { and within } 10 \mathrm{ft} \text { of toplighting edge }\end{array}$ & $\begin{array}{l}\text { Dim fixtures within } 15 \mathrm{ft} \text { of sidelighting edge, } \\
\text { and within } 10 \mathrm{ft} \text { of toplighting edge }\end{array}$ & $\begin{array}{l}\text { Dim fixtures within } 15 \mathrm{ft} \text { of sidelighting edge, } \\
\text { and within } 10 \mathrm{ft} \text { of toplighting edge }\end{array}$ & $\begin{array}{l}\text { Dim fixtures within } 15 \mathrm{ft} \text { of sidelighting edge, } \\
\text { and within } 10 \mathrm{ft} \text { of toplighting edge }\end{array}$ \\
\hline \multirow{12}{*}{\begin{tabular}{|l} 
Packaged DX \\
Rooftops (or \\
DX Split \\
Systems)
\end{tabular}} & Air Conditioner < 65 kBtu/h & T13 SEER & 13 SEER & 13 SEER & 13 SEER \\
\hline & Air Conditioner $>=65$ and $<135 \mathrm{kBtu} / \mathrm{h}$ & $11.0 \mathrm{EER}$ & Comply with Stan & Comply wi & Comply with St \\
\hline & Air Conditioner $>=135$ and $<240 \mathrm{kBtu} / \mathrm{h}$ & $10.8 \mathrm{EER}$ & Comply with Standard $90.1^{*}$ & Comply with Standard $90.1^{*}$ & Comply with Standard $90.1^{*}$ \\
\hline & Air Conditioner $>=240 \mathrm{kBtu} / \mathrm{h}$ & $10.0 \mathrm{EER} / 10.4 \mathrm{IPLV}$ & Comply with Standard $90.1^{*}$ & Comply with Standard $90.1^{*}$ & Comply with Standard $90.1^{*}$ \\
\hline & Heat Pump $<65 \mathrm{kBtu} / \mathrm{h}$ & 13.0 SEER/7.7 HPSF & 13.0 SEER/7.7 HPSF & 13.0 SEER/7.7 HPSF & 13.0 SEER/7.7 HPSF \\
\hline & Heat Pump $>=65$ and $<135 \mathrm{kBtu} / \mathrm{h}$ & $10.6 \mathrm{EER} / 3.2 \mathrm{COP}$ & Comply with Standard $90.1^{*}$ & Comply with Standard $90.1^{*}$ & Comply with Standard $90.1^{*}$ \\
\hline & Heat Pump $>=135 \mathrm{kBtu} / \mathrm{h}$ & $10.1 \mathrm{EER} / 11.0 \mathrm{IPLV} / 3.1 \mathrm{COP}$ & Comply with Standard $90.1^{*}$ & Comply with Standard $90.1^{*}$ & Comply with Standard 90.1 $1^{*}$ \\
\hline & Gas Furnace $<225 \mathrm{kBtuh}$ & $80 \%$ AFUE or $E_{t}$ & $80 \%$ AFUE or $\mathrm{t}_{\mathrm{t}}$ & $80 \%$ AFUE or $E_{t}$ & $80 \%$ AFUE or $E_{t}$ \\
\hline & Gas Furnace $>=225 \mathrm{kBtu} / \mathrm{h}$ & $80 \% \mathrm{E}_{\mathrm{c}}$ & $80 \% \mathrm{E}_{\mathrm{c}}$ & $80 \% \mathrm{E}_{\mathrm{c}}$ & $80 \% \mathrm{E}_{\mathrm{c}}$ \\
\hline & Economizer & $>54 \mathrm{kBtu} / \mathrm{h}$ & $>54 \mathrm{kBtu} / \mathrm{h}$ & $>54 \mathrm{kBtu} / \mathrm{h}$ & $>54 \mathrm{kBtu} / \mathrm{h}$ \\
\hline & Ventilation & Energy reco & Energy recove & Energy recov & Energy recovery or \\
\hline & Fans & $\begin{array}{l}\text { constant volume: } 1 \mathrm{hp} / 1000 \mathrm{cfm} \\
\text { variable volume: } 1.3 \mathrm{hp} / 1000 \mathrm{cfm}\end{array}$ & $\begin{array}{l}\text { constant volume: } 1 \mathrm{hp} / 1000 \mathrm{cfm} \\
\text { variable volume: } 1.3 \mathrm{hp} / 1000 \mathrm{cfm}\end{array}$ & $\begin{array}{l}\text { constant volume: } 1 \mathrm{hp} / 1000 \mathrm{cfm} \\
\text { variable volume: } 1.3 \mathrm{hp} / 1000 \mathrm{cfm}\end{array}$ & $\begin{array}{l}\text { constant volume: } 1 \mathrm{hp} / 1000 \mathrm{~cm} \\
\text { variable volume: } 1.3 \mathrm{hp} / 1000 \mathrm{cfm}\end{array}$ \\
\hline
\end{tabular}


Table 4-4 K-12 AEDG Recommendations for 30\% Savings over ASHRAE 90.1-1999: Climate Zones 5-8 (Cont.)

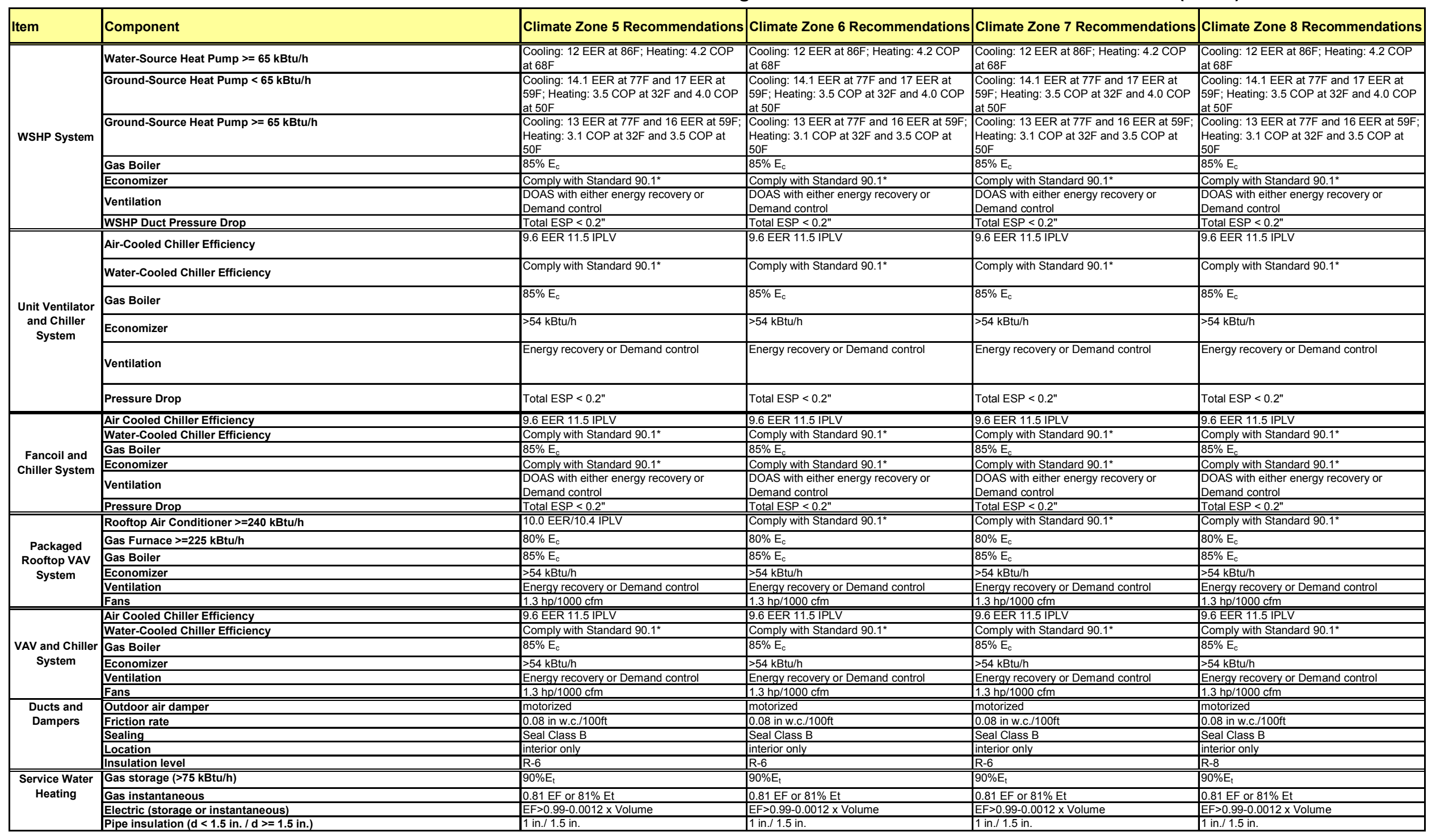




\subsection{Discussion of Recommendations}

\subsubsection{Envelope Recommendations}

The envelope recommendations cover the range of assemblies for the opaque and fenestration portions of the building. Opaque elements include the roof, walls, floors and slabs, as well as opaque doors. Fenestration elements include the vertical glazing (including doors). The Guide presents recommendations for a number of components of each building element. In general, the insulation recommendations increase as the climate becomes colder. An exception to this is the roof insulation entirely above deck recommendations. The R-value recommendation is constant across all climate zones. This recommendation was determined based on the TLCC analysis, which identified the optimal level of roof insulation specific to our prototype schools. Control of solar loads is more critical in the hotter, sunnier climates, and thus the SHGC tends to be more stringent (lower) in zone 1 and higher in zone 8 .

\subsubsection{Lighting and Daylighting Recommendations}

The lighting and daylighting recommendations cover a range of performance characteristics, including LPD, lighting controls, and daylighting fenestration areas. The recommended LPD for the non-daylit option in climate zones 1,2 , and 5 through 8 is $1.1 \mathrm{~W} / \mathrm{ft}^{2}\left(11.8 \mathrm{~W} / \mathrm{m}^{2}\right)$. In climate zones 3 and 4 , the recommended LPD is $0.9 \mathrm{~W} / \mathrm{ft}^{2}\left(9.7 \mathrm{~W} / \mathrm{m}^{2}\right)$. In these zones, the lighting load is a higher percentage of total energy use that results from smaller heating and cooling loads. Therefore, more aggressive LPDs that use the most current, energy-efficient lamps, ballasts, and integrated controls are recommended to meet the savings target of $30 \%$. The daylit options recommend a slightly higher LPD of $1.2 \mathrm{~W} / \mathrm{ft}^{2}(12.9$ $\mathrm{W} / \mathrm{m}^{2}$ ). The higher LPD is recommended for the daylit options because significant lighting savings are expected from the lights dimming or turning off from the daylight rather than an aggressive lighting power reduction.

An additional rationale the PC considered for allowing higher LPDs in the daylit options was that if a school designer put a limited amount of money into a good daylighting system, one would not need to spend a lot of money on a high-efficiency electric lighting system. This rationale works only if the energy savings goal is $30 \%$, and the school designer is trying to achieve that cost effectively. The PC felt that the most stringent LPDs combined with a classroom daylighting design would result in substantially more savings than needed, in a less cost-effective combination of technologies. Simulation results confirmed this thought, as 30\% savings were obtainable with both the high efficiency electrical lighting option without daylighting and the standard lighting option with daylit classrooms and gym.

A primary difference between ASHRAE 90.1-1999 and ASHRAE 90.1-2004 is the more aggressive limits on LPD. For example, classroom LPD was reduced from $1.6 \mathrm{~W} / \mathrm{ft}^{2}$ to $1.4 \mathrm{~W} / \mathrm{ft}^{2}\left(17.2 \mathrm{~W} / \mathrm{m}^{2}\right.$ to 15.1 $\mathrm{W} / \mathrm{m}^{2}$ ). In comparing the results of the low-energy non-daylit option to the ASHRAE 90.1-2004 baselines, we determined that the non-daylit option recommendations would not reach $30 \%$ savings in all climate zones. The climate zones that did not reach $30 \%$ savings were the temperate marine zones $3 \mathrm{C}$ and $4 \mathrm{C}$, as well as the hot and humid zones 1 and $2 \mathrm{~A}$. All of the daylit versions were still at $30 \%$ savings or above for the ASHRAE 90.1-2004 baseline, as the daylighting system energy savings were greater than the energy savings from the reduced LPD system. Therefore, the non-daylit option that is available for 30\% savings over ASHRAE 90.1-1999 is not available for 30\% savings over ASHRAE 90.1-2004.

The fenestration areas for the daylighting recommendations are provided as a range in the ratio of the daylighting fenestration area to floor area. The PC provided a range in the daylighting fenestration ratios as they felt that some level of detailed daylighting designs was necessary to fine tune the daylighting fenestration area for a specific school. The recommendations are constant across the climate zones, except for the use of skylights in the gym daylighting option. The K-12 AEDG recommends gym skylights in the temperate climate zones of $3 \mathrm{C}$ and $4 \mathrm{C}$ only. One benefit of a well-designed daylighting system is that the cooling equipment can be downsized. Often, this downsizing can pay for a significant portion of the daylighting system. Therefore, the PC focused on daylighting methods other than skylights 
that provided good daylighting and could result in downsizing of the cooling systems in warm climates. In addition, the PC felt that direct beam radiation in gyms should be avoided. This resulted in skylight recommendations for only the temperate climates, which have more overcast and diffuse sky conditions.

\subsubsection{HVAC Systems}

Unique recommendations are included for each HVAC system type in the climate-specific recommendation tables. The recommendations are provided based on how ASHRAE 90.1 specifies performance. The package rooftop cooling equipment efficiencies for small units are expressed in SEERs and EERs for larger rooftop products. Additionally, commercial cooling products have integrated part load values (IPLV) that express their performance during part load operation. Heating equipment efficiencies for rooftop products are expressed as annual fuel utilization efficiencies for gas furnaces and heating season performance factors for heat pumps. Heating efficiencies for larger commercial products are expressed as thermal efficiencies and combustion efficiencies or furnaces and COPs for heat pumps.

Cooling equipment efficiencies generally are higher in the hotter climates and lower in the colder climates for the larger commercial products. For the smaller rooftop units, the cooling efficiencies are constant across the climate zones. These levels have been adopted by federal law as the minimum mandatory manufacturing standards. For package rooftop unitary equipment, the heating efficiencies are constant across climates because higher efficiency equipment is not available from multiple manufacturers. Boiler efficiencies generally are higher in colder climates, where higher equipment efficiencies are available from multiple manufacturers.

Unique recommendations are included for each HVAC system type based on practicality of implementation and the goal to achieve $30 \%$ energy savings. For example, airside economizers are recommended for packaged DX rooftops units larger than $54,000 \mathrm{Btu} / \mathrm{h}(16 \mathrm{~kW})$ for all climate zones except 1 and 2A. This is because they are easy to add to the system and they help achieve the desired energy savings. However, higher chiller and boiler efficiencies are recommended for fan-coil systems and economizers are not. This is because airside economizers are less practical for dedicated outdoor air systems.

Because conditioning OA for ventilation is such a big contributor to the energy use in a K-12 school building, either exhaust-air energy recovery or demand controlled ventilation is recommended. The K-12 AEDG provides multiple options beyond code minimum for reducing OA loads, including scheduled OA control for all zones, $\mathrm{CO}_{2}$ demand controlled ventilation in all zones, and energy recovery from exhaust air. The PC felt that both $\mathrm{CO}_{2}$ demand controlled ventilation and ERVs was not practical technology combination and unneeded for $30 \%$ savings. Therefore, for all HVAC system types, either $\mathrm{CO}_{2}$ demand controlled ventilation or an ERV is recommended.

Some system types are not recommended for certain climate zones. For example, unit ventilators are not recommended in warm humid climates in climate zones 1,2A, and 3A. This was due to concern from the $\mathrm{PC}$ and from peer reviewers that unit ventilators cannot efficiently condition $\mathrm{OA}$ in humid climates. In addition, ERVs are not recommended in the coastal climate zones $3 \mathrm{C}$ and $4 \mathrm{C}$, because of their limited energy recovery potential.

SWH measures include recommendations for the use of instantaneous water heaters for fuel-fired applications and enhanced efficiencies for storage applications. In addition, recommendations are provided for enhanced pipe insulation values.

\subsection{Energy Savings Results}

The whole building energy savings results for the recommendations in the K-12 AEDG are shown in Table 4-5. Energy savings are relative to the ASHRAE 90.1-1999 baseline energy use, and include plug loads in the energy use of the baseline and low-energy models. The analysis shows that the recommendations in the K-12 AEDG succeeded in meeting the goal of 30\% or greater energy savings and that this goal can be met for daylit and non-daylit options with a range of HVAC system types. Energy 
savings are also shown for each elementary, middle, and high school prototype. In general, all the nondaylit models had less energy savings than the daylit equivalent. Note that the daylit models do not have a reduced LPD, but used less lighting energy than the non-daylit models. The non-daylit low-energy PSZ models were just above 30\% savings, and the PVAV daylit low-energy models were significantly above $30 \%$ energy savings. The PVAV system types performed the best, because of a combination of the higher VAV fan efficiency, higher compressor COP, and higher boiler efficiency. Energy savings by school type did not vary significantly for a given climate zone.

The energy savings results for the recommendations in the K-12 AEDG, relative to ASHRAE 90.1-2004 are shown in Table 4-6. The recommendations in the K-12 AEDG result in 30\% or greater energy savings over ASHRAE 90.1-2004 for just the daylit options with a range of HVAC system types. Energy savings are also shown for each elementary, middle, and high school prototype.

The end uses for each ASHRAE 90.1-1999 baseline and low-energy model are shown in Figure 4-1 through Figure 4-6. The end uses for each ASHRAE 90.1-2204 baseline and low-energy model are shown in Figure 4-7 through Figure 4-9.

The end use data and percent savings for the ASHRAE 90.1-1999 baseline and low-energy models are shown in tabular format in Appendix G. The ASHRAE 90.1-2004 baseline and low-energy model end uses and savings are shown in tabular format in Appendix $\mathrm{H}$. 
Table 4-5 Energy Savings: ASHRAE 90.1-1999 Baseline

\begin{tabular}{|c|c|c|c|c|c|c|c|}
\hline Climate & School Type & $\begin{array}{c}30 \% \text { - No } \\
\text { Daylight } \\
\text { PSZ }\end{array}$ & $\begin{array}{c}30 \%-\text { No } \\
\text { Daylight } \\
\text { VAV }\end{array}$ & $\begin{array}{c}30 \% \text { - No } \\
\text { Daylight } \\
\text { PVAV }\end{array}$ & $\begin{array}{c}30 \%- \\
\text { Daylit } \\
\text { PSZ }\end{array}$ & $\begin{array}{c}30 \%- \\
\text { Daylit } \\
\text { VAV }\end{array}$ & $\begin{array}{l}30 \%- \\
\text { Daylit } \\
\text { PVAV }\end{array}$ \\
\hline \multirow{3}{*}{$1 \mathrm{~A}$} & Elementary & $34 \%$ & $36 \%$ & $41 \%$ & $40 \%$ & $43 \%$ & $47 \%$ \\
\hline & Middle & $35 \%$ & $36 \%$ & $42 \%$ & $41 \%$ & $42 \%$ & $48 \%$ \\
\hline & High & $36 \%$ & $35 \%$ & $42 \%$ & $43 \%$ & $42 \%$ & $47 \%$ \\
\hline \multirow{3}{*}{$2 \mathrm{~A}$} & Elementary & $36 \%$ & $37 \%$ & $41 \%$ & $42 \%$ & $43 \%$ & $47 \%$ \\
\hline & Middle & $36 \%$ & $37 \%$ & $41 \%$ & $42 \%$ & $43 \%$ & $47 \%$ \\
\hline & High & $37 \%$ & $37 \%$ & $42 \%$ & $44 \%$ & $43 \%$ & $47 \%$ \\
\hline \multirow{3}{*}{ 2B } & Elementary & $37 \%$ & $40 \%$ & $44 \%$ & $44 \%$ & $47 \%$ & $50 \%$ \\
\hline & Middle & $38 \%$ & $40 \%$ & $44 \%$ & $44 \%$ & $46 \%$ & $50 \%$ \\
\hline & High & $39 \%$ & $39 \%$ & $44 \%$ & $46 \%$ & $46 \%$ & $50 \%$ \\
\hline \multirow{3}{*}{$3 A$} & Elementary & $36 \%$ & $36 \%$ & $40 \%$ & $38 \%$ & $39 \%$ & $42 \%$ \\
\hline & Middle & $36 \%$ & $37 \%$ & $40 \%$ & $38 \%$ & $39 \%$ & $42 \%$ \\
\hline & High & $36 \%$ & $36 \%$ & $40 \%$ & $39 \%$ & $39 \%$ & $42 \%$ \\
\hline \multirow{3}{*}{ 3B } & Elementary & $36 \%$ & $38 \%$ & $41 \%$ & $38 \%$ & $40 \%$ & $43 \%$ \\
\hline & Middle & $36 \%$ & $38 \%$ & $42 \%$ & $39 \%$ & $41 \%$ & $44 \%$ \\
\hline & High & $37 \%$ & $37 \%$ & $41 \%$ & $40 \%$ & $40 \%$ & $44 \%$ \\
\hline \multirow{3}{*}{$3 C$} & Elementary & $40 \%$ & $43 \%$ & $44 \%$ & $43 \%$ & $44 \%$ & $45 \%$ \\
\hline & Middle & $41 \%$ & $43 \%$ & $44 \%$ & $43 \%$ & $45 \%$ & $46 \%$ \\
\hline & High & $42 \%$ & $44 \%$ & $45 \%$ & $44 \%$ & $46 \%$ & $47 \%$ \\
\hline \multirow{3}{*}{$4 \mathrm{~A}$} & Elementary & $36 \%$ & $37 \%$ & $40 \%$ & $39 \%$ & $40 \%$ & $43 \%$ \\
\hline & Middle & $35 \%$ & $38 \%$ & $40 \%$ & $38 \%$ & $41 \%$ & $43 \%$ \\
\hline & High & $35 \%$ & $35 \%$ & $38 \%$ & $38 \%$ & $40 \%$ & $42 \%$ \\
\hline \multirow{3}{*}{$4 \mathrm{~B}$} & Elementary & $35 \%$ & $37 \%$ & $40 \%$ & $39 \%$ & $40 \%$ & $43 \%$ \\
\hline & Middle & $35 \%$ & $38 \%$ & $40 \%$ & $38 \%$ & $41 \%$ & $43 \%$ \\
\hline & High & $36 \%$ & $36 \%$ & $39 \%$ & $40 \%$ & $40 \%$ & $43 \%$ \\
\hline \multirow{3}{*}{$4 C$} & Elementary & $33 \%$ & $37 \%$ & $38 \%$ & $36 \%$ & $39 \%$ & $40 \%$ \\
\hline & Middle & $32 \%$ & $39 \%$ & $40 \%$ & $34 \%$ & $41 \%$ & $42 \%$ \\
\hline & High & $33 \%$ & $38 \%$ & $39 \%$ & $36 \%$ & $42 \%$ & $43 \%$ \\
\hline \multirow{3}{*}{$5 A$} & Elementary & $35 \%$ & $36 \%$ & $38 \%$ & $40 \%$ & $42 \%$ & $43 \%$ \\
\hline & Middle & $33 \%$ & $36 \%$ & $39 \%$ & $38 \%$ & $42 \%$ & $44 \%$ \\
\hline & High & $33 \%$ & $34 \%$ & $36 \%$ & $39 \%$ & $40 \%$ & $42 \%$ \\
\hline \multirow{3}{*}{$5 B$} & Elementary & $33 \%$ & $35 \%$ & $36 \%$ & $40 \%$ & $41 \%$ & $43 \%$ \\
\hline & Middle & $32 \%$ & $35 \%$ & $37 \%$ & $38 \%$ & $41 \%$ & $43 \%$ \\
\hline & High & $32 \%$ & $33 \%$ & $35 \%$ & $39 \%$ & $40 \%$ & $42 \%$ \\
\hline \multirow{3}{*}{$6 \mathrm{~A}$} & Elementary & $37 \%$ & $38 \%$ & $39 \%$ & $42 \%$ & $44 \%$ & $44 \%$ \\
\hline & Middle & $34 \%$ & $38 \%$ & $40 \%$ & $39 \%$ & $43 \%$ & $44 \%$ \\
\hline & High & $34 \%$ & $36 \%$ & $37 \%$ & $39 \%$ & $42 \%$ & $42 \%$ \\
\hline \multirow{3}{*}{$6 \mathrm{~B}$} & Elementary & $36 \%$ & $36 \%$ & $37 \%$ & $41 \%$ & $42 \%$ & $43 \%$ \\
\hline & Middle & $33 \%$ & $37 \%$ & $38 \%$ & $39 \%$ & $42 \%$ & $43 \%$ \\
\hline & High & $33 \%$ & $34 \%$ & $35 \%$ & $40 \%$ & $41 \%$ & $41 \%$ \\
\hline \multirow{3}{*}{$7 A$} & Elementary & $40 \%$ & $41 \%$ & $42 \%$ & $45 \%$ & $46 \%$ & $46 \%$ \\
\hline & Middle & $36 \%$ & $41 \%$ & $42 \%$ & $41 \%$ & $45 \%$ & $46 \%$ \\
\hline & High & $36 \%$ & $38 \%$ & $39 \%$ & $41 \%$ & $43 \%$ & $44 \%$ \\
\hline \multirow{3}{*}{$8 \mathrm{~A}$} & Elementary & $42 \%$ & $39 \%$ & $39 \%$ & $45 \%$ & $42 \%$ & $41 \%$ \\
\hline & Middle & $37 \%$ & $38 \%$ & $37 \%$ & $40 \%$ & $40 \%$ & $39 \%$ \\
\hline & High & $37 \%$ & $35 \%$ & $34 \%$ & $42 \%$ & $38 \%$ & $37 \%$ \\
\hline
\end{tabular}


Table 4-6 Energy Savings: ASHRAE 90.1-2004 Baseline

\begin{tabular}{|c|c|c|c|c|}
\hline Climate & $\begin{array}{l}\text { School } \\
\text { Type }\end{array}$ & $\begin{array}{c}30 \%- \\
\text { Daylit PSZ }\end{array}$ & $\begin{array}{c}30 \%- \\
\text { Daylit VAV }\end{array}$ & $\begin{array}{l}30 \%- \\
\text { Daylit } \\
\text { PVAV }\end{array}$ \\
\hline \multirow{3}{*}{$1 \mathrm{~A}$} & Elementary & $32 \%$ & $34 \%$ & $40 \%$ \\
\hline & Middle & $32 \%$ & $33 \%$ & $39 \%$ \\
\hline & High & $33 \%$ & $31 \%$ & $38 \%$ \\
\hline \multirow{3}{*}{$2 \mathrm{~A}$} & Elementary & $35 \%$ & $36 \%$ & $41 \%$ \\
\hline & Middle & $35 \%$ & $35 \%$ & $40 \%$ \\
\hline & High & $36 \%$ & $35 \%$ & $40 \%$ \\
\hline \multirow{3}{*}{$2 B$} & Elementary & $37 \%$ & $40 \%$ & $43 \%$ \\
\hline & Middle & $36 \%$ & $39 \%$ & $43 \%$ \\
\hline & High & $38 \%$ & $37 \%$ & $42 \%$ \\
\hline \multirow{3}{*}{$3 \mathrm{~A}$} & Elementary & $32 \%$ & $33 \%$ & $36 \%$ \\
\hline & Middle & $31 \%$ & $32 \%$ & $36 \%$ \\
\hline & High & $32 \%$ & $32 \%$ & $36 \%$ \\
\hline \multirow{3}{*}{$3 B$} & Elementary & $31 \%$ & $33 \%$ & $37 \%$ \\
\hline & Middle & $31 \%$ & $33 \%$ & $37 \%$ \\
\hline & High & $32 \%$ & $32 \%$ & $36 \%$ \\
\hline \multirow{3}{*}{$3 C$} & Elementary & $32 \%$ & $33 \%$ & $34 \%$ \\
\hline & Middle & $31 \%$ & $33 \%$ & $35 \%$ \\
\hline & High & $33 \%$ & $35 \%$ & $37 \%$ \\
\hline \multirow{3}{*}{$4 \mathrm{~A}$} & Elementary & $35 \%$ & $36 \%$ & $39 \%$ \\
\hline & Middle & $33 \%$ & $36 \%$ & $39 \%$ \\
\hline & High & $33 \%$ & $35 \%$ & $37 \%$ \\
\hline \multirow{3}{*}{ 4B } & Elementary & $33 \%$ & $35 \%$ & $38 \%$ \\
\hline & Middle & $32 \%$ & $35 \%$ & $38 \%$ \\
\hline & High & $33 \%$ & $34 \%$ & $37 \%$ \\
\hline \multirow{3}{*}{$4 C$} & Elementary & $31 \%$ & $35 \%$ & $36 \%$ \\
\hline & Middle & $30 \%$ & $37 \%$ & $38 \%$ \\
\hline & High & $31 \%$ & $37 \%$ & $38 \%$ \\
\hline \multirow{3}{*}{$5 \mathrm{~A}$} & Elementary & $37 \%$ & $39 \%$ & $41 \%$ \\
\hline & Middle & $34 \%$ & $38 \%$ & $40 \%$ \\
\hline & High & $35 \%$ & $37 \%$ & $39 \%$ \\
\hline \multirow{3}{*}{$5 B$} & Elementary & $36 \%$ & $37 \%$ & $39 \%$ \\
\hline & Middle & $33 \%$ & $37 \%$ & $39 \%$ \\
\hline & High & $34 \%$ & $36 \%$ & $38 \%$ \\
\hline \multirow{3}{*}{$6 A$} & Elementary & $40 \%$ & $41 \%$ & $42 \%$ \\
\hline & Middle & $36 \%$ & $41 \%$ & $42 \%$ \\
\hline & High & $37 \%$ & $39 \%$ & $40 \%$ \\
\hline \multirow{3}{*}{$6 B$} & Elementary & $39 \%$ & $40 \%$ & $41 \%$ \\
\hline & Middle & $36 \%$ & $39 \%$ & $40 \%$ \\
\hline & High & $36 \%$ & $37 \%$ & $38 \%$ \\
\hline \multirow{3}{*}{$7 \mathrm{~A}$} & Elementary & $44 \%$ & $45 \%$ & $45 \%$ \\
\hline & Middle & $39 \%$ & $44 \%$ & $44 \%$ \\
\hline & High & $39 \%$ & $41 \%$ & $42 \%$ \\
\hline \multirow{3}{*}{$8 \mathrm{~A}$} & Elementary & $44 \%$ & $41 \%$ & $40 \%$ \\
\hline & Middle & $39 \%$ & $39 \%$ & $38 \%$ \\
\hline & High & $40 \%$ & $37 \%$ & $36 \%$ \\
\hline
\end{tabular}




\subsubsection{End Uses for 30\% Savings over ASHRAE 90.1-1999}

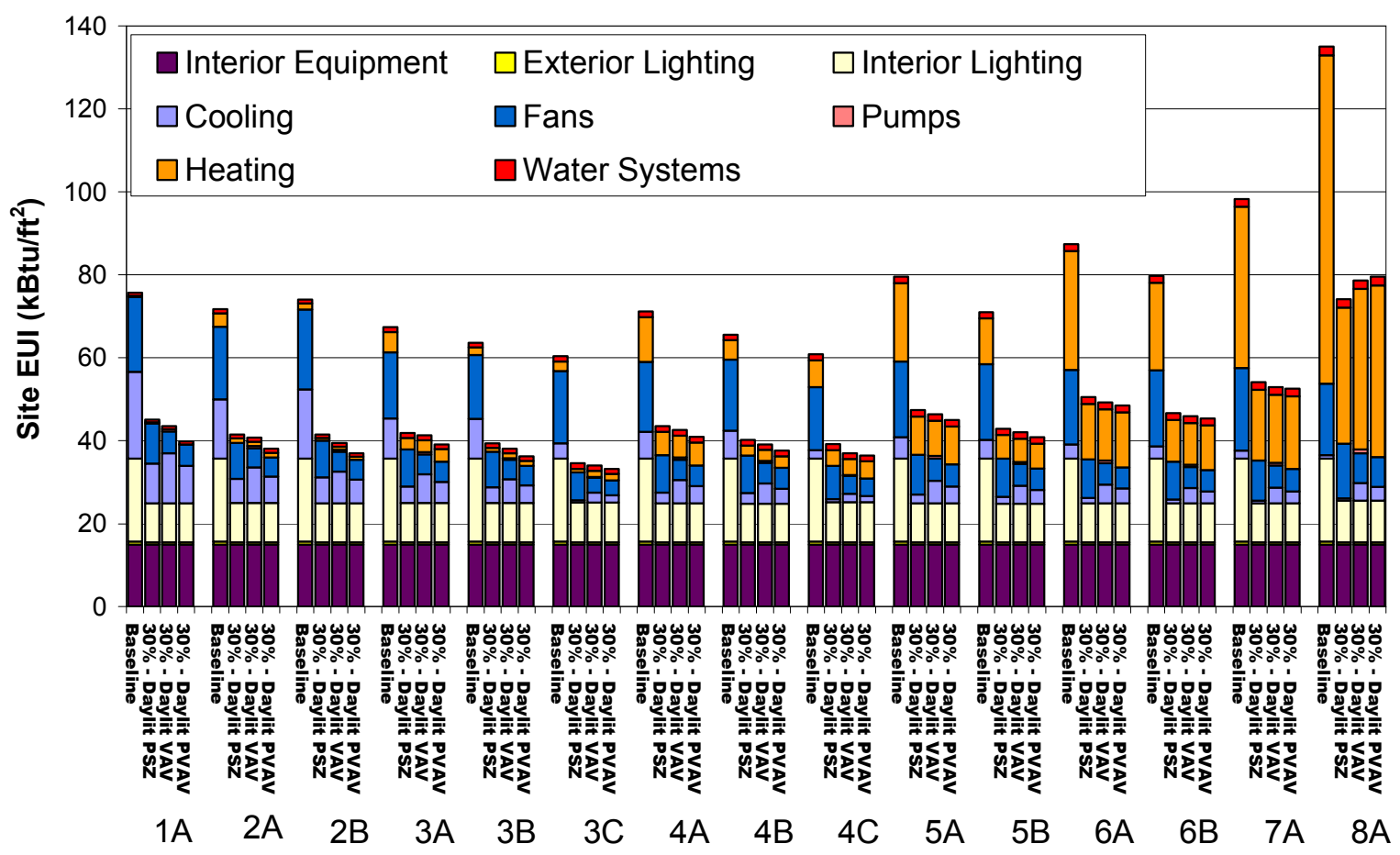

Figure 4-1 Elementary School End Uses: Daylit

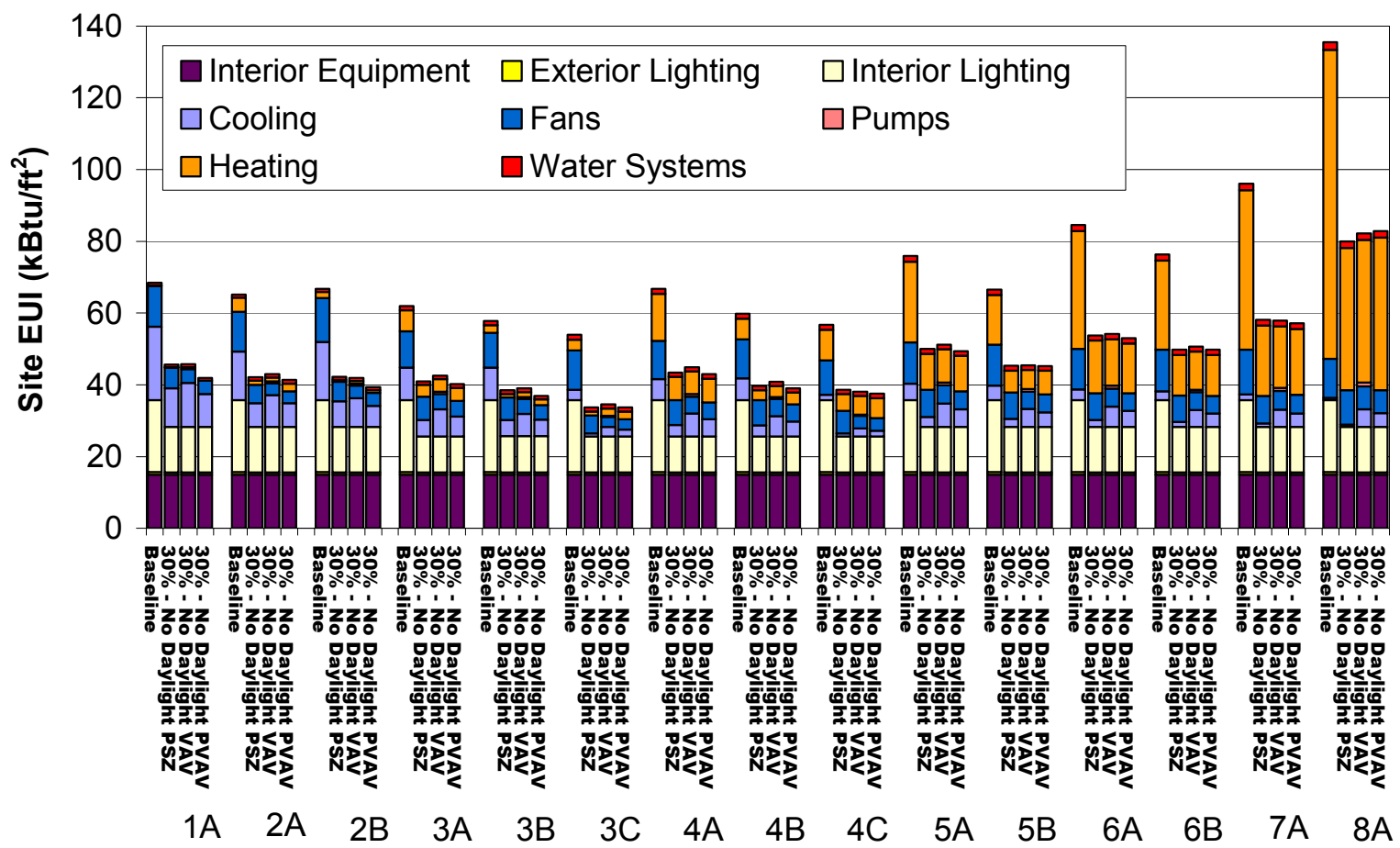

Figure 4-2 Elementary School End Uses: No Daylighting 


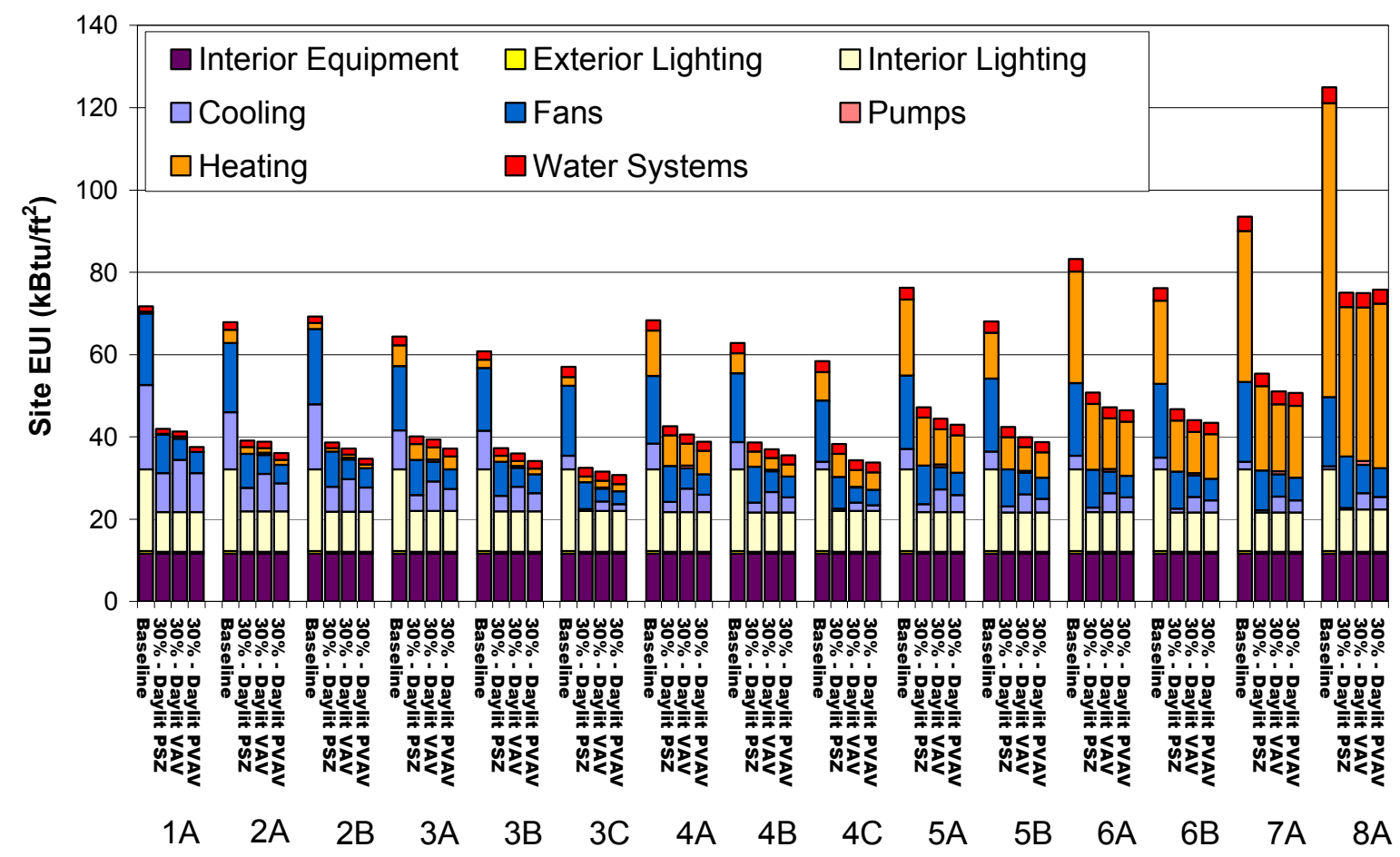

Figure 4-3 Middle School End Uses: Daylit

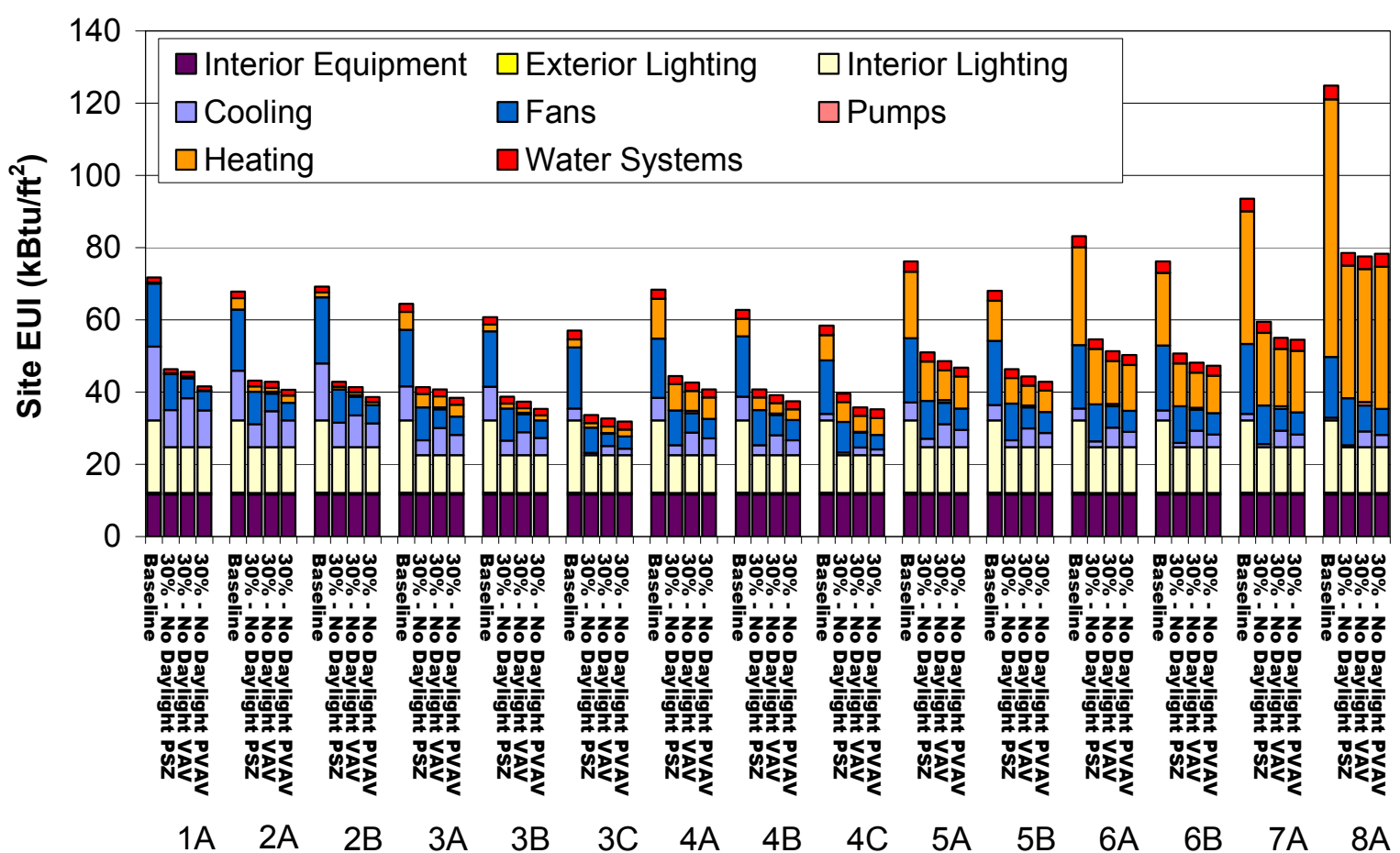

Figure 4-4 Middle School End Uses: No Daylighting 


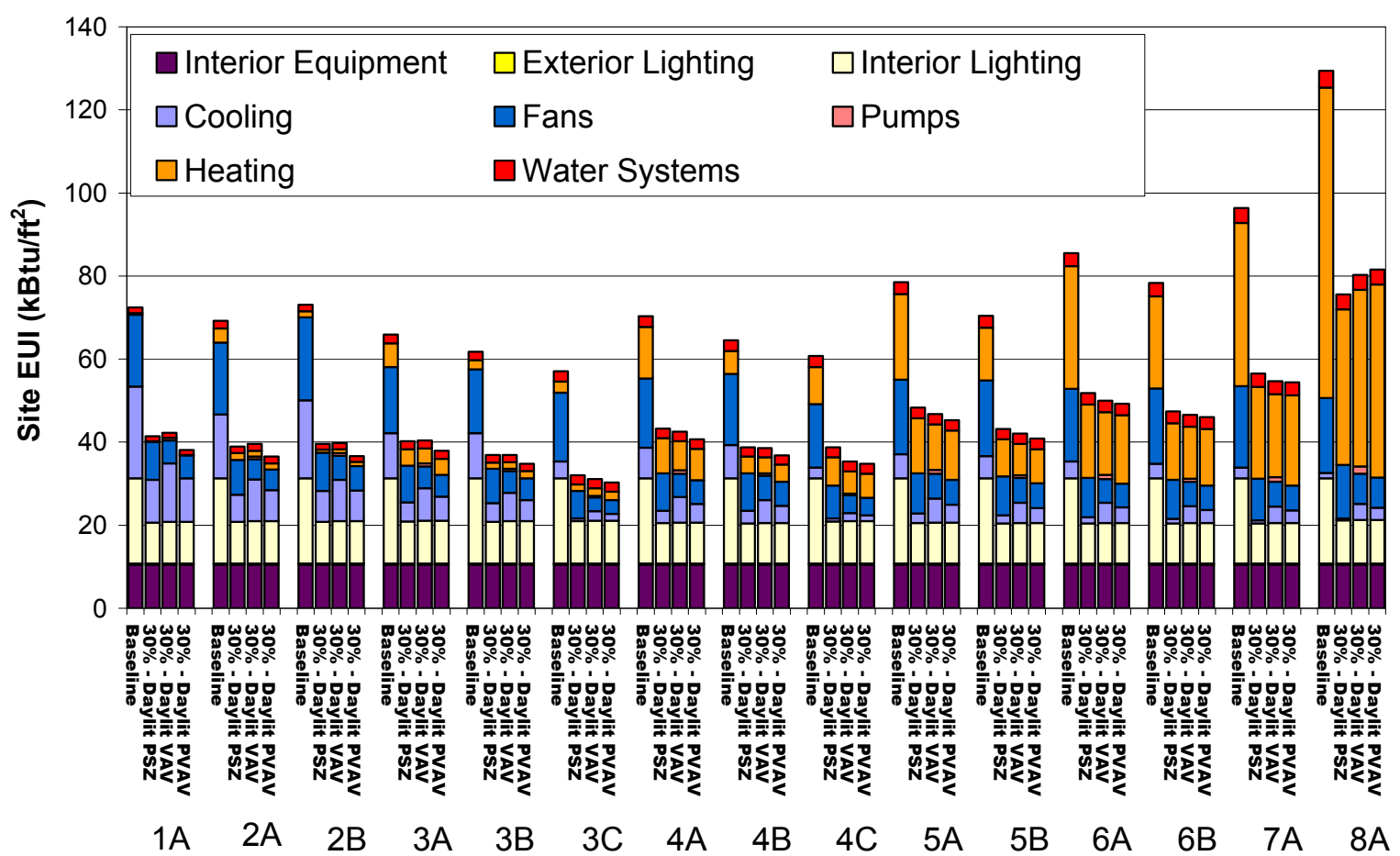

Figure 4-5 High School End Uses: Daylit

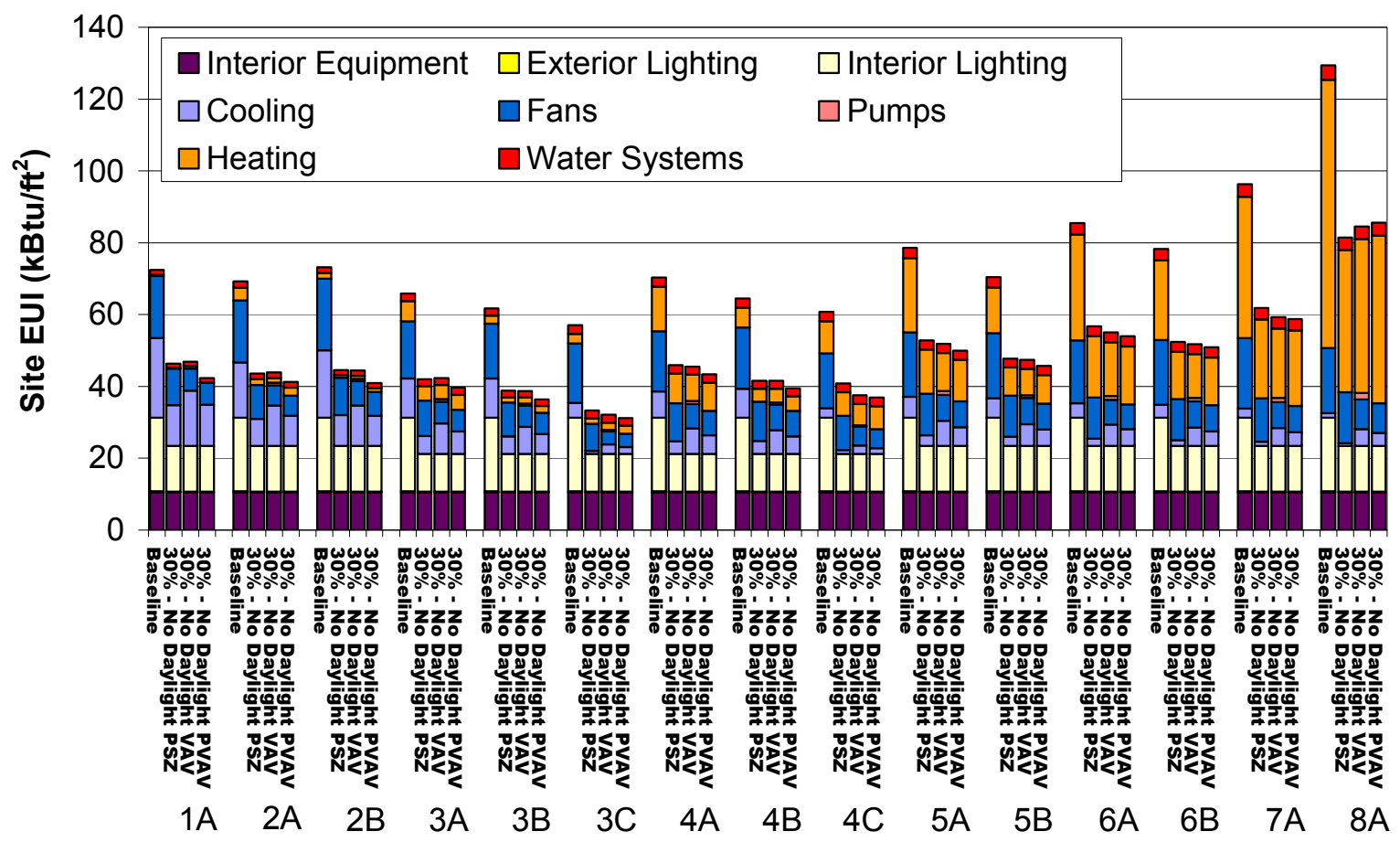

Figure 4-6 High School End Uses: No Daylighting 


\subsubsection{End uses for 30\% Savings over ASHRAE 90.1-2004}

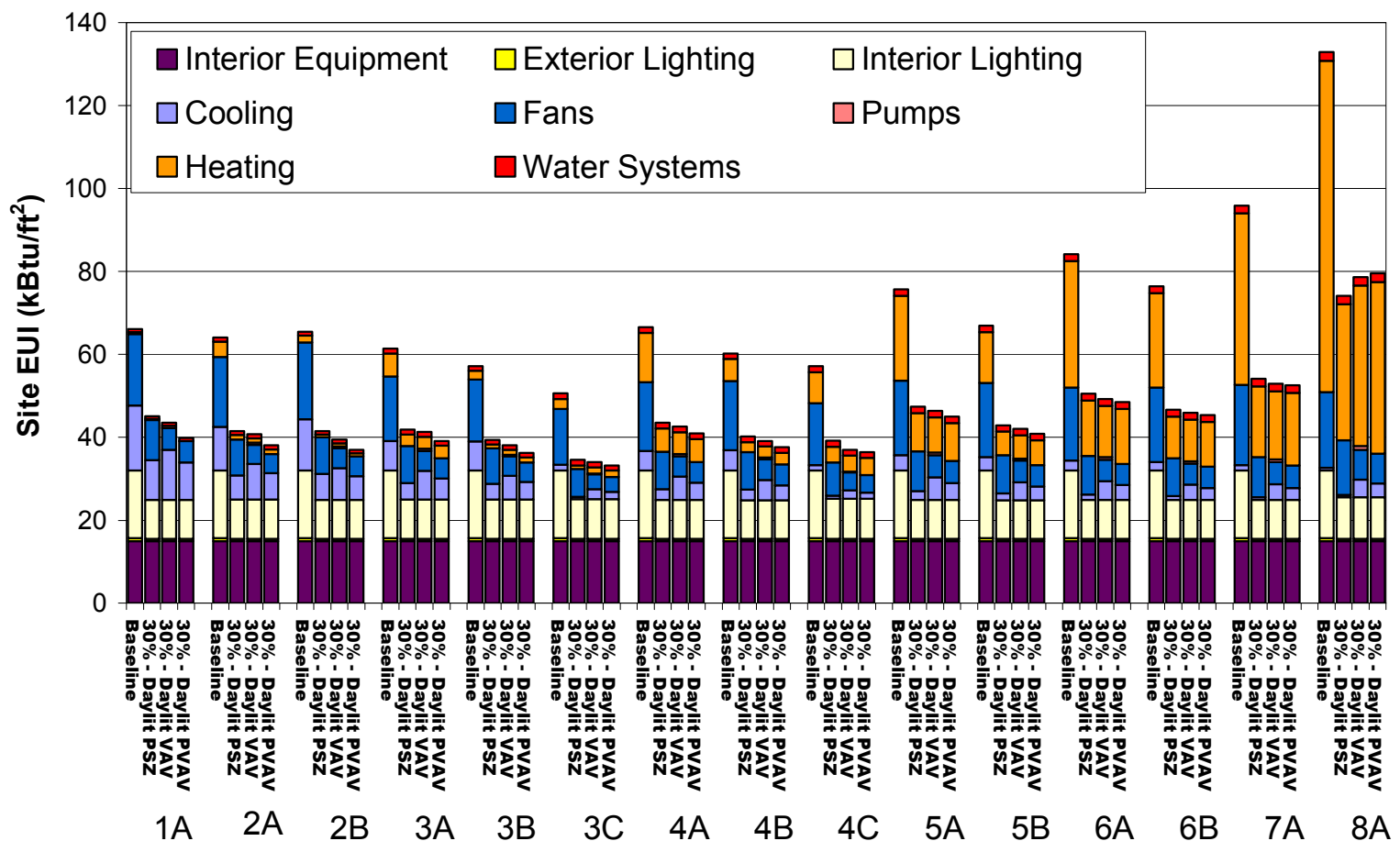

Figure 4-7 Elementary School End Uses: Daylit, ASHRAE 90.1-2004 Baseline

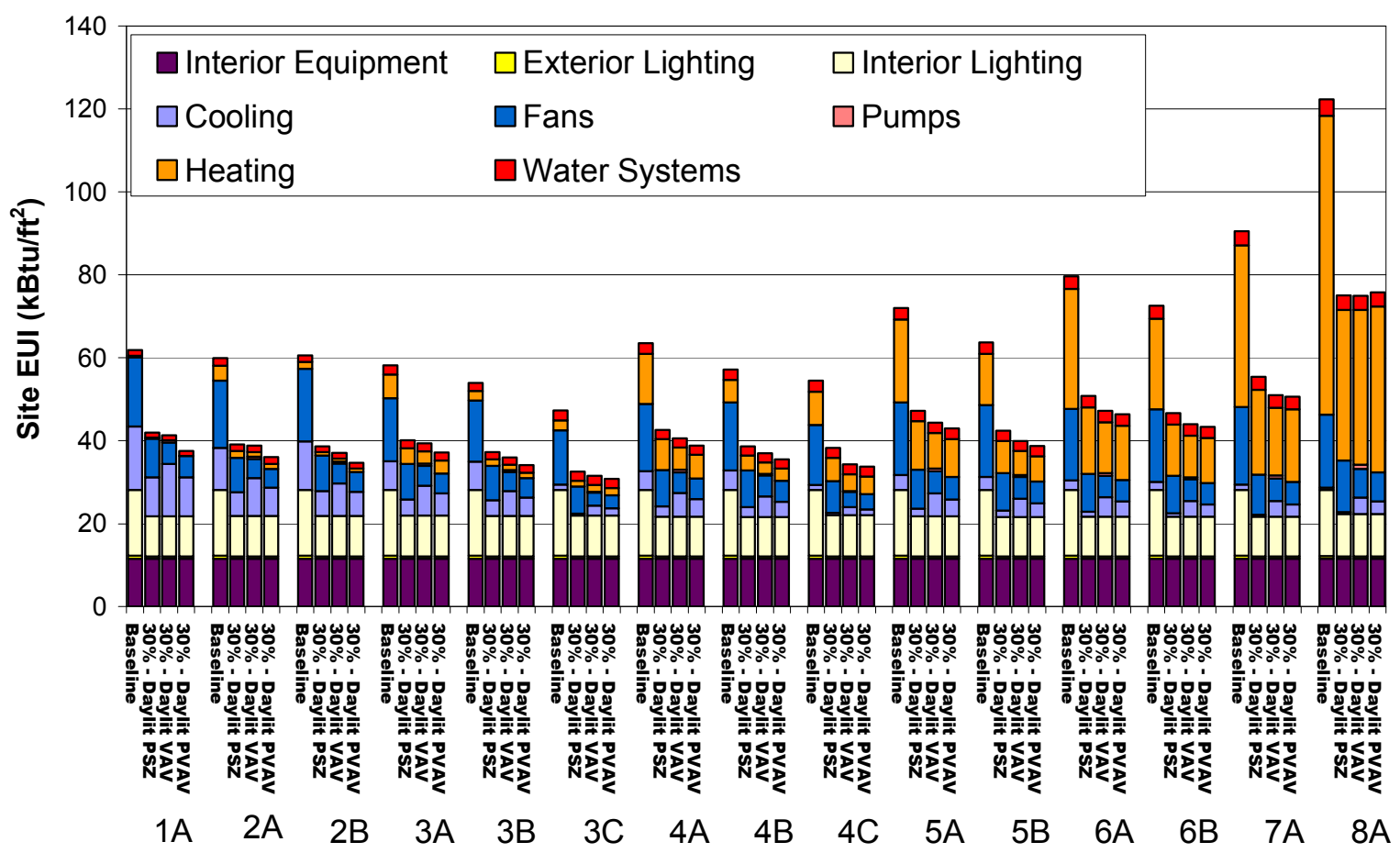

Figure 4-8 Middle School End Uses: Daylit, ASHRAE 90.1-2004 Baseline 


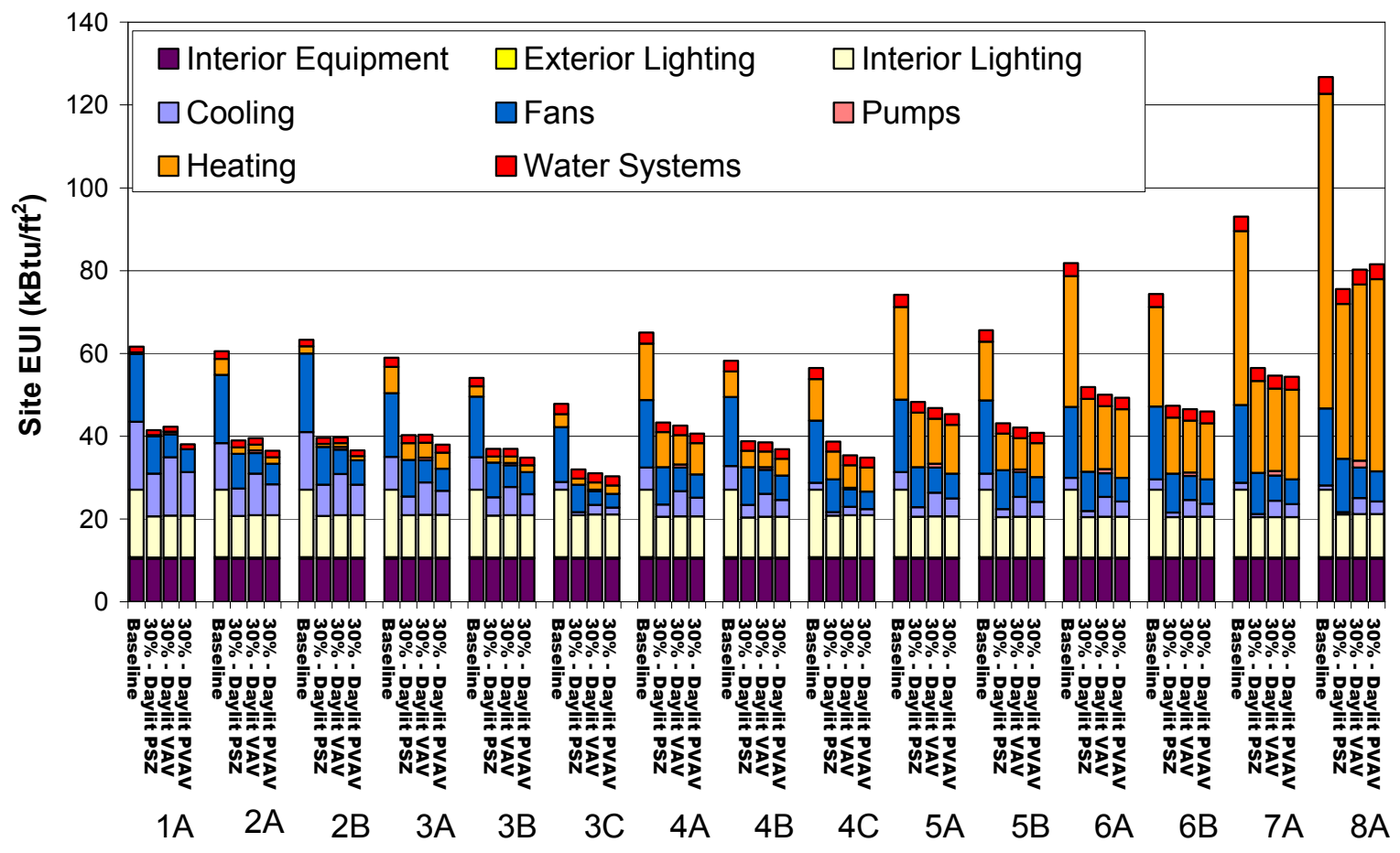

Figure 4-9 High School End Uses: Daylit, ASHRAE 90.1-2004 Baseline 


\section{Beyond $30 \%$ Energy Savings}

To inform the future development of more stringent guides, we performed a scoping study to understand which energy efficiency technologies would be needed to achieve $50 \%$ energy savings.

Recommendations included in the 50\% scoping analysis include the most stringent of each recommendation included in the 30\% guide, combined with plug load reductions caused by highefficiency distribution transformers and Energy Star equipment, daylighting in all zones, infiltration reduction, and water cooled chillers. We modeled these recommendations in a daylit middle school with a VAV to determine energy savings over ASHRAE 90.1-2004 in each of the 15 climate zones.

\section{$5.1 \quad 50 \%$ Energy Savings Model Inputs and Assumptions}

This section documents our modeling inputs and assumptions for the 50\% low-energy VAV middle school. The baseline used to determine 50\% energy savings was the same ASHRAE 90.1-2004 baselines used to determine $30 \%$ savings. We used the low-energy daylit VAV middle school as a starting point and modified or added the following additional efficiency characteristics:

- Added skylights and daylighting controls to all of the core and exterior zones that did not previously have daylighting. See Figure 5-1 for a model rendering of the fully daylit middle school.

- $\quad$ Reduced the peak infiltration to $0.3 \mathrm{ACH}$

- Reduced the LPD for all climate zones to $0.9 \mathrm{~W} / \mathrm{ft}^{2}\left(9.7 \mathrm{~W} / \mathrm{m}^{2}\right)$.

- Added $\mathrm{CO}_{2}$ demand controlled ventilation to all zones.

- Increased the total and sensible ERV effectiveness to $65 \%$.

- Increased the fan efficiency to $65 \%$ and the motor efficiency to $90 \%$, resulting in a fan/motor efficiency of $55 \%$.

- Reduced the friction rate of the duct work to 0.06 in. per $100 \mathrm{ft}$ of duct work (15 Pa per $30 \mathrm{~m})$, which reduced the total fan static pressure to 3.0 in. w.c. $(750 \mathrm{~Pa})$.

- Used a water cooled centrifugal chiller with a COP of 6.0.

- Added a condensing boiler with an increased boiler efficiency of $95 \%$.

- Added a condensing hot heater with an increased efficiency of $95 \%$.

- Applied the additional savings recommendations in the K-12 AEDG for reducing plug loads. We reduced the peak and nighttime plug loads through EnergyStar equipment and 98\% efficiency CSL-3 distribution transformers. CSL-3 distribution transformers not only have higher peak efficiency, the part load efficiencies are significantly better than standard distribution transformers. The equipment schedule was modified to represent these changes as shown in Table 3-28. This schedule represents a daytime plug reduction of $10 \%$ over the baseline schedule, and a nighttime plug reduction of 30\% during the school year and $40 \%$ during the summer over the baseline schedule. 


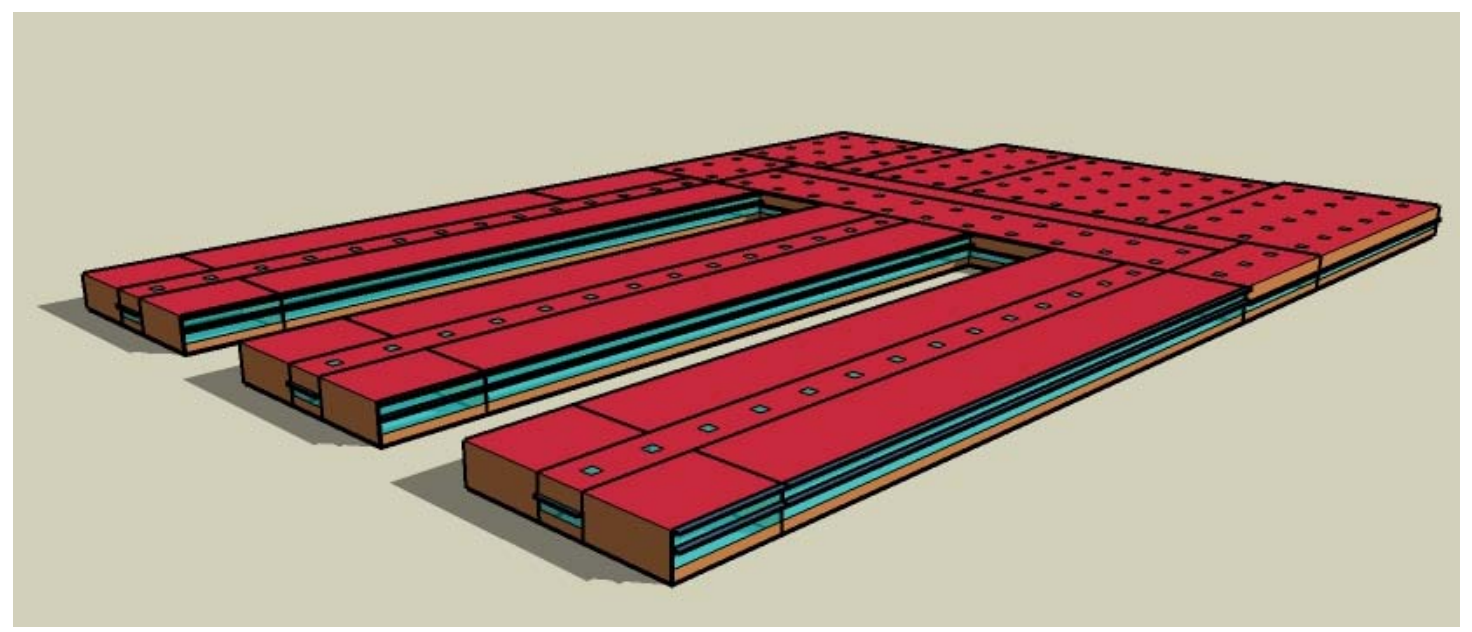

Figure 5-1 $50 \%$ Savings Fully Daylit Middle School Model Rendering 
Table 5-1 50\% Savings Building Equipment Schedule

\begin{tabular}{|c|c|c|c|c|c|}
\hline Hour & $\begin{array}{c}\text { Weekday } \\
\text { through } 6 / 30\end{array}$ & $\begin{array}{c}\text { Weekday } \\
\text { through } 9 / 01\end{array}$ & $\begin{array}{c}\text { Weekday } \\
\text { through 12/31 }\end{array}$ & $\begin{array}{c}\text { Weekends, } \\
\text { Holidays }\end{array}$ & $\begin{array}{c}\text { Weekends, } \\
\text { Holidays, } \\
\text { Summer }\end{array}$ \\
\hline 1 & 0.25 & 0.15 & 0.25 & 0.25 & 0.15 \\
\hline 2 & 0.25 & 0.15 & 0.25 & 0.25 & 0.15 \\
\hline 3 & 0.25 & 0.15 & 0.25 & 0.25 & 0.15 \\
\hline 4 & 0.25 & 0.15 & 0.25 & 0.25 & 0.15 \\
\hline 5 & 0.25 & 0.15 & 0.25 & 0.25 & 0.15 \\
\hline 6 & 0.25 & 0.15 & 0.25 & 0.25 & 0.15 \\
\hline 7 & 0.25 & 0.15 & 0.25 & 0.25 & 0.15 \\
\hline 8 & 0.25 & 0.15 & 0.25 & 0.25 & 0.15 \\
\hline 9 & 0.85 & 0.45 & 0.85 & 0.25 & 0.15 \\
\hline 10 & 0.85 & 0.45 & 0.85 & 0.25 & 0.15 \\
\hline 11 & 0.85 & 0.45 & 0.85 & 0.25 & 0.15 \\
\hline 12 & 0.85 & 0.45 & 0.85 & 0.25 & 0.15 \\
\hline 13 & 0.85 & 0.45 & 0.85 & 0.25 & 0.15 \\
\hline 14 & 0.85 & 0.45 & 0.85 & 0.25 & 0.15 \\
\hline 15 & 0.85 & 0.45 & 0.85 & 0.25 & 0.15 \\
\hline 16 & 0.85 & 0.45 & 0.85 & 0.25 & 0.15 \\
\hline 17 & 0.85 & 0.45 & 0.85 & 0.25 & 0.15 \\
\hline 18 & 0.25 & 0.15 & 0.25 & 0.25 & 0.15 \\
\hline 19 & 0.25 & 0.15 & 0.25 & 0.25 & 0.15 \\
\hline 20 & 0.25 & 0.15 & 0.25 & 0.25 & 0.15 \\
\hline 21 & 0.25 & 0.15 & 0.25 & 0.25 & 0.15 \\
\hline 22 & 0.25 & 0.15 & 0.25 & 0.25 & 0.15 \\
\hline 23 & 0.25 & 0.15 & 0.25 & 0.25 & 0.15 \\
\hline 24 & 0.25 & 0.15 & 0.25 & 0.25 & 0.15 \\
\hline
\end{tabular}

\section{$5.250 \%$ Energy Savings Results}

Based on this initial scoping study, $50 \%$ savings should be possible in all climates. The energy savings and end uses for the ASHRAE 90.1-2004 and 50\% low-energy middle school are shown in Figure 5-2. For the most temperate climates such as $3 \mathrm{C}$ and $4 \mathrm{C}$, energy savings are just above $50 \%$. Findings from this scoping study suggest that $50 \%$ savings are possible, but that nontraditional efficiency measures such as plug load reductions and infiltration reductions are required. Additional focus on "typical" plug load schedules in K-12 schools as well as the expected energy savings from EnergyStar equipment will be needed to accurately predict the plug load savings. Baseline infiltration inputs will also need to be further researched. For 50\% energy savings, additional work will be needed to truly optimize daylighting to provide as much savings as possible. The $50 \%$ recommendations may limit the types of systems that can be used. For example, only certain types of HVAC systems, such as water cooled chillers, high efficiency condensing boilers, or ground source heat pumps, may be available for a 50\% low-energy school.

Standard systems such as package single zone equipment or unit ventilators may not be able that meet the 
high efficiency needs for a 50\% savings school without additional lighting, plug load, or envelope measures.

The recommendations from this 50\% savings scoping study are summarized in Table 5-2 and Table 5-3.

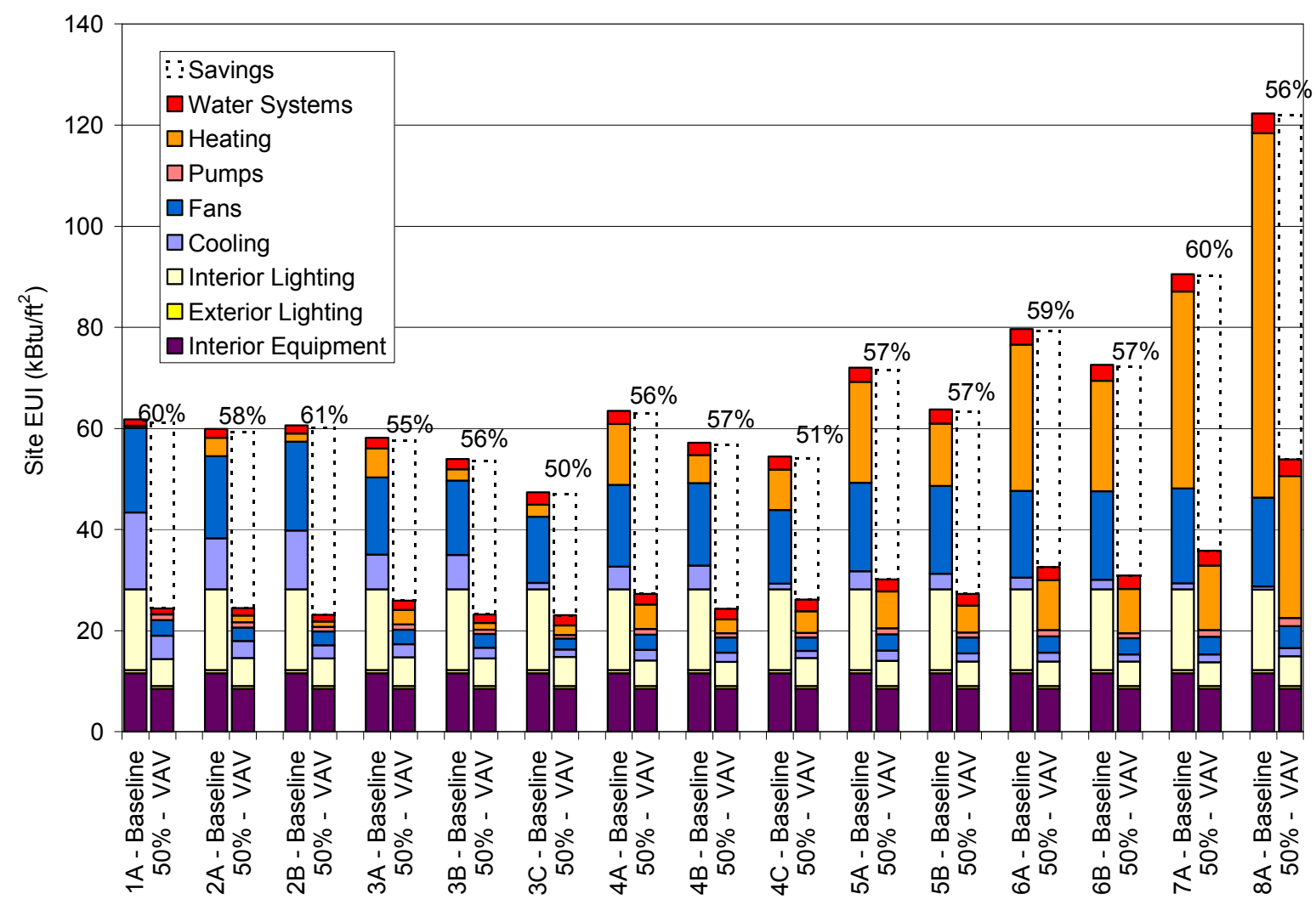

Figure 5-2 Middle School End Uses: $50 \%$ Savings 
Table 5-2 Recommendations for 50\% Savings over ASHRAE 90.1-2004: Climate Zones 1-4

\begin{tabular}{|c|c|c|c|c|c|}
\hline Item & Component & Climate Zone 1 Recommendations & Climate Zone 2 Recommendations & Climate Zone 3 Recommendations & Climate Zone 4 Recommendations \\
\hline \multirow{4}{*}{ Roofs } & Insulation Entirely Above Deck & R-25 ci & $\mathrm{R}-25 \mathrm{ci}$ & $\mathrm{R}-25 \mathrm{ci}$ & R-25 ci \\
\hline & Attic and Other & $R-30$ & $R-38$ & $R-38$ & $R-38$ \\
\hline & Metal Building & $R-19$ & $R-13.0+R-13.0$ & $R-13.0+R-13.0$ & $R-13.0+R-19.0$ \\
\hline & SRI & 0.78 & 0.78 & 0.78 & Comply with Standard $90.1^{*}$ \\
\hline \multirow{5}{*}{ Walls } & Mass $\left(\mathrm{HC}>7 \mathrm{Btu} / \mathrm{ft}^{2}\right)$ & $\mathrm{R}-5.7 \mathrm{ci}$ & R-7.6 ci & $\mathrm{R}-7.6 \mathrm{ci}$ & $\mathrm{R}-9.5 \mathrm{ci}$ \\
\hline & Steel Framed & $R-13$ & $\mathrm{R}-13$ & $\mathrm{R}-13+\mathrm{R}-3.8 \mathrm{ci}$ & $\mathrm{R}-13+\mathrm{R}-7.5 \mathrm{ci}$ \\
\hline & Wood Framed and Other & $\mathrm{R}-13$ & $\mathrm{R}-13$ & $\mathrm{R}-13$ & $\mathrm{R}-13$ \\
\hline & Metal Building & $R-16$ & $R-16$ & $R-16$ & $R-19$ \\
\hline & Below Grade Walls & Comply with Standard $90.1^{*}$ & Comply with Standard $90.1^{*}$ & Comply with Standard $90.1^{*}$ & Comply with Standard $90.1^{*}$ \\
\hline \multirow{2}{*}{ Slabs } & Unheated & Comply with Standard $90.1^{*}$ & Comply with Standard $90.1^{*}$ & Comply with Standard $90.1^{*}$ & Comply with Standard $90.1^{\star}$ \\
\hline & Heated & $R-7.5$ for 12 in. & R-7.5 for 12 in. & $R-10$ for 24 in. & $R-15$ for 24 in. \\
\hline \multirow{4}{*}{$\begin{array}{c}\text { Vertical } \\
\text { Fenestration }\end{array}$} & Total Fenestration to Gross Wall Area Ratio & $35 \% \operatorname{Max}$ & $35 \% \operatorname{Max}$ & $35 \% \operatorname{Max}$ & $35 \% \operatorname{Max}$ \\
\hline & Thermal transmittance- all types and orientations & $\mathrm{U}-0.56$ & $\mathrm{U}-0.45$ & $\mathrm{U}-0.45$ & $\mathrm{U}-0.42$ \\
\hline & $\begin{array}{l}\text { Solar heat gain coefficient (SHGC)- all types and } \\
\text { orientations }\end{array}$ & SHGC-0.25 & SHGC- 0.25 & SHGC- 0.25 & SHGC- 0.40 \\
\hline & Exterior Sun Control (S, E, W only) & Projection Factor $>0.5$ & Projection Factor > 0.5 & Projection Factor > 0.5 & Projection Factor $>0.5$ \\
\hline Interior Finishes & Interior room surface average reflectance & $\begin{array}{l}70 \%+\text { on ceilings and walls above } 7^{\prime}, 50 \%+ \\
\text { on walls below } 7\end{array}$ & $\begin{array}{l}\begin{array}{l}70 \%+\text { on ceilings and walls above } 7,50 \%+ \\
\text { on walls below } 7^{\prime}\end{array} \\
\end{array}$ & $\begin{array}{l}\begin{array}{l}70 \%+\text { on ceilings and walls above } 7 ', 50 \%+ \\
\text { on walls below } 77^{\prime}\end{array} \\
\end{array}$ & $\begin{array}{l}\begin{array}{l}70 \%+\text { on ceilings and walls above } 7 ', 50 \%+ \\
\text { on walls below } 7\end{array} \\
\end{array}$ \\
\hline Infiltration & Peak infiltration air changes $/ \mathrm{hr}$ & $0.3 \mathrm{ACH}$ & $0.3 \mathrm{ACH}$ & $0.3 \mathrm{ACH}$ & $0.3 \mathrm{ACH}$ \\
\hline \multirow{10}{*}{$\begin{array}{l}\text { Interior Lighting } \\
\text { Daylighted } \\
\text { Option }\end{array}$} & & $\begin{array}{l}\text { Toplit - } \\
\text { South Facing Roof Monitors: } 8 \%-11 \% \\
\text { North Facing Roof Monitors: } 12 \%-15 \% \\
\end{array}$ & $\begin{array}{l}\text { Toplit - } \\
\text { South Facing Roof Monitors: } 8 \%-11 \% \\
\text { North Facing Roof Monitors: } 12 \%-15 \% \\
\end{array}$ & $\begin{array}{l}\text { Toplit - } \\
\text { South Facing Roof Monitors: } 8 \%-11 \% \\
\text { North Facing Roof Monitors: } 12 \%-15 \% \\
\end{array}$ & \begin{tabular}{|l|} 
Toplit - \\
South Facing Roof Monitors: $8 \%-11 \%$ \\
North Facing Roof Monitors: $12 \%-15 \%$ \\
\end{tabular} \\
\hline & $\begin{array}{l}\text { Classroom Daylighting (Daylighting Fenestration to } \\
\text { Floor Area Ratio) }\end{array}$ & $\begin{array}{l}\text { Sidelit- } \\
\text { South Facing: } 8 \%-11 \% \\
\text { North Facing: } 15 \%-20 \% \\
\end{array}$ & $\begin{array}{l}\text { Sidelit- } \\
\text { South Facing: } 8 \%-11 \% \\
\text { North Facing: } 15 \%-20 \% \\
\end{array}$ & $\begin{array}{l}\text { Sidelit- } \\
\text { South Facing: } 8 \%-11 \% \\
\text { North Facing: } 15 \%-20 \% \\
\end{array}$ & $\begin{array}{l}\text { Sidelit- } \\
\text { South Facing: } 8 \%-11 \% \\
\text { North Facing: } 15 \%-20 \% \\
\end{array}$ \\
\hline & & $\begin{array}{l}\text { Combined Toplit and Sidelit- } \\
\text { South Facing Sidelit: 6\%-8\%, Toplit: } 2 \%-3 \% \\
\text { North Facing Sidelit: } 9 \%-13 \% \text {, Toplit: } 3 \%-5 \% \\
\end{array}$ & \begin{tabular}{|l|} 
Combined Toplit and Sidelit- \\
South Facing Sidelit: $6 \%-8 \%$, Toplit: $2 \%-3 \%$ \\
North Facing Sidelit: $9 \%-13 \%$, Toplit: $3 \%-5 \%$
\end{tabular} & \begin{tabular}{|l|} 
Combined Toplit and Sidelit- \\
South Facing Sidelit: 6\%-8\%, Toplit: 2\%-3\% \\
North Facing Sidelit: $9 \%-13 \%$, Toplit: 3\%-5\% \\
\end{tabular} & \begin{tabular}{|l|} 
Combined Toplit and Sidelit- \\
South Facing Sidelit: 6\%-8\%, Toplit: 2\%-3\% \\
North Facing Sidelit: $9 \%-13 \%$, Toplit: 3\%-5\% \\
\end{tabular} \\
\hline & $\begin{array}{l}\text { Gym Toplighting (Daylighting Fenestration to Floor Area } \\
\text { Ratio) }\end{array}$ & $\begin{array}{l}\text { South Facing Roof Monitors: } 5 \%-8 \% \\
\text { North Facing Roof Monitors 7\% to 10\% }\end{array}$ & $\begin{array}{l}\text { South Facing Roof Monitors: } 5 \%-8 \% \\
\text { North Facing Roof Monitors } 7 \% \text { to } 10 \%\end{array}$ & $\begin{array}{l}\text { South Facing Roof Monitors: } 5 \%-8 \% \text { North } \\
\text { Facing Roof Monitors } 7 \% \text { to } 10 \% \text { C Zones } \\
\text { Only: Skylights: } 2 \%-4 \%\end{array}$ & $\begin{array}{l}\text { South Facing Roof Monitors: } 5 \% \text { - } 8 \% \text { North } \\
\text { Facing Roof Monitors } 7 \% \text { to } 10 \% \\
\text { Zones Only: Skylights: } 3 \%-4 \%\end{array}$ \\
\hline & $\begin{array}{l}\text { Toplighting in Corridors, Offices, Media Center, } \\
\text { Bathrooms, Cafeteria, and Kitchen (Daylighting } \\
\text { Fenestration to Floor Area Ratio) }\end{array}$ & Skylights: $3 \%-4 \%$ & Skylights: $3 \%-4 \%$ & Skylights: $3 \%-4 \%$ & Skylights: $3 \%-4 \%$ \\
\hline & Lighting Power Density (LPD) & $0.9 \mathrm{~W} / \mathrm{ft}^{2}$ maximum & $0.9 \mathrm{~W} / \mathrm{ft}^{2}$ maximum & $0.9 \mathrm{~W} / \mathrm{ft}^{2}$ maximum & $0.9 \mathrm{~W} / \mathrm{ft}^{2}$ maximum \\
\hline & $\begin{array}{l}\text { Light Source system efficacy (linear fluorescent and } \\
\text { HID) }\end{array}$ & 85 mean lumens/watt minimum & 85 mean lumens/watt minimum & 85 mean lumens/watt minimum & 85 mean lumens/watt minimum \\
\hline & Light source system efficacy (all other sources) & 50 mean lumens/watt minimum & 50 mean lumens/watt minimum & 50 mean lumens/watt minimum & 50 mean lumens/watt minimum \\
\hline & Lighting Controls - general & Manual on, Auto-off all zones & Manual on, Auto-off all zones & Manual on, Auto-off all zones & Manual on, Auto-off all zones \\
\hline & Dimming Controls Daylight Harvesting & $\begin{array}{l}\text { Dim all fixtures in daylit spaces, and other } \\
\text { fixtures within } 15 \mathrm{ft} \mathrm{of} \mathrm{sidelighting} \mathrm{edge,} \mathrm{and} \\
\text { within } 10 \mathrm{ft} \text { of toplighting edge }\end{array}$ & $\begin{array}{l}\text { Dim all fixtures in daylit spaces, and other } \\
\text { fixtures within } 15 \mathrm{ft} \text { of sidelighting edge, and } \\
\text { within } 10 \mathrm{ft} \text { of toplighting edge }\end{array}$ & $\begin{array}{l}\text { Dim all fixtures in daylit spaces, and other } \\
\text { fixtures within } 15 \mathrm{ft} \text { of sidelighting edge, and } \\
\text { within } 10 \mathrm{ft} \text { of toplighting edge }\end{array}$ & $\begin{array}{l}\text { Dim all fixtures in daylit spaces, and other } \\
\text { fixtures within } 15 \mathrm{ft} \text { of sidelighting edge, and } \\
\text { within } 10 \mathrm{ft} \text { of toplighting edge }\end{array}$ \\
\hline \multirow{5}{*}{$\begin{array}{c}\text { VAV and Chiller } \\
\text { System }\end{array}$} & Water-Cooled Chiller Efficiency & $6.0 \mathrm{COP}$ & $6.0 \mathrm{COP}$ & $6.0 \mathrm{COP}$ & $6.0 \mathrm{COP}$ \\
\hline & Gas Boiler & $80 \% \mathrm{E}_{\mathrm{c}}$ & $80 \% \mathrm{E}_{\mathrm{c}}$ & $95 \% \mathrm{E}_{\mathrm{c}}$ & $95 \% \mathrm{E}_{\mathrm{c}}$ \\
\hline & Economizer & Comply with Standard $90.1^{*}$ & Comply with Standard $90.1^{*}$ & $>54 \mathrm{kBtu} / \mathrm{h}$ & $>54 \mathrm{kBtu} / \mathrm{h}$ \\
\hline & Ventilation & $\begin{array}{l}\text { 65\% effective total energy recovery AND } \\
\text { demand control }\end{array}$ & $\begin{array}{l}\begin{array}{l}65 \% \text { effective total energy recovery AND } \\
\text { demand control }\end{array} \\
\end{array}$ & $\begin{array}{l}\text { 65\% effective total energy recovery AND } \\
\text { demand control }\end{array}$ & $\begin{array}{l}\text { 65\% effective total energy recovery AND } \\
\text { demand control }\end{array}$ \\
\hline & Fans & $65 \%$ efficient fan, $90 \%$ efficient EC motor & $65 \%$ efficient fan, $90 \%$ efficient EC motor & $65 \%$ efficient fan, $90 \%$ efficient EC motor & $65 \%$ efficient fan, $90 \%$ efficient EC motor \\
\hline \multirow{5}{*}{$\begin{array}{l}\text { Ducts and } \\
\text { Dampers }\end{array}$} & Outdoor air damper & motorized & Imotorized & Imotorized & Imotorized \\
\hline & Friction rate & 0.06 in w.c./100ft & 0.06 in w.c./100ft & 0.06 in w.c./100ft & 0.06 in w.c./100ft \\
\hline & Sealing & Seal Class B & Sea & Seal Class B & Seal Class B \\
\hline & Location & interior only & interior only & interior only & interior only \\
\hline & $\sqrt{\text { Insulation level }}$ & $\mathrm{R}-6$ & $\mathrm{R}-6$ & $\mathrm{R}-6$ & $R-6$ \\
\hline \multirow{4}{*}{$\begin{array}{c}\begin{array}{c}\text { Service Water } \\
\text { Heating }\end{array} \\
\end{array}$} & Gas storage (>75 kBtu/h) & $95 \% \mathrm{Et}$ & $95 \% \mathrm{Et}$ & $95 \% \mathrm{Et}$ & $95 \% \mathrm{Et}$ \\
\hline & Gas instantaneous & $0.81 \mathrm{EF}$ or $81 \% \mathrm{Et}$ & $0.81 \mathrm{EF}$ or $81 \% \mathrm{Et}$ & $0.81 \mathrm{EF}$ or $81 \% \mathrm{Et}$ & $0.81 \mathrm{EF}$ or $81 \% \mathrm{Et}$ \\
\hline & Electric (storage or instantaneous) & EF>0.99-0.0012 $\times$ Volume & EF $>0.99-0.0012 \times$ Volume & EF $>0.99-0.0012 \times$ Volume & EF $>0.99-0.0012 \times$ Volume \\
\hline & Pipe insulation (d $<1.5 \mathrm{in} . / \mathrm{d}>=1.5 \mathrm{in})$. & $11 \mathrm{in} . / 1.5 \mathrm{in}$. & 1 in./ 1.5 in. & 11 in. $/ 1.5$ in. & $11 \mathrm{in} . / 1.5 \mathrm{in.}$ \\
\hline \multirow[t]{4}{*}{ Plug Loads } & Office Equipment & $\begin{array}{l}\text { EnergyStar equipment, nighttime standby } \\
\text { mode }\end{array}$ & $\begin{array}{l}\text { EnergyStar equipment, nighttime standby } \\
\text { mode }\end{array}$ & $\begin{array}{l}\text { EnergyStar equipment, nighttime standby } \\
\text { mode }\end{array}$ & $\begin{array}{l}\text { EnergyStar equipment, nighttime standby } \\
\text { mode }\end{array}$ \\
\hline & Computers & LCD monitors, EnergyStar equipment & LCD monitors, EnergyStar equipment & LCD monitors, EnergyStar equipment & LCD monitors, EnergyStar equipment \\
\hline & Transformers & $98 \%$ efficient CL-3 rated transformers & 98\% efficient CL-3 rated transformers & $98 \%$ efficient $\mathrm{CL}-3$ rated transformers & 98\% efficient CL-3 rated transformers \\
\hline & Misc. Equipment (Kitchen, Classrooms) & EnergyStar equipment & EnergyStar equipment & EnergyStar equipment & EnergyStar equipment \\
\hline
\end{tabular}


Table 5-3 Recommendations for 50\% Savings over ASHRAE 90.1-2004: Climate Zones 5-8

\begin{tabular}{|c|c|c|c|c|c|}
\hline Item & Component & Climate Zone 5 Recommendations & Climate Zone 6 Recommendations & Climate Zone 7 Recommendations & Climate Zone 8 Recommendations \\
\hline \multirow{4}{*}{ Roofs } & Insulation Entirely Above Deck & $\mathrm{R}-25 \mathrm{ci}$ & R-25 ci & $\mathrm{R}-25 \mathrm{ci}$ & $\overline{R-25 \mathrm{ci}}$ \\
\hline & Attic and Other & $R-38$ & $R-38$ & $R-60$ & $R-60$ \\
\hline & Metal Building & $R-13.0+R-19.0$ & $R-13.0+R-19.0$ & $R-13.0+R-19.0$ & $R-19.0+R-19.0$ \\
\hline & SRI & Comply with Standard $90.1^{*}$ & Comply with Standard 90.1* & Comply with Standard $90.1^{*}$ & Comply with Standard $90.1^{*}$ \\
\hline \multirow{5}{*}{ Walls } & Mass $\left(\mathrm{HC}>7 \mathrm{Btu} / \mathrm{ft}^{2}\right)$ & $\mathrm{R}-11.4 \mathrm{ci}$ & $\mathrm{R}-13.3 \mathrm{ci}$ & R-15.2 ci & R-15.2 ci \\
\hline & Steel Framed & $R-13+R-7.5 \mathrm{ci}$ & $R-13+R-7.5 \mathrm{ci}$ & $\mathrm{R}-13+\mathrm{R}-7.5 \mathrm{ci}$ & $R-13+R-21.6 c i$ \\
\hline & Wood Framed and Other & $R-13+R-3.8 \mathrm{ci}$ & $R-13+R-7.5 \mathrm{ci}$ & $R-13+R-7.5 \mathrm{ci}$ & $R-13+R-10 \mathrm{ci}$ \\
\hline & Metal Building & $R-13+R-13$ & $R-13+R-13$ & $R-13+R-13$ & $R-13+R-16$ \\
\hline & Below Grade Walls & $\mathrm{R}-7.5 \mathrm{ci}$ & $\mathrm{R}-7.5 \mathrm{ci}$ & $\mathrm{R}-7.5 \mathrm{ci}$ & $\mathrm{R}-15 \mathrm{ci}$ \\
\hline \multirow{2}{*}{ Slabs } & Unheated & Comply with Standard 90.1* & R-10 for 24 in. & R-15 for 24 in. & R-20 for 24 in. \\
\hline & Heated & $R-15$ for 24 in. & $\mathrm{R}-15$ for 24 in. & R-15 for full slab & R-15 for full slab \\
\hline \multirow{4}{*}{$\begin{array}{l}\text { Vertical } \\
\text { Fenestration }\end{array}$} & Total Fenestration to Gross Wall Area Ratio & $35 \%$ Max & $35 \% \operatorname{Max}$ & $35 \% \operatorname{Max}$ & $35 \% \operatorname{Max}$ \\
\hline & Thermal transmittance- all types and ori & $\mathrm{U}-0.42$ & $\mathrm{U}-0.42$ & $\mathrm{U}-0.33$ & $\mathrm{U}-0.33$ \\
\hline & $\begin{array}{l}\text { Solar heat gain coefficient (SHGC)- all types and } \\
\text { orientations }\end{array}$ & SHGC-0.40 & SHGC- 0.40 & SHGC- 0.45 & SHGC- 0.45 \\
\hline & Exterior Sun Control (S, E, W only) & Projection Factor $>0.5$ & Projection Factor $>0.5$ & Projection Factor $>0.5$ & Projection Factor > 0.5 \\
\hline Interior Finishes & Interior room surface average reflectance & $\begin{array}{l}70 \%+\text { on ceilings and walls above } 7,50 \%+ \\
\text { on walls below } 77^{\prime}\end{array}$ & $\begin{array}{l}70 \%+\text { on ceilings and walls above } 77^{\prime}, 50 \%+ \\
\text { on walls below } 7^{\prime}\end{array}$ & $\begin{array}{l}70 \%+\text { on ceilings and walls above } 7,50 \%+ \\
\text { on walls below } 77^{\prime}\end{array}$ & $\begin{array}{l}70 \%+\text { on ceilings and walls above } 7,50 \%+ \\
\text { on walls below } 77^{\prime}\end{array}$ \\
\hline Infiltration & Thole Building Infiltration Air Changes/hr & $10.3 \mathrm{ACH}$ & $0.3 \mathrm{ACH}$ & $0.3 \mathrm{ACH}$ & $0.3 \mathrm{ACH}$ \\
\hline \multirow{10}{*}{$\begin{array}{l}\text { Interior Lighting } \\
\text { Daylighted } \\
\text { Option }\end{array}$} & \multirow{3}{*}{$\begin{array}{l}\text { Classroom Daylighting (Daylighting Fenestration to } \\
\text { Floor Area Ratio) }\end{array}$} & $\begin{array}{l}\text { Toplit - } \\
\text { South Facing Roof Monitors: } 8 \%-11 \% \\
\text { North Facing Roof Monitors: } 12 \%-15 \% \\
\end{array}$ & \begin{tabular}{|l|} 
Toplit - \\
South Facing Roof Monitors: $8 \%-11 \%$ \\
North Facing Roof Monitors: $12 \%-15 \%$ \\
\end{tabular} & \begin{tabular}{|l|} 
Toplit - \\
South Facing Roof Monitors: $8 \%-11 \%$ \\
North Facing Roof Monitors: $12 \%-15 \%$ \\
\end{tabular} & \begin{tabular}{|l|} 
Toplit - \\
South Facing Roof Monitors: $8 \%-11 \%$ \\
North Facing Roof Monitors: $12 \%-15 \%$ \\
\end{tabular} \\
\hline & & $\begin{array}{l}\text { Sidelit- } \\
\text { South Facing: } 8 \%-11 \% \\
\text { North Facing: } 15 \%-20 \% \\
\end{array}$ & $\begin{array}{l}\text { Sidelit- } \\
\text { South Facing: } 8 \%-11 \% \\
\text { North Facing: } 15 \%-20 \% \\
\end{array}$ & $\begin{array}{l}\text { Sidelit- } \\
\text { South Facing: } 8 \%-11 \% \\
\text { North Facing: } 15 \%-20 \% \\
\end{array}$ & $\begin{array}{l}\text { Sidelit- } \\
\text { South Facing: } 8 \%-11 \% \\
\text { North Facing: } 15 \%-20 \% \\
\end{array}$ \\
\hline & & \begin{tabular}{|l|} 
Combined Toplit and Sidelit- \\
South Facing Sidelit: 6\%-8\%, Toplit: $2 \%-3 \%$ \\
North Facing Sidelit: $9 \%-13 \%$, Toplit: $3 \%-5 \%$ \\
\end{tabular} & $\begin{array}{l}\text { Combined Toplit and Sidelit- } \\
\text { South Facing Sidelit: 6\%-8\%, Toplit: 2\%-3\% } \\
\text { North Facing Sidelit: } 9 \%-13 \% \text {, Toplit: 3\%-5\% } \\
\end{array}$ & \begin{tabular}{|l|} 
Combined Toplit and Sidelit- \\
South Facing Sidelit: 6\%-8\%, Toplit: $2 \%-3 \%$ \\
North Facing Sidelit: $9 \%-13 \%$, Toplit: 3\%-5\% \\
\end{tabular} & \begin{tabular}{|l|} 
Combined Toplit and Sidelit- \\
South Facing Sidelit: $6 \%-8 \%$, Toplit: $2 \%-3 \%$ \\
North Facing Sidelit: $9 \%-13 \%$, Toplit: $3 \%-5 \%$ \\
\end{tabular} \\
\hline & $\begin{array}{l}\text { Gym Toplighting (Daylighting Fenestration to Floor Area } \\
\text { Ratio) }\end{array}$ & $\begin{array}{l}\text { South Facing Roof Monitors: } 5 \%-8 \% \\
\text { North Facing Roof Monitors } 7 \% \text { to } 10 \%\end{array}$ & $\begin{array}{l}\text { South Facing Roof Monitors: } 5 \%-8 \% \\
\text { North Facing Roof Monitors } 7 \% \text { to } 10 \%\end{array}$ & $\begin{array}{l}\text { South Facing Roof Monitors: } 5 \% \text { - } 8 \% \text { North } \\
\text { Facing Roof Monitors } 7 \% \text { to } 10 \%\end{array}$ & $\begin{array}{l}\text { South Facing Roof Monitors: } 5 \%-8 \% \text { North } \\
\text { Facing Roof Monitors } 7 \% \text { to } 10 \%\end{array}$ \\
\hline & $\begin{array}{l}\text { Toplighting in Corridors, Offices, Media Center, } \\
\text { Bathrooms, Cafeteria, and Kitchen (Daylighting } \\
\text { Fenestration to Floor Area Ratio) } \\
\end{array}$ & Skylights: $3 \%-4 \%$ & Skylights: $3 \%-4 \%$ & Skylights: $3 \%-4 \%$ & Skylights: $3 \%-4 \%$ \\
\hline & Lighting Power Density (LPD) & $0.9 \mathrm{~W} / \mathrm{ft}^{2}$ maximum & $0.9 \mathrm{~W} / \mathrm{ft}^{2}$ maximum & $0.9 \mathrm{~W} / \mathrm{ft}^{2}$ maximum & $0.9 \mathrm{~W} / \mathrm{ft}^{2}$ maximum \\
\hline & $\begin{array}{l}\text { Light Source system efficacy (linear fluorescent and } \\
\text { HID) }\end{array}$ & 85 mean lumens/ watt minimum & 85 mean lumens/ watt minimum & 85 mean lumens/ watt minimum & 85 mean lumens/ watt minimum \\
\hline & Light source system efficacy (all other sources) & 50 mean lumens/watt minimum & 50 mean lumens/watt minimum & 50 mean lumens/watt minimum & 50 mean lumens/watt minimum \\
\hline & Lighting Controls - general & Manual on, Auto-off all zones & Manual on, Auto-off all zones & Manual on, Auto-off all zones & Manual on, Auto-off all zones \\
\hline & Dimming Controls Daylight Harvesting & $\begin{array}{l}\text { Dim all fixtures in daylit spaces, and other } \\
\text { fixtures within } 15 \mathrm{ft} \text { of sidelighting edge, and } \\
\text { within } 10 \mathrm{ft} \text { of toplighting edge }\end{array}$ & $\begin{array}{l}\text { Dim all fixtures in daylit spaces, and other } \\
\text { fixtures within } 15 \mathrm{ft} \text { of sidelighting edge, and } \\
\text { within } 10 \mathrm{ft} \text { of toplighting edge }\end{array}$ & $\begin{array}{l}\text { Dim all fixtures in daylit spaces, and other } \\
\text { fixtures within } 15 \mathrm{ft} \text { of sidelighting edge, and } \\
\text { within } 10 \mathrm{ft} \text { of toplighting edge }\end{array}$ & $\begin{array}{l}\text { Dim all fixtures in daylit spaces, and other } \\
\text { fixtures within } 15 \mathrm{ft} \text { of sidelighting edge, and } \\
\text { within } 10 \mathrm{ft} \text { of toplighting edge }\end{array}$ \\
\hline \multirow{5}{*}{$\begin{array}{c}\begin{array}{l}\text { VAV and Chiller } \\
\text { System }\end{array} \\
\text { Sy }\end{array}$} & Water-Cooled Chiller Efficiency & $6.0 \mathrm{COP}$ & $6.0 \mathrm{COP}$ & $6.0 \mathrm{COP}$ & $6.0 \mathrm{COP}$ \\
\hline & Gas Boiler & $95 \% \mathrm{E}_{\mathrm{c}}$ & $95 \% \mathrm{E}_{\mathrm{c}}$ & $95 \% \mathrm{E}_{\mathrm{c}}$ & $95 \% \mathrm{E}_{\mathrm{c}}$ \\
\hline & Economizer & $>54 \mathrm{kBtu} / \mathrm{h}$ & $>54 \mathrm{kBtu} / \mathrm{h}$ & $>54 \mathrm{kBtu} / \mathrm{h}$ & $>54 \mathrm{kBtu} / \mathrm{h}$ \\
\hline & Ventilation & $\begin{array}{l}\text { 65\% effective total energy recovery AND } \\
\text { demand control }\end{array}$ & $\begin{array}{l}\text { 65\% effective total energy recovery AND } \\
\text { demand control }\end{array}$ & $\begin{array}{l}65 \% \text { effective total energy recovery AND } \\
\text { demand control }\end{array}$ & $\begin{array}{l}\text { 65\% effective total energy recovery AND } \\
\text { demand control }\end{array}$ \\
\hline & Fans & $65 \%$ efficient fan, $90 \%$ efficient EC motor & $65 \%$ efficient fan, $90 \%$ efficient EC motor & $65 \%$ efficient fan, $90 \%$ efficient EC motor & $65 \%$ efficient fan, $90 \%$ efficient EC motor \\
\hline \multirow{5}{*}{$\begin{array}{l}\text { Ducts and } \\
\text { Dampers }\end{array}$} & Outdoor air damper & Imotorized & Imotorized & Imotorized & motorized \\
\hline & \begin{tabular}{|l|l|} 
Friction rate \\
\end{tabular} & 0.06 in w.c./100ft & 0.06 in w.c./100ft & 0.06 in w.c./100ft & 0.06 in w.c./100ft \\
\hline & Sealing & Seal Class B & Seal Class B & Seal Class B & Seal Class B \\
\hline & Locati & interior only & interior only & interior only & interior only \\
\hline & Insulation & $\mathrm{R}-6$ & $\mathrm{R}-6$ & $\mathrm{R}-6$ & $\mathrm{R}-8$ \\
\hline \multirow{4}{*}{$\begin{array}{l}\text { Service Water } \\
\text { Heating }\end{array}$} & Gas storage (>75 kBtu/h) & $95 \% \mathrm{Et}$ & $95 \% \mathrm{Et}$ & $95 \% \mathrm{Et}$ & $95 \% \mathrm{Et}$ \\
\hline & Gas instantaneous & $0.81 \mathrm{EF}$ or $81 \% \mathrm{Et}$ & $0.81 \mathrm{EF}$ or $81 \% \mathrm{Et}$ & $0.81 \mathrm{EF}$ or $81 \% \mathrm{Et}$ & $0.81 \mathrm{EF}$ or $81 \% \mathrm{Et}$ \\
\hline & Electric & EF>0.99-0.0012 $\times$ Volume & $E F>0.99-0.0012 \times$ Volume & EF>0.99-0.0012 $\times$ Volume & EF $>0.99-0.0012 \times$ Volume \\
\hline & Pipe insulation $(\mathrm{d}<1.5$ & 1 in. $/ 1.5 \mathrm{in}$. & 1 in./ 1.5 in. & & 1 in. $/ 1.5$ in. \\
\hline \multirow[t]{4}{*}{ Plug Loads } & Office Equipment & $\begin{array}{l}\text { EnergyStar equipment, nighttime standby } \\
\text { mode }\end{array}$ & $\begin{array}{l}\text { EnergyStar equipment, nighttime standby } \\
\text { mode }\end{array}$ & $\begin{array}{l}\text { EnergyStar equipment, nighttime standby } \\
\text { mode }\end{array}$ & $\begin{array}{l}\begin{array}{l}\text { EnergyStar equipment, nighttime standby } \\
\text { mode }\end{array} \\
\text { a }\end{array}$ \\
\hline & Computers & LCD monitors, EnergyStar equipment & LCD monitors, EnergyStar equipment & LCD monitors, EnergyStar equipment & LCD monitors, EnergyStar equipment \\
\hline & Transformers & $98 \%$ efficient CL-3 rated transformers & 98\% efficient CL-3 rated transformers & 98\% efficient CL-3 rated transformers & $98 \%$ efficient $\mathrm{CL}-3$ rated transformers \\
\hline & Misc. Equipment (Kitchen, Classrooms) & EnergyStar equipment & EnergyStar equipment & EnergyStar equipment & EnergyStar equipment \\
\hline
\end{tabular}

102 


\section{References}

AEDG-SO (2004). Advanced Energy Design Guide for Small Office Buildings: Achieving 30\% Energy Savings Over ANSI/ASHRAE/IESNA Standard 90.1-1999, American Society of Heating, Refrigerating and Air-Conditioning Engineers, Atlanta, Georgia, 2004.

AEDG-SR (2006). Advanced Energy Design Guide for Small Retail Buildings: Achieving 30\% Energy Savings Over ANSI/ASHRAE/IESNA Standard 90.1-1999, American Society of Heating, Refrigerating and Air-Conditioning Engineers, Atlanta, Georgia, 2006.

ASHRAE (1989). ANSI/ASHRAE/IESNA Standard 90.1-1989 Energy Efficient Design of New Buildings Except Low-Rise Residential Buildings.. American Society of Heating, Refrigerating and AirConditioning Engineers, Inc. Atlanta, Georgia, 1989.

ASHRAE (1999). ANSI/ASHRAE/IESNA Standard 90.1-1999 Energy Standard for Buildings except Low-Rise Residential Buildings. American Society of Heating, Refrigerating and Air-Conditioning Engineers, Inc. Atlanta, Georgia, 1999.

ASHRAE (2001). ASHRAE Standard 62-2001 Ventilation for Acceptable Indoor Air Quality. American Society of Heating, Refrigerating and Air-Conditioning Engineers, Inc. Atlanta, Georgia, 2001.

ASHRAE (2004a). ANSI/ASHRAE/IESNA Standard 90.1-2004 Energy Standard for Buildings except Low-Rise Residential Buildings. American Society of Heating, Refrigerating and Air-Conditioning Engineers, Inc. Atlanta, Georgia, 2004.

ASHRAE (2004b). ANSI/ASHRAE Standard 62.1-2004 Ventilation for Acceptable Indoor Air Quality. American Society of Heating, Refrigerating and Air-Conditioning Engineers, Inc. Atlanta, Georgia, 2004.

ASHRAE (2005). ASHRAE Handbook: Fundamentals, American Society of Heating, Refrigerating and Air-Conditioning Engineers, Inc., Atlanta, Georgia, 2005.

ASHRAE (2007). ASHRAE Handbook: HVAC Applications, American Society of Heating, Refrigerating and Air-Conditioning Engineers, Inc., Atlanta, Georgia, 2007.

ASU (2006). American School and University $32^{\text {nd }}$ Annual Official Education Construction Report. May, 2006. http://asumag.com/ar/605asu21.pdf.

DOE (2007). EnergyPlus Energy Simulation Software. www.eere.energy.gov/buildings/energyplus/. Washington, D.C. U.S. Department of Energy.

EIA (2005). 2003 Commercial Buildings Energy Consumption Survey. Washington, DC: EIA. Available from www.eia.doe.gov/emeu/cbecs/cbecs2003/introduction.html.

Griffith, B.; Long, N.; Torcellini, P.; Judkoff, R.; Crawley, D.; Ryan, J. (2007). Methodology for Modeling Building Energy Performance across the Commercial Sector. September 2007. In Draft. NREL Report No. TP-550-41956. Golden, CO: NREL.

Jarnagin, R.E., et. al. (2006). Technical Support Document: Development of the Advanced Energy Design Guide for Small Office Buildings, November, 2006. Pacific Northwest National Laboratory, Report No. PNNL-16250. Richland, Washington.

Judkoff, R.; Neymark, J. (1995). International Energy Agency Building Energy Simulation Test (BESTEST) and Diagnostic Method. NREL Report No. TP-472-6231. Golden, CO: NREL.

Liu, B., et. al. (2006). Technical Support Document: Development of the Advanced Energy Design Guide for Small Retail Buildings, September, 2006. Pacific Northwest National Laboratory, Report No. PNNL-16031. Richland, Washington. 
North Carolina (2007). North Carolina State Suggested K-12 School Space Profiles, www.schoolclearinghouse.org/. Last Accessed May 2007.

SPM (2007). School Planning and Management 2007 Construction Report. www.peterli.com/global/pdfs/SPMConstruction2007.pdf Last Accessed May 2007.

Torcellini, P.; Pless, S.; Deru, M.; Griffith, B.; Long, N.; Judkoff R. (2006). Lessons Learned from Case Studies of Six High-Performance Buildings, National Renewable Energy Laboratory Report No. TP-55037542. www.nrel.gov/docs/fy06osti/37542.pdf.

USGBC (2006). New Construction \& Major Renovation, Version 2.2. Leadership in Energy and Environmental Design, U.S. Green Buildings Council, Washington, DC. 


\title{
Appendix A. Project Committee Meeting Agendas
}

\section{A.1 Meeting \#1 Agenda}

\author{
Agenda Meeting \#1 \\ Advanced Energy Design Guide-K12 \\ Project Committee Meeting \\ ASHRAE Headquarters \\ 1791 Tullie Circle \\ Atlanta, GA 30329 \\ 404-636-8400
}

Friday, December 8, 2006, 8:30 am - 5:30 pm

Saturday, December 9, 2006, 8:00 am - 2:00 pm

1. Welcome - Torcellini

Friday, 8:30 am

2. Introductions: Give Name/Affiliation

and experience in working on design of schools

3. Review of Agenda - Torcellini

9:00

4. AEDG Overview - Colliver

a) Organization of AEDG Series

b) Committee make-up structure/partnering organization

c) Scoping Document formation

d) Reference Case Determination

e) Definition of Project Committee/Focus Group/Resource Group

5. Lessons Learned on the Retail Guide - McBride

9:40

6. Break

7. Future Meeting Schedule (bring your calendars for next spring/summer)

8. Review and Questions on Scoping Document - Torcellini

a) Context of the other AEDGs

b) Goals \& Objectives of the Guide

c) Target Audience

d) Review of Scoping document

e) Resolve remaining scope issues:

- school size limit

- $30 \%$ apply to each space type or to entire campus

- Energy Savings Methods (plug or not plugs)

9. Lunch

f) Peer Review Process

10. Outline of AEDG

g) Review outline of previous Guides

h) Discuss possible modifications/changes

i) How will this guide be unique?

i) Literature review of existing materials (Pless)

ii) What new information will be provided?

11. Analysis Engine - Torcellini/Pless

12. Break

13. Benchmark/Reference Building - How is it defined? - Torcellini/Pless

j) CBECS background search (Pless) 
k) Elementary/High benchmarks

1) Define parameters (or identify where to find them)

i) Amenities provided

ii) Number/Size of classrooms, offices, gyms, foodservice, etc.

iii) Type of HVAC

14. Development of AEDG-Schools

Saturday, 8:00

m) Architectural Features

n) Lighting Criteria

o) Envelope Criteria

p) HVAC/Service water heating

q) Commissioning

r) Case Studies

s) Bonus Savings

t) Other?

15. Break

$10: 15$

16. Development of AEDG-Schools (cont.)

u) Architectural Features

v) Lighting Criteria

w) Envelope Criteria

x) HVAC/Service water heating

y) Commissioning

z) Case Studies

aa) Bonus Savings

bb) Other?

17. Lunch

18. Finalize Focus Group

cc) Roster confirmation

dd) Review draft questions

19. Finalize Resource Group

ee) Roster confirmation

ff) Technical Committees to be represented?

gg) Other representatives?

hh) How utilize this expertise?

20. Additional Issues

21. Review of Action Items

22. Next Meeting

23. Adjourn

Action Items

1. Review Scoping Document

2. Review AEDG-Retail (should have received one in the mail)

\section{A.2 Conference Call \#1 Agenda}

Conference Call 1/12/2007, 12:30pm to 3:30pm EST.

Items to discuss:

1) Review of old Action Items

2) Comments on Meeting \#1 minutes

3) Who is coming to the focus group meeting? PC Meeting \#2? 
4) Comments on updated focus group agenda/questions

a) Items to send to focus group

i) Agenda/questions

ii) Examples from SO and SR guides

iii) Scoping document

iv) $35 \%$ concept draft?

5) Review of concept draft input- we need some consistency in terms of detail and format for the $30 \%$ draft. All of the content should be in outline form.

6) Baseline Determination:

a) Campus vs single building? California new schools?

b) We had an email discussion about year round vs. no summer operation, and from what I heard, most schools are not operated fully year round, but do have some limited use during the summer. Do any PC members have any survey data on this, at the national level, or at a district level?

c) "Typical" HVAC systems- From John Murphy, all of these systems are standard, but vary by region and between high and elem:

i) Packaged and split DX systems with: indirect gas-fired heater, electric resistance heat, or heat pump.

ii) Water-source (or ground-source) heat pumps

iii) Liquid water chillers and boilers with classroom unit ventilators

iv) Liquid water chillers and boilers with central air handlers (constant-volume or VAV)

7) Review of new Action Items

8) Review of future meeting schedule

\section{A.3 Focus Group Agenda and Questions}

1. Fill in the posters on the walls answering the following questions:

a. Much material already exists on building energy efficiency and sustainability in schools. Will the information presented in this guide (as outlined in the scope) be a useful addition?

i. What existing guides for schools are you aware of?

ii. Do you use any of these guides?

iii. What audience do you think they are intended for?

iv. What are the gaps in these guides?

b. What would influence you to do an energy efficiency school?

2. Welcome - Torcellini

3. Introductions: Give Name/Affiliation and experience in working on design of schools

4. Review of Agenda - Torcellini

$11: 45$ am

5. AEDG Overview - Colliver

11:50 am

a. Organization of AEDG series

b. Review of scoping document and background

6. Group discussions addressing the following questions:

7. Discuss poster results

12:00 pm 
8. For the schools you are involved with, what is the common practice relative to the local standard energy standard applied?

a. Energy code compliant?

b. $10 \%$ better than code?

c. How difficult do you think achieving this guideline's 30\% goal might be (given a prescriptive path to do so).

d. Do you think the $30 \%$ goal is achievable?

9. What would influence you to do a $30 \%$ school?

$1: 00 \mathrm{pm}$

a. Or to not do it?

b. Would you consider using a different system type than your typical HVAC system?

c. Would you be willing to spend more money to achieve a sustainable building that could be used as an educational example?

10. What energy strategies should be addressed in the guide?

$1: 30 \mathrm{pm}$

a. Brainstorm energy strategies you would use

b. Brainstorm additional energy strategies you would consider (pros and cons of each)

c. Strategies you would not consider and why

d. Strategies that you would need for a 30\% savings school?

11. Do you feel recommendations should be individualized to separate school types and sizes (elem, middle, high)?

a. Describe what you consider to be a typical school (including size, types of spaces, HVAC system type)

b. Do we need recommendations on specialty uses or space types (swimming pools, sports complexes, hours of operation)?

c. Are there energy use issues related to public vs. private schools?

d. Middle vs. high schools?

12. What would an appropriate format look like (show examples and discuss)? What would be most helpful/usable way to present recommendations and results? 3:00 pm

a. Possible options include:

- An entire facility approach with (2) scenarios based on size, where the $30 \%$ savings are calculated for the overall facility? ( small $=$ elementary and large $=$ high)

- A multiple space approach, where the $30 \%$ savings are calculated for each space type separately? (Spaces to include administrative \& office, classrooms/hallways/restrooms, gymnasiums, assembly spaces, food preparation, library \& "clean" labs, etc).

- $\quad$ An integrated systems approach, where envelope \& lighting issues are addressed by space type and mechanical systems addressed through overall integration of the entire facility?

13. What makes a valuable case study?

$3: 15 \mathrm{pm}$

a. What type of info would you like to see? 
b. How much detail should be provided?

c. Are photos helpful?

d. How many case studies are appropriate?

e. Do you prefer whole building vs individual technology case studies?

f. Is the level of detail in our current case study list appropriate? (our current case study list will be provided at meeting)

14. Adjourn $3: 30 \mathrm{pm}$

Other questions to consider:

- Should we consider water-cooled equipment such as water-cooled chillers?

- Is there an issue with maintenance on water-cooled equipment that should stop us from considering it?

- Would it be worthwhile or would you be able to provide absenteeism statistics?

- What is the best way to tie-in all the goals of all the organizations together (AIA, USGBC, IESNA, DOE, ASHRAE)?

\title{
A.4 Meeting \#2 Agenda
}

\author{
Agenda Meeting \#2 \\ Advanced Energy Design Guide-K12 \\ Project Committee Meeting \\ ASHRAE Headquarters \\ 1791 Tullie Circle \\ Atlanta, GA 30329 \\ 404-636-8400
}

Friday, January 19, 2007, 8:30 am - 5:30 pm

Saturday, January 20, 2007, 8:00 am - 2:00 pm

\section{Business Casual Attire}

1. Welcome - Torcellini

2. Introductions: Review of Agenda - Torcellini

Friday, 8:30 am

9:00

3. Meeting Goals (to be done before we leave):

f) Establish benchmark so NREL can start running simulations

g) Develop action item list to get to $65 \%$ text completion by $2 / 9 / 07$

h) Identify holes in draft - determine appropriate scope and depth to each section

4. Next meeting 2/23-2/24 in Atlanta.

i) There is a conference call scheduled for 2/9? Can we move this to $2 / 8 / 07$ ? (The chairman is not available on 2/9.)

5. Old Action Items Review - Torcellini $\quad 9: 10$

6. Discuss Results from yesterday's Focus Group - Torcellini, Pratt, Hunn 9:20

$\begin{array}{ll}\text { 7. Break } & 10: 00\end{array}$

$\begin{array}{ll}\text { 8. Baseline Discussion - Torcellini/Pless } & 10: 15\end{array}$

j) Review proposed baseline model characteristics

k) Elem/middle/high model scorecards 
1) Outstanding baseline model issues:

(a) Campus type floor plan vs a single building floor plan? Do most new schools in temperate climates (California) have the corridors outside?

(b) Determine typical floor plans for elem, middle, and high schools

(c) We had an email discussion about year round vs. no summer operation, and from what I heard, most schools are not operated fully year round, but do have some limited use during the summer. Do any PC members have any survey data on this, at the national level, or at a district level?

(d) "Typical" HVAC systems- From John Murphy, all of these systems are standard, but vary by region and between high and elem:

(i) Packaged and split DX systems with: indirect gas-fired heater, electric resistance heat, or heat pump.

(ii) Water-source (or ground-source) heat pumps

(iii) Liquid water chillers and boilers with classroom unit ventilators

(iv) Liquid water chillers and boilers with central air handlers (constant-volume or VAV)

9. Lunch

10. Continue discussion on \#8

11. Begin list of energy efficiency measures (EEMs) to include in $30 \%$ advanced energy model and Chapter 3

m) Required measures vs. suggested measures

n) Cost and performance data?

o) How do we model the measure?

12. Break

13. Development of AEDG-Schools by subcommittee (Break up into groups)

$3: 15$

- Introduction - Torcellini

- Chapter 1 (Why, Who, How to use guide) - Nicklas, Schoff, O'Brien

- Chapter 2 (Process for Achieving Savings) - Sharma, Brenner

- Chapter 3 (Recommendation Tables) - Pless, Torcellini

- Chapter 4 (Case Studies) - Schoff

- Chapter 5 (How to recommendations)

- QAs/Commissioning - Sharma, Brenner

- Envelope - Nicklas (lead), McBride, O’Brien, Eley

- Lighting - Davis (lead), Benya, Eley, Nicklas

- HVAC - Murphy (lead), Goldman, Marriott

- SWH - Murphy (lead), Goldman, Marriott

- Electrical Distribution - Schoff (lead), Davis, Benya

- Bonus Savings - all

14. Develop agenda for TC 9.7 at ASHRAE Winter meeting (Milton/Shanti) Saturday, 8:00

p) They can help to answer some of the HVAC issues the focus group was not able to address.

15. Continue \#13 from Friday

16. Reconvene as group and discuss draft

$8: 30$

17. Discussion of Cover and other format issues

$10: 30$

18. Lunch

$11: 45$

19. Additional Issues

$12: 00$

20. Review of Action Items

1:00

21. Adjourn

$1: 30$

2:00 


\title{
A.5 Conference Call \#2 Agenda
}

\author{
Agenda Conference Call \#2 \\ Advanced Energy Design Guide-K12 \\ Thursday, February 8, 2007, 12:30 pm - 3:30 pm
}

Items to discuss:

1) Review of old Action Items (current AI List below)

2) Comments on Meeting \#2 minutes (will be sent out before conference call)

3) Confirm attendance for $2 / 23-2 / 24$ AEDG-Schools meeting in Atlanta

4) Review of TC 9.7 meeting at ASHRAE (meeting notes are below)

5) Review status of the current draft

a) Status of each section

b) Progress towards the $65 \%$ draft

6) Review of new Action Items

7) Review of future meeting schedule

\section{A.6 Meeting \#3 Agenda}

\author{
Agenda Meeting \#3 \\ Advanced Energy Design Guide-K12 \\ Project Committee Meeting \\ ASHRAE Headquarters \\ 1791 Tullie Circle \\ Atlanta, GA 30329 \\ 404-636-8400
}

Friday, February 23, 2007, 8:30 am - 5:30 pm

Saturday, February 24, 2007, 8:00 am - 2:00 pm

1) Welcome - Torcellini

\section{Business Casual Attire}

2) Introductions: Review of Agenda - Torcellini

3) Meeting Goals (to be done before we leave):

a) Establish energy efficiency measures to include in the advanced guide tables (Finalize format for the tables.)

b) Identify holes in draft-determine appropriate scope and depth to each section

c) Develop action item list to get to $65 \%$ Draft completed by $3 / 5 / 07$ to be published on web by $3 / 9 / 2007$.

4) Next meeting 4/12-4/13 in Golden.

a) Atlanta or Golden- Golden it is- we will send out info on Marriott Denver West- try to get our rate, transportation, car rental, .

5) Report on Steering Committee discussion - Colliver

9:00

a) Plug loads

b) Ventilation standard

c) $30 \%$ and $50 \%$

6) Comments on Conference Call \#2 minutes $\quad 9: 30$

7) Old Action Items Review - Torcellini 9:35

8) Break

9) Moved item 13-c here- 10:00 to lunch 10:00

10) Lunch $12: 00$ 
11) Discuss list of energy efficiency measures (EEMs) to include in $30 \%$

advanced energy model and Chapter 3

a) Required measures vs. suggested measures (bonus measures)

b) Cost and performance data?

c) How do we model the measure?

d) Requirements, but no energy savings (plug loads)

12) Review Status and Comments of each Chapter

a) Forward

b) Chapter 1 (intro), Chapter 2 (process)- they have been combined in Bill and Kathleen's draft

c) Chapter 3 - Recommendation table structure (without data)

i) Review Baseline model inputs and results. Show an example of how far we can get with the advanced energy measures currently available in the Analysis Platform

ii) Pages? New fields?

d) Chapter 4-Case Studies- review current list of case studies

e) Chapter 5 - How To Tips

i) Site Selection and Orientation

ii) Envelope

iii) Lighting/Daylighting

iv) HVAC

v) SWH

vi) Electrical/Plug load

vii) Bonus

13) Break

14) Continue discussion on $\# 12$

3:00

15) Review status of meeting goals

$3: 15$

16) Subcommittee breakouts

Saturday $\quad 8: 00 \mathrm{am}$

a) HVAC

b) Lighting

c) Envelope

d) Process/Commissioning/integrated design

e) Plug and Process Loads

17) Break

18) Case Study Discussion

$10: 15$

19) $65 \%$ Review process

11:00

a) Review notification

b) Collection of "Review Remarks"

c) Assembly of "Review Remarks"

20) Discussion of Cover and other format issues

a) ASHRAE Pubs will have some sort of mock-up for review

21) Lunch

22) Additional Issues

$1: 00$

23) Review of Action Items

$1: 30$

24) Adjourn

2:00 


\title{
A.7 Meeting \#4 Agenda
}

Thursday 4/12/2007

\author{
Agenda Meeting \#4 \\ Advanced Energy Design Guide-K12 \\ Project Committee Meeting \\ National Renewable Energy Laboratory \\ Wednesday, April 11, 2007 Afternoon Tours \\ Thursday, April 12, 2007 8:00 am - 5:30 pm \\ Friday, April 13, 2007 8:00 am - 1:30 pm
}

1) Continental Breakfast at NREL $\quad 7: 30 \mathrm{am}$

2) Welcome - Torcellini

$8: 30 \mathrm{am}$

3) Introductions: Review of Agenda - Torcellini

4) Meeting Goals (to be done before we leave):

a) Review simulation results

b) Address and document responses to remarks.

c) Identify holes in draft

d) Develop action item list to get to $90 \%$ Draft completed by $7 / 6 / 07$

5) Next meeting 6/4-6/5 in Golden.

6) Update on ASRHAE/IESNA/AIA/USGBC goals - Colliver $\quad 8: 45$

7) Comments on Meeting \#3 minutes $\quad 9: 00$

8) Old Action Items Review and update- Torcellini 9:15

a) See AI list Appendix- this has not been updated from 3/5/2007 version

9) Discuss simulation results - Pless and Torcellini

$9: 30$

a) Review advanced energy model scorecards

b) Discuss advanced energy measures currently modeled

10) Lunch

11) Review general $65 \%$ draft remarks and determine responses

a) Overall observations

b) Problems based on first look?

c) Major holes in $65 \%$ draft?

12) Break

13) Case study review

a) Review current list of possible case studies (Schoff lead)

b) we need to start making decisions on which case studies to include $\quad 3: 15$

14) Depart for Dinner at Table Mountain Inn, Golden

Friday, 4/13/2007

15) Continental Breakfast at NREL

16) Meeting Starts

17) Break up into chapter groups to address/draft outstanding TBD sections of the $65 \%$ draft:

Outstanding TBD sections include:

- Duct Friction in Chapter 3 Tables

- SHW Electric Storage and pipe insulation in Chapter 3 Tables

- Chapter 5- EL7: General Lighting Circuiting and Switching

- Sample Electrical Lighting Design for schools (sample designs to get to $0.9 \mathrm{~W} / \mathrm{ft} 2$ )

- EL8 Classroom Lighting 
○ EL9 Gym Lighting

- EL10 Corridor Lighting

- EL11 Office Lighting

- EL12 Auditorium Lighting

- DL-32 Skylights - sample gym skylight design to achieve the required DSP for gyms

- DL35 Select compatible light fixtures

- AS4 Exterior lighting (field and parking lot lights in additional savings)

- AS5 Water use savings

- AS6 Specialty space types or technologies

- Others?

18) Break

19) Discuss possible cover art/photos

$10: 45$

20) Discuss additional work to draft $90 \%$ draft

21) Lunch

22) Additional Issues

1:00

23) Review of Action Items

$1: 15$

24) Adjourn

$1: 30$

\title{
A.8 Conference Call \#3 Agenda
}

\section{AEDG-K12 Conference Call}

Date: Friday - May 18, 2007

Time: 12:30pm - 3:30pm EDT (11:30am CDT, 9:30am PDT)

Preliminary Agenda

1. Review Action Item list

2. Review overall schedule

3. Review status and unresolved items from $65 \%$ remarks

4. Review simulation results to date.

5. Review draft of case study for format

6. Discussion on which case studies to include

7. Create action items to complete $90 \%$ draft. We need to be nearly completed before the June AEDG Meeting in ATL.

a. Review each chapter and look at needs for completion

\section{A.9 Meeting \#5 Agenda}

\author{
Agenda Meeting \#5 \\ Advanced Energy Design Guide-K12 \\ Project Committee Meeting \\ ASHRAE Headquarters \\ 1791 Tullie Circle \\ Atlanta, GA 30329 \\ 404-636-8400
}

Monday, June 4, 2007, 8:30 am - 5:30 pm

Tuesday, June 5, 2007, 8:00 am - 12:30 pm

1) Welcome - Torcellini

Monday, 8:30 am

2) Introductions: Review of Agenda - Torcellini

3) Meeting Goals (to be done before we leave):

a) Identify holes in draft—determine missing pieces from each section 
b) Review and complete response letter for $65 \%$ remarks.

c) Develop action item list to get to $90 \%$ Draft completed by $7 / 6 / 07$ to be published on web by $7 / 9 / 2007$.

d) Agree on a path forward for the lighting/daylighting sections

4) Next meeting $8 / 2-8 / 3$ in Golden.

a) we will send out info on Marriott Denver West-

b) non-US citizens

5) Comments on Conference Call \#3 minutes

9:00

6) Action items review (see Appendix A) - Torcellini

$9: 35$

7) Break

8) Review general responses to 65\% Draft remarks

9) Review simulation results

a) Non-daylit, daylit, HVAC variations

b) Chapter 3 recommendation tables

10) Lunch

11) Subcommittee breakout to address outstanding items

a) Lighting/daylighting (complete tables in Appendix B)

b) HVAC

i) Eley, Benya, Nicklas, Davis, Pratt, Pless

i) Murphy, Marriott, Goldman, Colliver

c) Case studies/Front matter/Envelope

i) Brenner, O’brien, Schoff, Sharma, McBride

12) Review of subgroup progress

13) Dinner vote and vote counting

14) Review status of meeting goals

Tuesday, $\quad$ 8:00 am

15) Additional subcommittee breakouts

$8: 15 \mathrm{am}$

a) Lighting/daylighting

b) HVAC

c) Envelope

d) Case studies/Front matter

i) Review partially completed case studies

ii) Identify additional case studies?

16) Break

17) Continue number 15 from above

$10: 15$

18) $90 \%$ Review process

a) Review notification

b) Collection of "Review Remarks"

c) Assembly of "Review Remarks"

19) Discussion of Cover and other format issues

20) Lunch

$12: 00$

21) Additional Issues

$12: 30$

22) Review of Action Items

$12: 35$

23) Adjourn

$12: 40$ 


\section{A.10 Conference Call \#4 Agenda}

\section{AEDG-K12 Conference Call \#4}

Date: Tuesday- June 19, 2007

Time: 12:30pm - 2:00pm EDT (11:30am CDT, 9:30am PDT)

Agenda:

1. Review Action Items (page 36, 6/13 8:13 pm e-mail from Shanti Pless)

2. Discuss Cover Design (see Lilas e-mail)

3. Review simulation information (from earlier Shanti e-mail)

a. Information in spreadsheet (which will get translated to the recommendation tables)

b. Questions/comments

c. Issues?

4. Discuss status of $90 \%$ draft (latest draft was e-mailed out this morning)

d. Need to identify figures for AIA to recreate

e. Gaps in the text

5. Next draft (schedule)

6. Future conference call schedule (Currently scheduled for 12:30 EDT on 7/2-I will be on an airplane at that time)

7. Details on August/Denver Meeting

f. Foreign National Data Cards

g. August 2 (8:00-5:30 pm), August 3, (8:00-12:30 pm)

\section{A.11 Conference Call \#5 Agenda}

\section{AEDG-K12 Conference Call \#5}

Date: Monday, July 2, 2007

Time: 10:30pm - 1:30pm EDT (9:30am CDT, 8:30am MDT, 7:30am PDT)

Agenda:

1. Review Action Items (Conference Call \#4 Report, Appendix F, page 21)

2. Discuss status of $90 \%$ draft

a. Gaps in the text

b. Case study update

c. New lighting/daylighting chapter

3. Next draft (schedule)

4. Review simulation information (from earlier Shanti e-mail)

d. Chapter 3 Recommendation Tables Spreadsheet (which will get translated to the recommendation tables)

e. Questions/comments

f. Issues?

5. Details on August/Denver Meeting

g. Foreign National Data Cards

h. August 2 (8:00-5:30 pm), August 3, (8:00-12:30 pm) 


\title{
A.12 Meeting \#6 Agenda
}

\author{
Agenda Meeting \#6 \\ Advanced Energy Design Guide-K12 \\ Project Committee Meeting \\ National Renewable Energy Laboratory \\ Thermal Test Facility (TTF) Conference Room \\ 303-384-7538 \\ Wednesday, August 1, Arrivals \\ Thursday, August 2, 2007 8:00 am - 5:30 pm \\ Friday, August 3, 2007 8:00 am - 1:30 pm
}

\section{Wednesday:}

1. Van pick-up at Denver International Airport

4:45 pm

Thursday:

Continental Breakfast at NREL Main Campus: Conference Room in the TTF

$7: 30 \mathrm{am}$

2. Welcome - Torcellini

$8: 30 \mathrm{am}$

3. Introductions: Review of Agenda - Torcellini

4. Meeting Goals (to be done before we leave):

a) Identify holes in draft - determine missing pieces from each section

b) Draft response letter for $90 \%$ remarks.

c) Develop action item list to get to $100 \%$ Draft completed by $8 / 10 / 07$. See Appendix F for future due dates.

5. Comments on Conference Call \#5 report $\quad 8: 35$

6. Action items review (see Appendix H) - Torcellini $\quad 8: 40$

7. Update on the $90 \%$ draft development: $8: 45$

$\circ$ Reconfigured the daylighting section and some of the chapter 3 recommendation tables.

Should daylighting go in its own chapter?

- Completed case studies (no pics for the case studies without completed permission forms)

- Additional savings for Thermal Storage, PV, School as a teaching tool

8. Break

9. Review of general $90 \%$ draft review remarks

$\circ \quad$ Need to complete responses on the spreadsheet before Friday's meeting end

- HVAC Systems not included in the tables

- Not available for $30 \%$ savings (unit ventilators, water cooled chillers)

- OR-Available for $30 \%$ savings, only need to be code compliant

10. Lunch:

11. Subcommittee breakout to address $90 \%$ remarks

a) Lighting/daylighting

b) HVAC

i) Eley, Benya, Nicklas, Davis, Pless

i) Murphy, Marriott, Goldman, Colliver

c) Case studies/Front matter/Envelope

i) Brenner, O'brien, Schoff, Sharma, McBride

12. Review of subgroup progress 


\section{Friday:}

13. Review status of meeting goals

8:00 am

14. Additional subcommittee breakouts

8:15 am

a) Lighting/daylighting

b) HVAC

c) Envelope

d) Case studies/Front matter

$10: 00$

16. Develop Action items to address incomplete sections 10:15

- Identify sidebar bar case studies- Identify where technology side bar examples could be useful

- References

- EL-8: We currently reference CHPS to show how to design the electrical LPD of 0.9

$\mathrm{W} / \mathrm{ft} 2$ - Do we want to provide our own schematics and lighting layouts to meet 0.9 W.ft2?

- Further develop the how to's for the classroom sidelighting plus toplighting strategies

- Further develop the how to's for the gym skylights

$\circ$ Drawings- We need a list of graphics needed - make preliminary drawings that we can scan for later refinement.

17. Review simulation results

a) Non-daylit, daylit, HVAC variations

18. Case Studies ?

- All pics as high res tiffs

- Measured data difficult to collect

19. Final Approval of Cover and other format issues $11: 30$

20. Lunch $12: 00$

21. Additional Issues $\backslash$ Additional subcommittee breakouts

a) Lighting/daylighting

b) HVAC

c) Envelope

d) Case studies/Front matter

22. Adjourn 


\title{
Appendix B. Responses to 65\% Draft Review Remarks
}

\author{
SUMMARY RESPONSE TO \\ PEER REVIEW REMARKS AND RECOMMENDATIONS \\ RECEIVED ON \\ 65\% TECHNICAL REFINEMENT DRAFT OF
}

\author{
ADVANCED ENERGY DESIGN GUIDE: \\ K-12 SCHOOLS \\ June 20, 2007
}

On March 12, 2007, the Project Committee for the Advanced Energy Design Guide for K-12 School Buildings issued a 65\% Technical Refinement Draft of the document Advanced Energy Design Guide for K-12 School Buildings. Following the review period of March 12-23 the AEDG-K12 Project Committee met on April 12-13 and June 4-5 to review the recommendations received.

350 remarks and review recommendations were received from 27 reviewers representing ASHRAE SSPC 90.1, TC 9.7, AIA, IESNA, USGBC and the ASHRAE membership at large. The following documents the Project Committee's summary response to those remarks and recommendations. Although many of the suggestions dealt with details presented in the draft, this summary includes responses only to significant technical recommendations, especially those in which there was disagreement with what had been written or omitted. The specific and detailed suggestions and remarks have been, and will continue to be, reviewed and digested by the Project Committee as it prepares the next draft of the guide. The review remarks received fall into the following six categories.

1) General Comments

- It was suggested that language and terminology used in the guide should be consistent with that in Standard 90.1. This issue applies to dozens of places in the draft. Keeping in mind that the intended audience for this guide includes school administrators as well as engineering and architectural professionals, the committee established that the first priority will be readability; and the second, consistency. Thus specific terminology will in some cases depend on the context and the intent of the discussion; although consistency throughout the guide, with previous guides, and with the standard will be achieved to the extent possible.

- We emphasize that the guide presents a way, not the only way to achieve $30 \%$ energy savings so not all possible strategies will be included, especially specialty items. A balanced, multi-option approach is recommended.

- Energy use is considered the independent variable with cost effectiveness (i.e. simple payback or life cycle costing) as a dependent (or resulting) variable. While some the products or recommendations may be considered premium; all recommended equipment, systems, and technology specified in the document must be available from multiple manufacturers.

- While it is true that energy efficient construction costs can exceed standard construction costs, this is not a general rule. Thoughtfully designed, energy-efficient schools can actually cost less to build. When energy efficiency measures add to a school's construction cost, the savings in annual operating costs generally ensure a quick payback, often within a few years.

- As to the message to school administrators that advanced designs, especially daylighting, improve student performance, it was noted that some of these claims have been challenged. Wording will be changed to note that these are reported improvements, not necessarily established fact.

- Alaska and Hawaii are included in the climate zones and recommendation tables. 
- Criteria used in the advanced case will be no less stringent than Standard 90.1-2007 (including addenda $a s$ and at as approved and the proposed metal buildings update for roofs and walls effective for construction in 2007).

- Renewable energy options, such as photovoltaics (PV), solar hot water, and wind, will be addressed in the Additional Savings section of the AEDG, as they are not needed to achieve the $30 \%$ target.

- The references will be expanded and will include the Second Edition of the ASHRAE GreenGuide.

- All text that incorrectly references "retailers" or includes recommendations specifically for retail buildings will be removed from the document.

2) Introduction (Chapter 1)

- Discussion of commissioning in the Forward and Introduction is intended only to remind the reader that commissioning is essential to successful implementation of the design. The next draft will include a more comprehensive discussion of the commissioning process and requirements throughout the guide.

- A note will be added to explain that items not included in the Recommendation Tables must meet code minimum (typically Standard 90.1).

3) How to Use an Integrated Design Approach (Chapter 2)

- In the Pre-design phase discussion, the terms QA and commissioning are both used because commissioning goes from the beginning of design through the operational stage. It has been clarified in the text that commissioning is only one aspect of quality assurance.

- In the Occupancy phase discussion:

- Commissioning will be added to the occupancy phase discussion.

- The proposed development of a school district policy regarding plug loads will be added.

- The owner and designer will be added to preparation of punch list in Table 2.4.

- Discussion of a time limit for submission of O\&M manuals will be added to Table 2.4.

- More detail on the integration of building systems will be given in the next draft.

4) Recommendations by Climate (Chapter 3)

a) Envelope

- The roof recommendations will change from "Surface reflectance/emittance" to SRI=78, based on initial values listed by the Cool Roof Rating Council.

- All fenestration properties (U-factor, SHGC, VLT, etc.) will be NFRC rated values for actual products. Recommend fenestration properties will represent actual window and glass

- Recommendations for the minimum visible light transmittance will be coordinated between envelope and daylighting for consistency.

- Clear, prescriptive recommendations will be provided to meet the Daylighting Saturation \%, providing "a way but not the only way" to incorporate daylighting.

- The lighting section will provide guidance on view glazing and daylighting glazing properties. The recommendations and properties may be different for these two uses of glazing.

- The energy analysis by which the recommendations are compared between the base case and the AEDG buildings to assure that the $30 \%$ target is reached will follow the Standard 90.1, Appendix G, relating to the wall and fenestration areas. 
- Fenestration area exposures by orientation will be considered to achieve recommendations that provide good quality combined thermal and daylighting solutions

b) Lighting

- The interior lighting section of the tables will be redesigned for clarity and accuracy.

- Multiple daylighting strategies will be offered in the recommendation tables.

- Daylighting options and recommendations will be addressed as a total system package.

c) HVAC and SWH

- Most facilities predetermine the type of fuel that is available to the site. As a result, the savings of $30 \%$ will be met for both electric and gas heated/hot water facilities. Efficiency values will be provided for gas and electric systems independently to provide a $30 \%$ savings allowing users to choose their source of energy.

5) Technology Examples and Case Studies (Chapter 4)

- Additional case studies will be added for the next revision.

6) How to Implement Recommendations (Chapter 5)

a) Envelope

- The benefits of thermal mass will be discussed in the additional savings section of the next revision.

- Metal building roofs will be added to EN1 cool roofs.

- EN27, EN28, and EN29: How to tips will be defined by climate zone in the next revision.

b) Daylighting and Lighting

- Unfinished areas in the text will be completed and expanded incorporating the input received and clarifying the information as needed.

- A number of areas were pointed out where the information as presented is misleading or inaccurate. These areas will be rewritten for clarity and accuracy.

- Concern was raised about information being too general on some of the daylighting options. The daylighting section will be re-organized to provide specific design guidance for each of the daylighting options to be shown in the recommendation tables (see above).

- Climate specific information and additional technical details will be included as needed for clarity and understanding. Diagrams and tables will be added or modified as needed.

- Maintenance information will be added to address concerns about reliability and long term operation of controls, sensors, and other automatic lighting technology.

- Caution information about building expansions, in-class projection systems, and exterior lighting issues will be included.

- Concern was raised about the negative tone in some areas of the text. These areas will be rewritten to put the information and recommendations into a more positive tone.

- Additional references will be provided as needed to back-up statements made about the benefits of lighting and/or daylighting options. Text will be modified to remove editorial comments and unsubstantiated statements.

c) HVAC and SWH

- A number of areas will be rewritten to better clarify the information and to appropriately address the intended audience of architectural firms and consulting engineers.

- Issues were raised regarding the duct work design and construction section; this section will be rewritten for clarity. Acoustic concerns will be addressed in the noise control section. 
- Information on ventilation from a number of different sections will be consolidated in to the Ventilation section.

- A section on Dedicated Outdoor Air Systems (DOAS) will be added.

- Unit ventilators will be removed from the document, but fancoils will be added along with a section that specifically addresses associated good design practices.

- Fan power requirements will be verified and will be accounted for properly as determined by the results of the simulation runs.

- The information in the section on Relief versus Return Fans will be rewritten for clarity.

- Cautionary information on well field design will be added to a new Additional Savings section on ground source heat pumps.

- A maintenance section will be added to this chapter along with additional information in the commissioning chapter to address concerns about the calibration, reliability, and long term operation of controls, sensors, and other equipment.

- The sections on commissioning and hot water heating systems will be expanded.

- Information on the sizing and applicability of service hot water heating systems will be rewritten and expanded for clarity.

- Concern was raised about the climate applicability of recommendations for operable windows and humidity sensors. These recommendations will be rewritten to specify the appropriate conditions for use.

- Information on thermal displacement ventilation systems and thermal storage will be added to Additional Savings.

- While information from Codes, Standards, and Handbooks will not be duplicated in the document, additional references will be added and existing references will be clarified for applicability.

- Some questions were raised on recommended values as compared to standards 62.1 and 90.1; these values will be checked and verified.

- Recommendations will remain consistent with the applicable standards as the authors are not ready to adopt design and constructions methods for which consensus has not yet been reached in the industry.

d) Additional Savings:

- Due to the importance of the plug loads issue, wording on the need for school policy on the subject will be strengthened.

- It was pointed out that information on transformers is not always available during the bidding process. The recommendation will be qualified to point this out. 


\section{Appendix C. Elementary School Baseline Scorecards}

Table C-1 Elementary Baseline Scorecard: Climate Zones 1-3

\begin{tabular}{|c|c|c|c|c|c|}
\hline Program & & & & & \\
\hline Model Number & 1 & 2 & 3 & 4 & 5 \\
\hline Building Name & Elementary School & Elementary School & Elementary School & Elementary School & Elementary School \\
\hline \begin{tabular}{|l} 
Location \\
(Latitude, Longitude) \\
Weather File
\end{tabular} & $\begin{array}{c}\text { Miami, FL } \\
(25.8,-80.27) \\
\text { USA_FL_Miami_TMY2.epw }\end{array}$ & $\begin{array}{c}\text { Houston, TX } \\
(2998,-95.37) \\
\text { USA_TX_Houston-Intercontinental_TMY2.epw }\end{array}$ & $\begin{array}{c}\text { Phoenix, AZ } \\
\text { (33.43,-112.02) } \\
\text { USA_AZ_Phoenix_TMY2.epw }\end{array}$ & $\begin{array}{c}\text { Memphis, TN } \\
(35.05,-89.98) \\
\text { USA_TN_Memphis_TMY2.epw }\end{array}$ & $\begin{array}{c}\text { EI Paso, TX } \\
\text { (31.8,-106.4) } \\
\text { USA_TX_EI.Paso_TMY2.epw }\end{array}$ \\
\hline ASHRAE 90.1-2004 Climate Zone & $1 \mathrm{~A}$ & $2 \mathrm{~A}$ & $2 \mathrm{~B}$ & $3 \mathrm{~A}$ & $3 \mathrm{~B}$ \\
\hline \multicolumn{6}{|l|}{ Form } \\
\hline Total Floor Area $\left(f \mathrm{t}^{\wedge} 2\left[\mathrm{~m}^{\wedge} \mathrm{Z}\right]\right)$ & $73,958.83[6,871.00]$ & $73,958.83[6,871.00]$ & $73,958.83[6,871.00]$ & $73,958.83[6,871.00]$ & $73,958.83[6,871.00]$ \\
\hline Number of Floors & 1 & 1 & 1 & 1 & 1 \\
\hline Window Fraction (Window to Wall Ratio) & $\begin{array}{l}\text { South: } 0.35 \\
\text { East: } 0.35 \\
\text { North: } 0.35 \\
\text { West: } 0.35 \\
\text { Total: } 0.35\end{array}$ & $\begin{array}{l}\text { South: } 0.35 \\
\text { East: } 0.35 \\
\text { North: } 0.35 \\
\text { West: } 0.35 \\
\text { Total: } 0.35\end{array}$ & $\begin{array}{l}\text { South: } 0.35 \\
\text { East: } 0.35 \\
\text { North: } 0.35 \\
\text { West: } 0.35 \\
\text { Total: } 0.35\end{array}$ & $\begin{array}{l}\text { South: } 0.35 \\
\text { East: } 0.35 \\
\text { North: } 0.35 \\
\text { West: } 0.35 \\
\text { Total: } 0.35\end{array}$ & $\begin{array}{l}\text { South: } 0.35 \\
\text { East: } 0.35 \\
\text { North: } 0.35 \\
\text { West. } 0.35 \\
\text { Total: } 0.35\end{array}$ \\
\hline Skylight/TDD Percent & 0.19 & 0.19 & 0.19 & 0.19 & 0.19 \\
\hline Overhang Projection Factor & None & None & None & None & None \\
\hline Floor to Floor Height (ft [m]) & $13.12[4.00]$ & $13.12[4.00]$ & $13.12[4.00]$ & $13.12[4.00]$ & $13.12[4.00]$ \\
\hline \multicolumn{6}{|l|}{ Fabric } \\
\hline Exterior walls & & & & & \\
\hline Construction & $\mathrm{NR}$ & $\mathrm{NR}$ & $\mathrm{NR}$ & R-5.7 ci & R-5.7 ci \\
\hline R-value $\left(\mathrm{ft}^{\wedge} 2 \cdot \mathrm{hr} \cdot{ }^{\circ} \mathrm{F} / \mathrm{Btu}\left[\mathrm{m}^{\wedge} 2 \cdot \mathrm{K} / \mathrm{W}\right]\right)$ & $1.34[0.24]$ & $1.34[0.24]$ & $1.34[0.24]$ & $5.79[1.02]$ & $5.79[1.02]$ \\
\hline $\begin{array}{l}\text { Gross Dimensions - Total Area }\left(\mathrm{ft}^{\wedge} 2\right. \\
\left.\left[\mathrm{m}^{\wedge} \mathrm{2}\right]\right)\end{array}$ & $27,038.94[2,512.00]$ & $27,038.94[2,512.00]$ & $27,038.94[2,512.00]$ & $27,038.94[2,512.00]$ & $27,038.94[2,512.00]$ \\
\hline Net Dimensions - Total Area $\left(f^{\wedge} 2\left[\mathrm{~m}^{\wedge} 2\right]\right)$ & $17,574.02[1,632.68]$ & $17,574.02[1,632.68]$ & $17,574.02[1,632.68]$ & $17,574.02[1,632.68]$ & $17,574.02[1,632.68]$ \\
\hline \multicolumn{6}{|l|}{ Roof } \\
\hline Construction & R-15 ci & R-15 ci & $R-15 c i$ & R-15 ci & R-15ci \\
\hline R-value $\left(f t^{\wedge} 2 \cdot h \cdot \circ /\right.$ F $/$ Btu $\left.\left[m^{\wedge} 2 \cdot K / W\right]\right)$ & $14.82(2.61)$ & $14.82(2.61)$ & $14.82(2.61)$ & $14.82(2.61)$ & $14.82(2.61)$ \\
\hline $\begin{array}{l}\text { Gross Dimensions - Total Area }\left(\mathrm{ft}^{\wedge} 2\right. \\
\left.\left[\mathrm{m}^{\wedge} \mathrm{z}\right]\right)\end{array}$ & $73,958.83[6,871.00]$ & $73,958.83[6,871.00]$ & $73,958.83[6,871.00]$ & $73,958.83[6,871.00]$ & $73,958.83[6,871.00]$ \\
\hline Net Dimensions - Total Area $\left(f^{\wedge} \wedge\left[\mathrm{m}^{\wedge} 2\right]\right)$ & $73,814.70[6,857.61]$ & $73,814.70[6,857.61]$ & $73,814.70[6,857.61]$ & $73,814.70[6,857.61]$ & $73,814.70[6,857.61]$ \\
\hline \multicolumn{6}{|l|}{ Window } \\
\hline Dimensions - Total Area $\left(\mathrm{ft}^{\wedge} 2\left[\mathrm{~m}^{\wedge} 2\right]\right)$ & $\begin{array}{l}\text { South: } 3,496.76[324.86] \\
\text { East: } 1,235.70[114.80] \\
\text { North: } 3,496.55[324.84] \\
\text { West: } 1,235.80[114.81] \\
\text { Total: } 9,464.92[879.32]\end{array}$ & $\begin{array}{l}\text { South: } 3,496.76[324.86] \\
\text { East: } 1,235.70[114.80] \\
\text { North: } 3,496.55[324.84] \\
\text { West: } 1,235.80[114.81] \\
\text { Total: } 9,464.92[879.32]\end{array}$ & $\begin{array}{l}\text { South: } 3,496.76[324.86] \\
\text { East: } 1,235.70[114.80] \\
\text { North: } 3,496.55[324.84] \\
\text { West: } 1,235.80[114.81] \\
\text { Total: } 9,464.92[879.32]\end{array}$ & $\begin{array}{l}\text { South: } 3,496.76[324.86] \\
\text { East: } 1,235.70[114.80] \\
\text { North: } 3,496.55[324.84] \\
\text { West: } 1,235.80[114.81] \\
\text { Total: } 9,464.92[879.32]\end{array}$ & $\begin{array}{l}\text { South: } 3,496.76[324.86] \\
\text { East: } 1,235.70[114.80] \\
\text { North: } 3,496.55[324.84] \\
\text { West: } 1,235.80[114.81] \\
\text { Total: } 9,464.92[879.32]\end{array}$ \\
\hline Glass-type and frame & $\begin{array}{l}\text { Hypothetical window meeting U-factor and } \\
\text { SHGC shown below }\end{array}$ & $\begin{array}{l}\text { Hypothetical window meeting U-factor and } \\
\text { SHGC shown below }\end{array}$ & $\begin{array}{l}\text { Hypothetical window meeting U-factor and } \\
\text { SHGC shown below }\end{array}$ & $\begin{array}{l}\text { Hypothetical window meeting U-factor and } \\
\text { SHGC shown below }\end{array}$ & $\begin{array}{l}\text { Hypothetical window meeting U-factor and } \\
\text { SHGC shown below }\end{array}$ \\
\hline U-Factor $\left(\mathrm{Btu} / \mathrm{h} \cdot \mathrm{ft}^{\wedge} 2 \cdot{ }^{\circ} \mathrm{F}\left[\mathrm{W} / \mathrm{m}^{\wedge} 2 \cdot \mathrm{K}\right]\right)$ & $\begin{array}{l}\text { South: } 1.21[6.89] \\
\text { East } 1.21[6.89] \\
\text { North: } 1.21[6.89] \\
\text { West: } 1.21[6.89]\end{array}$ & $\begin{array}{l}\text { South: } 1.21[6.89] \\
\text { East: } 1.21[6.89] \\
\text { North: } 1.21[6.89] \\
\text { West: } 1.21[6.89]\end{array}$ & $\begin{array}{l}\text { South: } 1.21[6.89] \\
\text { East: } 1.21[6.89] \\
\text { North: } 1.21[6.89] \\
\text { West: } 1.21[6.89]\end{array}$ & $\begin{array}{l}\text { South: } 0.57[3.26] \\
\text { East: } 0.57[3.26] \\
\text { North: } 0.57[3.26] \\
\text { West: } 0.57[3.26]\end{array}$ & $\begin{array}{l}\text { Southt: } 0.57[3.26] \\
\text { East: } 0.57 \text { [3.26] } \\
\text { North: } 0.57[3.26] \\
\text { West: } 0.57[3.26]\end{array}$ \\
\hline SHGC & $\begin{array}{l}\text { South: } 0.25 \\
\text { East: } 0.25 \\
\text { North: } 0.61 \\
\text { West: } 0.25\end{array}$ & $\begin{array}{l}\text { South: } 0.25 \\
\text { East: } 0.25 \\
\text { North: } 0.61 \\
\text { West: } 0.25\end{array}$ & $\begin{array}{l}\text { South: } 0.25 \\
\text { East: } 0.25 \\
\text { North: } 0.61 \\
\text { West: } 0.25\end{array}$ & $\begin{array}{l}\text { South: } 0.25 \\
\text { East: } 0.25 \\
\text { North: } 0.39 \\
\text { West: } 0.25\end{array}$ & $\begin{array}{l}\text { South: } 0.25 \\
\text { East: } 0.25 \\
\text { North: } 0.39 \\
\text { West: } 0.25\end{array}$ \\
\hline \begin{tabular}{|l|} 
Visible transmittance \\
\end{tabular} & $\begin{array}{l}\text { South: } 0.25 \\
\text { East: } 0.25 \\
\text { North: } 0.67 \\
\text { West: } 0.25\end{array}$ & $\begin{array}{l}\text { South: } 0.25 \\
\text { East: } 0.25 \\
\text { North: } 0.67 \\
\text { West: } 0.25\end{array}$ & $\begin{array}{l}\text { South: } 0.25 \\
\text { East: } 0.25 \\
\text { North } 0.67 \\
\text { West: } 0.25\end{array}$ & $\begin{array}{l}\text { South: } 0.24 \\
\text { East: } 0.24 \\
\text { North: } 0.42 \\
\text { West: } 0.24\end{array}$ & $\begin{array}{l}\text { South: } 0.24 \\
\text { East: } 0.24 \\
\text { North: } 0.42 \\
\text { West: } 0.24\end{array}$ \\
\hline \multicolumn{6}{|l|}{ Foundation } \\
\hline Foundation Type & Mass Floor & Mass Floor & Mass Floor & Mass Floor & Mass Floor \\
\hline Construction & Carpet over heavy concrete and insulation & Carpet over heavy concrete and insulation & Carpet over heavy concrete and insulation & Carpet over heavy concrete and insulation & Carpet over heavy concrete and insulation \\
\hline R-value $\left(f t^{\wedge} 2 \cdot h \cdot h \cdot{ }^{\circ} / B\right.$ tut $\left.\left[m^{\wedge} 2 \cdot k / W\right]\right)$ & $2.11[0.37]$ & $2.11[0.37]$ & $2.11[0.37]$ & $2.11[0.37]$ & $2.11[0.37]$ \\
\hline Dimensions - Total Area $\left(\mathrm{ft}^{\wedge} 2\left[\mathrm{~m}^{\wedge} 2\right]\right)$ & $73,958.83[6,871.00]$ & $73,958.83[6,871.00]$ & $73,958.83[6,871.00]$ & $73,958.83[6,871.00]$ & $73,958.83[6,871.00]$ \\
\hline \multicolumn{6}{|l|}{ Interior Partitions } \\
\hline Construction & $2 \times 4$ steel-frame with gypsum board & $2 \times 4$ steel-frame with gypsum board & $2 \times 4$ steel-frame with gypsum board & $2 \times 4$ steel-frame with gypsum board & $2 \times 4$ steel-frame with gypsum board \\
\hline Dimensions - Total Area $\left(\mathrm{ft}^{\wedge} 2\left[\mathrm{~m}^{\wedge} 2\right]\right)$ & $31,559.79[2,932.00]$ & $31,559.79[2,932.00]$ & $31,559.79[2,932.00]$ & $31,559.79[2,932.00]$ & $31,559.79[2,932.00]$ \\
\hline \multicolumn{6}{|l|}{ Internal Mass } \\
\hline Construction & 6 inch wood & 6 inch wood & 6 inch wood & 6 inch wood & 6 inch wood \\
\hline Dimensions - Total Area $\left(\mathrm{ft}^{\wedge} 2\left[\mathrm{~m}^{\wedge} 2\right]\right)$ & $147,917.66[13,742.00]$ & $147,917.66[13,742.00]$ & $147,917.66[13,742.00]$ & $147,917.66[13,742.00]$ & $147,917.66[13,742.00]$ \\
\hline Thermal Properties $\left(\mathrm{lb} / \mathrm{ft}^{\wedge} 2\left[\mathrm{~kg} / \mathrm{m}^{\wedge} 2\right]\right)$ & $16.60[81.00]$ & $16.60[81.00]$ & $16.60[81.00]$ & $16.60[81.00]$ & $16.60[81.00]$ \\
\hline \multicolumn{6}{|l|}{ Air Barrier System } \\
\hline Infiltration (ACH) & 0.50 & 0.50 & 0.50 & 0.50 & 0.50 \\
\hline
\end{tabular}


Table C-2 Elementary Baseline Scorecard: Climate Zones 1-3 (Cont.)

\begin{tabular}{|c|c|c|c|c|c|}
\hline \multicolumn{6}{|l|}{ Program } \\
\hline Model Number & 1 & 2 & 3 & 4 & 5 \\
\hline Building Name & Elementary School & Elementary School & Elementary School & Elementary School & Elementary School \\
\hline $\begin{array}{l}\text { Location } \\
\text { (Latitude, Longitude) } \\
\text { Weather File }\end{array}$ & $\begin{array}{c}\text { Miami, FL } \\
(25.8,-80.27) \\
\text { USA_FL_Miami_TMY2.epw }\end{array}$ & $\begin{array}{c}\text { Houston, TX } \\
(29.98,-95.37) \\
\text { USA_TX_Houston-Intercontinental_TMY2.epw }\end{array}$ & $\begin{array}{c}\text { Phoenix, AZ } \\
(33.43,-112.02) \\
\text { USA_AZ_Phoenix_TMY2.epw } \\
\end{array}$ & $\begin{array}{c}\text { Memphis, TN } \\
\text { (35.05, -89.98) } \\
\text { USA_TN_Memphis_TMY2.epw } \\
\end{array}$ & $\begin{array}{c}\text { EI Paso, TX } \\
\text { (31.8,-106.4) } \\
\text { USA_TX_EI.Paso_TMY2.epw } \\
\end{array}$ \\
\hline ASHRAE 90.1-2004 Climate Zone & $1 \mathrm{~A}$ & $2 \mathrm{~A}$ & $2 \mathrm{~B}$ & $3 \mathrm{~A}$ & $3 B$ \\
\hline \multicolumn{6}{|l|}{ HVAC } \\
\hline System Type & & & & & \\
\hline $\begin{array}{l}\text { ASHRAE 90.1-2004 Appendix G Table } \\
\text { G3.1.1B System Number }\end{array}$ & 3: PSZ-AC & 3: PSZ-AC & 3: PSZ-AC & 3: PSZ-AC & 3: PSZ-AC \\
\hline Heating Type & Gas Furnace & Gas Furnace & Gas Furnace & Gas Furnace & Gas Furnace \\
\hline Cooling Type & Direct Expansion & Direct Expansion & Direct Expansion & Direct Expansion & Direct Expansion \\
\hline Fan Control & Constant Volume & Constant Volume & Constant Volume & Constant Volume & Constant Volume \\
\hline Distribution and Terminal Units & Single Zone/Direct Air & $\begin{array}{l}\text { Single Zone/Direct Air } \\
\end{array}$ & $\begin{array}{l}\text { Single Zone/Direct Air } \\
\end{array}$ & $\begin{array}{l}\text { Single Zone/Direct Air } \\
\end{array}$ & Single Zone/Direct Air \\
\hline \multicolumn{6}{|l|}{ HVAC Sizing } \\
\hline Air Conditioning (tons [kW]) & Autosized $(341.57[1,201.29])$ & Autosized $(329.58[1,159.14])$ & Autosized $(351.76[1,237.16])$ & Autosized $(308.97[1,086.64])$ & Autosized $(289.42[1,017.89])$ \\
\hline Heating (kBtu/h [kW]) & Autosized (180.86 [617.12]) & Autosized (207.51 [708.07]) & Autosized (200.09 [682.74]) & Autosized (212.57 [725.33]) & Autosized (177.99 [607.31]) \\
\hline \multicolumn{6}{|l|}{ HVAC Efficiency } \\
\hline Air Conditioning (COP) & 3.30 & 3.30 & 3.30 & 3.30 & 3.30 \\
\hline Heating Efficiency (\%) & 80.00 & 80.00 & 80.00 & 80.00 & 80.00 \\
\hline \multicolumn{6}{|l|}{ HVAC Control } \\
\hline $\begin{array}{l}\text { Before Terminal Temperature Schedule } \\
\left({ }^{\circ} \mathrm{F}\left[{ }^{\circ} \mathrm{C}\right]\right)\end{array}$ & 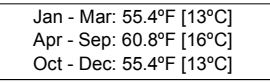 & $\begin{array}{l}\text { Jan - Mar: } 55.4^{\circ} \mathrm{F}\left[13^{\circ} \mathrm{C}\right] \\
\text { Apr - Sep: } 60.8^{\circ} \mathrm{F}\left[16^{\circ}\right] \\
\text { Oct - Dec: } 55.4^{\circ} \mathrm{F}\left[13^{\circ} \mathrm{C}\right]\end{array}$ & $\begin{array}{l}\text { Jan - Mar: } 55.4^{\circ} \mathrm{F}\left[13^{\circ} \mathrm{C}\right] \\
\text { Apr - Sep: } 60.8^{\circ} \mathrm{F}\left[16^{\circ}\right] \\
\text { Oct - Dec: } 55.4^{\circ} \mathrm{F}\left[13^{\circ} \mathrm{C}\right]\end{array}$ & $\begin{array}{l}\text { Jan - Mar: } 55.4^{\circ} \mathrm{F}\left[13^{\circ} \mathrm{C}\right] \\
\text { Apr - Sep: } 60.8^{\circ}\left[1^{\circ} \mathrm{C}\right] \\
\text { Oct - Dec: } 55.4^{\circ} \mathrm{F}\left[13^{\circ} \mathrm{C}\right] \\
\end{array}$ & $\begin{array}{l}\text { Jan - Mar: } 55.4^{\circ} \mathrm{F}\left[13^{\circ} \mathrm{C}\right] \\
\text { Apr - Sep: } 60.8^{\circ} \mathrm{F}\left[16^{\circ}\right] \\
\text { Oct - Dec: } 55.4^{\circ} \mathrm{F}\left[13^{\circ} \mathrm{C}\right] \\
\end{array}$ \\
\hline $\begin{array}{l}\text { Chilled Water Supply Temperatures ( }{ }^{\circ} \mathrm{F} \\
\left.\left[{ }^{\circ} \mathrm{C}\right]\right)\end{array}$ & $\mathrm{N} / \mathrm{A}$ & $\mathrm{N} / \mathrm{A}$ & $\mathrm{N} / \mathrm{A}$ & $\mathrm{N} / \mathrm{A}$ & $\mathrm{N} / \mathrm{A}$ \\
\hline Hot Water Supply Temperatures $\left({ }^{\circ} \mathrm{F}\left[{ }^{\circ} \mathrm{C}\right]\right)$ & N/A & N/A & $\mathrm{N} / \mathrm{A}$ & N/A & N/A \\
\hline Economizer & No & No & Yes & No & Yes \\
\hline Night Cycle & Yes & Yes & Yes & Yes & Yes \\
\hline Heat Recovery & No & No & No & No & No \\
\hline Demand Control Ventilation & Yes & Yes & Yes & Yes & Yes \\
\hline Ventilation $\left(\mathrm{cfm}\left[\mathrm{m}^{\wedge} 3 / \mathrm{s}\right]\right)$ & See Zone Level Information & See Zone Level Information & See Zone Level Information & See Zone Level Information & See Zone Level Information \\
\hline \multicolumn{6}{|l|}{ Fan and Pump Loads } \\
\hline Fan Schedules & Always available & Always available & Always available & Always available & Always available \\
\hline Supply Fan Efficiency (\%) & 55.00 & 55.00 & 55.00 & 55.00 & 55.00 \\
\hline $\begin{array}{l}\text { Supply Fan Volumetric Flow Rate (cfm } \\
\left.\left[\mathrm{m}^{\wedge} 3 / \mathrm{s}\right]\right)\end{array}$ & $150,847.09[71.19]$ & $144,774.38$ [68.33] & $157,533.22[74.35]$ & $131,155.07[61.90]$ & $130,291.20$ [61.49] \\
\hline Supply Fan Pressure Drop (in $\mathrm{H} 2 \mathrm{O}[\mathrm{Pa}]$ ) & $2.49[620.00]$ & $2.49[620.00]$ & $2.49[620.00]$ & $2.49[620.00]$ & $2.49[620.00]$ \\
\hline Cooling Tower Power (hp [kW]) & N/A & N/A & $\mathrm{N} / \mathrm{A}$ & N/A & N/A \\
\hline Pump Power (hp [kW]) & N/A & N/A & $\mathrm{N} / \mathrm{A}$ & N/A & N/A \\
\hline \multicolumn{6}{|l|}{ Service Hot Water } \\
\hline SWH Type & Storage Tank & Storage Tank & Storage Tank & Storage Tank & Storage Tank \\
\hline Fuel & Natural Gas & Natural Gas & Natural Gas & Natural Gas & Natural Gas \\
\hline Thermal Efficiency (\%) & 80.00 & 80.00 & 80.00 & 80.00 & 80.00 \\
\hline Temperature Setpoint $\left({ }^{\circ} \mathrm{F}\left[{ }^{\circ} \mathrm{C}\right]\right)$ & $140.00[60.00]$ & $140.00[60.00]$ & $140.00[60.00]$ & $140.00[60.00]$ & $140.00[60.00]$ \\
\hline Water Consumption (gal $\left[\mathrm{m}^{\wedge} 3\right]$ ) & $200,361.25[758.45]$ & $200,361.25[758.45]$ & $200,361.25[758.45]$ & $200,361.25[758.45]$ & $200,361.25[758.45]$ \\
\hline \multirow{2}{*}{\multicolumn{6}{|c|}{\begin{tabular}{|l} 
Internal Loads \& Schedules \\
Heating \& Cooling
\end{tabular}}} \\
\hline & & & & & \\
\hline \multicolumn{6}{|l|}{ Setpoint Schedule } \\
\hline Heating & See HTGSETP_SCH & See HTGSETP_SCH & See HTGSETP_SCH & See HTGSETP_SCH & See HTGSETP_SCH \\
\hline Cooling & See CLGSETP_SCH & See CLGSETP_SCH & See CLGSETP_SCH & See CLGSETP_SCH & See CLGSETP_SCH \\
\hline \multicolumn{6}{|l|}{ Lighting } \\
\hline Average Power Density $\left(\mathrm{W} / \mathrm{ft}^{\wedge} 2\left[\mathrm{~W} / \mathrm{m}^{\wedge} 2\right]\right)$ & $1.53[16.47]$ & $1.53[16.47]$ & $1.53[16.47]$ & $1.53[16.47]$ & $1.53[16.47]$ \\
\hline Schedule & See BLDG_LIGHT_SCH & See BLDG_LIGHT_SCH & See BLDG_LIGHT_SCH & See BLDG_LIGHT_SCH & See BLDG_LIGHT_SCH \\
\hline \multicolumn{6}{|l|}{ Plug loads } \\
\hline Average Power Density $\left(\mathrm{W} / \mathrm{ft}^{\wedge} 2\left[\mathrm{~W} / \mathrm{m}^{\wedge} 2\right]\right)$ & $1.06[11.38]$ & $1.06[11.38]$ & $1.06[11.38]$ & $1.06[11.38]$ & $1.06[11.38]$ \\
\hline Schedule & See BLDG_EQUIP_SCH & See BLDG_EQUIP_SCH & See BLDG_EQUIP_SCH & See BLDG_EQUIP_SCH & See BLDG_EQUIP_SCH \\
\hline \multicolumn{6}{|l|}{ Occupancy } \\
\hline Average People (\#/1000 ft^2 [\#/100 $\left.\left.\mathrm{m}^{\wedge} 2\right]\right)$ & $20.31[21.87]$ & $20.31[21.87]$ & $20.31[21.87]$ & $20.31[21.87]$ & $20.31[21.87]$ \\
\hline Schedule & See BLDG_OCC_SCH & See BLDG_OCC_SCH & See BLDG_OCC_SCH & See BLDG_OCC_SCH & See BLDG_OCC_SCH \\
\hline
\end{tabular}


Table C-3 Elementary Baseline Scorecard: Climate Zones 3-5

\begin{tabular}{|c|c|c|c|c|c|}
\hline \multicolumn{6}{|l|}{ Program } \\
\hline Model Number & 6 & 7 & 8 & 9 & 10 \\
\hline Building Name & Elementary School & Elementary School & Elementary School & Elementary School & Elementary School \\
\hline $\begin{array}{l}\mid \begin{array}{l}\text { Location } \\
\text { (Latitude, Longitude) } \\
\text { Weather File }\end{array} \\
\end{array}$ & $\begin{array}{c}\text { San Francisco, CA } \\
(37.62,-122.38) \\
\text { USA_CA_San.Francisco_TMY2.epw }\end{array}$ & $\begin{array}{c}\text { Baltimore, MD } \\
\text { (39.18, -76.67) } \\
\text { USA_MD_Baltimore_TMY2.epw }\end{array}$ & $\begin{array}{c}\text { Albuquerque, NM } \\
(35.05,-106.62) \\
\text { USA_NM_Albuquerque_TMY2.epw }\end{array}$ & $\begin{array}{c}\text { Seattle, WA } \\
(47.45,-122.3) \\
\text { USA_WA_Seattle-Tacoma_TMY2.epw }\end{array}$ & $\begin{array}{c}\text { Chicago-ohare, IL } \\
(41.78,-87.75) \\
\text { USA_L_Chicago-OHare_TMY2.epw }\end{array}$ \\
\hline \multicolumn{6}{|l|}{ Form } \\
\hline \begin{tabular}{|l|l|} 
Total Floor Area $\left(\mathrm{ft}^{\wedge} 2\left[\mathrm{~m}^{\wedge} 2\right]\right)$ \\
\end{tabular} & $73,958.83[6,871.00]$ & $73,958.83[6,871.00]$ & $73,958.83[6,871.00]$ & $73,958.83[6,871.00]$ & $73,958.83[6,871.00]$ \\
\hline Number of Floors & 1 & 1 & 1 & 1 & 1 \\
\hline Window Fraction (Window to Wall Ratio) & $\begin{array}{l}\text { South: } 0.35 \\
\text { East: } 0.35 \\
\text { North: } 0.35 \\
\text { West: } 0.35 \\
\text { Total: } 0.35\end{array}$ & $\begin{array}{l}\text { South: } 0.35 \\
\text { East: } 0.35 \\
\text { North: } 0.35 \\
\text { West: } 0.35 \\
\text { Total: } 0.35\end{array}$ & $\begin{array}{l}\text { South: } 0.35 \\
\text { East: } 0.35 \\
\text { North: } 0.35 \\
\text { West: } 0.35 \\
\text { Total: } 0.35\end{array}$ & $\begin{array}{l}\text { South: } 0.35 \\
\text { East: } 0.35 \\
\text { North: } 0.35 \\
\text { West: } 0.35 \\
\text { Total: } 0.35\end{array}$ & $\begin{array}{l}\text { South: } 0.35 \\
\text { East: } 0.35 \\
\text { North: } 0.35 \\
\text { West: } 0.35 \\
\text { Total: } 0.35\end{array}$ \\
\hline Skylight/TDD Percent & 0.19 & 0.19 & 0.19 & 0.19 & 0.19 \\
\hline Shading Geometry & None & None & None & None & None \\
\hline Floor to Floor Height (ft [m]) & $13.12[4.00]$ & $13.12[4.00]$ & $13.12[4.00]$ & $13.12[4.00]$ & $13.12[4.00]$ \\
\hline \multicolumn{6}{|l|}{ Fabric } \\
\hline \multicolumn{6}{|l|}{ Exterior walls } \\
\hline Construction & $\mathrm{R}-5.7 \mathrm{ci}$ & $\mathrm{R}-5.7 \mathrm{ci}$ & R-5.7 ci & $\mathrm{R}-5.7 \mathrm{ci}$ & $\mathrm{R}-7.6 \mathrm{ci}$ \\
\hline R-value $\left(\mathrm{ft}^{\wedge} 2 \cdot h \mathrm{hr} \cdot{ }^{\circ} \mathrm{F} / \mathrm{Btu}\left[\mathrm{m}^{\wedge} 2 \cdot \mathrm{K} / \mathrm{W}\right]\right)$ & $5.79[1.02]$ & $5.79[1.02]$ & $5.79[1.02]$ & $5.79[1.02]$ & $7.31[1.29]$ \\
\hline $\begin{array}{l}\begin{array}{l}\text { Gross Dimensions - Total Area }\left(f t^{\wedge} 2\right. \\
\left.\left[m^{\wedge} 2\right]\right)\end{array} \\
\end{array}$ & $27,038.94[2,512.00]$ & $27,038.94[2,512.00]$ & $27,038.94[2,512.00]$ & $27,038.94[2,512.00]$ & $27,038.94[2,512.00]$ \\
\hline Net Dimensions - Total Area $\left(\mathrm{ft}^{\wedge} 2\left[\mathrm{~m}^{\wedge} 2\right]\right)$ & $17,574.02[1,632.68]$ & $17,574.02[1,632.68]$ & $17,574.02[1,632.68]$ & $17,574.02[1,632.68]$ & $17,574.02[1,632.68]$ \\
\hline R-value $\left(\mathrm{ft}^{\wedge} 2 \cdot \mathrm{h}^{\circ} \cdot \mathrm{F} / \mathrm{Btu}\left[\mathrm{m}^{\wedge} 2 \cdot \mathrm{K} / \mathrm{W}\right]\right)$ & $9.69(1.71)$ & $14.82(2.61)$ & $14.82(2.61)$ & $14.82(2.61)$ & $14.82(2.61)$ \\
\hline $\begin{array}{l}\text { Gross Dimensions - Total Area }\left(\mathrm{ft}^{\wedge} 2\right. \\
\left.\left[\mathrm{m}^{\wedge} \mathrm{l}\right]\right)\end{array}$ & $73,958.83[6,871.00]$ & $73,958.83[6,871.00]$ & $73,958.83[6,871.00]$ & $73,958.83[6,871.00]$ & $73,958.83[6,871.00]$ \\
\hline Net Dimensions - Total Area $\left(\mathrm{ft}^{\wedge} 2\left[\mathrm{~m}^{\wedge} 2\right]\right)$ & $73,814.70[6,857.61]$ & $73,814.70[6,857.61]$ & $73,814.70[6,857.61]$ & $73,814.70[6,857.61]$ & $73,814.70[6,857.61]$ \\
\hline \multicolumn{6}{|l|}{ Window } \\
\hline Dimensions - Total Area $\left(f^{\wedge} 2\left[\mathrm{~m}^{\wedge} 2\right]\right)$ & $\begin{array}{l}\text { South: } 3,496.76[324.86] \\
\text { East: } 1,235.70[114.80] \\
\text { North: } 3,496.55[324.84] \\
\text { West: } 1,235.80[1144.81] \\
\text { Total: } 9,464.92[879.32]\end{array}$ & $\begin{array}{l}\text { South: } 3,496.76[324.86] \\
\text { East: } 1,235.70[114.80] \\
\text { North: } 3,496.55[324.84] \\
\text { West } 1,235.80 \text { [114.81] } \\
\text { Total: } 9,464.92[879.32]\end{array}$ & $\begin{array}{l}\text { South: } 3,496.76[324.86] \\
\text { East: } 1,235.70[114.80] \\
\text { North: } 3,496.55[324.84] \\
\text { West: } 1,235.80[114.81] \\
\text { Total: } 9,464.92[879.32]\end{array}$ & $\begin{array}{l}\text { South: } 3,496.76[324.86] \\
\text { East: } 1,235.70[114.80] \\
\text { North: } 3,496.55[324.84] \\
\text { West: } 1,235.80[1144.81] \\
\text { Total: } 9,464.92[879.32]\end{array}$ & $\begin{array}{l}\text { South: } 3,496.76[324.86] \\
\text { East: } 1,235.70[114.80] \\
\text { North: } 3,496.55[324.84] \\
\text { West: } 1,235.80[114.81] \\
\text { Total: } 9,464.92[879.32]\end{array}$ \\
\hline Glass-type and frame & $\begin{array}{l}\text { Hypothetical window meeting U-factor and } \\
\text { SHGC shown below }\end{array}$ & $\begin{array}{l}\text { Hypothetical window meeting U-factor and } \\
\text { SHGC shown below }\end{array}$ & $\begin{array}{l}\text { Hypothetical window meeting U-factor and } \\
\text { SHGC shown below }\end{array}$ & $\begin{array}{l}\text { Hypothetical window meeting U-factor and } \\
\text { SHGC shown below }\end{array}$ & $\begin{array}{l}\text { Hypothetical window meeting U-factor and } \\
\text { SHGC shown below }\end{array}$ \\
\hline U-Factor $\left(\mathrm{Btu} / \mathrm{h} \cdot \mathrm{ft}^{\wedge} 2 \cdot{ }^{\circ} \mathrm{F}\left[\mathrm{W} / \mathrm{m}^{\wedge} 2 \cdot \mathrm{K}\right]\right)$ & $\begin{array}{l}\text { South: } 1.21[6.89] \\
\text { East: } 1.21[6.89] \\
\text { North: } 1.21[6.89] \\
\text { West: } 1.21[6.89]\end{array}$ & $\begin{array}{l}\text { South: } 0.57[3.26] \\
\text { East: } 0.57[3.26] \\
\text { North: } 0.57[3.26] \\
\text { West: } 0.57[3.26]\end{array}$ & $\begin{array}{l}\text { South: } 0.57[3.26] \\
\text { East: } 0.57[3.26] \\
\text { North: } 0.57[3.26] \\
\text { West: } 0.57[3.26]\end{array}$ & $\begin{array}{l}\text { South: } 0.57[3.26]] \\
\text { East: } 0.57[3.26] \\
\text { North: } 0.57[3.26] \\
\text { West: } 0.57[3.26]\end{array}$ & $\begin{array}{l}\text { South: } 0.57[3.26] \\
\text { East: } 0.57[3.26] \\
\text { North: } 0.57[3.26] \\
\text { West: } 0.57[3.26]\end{array}$ \\
\hline SHGC & $\begin{array}{l}\text { South: } 0.61 \\
\text { East: } 0.61 \\
\text { North: } 0.61 \\
\text { West: } 0.61\end{array}$ & $\begin{array}{l}\text { South: } 0.39 \\
\text { East: } 0.39 \\
\text { North: } 0.49 \\
\text { West: } 0.39\end{array}$ & $\begin{array}{l}\text { South: } 0.39 \\
\text { East: } 0.39 \\
\text { North: } 0.49 \\
\text { West: } 0.39\end{array}$ & $\begin{array}{l}\text { South: } 0.39 \\
\text { East: } 0.39 \\
\text { North: } 0.49 \\
\text { West: } 0.39\end{array}$ & $\begin{array}{l}\text { South: } 0.39 \\
\text { East: } 0.39 \\
\text { North: } 0.49 \\
\text { West: } 0.39\end{array}$ \\
\hline Visible transmittance & $\begin{array}{l}\text { South: } 0.67 \\
\text { East: } 0.67 \\
\text { North: } 0.67 \\
\text { West: } 0.67\end{array}$ & $\begin{array}{l}\text { South: } 0.42 \\
\text { East: } 0.42 \\
\text { North: } 0.53 \\
\text { West: } 0.42\end{array}$ & $\begin{array}{l}\text { South: } 0.42 \\
\text { East: } 0.42 \\
\text { North: } 0.53 \\
\text { West: } 0.42\end{array}$ & $\begin{array}{l}\text { South: } 0.42 \\
\text { East: } 0.42 \\
\text { North: } 0.53 \\
\text { West: } 0.42\end{array}$ & $\begin{array}{l}\text { South: } 0.42 \\
\text { East: } 0.42 \\
\text { North: } 0.53 \\
\text { West: } 0.42\end{array}$ \\
\hline \multicolumn{6}{|l|}{ Foundation } \\
\hline Dimensions - Total Area $\left(\mathrm{ft}^{\wedge} 2\left[\mathrm{~m}^{\wedge} 2\right]\right)$ & $73,958.83[6,871.00]$ & $73,958.83[6,871.00]$ & $73,958.83[6,871.00]$ & $73,958.83[6,871.00]$ & $73,958.83[6,871.00]$ \\
\hline \multicolumn{6}{|l|}{ Interior Partitions } \\
\hline Construction & $2 \times 4$ steel-frame with gypsum board & $2 \times 4$ steel-frame with gypsum board & $2 \times 4$ steel-frame with gypsum board & $2 \times 4$ steel-frame with gypsum board & $2 \times 4$ steel-frame with gypsum board \\
\hline Dimensions - Total Area $\left(\mathrm{ft}^{\wedge} 2\left[\mathrm{~m}^{\wedge} \mathrm{2}\right]\right)$ & $31,559.79[2,932.00]$ & $31,559.79[2,932.00]$ & $31,559.79[2,932.00]$ & $31,559.79[2,932.00]$ & $31,559.79[2,932.00]$ \\
\hline \multicolumn{6}{|l|}{ Internal Mass } \\
\hline Construction & 6 inch wood & 6 inch wood & 6 inch wood & 6 inch wood & 6 inch wood \\
\hline Dimensions - Total Area $\left(\mathrm{ft}^{\wedge} 2\left[\mathrm{~m}^{\wedge} 2\right]\right)$ & $147,917.66[13,742.00]$ & $147,917.66[13,742.00]$ & $147,917.66[13,742.00]$ & $147,917.66[13,742.00]$ & $147,917.66[13,742.00]$ \\
\hline Thermal Properties $\left(\mathrm{b} / \mathrm{b} \mathrm{ft}^{\wedge} 2\left[\mathrm{~kg} / \mathrm{m}^{\wedge} 2\right]\right)$ & $16.60[81.00]$ & $16.60[81.00]$ & $16.60[81.00]$ & $16.60[81.00]$ & $16.60[81.00]$ \\
\hline Air Barrier System & & & & & \\
\hline Infiltration (ACH) & 0.50 & 0.50 & 0.50 & 0.50 & 0.50 \\
\hline
\end{tabular}


Table C-4 Elementary Baseline Scorecard: Climate Zones 3-5 (Cont.)

\begin{tabular}{|c|c|c|c|c|c|}
\hline Program & & & & & \\
\hline Model Number & 6 & 7 & 8 & 9 & 10 \\
\hline Building Name & Elementary School & Elementary School & Elementary School & Elementary School & Elementary School \\
\hline $\begin{array}{l}\text { Location } \\
\text { (Latitude, Longitude) } \\
\text { Weather File }\end{array}$ & $\begin{array}{c}\text { San Francisco, CA } \\
\text { (37.62, -122.38) } \\
\text { USA_CA_San.Francisco_TMY2.epw }\end{array}$ & $\begin{array}{c}\text { Baltimore, MD } \\
\text { (39.18, -76.67) } \\
\text { USA_MD_Baltimore_TMY2.epw }\end{array}$ & $\begin{array}{c}\text { Albuquerque, NM } \\
\text { (35.05, -106.62) } \\
\text { USA_NM_Albuquerque_TMY2.epw }\end{array}$ & $\begin{array}{c}\text { Seattle, WA } \\
(47.45,-122.3) \\
\text { USA_WA_Seattle-Tacoma_TMY2.epw }\end{array}$ & $\begin{array}{c}\text { Chicago-ohare, IL } \\
\text { (41.78, -87.75) } \\
\text { USA_Chicago-OHare_TMY2.epw }\end{array}$ \\
\hline ASHRAE 90.1-2004 Climate Zone & $3 \mathrm{C}$ & $4 \mathrm{~A}$ & $4 \mathrm{~B}$ & $4 \mathrm{C}$ & $5 \mathrm{~A}$ \\
\hline \multirow{2}{*}{\multicolumn{6}{|c|}{\begin{tabular}{|l|} 
HVAC \\
System Type
\end{tabular}}} \\
\hline & & & & & \\
\hline $\begin{array}{l}\text { ASHRAE 90.1-2004 Appendix G Table } \\
\text { G3.1.1B System Number }\end{array}$ & 3: PSZ-AC & 3: PSZ-AC & 3: PSZ-AC & 3: PSZ-AC & 3: PSZ-AC \\
\hline Heating Type & Gas Furnace & Gas Furnace & Gas Furnace & Gas Furnace & Gas Furnace \\
\hline Cooling Type & Direct Expansion & Direct Expansion & Direct Expansion & Direct Expansion & Direct Expansion \\
\hline Fan Control & Constant Volume & Constant Volume & Constant Volume & Constant Volume & Constant Volume \\
\hline Distribution and Terminal Units & Single Zone/Direct Air & Single Zone/Direct Air & Single Zone/Direct Air & Single Zone/Direct Air & Single Zone/Direct Air \\
\hline \multicolumn{6}{|l|}{ HVAC Sizing } \\
\hline Air Conditioning (tons [kW]) & Autosized (328.34 [1,154.79]) & Autosized $(298.39[1,049.45])$ & Autosized $(307.89[1,082.86])$ & Autosized (280.32 [985.88]) & Autosized $(299.32[1,052.72])$ \\
\hline Heating (kBtu/h [kW]) & Autosized (194.34 [663.12]) & Autosized (222.42 [758.94]) & Autosized (186.07 [634.89]) & Autosized (194.08 [662.21]) & Autosized (248.39 [847.53]) \\
\hline \multicolumn{6}{|l|}{ HVAC Efficiency } \\
\hline Air Conditioning (COP) & 3.30 & 3.30 & 3.30 & 3.30 & 3.30 \\
\hline Heating Efficiency (\%) & 80.00 & 80.00 & 80.00 & 80.00 & 80.00 \\
\hline \multicolumn{6}{|l|}{ HVAC Control } \\
\hline $\begin{array}{l}\text { Before Terminal Temperature Schedule } \\
\left({ }^{\circ} \mathrm{F}\left[{ }^{\circ} \mathrm{C}\right]\right)\end{array}$ & $\begin{array}{l}\text { Jan - Mar: } 55.4^{\circ} \mathrm{F}\left[13^{\circ} \mathrm{C}\right] \\
\text { Apr - Sep: } 60.8^{\circ} \mathrm{F}\left[16^{\circ} \mathrm{C}\right] \\
\text { Oct - Dec: } 55.4^{\circ} \mathrm{F}\left[13^{\circ} \mathrm{C}\right]\end{array}$ & $\begin{array}{l}\text { Jan - Mar: } 55.4^{\circ} \mathrm{F}\left[13^{\circ} \mathrm{C}\right] \\
\text { Apr - Sep: } 60.8^{\circ} \mathrm{F}\left[16^{\circ} \mathrm{C}\right] \\
\text { Oct - Dec: } 55.4^{\circ} \mathrm{F}\left[13^{\circ} \mathrm{C}\right]\end{array}$ & $\begin{array}{l}\text { Jan - Mar: } 55.4^{\circ} \mathrm{F}\left[13^{\circ} \mathrm{C}\right] \\
\text { Apr - Sep: } 6.8^{\circ} \mathrm{F}\left[16^{\circ} \mathrm{C}\right] \\
\text { Oct - Dec: } 55.4^{\circ} \mathrm{F}\left[13^{\circ} \mathrm{C}\right]\end{array}$ & $\begin{array}{l}\text { Jan - Mar: } 55.4^{\circ} \mathrm{F}\left[13^{\circ} \mathrm{C}\right] \\
\text { Apr - Sep: } 6.8^{\circ} \mathrm{F}\left[1^{\circ}\right] \\
\text { Oct - Dec: } 55.4^{\circ} \mathrm{F}\left[13^{\circ} \mathrm{C}\right]\end{array}$ & $\begin{array}{l}\text { Jan - Mar: } 55.4^{\circ} \mathrm{F}\left[13^{\circ} \mathrm{C}\right] \\
\text { Apr - Sep: } 6.8^{\circ} \mathrm{F}\left[16^{\circ}\right] \\
\text { Oct - Dec: } 554^{\circ} \mathrm{F}\left[13^{\circ} \mathrm{C}\right]\end{array}$ \\
\hline $\begin{array}{l}\text { Chilled Water Supply Temperatures }\left({ }^{\circ} \mathrm{F}\right. \\
\left.\left[{ }^{\circ} \mathrm{C}\right]\right)\end{array}$ & $\mathrm{N} / \mathrm{A}$ & $\mathrm{N} / \mathrm{A}$ & $\mathrm{N} / \mathrm{A}$ & $\mathrm{N} / \mathrm{A}$ & N/A \\
\hline Hot Water Supply Temperatures $\left({ }^{\circ}\left[{ }^{\circ} \mathrm{C}\right]\right)$ & N/A & N/A & N/A & N/A & N/A \\
\hline \begin{tabular}{|l|} 
Economizer \\
\end{tabular} & Yes & No & Yes & Yes & Yes \\
\hline Night Cycle & Yes & Yes & Yes & Yes & Yes \\
\hline Heat Recovery & No & No & No & No & No \\
\hline Demand Control Ventilation & Yes & Yes & Yes & Yes & Yes \\
\hline Ventilation $\left(\mathrm{cfm}\left[\mathrm{m}^{\wedge} 3 / \mathrm{s}\right]\right)$ & See Zone Level Information & See Zone Level Information & See Zone Level Information & See Zone Level Information & See Zone Level Information \\
\hline \multicolumn{6}{|l|}{ Fan and Pump Loads } \\
\hline Fan Schedules & Always available & Always available & Always available & Always available & Always available \\
\hline Supply Fan Efficiency (\%) & 55.00 & 55.00 & 55.00 & 55.00 & 55.00 \\
\hline $\begin{array}{l}\text { Supply Fan Volumetric Flow Rate (cfm } \\
{\left[\mathrm{m}^{\wedge} 3 / \mathrm{s}\right] \text { ) }}\end{array}$ & $147,814.13[69.76]$ & $131,733.52[62.17]$ & $138,607.59[65.42]$ & $126,194.56[59.56]$ & $132,669.22[62.61]$ \\
\hline Supply Fan Pressure Drop (in H2O [Pa]) & $2.49[620.00]$ & $2.49[620.00]$ & $2.49[620.00]$ & $2.49[620.00]$ & $2.49[620.00]$ \\
\hline Cooling Tower Power (hp [kW]) & $\mathrm{N} / \mathrm{A}$ & N/A & $\mathrm{N} / \mathrm{A}$ & $\mathrm{N} / \mathrm{A}$ & $\mathrm{N} / \mathrm{A}$ \\
\hline Pump Power (hp [kW]) & $\mathrm{N} / \mathrm{A}$ & N/A & N/A & N/A & N/A \\
\hline \multicolumn{6}{|l|}{ Service Hot Water } \\
\hline SWH Type & Storage Tank & Storage Tank & Storage Tank & Storage Tank & Storage Tank \\
\hline Fuel & Natural Gas & Natural Gas & Natural Gas & Natural Gas & Natural Gas \\
\hline Thermal Efficiency (\%) & 80.00 & 80.00 & 80.00 & 80.00 & 80.00 \\
\hline Temperature Setpoint $\left({ }^{\circ} \mathrm{F}\left[{ }^{\circ} \mathrm{C}\right]\right)$ & $140.00[60.00]$ & $140.00[60.00]$ & $140.00[60.00]$ & $140.00[60.00]$ & $140.00[60.00]$ \\
\hline Water Consumption (gal [ $\left.\left[\mathrm{m}^{\wedge} 3\right]\right)$ & $200,361.25[758.45]$ & $200,361.25[758.45]$ & $200,361.25[758.45]$ & $200,361.25[758.45]$ & $200,361.25[758.45]$ \\
\hline \multicolumn{6}{|l|}{ Internal Loads \& Schedules } \\
\hline \multicolumn{6}{|l|}{ Heating \& Cooling } \\
\hline \multicolumn{6}{|l|}{ Setpoint Schedule } \\
\hline Heating & See HTGSETP_SCH & See HTGSETP_SCH & See HTGSETP_SCH & See HTGSETP_SCH & See HTGSETP_SCH \\
\hline Cooling & See CLGSETP_SCH & See CLGSETP_SCH & See CLGSETP_SCH & See CLGSETP_SCH & See CLGSETP_SCH \\
\hline \multicolumn{6}{|l|}{ Lighting } \\
\hline Average Power Density (W/ft^ $\left.2\left[\mathrm{~W} / \mathrm{m}^{\wedge} 2\right]\right)$ & $1.53[16.47]$ & $1.53[16.47]$ & $1.53[16.47]$ & $1.53[16.47]$ & $1.53[16.47]$ \\
\hline Schedule & See BLDG_LIGHT_SCH & See BLDG_LIGHT_SCH & See BLDG_LIGHT_SCH & See BLDG_LIGHT_SCH & See BLDG_LIGHT_SCH \\
\hline \multicolumn{6}{|l|}{ Plug loads } \\
\hline Average Power Density (W/ft^ $\left.2\left[\mathrm{~W} / \mathrm{m}^{\wedge} 2\right]\right)$ & $1.06[11.38]$ & $1.06[11.38]$ & $1.06[11.38]$ & $1.06[11.38]$ & $1.06[11.38]$ \\
\hline Schedule & See BLDG_EQUIP_SCH & See BLDG_EQUIP_SCH & See BLDG_EQUIP_SCH & See BLDG_EQUIP_SCH & See BLDG_EQUIP_SCH \\
\hline \multicolumn{6}{|l|}{\begin{tabular}{|l|} 
Occupancy \\
\end{tabular}} \\
\hline Average People (\#/1000 $\left.\mathrm{ft}^{\wedge} 2\left[\# / 100 \mathrm{~m}^{\wedge} 2\right]\right)$ & $20.31[21.87]$ & $20.31[21.87]$ & $20.31[21.87]$ & $20.31[21.87]$ & $20.31[21.87]$ \\
\hline Schedule & See BLDG_OCC_SCH & See BLDG_OCC_SCH & See BLDG_OCC_SCH & See BLDG_OCC_SCH & See BLDG_OCC_SCH \\
\hline
\end{tabular}


Table C-5 Elementary Baseline Scorecard: Climate Zones 5-8

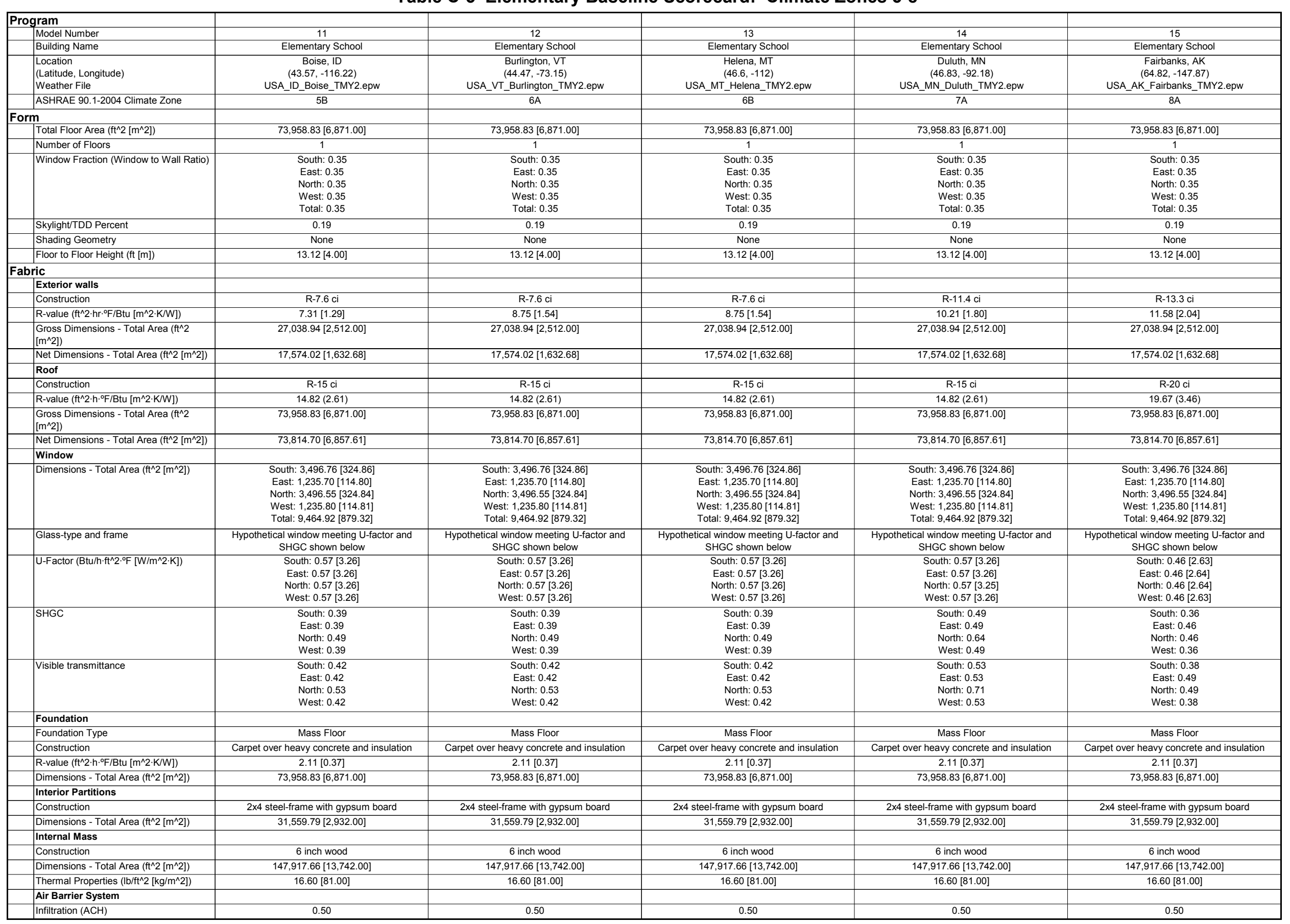


Table C-6 Elementary Baseline Scorecard: Climate Zones 5-8 (Cont.)

\begin{tabular}{|c|c|c|c|c|c|}
\hline Program & & & & & \\
\hline Model Number & 11 & 12 & 13 & 14 & 15 \\
\hline Building Name & Elementary School & Elementary School & Elementary School & Elementary School & Elementary School \\
\hline $\begin{array}{l}\text { Location } \\
\text { (Latitude, Longitude) } \\
\text { Weather File }\end{array}$ & $\begin{array}{c}\text { Boise, ID } \\
\text { (43.57, -116.22) } \\
\text { USA ID Boise TMY2.epw }\end{array}$ & $\begin{array}{c}\text { Burlington, VT } \\
(44.47,-73.15) \\
\text { USA VT Burlington TMY2.epw }\end{array}$ & $\begin{array}{c}\text { Helena, MT } \\
(46.6,-112) \\
\text { USA MT Helena_TMY2.epw }\end{array}$ & $\begin{array}{c}\text { Duluth, MN } \\
\text { (46.83, -92.18) } \\
\text { USA MN Duluth TMY2.epw }\end{array}$ & $\begin{array}{c}\text { Fairbanks, AK } \\
(64.82,-147.87) \\
\text { USA AK Fairbanks TMY2.epw }\end{array}$ \\
\hline ASHRAE 90.1-2004 Climate Zone & $5 B$ & $6 \mathrm{~A}$ & $6 \mathrm{~B}$ & $7 \mathrm{~A}$ & $8 \mathrm{~A}$ \\
\hline \multicolumn{6}{|l|}{ HVAC } \\
\hline System Type & & & & & \\
\hline $\begin{array}{l}\text { ASHRAE 90.1-2004 Appendix G Table } \\
\text { G3.1.1B System Number }\end{array}$ & 3: PSZ-AC & 3: PSZ-AC & 3: PSZ-AC & 3: PSZ-AC & 3: PSZ-AC \\
\hline Heating Type & Gas Furnace & Gas Furnace & Gas Furnace & Gas Furnace & Gas Furnace \\
\hline Cooling Type & Direct Expansion & Direct Expansion & Direct Expansion & Direct Expansion & Direct Expansion \\
\hline Fan Control & Constant Volume & Constant Volume & Constant Volume & Constant Volume & Constant Volume \\
\hline Distribution and Terminal Units & Single Zone/Direct Air & Single Zone/Direct Air & Single Zone/Direct Air & Single Zone/Direct Air & Single Zone/Direct Air \\
\hline \multicolumn{6}{|l|}{ HVAC Sizing } \\
\hline Air Conditioning (tons [kW]) & Autosized $(308.69[1,085.65])$ & Autosized (276.47 [972.34]) & Autosized $(293.83[1,033.40])$ & Autosized $(289.16[1,016.99])$ & Autosized (228.72 [804.39]) \\
\hline Heating (kBtu/h [kW]) & Autosized (221.91 [757.19]) & Autosized (249.83 [852.45]) & Autosized (236.61 [807.36]) & Autosized (262.34 [895.13]) & Autosized (282.70 [964.60]) \\
\hline \multicolumn{6}{|l|}{ HVAC Efficiency } \\
\hline Air Conditioning (COP) & 3.30 & 3.30 & 3.30 & 3.30 & 3.30 \\
\hline Heating Efficiency (\%) & 80.00 & 80.00 & 80.00 & 80.00 & 80.00 \\
\hline \multicolumn{6}{|l|}{ HVAC Control } \\
\hline \begin{tabular}{|l|} 
Before Terminal Temperature Schedule \\
$\left({ }^{\circ} \mathrm{F}\left[{ }^{\circ} \mathrm{C}\right]\right)$
\end{tabular} & $\begin{array}{l}\text { Jan - Mar: } 55.4^{\circ} \mathrm{F}\left[13^{\circ} \mathrm{C}\right] \\
\text { Apr - Sep: } 60.8^{\circ} \mathrm{F}\left[16^{\circ} \mathrm{C}\right] \\
\text { Oct - Dec: } 55.4^{\circ} \mathrm{F}\left[13^{\circ} \mathrm{C}\right]\end{array}$ & $\begin{array}{l}\text { Jan - Mar: } 55.4^{\circ} \mathrm{F}\left[13^{\circ} \mathrm{C}\right] \\
\text { Apr - Sep: } 60.8^{\circ} \mathrm{F}\left[16^{\circ} \mathrm{C}\right] \\
\text { Oct - Dec: } 55.4^{\circ} \mathrm{F}\left[13^{\circ} \mathrm{C}\right]\end{array}$ & $\begin{array}{l}\text { Jan - Mar: } 55.4^{\circ} \mathrm{F}\left[13^{\circ} \mathrm{C}\right] \\
\text { Apr - Sep: } 60.8^{\circ} \mathrm{F}\left[16^{\circ} \mathrm{C}\right] \\
\text { Oct - Dec: } 55.4^{\circ} \mathrm{F}\left[13^{\circ} \mathrm{C}\right]\end{array}$ & $\begin{array}{l}\text { Jan - Mar: } 55.4^{\circ} \mathrm{F}\left[13^{\circ} \mathrm{C}\right] \\
\text { Apr - Sep: } 60.8^{\circ} \mathrm{F}\left[16^{\circ} \mathrm{C}\right] \\
\text { Oct - Dec: } 55.4^{\circ} \mathrm{F}\left[13^{\circ} \mathrm{C}\right]\end{array}$ & $\begin{array}{l}\text { Jan - Mar: } 55.4^{4^{\circ} \mathrm{F}}\left[13^{\circ} \mathrm{C}\right] \\
\text { Apr - Sep: } 60.8^{\circ} \mathrm{F}\left[16^{\circ} \mathrm{C}\right] \\
\text { Oct - Dec: } 55.4^{\circ} \mathrm{F}\left[13^{\circ} \mathrm{C}\right]\end{array}$ \\
\hline $\begin{array}{l}\text { Chilled Water Supply Temperatures }\left({ }^{\circ} \mathrm{F}\right. \\
\left.\left[{ }^{\circ} \mathrm{C}\right]\right)\end{array}$ & $\mathrm{N} / \mathrm{A}$ & $\mathrm{N} / \mathrm{A}$ & $\mathrm{N} / \mathrm{A}$ & $\mathrm{N} / \mathrm{A}$ & $\mathrm{N} / \mathrm{A}$ \\
\hline Hot Water Supply Temperatures $\left({ }^{\circ}\left[{ }^{\circ} \mathrm{C}\right]\right)$ & N/A & N/A & N/A & N/A & N/A \\
\hline Economizer & Yes & Yes & Yes & Yes & Yes \\
\hline Night Cycle & Yes & Yes & Yes & Yes & Yes \\
\hline Heat Recovery & No & No & No & No & No \\
\hline Demand Control Ventilation & Yes & Yes & Yes & Yes & Yes \\
\hline Ventilation $\left(\mathrm{cfm}\left[\mathrm{m}^{\wedge} 3 / \mathrm{s}\right]\right)$ & See Zone Level Information & See Zone Level Information & See Zone Level Information & See Zone Level Information & See Zone Level Information \\
\hline \multicolumn{6}{|l|}{ Fan and Pump Loads } \\
\hline Fan Schedules & Always available & Always available & Always available & Always available & Always available \\
\hline Supply Fan Efficiency (\%) & 55.00 & 55.00 & 55.00 & 55.00 & 55.00 \\
\hline $\begin{array}{l}\text { Supply Fan Volumetric Flow Rate (cfm } \\
{\left[\mathrm{m}^{\wedge} 3 / \mathrm{s}\right] \text { ) }}\end{array}$ & $138,965.47[65.58]$ & $123,687.29[58.37]$ & $132,276.17[62.43]$ & $130,175.72[61.44]$ & $102,963.01[48.59]$ \\
\hline Supply Fan Pressure Drop (in H2O [Pa]) & $2.49[620.00]$ & $2.49[620.00]$ & $2.49[620.00]$ & $2.49[620.00]$ & $2.49[620.00]$ \\
\hline Cooling Tower Power (hp [kW]) & $\mathrm{N} / \mathrm{A}$ & $\mathrm{N} / \mathrm{A}$ & $\mathrm{N} / \mathrm{A}$ & N/A & $\mathrm{N} / \mathrm{A}$ \\
\hline Pump Power (hp [kW]) & N/A & N/A & N/A & N/A & N/A \\
\hline \multicolumn{6}{|l|}{ Service Hot Water } \\
\hline SWH Type & Storage Tank & Storage Tank & Storage Tank & Storage Tank & Storage Tank \\
\hline Fuel & Natural Gas & Natural Gas & Natural Gas & Natural Gas & Natural Gas \\
\hline Thermal Efficiency (\%) & 80.00 & 80.00 & 80.00 & 80.00 & 80.00 \\
\hline Temperature Setpoint $\left({ }^{\circ} \mathrm{F}\left[{ }^{\circ} \mathrm{C}\right]\right)$ & $140.00[60.00]$ & $140.00[60.00]$ & $140.00[60.00]$ & $140.00[60.00]$ & $140.00[60.00]$ \\
\hline Water Consumption $\left(\right.$ gal $\left.\left[\mathrm{m}^{\wedge} 3\right]\right)$ & $200,361.25[758.45]$ & $200,361.25[758.45]$ & $200,361.25$ [758.45] & $200,361.25[758.45]$ & $200,361.25[758.45]$ \\
\hline \multicolumn{6}{|l|}{ Internal Loads \& Schedules } \\
\hline \multicolumn{6}{|l|}{ Heating \& Cooling } \\
\hline \multicolumn{6}{|l|}{ Setpoint Schedule } \\
\hline Heating & See HTGSETP_SCH & See HTGSETP_SCH & See HTGSETP_SCH & See HTGSETP_SCH & See HTGSETP_SCH \\
\hline Cooling & See CLGSETP_SCH & See CLGSETP_SCH & See CLGSETP_SCH & See CLGSETP_SCH & See CLGSETP_SCH \\
\hline \multicolumn{6}{|l|}{ Lighting } \\
\hline Average Power Density $\left(\mathrm{W} / \mathrm{ft}^{\wedge} 2\left[\mathrm{~W} / \mathrm{m}^{\wedge} \mathrm{2}\right]\right)$ & $1.53[16.47]$ & $1.53[16.47]$ & $1.53[16.47]$ & $1.53[16.47]$ & $1.53[16.47]$ \\
\hline Schedule & See BLDG_LIGHT_SCH & See BLDG_LIGHT_SCH & See BLDG_LIGHT_SCH & See BLDG_LIGHT_SCH & See BLDG_LIGHT_SCH \\
\hline \multicolumn{6}{|l|}{ Plug loads } \\
\hline Average Power Density $\left(\mathrm{W} / \mathrm{ft}^{\wedge} 2\left[\mathrm{~W} / \mathrm{m}^{\wedge} 2\right]\right)$ & $1.06[11.38]$ & $1.06[11.38]$ & $1.06[11.38]$ & $1.06[11.38]$ & $1.06[11.38]$ \\
\hline Schedule & See BLDG_EQUIP_SCH & See BLDG_EQUIP_SCH & See BLDG_EQUIP_SCH & See BLDG_EQUIP_SCH & See BLDG_EQUIP_SCH \\
\hline \multicolumn{6}{|l|}{ Occupancy } \\
\hline Average People (\#/1000 ft^ $\left.\left[\# / 100 \mathrm{~m}^{\wedge} 2\right]\right)$ & $20.31[21.87]$ & $20.31[21.87]$ & $20.31[21.87]$ & $20.31[21.87]$ & $20.31[21.87]$ \\
\hline Schedule & See BLDG_OCC_SCH & See BLDG_OCC_SCH & See BLDG_OCC_SCH & See BLDG_OCC_SCH & See BLDG_OCC_SCH \\
\hline
\end{tabular}




\section{Appendix D. Middle School Baseline Scorecard}

Table D-1 Middle Baseline Scorecard: Climate Zones 1-3

\begin{tabular}{|c|c|c|c|c|c|}
\hline Program & & & & & \\
\hline Model Number & 1 & 2 & 3 & 4 & 5 \\
\hline Building Name & Middle School & Middle School & Middle School & Middle School & Middle School \\
\hline \begin{tabular}{|l|} 
Location \\
(Latitude, Longitude) \\
Weather File
\end{tabular} & $\begin{array}{c}\text { Miami, FL } \\
(25.8,-80.27) \\
\text { USA_FL_Miami_TMY2.epw }\end{array}$ & $\begin{array}{c}\text { Houston, TX } \\
(29.98,-95.37) \\
\text { USA_TX_Houston-Intercontinental_TMY2.epw }\end{array}$ & $\begin{array}{c}\text { Phoenix, AZ } \\
(33.43,-112.02) \\
\text { USA_AZ Phoenix_TMY2.epw }\end{array}$ & $\begin{array}{c}\text { Memphis, TN } \\
\text { (35.05, -89.98) } \\
\text { USA_TN_Memphis_TMY2.epw }\end{array}$ & $\begin{array}{c}\text { EI Paso, TX } \\
\text { (31.8, -106.4) } \\
\text { USA_TX_El.Paso_TMY2.epw }\end{array}$ \\
\hline ASHRAE 90.1-2004 Climate Zone & $1 \mathrm{~A}$ & $2 \mathrm{~A}$ & $2 \mathrm{~B}$ & $3 \mathrm{~A}$ & $3 B$ \\
\hline \multicolumn{6}{|l|}{ Form } \\
\hline Total Floor Area $\left(\mathrm{t}^{\wedge} 2\left[\mathrm{~m}^{\wedge} 2\right]\right)$ & $116,121.07[10,788.00]$ & $116,121.07[10,788.00]$ & $116,121.07[10,788.00]$ & $116,121.07[10,788.00]$ & $116,121.07[10,788.00]$ \\
\hline Number of Floors & 1 & 1 & 1 & 1 & 1 \\
\hline Window Fraction (Window to Wall Ratio) & $\begin{array}{l}\text { South: } 0.35 \\
\text { East: } 0.33 \\
\text { North } 0.35 \\
\text { Westa } 0.35 \\
\text { Total: } 0.35\end{array}$ & $\begin{array}{l}\text { South: } 0.35 \\
\text { East: } 0.33 \\
\text { North } 0.35 \\
\text { West } 0.35 \\
\text { Total: } 0.35\end{array}$ & $\begin{array}{l}\text { South: } 0.35 \\
\text { East: } 0.33 \\
\text { North } 0.35 \\
\text { Westa } 0.35 \\
\text { Total: } 0.35\end{array}$ & $\begin{array}{l}\text { South: } 0.35 \\
\text { East: } 0.33 \\
\text { North: } 0.35 \\
\text { West: } 0.35 \\
\text { Total: } 0.35\end{array}$ & $\begin{array}{l}\text { South: } 0.35 \\
\text { East } 0.33 \\
\text { North } 0.35 \\
\text { Westa } 0.35 \\
\text { Total: } 0.35\end{array}$ \\
\hline Skylight/TDD Percent & 0.41 & 0.41 & 0.41 & 0.41 & 0.41 \\
\hline Shading & None & None & None & None & None \\
\hline Floor to Floor Height (ft [m]) & $13.12[4.00]$ & $13.12[4.00]$ & $13.12[4.00]$ & $13.12[4.00]$ & $13.12[4.00]$ \\
\hline \multicolumn{6}{|l|}{ Fabric } \\
\hline \multicolumn{6}{|l|}{\begin{tabular}{|l|l|} 
Exterior walls \\
\end{tabular}} \\
\hline Construction & $\mathrm{NR}$ & NR & $\mathrm{NR}$ & R-5.7 ci & R-5.7 ci \\
\hline R-value $\left(\mathrm{ft}^{\wedge} 2 \cdot h \mathrm{hr} \cdot{ }^{\circ} \mathrm{F} / \mathrm{Btu}\left[\mathrm{m}^{\wedge} 2 \cdot \mathrm{K} / \mathrm{W}\right]\right)$ & $1.34[0.24]$ & $1.34[0.24]$ & $1.34[0.24]$ & $5.79[1.02]$ & $5.79[1.02]$ \\
\hline $\begin{array}{l}\text { Gross Dimensions - Total Area }\left(\mathrm{f}^{\wedge} 2\right. \\
\left.\left[\mathrm{m}^{\wedge} 2\right]\right)\end{array}$ & $34,875.07[3,240.00]$ & $34,875.07[3,240.00]$ & $34,875.07[3,240.00]$ & $34,875.07[3,240.00]$ & $34,875.07[3,240.00]$ \\
\hline Net Dimensions - Total Area $\left(\mathrm{ft}^{\wedge} 2\left[\mathrm{~m}^{\wedge} 2\right]\right)$ & $22,770.94[2,115.49]$ & $22,770.94[2,115.49]$ & $22,770.94[2,115.49]$ & $22,770.94[2,115.49]$ & $22,770.94[2,115.49]$ \\
\hline \multicolumn{6}{|l|}{ Roof } \\
\hline Construction & $R-15 \mathrm{ci}$ & $R-15 \mathrm{ci}$ & $R-15 \mathrm{ci}$ & $\mathrm{R}-15 \mathrm{ci}$ & $R-15 \mathrm{ci}$ \\
\hline$R$-value $\left(\mathrm{ft}^{\wedge} 2 \cdot \mathrm{h} \cdot \mathrm{O}^{\circ} / \mathrm{Btu}\left[\mathrm{m}^{\wedge} 2 \cdot \mathrm{K} / \mathrm{W}\right]\right)$ & $14.82(2.61)$ & $14.82(2.61)$ & $14.82(2.61)$ & $14.82(2.61)$ & $14.82(2.61)$ \\
\hline $\begin{array}{l}\text { Gross Dimensions - Total Area }\left(\mathrm{ft}^{\wedge} 2\right. \\
\left.\left[\mathrm{m}^{\wedge} \mathrm{N}\right]\right)\end{array}$ & $116,121.07[10,788.00]$ & $116,121.07[10,788.00]$ & $116,121.07[10,788.00]$ & $116,121.07[10,788.00]$ & $116,121.07[10,788.00]$ \\
\hline Net Dimensions - Total Area $\left(\mathrm{ft}^{\wedge} 2\left[\mathrm{~m}^{\wedge} 2\right]\right)$ & $115,640.46[10,743.35]$ & $115,640.46[10,743.35]$ & $115,640.46[10,743.35]$ & $115,640.46[10,743.35]$ & $115,640.46[10,743.35]$ \\
\hline \multicolumn{6}{|l|}{ Window } \\
\hline Dimensions - Total Area $\left(\mathrm{ft}^{\wedge} 2\left[\mathrm{~m}^{\wedge} \mathrm{2}\right]\right)$ & $\begin{array}{c}\text { South: } 4,702.00[436.83] \\
\text { East: } 1,337.20[124.23] \\
\text { North: } 4,663.14[433.22] \\
\text { West: } 1,401.78[130.23] \\
\text { Total: } 12,104.12[1,124.51]\end{array}$ & $\begin{array}{c}\text { South: } 4,702.00[436.83] \\
\text { East: } 1,337.20[124.23] \\
\text { North: } 4,663.14[433.22] \\
\text { West: } 1,401.78[130.23] \\
\text { Total: } 12,104.12[1,124.51]\end{array}$ & $\begin{array}{c}\text { South: } 4,702.00[436.83] \\
\text { East: } 1,337.20[124.23] \\
\text { North: } 4,663.14[433.22] \\
\text { West: } 1,401.78[130.23] \\
\text { Total: } 12,104.12[1,124.51]\end{array}$ & $\begin{array}{c}\text { South: } 4,702.00[436.83] \\
\text { East: } 1,337.20[124.23] \\
\text { North: } 4,663.14[433.22] \\
\text { West: } 1,401.78[130.23] \\
\text { Total: } 12,104.12[1,124.51]\end{array}$ & $\begin{array}{c}\text { South: } 4,702.00[436.83] \\
\text { East: } 1,337.20[124.23] \\
\text { North: } 4,663.14[433.22] \\
\text { West: } 1,401.78[130.23] \\
\text { Total: } 12,104.12[1,124.51]\end{array}$ \\
\hline Glass-type and frame & $\begin{array}{l}\text { Hypothetical window meeting U-factor and } \\
\text { SHGC shown below }\end{array}$ & $\begin{array}{l}\text { Hypothetical window meeting U-factor and } \\
\text { SHGC shown below }\end{array}$ & $\begin{array}{l}\text { Hypothetical window meeting U-factor and } \\
\text { SHGC shown below }\end{array}$ & $\begin{array}{l}\text { Hypothetical window meeting U-factor and } \\
\text { SHGC shown below }\end{array}$ & $\begin{array}{l}\text { Hypothetical window meeting U-factor and } \\
\text { SHGC shown below }\end{array}$ \\
\hline U-Factor (Btu/h:f(t八2.0F $\left.\left[\mathrm{W} / \mathrm{m}^{\wedge} 2 \cdot \mathrm{K}\right]\right)$ & $\begin{array}{l}\text { South: } 1.21[6.89] \\
\text { East: } 1.21[6.89] \\
\text { North: } 1.21[6.89] \\
\text { West: } 1.21[6.89]\end{array}$ & $\begin{array}{l}\text { South: } 1.21[6.89] \\
\text { East: } 1.21[6.89] \\
\text { North: } 1.21[6.89] \\
\text { West: } 1.21[6.89]\end{array}$ & $\begin{array}{l}\text { South: } 1.21[6.89] \\
\text { East } 1.21[6.89] \\
\text { North: } 1.21[6.89] \\
\text { West: } 1.21[6.89]\end{array}$ & $\begin{array}{l}\text { South: } 0.57[3.26] \\
\text { East: } 0.57 \text { [3.26] } \\
\text { North: } 0.57[3.26] \\
\text { West: } 0.57[3.26]\end{array}$ & $\begin{array}{l}\text { South: } 0.57[3.26] \\
\text { East: } 0.57[3.26] \\
\text { North: } 0.57[3.26] \\
\text { West: } 0.57[3.26]\end{array}$ \\
\hline SHGC & $\begin{array}{l}\text { South: } 0.25 \\
\text { East: } 0.25 \\
\text { North: } 0.61 \\
\text { West: } 0.25\end{array}$ & $\begin{array}{l}\text { South: } 0.25 \\
\text { East: } 0.25 \\
\text { North: } 0.61 \\
\text { West: } 0.25 \\
\end{array}$ & $\begin{array}{l}\text { South: } 0.25 \\
\text { East: } 0.25 \\
\text { North: } 0.61 \\
\text { West: } 0.25\end{array}$ & $\begin{array}{l}\text { South: } 0.25 \\
\text { East: } 0.25 \\
\text { North: } 0.39 \\
\text { West: } 0.25 \\
\end{array}$ & $\begin{array}{l}\text { South: } 0.25 \\
\text { East: } 0.25 \\
\text { North: } 0.39 \\
\text { West: } 0.25\end{array}$ \\
\hline Visible transmittance & $\begin{array}{l}\text { South: } 0.25 \\
\text { East: } 0.25 \\
\text { North: } 0.67 \\
\text { West: } 0.25\end{array}$ & $\begin{array}{l}\text { South: } 0.25 \\
\text { East: } 0.25 \\
\text { North: } 0.67 \\
\text { West: } 0.25\end{array}$ & $\begin{array}{l}\text { South: } 0.25 \\
\text { East: } 0.25 \\
\text { North: } 0.67 \\
\text { West: } 0.25\end{array}$ & $\begin{array}{l}\text { South: } 0.24 \\
\text { East: } 0.24 \\
\text { North: } 0.42 \\
\text { West: } 0.24\end{array}$ & $\begin{array}{l}\text { South: } 0.24 \\
\text { East: } 0.24 \\
\text { North: } 0.42 \\
\text { West: } 0.24\end{array}$ \\
\hline \multicolumn{6}{|l|}{\begin{tabular}{|l|} 
Foundation \\
\end{tabular}} \\
\hline Foundation Type & Mass Floor & Mass Floor & Mass Floor & Mass Floor & Mass Floor \\
\hline Construction & Carpet over heavy concrete and insulation & Carpet over heavy concrete and insulation & Carpet over heavy concrete and insulation & Carpet over heavy concrete and insulation & Carpet over heavy concrete and insulation \\
\hline R-value $\left(f t^{\wedge} 2 \cdot h \cdot \cdot \cdot F / B t u\left[m^{\wedge} 2 \cdot K / W\right]\right)$ & $2.11[0.37]$ & $2.11[0.37]$ & $2.11[0.37]$ & $2.11[0.37]$ & $2.11[0.37]$ \\
\hline Dimensions - Total Area $\left(\mathrm{ft}^{\wedge} 2\left[\mathrm{~m}^{\wedge} \mathrm{2}\right]\right)$ & $116,121.07[10,788.00]$ & $116,121.07[10,788.00]$ & $116,121.07[10,788.00]$ & $116,121.07[10,788.00]$ & $116,121.07[10,788.00]$ \\
\hline \multicolumn{6}{|l|}{ Interior Partitions } \\
\hline Construction & $2 \times 4$ steel-frame with gypsum board & $2 \times 4$ steel-frame with gypsum board & $2 \times 4$ steel-frame with gypsum board & $2 \times 4$ steel-frame with gypsum board & $2 \times 4$ steel-frame with gypsum board \\
\hline Dimensions - Total Area $\left(\mathrm{ft}^{\wedge} 2\left[\mathrm{~m}^{\wedge} 2\right]\right)$ & $41,720.92[3,876.00]$ & $41,720.92[3,876.00]$ & $41,720.92[3,876.00]$ & $41,720.92[3,876.00]$ & $41,720.92[3,876.00]$ \\
\hline \multicolumn{6}{|l|}{ Internal Mass } \\
\hline Construction & 6 inch wood & 6 inch wood & 6 inch wood & 6 inch wood & 6 inch wood \\
\hline Dimensions - Total Area $\left(f^{\wedge} 2\left[\mathrm{~m}^{\wedge} 2\right]\right)$ & $232,242.13[21,576.00]$ & $232,242.13[21,576.00]$ & $232,242.13[21,576.00]$ & $232,242.13[21,576.00]$ & $232,242.13[21,576.00]$ \\
\hline Thermal Properties $\left(\mathrm{lb} / \mathrm{f} / \mathrm{t}^{\wedge} 2\left[\mathrm{~kg} / \mathrm{m}^{\wedge} 2\right]\right)$ & $16.60[81.00]$ & $16.60[81.00]$ & $16.60[81.00]$ & $16.60[81.00]$ & $16.60[81.00]$ \\
\hline \multicolumn{6}{|l|}{ Air Barrier System } \\
\hline Infiltration (ACH) & 0.50 & 0.50 & 0.50 & 0.50 & 0.50 \\
\hline
\end{tabular}


Table D-2 Middle Baseline Scorecard: Climate Zones 1-3 (Cont.)

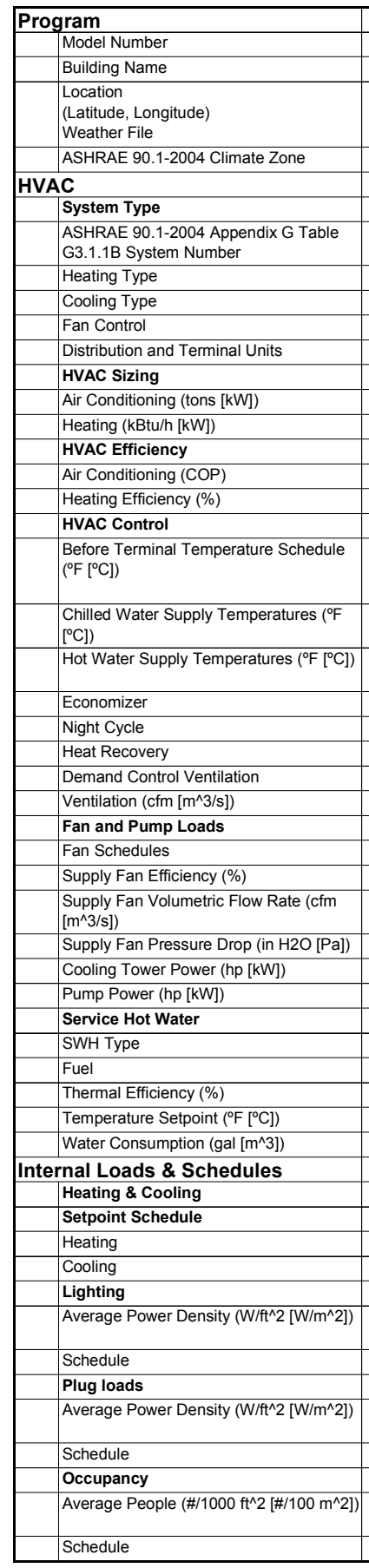

\begin{tabular}{|c|c|c|c|c|}
\hline 1 & 2 & 3 & 4 & 5 \\
\hline Middle School & Middle School & Middle School & Middle School & Middle School \\
\hline $\begin{array}{c}\text { Miami, FL } \\
(25.8,-80.27) \\
\text { USA FL Miami TMY2.epw }\end{array}$ & $\begin{array}{c}\text { Houston, TX } \\
(29.98,-95.37) \\
\text { USA TX Houston-Intercontinental TMY2.epw }\end{array}$ & $\begin{array}{c}\text { Phoenix, AZ } \\
\text { (33.43,-112.02) } \\
\text { USA AZ Phoenix TMY2.epw }\end{array}$ & $\begin{array}{c}\text { Memphis, TN } \\
\text { (35.05, -89.98) } \\
\text { USA TN Memphis TMY2.epw }\end{array}$ & $\begin{array}{c}\text { EI Paso, TX } \\
(31.8,-106.4) \\
\text { USA TX El.Paso TMY2.epw }\end{array}$ \\
\hline $1 \mathrm{~A}$ & $2 \mathrm{~A}$ & $2 \mathrm{~B}$ & $3 \mathrm{~A}$ & $3 B$ \\
\hline & & & & \\
\hline 3: PSZ-AC & 3: PSZ-AC & 3: PSZ-AC & 3: PSZ-AC & 3: PSZ-AC \\
\hline Gas Furnace & Gas Furnace & Gas Furnace & Gas Furnace & Gas Furnace \\
\hline Direct Expansion & Direct Expansion & Direct Expansion & Direct Expansion & Direct Expansion \\
\hline Constant Volume & Constant Volume & Constant Volume & Constant Volume & Constant Volume \\
\hline Single Zone/Direct Air & Single Zone/Direct Air & Single Zone/Direct Air & Single Zone/Direct Air & Single Zone/Direct Air \\
\hline Autosized (511.56 [1,799.17]) & Autosized (492.46 [1,731.98]) & Autosized $(522.62[1,838.04])$ & Autosized $(466.25[1,639.79])$ & Autosized (446.17 [1,569.17]) \\
\hline Autosized (259.21 [884.46]) & Autosized (290.41 [990.94]) & Autosized (281.31 [959.87]) & Autosized $(295.01[1,006.61])$ & Autosized (249.62 [851.74]) \\
\hline 3.30 & 3.30 & 3.30 & 3.30 & 3.30 \\
\hline 80.00 & 80.00 & 80.00 & 80.00 & 80.00 \\
\hline & & & & \\
\hline Jan - Mar: $55.4^{\circ} \mathrm{F}\left[13^{\circ} \mathrm{C}\right]$ & Jan - Mar: $55.4^{\circ} \mathrm{F}\left[13^{\circ} \mathrm{C}\right]$ & Jan - Mar: $55.4^{\circ} \mathrm{F}\left[13^{\circ} \mathrm{C}\right]$ & Jan - Mar: $55.4^{\circ} \mathrm{F}\left[13^{\circ} \mathrm{C}\right]$ & Jan - Mar: $55.4^{\circ} \mathrm{F}\left[13^{\circ} \mathrm{C}\right]$ \\
\hline $\begin{array}{l}\text { Apr - Sep: } 60.8^{\circ} \mathrm{F}\left[16^{\circ} \mathrm{C}\right] \\
\text { Oct - Dec: } 55.4^{\circ} \mathrm{F}\left[13^{\circ} \mathrm{C}\right]\end{array}$ & $\begin{array}{l}\text { Apr - Sep: } 60.8^{\circ} \mathrm{F}\left[16^{\circ} \mathrm{C}\right] \\
\text { Oct - Dec: } 55.4^{\circ}\left[13^{\circ} \mathrm{C}\right]\end{array}$ & $\begin{array}{l}\text { Apr - Sep: } 60.8^{\circ} \mathrm{F}\left[16^{\circ} \mathrm{C}\right] \\
\text { Oct - Dec: } 55.4^{\circ} \mathrm{F}\left[13^{\circ} \mathrm{C}\right]\end{array}$ & $\begin{array}{l}\text { Apr - Sep: } 60.8^{\circ} \mathrm{F}\left[16^{\circ} \mathrm{C}\right] \\
\text { Oct - Dec: } 55.4^{\circ} \mathrm{F}\left[13^{\circ} \mathrm{C}\right]\end{array}$ & $\begin{array}{l}\text { Apr - Sep: } 60.8^{\circ} \mathrm{F}\left[16^{\circ} \mathrm{C}\right] \\
\text { Oct - Dec: } 55.4^{\circ} \mathrm{F}\left[13^{\circ} \mathrm{C}\right]\end{array}$ \\
\hline N/A & $\mathrm{N} / \mathrm{A}$ & $\mathrm{N} / \mathrm{A}$ & N/A & $\mathrm{N} / \mathrm{A}$ \\
\hline N/A & $\mathrm{N} / \mathrm{A}$ & $\mathrm{N} / \mathrm{A}$ & $\mathrm{N} / \mathrm{A}$ & $\mathrm{N} / \mathrm{A}$ \\
\hline No & No & Yes & No & Yes \\
\hline Yes & Yes & Yes & Yes & Yes \\
\hline No & No & No & No & No \\
\hline Yes & Yes & Yes & Yes & Yes \\
\hline See Zone Level Information & See Zone Level Information & See Zone Level Information & See Zone Level Information & See Zone Level Information \\
\hline Always available & Always available & Always available & Always available & Always available \\
\hline 65.00 & 65.00 & 65.00 & 65.00 & 65.00 \\
\hline $228,030.05[107.62]$ & $218,167.30[102.96]$ & $235,273.87[111.04]$ & $200,179.49[94.47]$ & $200,855.84[94.79]$ \\
\hline $2.51[625.00]$ & $2.51[625.00]$ & $2.51[625.00]$ & $2.51[625.00]$ & $2.51[625.00]$ \\
\hline N/A & $\mathrm{N} / \mathrm{A}$ & N/A & N/A & N/A \\
\hline $\mathrm{N} / \mathrm{A}$ & N/A & N/A & $\mathrm{N} / \mathrm{A}$ & $\mathrm{N} / \mathrm{A}$ \\
\hline Storage Tank & Storage Tank & Storage Tank & Storage Tank & Storage Tank \\
\hline Natural Gas & Natural Gas & Natural Gas & Natural Gas & Natural Gas \\
\hline 80.00 & 80.00 & 80.00 & 80.00 & 80.00 \\
\hline 140.00 [60.00] & $140.00[60.00]$ & $140.00[60.00]$ & $140.00[60.00]$ & $140.00[60.00]$ \\
\hline $610,884.54[2,312.45]$ & $610,884.54[2,312.45]$ & $610,884.54[2,312.45]$ & $610,884.54[2,312.45]$ & $610,884.54[2,312.45]$ \\
\hline & & & & \\
\hline & & & & \\
\hline See HTGSETP_SCH & See HTGSETP_SCH & See HTGSETP_SCH & See HTGSETP_SCH & See HTGSETP_SCH \\
\hline See CLGSETP_SCH & See CLGSETP_SCH & See CLGSETP_SCH & See CLGSETP_SCH & See CLGSETP_SCH \\
\hline $1.52[16.40]$ & $1.52[16.40]$ & $1.52[16.40]$ & $1.52[16.40]$ & $1.52[16.40]$ \\
\hline See BLDG_LIGHT_SCH & See BLDG_LIGHT_SCH & See BLDG_LIGHT_SCH & See BLDG_LIGHT_SCH & See BLDG_LIGHT_SCH \\
\hline $0.82[8.84]$ & $0.82[8.84]$ & $0.82[8.84]$ & $0.82[8.84]$ & $0.82[8.84]$ \\
\hline See BLDG_EQUIP_SCH & See BLDG_EQUIP_SCH & See BLDG_EQUIP_SCH & See BLDG_EQUIP_SCH & See BLDG_EQUIP_SCH \\
\hline $27.05[29.11]$ & $27.05[29.11]$ & $27.05[29.11]$ & $27.05[29.11]$ & 27.05 [29.11] \\
\hline See BLDG_OCC_SCH & See BLDG_OCC_SCH & See BLDG_OCC_SCH & See BLDG_OCC_SCH & See BLDG_OCC_SCH \\
\hline
\end{tabular}


Table D-3 Middle Baseline Scorecard: Climate Zones 3-5

\begin{tabular}{|c|c|c|c|c|c|}
\hline Program & & & & & \\
\hline Model Number & 6 & 7 & 8 & 9 & 10 \\
\hline Building Name & Middle School & Middle School & Middle School & Middle School & Middle School \\
\hline $\begin{array}{l}\text { Location } \\
\text { (Latitude, Longitude) } \\
\text { Weather File }\end{array}$ & $\begin{array}{c}\text { San Francisco, CA } \\
(37.62,-122.38) \\
\text { USA_CA_San.Francisco_TMY2.epw }\end{array}$ & $\begin{array}{c}\text { Baltimore, MD } \\
\text { (39.18, -76.67) } \\
\text { USA_MD_Baltimore_TMY2.epw }\end{array}$ & $\begin{array}{c}\text { Albuquerque, NM } \\
(35.05,-106.62) \\
\text { USA_NM_Albuquerque_TMY2.epw }\end{array}$ & $\begin{array}{c}\text { Seattle, WA } \\
(47.45,-122.3) \\
\text { USA_WA_Seattle-Tacoma_TMY2.epw }\end{array}$ & $\begin{array}{c}\text { Chicago-ohare, IL } \\
(41.78,-87.75) \\
\text { USA_LL_Chicago-OHare_TMY2.epw }\end{array}$ \\
\hline ASHRAE 90.1-2004 Climate Zone & $3 \mathrm{C}$ & $4 \mathrm{~A}$ & 4B & $4 \mathrm{C}$ & $5 \mathrm{~A}$ \\
\hline \multicolumn{6}{|l|}{ Form } \\
\hline Total Floor Area $\left(\mathrm{ft}^{\wedge} 2\left[\mathrm{~m}^{\wedge} 2\right]\right)$ & $116,121.07[10,788.00]$ & $116,121.07[10,788.00]$ & $116,121.07[10,788.00]$ & $116,121.07[10,788.00]$ & $116,121.07[10,788.00]$ \\
\hline Number of Floors & 1 & 1 & 1 & 1 & 1 \\
\hline Window Fraction (Window to Wall Ratio) & $\begin{array}{l}\text { South: } 0.35 \\
\text { East: } 0.33 \\
\text { North: } 0.35 \\
\text { West: } 0.35 \\
\text { Total: } 0.35\end{array}$ & $\begin{array}{l}\text { South: } 0.35 \\
\text { East: } 0.33 \\
\text { North: } 0.35 \\
\text { West: } 0.35 \\
\text { Total: } 0.35\end{array}$ & $\begin{array}{l}\text { South: } 0.35 \\
\text { East: } 0.33 \\
\text { North: } 0.35 \\
\text { West: } 0.35 \\
\text { Total: } 0.35\end{array}$ & $\begin{array}{l}\text { South: } 0.35 \\
\text { East: } 0.33 \\
\text { North: } 0.35 \\
\text { West: } 0.35 \\
\text { Total: } 0.35\end{array}$ & $\begin{array}{l}\text { South: } 0.35 \\
\text { East: } 0.33 \\
\text { North: } 0.35 \\
\text { West: }: .35 \\
\text { Total: } 0.35\end{array}$ \\
\hline Skylight/TDD Percent & 0.41 & 0.41 & 0.41 & 0.41 & 0.41 \\
\hline Shading & None & None & None & None & None \\
\hline Floor to Floor Height (ft [m]) & $13.12[4.00]$ & $13.12[4.00]$ & $13.12[4.00]$ & $13.12[4.00]$ & $13.12[4.00]$ \\
\hline \multicolumn{6}{|l|}{ Fabric } \\
\hline \multicolumn{6}{|l|}{ Exterior walls } \\
\hline \begin{tabular}{|l} 
Construction \\
\end{tabular} & $\mathrm{R}-5.7 \mathrm{ci}$ & $\mathrm{R}-5.7 \mathrm{ci}$ & R-5.7 ci & R-5.7 ci & R-7.6 ci \\
\hline R-value $\left(\mathrm{ft}^{\wedge} 2 \cdot \mathrm{hr} \cdot{ }^{\circ} \mathrm{F} / \mathrm{Btu}\left[\mathrm{m}^{\wedge} 2 \cdot \mathrm{K} / \mathrm{W}\right]\right)$ & $5.79[1.02]$ & $5.79[1.02]$ & $5.79[1.02]$ & $5.79[1.02]$ & $7.31[1.29]$ \\
\hline $\begin{array}{l}\text { Gross Dimensions - Total Area }\left(\mathrm{ft}^{\wedge} 2\right. \\
\left.\left[\mathrm{m}^{\wedge} 2\right]\right)\end{array}$ & $34,875.07[3,240.00]$ & $34,875.07[3,240.00]$ & $34,875.07[3,240.00]$ & $34,875.07[3,240.00]$ & $34,875.07[3,240.00]$ \\
\hline Net Dimensions - Total Area $\left(\mathrm{ft}^{\wedge} 2\left[\mathrm{~m}^{\wedge} 2\right]\right)$ & $22,770.94[2,115.49]$ & $22,770.94[2,115.49]$ & $22,770.94[2,115.49]$ & $22,770.94[2,115.49]$ & $22,770.94[2,115.49]$ \\
\hline \multicolumn{6}{|l|}{ Roof } \\
\hline Construction & $R-10 c i$ & $\mathrm{R}-15 \mathrm{ci}$ & $\mathrm{R}-15 \mathrm{ci}$ & $\mathrm{R}-15 \mathrm{ci}$ & $\mathrm{R}-15 \mathrm{ci}$ \\
\hline R-value $\left(\mathrm{ft}^{\wedge} 2 \cdot \mathrm{h} \cdot{ }^{\circ} \mathrm{F} / \mathrm{Btu}\left[\mathrm{m}^{\wedge} 2 \cdot \mathrm{K} / \mathrm{W}\right]\right)$ & $9.69(1.71)$ & $14.82(2.61)$ & $14.82(2.61)$ & $14.82(2.61)$ & $14.82(2.61)$ \\
\hline $\begin{array}{l}\text { Gross Dimensions - Total Area }\left(\mathrm{ft}^{\wedge} 2\right. \\
\left.\left[\mathrm{m}^{\wedge} 2\right]\right)\end{array}$ & $116,121.07[10,788.00]$ & $116,121.07[10,788.00]$ & $116,121.07[10,788.00]$ & $116,121.07[10,788.00]$ & $116,121.07[10,788.00]$ \\
\hline Net Dimensions - Total Area $\left(\mathrm{ft}^{\wedge} 2\left[\mathrm{~m}^{\wedge} 2\right]\right)$ & $115,640.46[10,743.35]$ & $115,640.46[10,743.35]$ & $115,640.46[10,743.35]$ & $115,640.46[10,743.35]$ & $115,640.46[10,743.35]$ \\
\hline \multicolumn{6}{|l|}{ Window } \\
\hline Dimensions - Total Area $\left(\mathrm{ft}^{\wedge} 2\left[\mathrm{~m}^{\wedge} \mathrm{2}\right]\right)$ & $\begin{array}{c}\text { South: } 4,702.00[436.83] \\
\text { East: } 1,337.20[124.23] \\
\text { North: } 4,663.14[433.22] \\
\text { West: } 1,401.78[130.23] \\
\text { Total: } 12,104.12[1,124.51]\end{array}$ & $\begin{array}{c}\text { South: } 4,702.00[436.83] \\
\text { East: } 1,337.20[124.23] \\
\text { North: } 4,663.14[433.22] \\
\text { West: } 1,401.78[130.23] \\
\text { Total: } 12,104.12[1,124.51]\end{array}$ & $\begin{array}{c}\text { South: } 4,702.00[436.83] \\
\text { East: } 1,337.20[124.23] \\
\text { North: } 4,663.14[433.22] \\
\text { West: } 1,401.78[130.23] \\
\text { Total: } 12,104.12[1,124.51]\end{array}$ & $\begin{array}{c}\text { South: } 4,702.00[436.83] \\
\text { East: } 1,337.20[124.23] \\
\text { North: } 4,663.14[433.22] \\
\text { West: } 1,401.78[130.23] \\
\text { Total: } 12,104.12[1,124.51]\end{array}$ & $\begin{array}{c}\text { South: } 4,702.00[436.83] \\
\text { East: } 1,337.20[124.23] \\
\text { North: } 4,663.14[433.22] \\
\text { West: } 1,401.78[130.23] \\
\text { Total: } 12,104.12[1,124.51]\end{array}$ \\
\hline Glass-type and frame & $\begin{array}{l}\text { Hypothetical window meeting U-factor and } \\
\text { SHGC shown below }\end{array}$ & $\begin{array}{l}\text { Hypothetical window meeting U-factor and } \\
\text { SHGC shown below }\end{array}$ & $\begin{array}{l}\text { Hypothetical window meeting U-factor and } \\
\text { SHGC shown below }\end{array}$ & $\begin{array}{l}\text { Hypothetical window meeting U-factor and } \\
\text { SHGC shown below }\end{array}$ & $\begin{array}{l}\text { Hypothetical window meeting U-factor and } \\
\text { SHGC shown below }\end{array}$ \\
\hline U-Factor $\left(B t u / h \cdot f^{\wedge} 2 \cdot{ }^{\circ} F\left[W / m^{\wedge} 2 \cdot K\right]\right)$ & $\begin{array}{l}\text { South: } 1.21[6.89] \\
\text { East: } 1.21[6.89] \\
\text { North: } 1.21[6.89] \\
\text { West: } 1.21[6.89]\end{array}$ & $\begin{array}{l}\text { South: } 0.57[3.26] \\
\text { East: } 0.57 \text { [3.26] } \\
\text { North: } 0.57[3.26] \\
\text { West: } 0.57[3.26]\end{array}$ & $\begin{array}{l}\text { South: } 0.57[3.26] \\
\text { East: } 0.57[3.26] \\
\text { North: } 0.57[3.26] \\
\text { West: } 0.57[3.26]\end{array}$ & $\begin{array}{l}\text { South: } 0.57[3.26] \\
\text { East: } 0.57 \text { [3.26] } \\
\text { North: } 0.57[3.26] \\
\text { West: } 0.57[3.26]\end{array}$ & $\begin{array}{l}\text { South: } 0.57[3.26] \\
\text { East: } 0.57[3.26] \\
\text { North: } 0.57[3.26] \\
\text { West: } 0.57[3.26]\end{array}$ \\
\hline SHGC & $\begin{array}{l}\text { South: } 0.61 \\
\text { East: } 0.61 \\
\text { North: } 0.61 \\
\text { West: } 0.61\end{array}$ & $\begin{array}{l}\text { South: } 0.39 \\
\text { East: } 0.39 \\
\text { North: } 0.49 \\
\text { West: } 0.39\end{array}$ & $\begin{array}{l}\text { South: } 0.39 \\
\text { East: } 0.39 \\
\text { North: } 0.49 \\
\text { West: } 0.39\end{array}$ & $\begin{array}{l}\text { South: } 0.39 \\
\text { East: } 0.39 \\
\text { North: } 0.49 \\
\text { West: } 0.39\end{array}$ & $\begin{array}{l}\text { South: } 0.39 \\
\text { East: } 0.39 \\
\text { North: } 0.49 \\
\text { West: } 0.39\end{array}$ \\
\hline Visible transmittance & $\begin{array}{l}\text { South: } 0.67 \\
\text { East: } 0.67 \\
\text { North: } 0.67 \\
\text { West: } 0.67\end{array}$ & $\begin{array}{l}\text { South: } 0.42 \\
\text { East: } 0.42 \\
\text { North: } 0.53 \\
\text { West: } 0.42\end{array}$ & $\begin{array}{l}\text { South: } 0.42 \\
\text { East: } 0.42 \\
\text { North: } 0.53 \\
\text { West: } 0.42\end{array}$ & $\begin{array}{l}\text { South: } 0.42 \\
\text { East: } 0.42 \\
\text { North: } 0.53 \\
\text { West: } 0.42\end{array}$ & $\begin{array}{l}\text { South: } 0.42 \\
\text { East: } 0.42 \\
\text { North: } 0.53 \\
\text { West: } 0.42\end{array}$ \\
\hline \multicolumn{6}{|l|}{ Foundation } \\
\hline Foundation Type & Mass Floor & Mass Floor & Mass Floor & Mass Floor & Mass Floor \\
\hline Construction & Carpet over heavy concrete and insulation & Carpet over heavy concrete and insulation & Carpet over heavy concrete and insulation & Carpet over heavy concrete and insulation & Carpet over heavy concrete and insulation \\
\hline R-value $\left(\mathrm{ft}^{\wedge} 2 \cdot \mathrm{h} \cdot \mathrm{o}^{\circ} \mathrm{F} / \mathrm{Btu}\left[\mathrm{m}^{\wedge} 2 \cdot \mathrm{K} / \mathrm{W}\right]\right)$ & $2.11[0.37]$ & $2.11[0.37]$ & $2.11[0.37]$ & $2.11[0.37]$ & $2.11[0.37]$ \\
\hline Dimensions - Total Area $\left(\mathrm{t}^{\wedge} 2\left[\mathrm{~m}^{\wedge} 2\right]\right)$ & $116,121.07[10,788.00]$ & $116,121.07[10,788.00]$ & $116,121.07[10,788.00]$ & $116,121.07[10,788.00]$ & $116,121.07[10,788.00]$ \\
\hline \multicolumn{6}{|l|}{ Interior Partitions } \\
\hline Construction & $2 \times 4$ steel-frame with gypsum board & $2 \times 4$ steel-frame with gypsum board & $2 \times 4$ steel-frame with gypsum board & $2 \times 4$ steel-frame with gypsum board & $2 \times 4$ steel-frame with gypsum board \\
\hline Dimensions - Total Area $\left(\mathrm{ft}^{\wedge} 2\left[\mathrm{~m}^{\wedge} 2\right]\right)$ & $41,720.92[3,876.00]$ & $41,720.92[3,876.00]$ & $41,720.92[3,876.00]$ & $41,720.92[3,876.00]$ & $41,720.92[3,876.00]$ \\
\hline \multicolumn{6}{|l|}{ Internal Mass } \\
\hline Construction & 6 inch wood & 6 inch wood & 6 inch wood & 6 inch wood & 6 inch wood \\
\hline Dimensions - Total Area $\left(\mathrm{ft}^{\wedge} 2\left[\mathrm{~m}^{\wedge} 2\right]\right)$ & $232,242.13[21,576.00]$ & $232,242.13[21,576.00]$ & $232,242.13[21,576.00]$ & $232,242.13[21,576.00]$ & $232,242.13[21,576.00]$ \\
\hline Thermal Properties $\left(\mathrm{lb} / \mathrm{ft}^{\wedge} \Omega\left[\mathrm{kg} / \mathrm{m}^{\wedge} 2\right]\right)$ & $16.60[81.00]$ & $16.60[81.00]$ & $16.60[81.00]$ & $16.60[81.00]$ & $16.60[81.00]$ \\
\hline \multicolumn{6}{|l|}{ Air Barrier System } \\
\hline Infiltration (ACH) & 0.50 & 0.50 & 0.50 & 0.50 & 0.50 \\
\hline
\end{tabular}


Table D-4 Middle Baseline Scorecard: Climate Zones 3-5 (Cont.)

\begin{tabular}{|c|c|}
\hline & gram \\
\hline & Model Number \\
\hline & Building Name \\
\hline & $\begin{array}{l}\text { Location } \\
\text { (Latitude, Longitude) }\end{array}$ \\
\hline & Weather File \\
\hline & ASHRAE 90.1-2004 Climate Zone \\
\hline HV/ & \\
\hline & System Type \\
\hline & $\begin{array}{l}\text { ASHRAE 90.1-2004 Appendix G Table } \\
\text { G3.1.1B System Number }\end{array}$ \\
\hline & Heating Type \\
\hline & Cooling Type \\
\hline & Fan Control \\
\hline & Distribution and Terminal Units \\
\hline & HVAC Sizing \\
\hline & Air Conditioning (tons $[\mathrm{kW}]$ ) \\
\hline & Heating (kBtu/h [kW]) \\
\hline & HVAC Efficiency \\
\hline & Air Conditioning (COP) \\
\hline & Heating Efficiency (\%) \\
\hline & HVAC Control \\
\hline & $\begin{array}{l}\begin{array}{l}\text { Before Terminal Temperature Schedule } \\
\left({ }^{\circ}\left[{ }^{\circ} \mathrm{C}\right]\right)\end{array} \\
\end{array}$ \\
\hline & $\begin{array}{l}\text { Chilled Water Supply Temperatures }\left({ }^{\circ} \mathrm{F}\right. \\
\left.\left[{ }^{\circ} \mathrm{C}\right]\right)\end{array}$ \\
\hline & Hot Water Supply Temperatures $\left({ }^{\circ}\left[{ }^{\circ} \mathrm{C}\right]\right)$ \\
\hline & Economizer \\
\hline & Night Cycle \\
\hline & Heat Recovery \\
\hline & Demand Control Ventilation \\
\hline & Ventilation (cfm $\left.\left[\mathrm{m}^{\wedge} 3 / \mathrm{s}\right]\right)$ \\
\hline & Fan and Pump Loads \\
\hline & Fan Schedules \\
\hline & Supply Fan Efficiency (\%) \\
\hline & $\begin{array}{l}\text { Supply Fan Volumetric Flow Rate (cfm } \\
\left.\left[\mathrm{m}^{\wedge} 3 / \mathrm{s}\right]\right)\end{array}$ \\
\hline & Supply Fan Pressure Drop (in H2O [Pa]) \\
\hline & Cooling Tower Power (hp [kW]) \\
\hline & Pump Power (hp [kW]) \\
\hline & Service Hot Water \\
\hline & SWH Type \\
\hline & Fuel \\
\hline & Thermal Efficiency (\%) \\
\hline & Temperature Setpoint $\left({ }^{\circ} \mathrm{F}\left[{ }^{\circ} \mathrm{C}\right]\right)$ \\
\hline & Water Consumption (gal [ $\left.\left.\mathrm{m}^{\wedge} 3\right]\right)$ \\
\hline Inte & Inal Loads \& Schedules \\
\hline & Setpoint Schedule \\
\hline & Heating \\
\hline & Cooling \\
\hline & Lighting \\
\hline & Average Power Density $\left(\mathrm{W} / \mathrm{ft}^{\wedge} 2\left[\mathrm{~W} / \mathrm{m}^{\wedge} \mathrm{k}\right]\right)$ \\
\hline & Schedule \\
\hline & Plug loads \\
\hline & Average Power Density $\left(\mathrm{W} / \mathrm{ft}^{\wedge} 2\left[\mathrm{~W} / \mathrm{m}^{\wedge} \mathrm{k}\right]\right)$ \\
\hline & Schedule \\
\hline & Occupancy \\
\hline & Average People $\left(\# / 1000 \mathrm{ft}^{\wedge} 2\left[\# / 100 \mathrm{~m}^{\wedge}\right.\right.$ \\
\hline & Schedule \\
\hline
\end{tabular}

\begin{tabular}{|c|c|c|c|c|}
\hline & & & & \\
\hline 6 & 7 & 8 & 9 & 10 \\
\hline Middle School & Middle School & Middle School & Middle School & Middle School \\
\hline $\begin{array}{c}\text { San Francisco, CA } \\
(37.62,-122,38) \\
\text { USA_CA_San.Francisco_TMY2.epw }\end{array}$ & $\begin{array}{c}\text { Baltimore, MD } \\
\text { (39.18, -76.67) } \\
\text { USA_MD_Baltimore_TMY2.epw }\end{array}$ & $\begin{array}{c}\text { Albuquerque, NM } \\
\text { (35.05,-106.62) } \\
\text { USA_NM_Albuquerque_TMY2.epw }\end{array}$ & $\begin{array}{c}\text { Seattle,WA } \\
\text { (47.45, }-122.3) \\
\text { USA_WA_Seattle-Tacoma_TMY2.epw }\end{array}$ & $\begin{array}{c}\text { Chicago-ohare, IL } \\
\text { (41.78, -87.75) } \\
\text { USA_Chicago-OHare_TMY2.epw }\end{array}$ \\
\hline $3 \mathrm{C}$ & $4 \mathrm{~A}$ & $4 \mathrm{~B}$ & $4 \mathrm{C}$ & $5 \mathrm{~A}$ \\
\hline & & & & \\
\hline 3: PSZ-AC & 3: PSZ-AC & 3: PSZ-AC & 3: PSZ-AC & 3: PSZ-AC \\
\hline Gas Furnace & Gas Furnace & Gas Furnace & Gas Furnace & Gas Furnace \\
\hline Direct Expansion & Direct Expansion & Direct Expansion & Direct Expansion & Direct Expansion \\
\hline Constant Volume & Constant Volume & Constant Volume & Constant Volume & Constant Volume \\
\hline Single Zone/Direct Air & Single Zone/Direct Air & Single Zone/Direct Air & Single Zone/Direct Air & Single Zone/Direct Air \\
\hline Autosized (497.39 [1,749.32]) & Autosized (448.96 [1,579.00]) & Autosized (470.10 [1,653.33]) & Autosized (425.38 [1,496.06]) & Autosized (449.74 [1,581.74]) \\
\hline Autosized (276.32 [942.84]) & Autosized (306.32 [1,045.19]) & Autosized (258.31 [881.39]) & Autosized (270.49 [922.95]) & Autosized $(337.56[1,151.80])$ \\
\hline & & & & \\
\hline 3.30 & 3.30 & 3.30 & 3.30 & 3.30 \\
\hline 80.00 & 80.00 & 80.00 & 80.00 & 80.00 \\
\hline & & & & \\
\hline $\begin{array}{l}\text { Jan - Mar: } 55.4^{\circ} \mathrm{F}\left[13^{\circ} \mathrm{C}\right] \\
\text { Apr - Sep: } 6.8^{\circ}\left[16^{\circ} \mathrm{C}\right] \\
\text { Oct - Dec: } 55.4^{\circ} \mathrm{F}\left[13^{\circ} \mathrm{C}\right]\end{array}$ & $\begin{array}{l}\text { Jan - Mar: } 55.4^{\circ} \mathrm{F}\left[13^{\circ} \mathrm{C}\right] \\
\text { Apr - Sep: } 6.8^{\circ}\left[16^{\circ} \mathrm{C}\right] \\
\text { Oct - Dec: } 55.4^{\circ} \mathrm{F}\left[13^{\circ} \mathrm{C}\right]\end{array}$ & $\begin{array}{l}\text { Jan - Mar: } 55.4^{\circ} \mathrm{F}\left[13^{\circ} \mathrm{C}\right] \\
\text { Apr - Sep: } 6.8^{\circ} \mathrm{F}\left[16^{\circ} \mathrm{C}\right] \\
\text { Oct - Dec: } 55.4^{\circ} \mathrm{F}\left[13^{\circ} \mathrm{C}\right]\end{array}$ & $\begin{array}{l}\text { Jan - Mar: } 55.4^{\circ} \mathrm{F}\left[13^{\circ} \mathrm{C}\right] \\
\text { Apr - Sep: } 6.8^{\circ} \mathrm{F}\left[16^{\circ} \mathrm{C}\right] \\
\text { Oct - Dec: } 55.4^{\circ} \mathrm{F}\left[13^{\circ} \mathrm{C}\right]\end{array}$ & $\begin{array}{l}\text { Jan - Mar: } 55.4^{\circ} \mathrm{F}\left[13^{\circ} \mathrm{C}\right] \\
\text { Apr - Sep: } 60.8^{\circ} \mathrm{F}\left[16^{\circ} \mathrm{C}\right] \\
\text { Oct - Dee. } 54^{\circ 0 \mathrm{~F}}\left[13^{\circ} \mathrm{C}\right.\end{array}$ \\
\hline$\frac{\text { Oct - Dec: } 55.4^{\circ} F\left[13^{\circ} \mathrm{C}\right]}{\mathrm{N} / \mathrm{A}}$ & $\frac{\text { Oct - Dec: } 55.4^{4} F\left[13^{\circ} \mathrm{C}\right]}{\mathrm{N} / \mathrm{A}}$ & $\frac{\text { Oct - Dec: } 55.4^{4} F\left[13^{\circ} \mathrm{C}\right]}{\mathrm{N} / \mathrm{A}}$ & $\frac{0 \text { ct - Dec: } 55.4^{\circ} F\left[13^{\circ} \mathrm{C}\right]}{\mathrm{N} / \mathrm{A}}$ & $\frac{0 \text { ct - Dec: } 55.4^{\circ} \mathrm{F}\left[13^{\mathrm{C}}\right]}{\mathrm{N} / \mathrm{A}}$ \\
\hline N/A & N/A & $\mathrm{N} / \mathrm{A}$ & N/A & N/A \\
\hline Yes & No & Yes & Yes & Yes \\
\hline Yes & Yes & Yes & Yes & Yes \\
\hline No & No & No & No & No \\
\hline Yes & Yes & Yes & Yes & Yes \\
\hline See Zone Level Information & See Zone Level Information & See Zone Level Information & See Zone Level Information & See Zone Level Information \\
\hline & & & & \\
\hline Always available & Always available & Always available & Always available & Always available \\
\hline 65.00 & 65.00 & 65.00 & 65.00 & 65.00 \\
\hline $223,916.25[105.68]$ & $199,960.40[94.37]$ & $211,626.95[99.88]$ & $191,497.81[90.38]$ & $201,449.76[95.07]$ \\
\hline $2.51[625.00]$ & $2.51[625.00]$ & $2.51[625.00]$ & $2.51[625.00]$ & $2.51[625.00]$ \\
\hline N/A & N/A & $\mathrm{N} / \mathrm{A}$ & $\mathrm{N} / \mathrm{A}$ & $\mathrm{N} / \mathrm{A}$ \\
\hline N/A & N/A & N/A & N/A & N/A \\
\hline & & & & \\
\hline Storage Tank & Storage Tank & Storage Tank & Storage Tank & Storage Tank \\
\hline Natural Gas & Natural Gas & Natural Gas & Natural Gas & Natural Gas \\
\hline 80.00 & 80.00 & 80.00 & 80.00 & 80.00 \\
\hline $140.00[60.00]$ & $140.00[60.00]$ & $140.00[60.00]$ & $140.00[60.00]$ & $140.00[60.00]$ \\
\hline $610,884.54[2,312.45]$ & $610,884.54[2,312.45]$ & $610,884.54[2,312.45]$ & $610,884.54[2,312.45]$ & $610,884.54[2,312.45]$ \\
\hline & & & & \\
\hline & & & & \\
\hline See HTGSETP_SCH & See HTGSETP_SCH & See HTGSETP_SCH & See HTGSETP_SCH & See HTGSETP_SCH \\
\hline See CLGSETP_SCH & See CLGSETP_SCH & See CLGSETP_SCH & See CLGSETP_SCH & See CLGSETP_SCH \\
\hline $1.52[16.40]$ & $1.52[16.40]$ & $1.52[16.40]$ & $1.52[16.40]$ & $1.52[16.40]$ \\
\hline See BLDG_LIGHT_SCH & See BLDG_LIGHT_SCH & See BLDG_LIGHT_SCH & See BLDG_LIGHT_SCH & See BLDG_LIGHT_SCH \\
\hline & & & & \\
\hline $0.82[8.84]$ & $0.82[8.84]$ & $0.82[8.84]$ & $0.82[8.84]$ & $0.82[8.84]$ \\
\hline See BLDG_EQUIP_SCH & See BLDG_EQUIP_SCH & See BLDG_EQUIP_SCH & See BLDG_EQUIP_SCH & See BLDG_EQUIP_SCH \\
\hline $27.05[29.11]$ & $27.05[29.11]$ & $27.05[29.11]$ & $27.05[29.11]$ & $27.05[29.11]$ \\
\hline See BLDG_OCC_SCH & See BLDG_OCC_SCH & See BLDG_OCC_SCH & See BLDG_OCC_SCH & See BLDG_OCC_SCH \\
\hline
\end{tabular}


Table D-5 Middle Baseline Scorecard: Climate Zones 5-8

\begin{tabular}{|c|c|c|c|c|c|}
\hline \multicolumn{6}{|l|}{ Program } \\
\hline Model Number & 11 & 12 & 13 & 14 & 15 \\
\hline Building Name & Middle School & Middle School & Middle School & Middle School & Middle School \\
\hline $\begin{array}{l}\text { Location } \\
\text { Latitude, Longitude) } \\
\text { Weather File }\end{array}$ & $\begin{array}{c}\text { Boise, ID } \\
\text { (43.57,-116.22) } \\
\text { USA_ID_Boise_TMY2.epw }\end{array}$ & $\begin{array}{c}\text { Burlington, VT } \\
\text { (44.47, } 73.15 \text { ) } \\
\text { USA_VT_Burlington_TMY2.epw }\end{array}$ & $\begin{array}{c}\text { Helena, MT } \\
\text { (46.6,-112) } \\
\text { USA_MT_Helena_TMY2.epw }\end{array}$ & $\begin{array}{c}\text { Duluth, MN } \\
\text { (46.83,-92.18) } \\
\text { USA_MN_Duluth_TMY2.epw }\end{array}$ & $\begin{array}{c}\text { Fairbanks, AK } \\
\text { (64.82, -174.87) } \\
\text { USA_AK_Fairbanks_TMY2.epw }\end{array}$ \\
\hline ASHRAE 90.1-2004 Climate Zone & $5 \mathrm{~B}$ & $6 \mathrm{~A}$ & $6 \mathrm{~B}$ & $7 \mathrm{~A}$ & $8 \mathrm{~A}$ \\
\hline \multicolumn{6}{|l|}{ Form } \\
\hline Total Floor Area $\left(\mathrm{ft}^{\wedge} 2\left[\mathrm{~m}^{\wedge} \mathrm{2}\right]\right)$ & $116,121.07[10,788.00]$ & $116,121.07[10,788.00]$ & $116,121.07[10,788.00]$ & $116,121.07[10,788.00]$ & $116,121.07[10,788.00]$ \\
\hline Number of Floors & 1 & 1 & 1 & 1 & 1 \\
\hline Window Fraction (Window to Wall Ratio) & $\begin{array}{l}\text { South: } 0.35 \\
\text { East: } 0.33 \\
\text { North: } 0.35 \\
\text { West: } 0.35 \\
\text { Total: } 0.35\end{array}$ & $\begin{array}{l}\text { South: } 0.35 \\
\text { East: } 0.33 \\
\text { North: } 0.35 \\
\text { West: } 0.35 \\
\text { Total: } 0.35\end{array}$ & $\begin{array}{c}\text { South: } 0.35 \\
\text { East: } 0.33 \\
\text { North: } 0.35 \\
\text { West: } 0.35 \\
\text { Total: } 0.35\end{array}$ & $\begin{array}{l}\text { South: } 0.35 \\
\text { East: } 0.33 \\
\text { North: } 0.35 \\
\text { West: } 0.35 \\
\text { Total: } 0.35\end{array}$ & $\begin{array}{l}\text { South: } 0.35 \\
\text { East: } 0.33 \\
\text { North: } 0.35 \\
\text { West: } 0.35 \\
\text { Total: } 0.35\end{array}$ \\
\hline Skylight/TDD Percent & 0.41 & 0.41 & 0.41 & 0.41 & 0.41 \\
\hline Shading & None & None & None & None & None \\
\hline Floor to Floor Height (ft [m]) & $13.12[4.00]$ & $13.12[4.00]$ & $13.12[4.00]$ & $13.12[4.00]$ & $13.12[4.00]$ \\
\hline \multicolumn{6}{|l|}{ Fabric } \\
\hline \multicolumn{6}{|l|}{ Exterior walls } \\
\hline Construction & R-7.6 ci & R-7.6 ci & R-7.6 ci & $\mathrm{R}-11.4 \mathrm{ci}$ & $\mathrm{R}-13.3 \mathrm{ci}$ \\
\hline R-value $\left(\mathrm{ft}^{\wedge} 2 \cdot \mathrm{hr} \cdot{ }^{\circ} \mathrm{F} / \mathrm{Btu}\left[\mathrm{m}^{\wedge} 2 \cdot \mathrm{K} / \mathrm{W}\right]\right)$ & $7.31[1.29]$ & $8.75[1.54]$ & 8.75 [1.54] & $10.21[1.80]$ & $11.58[2.04]$ \\
\hline $\begin{array}{l}\text { Gross Dimensions - Total Area }\left(\mathrm{ft}^{\wedge} 2\right. \\
\left.\left[\mathrm{m}^{\wedge} \mathrm{2}\right]\right)\end{array}$ & $34,875.07[3,240.00]$ & $34,875.07[3,240.00]$ & $34,875.07[3,240.00]$ & $34,875.07[3,240.00]$ & $34,875.07[3,240.00]$ \\
\hline Net Dimensions - Total Area $\left(\mathrm{ft}^{\wedge} 2\left[\mathrm{~m}^{\wedge} 2\right]\right)$ & $22,770.94[2,115.49]$ & $22,770.94[2,115.49]$ & $22,770.94[2,115.49]$ & $22,770.94[2,115.49]$ & $22,770.94[2,115.49]$ \\
\hline \multicolumn{6}{|l|}{ Roof } \\
\hline Construction & $\mathrm{R}-15 \mathrm{ci}$ & $\mathrm{R}-15 \mathrm{ci}$ & $\mathrm{R}-15 \mathrm{ci}$ & $\mathrm{R}-15 \mathrm{ci}$ & $\mathrm{R}-20 \mathrm{ci}$ \\
\hline R-value $\left(\mathrm{ft}^{\wedge} 2 \cdot h \cdot{ }^{\circ} \mathrm{F} / \mathrm{Btu}\left[\mathrm{m}^{\wedge} 2 \cdot \mathrm{K} / \mathrm{W}\right]\right)$ & $14.82(2.61)$ & $14.82(2.61)$ & $14.82(2.61)$ & $14.82(2.61)$ & $19.67(3.46)$ \\
\hline $\begin{array}{l}\text { Gross Dimensions - Total Area ( } \mathrm{ft}^{\wedge} 2 \\
{\left[\mathrm{~m}^{\wedge} 2\right] \text { ) }}\end{array}$ & $116,121.07[10,788.00]$ & $116,121.07[10,788.00]$ & $116,121.07[10,788.00]$ & $116,121.07[10,788.00]$ & $116,121.07[10,788.00]$ \\
\hline Net Dimensions - Total Area $\left(\mathrm{ft}^{\wedge} 2\left[\mathrm{~m}^{\wedge} \mathrm{2}\right]\right)$ & $115,640.46[10,743.35]$ & $115,640.46[10,743.35]$ & $115,640.46[10,743.35]$ & $115,640.46[10,743.35]$ & $115,640.46[10,743.35]$ \\
\hline \multicolumn{6}{|l|}{ Window } \\
\hline Dimensions - Total Area $\left(\mathrm{ft}^{\wedge} 2\left[\mathrm{~m}^{\wedge} 2\right]\right)$ & $\begin{array}{c}\text { South: } 4,702.00[436.83] \\
\text { East: } 1,337.20[124.23] \\
\text { North: } 4,663.14[433.22] \\
\text { West: } 1,401.78[130.23] \\
\text { Total: } 12,104.12[1,124.51]\end{array}$ & $\begin{array}{c}\text { South: } 4,702.00[436.83] \\
\text { East: } 1,337.20[124.23] \\
\text { North: } 4,663.14[433.22] \\
\text { West: } 1,401.78[130.23] \\
\text { Total: } 12,104.12[1,124.51]\end{array}$ & $\begin{array}{c}\text { South: } 4,702.00[436.83] \\
\text { East: } 1,337.20[124.23] \\
\text { North: } 4,663.14[433.22] \\
\text { West: } 1,401.78[130.23] \\
\text { Total: } 12,104.12[1,124.51]\end{array}$ & $\begin{array}{c}\text { South: } 4,702.00[436.83] \\
\text { East: } 1,337.20[124.23] \\
\text { North: } 4,663.14[433.22] \\
\text { West: } 1,401.78[130.23] \\
\text { Total: } 12,104.12[1,124.51]\end{array}$ & $\begin{array}{c}\text { South: } 4,702.00[436.83] \\
\text { East: } 1,337.20[124.23] \\
\text { North: } 4,663.14[433.22] \\
\text { West: } 1,401.78[130.23] \\
\text { Total: } 12,104.12[1,124.51]\end{array}$ \\
\hline Glass-type and frame & $\begin{array}{l}\text { Hypothetical window meeting U-factor and } \\
\text { SHGC shown below }\end{array}$ & $\begin{array}{l}\text { Hypothetical window meeting U-factor and } \\
\text { SHGC shown below }\end{array}$ & $\begin{array}{l}\text { Hypothetical window meeting U-factor and } \\
\text { SHGC shown below }\end{array}$ & $\begin{array}{l}\text { Hypothetical window meeting U-factor and } \\
\text { SHGC shown below }\end{array}$ & $\begin{array}{l}\text { Hypothetical window meeting U-factor and } \\
\text { SHGC shown below }\end{array}$ \\
\hline 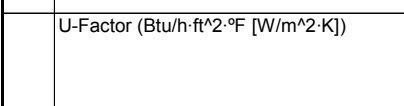 & $\begin{array}{l}\text { South: } 0.57[3.26] \\
\text { East: } 0.57[3.26] \\
\text { North: } 0.57[3.26] \\
\text { West: } 0.57[3.26]\end{array}$ & 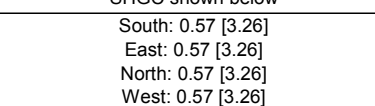 & $\begin{array}{l}\text { South: } 0.57[3.26] \\
\text { East: } 0.57[3.26] \\
\text { North: } 0.57[3.26] \\
\text { West: } 0.57[3.26]\end{array}$ & $\begin{array}{l}\text { South: } 0.57[3.26] \\
\text { East: } 0.57[3.26] \\
\text { North: } 0.57[3.25] \\
\text { West: } 0.57[3.26]\end{array}$ & $\begin{array}{l}\text { South: } 0.46[2.63] \\
\text { East: } 0.46[2.64] \\
\text { North: } 0.46[2.64] \\
\text { West: } 0.46[2.63]\end{array}$ \\
\hline SHGC & $\begin{array}{l}\text { South: } 0.39 \\
\text { East: } 0.39 \\
\text { North: } 0.49 \\
\text { West: } 0.39\end{array}$ & $\begin{array}{l}\text { South: } 0.39 \\
\text { East: } 0.39 \\
\text { North: } 0.49 \\
\text { West: } 0.39\end{array}$ & $\begin{array}{l}\text { South: } 0.39 \\
\text { East: } 0.39 \\
\text { North: } 0.49 \\
\text { West: } 0.39\end{array}$ & $\begin{array}{l}\text { South: } 0.49 \\
\text { East } 0.49 \\
\text { North: } 0.64 \\
\text { West: } 0.49\end{array}$ & $\begin{array}{l}\text { South: } 0.36 \\
\text { East: } 0.46 \\
\text { North: } 0.46 \\
\text { West: } 0.36\end{array}$ \\
\hline Visible transmittance & $\begin{array}{l}\text { South: } 0.42 \\
\text { East: } 0.42 \\
\text { North: } 0.53 \\
\text { West: } 0.42\end{array}$ & $\begin{array}{l}\text { South: } 0.42 \\
\text { East: } 0.42 \\
\text { North: } 0.53 \\
\text { West: } 0.42\end{array}$ & $\begin{array}{l}\text { South: } 0.42 \\
\text { East } 0.42 \\
\text { North: } 0.53 \\
\text { West: } 0.42\end{array}$ & $\begin{array}{l}\text { South: } 0.53 \\
\text { East: } 0.53 \\
\text { North: } 0.71 \\
\text { West: } 0.53\end{array}$ & $\begin{array}{l}\text { South: } 0.38 \\
\text { East: } 0.49 \\
\text { North: } 0.49 \\
\text { West: } 0.38\end{array}$ \\
\hline \multicolumn{6}{|l|}{ Foundation } \\
\hline Foundation Type & Mass Floor & Mass Floor & Mass Floor & Mass Floor & Mass Floor \\
\hline Construction & Carpet over heavy concrete and insulation & Carpet over heavy concrete and insulation & Carpet over heavy concrete and insulation & Carpet over heavy concrete and insulation & Carpet over heavy concrete and insulation \\
\hline 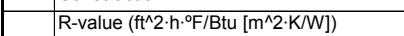 & $2.11[0.37]$ & $2.11[0.37]$ & $2.11[0.37]$ & $2.11[0.37]$ & $2.11[0.37]$ \\
\hline Dimensions - Total Area $\left(\mathrm{f}^{\wedge} \mathrm{N} 2\left[\mathrm{~m}^{\wedge} 2\right]\right)$ & $116,121.07[10,788.00]$ & $116,121.07[10,788.00]$ & $116,121.07[10,788.00]$ & $116,121.07[10,788.00]$ & $116,121.07[10,788.00]$ \\
\hline \multicolumn{6}{|l|}{ Interior Partitions } \\
\hline Construction & $2 \times 4$ steel-frame with gypsum board & $2 \times 4$ steel-frame with gypsum board & $2 \times 4$ steel-frame with gypsum board & $2 \times 4$ steel-frame with gypsum board & $2 \times 4$ steel-frame with gypsum board \\
\hline Dimensions - Total Area $\left(\mathrm{ft}^{\wedge} 2\left[\mathrm{~m}^{\wedge} 2\right]\right)$ & $41,720.92[3,876.00]$ & $41,720.92[3,876.00]$ & $41,720.92[3,876.00]$ & $41,720.92[3,876.00]$ & $41,720.92[3,876.00]$ \\
\hline \multicolumn{6}{|l|}{ Internal Mass } \\
\hline Construction & 6 inch wood & 6 inch wood & 6 inch wood & 6 inch wood & 6 inch wood \\
\hline Dimensions - Total Area $\left(\mathrm{ft}^{\wedge} 2\left[\mathrm{~m}^{\wedge} 2\right]\right)$ & $232,242.13[21,576.00]$ & $232,242.13[21,576.00]$ & $232,242.13[21,576.00]$ & $232,242.13[21,576.00]$ & $232,242.13[21,576.00]$ \\
\hline Thermal Properties $\left(\mathrm{lb} / \mathrm{ft}^{\wedge} 2\left[\mathrm{~kg} / \mathrm{m}^{\wedge} \mathrm{Z}\right]\right)$ & $16.60[81.00]$ & $16.60[81.00]$ & $16.60[81.00]$ & $16.60[81.00]$ & $16.60[81.00]$ \\
\hline Air Barrier System & & & & & \\
\hline Infiltration (ACH) & 0.50 & 0.50 & 0.50 & 0.50 & 0.50 \\
\hline
\end{tabular}


Table D-6 Middle Baseline Scorecard: Climate Zones 5-8 (Cont.)

\begin{tabular}{|c|c|c|c|c|c|}
\hline Program & & & & & \\
\hline Model Number & 11 & 12 & 13 & 14 & 15 \\
\hline Building Name & Middle School & Middle School & Middle School & Middle School & Middle School \\
\hline $\begin{array}{l}\text { Location } \\
\text { (Latitude, Longitude) } \\
\text { Weather File }\end{array}$ & $\begin{array}{c}\text { Boise, ID } \\
\text { (43.57, -116.22) } \\
\text { USA ID_Boise_TMY2.epw }\end{array}$ & $\begin{array}{c}\text { Burlington, VT } \\
\text { (44.47, } 73.15 \text { ) } \\
\text { USA VT Burlington_TMY2.epw }\end{array}$ & $\begin{array}{c}\text { Helena, MT } \\
(46.6,-112) \\
\text { USA MT_Helena_TMY2.epw }\end{array}$ & $\begin{array}{c}\text { Duluth, MN } \\
\text { (46.83,-92.18) } \\
\text { USA MN Duluth TMY2.epw }\end{array}$ & $\begin{array}{c}\text { Fairbanks, AK } \\
(64.82,-147.87) \\
\text { USA AK Fairbanks TMY2.epw }\end{array}$ \\
\hline ASHRAE 90.1-2004 Climate Zone & $5 \mathrm{~B}$ & $6 \mathrm{~A}$ & $6 \mathrm{~B}$ & $7 \mathrm{~A}$ & $8 \mathrm{~A}$ \\
\hline \multicolumn{6}{|l|}{ HVAC } \\
\hline System Type & & & & & \\
\hline $\begin{array}{l}\text { ASHRAE 90.1-2004 Appendix G Table } \\
\text { G3.1.1B System Number }\end{array}$ & 3: PSZ-AC & 3: PSZ-AC & 3: PSZ-AC & 3: PSZ-AC & 3: PSZ-AC \\
\hline Heating Type & Gas Furnace & Gas Furnace & Gas Furnace & Gas Furnace & Gas Furnace \\
\hline Cooling Type & Direct Expansion & Direct Expansion & Direct Expansion & Direct Expansion & Direct Expansion \\
\hline Fan Control & Constant Volume & Constant Volume & Constant Volume & Constant Volume & Constant Volume \\
\hline Distribution and Terminal Units & Single Zone/Direct Air & Single Zone/Direct Air & Single Zone/Direct Air & Single Zone/Direct Air & Single Zone/Direct Air \\
\hline \multicolumn{6}{|l|}{ HVAC Sizing } \\
\hline Air Conditioning (tons [kW]) & Autosized $(468.15[1,646.48])$ & Autosized (417.88 [1,469.69]) & Autosized (447.04 [1,572.24]) & Autosized (439.27 [1,544.92]) & Autosized $(346.16[1,217.45])$ \\
\hline Heating (kBtu/h [kW]) & Autosized $(303.94[1,037.08])$ & Autosized (338.56 [1,155.21]) & Autosized $(319.34[1,089.62])$ & Autosized $(352.81[1,203.83])$ & Autosized $(374.36[1,277.37])$ \\
\hline \multicolumn{6}{|l|}{ HVAC Efficiency } \\
\hline Air Conditioning (COP) & 3.30 & 3.30 & 3.30 & 3.30 & 3.30 \\
\hline Heating Efficiency (\%) & 80.00 & 80.00 & 80.00 & 80.00 & 80.00 \\
\hline \multicolumn{6}{|l|}{ HVAC Control } \\
\hline $\begin{array}{l}\text { Before Terminal Temperature Schedule } \\
\left({ }^{\circ} \mathrm{F}\left[{ }^{\circ} \mathrm{C}\right]\right)\end{array}$ & $\begin{array}{l}\text { Jan - Mar: } 55.4^{\circ} \mathrm{F}\left[13^{\circ} \mathrm{C}\right] \\
\text { Apr - Sep: } 60.8^{\circ} \mathrm{F}\left[16^{\circ} \mathrm{C}\right] \\
\text { Oct - Dec: } 5.4^{\circ} \mathrm{F}\left[13^{\circ} \mathrm{C}\right]\end{array}$ & $\begin{array}{l}\text { Jan - Mar: } 55.4^{\circ} \mathrm{F}\left[13^{\circ} \mathrm{C}\right] \\
\text { Apr - Sep: } 60.8^{\circ}\left[16^{\circ} \mathrm{C}\right] \\
\text { Oct - Dec: } 55.4^{\circ} \mathrm{F}\left[13^{\circ} \mathrm{C}\right]\end{array}$ & $\begin{array}{l}\text { Jan - Mar: } 55.4^{\circ} \mathrm{F}\left[13^{\circ} \mathrm{C}\right] \\
\text { Apr - Sep: } 60.8^{\circ}\left[16^{\circ} \mathrm{F}\right] \\
\text { Oct - Dec: } 55.4^{\circ} \mathrm{F}\left[13^{\circ} \mathrm{C}\right]\end{array}$ & $\begin{array}{l}\text { Jan - Mar: } 55.4^{\circ} \mathrm{F}\left[13^{\circ} \mathrm{C}\right] \\
\text { Apr - Sep: } 60.8^{\circ}\left[16^{\circ} \mathrm{C}\right] \\
\text { Oct - Dec: } 55.4^{\circ} \mathrm{F}\left[13^{\circ} \mathrm{C}\right]\end{array}$ & $\begin{array}{l}\text { Jan - Mar: } 55.4^{\circ} \mathrm{F}\left[13^{\circ} \mathrm{C}\right] \\
\text { Apr - Sep: } 60.8^{\circ}\left[16^{\circ} \mathrm{C}\right] \\
\text { Oct - Dec: } 55.4^{\circ} \mathrm{F}\left[13^{\circ} \mathrm{C}\right]\end{array}$ \\
\hline $\begin{array}{l}\begin{array}{l}\text { Chilled Water Supply Temperatures }\left({ }^{\circ} \mathrm{F}\right. \\
\left.\left[{ }^{\circ} \mathrm{C}\right]\right)\end{array}\end{array}$ & $\mathrm{N} / \mathrm{A}$ & $\mathrm{N} / \mathrm{A}$ & $\mathrm{N} / \mathrm{A}$ & $\mathrm{N} / \mathrm{A}$ & $\mathrm{N} / \mathrm{A}$ \\
\hline Hot Water Supply Temperatures $\left({ }^{\circ} \mathrm{F}\left[{ }^{\circ} \mathrm{C}\right]\right)$ & N/A & N/A & N/A & N/A & N/A \\
\hline Economizer & Yes & Yes & Yes & Yes & Yes \\
\hline Night Cycle & Yes & Yes & Yes & Yes & Yes \\
\hline Heat Recovery & No & No & No & No & No \\
\hline Demand Control Ventilation & Yes & Yes & Yes & Yes & Yes \\
\hline Ventilation $\left(\mathrm{cfm}\left[\mathrm{m}^{\wedge} 3 / \mathrm{s}\right]\right)$ & See Zone Level Information & See Zone Level Information & See Zone Level Information & See Zone Level Information & See Zone Level Information \\
\hline \multicolumn{6}{|l|}{ Fan and Pump Loads } \\
\hline Fan Schedules & Always available & Always available & Always available & Always available & Always available \\
\hline Supply Fan Efficiency (\%) & 65.00 & 65.00 & 65.00 & 65.00 & 65.00 \\
\hline $\begin{array}{l}\text { Supply Fan Volumetric Flow Rate (cfm } \\
\left.\left[\mathrm{m}^{\wedge} 3 / \mathrm{s}\right]\right)\end{array}$ & $210,752.28[99.46]$ & $188,121.79[88.78]$ & $201,249.53[94.98]$ & $197,750.83[93.33]$ & $155,834.87[73.55]$ \\
\hline Supply Fan Pressure Drop (in H2O [Pa]) & $2.51[625.00]$ & $2.51[625.00]$ & $2.51[625.00]$ & $2.51[625.00]$ & $2.51[625.00]$ \\
\hline Cooling Tower Power (hp [kW]) & N/A & N/A & N/A & N/A & N/A \\
\hline Pump Power (hp [kW]) & $\mathrm{N} / \mathrm{A}$ & N/A & N/A & $\mathrm{N} / \mathrm{A}$ & N/A \\
\hline \multicolumn{6}{|l|}{ Service Hot Water } \\
\hline SWH Type & Storage Tank & Storage Tank & Storage Tank & Storage Tank & Storage Tank \\
\hline Fuel & Natural Gas & Natural Gas & Natural Gas & Natural Gas & Natural Gas \\
\hline Thermal Efficiency (\%) & 80.00 & 80.00 & 80.00 & 80.00 & 80.00 \\
\hline Temperature Setpoint $\left({ }^{\circ} \mathrm{F}\left[{ }^{\circ} \mathrm{C}\right]\right)$ & $140.00[60.00]$ & $140.00[60.00]$ & $140.00[60.00]$ & $140.00[60.00]$ & $140.00[60.00]$ \\
\hline Water Consumption (gal [ $\left.\mathrm{m}^{\wedge} 3\right]$ ) & $610,884.54[2,312.45]$ & $610,884.54[2,312.45]$ & $610,884.54[2,312.45]$ & $610,884.54[2,312.45]$ & $610,884.54[2,312.45]$ \\
\hline \multicolumn{6}{|l|}{ Internal Loads \& Schedules } \\
\hline \multicolumn{6}{|l|}{ Heating \& Cooling } \\
\hline \multicolumn{6}{|l|}{ Setpoint Schedule } \\
\hline Heating & See HTGSETP_SCH & See HTGSETP_SCH & See HTGSETP_SCH & See HTGSETP_SCH & See HTGSETP_SCH \\
\hline Cooling & See CLGSETP_SCH & See CLGSETP_SCH & See CLGSETP_SCH & See CLGSETP_SCH & See CLGSETP_SCH \\
\hline \multicolumn{6}{|l|}{ Lighting } \\
\hline Average Power Density $\left(\mathrm{W} / \mathrm{ft}^{\wedge} 2\left[\mathrm{~W} / \mathrm{m}^{\wedge} 2\right]\right)$ & $1.52[16.40]$ & $1.52[16.40]$ & $1.52[16.40]$ & $1.52[16.40]$ & $1.52[16.40]$ \\
\hline Schedule & See BLDG_LIGHT_SCH & See BLDG_LIGHT_SCH & See BLDG_LIGHT_SCH & See BLDG_LIGHT_SCH & See BLDG_LIGHT_SCH \\
\hline \multicolumn{6}{|l|}{ Plug loads } \\
\hline Average Power Density $\left(\mathrm{W} / \mathrm{ft}^{\wedge} 2\left[\mathrm{~W} / \mathrm{m}^{\wedge} \mathrm{2}\right]\right)$ & $0.82[8.84]$ & $0.82[8.84]$ & $0.82[8.84]$ & $0.82[8.84]$ & $0.82[8.84]$ \\
\hline Schedule & See BLDG_EQUIP_SCH & See BLDG_EQUIP_SCH & See BLDG_EQUIP_SCH & See BLDG_EQUIP_SCH & See BLDG_EQUIP_SCH \\
\hline \multicolumn{6}{|l|}{ Occupancy } \\
\hline Average People (\#/1000 ft^2[\#/100 $\left.\left.\mathrm{m}^{\wedge} 2\right]\right)$ & $27.05[29.11]$ & $27.05[29.11]$ & $27.05[29.11]$ & $27.05[29.11]$ & $27.05[29.11]$ \\
\hline Schedule & See BLDG_OCC_SCH & See BLDG_OCC_SCH & See BLDG_OCC_SCH & See BLDG_OCC_SCH & See BLDG_OCC_SCH \\
\hline
\end{tabular}




\section{Appendix E. High School Baseline Scorecard}

Table E-1 High Baseline Scorecard: Climate Zones 1-3

\begin{tabular}{|c|c|c|c|c|c|}
\hline Program & & & & & \\
\hline Model Number & 1 & 2 & 3 & 4 & 5 \\
\hline Building Name & High School & High School & High School & High School & High School \\
\hline \begin{tabular}{|l|} 
Location \\
(Latitude, Longitude) \\
Weather File
\end{tabular} & $\begin{array}{c}\text { Miami, FL } \\
(25.8,-80.27) \\
\text { USA_FL_Miami_TMY2.epw }\end{array}$ & $\begin{array}{c}\text { Houston, TX } \\
(29.98,-95.37) \\
\text { USA_TX_Houston-Intercontinental_TMY2.epw }\end{array}$ & $\begin{array}{c}\text { Phoenix, AZ } \\
(33.43,-112.02) \\
\text { USA_AZ_Phoenix_TMY2.epw }\end{array}$ & $\begin{array}{c}\text { Memphis, TN } \\
(35.05,-89.98) \\
\text { USA_TN_Memphis_TMY2.epw }\end{array}$ & $\begin{array}{c}\text { EIPaso, TX } \\
\text { (31.8,-106.4) } \\
\text { USA_TX_El.Paso_TMY2.epw }\end{array}$ \\
\hline ASHRAE 90.1-2004 Climate Zone & $1 \mathrm{~A}$ & $2 \mathrm{~A}$ & $2 \mathrm{~B}$ & $3 \mathrm{~A}$ & $3 \mathrm{~B}$ \\
\hline \multicolumn{6}{|l|}{ Form } \\
\hline Total Floor Area $\left(\mathrm{ft}^{\wedge} 2\left[\mathrm{~m}^{\wedge} 2\right]\right)$ & $210,886.53[19,592.00]$ & $210,886.53[19,592.00]$ & $210,886.53[19,592.00]$ & $210,886.53[19,592.00]$ & $210,886.53[19,592.00]$ \\
\hline Number of Floors & 2 & 2 & 2 & 2 & 2 \\
\hline Window Fraction (Window to Wall Ratio) & $\begin{array}{l}\text { South: } 0.35 \\
\text { East: } 0.35 \\
\text { North: } 0.35 \\
\text { West } 0.35 \\
\text { Total: } 0.35\end{array}$ & $\begin{array}{l}\text { South: } 0.35 \\
\text { East } 0.35 \\
\text { North } 0.35 \\
\text { West } 0.35 \\
\text { Total: } 0.35\end{array}$ & $\begin{array}{l}\text { South: } 0.35 \\
\text { East } 0.35 \\
\text { North: } 0.35 \\
\text { West } 0.35 \\
\text { Total: } 0.35\end{array}$ & $\begin{array}{l}\text { South: } 0.35 \\
\text { East: } 0.35 \\
\text { North: } 0.35 \\
\text { West } 0.35 \\
\text { Total: } 0.35\end{array}$ & $\begin{array}{l}\text { South: } 0.35 \\
\text { East: } 0.35 \\
\text { North } 0.35 \\
\text { West } 0.35 \\
\text { Total: } 0.35\end{array}$ \\
\hline Window Locations & See Picture & See Picture & See Picture & See Picture & See Picture \\
\hline Skylight/TDD Percent & 1.05 & 1.05 & 1.05 & 1.05 & 1.05 \\
\hline Shading & None & None & None & None & None \\
\hline Floor to Floor Height (ft [m]) & $13.12[4.00]$ & $13.12[4.00]$ & $13.12[4.00]$ & $13.12[4.00]$ & $13.12[4.00]$ \\
\hline \multicolumn{6}{|l|}{ Fabric } \\
\hline \multicolumn{6}{|l|}{ Exterior walls } \\
\hline Construction & $\mathrm{NR}$ & NR & NR & R-5.7 ci & R-5.7 ci \\
\hline R-value $\left(f t^{\wedge} 2 \cdot h r \cdot \circ / B / B t u\left[m^{\wedge} 2 \cdot k / W\right]\right)$ & $1.34[0.24]$ & $1.34[0.24]$ & $1.34[0.24]$ & $5.79[1.02]$ & $5.79[1.02]$ \\
\hline Gross Dimensions - Total Area $\left(\mathrm{ft}^{\wedge} 2\left[\mathrm{~m}^{\wedge} \mathrm{2}\right]\right)$ & $68,716.80[6,384.00]$ & $68,716.80[6,384.00]$ & $68,716.80[6,384.00]$ & $68,716.80[6,384.00]$ & $68,716.80[6,384.00]$ \\
\hline Net Dimensions - Total Area $\left(\mathrm{ft}^{\wedge} 2\left[\mathrm{~m}^{\wedge} \mathrm{z}\right]\right)$ & $44,662.69[4,149.30]$ & $44,662.69[4,149.30]$ & $44,662.69[4,149.30]$ & $44,662.69[4,149.30]$ & $44,662.69[4,149.30]$ \\
\hline \multicolumn{6}{|l|}{ Roof } \\
\hline Construction & $\mathrm{R}-15 \mathrm{ci}$ & $\mathrm{R}-15 \mathrm{ci}$ & $\mathrm{R}-15 \mathrm{ci}$ & $\mathrm{R}-15 \mathrm{ci}$ & $R-15 c i$ \\
\hline R-value $\left(\mathrm{t}^{\wedge} 2 \cdot h \cdot \cdot \cdot \mathrm{O} / \mathrm{B}\right.$ tu $\left.\left[\mathrm{m}^{\wedge} \mathrm{2} \cdot \mathrm{K} / \mathrm{W}\right]\right)$ & $14.82(2.61)$ & $14.82(2.61)$ & $14.82(2.61)$ & $14.82(2.61)$ & $14.82(2.61)$ \\
\hline Gross Dimensions - Total Area $\left(\mathrm{ft}^{\wedge} 2\left[\mathrm{~m}^{\wedge} \mathrm{2}\right]\right)$ & $128,112.06[11,902.00]$ & $128,112.06[11,902.00]$ & $128,112.06[11,902.00]$ & $128,112.06[11,902.00]$ & $128,112.06[11,902.00]$ \\
\hline Net Dimensions - Total Area $\left(\mathrm{ft}^{\wedge} 2\left[\mathrm{~m}^{\wedge} 2\right]\right)$ & $126,767.11[11,777.05]$ & $126,767.11[11,777.05]$ & $126,767.11[11,777.05]$ & $126,767.11[11,777.05]$ & $126,767.11[11,777.05]$ \\
\hline \multicolumn{6}{|l|}{ Window } \\
\hline Dimensions - Total Area $\left(f^{\wedge} 2\left[\mathrm{~m}^{\wedge} 2\right]\right)$ & 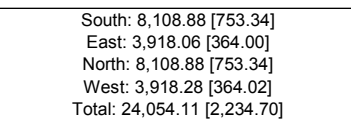 & $\begin{array}{c}\text { South: } 8,108.88[753.34] \\
\text { East: } 3,918.06[364.00] \\
\text { North: } 8,108.88[753.34] \\
\text { West: } 3,918.28[364.02] \\
\text { Total: } 24,054.11[2,234.70]\end{array}$ & 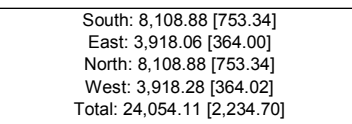 & 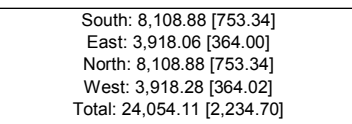 & 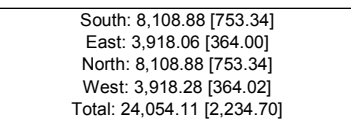 \\
\hline Glass-type and frame & $\begin{array}{l}\text { Hypothetical window meeting U-factor and } \\
\text { SHGC shown below }\end{array}$ & $\begin{array}{l}\text { Hypothetical window meeting U-factor and } \\
\text { SHGC shown below }\end{array}$ & $\begin{array}{l}\text { Hypothetical window meeting U-factor and } \\
\text { SHGC shown below }\end{array}$ & $\begin{array}{l}\text { Hypothetical window meeting U-factor and } \\
\text { SHGC shown below }\end{array}$ & $\begin{array}{l}\text { Hypothetical window meeting U-factor and } \\
\text { SHGC shown below }\end{array}$ \\
\hline U-Factor (Btu/h:f(t^2:oF $\left.\left[\mathrm{W} / \mathrm{m}^{\wedge} 2 \cdot \mathrm{K}\right]\right)$ & $\begin{array}{l}\text { South: } 1.21[6.89] \\
\text { East: } 1.21[6.89] \\
\text { North: } 1.21[6.89] \\
\text { West: } 1.21[6.89]\end{array}$ & $\begin{array}{c}\text { South: } 1.21[6.89] \\
\text { East: } 1.21[6.89] \\
\text { North: } 1.21[6.89] \\
\text { West: } 1.21[6.89] \\
\end{array}$ & $\begin{array}{l}\text { South: } 1.21[6.89] \\
\text { East: } 1.21[6.89] \\
\text { North: } 1.21[6.89] \\
\text { West: } 1.21[6.89] \\
\end{array}$ & $\begin{array}{l}\text { South: } 0.57[3.26] \\
\text { East: } 0.57[3.26] \\
\text { North: } 0.57[3.26] \\
\text { West: } 0.57[3.26]\end{array}$ & $\begin{array}{l}\text { South: } 0.57[3.26] \\
\text { East: } 0.57[3.26] \\
\text { North: } 0.57[3.26] \\
\text { West: } 0.57[3.26] \\
\end{array}$ \\
\hline SHGC & $\begin{array}{l}\text { South: } 0.25 \\
\text { East: } 0.25 \\
\text { North: } 0.61 \\
\text { West: } 0.25\end{array}$ & $\begin{array}{l}\text { South: } 0.25 \\
\text { East: } 0.25 \\
\text { North: } 0.61 \\
\text { West: } 0.25\end{array}$ & $\begin{array}{l}\text { South: } 0.25 \\
\text { East: } 0.25 \\
\text { North: } 0.61 \\
\text { West: } 0.25\end{array}$ & $\begin{array}{l}\text { South: } 0.25 \\
\text { East: } 0.25 \\
\text { North: } 0.39 \\
\text { West: } 0.25\end{array}$ & $\begin{array}{l}\text { South: } 0.25 \\
\text { East: } 0.25 \\
\text { North: } 0.39 \\
\text { West: } 0.25\end{array}$ \\
\hline Visible transmittance & $\begin{array}{l}\text { South: } 0.25 \\
\text { East: } 0.25 \\
\text { North: } 0.67 \\
\text { West: } 0.25 \\
\end{array}$ & $\begin{array}{l}\text { South: } 0.25 \\
\text { East: } 0.25 \\
\text { North: } 0.67 \\
\text { West: } 0.25\end{array}$ & $\begin{array}{l}\text { South: } 0.25 \\
\text { East: } 0.25 \\
\text { North } 0.67 \\
\text { West: } 0.25\end{array}$ & $\begin{array}{l}\text { South: } 0.24 \\
\text { East: } 0.24 \\
\text { North: } 0.42 \\
\text { West: } 0.24\end{array}$ & $\begin{array}{l}\text { South: } 0.24 \\
\text { East: } 0.24 \\
\text { North: } 0.42 \\
\text { West: } 0.24\end{array}$ \\
\hline \multicolumn{6}{|l|}{ Foundation } \\
\hline Foundation Type & Mass Floor & Mass Floor & Mass Floor & Mass Floor & Mass Floor \\
\hline Construction & Carpet over heavy concrete and insulation & Carpet over heavy concrete and insulation & Carpet over heavy concrete and insulation & Carpet over heavy concrete and insulation & Carpet over heavy concrete and insulation \\
\hline R-value $\left(f \mathrm{t}^{\wedge} 2 \cdot h \cdot \circ \mathrm{F} / \mathrm{Btu}\left[\mathrm{m}^{\wedge} 2 \cdot \mathrm{K} / \mathrm{W}\right]\right)$ & $2.11[0.37]$ & $2.11[0.37]$ & $2.11[0.37]$ & $2.11[0.37]$ & $2.11[0.37]$ \\
\hline Dimensions - Total Area $\left(\mathrm{ft}^{\wedge} 2\left[\mathrm{~m}^{\wedge} 2\right]\right)$ & $128,112.06[11,902.00]$ & $128,112.06[11,902.00]$ & $128,112.06[11,902.00]$ & $128,112.06[11,902.00]$ & $128,112.06[11,902.00]$ \\
\hline \multicolumn{6}{|l|}{ Interior Partitions } \\
\hline Construction & $2 \times 4$ steel-frame with gypsum board & $2 \times 4$ steel-frame with gypsum board & $2 \times 4$ steel-frame with gypsum board & $2 \times 4$ steel-frame with gypsum board & $2 \times 4$ steel-frame with gypsum board \\
\hline Dimensions - Total Area $\left(\mathrm{ft}^{\wedge} 2\left[\mathrm{~m}^{\wedge} 2\right]\right)$ & $74,141.81[6,888.00]$ & $74,141.81[6,888.00]$ & $74,141.81[6,888.00]$ & $74,141.81[6,888.00]$ & $74,141.81[6,888.00]$ \\
\hline \multicolumn{6}{|l|}{ Internal Mass } \\
\hline Construction & 6 inch wood & 6 inch wood & 6 inch wood & 6 inch wood & 6 inch wood \\
\hline Dimensions - Total Area $\left(\mathrm{ft}^{\wedge} 2\left[\mathrm{~m}^{\wedge} 2\right]\right)$ & $512,448.25[47,608.00]$ & $512,448.25[47,608.00]$ & $512,448.25[47,608.00]$ & $512,448.25[47,608.00]$ & $512,448.25[47,608.00]$ \\
\hline Thermal Properties $\left(\mathrm{lb} / \mathrm{ft}^{\wedge} 2\left[\mathrm{~kg} / \mathrm{m}^{\wedge} \mathrm{2}\right]\right)$ & $16.60[81.00]$ & $16.60[81.00]$ & $16.60[81.00]$ & $16.60[81.00]$ & $16.60[81.00]$ \\
\hline \multicolumn{6}{|l|}{ Air Barrier System } \\
\hline Infiltration (ACH) & 0.50 & 0.50 & 0.50 & 0.50 & 0.50 \\
\hline
\end{tabular}


Table E-2 High Baseline Scorecard: Climate Zones 1-3 (Cont.)

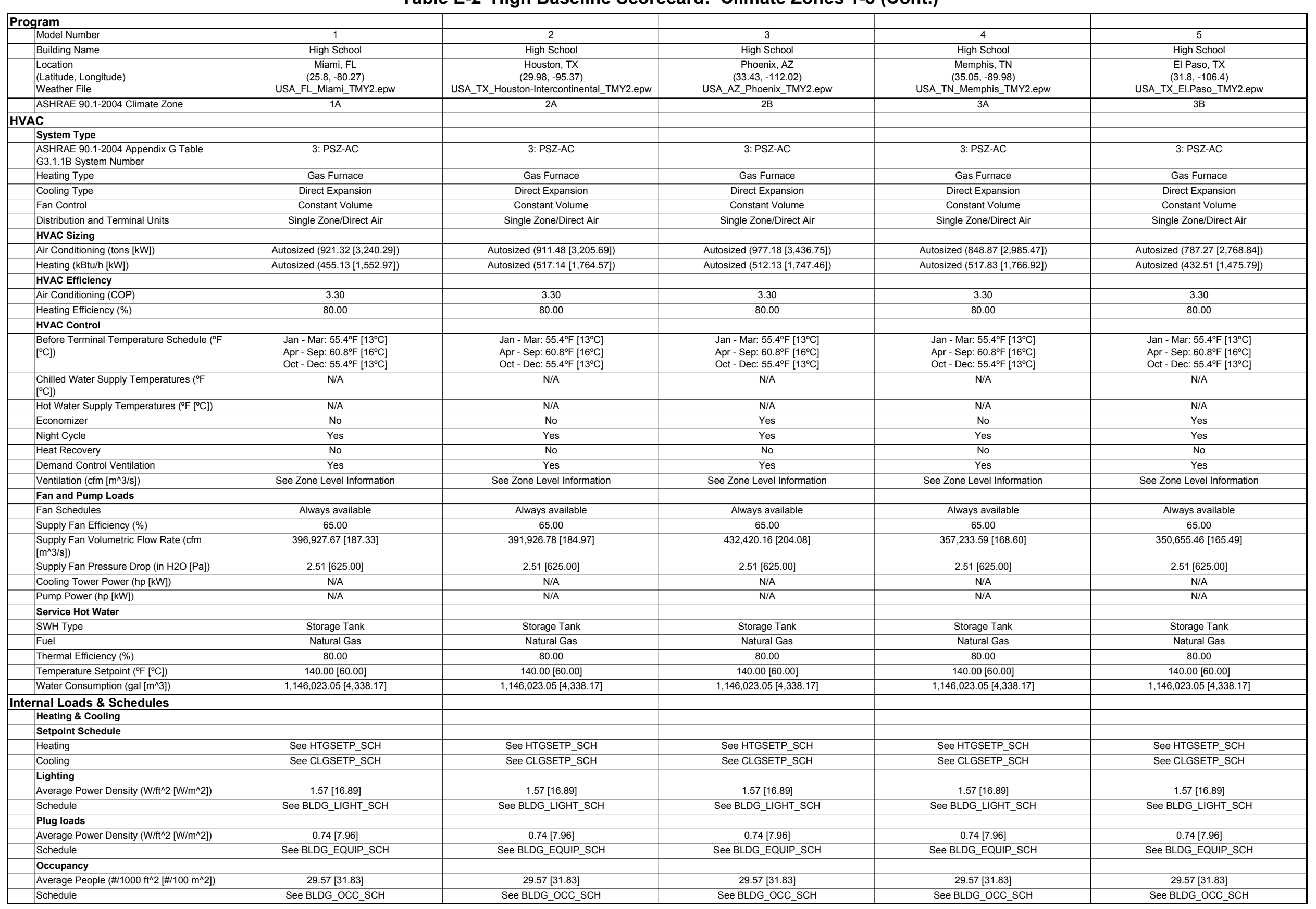


Table E-3 High Baseline Scorecard: Climate Zones 3-5

\begin{tabular}{|c|c|c|c|c|c|}
\hline Program & & & & & \\
\hline Model Number & 6 & 7 & 8 & 9 & 10 \\
\hline Building Name & High School & High School & High School & High School & High School \\
\hline $\begin{array}{l}\begin{array}{l}\text { Location } \\
\text { (Latitude, Longitude) } \\
\text { Weather File }\end{array} \\
\end{array}$ & $\begin{array}{c}\text { San Francisco, CA } \\
(37.62,-122.38) \\
\text { USA_CA_San.Francisco_TMY2.epw }\end{array}$ & $\begin{array}{c}\text { Baltimore, MD } \\
\text { (39.18,-76.67) } \\
\text { USA_MD_Baltimore_TMY2.epw }\end{array}$ & $\begin{array}{c}\text { Albuquerque, NM } \\
(35.05,-106.62) \\
\text { USA_NM_Albuquerque_TMY2.epw }\end{array}$ & $\begin{array}{c}\text { Seattle, WA } \\
(47.45,-122.3) \\
\text { USA_WA_Seattle-Tacoma_TMY2.epw }\end{array}$ & $\begin{array}{c}\text { Chicago-ohare, IL } \\
\text { (41.78,-87.75) } \\
\text { USA__L_Chicago-OHare_TMY2.epw }\end{array}$ \\
\hline \multicolumn{6}{|l|}{ Form } \\
\hline Total Floor Area $\left(\mathrm{ft}^{\wedge} 2\left[\mathrm{~m}^{\wedge} 2\right]\right)$ & $210,886.53[19,592.00]$ & $210,886.53[19,592.00]$ & $210,886.53[19,592.00]$ & $210,886.53[19,592.00]$ & $210,886.53[19,592.00]$ \\
\hline Number of Floors & 2 & 2 & 2 & 2 & 2 \\
\hline Window Fraction (Window to Wall Ratio) & $\begin{array}{l}\text { South: } 0.35 \\
\text { East: } 0.35 \\
\text { North: } 0.35 \\
\text { West: } 0.35 \\
\text { Total: } 0.35\end{array}$ & $\begin{array}{l}\text { South: } 0.35 \\
\text { East: } 0.35 \\
\text { North: } 0.35 \\
\text { West: } 0.35 \\
\text { Total: } 0.35\end{array}$ & $\begin{array}{l}\text { South: } 0.35 \\
\text { East: } 0.35 \\
\text { North: } 0.35 \\
\text { West: } 0.35 \\
\text { Total: } 0.35\end{array}$ & $\begin{array}{l}\text { South: } 0.35 \\
\text { East: } 0.35 \\
\text { North: } 0.35 \\
\text { West: } 0.35 \\
\text { Total: } 0.35\end{array}$ & $\begin{array}{l}\text { South: } 0.35 \\
\text { East: } 0.35 \\
\text { North: } 0.35 \\
\text { West: } 0.35 \\
\text { Total: } 0.35\end{array}$ \\
\hline Window Locations & See Picture & See Picture & See Picture & See Picture & See Picture \\
\hline Skylight/TDD Percent & 1.05 & 1.05 & 1.05 & 1.05 & 1.05 \\
\hline Shading & None & None & None & None & None \\
\hline Floor to Floor Height (ft [m]) & $13.12[4.00]$ & $13.12[4.00]$ & $13.12[4.00]$ & $13.12[4.00]$ & $13.12[4.00]$ \\
\hline \multicolumn{6}{|l|}{ Fabric } \\
\hline Exterior walls & & & & & \\
\hline Construction & R-5.7 ci & R-5.7 ci & R-5.7 ci & R-5.7 ci & R-7.6 ci \\
\hline $\mathrm{R}$-value $\left(\mathrm{ft}^{\wedge} 2 \cdot \mathrm{hr} \cdot{ }^{\circ} \mathrm{F} / \mathrm{Btu}\left[\mathrm{m}^{\wedge} 2 \cdot \mathrm{K} / \mathrm{W}\right]\right)$ & $5.79[1.02]$ & $5.79[1.02]$ & $5.79[1.02]$ & $5.79[1.02]$ & $7.31[1.29]$ \\
\hline Gross Dimensions - Total Area $\left(\mathrm{f}^{\wedge} 2\left[\mathrm{~m}^{\wedge} 2\right]\right)$ & $68,716.80[6,384.00]$ & $68,716.80[6,384.00]$ & $68,716.80[6,384.00]$ & $68,716.80[6,384.00]$ & $68,716.80[6,384.00]$ \\
\hline Construction & $R-10 \mathrm{ci}$ & $\mathrm{R}-15 \mathrm{ci}$ & $R-15 \mathrm{ci}$ & R-15 ci & R-15 ci \\
\hline R-value $\left(\mathrm{ft}^{\wedge} 2 \cdot h \cdot \mathrm{h}^{\circ} \mathrm{F} / \mathrm{Btu}\left[\mathrm{m}^{\wedge} 2 \cdot \mathrm{K} / \mathrm{W}\right]\right)$ & $9.69(1.71)$ & $14.82(2.61)$ & $14.82(2.61)$ & $14.82(2.61)$ & $14.82(2.61)$ \\
\hline Gross Dimensions - Total Area $\left(\mathrm{ft}^{\wedge} 2\left[\mathrm{~m}^{\wedge} 2\right]\right)$ & $128,112.06[11,902.00]$ & $128,112.06[11,902.00]$ & $128,112.06[11,902.00]$ & $128,112.06[11,902.00]$ & $128,112.06[11,902.00]$ \\
\hline Net Dimensions - Total Area $\left(\mathrm{ft}^{\wedge} 2\left[\mathrm{~m}^{\wedge} 2\right]\right)$ & $126,767.11[11,777.05]$ & $126,767.11[11,777.05]$ & $126,767.11[11,777.05]$ & $126,767.11[11,777.05]$ & $126,767.11[11,777.05]$ \\
\hline \multicolumn{6}{|l|}{ Window } \\
\hline Dimensions - Total Area $\left(\mathrm{ft}^{\wedge} 2\left[\mathrm{~m}^{\wedge} 2\right]\right)$ & $\begin{array}{c}\text { South: } 8,108.88[753.34] \\
\text { East: } 3,918.06[364.00] \\
\text { North: } 8,108.88[753.34] \\
\text { West: } 3,918.28[364.02] \\
\text { Total: } 24,054.11[2,234.70]\end{array}$ & $\begin{array}{c}\text { South: } 8,108.88[753.34] \\
\text { East: } 3,918.06[364.00] \\
\text { North: 8,108.88 [753.34] } \\
\text { West: } 3,918.28[364.02] \\
\text { Total: } 24,054.11[2,234.70]\end{array}$ & $\begin{array}{c}\text { South: } 8,108.88[753.34] \\
\text { East: } 3,918.06[364.00] \\
\text { North: } 8,108.88[753.34] \\
\text { West: } 3,918.28[364.02] \\
\text { Total: } 24,054.11[2,234.70]\end{array}$ & $\begin{array}{c}\text { South: } 8,108.88[753.34] \\
\text { East: } 3,918.06[364.00] \\
\text { North: } 8,108.88[753.34] \\
\text { West: } 3,918.28[364.02] \\
\text { Total: } 24,054.11[2,234.70]\end{array}$ & $\begin{array}{c}\text { South: } 8,108.88[753.34] \\
\text { East: } 3,918.06[364.00] \\
\text { North: } 8,108.88[753.34] \\
\text { West: } 3,918.28[364.02] \\
\text { Total: } 24,054.11[2,234.70]\end{array}$ \\
\hline Glass-type and frame & $\begin{array}{l}\text { Hypothetical window meeting U-factor and } \\
\text { SHGC shown below }\end{array}$ & $\begin{array}{l}\text { Hypothetical window meeting U-factor and } \\
\text { SHGC shown below }\end{array}$ & $\begin{array}{l}\text { Hypothetical window meeting U-factor and } \\
\text { SHGC shown below }\end{array}$ & $\begin{array}{l}\text { Hypothetical window meeting U-factor and } \\
\text { SHGC shown below }\end{array}$ & $\begin{array}{l}\text { Hypothetical window meeting U-factor and } \\
\text { SHGC shown below }\end{array}$ \\
\hline U-Factor $\left(\mathrm{Btu} / \mathrm{h} \cdot \mathrm{ft}^{\wedge} 2 \cdot{ }^{\circ} \mathrm{F}\left[\mathrm{W} / \mathrm{m}^{\wedge} 2 \cdot \mathrm{K}\right]\right)$ & $\begin{array}{l}\text { South: } 1.21[6.89] \\
\text { East: } 1.21[6.89] \\
\text { North: } 1.21[6.89] \\
\text { West: } 1.21[6.89]\end{array}$ & $\begin{array}{l}\text { South: } 0.57[3.26] \\
\text { East: } 0.57[3.26] \\
\text { North: } 0.57[3.26] \\
\text { West: } 0.57[3.26]\end{array}$ & $\begin{array}{l}\text { South: } 0.57[3.26] \\
\text { East: } 0.57[3.26] \\
\text { North: } 0.57[3.26] \\
\text { West: } 0.57[3.26]\end{array}$ & $\begin{array}{l}\text { South: } 0.57[3.26] \\
\text { East: } 0.57[3.26] \\
\text { North: } 0.57[3.26] \\
\text { West: } 0.57[3.26]\end{array}$ & $\begin{array}{l}\text { South: } 0.57[3.26] \\
\text { East: } 0.57[3.26] \\
\text { North: } 0.57[3.26] \\
\text { West: } 0.57[3.26]\end{array}$ \\
\hline SHGC & $\begin{array}{l}\text { South: } 0.61 \\
\text { East: } 0.61 \\
\text { North: } 0.61 \\
\text { West: } 0.61\end{array}$ & $\begin{array}{l}\text { South: } 0.39 \\
\text { East: } 0.39 \\
\text { North: } 0.49 \\
\text { West: } 0.39\end{array}$ & $\begin{array}{l}\text { South: } 0.39 \\
\text { East: } 0.39 \\
\text { North: } 0.49 \\
\text { West: } 0.39\end{array}$ & $\begin{array}{l}\text { South: } 0.39 \\
\text { East: } 0.39 \\
\text { North: } 0.49 \\
\text { West: } 0.39\end{array}$ & $\begin{array}{l}\text { South: } 0.39 \\
\text { East: } 0.39 \\
\text { North: } 0.49 \\
\text { West: } 0.39\end{array}$ \\
\hline Visible transmittance & $\begin{array}{l}\text { South: } 0.67 \\
\text { East: } 0.67 \\
\text { North: } 0.67 \\
\text { West: } 0.67\end{array}$ & $\begin{array}{l}\text { South: } 0.42 \\
\text { East: } 0.42 \\
\text { North: } 0.53 \\
\text { West: } 0.42\end{array}$ & $\begin{array}{l}\text { South: } 0.42 \\
\text { East: } 0.42 \\
\text { North: } 0.53 \\
\text { West: } 0.42\end{array}$ & $\begin{array}{l}\text { South: } 0.42 \\
\text { East: } 0.42 \\
\text { North: } 0.53 \\
\text { West: } 0.42\end{array}$ & $\begin{array}{l}\text { South: } 0.42 \\
\text { East: } 0.42 \\
\text { North: } 0.53 \\
\text { West: } 0.42\end{array}$ \\
\hline \multicolumn{6}{|l|}{ Foundation } \\
\hline R-value $\left(\mathrm{ft}^{\wedge} 2 \cdot \mathrm{h}^{\circ} \cdot \mathrm{F} / \mathrm{Btu}\left[\mathrm{m}^{\wedge} 2 \cdot \mathrm{K} / \mathrm{W}\right]\right)$ & $2.11[0.37]$ & $2.11[0.37]$ & $2.11[0.37]$ & $2.11[0.37]$ & $2.11[0.37]$ \\
\hline Dimensions - Total Area $\left(\mathrm{ft}^{\wedge} 2\left[\mathrm{~m}^{\wedge} \mathrm{\Omega}\right]\right)$ & $128,112.06[11,902.00]$ & $128,112.06[11,902.00]$ & $128,112.06[11,902.00]$ & $128,112.06[11,902.00]$ & $128,112.06[11,902.00]$ \\
\hline \multicolumn{6}{|l|}{ Interior Partitions } \\
\hline Construction & $2 \times 4$ steel-frame with gypsum board & $2 \times 4$ steel-frame with gypsum board & $2 \times 4$ steel-frame with gypsum board & $2 \times 4$ steel-frame with gypsum board & $2 \times 4$ steel-frame with gypsum board \\
\hline Dimensions - Total Area $\left(\mathrm{ft}^{\wedge} 2\left[\mathrm{~m}^{\wedge} \mathrm{z}\right]\right)$ & $74,141.81[6,888.00]$ & $74,141.81[6,888.00]$ & $74,141.81[6,888.00]$ & $74,141.81[6,888.00]$ & $74,141.81[6,888.00]$ \\
\hline \multicolumn{6}{|l|}{ Internal Mass } \\
\hline Construction & 6 inch wood & 6 inch wood & 6 inch wood & 6 inch wood & 6 inch wood \\
\hline Dimensions - Total Area $\left(\mathrm{ft}^{\wedge} 2\left[\mathrm{~m}^{\wedge} \mathrm{z}\right]\right)$ & $512,448.25[47,608.00]$ & $512,448.25[47,608.00]$ & $512,448.25[47,608.00]$ & $512,448.25[47,608.00]$ & $512,448.25[47,608.00]$ \\
\hline Thermal Properties $\left(\mathrm{lb} / \mathrm{ft}^{\wedge} \mathrm{\wedge} 2\left[\mathrm{~kg} / \mathrm{m}^{\wedge} \mathrm{z}\right]\right)$ & $16.60[81.00]$ & $16.60[81.00]$ & $16.60[81.00]$ & $16.60[81.00]$ & $16.60[81.00]$ \\
\hline Air Barrier System & & & & & \\
\hline Infiltration (ACH) & 0.50 & 0.50 & 0.50 & 0.50 & 0.50 \\
\hline
\end{tabular}


Table E-4 High Baseline Scorecard: Climate Zones 3-5 (Cont.)

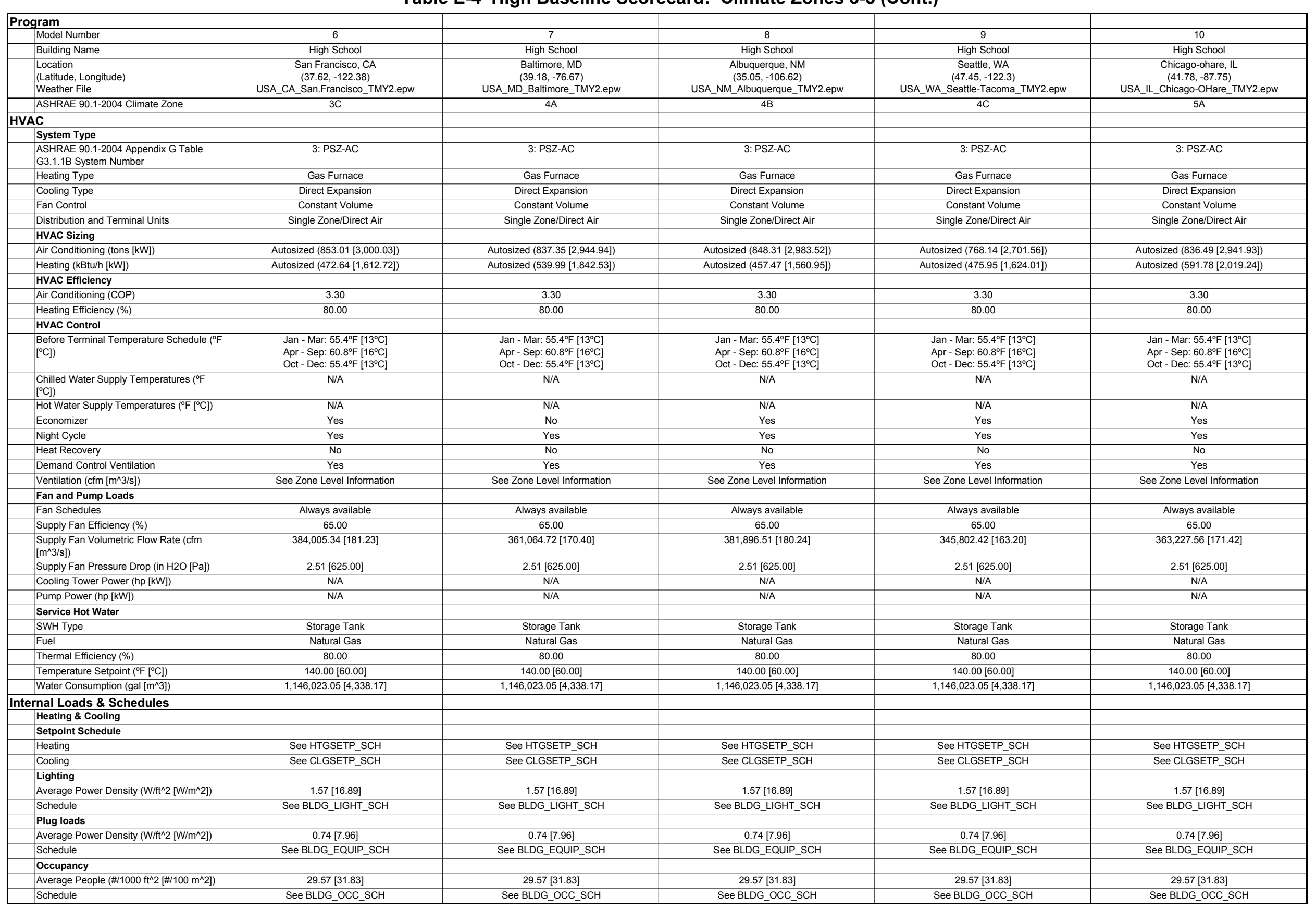


Table E-5 High Baseline Scorecard: Climate Zones 5-8

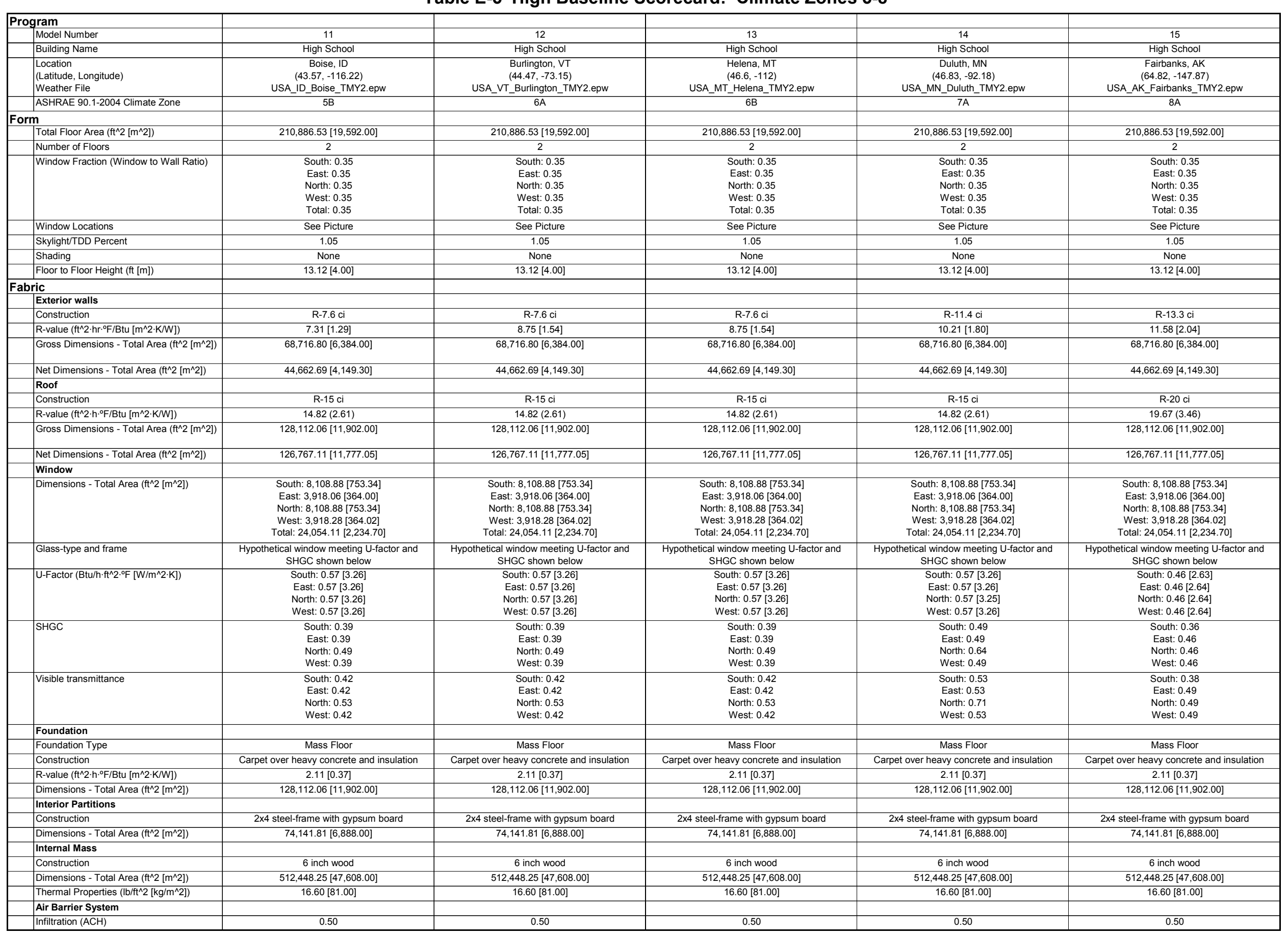


Table E-6 High Baseline Scorecard: Climate Zones 5-8 (Cont.)

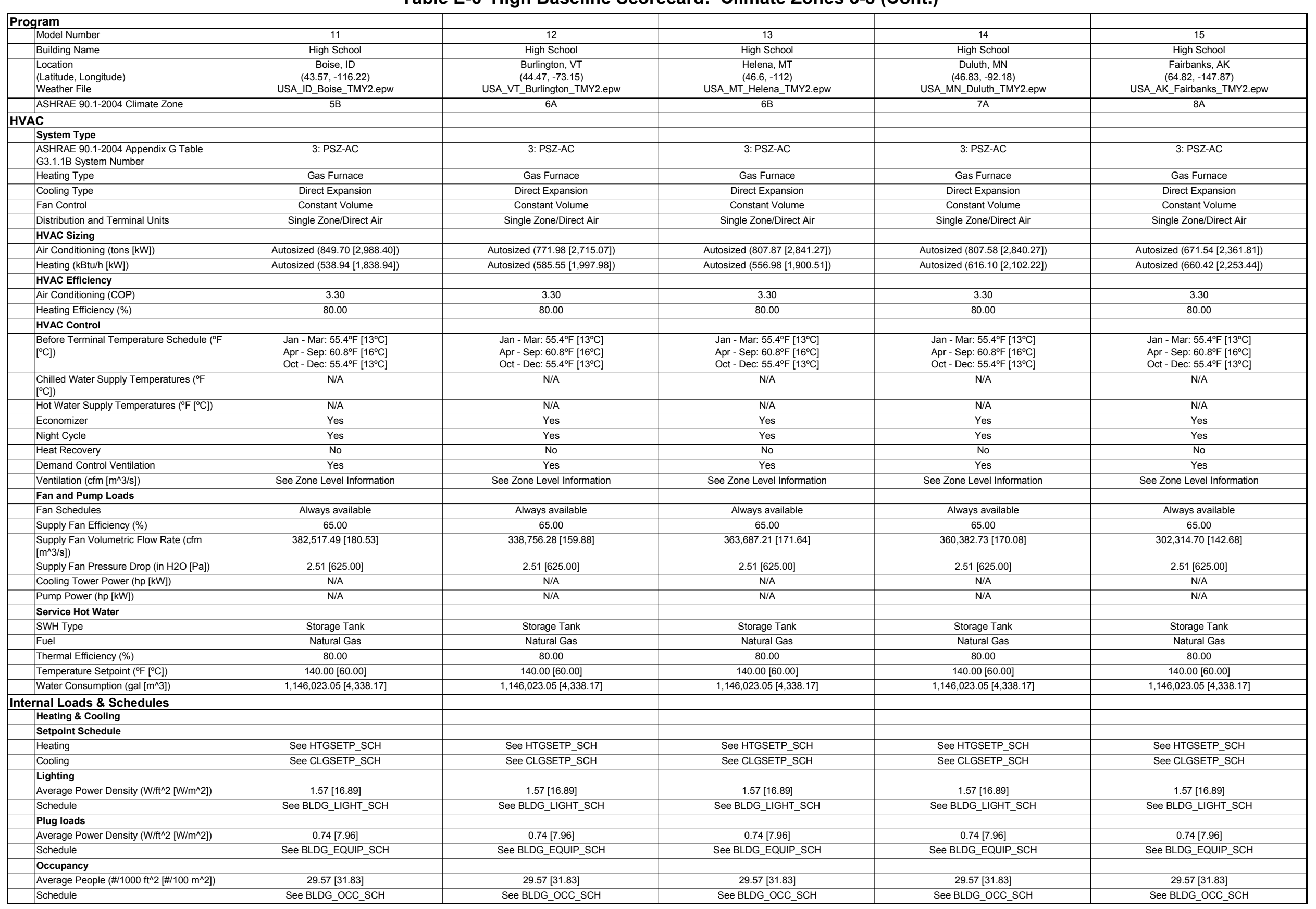




\section{Appendix F. Envelope Optimizations}

This appendix presents the optimization result tables and curves for the full range of roof and wall insulation options considered in the optimization (Appendix F.1 and F.2, respectively). For each climate zone (1 through 8), the lowest point on the optimization curve was selected as the lowest TLCC option. The options selected for the K-12 AEDG recommendations are highlighted with dark cell lines. The percent savings for both TLCC and energy savings use the SO AEDG insulation levels as the reference. The 0,0 point in the optimization curves and results tables represent this starting point. The SO AEDG, ASHRAE 90.1-1999, ASHRAE 90.1-2007 (with Addendum AS), and the K-12 AEDG insulation levels are shown in the results table. 


\section{F.1 Insulation above Deck Optimization Results}

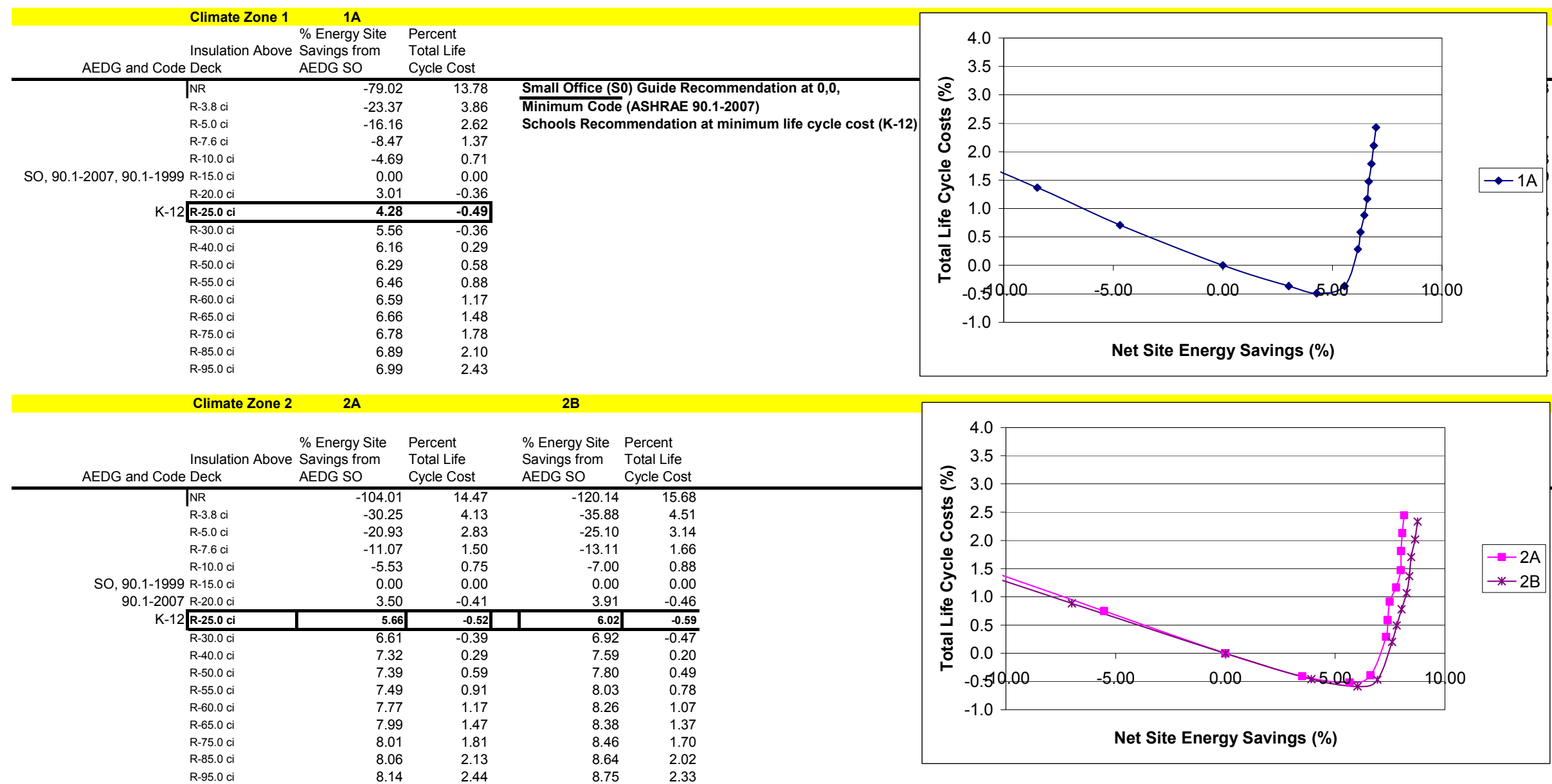




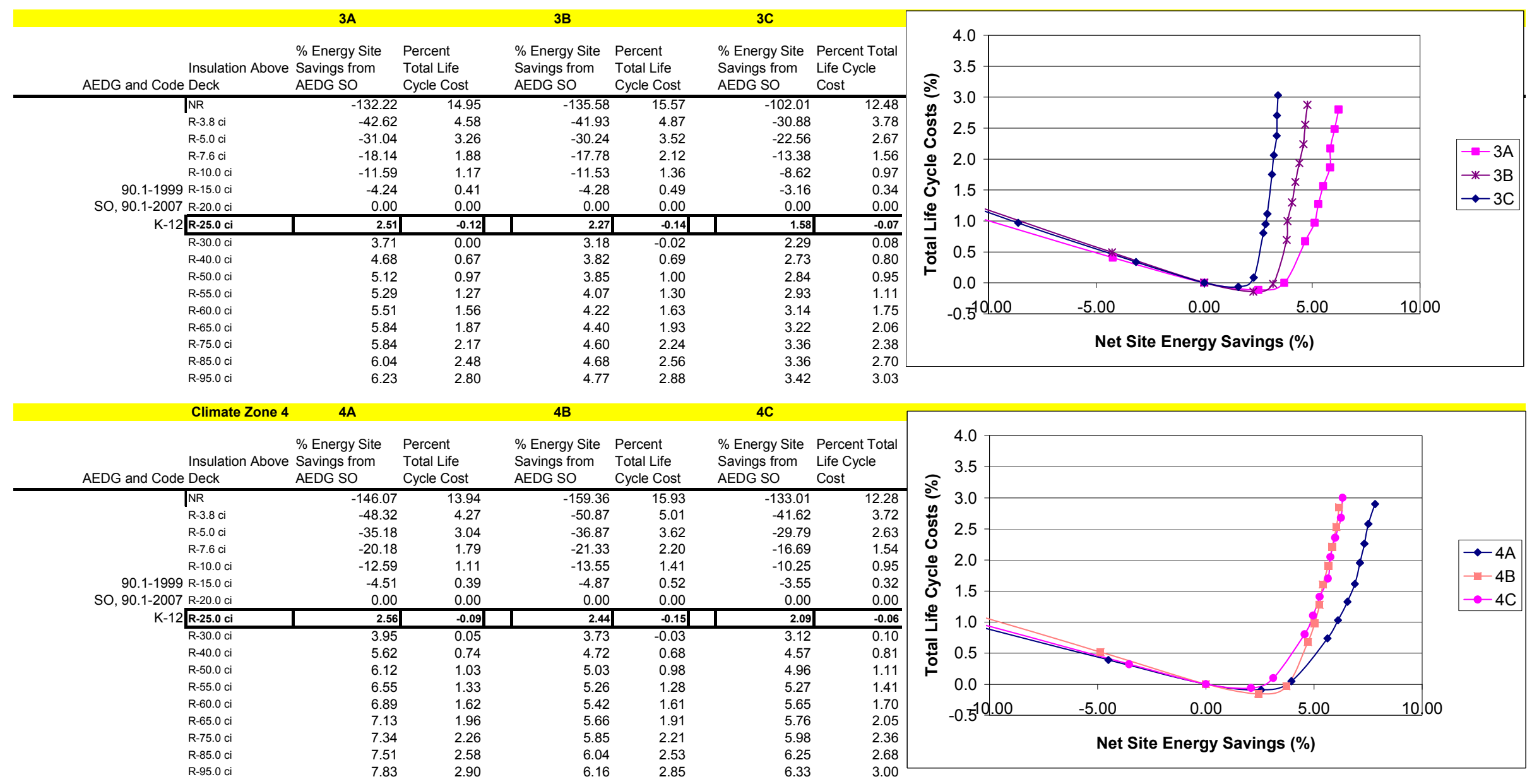




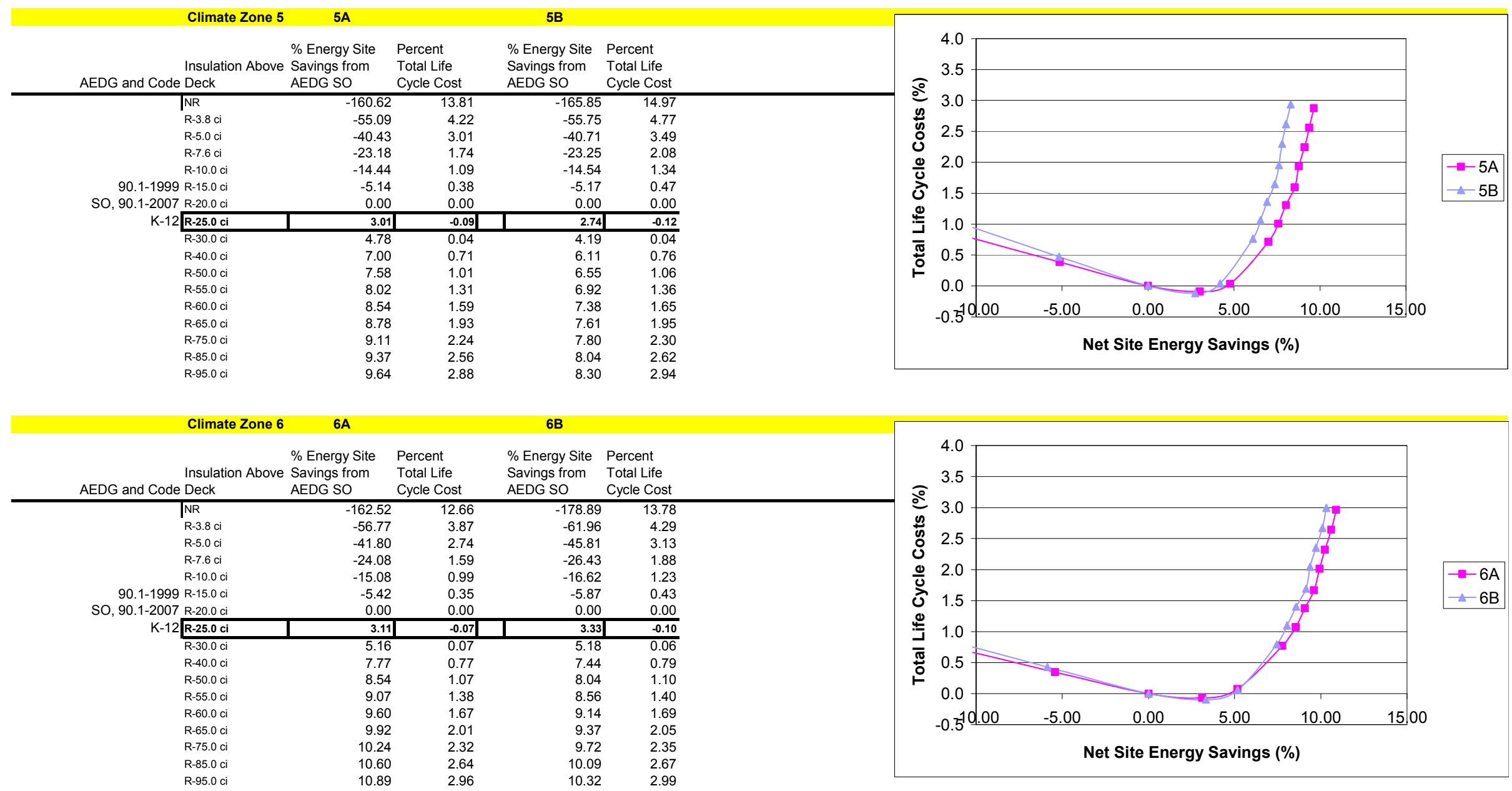




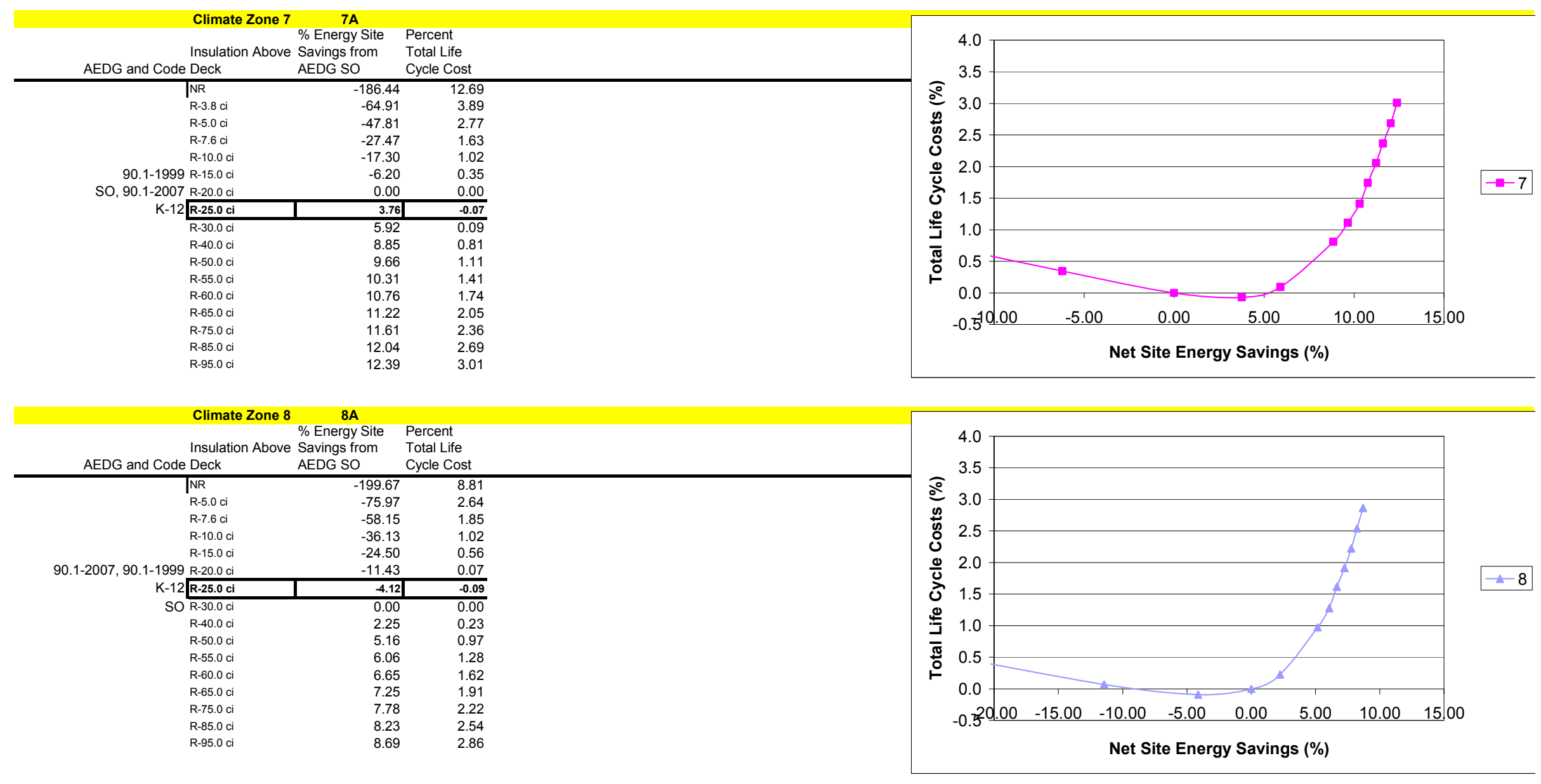




\section{F.2 Mass Wall Insulation Optimization Results}

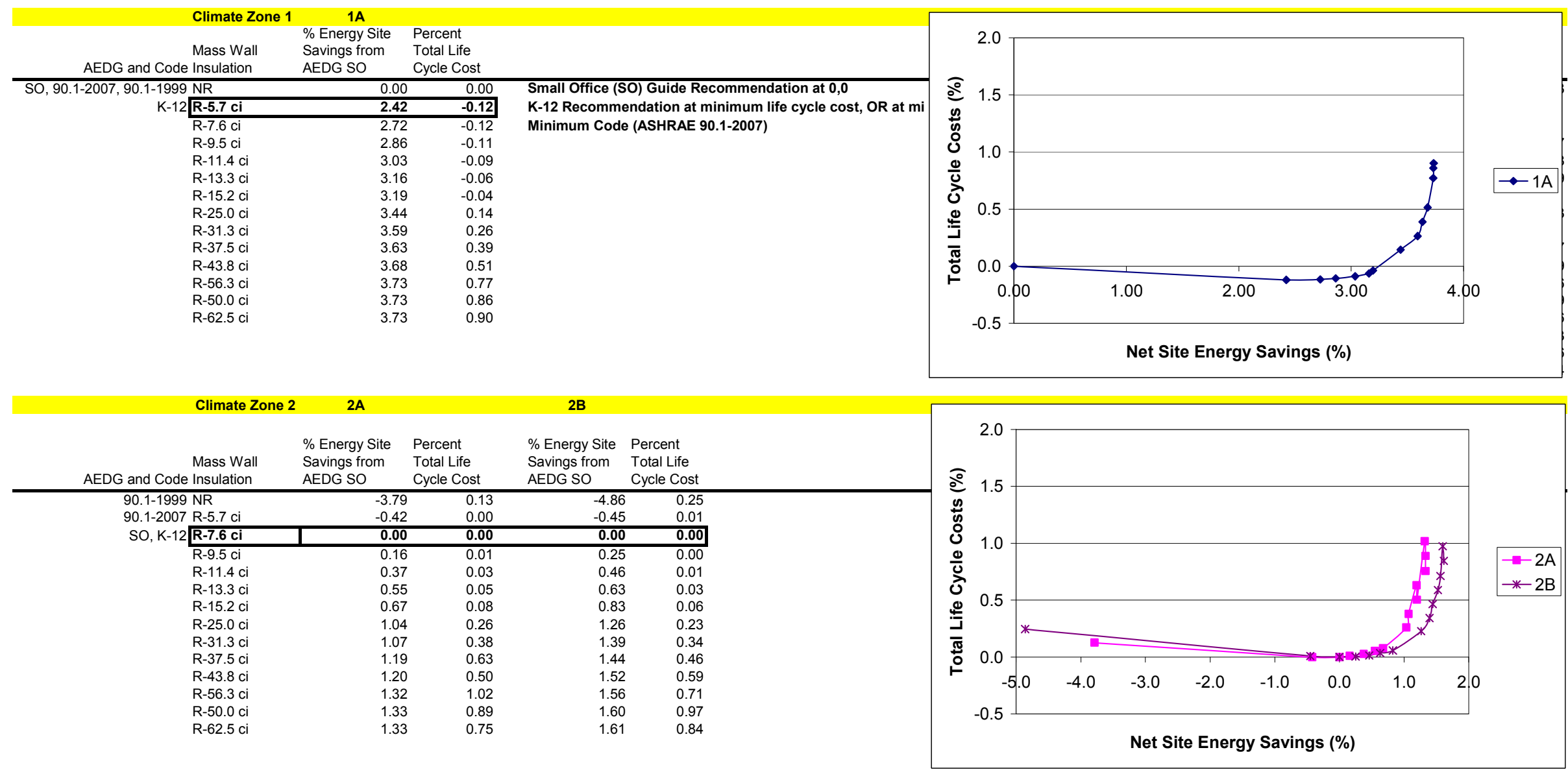




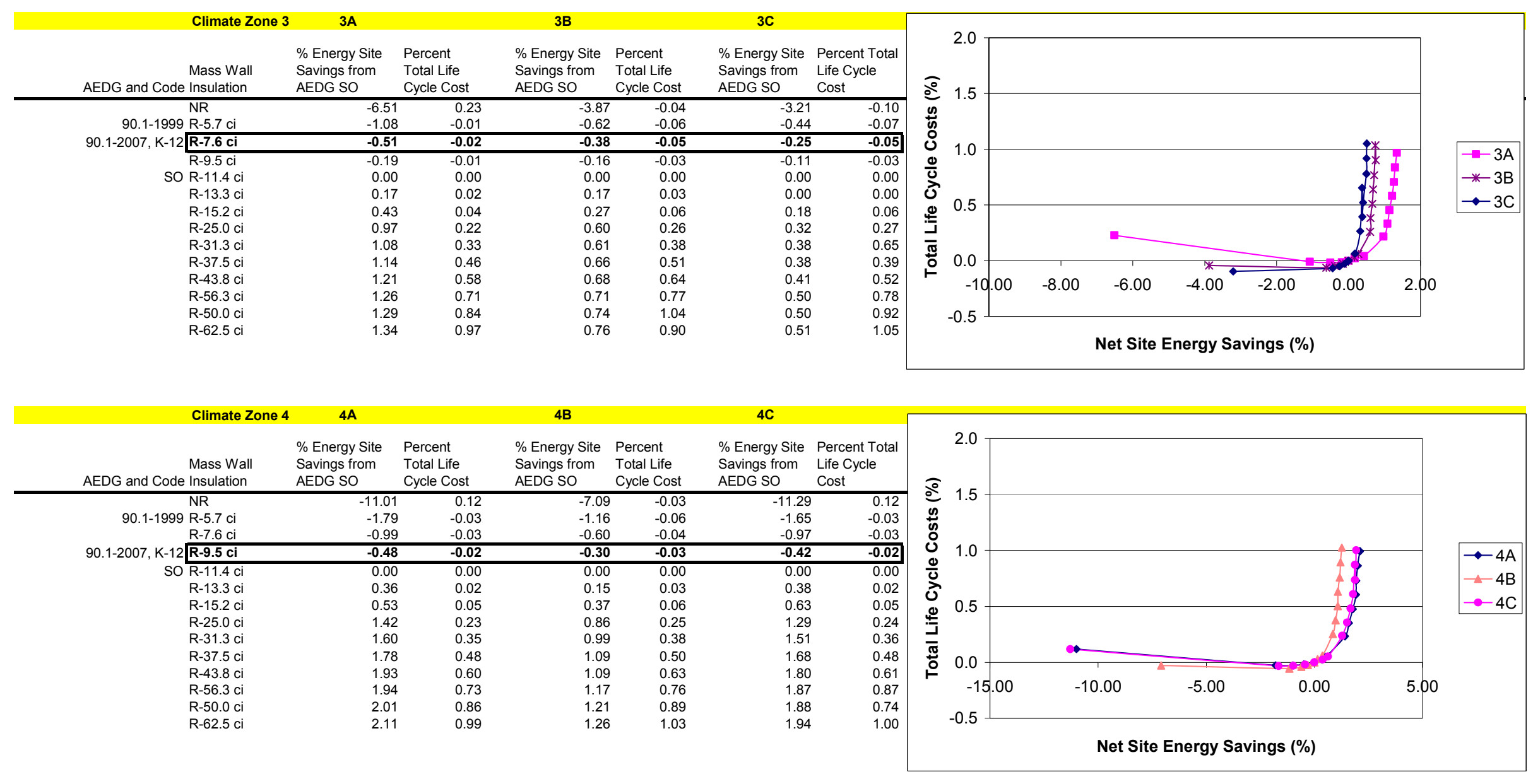




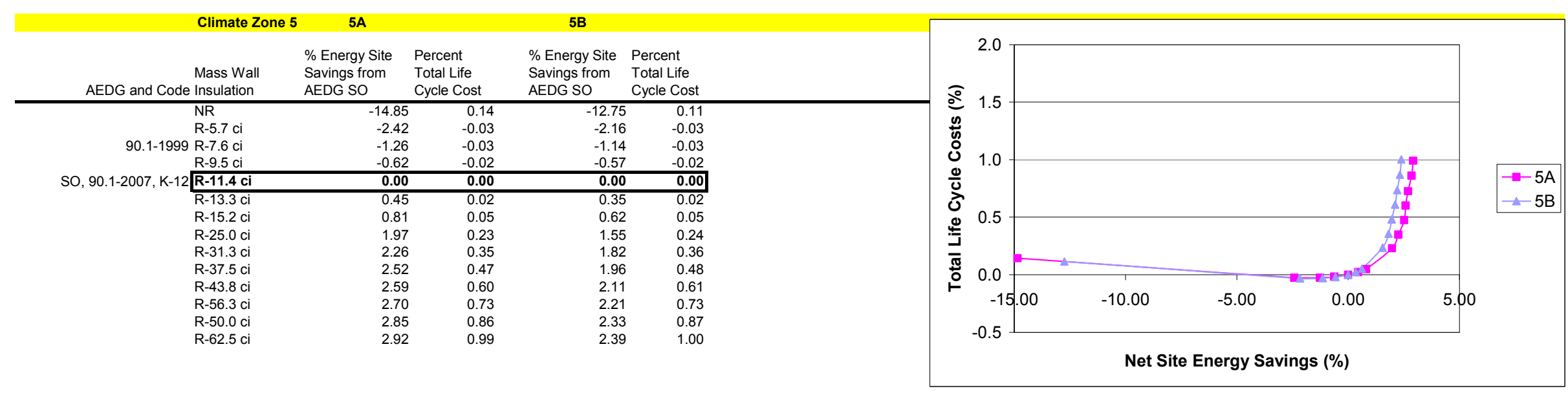

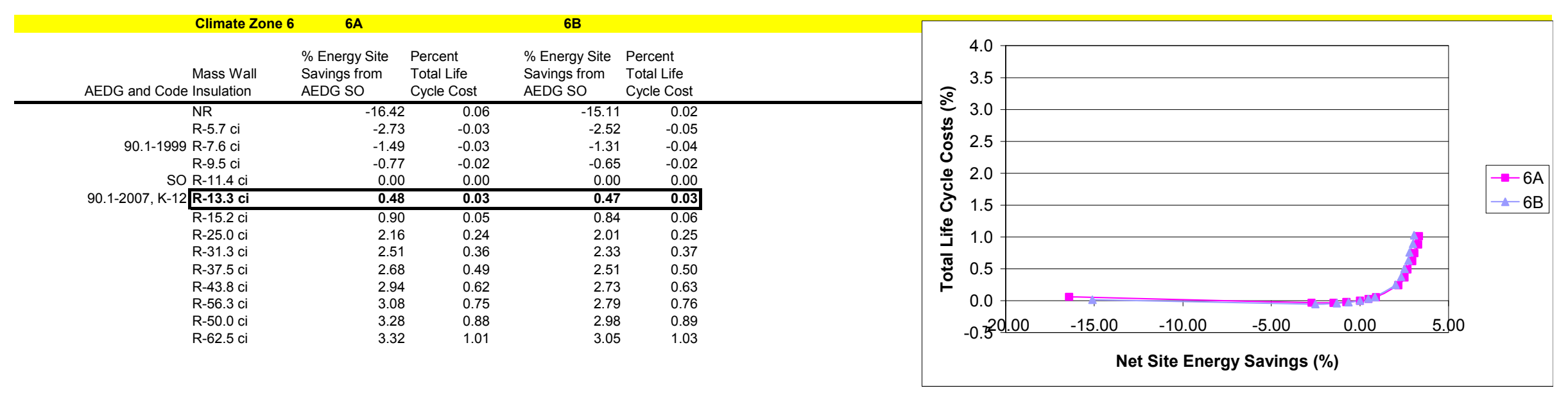




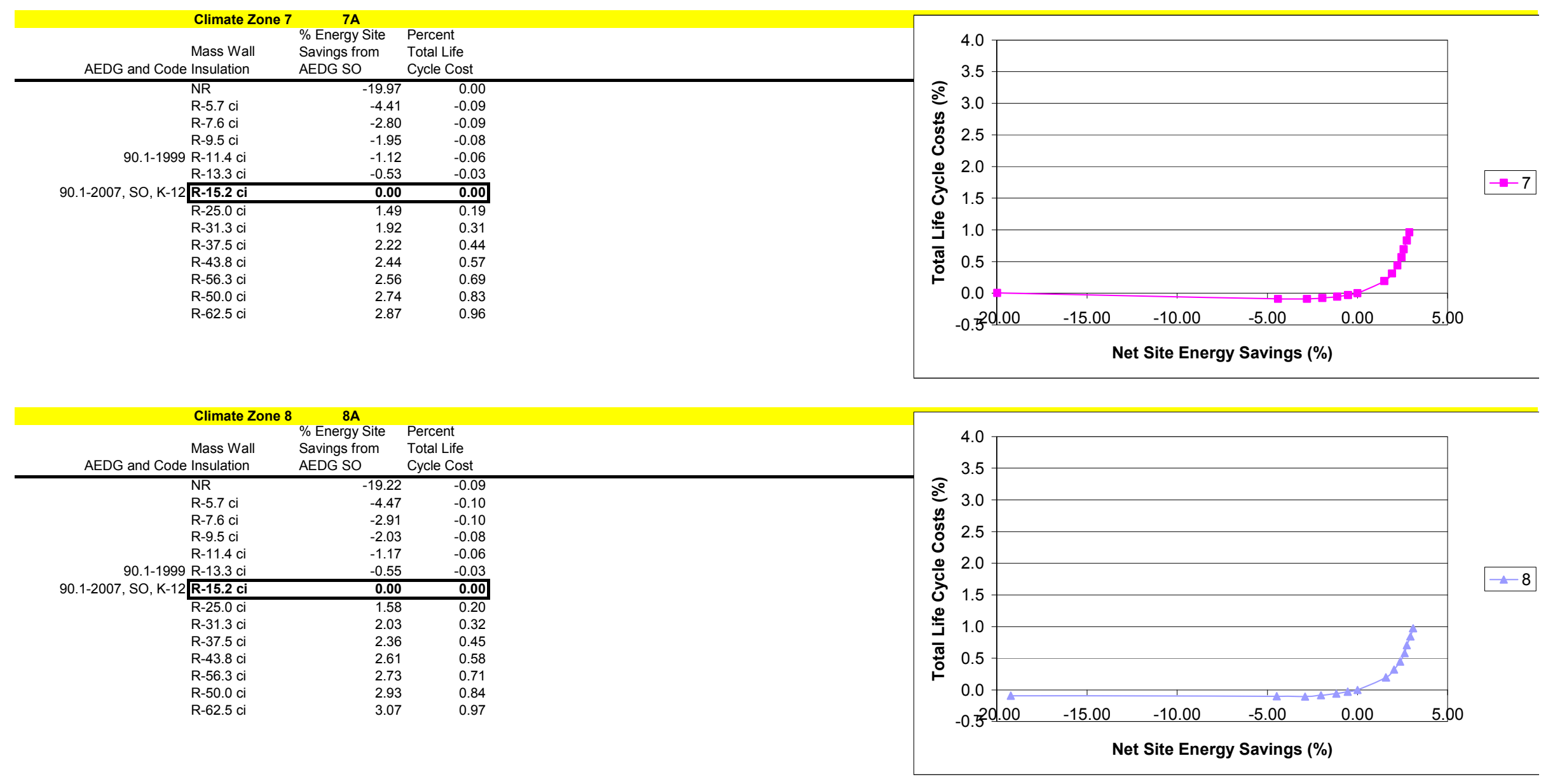


Appendix G. Energy Savings End Use Tables: ASHRAE 90.1-1999 Baseline

Table G-1 Elementary End Uses: Climate Zones 1-4

\begin{tabular}{|c|c|c|c|c|c|c|c|c|c|c|c|}
\hline \multicolumn{2}{|c|}{ Elementary School End Uses } & \multicolumn{6}{|c|}{ Electricity (kBtu/ft $\left.{ }^{2}\right)$} & \multicolumn{2}{|c|}{ Gas (kBtu/ft $\left.{ }^{2}\right)$} & \multirow{2}{*}{$\begin{array}{l}\text { Total End } \\
\text { Uses } \\
\text { (kBtu/ft') }\end{array}$} & \multirow{2}{*}{$\underset{\%}{\text { Savings }}$} \\
\hline Climate & Strategy & Cooling & $\begin{array}{c}\text { Int. } \\
\text { Lights }\end{array}$ & $\begin{array}{c}\text { Ext. } \\
\text { Lights }\end{array}$ & $\begin{array}{l}\text { Int. } \\
\text { Equip }\end{array}$ & Fans & Pumps & Heating & $\begin{array}{c}\text { Water } \\
\text { Systems }\end{array}$ & & \\
\hline \multirow{7}{*}{$1 \mathrm{~A}$} & Baseline & 20.9 & 20.0 & 0.8 & 14.9 & 18.0 & $\begin{array}{ll}0.0 \\
\end{array}$ & 0.4 & 0.7 & 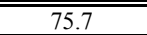 & $\overline{\mathrm{NA}}$ \\
\hline & $30 \%$ - No Daylight PSZ & 10.4 & 12.7 & 0.6 & 14.9 & 10.4 & 0.0 & 0.2 & 0.8 & 50.0 & $34.0 \%$ \\
\hline & $30 \%$ - No Daylight VAV & 13.1 & 12.7 & 0.6 & 14.9 & 5.6 & 0.6 & 0.0 & 0.8 & 48.3 & $36.3 \%$ \\
\hline & $30 \%$ - No Daylight PVAV & 9.7 & 12.7 & 0.6 & 14.9 & 5.6 & 0.0 & 0.0 & 0.8 & 44.4 & $41.4 \%$ \\
\hline & $30 \%$ - Daylit PSZ & 9.6 & 9.3 & 0.6 & 14.9 & 9.7 & 0.0 & 0.2 & 0.7 & 45.1 & $40.4 \%$ \\
\hline & 30\% - Daylit VAV & 12.1 & 9.3 & 0.6 & 14.9 & 5.2 & 0.6 & 0.0 & 0.7 & 43.5 & $42.5 \%$ \\
\hline & $30 \%$ - Daylit PVAV & 9.0 & 9.3 & 0.6 & 14.9 & 5.2 & 0.0 & 0.0 & 0.7 & 39.9 & $47.4 \%$ \\
\hline \multirow{7}{*}{$2 A$} & Baseline & 14.2 & 20.0 & 0.8 & 14.9 & 17.5 & 0.0 & 3.3 & 1.0 & 71.8 & NA \\
\hline & $30 \%$ - No Daylight PSZ & 6.6 & 12.7 & 0.6 & 14.9 & 9.3 & 0.0 & 1.0 & 1.0 & 46.2 & $35.7 \%$ \\
\hline & $30 \%$ - No Daylight VAV & 9.4 & 12.7 & 0.6 & 14.9 & 5.0 & 0.6 & 1.0 & 1.0 & 45.2 & $37.0 \%$ \\
\hline & $30 \%$ - No Daylight PVAV & 7.0 & 12.7 & 0.6 & 14.9 & 5.0 & 0.0 & 1.8 & 1.0 & 42.3 & $41.1 \%$ \\
\hline & $30 \%$ - Daylit PSZ & 5.9 & 9.4 & 0.6 & 14.9 & 8.6 & 0.0 & 1.1 & 1.0 & 41.6 & $42.1 \%$ \\
\hline & 30\% - Daylit VAV & 8.7 & 9.4 & 0.6 & 14.9 & 4.6 & 0.5 & 1.1 & 1.0 & 40.8 & $43.2 \%$ \\
\hline & $30 \%$ - Daylit PVAV & 6.4 & 9.4 & 0.6 & 14.9 & 4.6 & 0.0 & 1.1 & 1.0 & 38.1 & $46.9 \%$ \\
\hline \multirow{7}{*}{ 2B } & Baseline & 16.6 & 20.0 & 0.8 & 14.9 & 19.3 & 0.0 & 1.5 & 0.9 & 74.0 & $\overline{\mathrm{NA}}$ \\
\hline & $30 \%$ - No Daylight PSZ & 7.1 & 12.7 & 0.6 & 14.9 & 9.8 & 0.0 & 0.6 & 0.9 & 46.6 & $37.1 \%$ \\
\hline & $30 \%$ - No Daylight VAV & 8.6 & 12.7 & 0.6 & 14.9 & 5.3 & 0.5 & 0.7 & 0.9 & 44.3 & $40.2 \%$ \\
\hline & 30\% - No Daylight PVAV & 6.4 & 12.7 & 0.6 & 14.9 & 5.3 & 0.0 & 0.7 & 0.9 & 41.6 & $43.8 \%$ \\
\hline & $30 \%$ - Daylit PSZ & 6.2 & 9.4 & 0.6 & 14.9 & 8.9 & 0.0 & 0.6 & 0.9 & 41.6 & $43.9 \%$ \\
\hline & $30 \%$ - Daylit VAV & 7.7 & 9.4 & 0.6 & 14.9 & 4.8 & 0.5 & 0.7 & 0.9 & 39.4 & $46.7 \%$ \\
\hline & $30 \%$ - Daylit PVAV & 5.7 & 9.4 & 0.6 & 14.9 & 4.8 & 0.0 & 0.7 & 0.9 & 37.0 & $50.0 \%$ \\
\hline \multirow{7}{*}{ 3A } & Baseline & 9.7 & 20.0 & 0.8 & 14.9 & 16.0 & 0.0 & 4.9 & 1.2 & 67.4 & NA \\
\hline & $30 \%$ - No Daylight PSZ & 4.3 & 10.1 & 0.6 & 14.9 & 9.5 & 0.0 & 2.7 & 1.2 & 43.3 & $35.8 \%$ \\
\hline & $30 \%$ - No Daylight VAV & 7.3 & 10.1 & 0.6 & 14.9 & 5.1 & 0.6 & 3.0 & 1.2 & 42.8 & $36.4 \%$ \\
\hline & $30 \%$ - No Daylight PVAV & 5.4 & 10.1 & 0.6 & 14.9 & 5.1 & 0.0 & 3.2 & 1.2 & 40.6 & $39.8 \%$ \\
\hline & $30 \%$ - Daylit PSZ & 4.0 & 9.5 & 0.6 & 14.9 & 8.9 & 0.0 & 2.8 & 1.2 & 41.9 & $37.8 \%$ \\
\hline & $30 \%$ - Daylit VAV & 6.9 & 9.5 & 0.6 & 14.9 & 4.8 & 0.6 & 2.9 & 1.2 & 41.3 & $38.7 \%$ \\
\hline & $30 \%$ - Daylit PVAV & 5.1 & 9.5 & 0.6 & 14.9 & 4.8 & 0.0 & 3.0 & 1.2 & 39.2 & $41.9 \%$ \\
\hline \multirow{7}{*}{ 3B } & Baseline & 9.6 & 20.0 & 0.8 & 14.9 & 15.5 & 0.0 & 1.8 & 1.1 & 63.7 & $\overline{\mathrm{NA}}$ \\
\hline & $30 \%$ - No Daylight PSZ & 4.2 & 10.1 & 0.6 & 14.9 & 9.1 & 0.0 & 0.9 & 1.1 & 41.0 & $35.6 \%$ \\
\hline & $30 \%$ - No Daylight VAV & 6.2 & 10.1 & 0.6 & 14.9 & 5.0 & 0.5 & 1.2 & 1.1 & 39.6 & $37.8 \%$ \\
\hline & $30 \%$ - No Daylight PVAV & 4.6 & 10.1 & 0.6 & 14.9 & 5.0 & 0.0 & 1.3 & 1.1 & 37.6 & $40.9 \%$ \\
\hline & $30 \%$ - Daylit PSZ & 3.9 & 9.4 & 0.6 & 14.9 & 8.5 & 0.0 & 1.0 & 1.1 & 39.4 & $38.1 \%$ \\
\hline & $30 \%$ - Daylit VAV & 5.8 & 9.4 & 0.6 & 14.9 & 4.6 & 0.4 & 1.2 & 1.1 & 38.1 & $40.2 \%$ \\
\hline & $30 \%$ - Daylit PVAV & 4.3 & 9.4 & 0.6 & 14.9 & 4.6 & 0.0 & 1.3 & 1.1 & 36.2 & $43.1 \%$ \\
\hline \multirow{7}{*}{$3 C$} & Baseline & 3.7 & 20.0 & 0.8 & 14.9 & 17.5 & 0.0 & 2.3 & 1.3 & 60.4 & NA \\
\hline & 30\% - No Daylight PSZ & 0.8 & 10.1 & 0.6 & 14.9 & 7.4 & 0.0 & 0.8 & 1.3 & 36.0 & $40.4 \%$ \\
\hline & $30 \%$ - No Daylight VAV & 2.5 & 10.1 & 0.6 & 14.9 & 3.4 & 0.3 & 1.6 & 1.3 & 34.7 & $42.6 \%$ \\
\hline & $30 \%$ - No Daylight PVAV & 1.8 & 10.1 & 0.6 & 14.9 & 3.4 & 0.0 & 1.8 & 1.3 & 33.9 & $43.9 \%$ \\
\hline & $30 \%$ - Daylit PSZ & 0.6 & 9.5 & 0.6 & 14.9 & 6.8 & 0.0 & 0.8 & 1.4 & 34.6 & $42.8 \%$ \\
\hline & 30\% - Daylit VAV & 2.4 & 9.5 & 0.6 & 14.9 & 3.6 & 0.3 & 1.5 & 1.3 & 34.1 & $43.6 \%$ \\
\hline & $30 \%$ - Daylit PVAV & 1.8 & 9.5 & 0.6 & 14.9 & 3.6 & 0.0 & 1.6 & 1.3 & 33.3 & $44.9 \%$ \\
\hline \multirow{7}{*}{$4 \mathrm{~A}$} & Baseline & 6.5 & 20.0 & 0.8 & 14.9 & 16.9 & 0.0 & 10.8 & 1.4 & 71.2 & NA \\
\hline & $30 \%$ - No Daylight PSZ & 3.0 & 10.1 & 0.6 & 14.9 & 10.2 & 0.0 & 5.4 & 1.4 & 45.5 & $36.1 \%$ \\
\hline & $30 \%$ - No Daylight VAV & 6.2 & 10.1 & 0.6 & 14.9 & 5.6 & 0.6 & 5.5 & 1.4 & 44.9 & $36.9 \%$ \\
\hline & $30 \%$ - No Daylight PVAV & 4.6 & 10.1 & 0.6 & 14.9 & 5.6 & 0.0 & 5.9 & 1.4 & 43.0 & $39.6 \%$ \\
\hline & $30 \%$ - Daylit PSZ & 2.6 & 9.4 & 0.6 & 14.9 & 9.0 & 0.0 & 5.6 & 1.4 & 43.5 & $38.9 \%$ \\
\hline & $30 \%$ - Daylit VAV & 5.6 & 9.4 & 0.6 & 14.9 & 5.0 & 0.6 & 5.2 & 1.4 & 42.6 & $40.2 \%$ \\
\hline & $30 \%$ - Daylit PVAV & 4.1 & 9.4 & 0.6 & 14.9 & 5.0 & 0.0 & 5.6 & 1.4 & 40.9 & $42.5 \%$ \\
\hline \multirow{7}{*}{ 4B } & Baseline & 6.8 & 20.0 & 0.8 & 14.9 & 17.1 & $\overline{0.0}$ & 4.7 & 1.3 & 65.6 & NA \\
\hline & $30 \%$ - No Daylight PSZ & 2.9 & 10.1 & 0.6 & 14.9 & 10.2 & 0.0 & 2.3 & 1.4 & 42.5 & $35.2 \%$ \\
\hline & $30 \%$ - No Daylight VAV & 5.5 & 10.1 & 0.6 & 14.9 & 5.7 & 0.5 & 2.7 & 1.3 & 41.4 & $36.9 \%$ \\
\hline & $30 \%$ - No Daylight PVAV & 4.1 & 10.1 & 0.6 & 14.9 & 5.7 & 0.0 & 2.9 & 1.3 & 39.7 & $39.5 \%$ \\
\hline & $30 \%$ - Daylit PSZ & 2.6 & 9.2 & 0.6 & 14.9 & 9.1 & 0.0 & 2.4 & 1.4 & 40.2 & $38.7 \%$ \\
\hline & $30 \%$ - Daylit VAV & 4.9 & 9.2 & 0.6 & 14.9 & 5.0 & 0.4 & 2.6 & 1.3 & 39.1 & $40.3 \%$ \\
\hline & $30 \%$ - Daylit PVAV & 3.6 & 9.2 & 0.6 & 14.9 & 5.0 & 0.0 & 2.8 & 1.3 & 37.6 & $42.6 \%$ \\
\hline
\end{tabular}


Table G-2 Elementary School End Uses: Climate Zones 4-8

\begin{tabular}{|c|c|c|c|c|c|c|c|c|c|c|c|}
\hline \multicolumn{2}{|c|}{ Elementary School End Uses } & \multicolumn{6}{|c|}{ Electricity (kBtu/ft ${ }^{2}$ ) } & \multicolumn{2}{|c|}{ Gas (kBtu/ft ${ }^{2}$ ) } & \multirow{2}{*}{$\begin{array}{c}\text { Total } \\
\text { End } \\
\text { Uses } \\
\text { (kBtu/ft }{ }^{2} \text { ) }\end{array}$} & \multirow{2}{*}{$\begin{array}{c}\text { Savings } \\
\%\end{array}$} \\
\hline Climate & Strategy & Cooling & $\begin{array}{l}\text { Int. } \\
\text { Lights }\end{array}$ & $\begin{array}{l}\text { Ext. } \\
\text { Lights }\end{array}$ & $\begin{array}{l}\text { Int. } \\
\text { Equi } \\
\text { p }\end{array}$ & Fans & Pumps & Heating & $\begin{array}{c}\text { Water } \\
\text { Systems }\end{array}$ & & \\
\hline \multirow{7}{*}{$4 C$} & Baseline & 2.0 & 20.0 & 0.8 & 1414.9 & 15.3 & 0.0 & 6.4 & 1.4 & 60.9 & NA \\
\hline & $30 \%$ - No Daylight PSZ & 0.9 & 10.1 & 0.6 & 14.9 & 9.1 & 0.0 & 3.7 & 1.5 & 40.8 & $33.0 \%$ \\
\hline & $30 \%$ - No Daylight VAV & 2.2 & 10.1 & 0.6 & 14.9 & 4.2 & 0.2 & 4.4 & 1.4 & 38.0 & $37.5 \%$ \\
\hline & $30 \%$ - No Daylight PVAV & 1.5 & 10.1 & 0.6 & 14.9 & 4.2 & 0.0 & 4.7 & 1.4 & 37.5 & $38.4 \%$ \\
\hline & $30 \%$ - Daylit PSZ & 0.7 & 9.7 & 0.6 & 14.9 & 8.0 & 0.0 & 3.8 & 1.5 & 39.2 & $35.6 \%$ \\
\hline & $30 \%$ - Daylit VAV & 2.0 & 9.7 & 0.6 & 14.9 & 4.3 & 0.2 & 3.8 & 1.4 & 37.0 & $39.2 \%$ \\
\hline & $30 \%$ - Daylit PVAV & 1.4 & 9.7 & 0.6 & 14.9 & 4.3 & 0.0 & 4.1 & 1.4 & 36.5 & $40.1 \%$ \\
\hline \multirow{7}{*}{$5 A$} & Baseline & 5.1 & 20.0 & 0.8 & 14.9 & 18.3 & 0.0 & 18.9 & 1.5 & 79.6 & NA \\
\hline & $30 \%$ - No Daylight PSZ & 2.5 & 12.7 & 0.6 & 14.9 & 11.0 & 0.0 & 8.3 & 1.5 & 51.6 & $35.1 \%$ \\
\hline & $30 \%$ - No Daylight VAV & 6.2 & 12.7 & 0.6 & 14.9 & 6.1 & 0.7 & 8.4 & 1.5 & 51.2 & $35.7 \%$ \\
\hline & $30 \%$ - No Daylight PVAV & 4.7 & 12.7 & 0.6 & 14.9 & 6.1 & 0.0 & 8.9 & 1.5 & 49.5 & $37.8 \%$ \\
\hline & $30 \%$ - Daylit PSZ & 2.1 & 9.4 & 0.6 & 14.9 & 9.6 & 0.0 & 9.3 & 1.5 & 47.4 & $40.4 \%$ \\
\hline & $30 \%$ - Daylit VAV & 5.4 & 9.4 & 0.6 & 14.9 & 5.3 & 0.6 & 8.6 & 1.5 & 46.4 & $41.7 \%$ \\
\hline & $30 \%$ - Daylit PVAV & 4.0 & 9.4 & 0.6 & 14.9 & 5.3 & 0.0 & 9.1 & 1.5 & 45.0 & $43.4 \%$ \\
\hline \multirow{7}{*}{$5 B$} & Baseline & 4.5 & 20.0 & 0.8 & 14.9 & 18.2 & 0.0 & 11.1 & 1.5 & 71.0 & NA \\
\hline & $30 \%$ - No Daylight PSZ & 2.1 & 12.7 & 0.6 & 14.9 & 10.7 & 0.0 & 5.0 & 1.5 & 47.5 & $33.2 \%$ \\
\hline & $30 \%$ - No Daylight VAV & 4.9 & 12.7 & 0.6 & 14.9 & 5.8 & 0.5 & 4.9 & 1.5 & 45.9 & $35.3 \%$ \\
\hline & $30 \%$ - No Daylight PVAV & 3.9 & 12.7 & 0.6 & 14.9 & 5.9 & 0.0 & 5.9 & 1.5 & 45.5 & $36.0 \%$ \\
\hline & $30 \%$ - Daylit PSZ & 1.6 & 9.3 & 0.6 & 14.9 & 9.3 & 0.0 & 5.7 & 1.5 & 42.9 & $39.5 \%$ \\
\hline & $30 \%$ - Daylit VAV & 4.4 & 9.3 & 0.6 & 14.9 & 5.2 & 0.5 & 5.7 & 1.5 & 42.0 & $40.8 \%$ \\
\hline & $30 \%$ - Daylit PVAV & 3.3 & 9.3 & 0.6 & 14.9 & 5.2 & 0.0 & 6.0 & 1.5 & 40.8 & $42.5 \%$ \\
\hline \multirow{7}{*}{ 6A } & Baseline & 3.5 & 20.0 & 0.8 & 14.9 & 17.9 & 0.0 & 28.6 & 1.7 & 87.4 & NA \\
\hline & $30 \%$ - No Daylight PSZ & 1.7 & 12.7 & 0.6 & 14.9 & 10.8 & 0.0 & 12.3 & 1.7 & 54.7 & $37.3 \%$ \\
\hline & $30 \%$ - No Daylight VAV & 5.4 & 12.7 & 0.6 & 14.9 & 6.0 & 0.7 & 12.1 & 1.7 & 54.0 & $38.2 \%$ \\
\hline & $30 \%$ - No Daylight PVAV & 4.2 & 12.7 & 0.6 & 14.9 & 6.0 & 0.0 & 12.9 & 1.7 & 52.9 & $39.4 \%$ \\
\hline & $30 \%$ - Daylit PSZ & 1.3 & 9.4 & 0.6 & 14.9 & 9.3 & 0.0 & 13.3 & 1.7 & 50.5 & $42.2 \%$ \\
\hline & $30 \%$ - Daylit VAV & 4.6 & 9.4 & 0.6 & 14.9 & 5.1 & 0.6 & 12.4 & 1.7 & 49.3 & $43.6 \%$ \\
\hline & $30 \%$ - Daylit PVAV & 3.6 & 9.4 & 0.6 & 14.9 & 5.1 & 0.0 & 13.2 & 1.7 & 48.5 & $44.5 \%$ \\
\hline \multirow{7}{*}{$6 B$} & Baseline & 2.9 & 20.0 & 0.8 & 14.9 & 18.4 & 0.0 & 21.1 & 1.7 & 79.8 & NA \\
\hline & $30 \%$ - No Daylight PSZ & 1.3 & 12.7 & 0.6 & 14.9 & 10.6 & 0.0 & 9.3 & 1.7 & 51.2 & $35.9 \%$ \\
\hline & $30 \%$ - No Daylight VAV & 4.5 & 12.7 & 0.6 & 14.9 & 5.9 & 0.5 & 9.9 & 1.7 & 50.8 & $36.4 \%$ \\
\hline & $30 \%$ - No Daylight PVAV & 3.5 & 12.7 & 0.6 & 14.9 & 5.9 & 0.0 & 10.6 & 1.7 & 49.9 & $37.4 \%$ \\
\hline & $30 \%$ - Daylit PSZ & 1.0 & 9.3 & 0.6 & 14.9 & 9.1 & 0.0 & 10.1 & 1.7 & 46.7 & $41.5 \%$ \\
\hline & $30 \%$ - Daylit VAV & 3.7 & 9.3 & 0.6 & 14.9 & 5.1 & 0.5 & 10.1 & 1.7 & 46.0 & $42.4 \%$ \\
\hline & $30 \%$ - Daylit PVAV & 2.9 & 9.3 & 0.6 & 14.9 & 5.1 & 0.0 & 10.8 & 1.7 & 45.4 & $43.1 \%$ \\
\hline \multirow{7}{*}{$7 \mathrm{~A}$} & Baseline & 2.0 & 20.0 & 0.8 & 14.9 & 19.8 & 0.0 & 38.9 & 1.9 & 98.3 & NA \\
\hline & $30 \%$ - No Daylight PSZ & 0.9 & 12.7 & 0.6 & 14.9 & 11.2 & 0.0 & 16.3 & 1.9 & 58.5 & $40.4 \%$ \\
\hline & $30 \%$ - No Daylight VAV & 4.5 & 12.7 & 0.6 & 14.9 & 6.2 & 0.7 & 16.1 & 1.9 & 57.7 & $41.3 \%$ \\
\hline & $30 \%$ - No Daylight PVAV & 3.5 & 12.7 & 0.6 & 14.9 & 6.2 & 0.0 & 17.2 & 1.9 & 57.1 & $41.9 \%$ \\
\hline & $30 \%$ - Daylit PSZ & 0.6 & 9.3 & 0.6 & 14.9 & 9.7 & 0.0 & 17.1 & 1.9 & 54.1 & $44.9 \%$ \\
\hline & $30 \%$ - Daylit VAV & 3.8 & 9.3 & 0.6 & 14.9 & 5.4 & 0.7 & 16.4 & 1.8 & 52.9 & $46.1 \%$ \\
\hline & $30 \%$ - Daylit PVAV & 2.9 & 9.3 & 0.6 & 14.9 & 5.4 & 0.0 & 17.6 & 1.8 & 52.6 & $46.5 \%$ \\
\hline \multirow{7}{*}{8} & Baseline & 0.8 & 20.0 & 0.8 & 14.9 & 17.2 & 0.0 & 79.2 & 2.1 & 135.0 & NA \\
\hline & $30 \%$ - No Daylight PSZ & 0.6 & 12.7 & 0.6 & 14.9 & 14.0 & 0.0 & 33.3 & 2.1 & 78.2 & $42.1 \%$ \\
\hline & $30 \%$ - No Daylight VAV & 4.6 & 12.7 & 0.6 & 14.9 & 7.6 & 1.0 & 38.2 & 2.1 & 81.7 & $39.5 \%$ \\
\hline & $30 \%$ - No Daylight PVAV & 3.6 & 12.7 & 0.6 & 14.9 & 7.6 & 0.0 & 40.9 & 2.1 & 82.4 & $38.9 \%$ \\
\hline & $30 \%$ - Daylit PSZ & 0.5 & 10.1 & 0.6 & 14.9 & 13.3 & 0.0 & 32.8 & 2.1 & 74.2 & $45.1 \%$ \\
\hline & $30 \%$ - Daylit VAV & 4.2 & 10.1 & 0.6 & 14.9 & 7.2 & 0.9 & 38.7 & 2.1 & 78.7 & $41.7 \%$ \\
\hline & 30\% - Daylit PVAV & 3.3 & 10.1 & 0.6 & 14.9 & 7.2 & 0.0 & 41.4 & 2.1 & 79.6 & $41.1 \%$ \\
\hline
\end{tabular}


Table G-3 Middle School End Uses: Climate Zones 1-4

\begin{tabular}{|c|c|c|c|c|c|c|c|c|c|c|c|}
\hline \multicolumn{2}{|c|}{ Middle School End Uses } & \multicolumn{6}{|c|}{ Electricity (kBtu/ft ${ }^{2}$ ) } & \multicolumn{2}{|c|}{ Gas (kBtu/ft ${ }^{2}$ ) } & \multirow{2}{*}{$\begin{array}{c}\text { Total End } \\
\text { Uses } \\
\left.\text { (kBtu/ft }^{2}\right)\end{array}$} & \multirow{2}{*}{ Savings $\%$} \\
\hline Climate & Strategy & Cooling & $\begin{array}{c}\text { Int. } \\
\text { Lights }\end{array}$ & $\begin{array}{c}\text { Ext. } \\
\text { Lights }\end{array}$ & $\begin{array}{l}\text { Int. } \\
\text { Equip }\end{array}$ & Fans & Pumps & Heating & $\begin{array}{c}\text { Water } \\
\text { Systems }\end{array}$ & & \\
\hline \multirow{7}{*}{$1 \mathrm{~A}$} & Baseline & 20.5 & 19.9 & 0.7 & 11.6 & 17.4 & 0.0 & 0.4 & 1.3 & 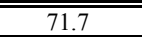 & NA \\
\hline & $30 \%$ - No Daylight PSZ & 10.2 & 12.7 & 0.5 & 11.6 & 10.0 & 0.0 & 0.2 & 1.2 & 46.4 & $35.4 \%$ \\
\hline & $30 \%$ - No Daylight VAV & 13.5 & 12.7 & 0.5 & 11.6 & 5.5 & 0.6 & 0.0 & 1.2 & 45.6 & $36.4 \%$ \\
\hline & $30 \%$ - No Daylight PVAV & 10.1 & 12.7 & 0.5 & 11.6 & 5.5 & 0.0 & 0.0 & 1.2 & 41.6 & $42.1 \%$ \\
\hline & $30 \%$ - Daylit PSZ & 9.4 & 9.7 & 0.5 & 11.6 & 9.4 & 0.0 & 0.2 & 1.2 & 42.0 & $41.5 \%$ \\
\hline & $30 \%$ - Daylit VAV & 12.6 & 9.7 & 0.5 & 11.6 & 5.1 & 0.6 & 0.0 & 1.2 & 41.3 & $42.4 \%$ \\
\hline & $30 \%$ - Daylit PVAV & 9.4 & 9.7 & 0.5 & 11.6 & 5.1 & 0.0 & 0.0 & 1.2 & 37.5 & $47.7 \%$ \\
\hline \multirow{7}{*}{$2 A$} & Baseline & 13.8 & 19.9 & 0.7 & 11.6 & 16.9 & 0.0 & 3.2 & 1.8 & 67.8 & NA \\
\hline & $30 \%$ - No Daylight PSZ & 6.3 & 12.7 & 0.5 & 11.6 & 9.0 & 0.0 & 1.5 & 1.6 & 43.2 & $36.3 \%$ \\
\hline & $30 \%$ - No Daylight VAV & 9.8 & 12.7 & 0.5 & 11.6 & 4.9 & 0.6 & 1.1 & 1.6 & 42.8 & $36.9 \%$ \\
\hline & $30 \%$ - No Daylight PVAV & 7.3 & 12.7 & 0.5 & 11.6 & 4.9 & 0.0 & 2.0 & 1.6 & 39.8 & $41.3 \%$ \\
\hline & $30 \%$ - Daylit PSZ & 5.7 & 9.8 & 0.5 & 11.6 & 8.3 & 0.0 & 1.6 & 1.6 & 39.1 & $42.3 \%$ \\
\hline & $30 \%$ - Daylit VAV & 9.1 & 9.8 & 0.5 & 11.6 & 4.6 & 0.5 & 1.1 & 1.6 & 38.9 & $42.7 \%$ \\
\hline & $30 \%$ - Daylit PVAV & 6.8 & 9.8 & 0.5 & 11.6 & 4.6 & 0.0 & 1.2 & 1.6 & 36.1 & $46.8 \%$ \\
\hline \multirow{7}{*}{ 2B } & Baseline & 15.8 & 19.9 & 0.7 & 11.6 & 18.3 & 0.0 & 1.4 & 1.6 & 69.2 & NA \\
\hline & $30 \%$ - No Daylight PSZ & 6.7 & 12.7 & 0.5 & 11.6 & 9.2 & 0.0 & 0.7 & 1.4 & 42.9 & $38.0 \%$ \\
\hline & $30 \%$ - No Daylight VAV & 8.7 & 12.7 & 0.5 & 11.6 & 5.1 & 0.5 & 0.8 & 1.4 & 41.4 & $40.2 \%$ \\
\hline & $30 \%$ - No Daylight PVAV & 6.5 & 12.7 & 0.5 & 11.6 & 5.1 & 0.0 & 0.8 & 1.4 & 38.7 & $44.1 \%$ \\
\hline & 30\% - Daylit PSZ & 6.1 & 9.7 & 0.5 & 11.6 & 8.5 & 0.0 & 0.8 & 1.4 & 38.7 & $44.1 \%$ \\
\hline & $30 \%$ - Daylit VAV & 7.9 & 9.7 & 0.5 & 11.6 & 4.7 & 0.5 & 0.8 & 1.4 & 37.1 & $46.3 \%$ \\
\hline & $30 \%$ - Daylit PVAV & 5.9 & 9.7 & 0.5 & 11.6 & 4.7 & 0.0 & 0.8 & 1.4 & 34.7 & $49.9 \%$ \\
\hline \multirow{7}{*}{$3 \mathbf{A}$} & Baseline & 9.4 & 19.9 & 0.7 & 11.6 & 15.7 & 0.0 & 5.1 & 2.1 & 64.4 & NA \\
\hline & $30 \%$ - No Daylight PSZ & 4.1 & 10.4 & 0.5 & 11.6 & 9.1 & 0.0 & 3.7 & 1.9 & 41.4 & $35.7 \%$ \\
\hline & $30 \%$ - No Daylight VAV & 7.6 & 10.4 & 0.5 & 11.6 & 5.1 & 0.6 & 3.1 & 1.9 & 40.8 & $36.7 \%$ \\
\hline & $30 \%$ - No Daylight PVAV & 5.6 & 10.4 & 0.5 & 11.6 & 5.1 & 0.0 & 3.3 & 1.9 & 38.4 & $40.4 \%$ \\
\hline & $30 \%$ - Daylit PSZ & 3.8 & 9.9 & 0.5 & 11.6 & 8.6 & 0.0 & 3.8 & 1.9 & 40.2 & $37.7 \%$ \\
\hline & $30 \%$ - Daylit VAV & 7.2 & 9.9 & 0.5 & 11.6 & 4.8 & 0.6 & 2.9 & 1.9 & 39.4 & $38.9 \%$ \\
\hline & $30 \%$ - Daylit PVAV & 5.3 & 9.9 & 0.5 & 11.6 & 4.8 & 0.0 & 3.1 & 1.9 & 37.2 & $42.3 \%$ \\
\hline \multirow{7}{*}{ 3B } & Baseline & 9.4 & 19.9 & 0.7 & 11.6 & 15.3 & 0.0 & 2.0 & 2.0 & 60.8 & NA \\
\hline & $30 \%$ - No Daylight PSZ & 4.1 & 10.4 & 0.5 & 11.6 & 8.8 & 0.0 & 1.5 & 1.8 & 38.7 & $36.3 \%$ \\
\hline & $30 \%$ - No Daylight VAV & 6.4 & 10.4 & 0.5 & 11.6 & 4.9 & 0.5 & 1.3 & 1.8 & 37.4 & $38.4 \%$ \\
\hline & $30 \%$ - No Daylight PVAV & 4.7 & 10.4 & 0.5 & 11.6 & 4.9 & 0.0 & 1.4 & 1.8 & 35.4 & $41.7 \%$ \\
\hline & $30 \%$ - Daylit PSZ & 3.8 & 9.8 & 0.5 & 11.6 & 8.3 & 0.0 & 1.6 & 1.8 & 37.3 & $38.7 \%$ \\
\hline & $30 \%$ - Daylit VAV & 6.0 & 9.8 & 0.5 & 11.6 & 4.6 & 0.4 & 1.3 & 1.8 & 36.0 & $40.8 \%$ \\
\hline & $30 \%$ - Daylit PVAV & 4.4 & 9.8 & 0.5 & 11.6 & 4.6 & 0.0 & 1.3 & 1.8 & 34.1 & $43.9 \%$ \\
\hline \multirow{7}{*}{$3 C$} & Baseline & 3.3 & 19.9 & 0.7 & 11.6 & 17.0 & 0.0 & 2.2 & 2.4 & 57.0 & NA \\
\hline & $30 \%$ - No Daylight PSZ & 0.6 & 10.4 & 0.5 & 11.6 & 7.1 & 0.0 & 1.3 & 2.2 & 33.7 & $41.0 \%$ \\
\hline & $30 \%$ - No Daylight VAV & 2.5 & 10.4 & 0.5 & 11.6 & 3.4 & 0.3 & 1.8 & 2.2 & 32.7 & $42.7 \%$ \\
\hline & $30 \%$ - No Daylight PVAV & 1.8 & 10.4 & 0.5 & 11.6 & 3.4 & 0.0 & 1.9 & 2.2 & 31.8 & $44.2 \%$ \\
\hline & $30 \%$ - Daylit PSZ & 0.5 & 9.9 & 0.5 & 11.6 & 6.6 & 0.0 & 1.4 & 2.2 & 32.6 & $42.9 \%$ \\
\hline & $30 \%$ - Daylit VAV & 2.3 & 9.9 & 0.5 & 11.6 & 3.1 & 0.3 & 1.6 & 2.2 & 31.6 & $44.7 \%$ \\
\hline & $30 \%$ - Daylit PVAV & 1.7 & 9.9 & 0.5 & 11.6 & 3.1 & 0.0 & 1.7 & 2.2 & 30.8 & $46.0 \%$ \\
\hline \multirow{7}{*}{$4 A$} & Baseline & 6.2 & 19.9 & 0.7 & 11.6 & 16.5 & 0.0 & 11.0 & 2.5 & 68.4 & NA \\
\hline & $30 \%$ - No Daylight PSZ & 2.8 & 10.4 & 0.5 & 11.6 & 9.6 & 0.0 & 7.3 & 2.3 & 44.5 & $34.9 \%$ \\
\hline & $30 \%$ - No Daylight VAV & 6.2 & 10.4 & 0.5 & 11.6 & 5.4 & 0.6 & 5.5 & 2.3 & 42.6 & $37.7 \%$ \\
\hline & $30 \%$ - No Daylight PVAV & 4.6 & 10.4 & 0.5 & 11.6 & 5.4 & 0.0 & 5.9 & 2.3 & 40.7 & $40.4 \%$ \\
\hline & 30\% - Daylit PSZ & 2.5 & 9.6 & 0.5 & 11.6 & 8.8 & 0.0 & 7.5 & 2.3 & 42.7 & $37.6 \%$ \\
\hline & $30 \%$ - Daylit VAV & 5.7 & 9.6 & 0.5 & 11.6 & 5.0 & 0.6 & 5.3 & 2.3 & 40.6 & $40.6 \%$ \\
\hline & $30 \%$ - Daylit PVAV & 4.2 & 9.6 & 0.5 & 11.6 & 5.0 & 0.0 & 5.7 & 2.3 & 38.9 & $43.1 \%$ \\
\hline \multirow{7}{*}{ 4B } & Baseline & 6.6 & 19.9 & 0.7 & 11.6 & 16.8 & 0.0 & 4.9 & 2.5 & 62.8 & NA \\
\hline & $30 \%$ - No Daylight PSZ & 2.8 & 10.4 & 0.5 & 11.6 & 9.7 & 0.0 & 3.5 & 2.2 & 40.7 & $35.2 \%$ \\
\hline & $30 \%$ - No Daylight VAV & 5.5 & 10.4 & 0.5 & 11.6 & 5.6 & 0.5 & 2.9 & 2.2 & 39.2 & $37.6 \%$ \\
\hline & $30 \%$ - No Daylight PVAV & 4.1 & 10.4 & 0.5 & 11.6 & 5.6 & 0.0 & 3.1 & 2.2 & 37.5 & $40.3 \%$ \\
\hline & $30 \%$ - Daylit PSZ & 2.4 & 9.5 & 0.5 & 11.6 & 8.8 & 0.0 & 3.7 & 2.2 & 38.7 & $38.4 \%$ \\
\hline & $30 \%$ - Daylit VAV & 5.0 & 9.5 & 0.5 & 11.6 & 5.1 & 0.4 & 2.8 & 2.2 & 37.0 & $41.0 \%$ \\
\hline & $30 \%$ - Daylit PVAV & 3.7 & 9.5 & 0.5 & 11.6 & 5.1 & 0.0 & 3.0 & 2.2 & 35.5 & $43.5 \%$ \\
\hline
\end{tabular}


Table G-4 Middle School End Uses: Climate Zones 4-8

\begin{tabular}{|c|c|c|c|c|c|c|c|c|c|c|c|}
\hline \multicolumn{2}{|c|}{ Middle School End Uses } & \multicolumn{6}{|c|}{ Electricity (kBtu/ft ${ }^{2}$ ) } & \multicolumn{2}{|c|}{ Gas (kBtu/ft $\left.{ }^{2}\right)$} & \multirow{2}{*}{$\begin{array}{c}\text { Total } \\
\text { End } \\
\text { Uses } \\
\left.\text { (kBtu/ft }{ }^{2}\right)\end{array}$} & \multirow{2}{*}{$\begin{array}{c}\text { Savings } \\
\%\end{array}$} \\
\hline Climate & Strategy & Cooling & $\begin{array}{c}\text { Int. } \\
\text { Lights }\end{array}$ & $\begin{array}{c}\text { Ext. } \\
\text { Lights }\end{array}$ & $\begin{array}{c}\text { Int. } \\
\text { Equip }\end{array}$ & Fans & Pumps & Heating & $\begin{array}{c}\text { Water } \\
\text { Systems }\end{array}$ & & \\
\hline \multirow{7}{*}{$4 C$} & Baseline & 1.8 & 19.9 & 0.7 & 11.6 & 14.9 & 0.0 & 6.9 & 2.6 & 58.4 & NA \\
\hline & $30 \%$ - No Daylight PSZ & 0.7 & 10.4 & 0.5 & 11.6 & 8.5 & 0.0 & 5.5 & 2.4 & 39.6 & $32.2 \%$ \\
\hline & $30 \%$ - No Daylight VAV & 2.2 & 10.4 & 0.5 & 11.6 & 4.1 & 0.2 & 4.4 & 2.4 & 35.8 & $38.7 \%$ \\
\hline & $30 \%$ - No Daylight PVAV & 1.5 & 10.4 & 0.5 & 11.6 & 4.1 & 0.0 & 4.7 & 2.4 & 35.2 & $39.7 \%$ \\
\hline & $30 \%$ - Daylit PSZ & 0.5 & 9.9 & 0.5 & 11.6 & 7.7 & 0.0 & 5.6 & 2.4 & 38.3 & $34.5 \%$ \\
\hline & $30 \%$ - Daylit VAV & 1.9 & 9.9 & 0.5 & 11.6 & 3.7 & 0.2 & 4.0 & 2.4 & 34.3 & $41.3 \%$ \\
\hline & $30 \%$ - Daylit PVAV & 1.4 & 9.9 & 0.5 & 11.6 & 3.7 & 0.0 & 4.3 & 2.4 & 33.8 & $42.1 \%$ \\
\hline \multirow{7}{*}{$5 A$} & Baseline & 5.0 & 19.9 & 0.7 & 11.6 & 17.9 & 0.0 & 18.4 & 2.8 & 76.2 & NA \\
\hline & $30 \%$ - No Daylight PSZ & 2.3 & 12.7 & 0.5 & 11.6 & 10.5 & 0.0 & 10.9 & 2.5 & 51.1 & $33.0 \%$ \\
\hline & $30 \%$ - No Daylight VAV & 6.3 & 12.7 & 0.5 & 11.6 & 6.0 & 0.7 & 8.3 & 2.5 & 48.5 & $36.3 \%$ \\
\hline & $30 \%$ - No Daylight PVAV & 4.7 & 12.7 & 0.5 & 11.6 & 6.0 & 0.0 & 8.8 & 2.5 & 46.8 & $38.6 \%$ \\
\hline & $30 \%$ - Daylit PSZ & 1.9 & 9.6 & 0.5 & 11.6 & 9.4 & 0.0 & 11.7 & 2.5 & 47.2 & $38.0 \%$ \\
\hline & $30 \%$ - Daylit VAV & 5.5 & 9.6 & 0.5 & 11.6 & 5.4 & 0.6 & 8.6 & 2.5 & 44.4 & $41.7 \%$ \\
\hline & $30 \%$ - Daylit PVAV & 4.1 & 9.6 & 0.5 & 11.6 & 5.4 & 0.0 & 9.2 & 2.5 & 42.9 & $43.7 \%$ \\
\hline \multirow{7}{*}{$5 B$} & Baseline & 4.3 & 19.9 & 0.7 & 11.6 & 17.7 & 0.0 & 11.1 & 2.8 & 68.0 & NA \\
\hline & $30 \%$ - No Daylight PSZ & 1.9 & 12.7 & 0.5 & 11.6 & 10.1 & 0.0 & 7.1 & 2.5 & 46.4 & $31.8 \%$ \\
\hline & $30 \%$ - No Daylight VAV & 5.1 & 12.7 & 0.5 & 11.6 & 5.8 & 0.5 & 5.5 & 2.5 & 44.3 & $34.9 \%$ \\
\hline & $30 \%$ - No Daylight PVAV & 3.8 & 12.7 & 0.5 & 11.6 & 5.8 & 0.0 & 5.9 & 2.5 & 42.9 & $37.0 \%$ \\
\hline & $30 \%$ - Daylit PSZ & 1.5 & 9.5 & 0.5 & 11.6 & 9.0 & 0.0 & 7.8 & 2.5 & 42.5 & $37.6 \%$ \\
\hline & $30 \%$ - Daylit VAV & 4.4 & 9.5 & 0.5 & 11.6 & 5.2 & 0.5 & 5.8 & 2.5 & 40.0 & $41.2 \%$ \\
\hline & 30\% - Daylit PVAV & 3.3 & 9.5 & 0.5 & 11.6 & 5.2 & 0.0 & 6.1 & 2.5 & 38.8 & $43.0 \%$ \\
\hline \multirow{7}{*}{ 6A } & Baseline & 3.3 & 19.9 & 0.7 & 11.6 & 17.6 & 0.0 & 27.1 & 3.1 & 83.2 & NA \\
\hline & $30 \%$ - No Daylight PSZ & 1.5 & 12.7 & 0.5 & 11.6 & 10.3 & 0.0 & 15.3 & 2.7 & 54.7 & $34.3 \%$ \\
\hline & $30 \%$ - No Daylight VAV & 5.4 & 12.7 & 0.5 & 11.6 & 5.9 & 0.7 & 11.9 & 2.7 & 51.4 & $38.3 \%$ \\
\hline & $30 \%$ - No Daylight PVAV & 4.2 & 12.7 & 0.5 & 11.6 & 5.9 & 0.0 & 12.7 & 2.7 & 50.3 & $39.6 \%$ \\
\hline & $30 \%$ - Daylit PSZ & 1.2 & 9.6 & 0.5 & 11.6 & 9.2 & 0.0 & 16.0 & 2.7 & 50.8 & $39.0 \%$ \\
\hline & $30 \%$ - Daylit VAV & 4.7 & 9.6 & 0.5 & 11.6 & 5.2 & 0.6 & 12.3 & 2.7 & 47.2 & $43.2 \%$ \\
\hline & 30\% - Daylit PVAV & 3.6 & 9.6 & 0.5 & 11.6 & 5.2 & 0.0 & 13.1 & 2.7 & 46.4 & $44.2 \%$ \\
\hline \multirow{7}{*}{$6 B$} & Baseline & 2.8 & 19.9 & 0.7 & 11.6 & 18.0 & 0.0 & 20.2 & 3.1 & 76.2 & $\overline{\mathrm{NA}}$ \\
\hline & $30 \%$ - No Daylight PSZ & 1.1 & 12.7 & 0.5 & 11.6 & 10.2 & 0.0 & 11.8 & 2.8 & 50.7 & $33.5 \%$ \\
\hline & $30 \%$ - No Daylight VAV & 4.5 & 12.7 & 0.5 & 11.6 & 5.9 & 0.6 & 9.8 & 2.8 & 48.2 & $36.7 \%$ \\
\hline & $30 \%$ - No Daylight PVAV & 3.5 & 12.7 & 0.5 & 11.6 & 5.9 & 0.0 & 10.4 & 2.8 & 47.4 & $37.8 \%$ \\
\hline & $30 \%$ - Daylit PSZ & 0.9 & 9.6 & 0.5 & 11.6 & 9.0 & 0.0 & 12.4 & 2.8 & 46.7 & $38.7 \%$ \\
\hline & $30 \%$ - Daylit VAV & 3.8 & 9.6 & 0.5 & 11.6 & 5.2 & 0.5 & 10.1 & 2.8 & 44.0 & $42.2 \%$ \\
\hline & $30 \%$ - Daylit PVAV & 3.0 & 9.6 & 0.5 & 11.6 & 5.2 & 0.0 & 10.8 & 2.8 & 43.4 & $43.0 \%$ \\
\hline \multirow{7}{*}{$7 A$} & Baseline & 1.8 & 19.9 & 0.7 & 11.6 & 19.4 & 0.0 & 36.7 & 3.5 & 93.5 & NA \\
\hline & $30 \%$ - No Daylight PSZ & 0.8 & 12.7 & 0.5 & 11.6 & 10.8 & 0.0 & 20.1 & 3.1 & 59.5 & $36.4 \%$ \\
\hline & $30 \%$ - No Daylight VAV & 4.5 & 12.7 & 0.5 & 11.6 & 6.1 & 0.7 & 15.9 & 3.1 & 55.1 & $41.1 \%$ \\
\hline & $30 \%$ - No Daylight PVAV & 3.5 & 12.7 & 0.5 & 11.6 & 6.1 & 0.0 & 17.0 & 3.1 & 54.5 & $41.8 \%$ \\
\hline & 30\% - Daylit PSZ & 0.5 & 9.6 & 0.5 & 11.6 & 9.6 & 0.0 & 20.5 & 3.1 & 55.4 & $40.8 \%$ \\
\hline & $30 \%$ - Daylit VAV & 3.8 & 9.6 & 0.5 & 11.6 & 5.5 & 0.7 & 16.3 & 3.1 & 51.0 & $45.5 \%$ \\
\hline & $30 \%$ - Daylit PVAV & 3.0 & 9.6 & 0.5 & 11.6 & 5.5 & 0.0 & 17.5 & 3.1 & 50.6 & $45.9 \%$ \\
\hline \multirow{7}{*}{8} & Baseline & 0.8 & 19.9 & 0.6 & 11.6 & 16.8 & 0.0 & 71.4 & 3.9 & 124.9 & $\overline{\mathrm{NA}}$ \\
\hline & $30 \%$ - No Daylight PSZ & 0.5 & 12.7 & 0.5 & 11.6 & 13.0 & 0.0 & 36.8 & 3.5 & 78.5 & $37.2 \%$ \\
\hline & $30 \%$ - No Daylight VAV & 4.3 & 12.7 & 0.5 & 11.6 & 7.3 & 0.9 & 36.8 & 3.5 & 77.6 & $37.9 \%$ \\
\hline & $30 \%$ - No Daylight PVAV & 3.3 & 12.7 & 0.5 & 11.6 & 7.3 & 0.0 & 39.4 & 3.5 & 78.3 & $37.3 \%$ \\
\hline & $30 \%$ - Daylit PSZ & 0.4 & 10.3 & 0.5 & 11.6 & 12.5 & 0.0 & 36.3 & 3.5 & 75.1 & $39.9 \%$ \\
\hline & $30 \%$ - Daylit VAV & 3.9 & 10.3 & 0.5 & 11.6 & 7.0 & 0.9 & 37.3 & 3.5 & 75.0 & $40.0 \%$ \\
\hline & $30 \%$ - Daylit PVAV & 3.0 & 10.3 & 0.5 & 11.6 & 7.0 & 0.0 & 40.0 & 3.5 & 75.8 & $39.3 \%$ \\
\hline
\end{tabular}


Table G-5 High School End Uses: Climate Zones 1-4

\begin{tabular}{|c|c|c|c|c|c|c|c|c|c|c|c|}
\hline \multicolumn{2}{|c|}{ High School End Uses } & \multicolumn{6}{|c|}{ Electricity (kBtu/ft ${ }^{2}$ ) } & \multicolumn{2}{|c|}{ Gas (kBtu/ft' $\left.{ }^{2}\right)$} & \multirow{2}{*}{$\begin{array}{c}\text { Total End } \\
\text { Uses } \\
\left.\text { (kBtu/ft }^{2}\right)\end{array}$} & \multirow{2}{*}{ Savings $\%$} \\
\hline Climate & Strategy & Cooling & Int. Lights & $\begin{array}{c}\text { Ext. } \\
\text { Lights }\end{array}$ & $\begin{array}{l}\text { Int. } \\
\text { Equip }\end{array}$ & Fans & Pumps & Heating & $\begin{array}{c}\text { Water } \\
\text { Systems }\end{array}$ & & \\
\hline \multirow{7}{*}{$1 \mathrm{~A}$} & Baseline & 22.1 & 20.5 & 0.4 & 10.4 & 17.4 & 0.0 & 0.3 & 1.3 & $\overline{772.4}$ & NA \\
\hline & $30 \%$ - No Daylight PSZ & 11.4 & 12.7 & 0.3 & 10.4 & 10.2 & 0.0 & 0.2 & 1.2 & 46.4 & $36.0 \%$ \\
\hline & $30 \%$ - No Daylight VAV & 15.4 & 12.7 & 0.3 & 10.4 & 6.2 & 0.7 & 0.0 & 1.2 & 46.9 & $35.3 \%$ \\
\hline & $30 \%$ - No Daylight PVAV & 11.5 & 12.7 & 0.3 & 10.4 & 6.1 & 0.0 & 0.0 & 1.2 & 42.3 & $41.6 \%$ \\
\hline & $30 \%$ - Daylit PSZ & 10.3 & 9.9 & 0.3 & 10.4 & 9.1 & 0.0 & 0.2 & 1.2 & 41.4 & $42.8 \%$ \\
\hline & $30 \%$ - Daylit VAV & 14.1 & 10.1 & 0.3 & 10.4 & 5.5 & 0.6 & 0.0 & 1.2 & 42.3 & $41.6 \%$ \\
\hline & $30 \%$ - Daylit PVAV & 10.5 & 10.1 & 0.3 & 10.4 & 5.5 & 0.0 & 0.0 & 1.2 & 38.1 & $47.4 \%$ \\
\hline \multirow{7}{*}{$2 A$} & Baseline & 15.4 & 20.5 & 0.4 & 10.4 & 17.3 & 0.0 & 3.5 & 1.8 & 69.3 & NA \\
\hline & $30 \%$ - No Daylight PSZ & 7.5 & 12.7 & 0.3 & 10.4 & 9.5 & 0.0 & 1.5 & 1.6 & 43.6 & $37.1 \%$ \\
\hline & $30 \%$ - No Daylight VAV & 11.2 & 12.7 & 0.3 & 10.4 & 5.7 & 0.7 & 1.4 & 1.6 & 44.0 & $36.5 \%$ \\
\hline & $30 \%$ - No Daylight PVAV & 8.3 & 12.7 & 0.3 & 10.4 & 5.7 & 0.0 & 2.2 & 1.6 & 40.5 & $41.5 \%$ \\
\hline & $30 \%$ - Daylit PSZ & 6.6 & 10.1 & 0.3 & 10.4 & 8.4 & 0.0 & 1.6 & 1.6 & 39.0 & $43.8 \%$ \\
\hline & $30 \%$ - Daylit VAV & 10.0 & 10.2 & 0.3 & 10.4 & 5.0 & 0.6 & 1.4 & 1.6 & 39.6 & $42.8 \%$ \\
\hline & $30 \%$ - Daylit PVAV & 7.5 & 10.2 & 0.3 & 10.4 & 5.0 & 0.0 & 1.5 & 1.6 & 36.5 & $47.3 \%$ \\
\hline \multirow{7}{*}{ 2B } & Baseline & 18.8 & 20.5 & 0.4 & 10.4 & 19.9 & 0.0 & 1.6 & 1.6 & 73.2 & NA \\
\hline & $30 \%$ - No Daylight PSZ & 8.6 & 12.7 & 0.3 & 10.4 & 10.4 & 0.0 & 0.7 & 1.4 & 44.6 & $39.1 \%$ \\
\hline & $30 \%$ - No Daylight VAV & 11.3 & 12.7 & 0.3 & 10.4 & 6.7 & 0.7 & 0.9 & 1.4 & 44.4 & $39.3 \%$ \\
\hline & $30 \%$ - No Daylight PVAV & 8.4 & 12.7 & 0.3 & 10.4 & 6.7 & 0.0 & 1.0 & 1.4 & 40.9 & $44.1 \%$ \\
\hline & 30\% - Daylit PSZ & 7.5 & 10.1 & 0.3 & 10.4 & 9.2 & 0.0 & 0.7 & 1.4 & 39.6 & $45.9 \%$ \\
\hline & $30 \%$ - Daylit VAV & 10.0 & 10.2 & 0.3 & 10.4 & 5.9 & 0.6 & 0.9 & 1.4 & 39.7 & $45.7 \%$ \\
\hline & $30 \%$ - Daylit PVAV & 7.4 & 10.2 & 0.3 & 10.4 & 5.9 & 0.0 & 1.0 & 1.4 & 36.7 & $49.9 \%$ \\
\hline \multirow{7}{*}{$3 \mathbf{A}$} & Baseline & 10.9 & 20.5 & 0.4 & 10.4 & 16.0 & 0.0 & 5.6 & 2.2 & 65.9 & NA \\
\hline & $30 \%$ - No Daylight PSZ & 5.0 & 10.4 & 0.3 & 10.4 & 9.8 & 0.0 & 4.1 & 1.9 & 42.0 & $36.2 \%$ \\
\hline & $30 \%$ - No Daylight VAV & 8.6 & 10.4 & 0.3 & 10.4 & 6.0 & 0.8 & 3.9 & 1.9 & 42.3 & $35.9 \%$ \\
\hline & $30 \%$ - No Daylight PVAV & 6.3 & 10.4 & 0.3 & 10.4 & 6.0 & 0.0 & 4.2 & 1.9 & 39.6 & $39.9 \%$ \\
\hline & $30 \%$ - Daylit PSZ & 4.6 & 10.2 & 0.3 & 10.4 & 8.9 & 0.0 & 4.0 & 1.9 & 40.3 & $38.9 \%$ \\
\hline & $30 \%$ - Daylit VAV & 7.8 & 10.3 & 0.3 & 10.4 & 5.3 & 0.7 & 3.6 & 1.9 & 40.4 & $38.7 \%$ \\
\hline & $30 \%$ - Daylit PVAV & 5.8 & 10.3 & 0.3 & 10.4 & 5.3 & 0.0 & 3.9 & 1.9 & 38.0 & $42.4 \%$ \\
\hline \multirow{7}{*}{ 3B } & Baseline & 10.9 & 20.5 & 0.4 & 10.4 & 15.4 & 0.0 & 2.2 & 2.1 & 61.8 & NA \\
\hline & $30 \%$ - No Daylight PSZ & 5.0 & 10.4 & 0.3 & 10.4 & 9.4 & 0.0 & 1.5 & 1.8 & 38.8 & $37.2 \%$ \\
\hline & $30 \%$ - No Daylight VAV & 7.5 & 10.4 & 0.3 & 10.4 & 5.9 & 0.6 & 1.7 & 1.8 & 38.8 & $37.3 \%$ \\
\hline & $30 \%$ - No Daylight PVAV & 5.6 & 10.4 & 0.3 & 10.4 & 5.9 & 0.0 & 1.9 & 1.8 & 36.4 & $41.1 \%$ \\
\hline & $30 \%$ - Daylit PSZ & 4.5 & 10.1 & 0.3 & 10.4 & 8.3 & 0.0 & 1.5 & 1.8 & 36.9 & $40.2 \%$ \\
\hline & $30 \%$ - Daylit VAV & 6.8 & 10.3 & 0.3 & 10.4 & 5.3 & 0.5 & 1.6 & 1.8 & 37.0 & $40.2 \%$ \\
\hline & $30 \%$ - Daylit PVAV & 5.1 & 10.3 & 0.3 & 10.4 & 5.3 & 0.0 & 1.7 & 1.8 & 34.8 & $43.6 \%$ \\
\hline \multirow{7}{*}{$3 C$} & Baseline & 4.1 & 20.5 & 0.4 & 10.4 & 16.6 & 0.0 & 2.7 & 2.5 & 57.1 & NA \\
\hline & $30 \%$ - No Daylight PSZ & 0.9 & 10.4 & 0.3 & 10.4 & 7.5 & 0.0 & 1.5 & 2.2 & 33.3 & $41.7 \%$ \\
\hline & $30 \%$ - No Daylight VAV & 2.6 & 10.4 & 0.3 & 10.4 & 3.7 & 0.4 & 2.1 & 2.2 & 32.1 & $43.8 \%$ \\
\hline & $30 \%$ - No Daylight PVAV & 1.9 & 10.4 & 0.3 & 10.4 & 3.7 & 0.0 & 2.2 & 2.2 & 31.2 & $45.4 \%$ \\
\hline & $30 \%$ - Daylit PSZ & 0.7 & 10.2 & 0.3 & 10.4 & 6.7 & 0.0 & 1.5 & 2.2 & 32.0 & $44.0 \%$ \\
\hline & $30 \%$ - Daylit VAV & 2.3 & 10.4 & 0.3 & 10.4 & 3.3 & 0.3 & 1.9 & 2.2 & 31.1 & $45.6 \%$ \\
\hline & $30 \%$ - Daylit PVAV & 1.7 & 10.4 & 0.3 & 10.4 & 3.3 & 0.0 & 2.0 & 2.2 & 30.3 & $47.0 \%$ \\
\hline \multirow{7}{*}{$4 A$} & Baseline & 7.3 & 20.5 & 0.4 & 10.4 & 16.7 & 0.0 & 12.4 & 2.6 & 70.3 & NA \\
\hline & $30 \%$ - No Daylight PSZ & 3.5 & 10.4 & 0.3 & 10.4 & 10.6 & 0.0 & 8.3 & 2.3 & 45.9 & $34.8 \%$ \\
\hline & $30 \%$ - No Daylight VAV & 7.1 & 10.4 & 0.3 & 10.4 & 6.8 & 0.9 & 7.3 & 2.3 & 45.5 & $35.3 \%$ \\
\hline & $30 \%$ - No Daylight PVAV & 5.3 & 10.4 & 0.3 & 10.4 & 6.8 & 0.0 & 7.8 & 2.3 & 43.3 & $38.4 \%$ \\
\hline & $30 \%$ - Daylit PSZ & 3.0 & 9.8 & 0.3 & 10.4 & 9.0 & 0.0 & 8.5 & 2.3 & 43.3 & $38.5 \%$ \\
\hline & $30 \%$ - Daylit VAV & 6.2 & 9.9 & 0.3 & 10.4 & 5.6 & 0.8 & 7.0 & 2.3 & 42.5 & $39.5 \%$ \\
\hline & $30 \%$ - Daylit PVAV & 4.5 & 9.9 & 0.3 & 10.4 & 5.6 & 0.0 & 7.6 & 2.3 & 40.7 & $42.2 \%$ \\
\hline \multirow{7}{*}{ 4B } & Baseline & 8.0 & 20.5 & 0.4 & 10.4 & 17.2 & 0.0 & 5.5 & 2.5 & 64.5 & $\overline{\mathrm{NA}}$ \\
\hline & $30 \%$ - No Daylight PSZ & 3.6 & 10.4 & 0.3 & 10.4 & 10.9 & 0.0 & 3.6 & 2.2 & 41.6 & $35.6 \%$ \\
\hline & $30 \%$ - No Daylight VAV & 6.6 & 10.4 & 0.3 & 10.4 & 7.1 & 0.7 & 3.8 & 2.2 & 41.5 & $35.6 \%$ \\
\hline & $30 \%$ - No Daylight PVAV & 4.9 & 10.4 & 0.3 & 10.4 & 7.1 & 0.0 & 4.1 & 2.3 & 39.5 & $38.8 \%$ \\
\hline & $30 \%$ - Daylit PSZ & 3.0 & 9.7 & 0.3 & 10.4 & 9.1 & 0.0 & 4.0 & 2.2 & 38.8 & $39.9 \%$ \\
\hline & $30 \%$ - Daylit VAV & 5.6 & 9.8 & 0.3 & 10.4 & 5.8 & 0.6 & 3.8 & 2.2 & 38.6 & $40.2 \%$ \\
\hline & $30 \%$ - Daylit PVAV & 4.1 & 9.8 & 0.3 & 10.4 & 5.8 & 0.0 & 4.1 & 2.2 & 36.9 & $42.9 \%$ \\
\hline
\end{tabular}


Table G-6 High School End Uses: Climate Zones 4-8

\begin{tabular}{|c|c|c|c|c|c|c|c|c|c|c|c|}
\hline \multicolumn{2}{|c|}{ High School End Uses } & \multicolumn{6}{|c|}{ Electricity (kBtu/ft ${ }^{2}$ ) } & \multicolumn{2}{|c|}{ Gas (kBtu/ft $\left.{ }^{2}\right)$} & \multirow{2}{*}{$\begin{array}{c}\text { Total } \\
\text { End } \\
\text { Uses } \\
\left.\text { (kBtu/ft }{ }^{2}\right)\end{array}$} & \multirow{2}{*}{$\begin{array}{c}\text { Savings } \\
\%\end{array}$} \\
\hline Climate & Strategy & Cooling & $\begin{array}{c}\text { Int. } \\
\text { Lights }\end{array}$ & $\begin{array}{c}\text { Ext. } \\
\text { Lights }\end{array}$ & $\begin{array}{c}\text { Int. } \\
\text { Equip }\end{array}$ & Fans & Pumps & Heating & $\begin{array}{c}\text { Water } \\
\text { Systems }\end{array}$ & & \\
\hline \multirow{7}{*}{$4 C$} & Baseline & 2.6 & 20.5 & 0.4 & 10.4 & 15.3 & 0.0 & 8.9 & 2.7 & 60.8 & NA \\
\hline & $30 \%$ - No Daylight PSZ & 1.1 & 10.4 & 0.3 & 10.4 & 9.5 & 0.0 & 6.6 & 2.4 & 40.8 & $32.9 \%$ \\
\hline & $30 \%$ - No Daylight VAV & 2.4 & 10.4 & 0.3 & 10.4 & 5.2 & 0.4 & 5.9 & 2.4 & 37.5 & $38.3 \%$ \\
\hline & $30 \%$ - No Daylight PVAV & 1.7 & 10.4 & 0.3 & 10.4 & 5.2 & 0.0 & 6.4 & 2.4 & 36.9 & $39.3 \%$ \\
\hline & $30 \%$ - Daylit PSZ & 0.8 & 10.2 & 0.3 & 10.4 & 8.0 & 0.0 & 6.7 & 2.4 & 38.7 & $36.3 \%$ \\
\hline & $30 \%$ - Daylit VAV & 2.0 & 10.3 & 0.3 & 10.4 & 4.3 & 0.4 & 5.4 & 2.4 & 35.4 & $41.8 \%$ \\
\hline & $30 \%$ - Daylit PVAV & 1.4 & 10.3 & 0.3 & 10.4 & 4.3 & 0.0 & 5.8 & 2.4 & 34.9 & $42.7 \%$ \\
\hline \multirow{7}{*}{$5 A$} & Baseline & 5.9 & 20.5 & 0.4 & 10.4 & 17.9 & 0.0 & 20.6 & 2.9 & 78.6 & NA \\
\hline & $30 \%$ - No Daylight PSZ & 3.0 & 12.7 & 0.3 & 10.4 & 11.6 & 0.0 & 12.3 & 2.6 & 52.9 & $32.7 \%$ \\
\hline & $30 \%$ - No Daylight VAV & 7.0 & 12.7 & 0.3 & 10.4 & 7.2 & 1.0 & 10.6 & 2.6 & 51.8 & $34.0 \%$ \\
\hline & $30 \%$ - No Daylight PVAV & 5.2 & 12.7 & 0.3 & 10.4 & 7.2 & 0.0 & 11.5 & 2.6 & 49.9 & $36.5 \%$ \\
\hline & $30 \%$ - Daylit PSZ & 2.3 & 9.8 & 0.3 & 10.4 & 9.7 & 0.0 & 13.2 & 2.6 & 48.3 & $38.6 \%$ \\
\hline & $30 \%$ - Daylit VAV & 5.8 & 9.9 & 0.3 & 10.4 & 6.0 & 0.9 & 10.9 & 2.6 & 46.8 & $40.4 \%$ \\
\hline & $30 \%$ - Daylit PVAV & 4.3 & 9.9 & 0.3 & 10.4 & 6.0 & 0.0 & 11.8 & 2.6 & 45.3 & $42.3 \%$ \\
\hline \multirow{7}{*}{$5 B$} & Baseline & 5.4 & 20.5 & 0.4 & 10.4 & 18.1 & 0.0 & 12.8 & 2.8 & 70.4 & NA \\
\hline & $30 \%$ - No Daylight PSZ & 2.5 & 12.7 & 0.3 & 10.4 & 11.5 & 0.0 & 7.8 & 2.5 & 47.8 & $32.2 \%$ \\
\hline & $30 \%$ - No Daylight VAV & 6.1 & 12.7 & 0.3 & 10.4 & 7.3 & 0.8 & 7.3 & 2.5 & 47.4 & $32.7 \%$ \\
\hline & $30 \%$ - No Daylight PVAV & 4.5 & 12.7 & 0.3 & 10.4 & 7.3 & 0.0 & 7.9 & 2.5 & 45.7 & $35.2 \%$ \\
\hline & $30 \%$ - Daylit PSZ & 1.9 & 9.7 & 0.3 & 10.4 & 9.5 & 0.0 & 8.8 & 2.5 & 43.2 & $38.7 \%$ \\
\hline & $30 \%$ - Daylit VAV & 4.8 & 9.8 & 0.3 & 10.4 & 6.0 & 0.7 & 7.6 & 2.5 & 42.1 & $40.2 \%$ \\
\hline & 30\% - Daylit PVAV & 3.6 & 9.8 & 0.3 & 10.4 & 6.0 & 0.0 & 8.2 & 2.5 & 40.8 & $42.0 \%$ \\
\hline \multirow{7}{*}{ 6A } & Baseline & 4.0 & 20.5 & 0.4 & 10.4 & 17.5 & 0.0 & 29.5 & 3.1 & 85.5 & $\overline{\mathrm{NA}}$ \\
\hline & $30 \%$ - No Daylight PSZ & 2.0 & 12.7 & 0.3 & 10.4 & 11.4 & 0.0 & 17.1 & 2.8 & 56.8 & $33.6 \%$ \\
\hline & $30 \%$ - No Daylight VAV & 5.9 & 12.7 & 0.3 & 10.4 & 6.9 & 1.1 & 14.9 & 2.8 & 55.0 & $35.6 \%$ \\
\hline & $30 \%$ - No Daylight PVAV & 4.6 & 12.7 & 0.3 & 10.4 & 6.9 & 0.0 & 16.2 & 2.8 & 53.9 & $36.9 \%$ \\
\hline & $30 \%$ - Daylit PSZ & 1.5 & 9.8 & 0.3 & 10.4 & 9.5 & 0.0 & 17.7 & 2.8 & 51.8 & $39.4 \%$ \\
\hline & $30 \%$ - Daylit VAV & 4.8 & 9.8 & 0.3 & 10.4 & 5.7 & 1.0 & 15.2 & 2.8 & 50.0 & $41.5 \%$ \\
\hline & 30\% - Daylit PVAV & 3.7 & 9.8 & 0.3 & 10.4 & 5.7 & 0.0 & 16.5 & 2.8 & 49.3 & $42.4 \%$ \\
\hline \multirow{7}{*}{$6 B$} & Baseline & 3.6 & 20.5 & 0.4 & 10.4 & 18.1 & 0.0 & 22.2 & 3.2 & 78.3 & $\overline{\mathrm{NA}}$ \\
\hline & $30 \%$ - No Daylight PSZ & 1.6 & 12.7 & 0.3 & 10.4 & 11.5 & 0.0 & 13.1 & 2.8 & 52.4 & $33.1 \%$ \\
\hline & $30 \%$ - No Daylight VAV & 5.1 & 12.7 & 0.3 & 10.4 & 7.3 & 0.9 & 12.3 & 2.8 & 51.8 & $33.9 \%$ \\
\hline & $30 \%$ - No Daylight PVAV & 4.0 & 12.7 & 0.3 & 10.4 & 7.3 & 0.0 & 13.3 & 2.8 & 50.8 & $35.1 \%$ \\
\hline & $30 \%$ - Daylit PSZ & 1.1 & 9.7 & 0.3 & 10.4 & 9.4 & 0.0 & 13.6 & 2.8 & 47.4 & $39.5 \%$ \\
\hline & $30 \%$ - Daylit VAV & 4.0 & 9.8 & 0.3 & 10.4 & 5.9 & 0.8 & 12.5 & 2.8 & 46.6 & $40.5 \%$ \\
\hline & $30 \%$ - Daylit PVAV & 3.1 & 9.8 & 0.3 & 10.4 & 5.9 & 0.0 & 13.6 & 2.8 & 46.0 & $41.3 \%$ \\
\hline \multirow{7}{*}{$7 A$} & Baseline & 2.6 & 20.5 & 0.4 & 10.4 & 19.6 & 0.0 & 39.3 & 3.5 & 96.3 & NA \\
\hline & $30 \%$ - No Daylight PSZ & 1.1 & 12.7 & 0.3 & 10.4 & 12.1 & 0.0 & 22.0 & 3.2 & 61.8 & $35.9 \%$ \\
\hline & $30 \%$ - No Daylight VAV & 5.0 & 12.7 & 0.3 & 10.4 & 7.2 & 1.2 & 19.4 & 3.2 & 59.3 & $38.4 \%$ \\
\hline & $30 \%$ - No Daylight PVAV & 3.8 & 12.7 & 0.3 & 10.4 & 7.2 & 0.0 & 21.1 & 3.2 & 58.7 & $39.1 \%$ \\
\hline & 30\% - Daylit PSZ & 0.8 & 9.7 & 0.3 & 10.4 & 10.0 & 0.0 & 22.2 & 3.2 & 56.5 & $41.3 \%$ \\
\hline & $30 \%$ - Daylit VAV & 4.0 & 9.8 & 0.3 & 10.4 & 6.0 & 1.1 & 19.9 & 3.1 & 54.7 & $43.3 \%$ \\
\hline & $30 \%$ - Daylit PVAV & 3.1 & 9.8 & 0.3 & 10.4 & 6.0 & 0.0 & 21.7 & 3.1 & 54.4 & $43.5 \%$ \\
\hline \multirow{7}{*}{8} & Baseline & 1.3 & 20.5 & 0.4 & 10.4 & 18.1 & 0.0 & 74.7 & 4.0 & 129.4 & $\overline{\mathrm{NA}}$ \\
\hline & $30 \%$ - No Daylight PSZ & 0.7 & 12.7 & 0.3 & 10.4 & 14.3 & 0.0 & 39.5 & 3.6 & 81.5 & $37.1 \%$ \\
\hline & $30 \%$ - No Daylight VAV & 4.6 & 12.7 & 0.3 & 10.4 & 8.3 & 1.8 & 42.9 & 3.6 & 84.6 & $34.6 \%$ \\
\hline & $30 \%$ - No Daylight PVAV & 3.6 & 12.7 & 0.3 & 10.4 & 8.3 & 0.0 & 46.7 & 3.6 & 85.6 & $33.9 \%$ \\
\hline & 30\% - Daylit PSZ & 0.5 & 10.4 & 0.3 & 10.4 & 12.9 & 0.0 & 37.5 & 3.6 & 75.6 & $41.6 \%$ \\
\hline & $30 \%$ - Daylit VAV & 3.9 & 10.5 & 0.3 & 10.4 & 7.3 & 1.7 & 42.6 & 3.6 & 80.3 & $38.0 \%$ \\
\hline & $30 \%$ - Daylit PVAV & 3.0 & 10.5 & 0.3 & 10.4 & 7.3 & 0.0 & 46.4 & 3.6 & 81.5 & $37.0 \%$ \\
\hline
\end{tabular}


Appendix H. Energy Savings End Use Tables: ASHRAE 90.1-2004 Baseline

Table H-1 Elementary School End Uses: Climate Zones 1-8

\begin{tabular}{|c|c|c|c|c|c|c|c|c|c|c|c|}
\hline \multicolumn{2}{|c|}{$\begin{array}{c}\text { Elementary School } \\
\text { End Uses }\end{array}$} & \multicolumn{6}{|c|}{ Electricity (kBtu/ft $\left.{ }^{2}\right)$} & \multicolumn{2}{|c|}{ Gas (kBtu/ft ${ }^{2}$ ) } & \multirow{2}{*}{$\begin{array}{c}\text { Total End } \\
\text { Uses } \\
\left(\mathbf{k B t u} / \mathrm{ft}^{2}\right)\end{array}$} & \multirow{2}{*}{ Savings $\%$} \\
\hline Climate & Strategy & Cooling & $\begin{array}{c}\text { Int. } \\
\text { Lights }\end{array}$ & $\begin{array}{l}\text { Ext. } \\
\text { Lights }\end{array}$ & $\begin{array}{c}\text { Int. } \\
\text { Equip }\end{array}$ & Fans & Pumps & Heating & $\begin{array}{l}\text { Water } \\
\text { Systems }\end{array}$ & & \\
\hline \multirow{4}{*}{$1 \mathrm{~A}$} & 2004 Baseline & 15.7 & 16.3 & 0.8 & 14.9 & $\begin{array}{c}17.3 \\
\end{array}$ & 0.0 & 0.4 & 0.7 & 66.1 & NA \\
\hline & $30 \%$ - Daylit PSZ & 9.6 & 9.3 & 0.6 & 14.9 & 9.7 & 0.0 & 0.2 & 0.7 & 45.1 & $31.7 \%$ \\
\hline & $30 \%$ - Daylit VAV & 12.1 & 9.3 & 0.6 & 14.9 & 5.2 & 0.6 & 0.0 & 0.7 & 43.5 & $34.1 \%$ \\
\hline & $30 \%$ - Daylit PVAV & 9.0 & 9.3 & 0.6 & 14.9 & 5.2 & 0.0 & 0.0 & 0.7 & 39.9 & $39.7 \%$ \\
\hline \multirow{4}{*}{$2 A$} & 2004 Baseline & 10.5 & 16.3 & 0.8 & 14.9 & 16.9 & 0.0 & 3.7 & 1.0 & 64.1 & $\mathrm{NA}$ \\
\hline & $30 \%$ - Daylit PSZ & 5.9 & 9.4 & 0.6 & 14.9 & 8.6 & 0.0 & 1.1 & 1.0 & 41.6 & $35.2 \%$ \\
\hline & $30 \%$ - Daylit VAV & 8.7 & 9.4 & 0.6 & 14.9 & 4.6 & 0.5 & 1.1 & 1.0 & 40.8 & $36.4 \%$ \\
\hline & 30\% - Daylit PVAV & 6.4 & 9.4 & 0.6 & 14.9 & 4.6 & 0.0 & 1.1 & 1.0 & 38.1 & $40.5 \%$ \\
\hline \multirow{4}{*}{ 2B } & 2004 Baseline & 12.3 & 16.3 & 0.8 & 14.9 & 18.6 & 0.0 & 1.7 & 0.9 & 65.5 & NA \\
\hline & 30\% - Daylit PSZ & 6.2 & 9.4 & 0.6 & 14.9 & 8.9 & 0.0 & 0.6 & 0.9 & 41.6 & $36.5 \%$ \\
\hline & $30 \%$ - Daylit VAV & 7.7 & 9.4 & 0.6 & 14.9 & 4.8 & 0.5 & 0.7 & 0.9 & 39.4 & $39.8 \%$ \\
\hline & $30 \%$ - Daylit PVAV & 5.7 & 9.4 & 0.6 & 14.9 & 4.8 & 0.0 & 0.7 & 0.9 & 37.0 & $43.4 \%$ \\
\hline \multirow{4}{*}{$3 A$} & 2004 Baseline & 7.1 & 16.3 & 0.8 & 14.9 & 15.6 & 0.0 & 5.5 & 1.2 & 61.4 & NA \\
\hline & 30\% - Daylit PSZ & 4.0 & 9.5 & 0.6 & 14.9 & 8.9 & 0.0 & 2.8 & 1.2 & 41.9 & $31.8 \%$ \\
\hline & $30 \%$ - Daylit VAV & 6.9 & 9.5 & 0.6 & 14.9 & 4.8 & 0.6 & 2.9 & 1.2 & 41.3 & $32.7 \%$ \\
\hline & $30 \%$ - Daylit PVAV & 5.1 & 9.5 & 0.6 & 14.9 & 4.8 & 0.0 & 3.0 & 1.2 & 39.2 & $36.2 \%$ \\
\hline \multirow{4}{*}{ 3B } & 2004 Baseline & 7.0 & 16.3 & 0.8 & 14.9 & 14.9 & 0.0 & 2.1 & 1.1 & 57.2 & $\mathrm{NA}$ \\
\hline & 30\% - Daylit PSZ & 3.9 & 9.4 & 0.6 & 14.9 & 8.5 & 0.0 & 1.0 & 1.1 & 39.4 & $31.1 \%$ \\
\hline & $30 \%$ - Daylit VAV & 5.8 & 9.4 & 0.6 & 14.9 & 4.6 & 0.4 & 1.2 & 1.1 & 38.1 & $33.4 \%$ \\
\hline & $30 \%$ - Daylit PVAV & 4.3 & 9.4 & 0.6 & 14.9 & 4.6 & 0.0 & 1.3 & 1.1 & 36.2 & $36.6 \%$ \\
\hline \multirow{4}{*}{$3 C$} & 2004 Baseline & 1.4 & 16.3 & 0.8 & 14.9 & 13.4 & 0.0 & 2.5 & 1.3 & 50.6 & NA \\
\hline & 30\% - Daylit PSZ & 0.6 & 9.5 & 0.6 & 14.9 & 6.8 & 0.0 & 0.8 & 1.4 & 34.6 & $31.7 \%$ \\
\hline & $30 \%$ - Daylit VAV & 2.4 & 9.5 & 0.6 & 14.9 & 3.6 & 0.3 & 1.5 & 1.3 & 34.1 & $32.7 \%$ \\
\hline & $30 \%$ - Daylit PVAV & 1.8 & 9.5 & 0.6 & 14.9 & 3.6 & 0.0 & 1.6 & 1.3 & 33.3 & $34.3 \%$ \\
\hline \multirow{4}{*}{ 4A } & 2004 Baseline & 4.7 & 16.3 & 0.8 & 14.9 & 16.6 & 0.0 & 11.9 & 1.4 & 66.6 & NA \\
\hline & 30\% - Daylit PSZ & 2.6 & 9.4 & 0.6 & 14.9 & 9.0 & 0.0 & 5.6 & 1.4 & 43.5 & $34.7 \%$ \\
\hline & $30 \%$ - Daylit VAV & 5.6 & 9.4 & 0.6 & 14.9 & 5.0 & 0.6 & 5.2 & 1.4 & 42.6 & $36.0 \%$ \\
\hline & 30\% - Daylit PVAV & 4.1 & 9.4 & 0.6 & 14.9 & 5.0 & 0.0 & 5.6 & 1.4 & 40.9 & $38.6 \%$ \\
\hline & 2004 Baseline & 4.9 & 16.3 & 0.8 & 14.9 & 16.7 & 0.0 & 5.3 & 1.4 & 60.3 & NA \\
\hline $4 B$ & $30 \%$ - Daylit PSZ & 2.6 & 9.2 & 0.6 & 14.9 & 9.1 & 0.0 & 2.4 & 1.4 & 40.2 & $33.3 \%$ \\
\hline & $30 \%$ - Daylit VAV & 4.9 & 9.2 & 0.6 & 14.9 & 5.0 & 0.4 & 2.6 & 1.3 & 39.1 & $35.1 \%$ \\
\hline & 30\% - Daylit PVAV & 3.6 & 9.2 & 0.6 & 14.9 & 5.0 & 0.0 & 2.8 & 1.3 & 37.6 & $37.6 \%$ \\
\hline & 2004 Baseline & 1.3 & 16.3 & 0.8 & 14.9 & 14.9 & 0.0 & 7.5 & 1.4 & 57.2 & NA \\
\hline $1 C$ & $30 \%$ - Daylit PSZ & 0.7 & 9.7 & 0.6 & 14.9 & 8.0 & 0.0 & 3.8 & 1.5 & 39.2 & $31.5 \%$ \\
\hline $4 \mathrm{C}$ & $30 \%$ - Daylit VAV & 2.0 & 9.7 & 0.6 & 14.9 & 4.3 & 0.2 & 3.8 & 1.4 & 37.0 & $35.3 \%$ \\
\hline & $30 \%$ - Daylit PVAV & 1.4 & 9.7 & 0.6 & 14.9 & 4.3 & 0.0 & 4.1 & 1.4 & 36.5 & $36.2 \%$ \\
\hline & 2004 Baseline & 3.7 & 16.3 & 0.8 & 14.9 & 18.0 & 0.0 & 20.5 & 1.5 & 75.7 & $\mathrm{NA}$ \\
\hline 5 & $30 \%$ - Daylit PSZ & 2.1 & 9.4 & 0.6 & 14.9 & 9.6 & 0.0 & 9.3 & 1.5 & 47.4 & $37.4 \%$ \\
\hline $5 A$ & $30 \%$ - Daylit VAV & 5.4 & 9.4 & 0.6 & 14.9 & 5.3 & 0.6 & 8.6 & 1.5 & 46.4 & $38.7 \%$ \\
\hline & $30 \%$ - Daylit PVAV & 4.0 & 9.4 & 0.6 & 14.9 & 5.3 & 0.0 & 9.1 & 1.5 & 45.0 & $40.6 \%$ \\
\hline & 2004 Baseline & 3.3 & 16.3 & 0.8 & 14.9 & 17.9 & 0.0 & 12.3 & 1.5 & 66.9 & $\mathrm{NA}$ \\
\hline 5D & $30 \%$ - Daylit PSZ & 1.6 & 9.3 & 0.6 & 14.9 & 9.3 & 0.0 & 5.7 & 1.5 & 42.9 & $35.9 \%$ \\
\hline JD & $30 \%$ - Daylit VAV & 4.4 & 9.3 & 0.6 & 14.9 & 5.2 & 0.5 & 5.7 & 1.5 & 42.0 & $37.2 \%$ \\
\hline & $30 \%$ - Daylit PVAV & 3.3 & 9.3 & 0.6 & 14.9 & 5.2 & 0.0 & 6.0 & 1.5 & 40.8 & $39.0 \%$ \\
\hline & 2004 Baseline & 2.4 & 16.3 & 0.8 & 14.9 & 17.5 & 0.0 & 30.5 & 1.7 & 84.1 & $\mathrm{NA}$ \\
\hline 64 & $30 \%$ - Daylit PSZ & 1.3 & 9.4 & 0.6 & 14.9 & 9.3 & 0.0 & 13.3 & 1.7 & 50.5 & $40.0 \%$ \\
\hline$O A$ & $30 \%$ - Daylit VAV & 4.6 & 9.4 & 0.6 & 14.9 & 5.1 & 0.6 & 12.4 & 1.7 & 49.3 & $41.4 \%$ \\
\hline & $30 \%$ - Daylit PVAV & 3.6 & 9.4 & 0.6 & 14.9 & 5.1 & 0.0 & 13.2 & 1.7 & 48.5 & $42.4 \%$ \\
\hline & 2004 Baseline & 2.1 & 16.3 & 0.8 & 14.9 & 17.9 & 0.0 & 22.8 & 1.7 & 76.5 & $\mathrm{NA}$ \\
\hline R & $30 \%$ - Daylit PSZ & 1.0 & 9.3 & 0.6 & 14.9 & 9.1 & 0.0 & 10.1 & 1.7 & 46.7 & $38.9 \%$ \\
\hline DO & $30 \%$ - Daylit VAV & 3.7 & 9.3 & 0.6 & 14.9 & 5.1 & 0.5 & 10.1 & 1.7 & 46.0 & $39.9 \%$ \\
\hline & $30 \%$ - Daylit PVAV & 2.9 & 9.3 & 0.6 & 14.9 & 5.1 & 0.0 & 10.8 & 1.7 & 45.4 & $40.7 \%$ \\
\hline & 2004 Baseline & 1.3 & 16.3 & 0.8 & 14.9 & 19.3 & 0.0 & 41.4 & 1.9 & 95.9 & NA \\
\hline 70 & $30 \%$ - Daylit PSZ & 0.6 & 9.3 & 0.6 & 14.9 & 9.7 & 0.0 & 17.1 & 1.9 & 54.1 & $43.5 \%$ \\
\hline $1 \mathrm{~A}$ & $30 \%$ - Daylit VAV & 3.8 & 9.3 & 0.6 & 14.9 & 5.4 & 0.7 & 16.4 & 1.8 & 52.9 & $44.8 \%$ \\
\hline & $30 \%$ - Daylit PVAV & 2.9 & 9.3 & 0.6 & 14.9 & 5.4 & 0.0 & 17.6 & 1.8 & 52.6 & $45.1 \%$ \\
\hline & 2004 Baseline & 0.7 & 16.3 & 0.8 & 14.9 & 18.2 & 0.0 & 79.9 & 2.1 & 132.9 & NA \\
\hline 8 & $30 \%$ - Daylit PSZ & 0.5 & 10.1 & 0.6 & 14.9 & 13.3 & 0.0 & 32.8 & 2.1 & 74.2 & $44.2 \%$ \\
\hline 8 & $30 \%$ - Daylit VAV & 4.2 & 10.1 & 0.6 & 14.9 & 7.2 & 0.9 & 38.7 & 2.1 & 78.7 & $40.8 \%$ \\
\hline & $30 \%$ - Daylit PVAV & 3.3 & 10.1 & 0.6 & 14.9 & 7.2 & 0.0 & 41.4 & 2.1 & 79.6 & $40.1 \%$ \\
\hline
\end{tabular}


Table H-2 Middle School End Uses: Climate Zones 1-8

\begin{tabular}{|c|c|c|c|c|c|c|c|c|c|c|c|}
\hline \multicolumn{2}{|c|}{ Middle School End Uses } & \multicolumn{6}{|c|}{ Electricity (kBtu/ft ${ }^{2}$ ) } & \multicolumn{2}{|c|}{ Gas (kBtu/ft' } & \multirow{2}{*}{$\begin{array}{c}\text { Total End } \\
\text { Uses } \\
\left.\text { (kBtu/ft }^{2}\right)\end{array}$} & \multirow{2}{*}{$\begin{array}{c}\text { Savings } \\
\%\end{array}$} \\
\hline Climate & Strategy & Cooling & $\begin{array}{c}\text { Int. } \\
\text { Lights }\end{array}$ & $\begin{array}{c}\text { Ext. } \\
\text { Lights }\end{array}$ & $\begin{array}{c}\text { Int. } \\
\text { Equip }\end{array}$ & Fans & Pumps & Heating & $\begin{array}{c}\text { Water } \\
\text { Systems }\end{array}$ & & \\
\hline \multirow{4}{*}{$1 \mathrm{~A}$} & 2004 Baseline & 15.3 & 15.9 & 0.7 & 11.6 & 16.7 & 0.0 & 0.4 & 1.3 & 61.8 & NA \\
\hline & $30 \%$ - Daylit PSZ & 9.4 & 9.7 & 0.5 & 11.6 & 9.4 & 0.0 & 0.2 & 1.2 & 42.0 & $32.1 \%$ \\
\hline & $30 \%$ - Daylit VAV & 12.6 & 9.7 & 0.5 & 11.6 & 5.1 & 0.6 & 0.0 & 1.2 & 41.3 & $33.2 \%$ \\
\hline & $30 \%$ - Daylit PVAV & 9.4 & 9.7 & 0.5 & 11.6 & 5.1 & 0.0 & 0.0 & 1.2 & 37.5 & $39.3 \%$ \\
\hline \multirow{4}{*}{$2 A$} & 2004 Baseline & 10.2 & 15.9 & 0.7 & 11.6 & 16.2 & 0.0 & 3.6 & 1.8 & 59.9 & $\overline{\mathrm{NA}}$ \\
\hline & $30 \%$ - Daylit PSZ & 5.7 & 9.8 & 0.5 & 11.6 & 8.3 & 0.0 & 1.6 & 1.6 & 39.1 & $34.7 \%$ \\
\hline & $30 \%$ - Daylit VAV & 9.1 & 9.8 & 0.5 & 11.6 & 4.6 & 0.5 & 1.1 & 1.6 & 38.9 & $35.1 \%$ \\
\hline & $30 \%$ - Daylit PVAV & 6.8 & 9.8 & 0.5 & 11.6 & 4.6 & 0.0 & 1.2 & 1.6 & 36.1 & $39.8 \%$ \\
\hline \multirow{4}{*}{ 2B } & 2004 Baseline & 11.7 & 15.9 & 0.7 & 11.6 & 17.6 & 0.0 & 1.6 & 1.6 & 60.6 & NA \\
\hline & $30 \%$ - Daylit PSZ & 6.1 & 9.7 & 0.5 & 11.6 & 8.5 & 0.0 & 0.8 & 1.4 & 38.7 & $36.2 \%$ \\
\hline & $30 \%$ - Daylit VAV & 7.9 & 9.7 & 0.5 & 11.6 & 4.7 & 0.5 & 0.8 & 1.4 & 37.1 & $38.7 \%$ \\
\hline & $30 \%$ - Daylit PVAV & 5.9 & 9.7 & 0.5 & 11.6 & 4.7 & 0.0 & 0.8 & 1.4 & 34.7 & $42.7 \%$ \\
\hline \multirow{4}{*}{$3 A$} & 2004 Baseline & 6.9 & 15.9 & 0.7 & 11.6 & 15.3 & 0.0 & 5.7 & 2.1 & 58.2 & NA \\
\hline & $30 \%$ - Daylit PSZ & 3.8 & 9.9 & 0.5 & 11.6 & 8.6 & 0.0 & 3.8 & 1.9 & 40.2 & $31.0 \%$ \\
\hline & $30 \%$ - Daylit VAV & 7.2 & 9.9 & 0.5 & 11.6 & 4.8 & 0.6 & 2.9 & 1.9 & 39.4 & $32.3 \%$ \\
\hline & $30 \%$ - Daylit PVAV & 5.3 & 9.9 & 0.5 & 11.6 & 4.8 & 0.0 & 3.1 & 1.9 & 37.2 & $36.1 \%$ \\
\hline \multirow{4}{*}{$3 B$} & 2004 Baseline & 6.8 & 15.9 & 0.7 & 11.6 & 14.7 & 0.0 & 2.3 & 2.0 & 54.0 & NA \\
\hline & $30 \%$ - Daylit PSZ & 3.8 & 9.8 & 0.5 & 11.6 & 8.3 & 0.0 & 1.6 & 1.8 & 37.3 & $31.0 \%$ \\
\hline & $30 \%$ - Daylit VAV & 6.0 & 9.8 & 0.5 & 11.6 & 4.6 & 0.4 & 1.3 & 1.8 & 36.0 & $33.3 \%$ \\
\hline & $30 \%$ - Daylit PVAV & 4.4 & 9.8 & 0.5 & 11.6 & 4.6 & 0.0 & 1.3 & 1.8 & 34.1 & $36.8 \%$ \\
\hline \multirow{4}{*}{$3 C$} & 2004 Baseline & 1.3 & 15.9 & 0.7 & 11.6 & 13.1 & 0.0 & 2.4 & 2.4 & 47.4 & NA \\
\hline & $30 \%$ - Daylit PSZ & 0.5 & 9.9 & 0.5 & 11.6 & 6.6 & 0.0 & 1.4 & 2.2 & 32.6 & $31.2 \%$ \\
\hline & $30 \%$ - Daylit VAV & 2.3 & 9.9 & 0.5 & 11.6 & 3.1 & 0.3 & 1.6 & 2.2 & 31.6 & $33.4 \%$ \\
\hline & $30 \%$ - Daylit PVAV & 1.7 & 9.9 & 0.5 & 11.6 & 3.1 & 0.0 & 1.7 & 2.2 & 30.8 & $35.0 \%$ \\
\hline \multirow{4}{*}{$4 A$} & 2004 Baseline & 4.5 & 15.9 & 0.7 & 11.6 & 16.2 & 0.0 & 12.1 & 2.6 & 63.5 & $\overline{\mathrm{NA}}$ \\
\hline & $30 \%$ - Daylit PSZ & 2.5 & 9.6 & 0.5 & 11.6 & 8.8 & 0.0 & 7.5 & 2.3 & 42.7 & $32.8 \%$ \\
\hline & $30 \%$ - Daylit VAV & 5.7 & 9.6 & 0.5 & 11.6 & 5.0 & 0.6 & 5.3 & 2.3 & 40.6 & $36.1 \%$ \\
\hline & $30 \%$ - Daylit PVAV & 4.2 & 9.6 & 0.5 & 11.6 & 5.0 & 0.0 & 5.7 & 2.3 & 38.9 & $38.8 \%$ \\
\hline & 2004 Baseline & 4.7 & 15.9 & 0.7 & 11.6 & 16.3 & 0.0 & 5.5 & 2.5 & 57.2 & NA \\
\hline 4B & $30 \%$ - Daylit PSZ & 2.4 & 9.5 & 0.5 & 11.6 & 8.8 & 0.0 & 3.7 & 2.2 & 38.7 & $32.4 \%$ \\
\hline & $30 \%$ - Daylit VAV & 5.0 & 9.5 & 0.5 & 11.6 & 5.1 & 0.4 & 2.8 & 2.2 & 37.0 & $35.3 \%$ \\
\hline & $30 \%$ - Daylit PVAV & 3.7 & 9.5 & 0.5 & 11.6 & 5.1 & 0.0 & 3.0 & 2.2 & 35.5 & $37.9 \%$ \\
\hline & 2004 Baseline & 1.2 & 15.9 & 0.7 & 11.6 & 14.5 & 0.0 & 8.0 & 2.6 & 54.5 & NA \\
\hline $1 C$ & $30 \%$ - Daylit PSZ & 0.5 & 9.9 & 0.5 & 11.6 & 7.7 & 0.0 & 5.6 & 2.4 & 38.3 & $29.7 \%$ \\
\hline $4 C$ & $30 \%$ - Daylit VAV & 1.9 & 9.9 & 0.5 & 11.6 & 3.7 & 0.2 & 4.0 & 2.4 & 34.3 & $37.0 \%$ \\
\hline & $30 \%$ - Daylit PVAV & 1.4 & 9.9 & 0.5 & 11.6 & 3.7 & 0.0 & 4.3 & 2.4 & 33.8 & $38.0 \%$ \\
\hline & 2004 Baseline & 3.6 & 15.9 & 0.7 & 11.6 & 17.5 & 0.0 & 20.0 & 2.8 & 72.0 & NA \\
\hline & $30 \%$ - Daylit PSZ & 1.9 & 9.6 & 0.5 & 11.6 & 9.4 & 0.0 & 11.7 & 2.5 & 47.2 & $34.4 \%$ \\
\hline SA & $30 \%$ - Daylit VAV & 5.5 & 9.6 & 0.5 & 11.6 & 5.4 & 0.6 & 8.6 & 2.5 & 44.4 & $38.4 \%$ \\
\hline & $30 \%$ - Daylit PVAV & 4.1 & 9.6 & 0.5 & 11.6 & 5.4 & 0.0 & 9.2 & 2.5 & 42.9 & $40.4 \%$ \\
\hline & 2004 Baseline & 3.1 & 15.9 & 0.7 & 11.6 & 17.4 & 0.0 & 12.4 & 2.8 & 63.7 & NA \\
\hline & $30 \%$ - Daylit PSZ & 1.5 & 9.5 & 0.5 & 11.6 & 9.0 & 0.0 & 7.8 & 2.5 & 42.5 & $33.4 \%$ \\
\hline $5 B$ & $30 \%$ - Daylit VAV & 4.4 & 9.5 & 0.5 & 11.6 & 5.2 & 0.5 & 5.8 & 2.5 & 40.0 & $37.3 \%$ \\
\hline & $30 \%$ - Daylit PVAV & 3.3 & 9.5 & 0.5 & 11.6 & 5.2 & 0.0 & 6.1 & 2.5 & 38.8 & $39.2 \%$ \\
\hline & 2004 Baseline & 2.3 & 15.9 & 0.7 & 11.6 & 17.2 & 0.0 & 28.9 & 3.1 & 79.7 & NA \\
\hline 64 & $30 \%$ - Daylit PSZ & 1.2 & 9.6 & 0.5 & 11.6 & 9.2 & 0.0 & 16.0 & 2.7 & 50.8 & $36.3 \%$ \\
\hline 6A & $30 \%$ - Daylit VAV & 4.7 & 9.6 & 0.5 & 11.6 & 5.2 & 0.6 & 12.3 & 2.7 & 47.2 & $40.7 \%$ \\
\hline & $30 \%$ - Daylit PVAV & 3.6 & 9.6 & 0.5 & 11.6 & 5.2 & 0.0 & 13.1 & 2.7 & 46.4 & $41.7 \%$ \\
\hline & 2004 Baseline & 1.9 & 15.9 & 0.7 & 11.6 & 17.5 & 0.0 & 21.9 & 3.1 & 72.6 & NA \\
\hline GR & $30 \%$ - Daylit PSZ & 0.9 & 9.6 & 0.5 & 11.6 & 9.0 & 0.0 & 12.4 & 2.8 & 46.7 & $35.6 \%$ \\
\hline $6 \mathrm{~B}$ & $30 \%$ - Daylit VAV & 3.8 & 9.6 & 0.5 & 11.6 & 5.2 & 0.5 & 10.1 & 2.8 & 44.0 & $39.3 \%$ \\
\hline & $30 \%$ - Daylit PVAV & 3.0 & 9.6 & 0.5 & 11.6 & 5.2 & 0.0 & 10.8 & 2.8 & 43.4 & $40.2 \%$ \\
\hline & 2004 Baseline & 1.2 & 15.9 & 0.7 & 11.6 & 18.8 & 0.0 & 38.9 & 3.5 & 90.5 & NA \\
\hline & $30 \%$ - Daylit PSZ & 0.5 & 9.6 & 0.5 & 11.6 & 9.6 & 0.0 & 20.5 & 3.1 & 55.4 & $38.8 \%$ \\
\hline $7 \mathrm{~A}$ & $30 \%$ - Daylit VAV & 3.8 & 9.6 & 0.5 & 11.6 & 5.5 & 0.7 & 16.3 & 3.1 & 51.0 & $43.7 \%$ \\
\hline & $30 \%$ - Daylit PVAV & 3.0 & 9.6 & 0.5 & 11.6 & 5.5 & 0.0 & 17.5 & 3.1 & 50.6 & $44.1 \%$ \\
\hline & 2004 Baseline & 0.6 & 15.9 & 0.6 & 11.6 & 17.6 & 0.0 & 72.1 & 3.9 & 122.3 & NA \\
\hline 8 & $30 \%$ - Daylit PSZ & 0.4 & 10.3 & 0.5 & 11.6 & 12.5 & 0.0 & 36.3 & 3.5 & 75.1 & $38.6 \%$ \\
\hline 8 & $30 \%$ - Daylit VAV & 3.9 & 10.3 & 0.5 & 11.6 & 7.0 & 0.9 & 37.3 & 3.5 & 75.0 & $38.7 \%$ \\
\hline & $30 \%$ - Daylit PVAV & 3.0 & 10.3 & 0.5 & 11.6 & 7.0 & 0.0 & 40.0 & 3.5 & 75.8 & $38.0 \%$ \\
\hline
\end{tabular}


Table H-3 High School End Uses: Climate Zones 1-8

\begin{tabular}{|c|c|c|c|c|c|c|c|c|c|c|c|}
\hline \multicolumn{2}{|c|}{ High School End Uses } & \multicolumn{6}{|c|}{ Electricity (kBtu/ft ${ }^{2}$ ) } & \multicolumn{2}{|c|}{ Gas (kBtu/ft $\left.{ }^{2}\right)$} & \multirow{2}{*}{$\begin{array}{l}\text { Total End } \\
\text { Uses } \\
\text { (kBtu/ft' }\end{array}$} & \multirow{2}{*}{ Savings $\%$} \\
\hline Climate & Strategy & Cooling & $\begin{array}{c}\text { Int. } \\
\text { Lights }\end{array}$ & $\begin{array}{c}\text { Ext. } \\
\text { Lights }\end{array}$ & $\begin{array}{c}\text { Int. } \\
\text { Equip }\end{array}$ & Fans & Pumps & Heating & $\begin{array}{c}\text { Water } \\
\text { Systems }\end{array}$ & & \\
\hline \multirow{4}{*}{$1 \mathrm{~A}$} & 2004 Baseline & ב16.3 & "16.3 & (20.4 & "10.4 & "16.5 & "0.0 & (20.4 & "1.3 & (21.6 & 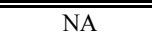 \\
\hline & $30 \%$ - Daylit PSZ & 10.3 & 9.9 & 0.3 & 10.4 & 9.1 & 0.0 & 0.2 & 1.2 & 41.4 & $32.8 \%$ \\
\hline & $30 \%$ - Daylit VAV & 14.1 & 10.1 & 0.3 & 10.4 & 5.5 & 0.6 & 0.0 & 1.2 & 42.3 & $31.4 \%$ \\
\hline & $30 \%$ - Daylit PVAV & 10.5 & 10.1 & 0.3 & 10.4 & 5.5 & 0.0 & 0.0 & 1.2 & 38.1 & $38.2 \%$ \\
\hline \multirow{4}{*}{$2 A$} & 2004 Baseline & 11.2 & 16.3 & 0.4 & 10.4 & 16.5 & 0.0 & 3.9 & 1.8 & 60.6 & NA \\
\hline & $30 \%$ - Daylit PSZ & 6.6 & 10.1 & 0.3 & 10.4 & 8.4 & 0.0 & 1.6 & 1.6 & 39.0 & $35.7 \%$ \\
\hline & $30 \%$ - Daylit VAV & 10.0 & 10.2 & 0.3 & 10.4 & 5.0 & 0.6 & 1.4 & 1.6 & 39.6 & $34.7 \%$ \\
\hline & $30 \%$ - Daylit PVAV & 7.5 & 10.2 & 0.3 & 10.4 & 5.0 & 0.0 & 1.5 & 1.6 & 36.5 & $39.8 \%$ \\
\hline \multirow{4}{*}{ 2B } & 2004 Baseline & 13.9 & 16.3 & 0.4 & 10.4 & 19.0 & 0.0 & 1.8 & 1.6 & 63.4 & NA \\
\hline & 30\% - Daylit PSZ & 7.5 & 10.1 & 0.3 & 10.4 & 9.2 & 0.0 & 0.7 & 1.4 & 39.6 & $37.5 \%$ \\
\hline & $30 \%$ - Daylit VAV & 10.0 & 10.2 & 0.3 & 10.4 & 5.9 & 0.6 & 0.9 & 1.4 & 39.7 & $37.3 \%$ \\
\hline & $30 \%$ - Daylit PVAV & 7.4 & 10.2 & 0.3 & 10.4 & 5.9 & 0.0 & 1.0 & 1.4 & 36.7 & $42.2 \%$ \\
\hline \multirow{4}{*}{$3 A$} & 2004 Baseline & 7.9 & 16.3 & 0.4 & 10.4 & 15.4 & 0.0 & 6.4 & 2.2 & 59.0 & NA \\
\hline & 30\% - Daylit PSZ & 4.6 & 10.2 & 0.3 & 10.4 & 8.9 & 0.0 & 4.0 & 1.9 & 40.3 & $31.7 \%$ \\
\hline & $30 \%$ - Daylit VAV & 7.8 & 10.3 & 0.3 & 10.4 & 5.3 & 0.7 & 3.6 & 1.9 & 40.4 & $31.5 \%$ \\
\hline & $30 \%$ - Daylit PVAV & 5.8 & 10.3 & 0.3 & 10.4 & 5.3 & 0.0 & 3.9 & 1.9 & 38.0 & $35.7 \%$ \\
\hline \multirow{4}{*}{$3 B$} & 2004 Baseline & 7.8 & 16.3 & 0.4 & 10.4 & 14.6 & 0.0 & 2.5 & 2.1 & 54.1 & $\mathrm{NA}$ \\
\hline & $30 \%$ - Daylit PSZ & 4.5 & 10.1 & 0.3 & 10.4 & 8.3 & 0.0 & 1.5 & 1.8 & 36.9 & $31.8 \%$ \\
\hline & $30 \%$ - Daylit VAV & 6.8 & 10.3 & 0.3 & 10.4 & 5.3 & 0.5 & 1.6 & 1.8 & 37.0 & $31.7 \%$ \\
\hline & $30 \%$ - Daylit PVAV & 5.1 & 10.3 & 0.3 & 10.4 & 5.3 & 0.0 & 1.7 & 1.8 & 34.8 & $35.6 \%$ \\
\hline \multirow{4}{*}{$3 C$} & 2004 Baseline & 1.8 & 16.3 & 0.4 & 10.4 & 13.3 & 0.0 & 3.1 & 2.5 & 47.8 & NA \\
\hline & 30\% - Daylit PSZ & 0.7 & 10.2 & 0.3 & 10.4 & 6.7 & 0.0 & 1.5 & 2.2 & 32.0 & $33.1 \%$ \\
\hline & $30 \%$ - Daylit VAV & 2.3 & 10.4 & 0.3 & 10.4 & 3.3 & 0.3 & 1.9 & 2.2 & 31.1 & $35.0 \%$ \\
\hline & $30 \%$ - Daylit PVAV & 1.7 & 10.4 & 0.3 & 10.4 & 3.3 & 0.0 & 2.0 & 2.2 & 30.3 & $36.7 \%$ \\
\hline \multirow{4}{*}{$4 A$} & 2004 Baseline & 5.3 & 16.3 & 0.4 & 10.4 & 16.3 & 0.0 & 13.7 & 2.6 & 65.0 & $\mathrm{NA}$ \\
\hline & 30\% - Daylit PSZ & 3.0 & 9.8 & 0.3 & 10.4 & 9.0 & 0.0 & 8.5 & 2.3 & 43.3 & $33.4 \%$ \\
\hline & $30 \%$ - Daylit VAV & 6.2 & 9.9 & 0.3 & 10.4 & 5.6 & 0.8 & 7.0 & 2.3 & 42.5 & $34.6 \%$ \\
\hline & $30 \%$ - Daylit PVAV & 4.5 & 9.9 & 0.3 & 10.4 & 5.6 & 0.0 & 7.6 & 2.3 & 40.7 & $37.4 \%$ \\
\hline & 2004 Baseline & 5.7 & 16.3 & 0.4 & 10.4 & 16.7 & 0.0 & 6.2 & 2.5 & 58.2 & $\mathrm{NA}$ \\
\hline 4B & 30\% - Daylit PSZ & 3.0 & 9.7 & 0.3 & 10.4 & 9.1 & 0.0 & 4.0 & 2.2 & 38.8 & $33.4 \%$ \\
\hline & $30 \%$ - Daylit VAV & 5.6 & 9.8 & 0.3 & 10.4 & 5.8 & 0.6 & 3.8 & 2.2 & 38.6 & $33.8 \%$ \\
\hline & $30 \%$ - Daylit PVAV & 4.1 & 9.8 & 0.3 & 10.4 & 5.8 & 0.0 & 4.1 & 2.2 & 36.9 & $36.7 \%$ \\
\hline & 2004 Baseline & 1.7 & 16.3 & 0.4 & 10.4 & 15.0 & 0.0 & 10.0 & 2.7 & 56.5 & $\mathrm{NA}$ \\
\hline 10 & $30 \%$ - Daylit PSZ & 0.8 & 10.2 & 0.3 & 10.4 & 8.0 & 0.0 & 6.7 & 2.4 & 38.7 & $31.5 \%$ \\
\hline 4C & $30 \%$ - Daylit VAV & 2.0 & 10.3 & 0.3 & 10.4 & 4.3 & 0.4 & 5.4 & 2.4 & 35.4 & $37.4 \%$ \\
\hline & $30 \%$ - Daylit PVAV & 1.4 & 10.3 & 0.3 & 10.4 & 4.3 & 0.0 & 5.8 & 2.4 & 34.9 & $38.3 \%$ \\
\hline & 2004 Baseline & 4.2 & 16.3 & 0.4 & 10.4 & 17.6 & 0.0 & 22.4 & 2.9 & 74.2 & $\mathrm{NA}$ \\
\hline 5 & $30 \%$ - Daylit PSZ & 2.3 & 9.8 & 0.3 & 10.4 & 9.7 & 0.0 & 13.2 & 2.6 & 48.3 & $34.9 \%$ \\
\hline $5 \mathrm{~A}$ & $30 \%$ - Daylit VAV & 5.8 & 9.9 & 0.3 & 10.4 & 6.0 & 0.9 & 10.9 & 2.6 & 46.8 & $36.9 \%$ \\
\hline & $30 \%$ - Daylit PVAV & 4.3 & 9.9 & 0.3 & 10.4 & 6.0 & 0.0 & 11.8 & 2.6 & 45.3 & $38.9 \%$ \\
\hline & 2004 Baseline & 3.8 & 16.3 & 0.4 & 10.4 & 17.7 & 0.0 & 14.1 & 2.8 & 65.6 & NA \\
\hline סז & $30 \%$ - Daylit PSZ & 1.9 & 9.7 & 0.3 & 10.4 & 9.5 & 0.0 & 8.8 & 2.5 & 43.2 & $34.3 \%$ \\
\hline 5B & $30 \%$ - Daylit VAV & 4.8 & 9.8 & 0.3 & 10.4 & 6.0 & 0.7 & 7.6 & 2.5 & 42.1 & $35.9 \%$ \\
\hline & $30 \%$ - Daylit PVAV & 3.6 & 9.8 & 0.3 & 10.4 & 6.0 & 0.0 & 8.2 & 2.5 & 40.8 & $37.8 \%$ \\
\hline & 2004 Baseline & 2.8 & 16.3 & 0.4 & 10.4 & 17.1 & 0.0 & 31.6 & 3.1 & 81.8 & NA \\
\hline$c$ & $30 \%$ - Daylit PSZ & 1.5 & 9.8 & 0.3 & 10.4 & 9.5 & 0.0 & 17.7 & 2.8 & 51.8 & $36.6 \%$ \\
\hline $6 \mathrm{~A}$ & $30 \%$ - Daylit VAV & 4.8 & 9.8 & 0.3 & 10.4 & 5.7 & 1.0 & 15.2 & 2.8 & 50.0 & $38.8 \%$ \\
\hline & $30 \%$ - Daylit PVAV & 3.7 & 9.8 & 0.3 & 10.4 & 5.7 & 0.0 & 16.5 & 2.8 & 49.3 & $39.7 \%$ \\
\hline & 2004 Baseline & 2.4 & 16.3 & 0.4 & 10.4 & 17.6 & 0.0 & 24.0 & 3.2 & 74.4 & NA \\
\hline CD & $30 \%$ - Daylit PSZ & 1.1 & 9.7 & 0.3 & 10.4 & 9.4 & 0.0 & 13.6 & 2.8 & 47.4 & $36.3 \%$ \\
\hline 6B & $30 \%$ - Daylit VAV & 4.0 & 9.8 & 0.3 & 10.4 & 5.9 & 0.8 & 12.5 & 2.8 & 46.6 & $37.4 \%$ \\
\hline & $30 \%$ - Daylit PVAV & 3.1 & 9.8 & 0.3 & 10.4 & 5.9 & 0.0 & 13.6 & 2.8 & 46.0 & $38.1 \%$ \\
\hline & 2004 Baseline & 1.6 & 16.3 & 0.4 & 10.4 & 18.8 & 0.0 & 42.0 & 3.5 & 93.1 & NA \\
\hline 70 & $30 \%$ - Daylit PSZ & 0.8 & 9.7 & 0.3 & 10.4 & 10.0 & 0.0 & 22.2 & 3.2 & 56.5 & $39.3 \%$ \\
\hline 7A & $30 \%$ - Daylit VAV & 4.0 & 9.8 & 0.3 & 10.4 & 6.0 & 1.1 & 19.9 & 3.1 & 54.7 & $41.3 \%$ \\
\hline & $30 \%$ - Daylit PVAV & 3.1 & 9.8 & 0.3 & 10.4 & 6.0 & 0.0 & 21.7 & 3.1 & 54.4 & $41.6 \%$ \\
\hline & 2004 Baseline & 0.9 & 16.3 & 0.4 & 10.4 & 18.6 & 0.0 & 76.1 & 4.0 & 126.8 & NA \\
\hline 8 & $30 \%$ - Daylit PSZ & 0.5 & 10.4 & 0.3 & 10.4 & 12.9 & 0.0 & 37.5 & 3.6 & 75.6 & $40.4 \%$ \\
\hline 8 & $30 \%$ - Daylit VAV & 3.9 & 10.5 & 0.3 & 10.4 & 7.3 & 1.7 & 42.6 & 3.6 & 80.3 & $36.7 \%$ \\
\hline & $30 \%$ - Daylit PVAV & 3.0 & 10.5 & 0.3 & 10.4 & 7.3 & 0.0 & 46.4 & 3.6 & 81.5 & $35.7 \%$ \\
\hline
\end{tabular}




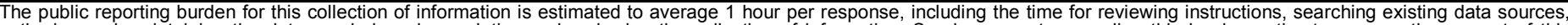

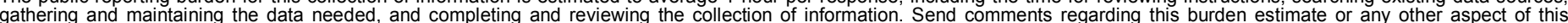

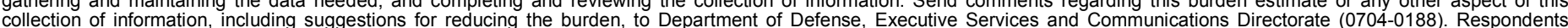

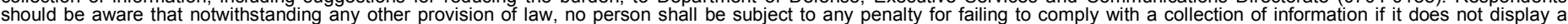

should be aware that notwithstanding

PLEASE DO NOT RETURN YOUR FORM TO THE ABOVE ORGANIZATION.

\begin{tabular}{l|l|l|l} 
1. REPORT DATE $(D D-M M-Y Y Y Y)$ & 2. & REPORT TYPE & 3. DATES COVERED (FrOm - TO)
\end{tabular}

September 2007

Technical Report

4. TITLE AND SUBTITLE

Technical Support Document: Development of the Advanced Energy

Design Guide for K-12 Schools--30\% Energy Savings

5a. CONTRACT NUMBER

DE-AC36-99-GO10337

5b. GRANT NUMBER

5c. PROGRAM ELEMENT NUMBER

6. AUTHOR(S)

S. Pless, P. Torcellini, and N. Long

5d. PROJECT NUMBER

NREL/TP-550-42114

5e. TASK NUMBER

BEC71011

5f. WORK UNIT NUMBER
7. PERFORMING ORGANIZATION NAME(S) AND ADDRESS(ES)

National Renewable Energy Laboratory

1617 Cole Blvd.

Golden, CO 80401-3393
8. PERFORMING ORGANIZATION REPORT NUMBER

NREL/TP-550-42114

9. SPONSORING/MONITORING AGENCY NAME(S) AND ADDRESS(ES)

10. SPONSOR/MONITOR'S ACRONYM(S) NREL

11. SPONSORING/MONITORING AGENCY REPORT NUMBER

12. DISTRIBUTION AVAILABILITY STATEMENT

National Technical Information Service

U.S. Department of Commerce

5285 Port Royal Road

Springfield, VA 22161

13. SUPPLEMENTARY NOTES

14. ABSTRACT (Maximum 200 Words)

This Technical Support Document describes the process and methodology for the development of the Advanced Energy Design Guide for K-12 School Buildings (K-12 AEDG), a design guidance document intended to provide recommendations for achieving 30\% energy savings in K-12 Schools over levels contained in ANSI/ASHRAE/IESNA Standard 90.1-1999, Energy Standard for Buildings Except Low-Rise Residential Buildings. The 30\% energy savings target is the first step toward achieving net-zero energy schools; schools that, on an annual basis, draw from outside sources less or equal energy than they generate on site from renewable energy sources.

15. SUBJECT TERMS

advanced energy design guide; zero energy schools; renewable energy

16. SECURITY CLASSIFICATION OF:
\begin{tabular}{|l|l|l|}
\hline $\begin{array}{l}\text { a. REPORT } \\
\text { Unclassified }\end{array}$ & $\begin{array}{c}\text { b. ABSTRACT } \\
\text { Unclassified }\end{array}$ & $\begin{array}{l}\text { c. THIS PAGE } \\
\text { Unclassified }\end{array}$ \\
\hline
\end{tabular}

\begin{tabular}{l|l} 
17. LIMITATION & 18. \\
OF AMSTRACT & OF PAGES \\
UL & \\
& \\
\hline
\end{tabular}

19a. NAME OF RESPONSIBLE PERSON

19b. TELEPHONE NUMBER (Include area code) 